

Lovers of ithe

forse (马) 
$\therefore 2-2 \cdot 25=$

57.250 .1200

(1)

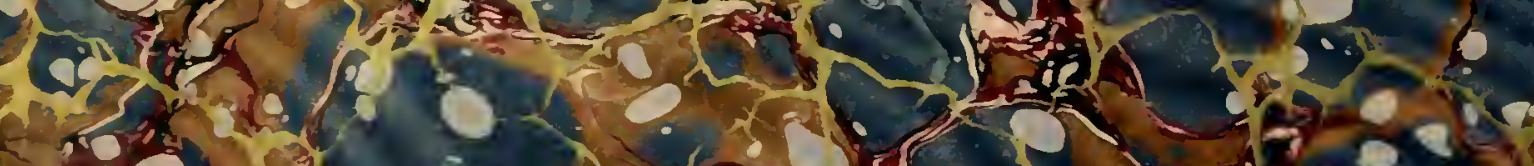

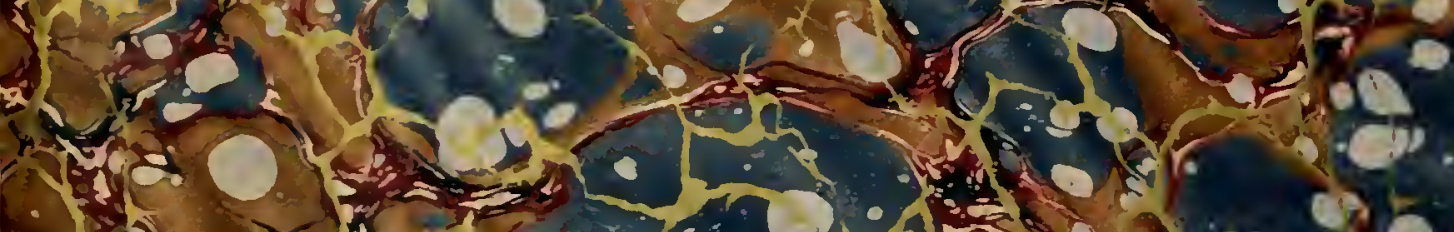

30.00 .09 .90

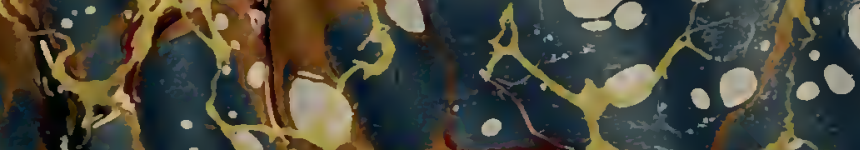

30.000000

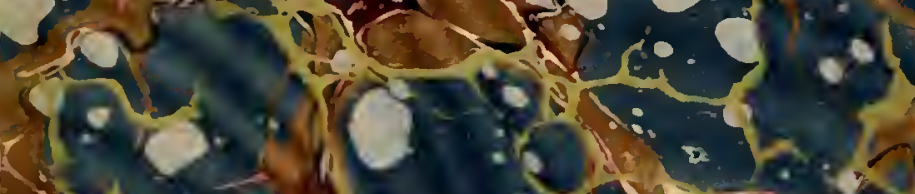

9)

: ${ }^{3}$

3. 25.

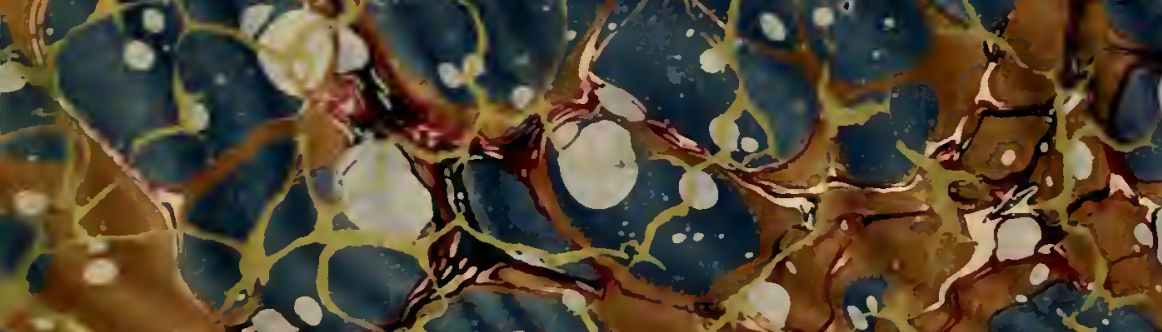

- -10

in. it sin an?

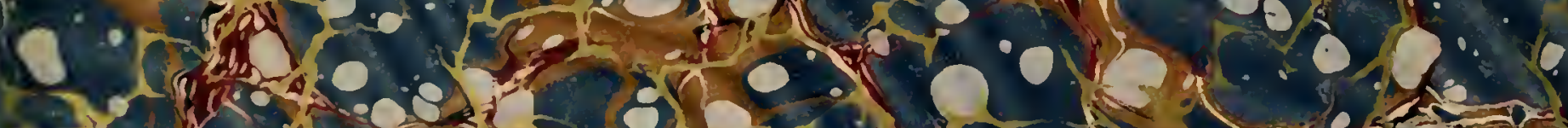

ax $x=92+1$

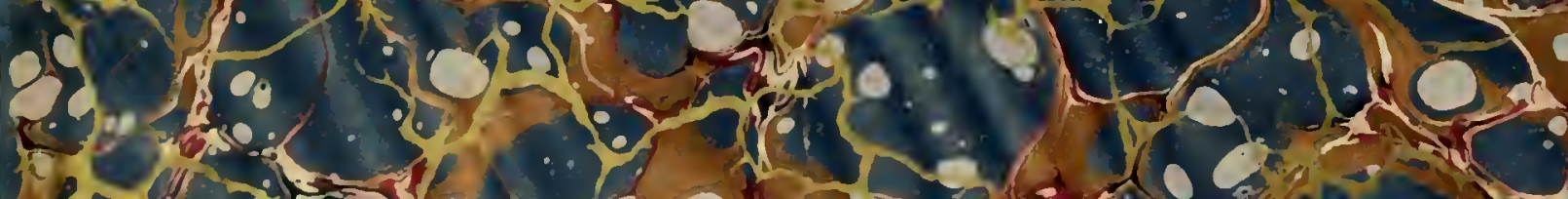

2. 0.75

$9+1,2 \times 1$

300402

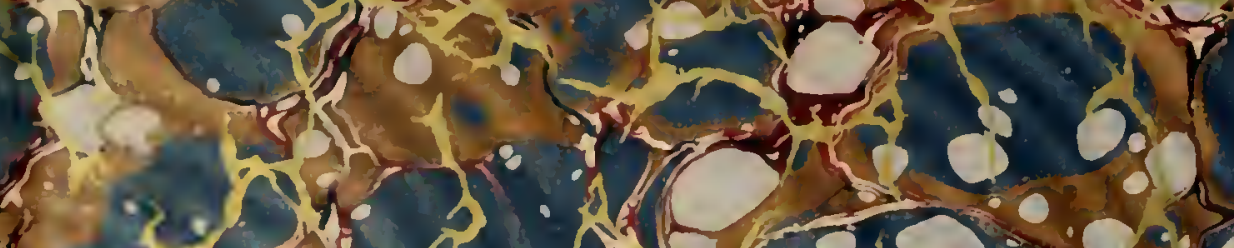

) a. 1.20

a)

$x+7 \rightarrow 0$

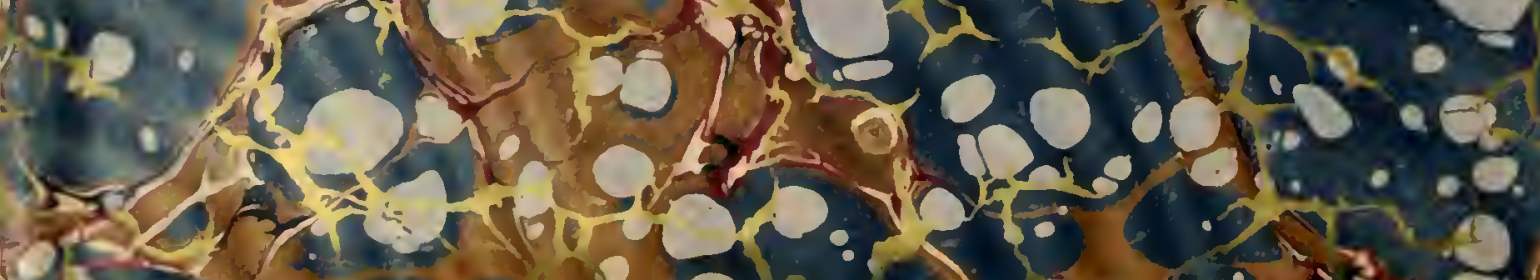

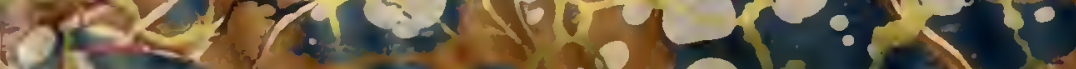

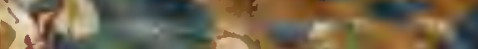




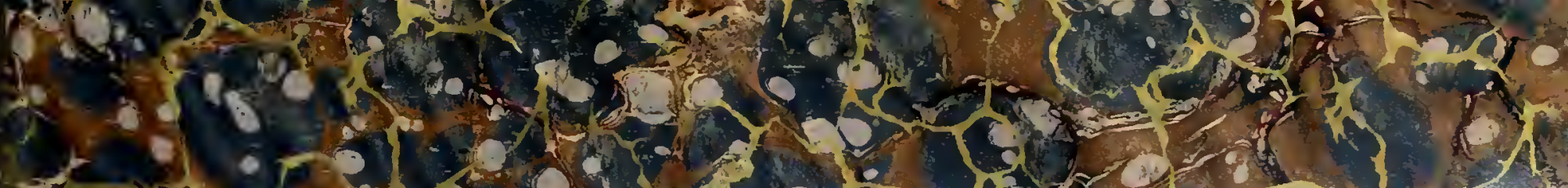

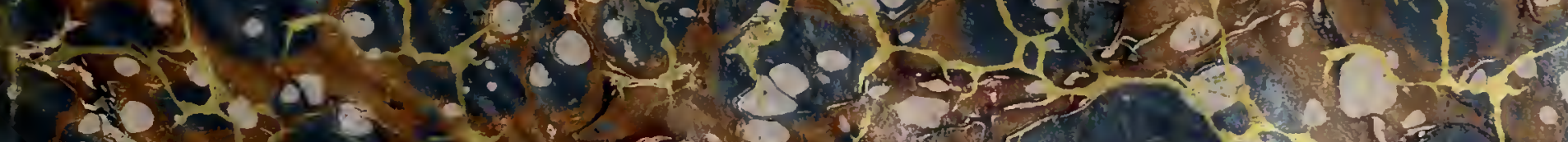

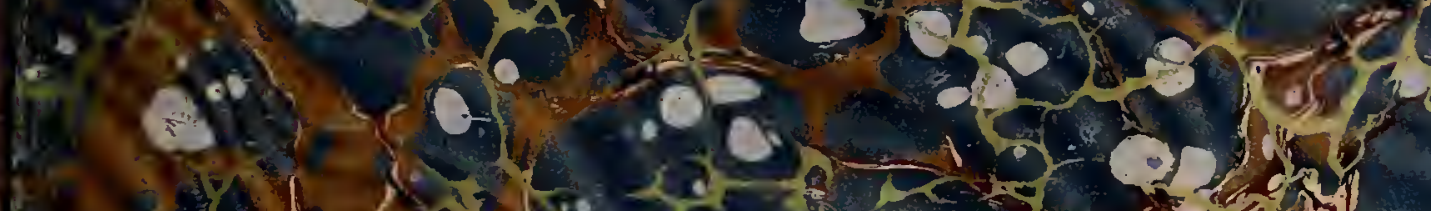

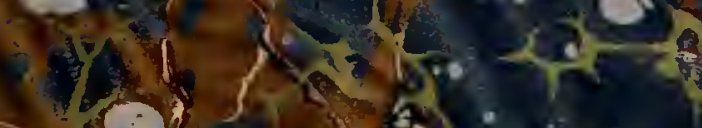
d.

$$
\text { if } 10
$$

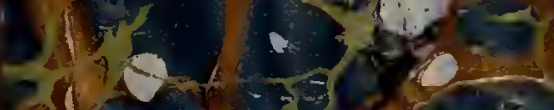

wary 10.98 retes o. - 5120 $\infty$ - $5 \frac{0.03}{20} \cdot 4$

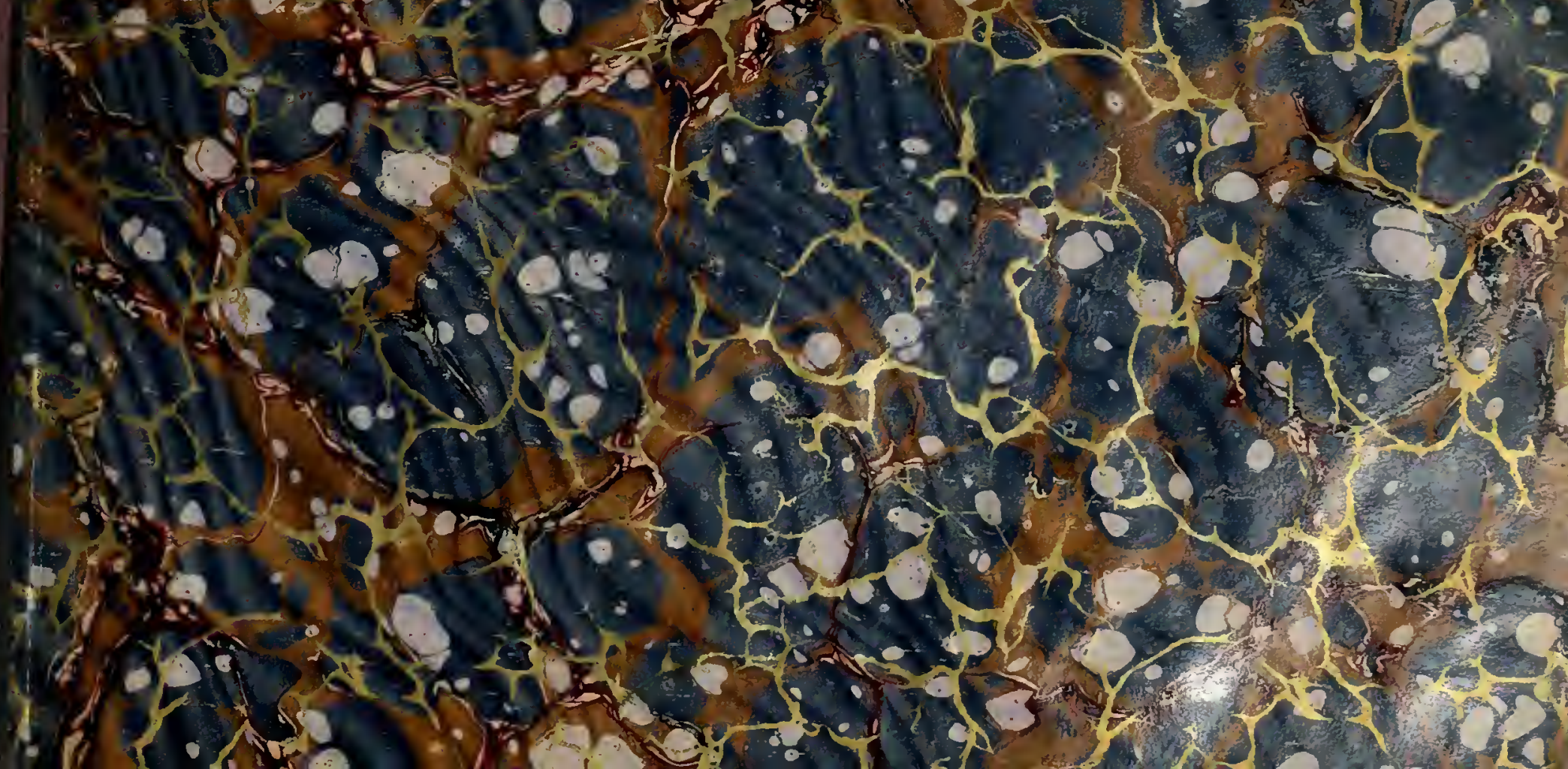

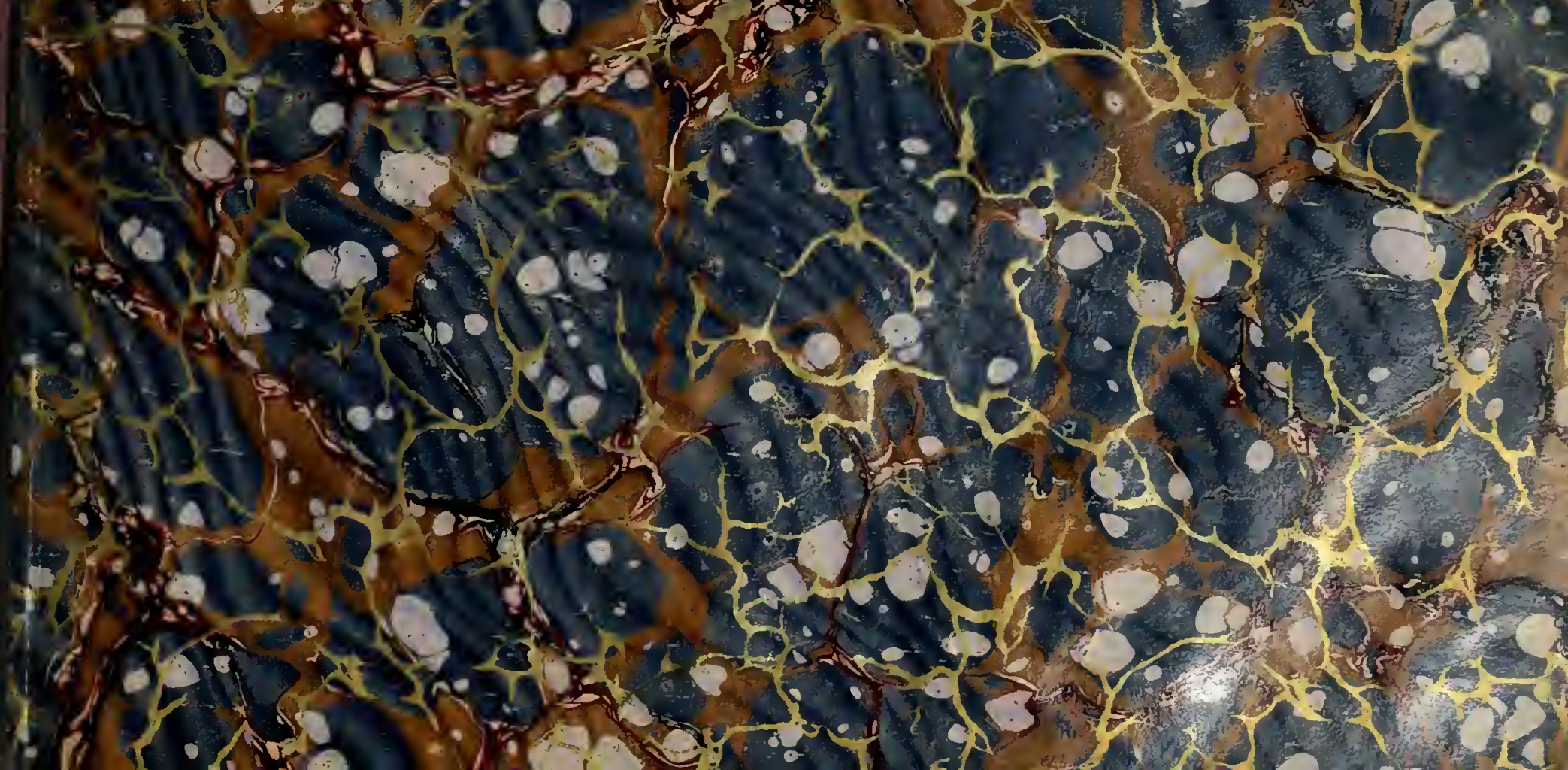

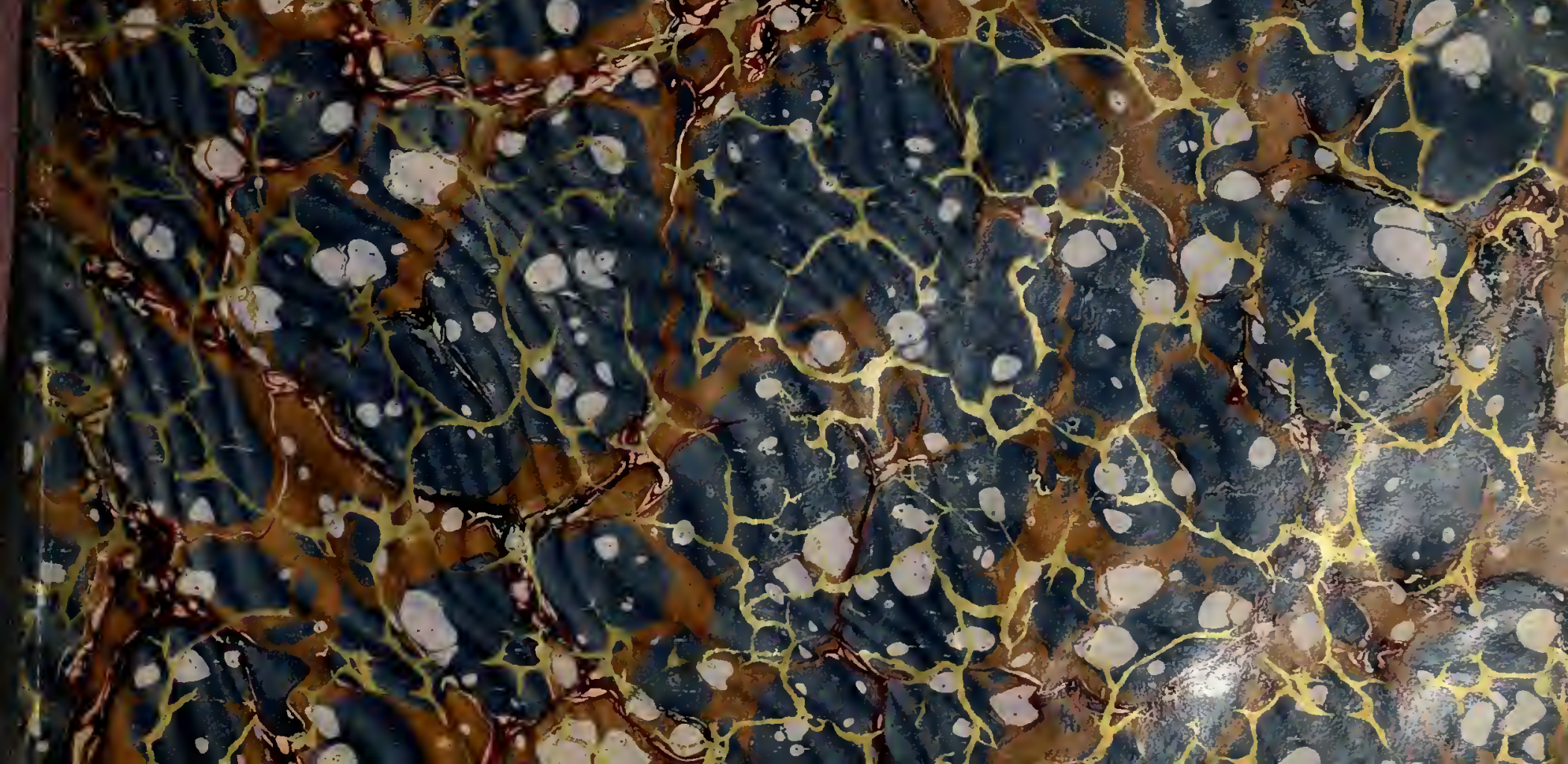

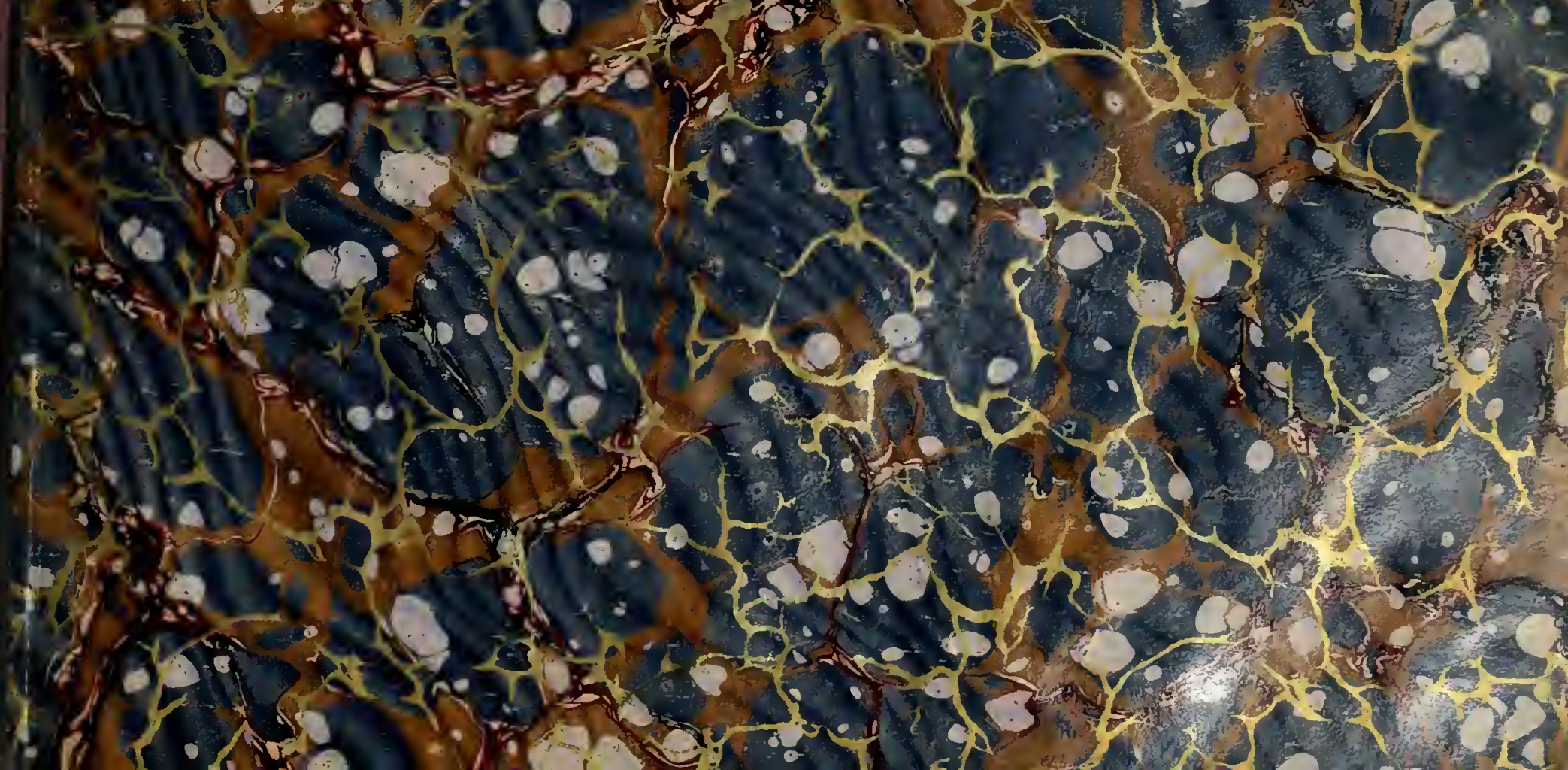

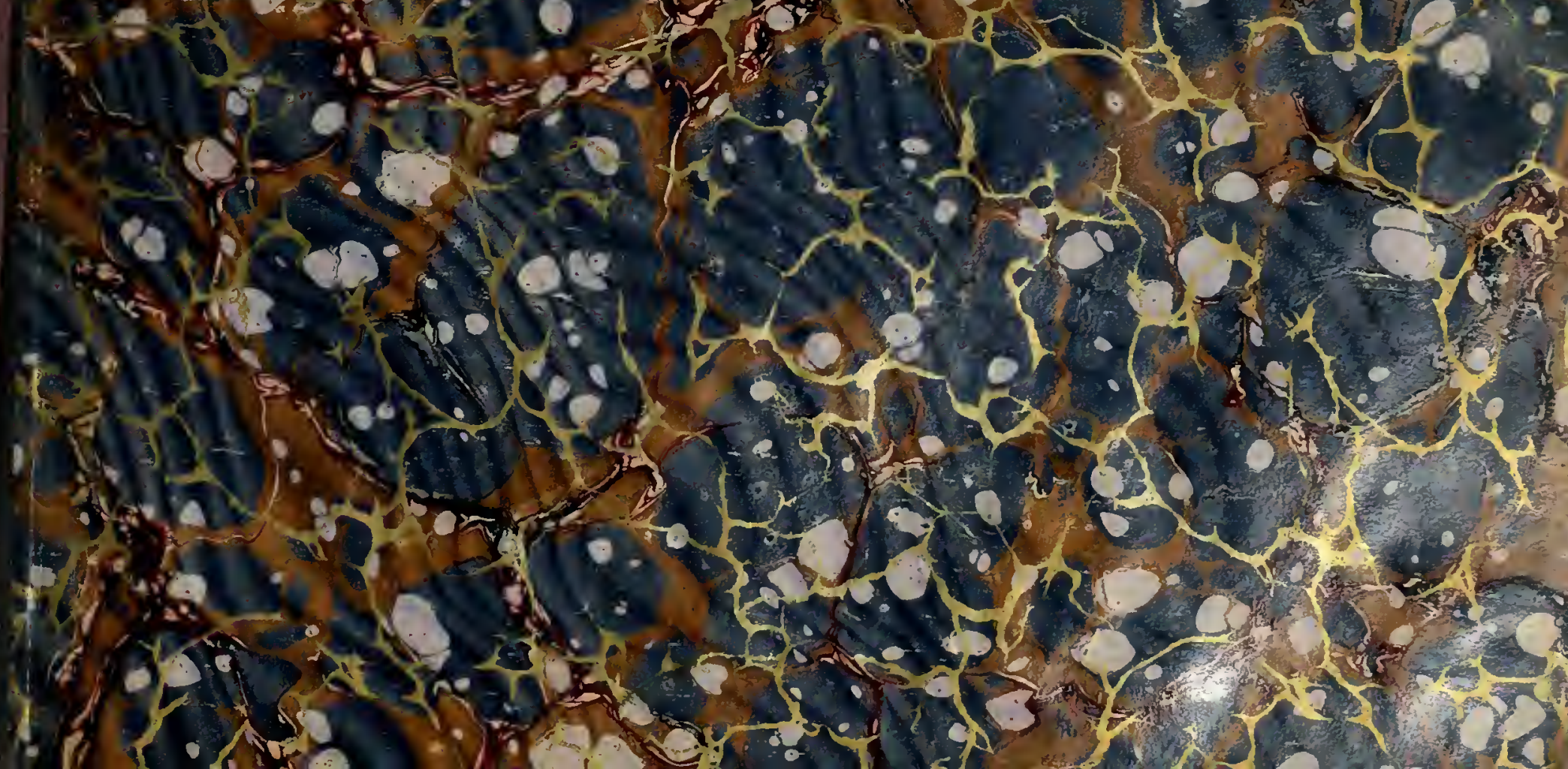











\section{LOVERS OF THE HORSE}

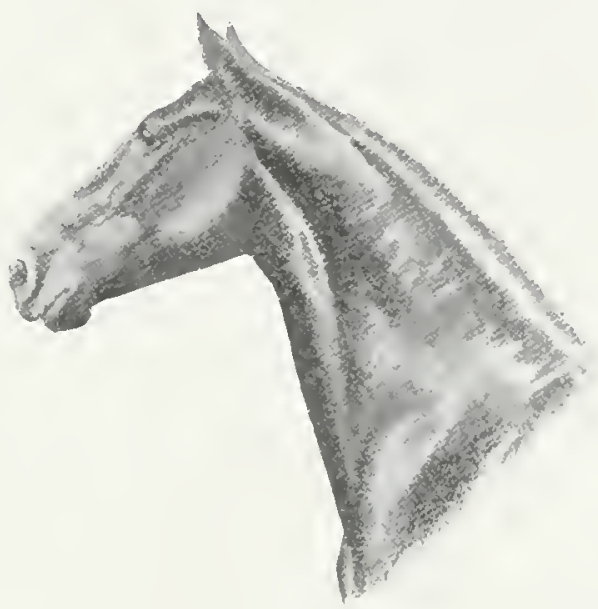

BRIEF SKETCHES OF MEN AND WOMEN OF THE DOMINION OF CANADA DEVOTED TO

THE NOBLEST OF ANIMALS 


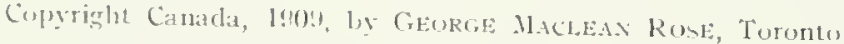

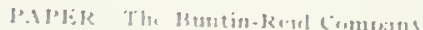

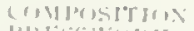

I'Rlissirith

The Ituster, Rose (n, I,imited

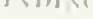

(iriv, I mnitud

6 
$\mathrm{T}$ ILE British nation is, without a koubt, the most sportsmanlike in the workd, and we, the people of its lalderest and most influential colony, alre grand to feet that we are no whit behind the mother comntry in onr sporting instinets.

The Ilorse is one of om great delights and horse-lates. horseshows and fairs alike bring forth an atmiring and erep-increasing throug of fair women and brave men.

Cillatal seems to be forging rapidly to the front as a holsebreeding comntry, and canadian horses ane acculuing, on this continent, in Great Britain, in Europe and elsewhere, an emviable repmtation for endurance and speed, as well as for general excellence.

While the rank and file of Canadians have doubtless done mach to keep alive the sporting instinct by their enthusiasm and encomragement, the pre-eminence of Canadian horses is due manly to the effosts of a few men and women who, by the expenditure of time, energy and money, and the adoption and maintemance of dean, homorable and sportsmanlike methods, hare kept horse-life in Camalal mp to the very highest stamblart.

It is to commenumate these men and women and their afforts in the eanse of the Horse that this book is publishert, and we feet that the importance of their work demands the hest and most finisherd setting. 



\section{INTRODUCTORY}

A $1 t$ is in the nature ol man to want to test the stremglh, staminat and speed of the light lonse, and it is impossible to imagine that any sance and healthy

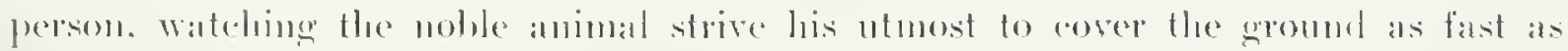

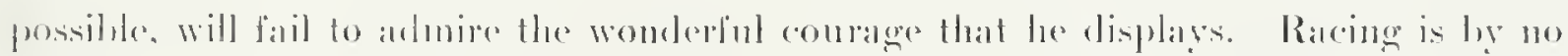
means the gambling game that uttra-moralists eloose to think it is. and wish to make

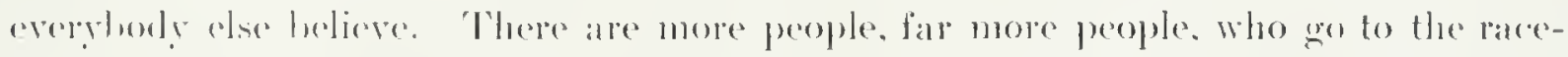

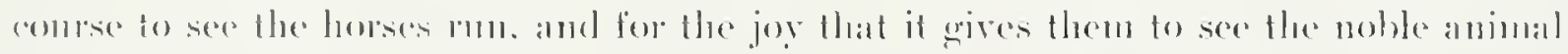

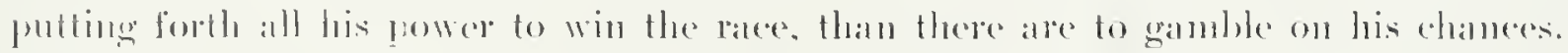

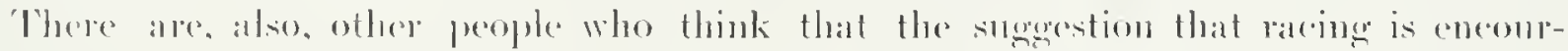

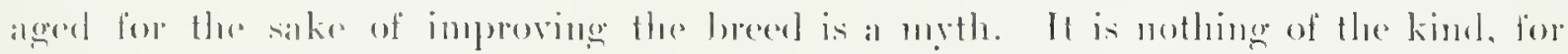

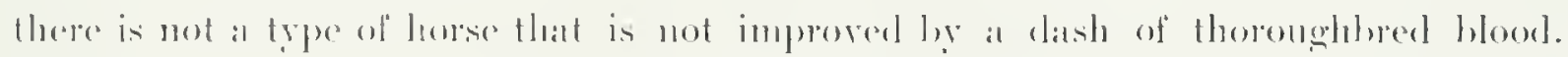

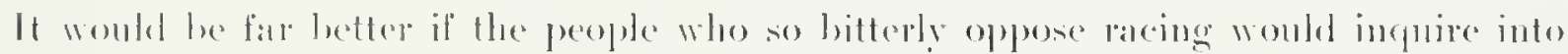

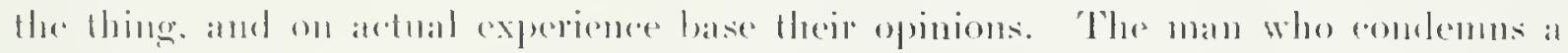
fyort that detights humberls of thomsands of his fellow-ereatures without making in-

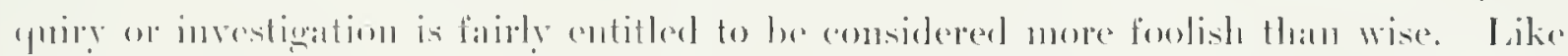

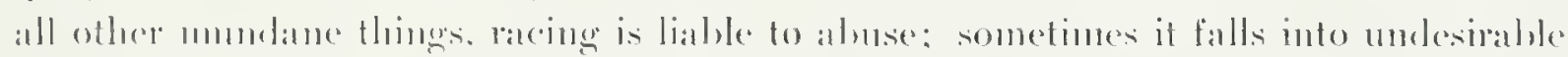

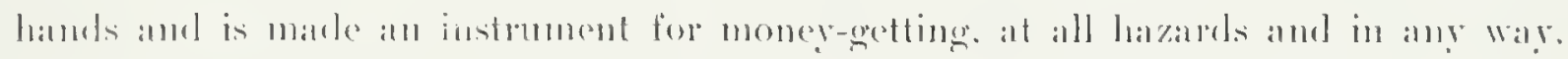
Bul surd a thing is the rarest exreption and not ly any means the eneneral rule.

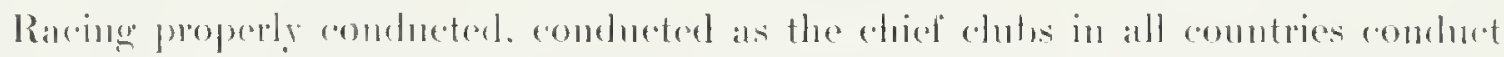

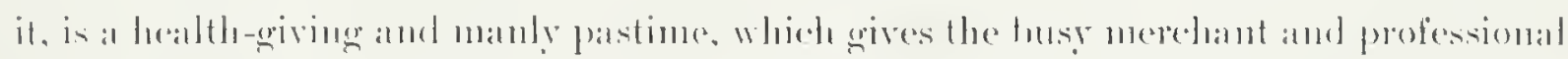

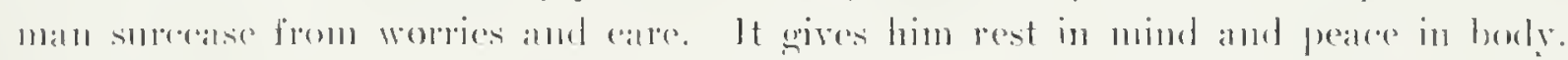

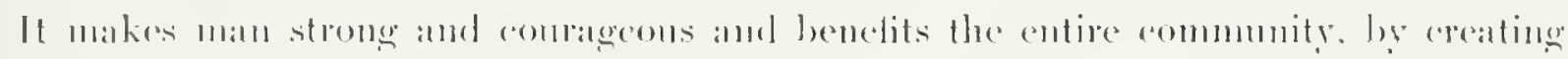
a love for the animal and tromlening the minds of mon. So fall as gambling is concermol, popte who ale bent that way will sperolate on anythinge: they will make the

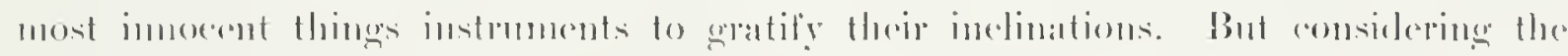
trementoms mumber of people who have a love for this pastime. Heere is not halt the

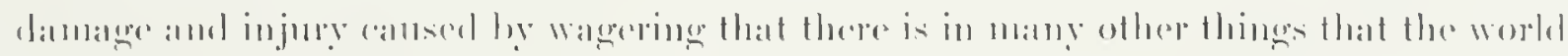

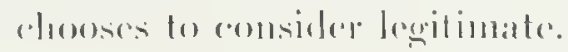

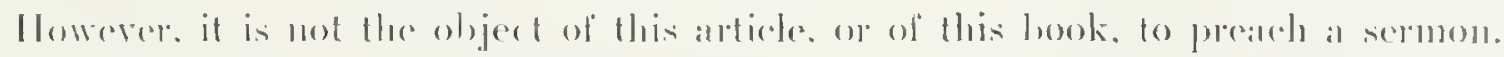

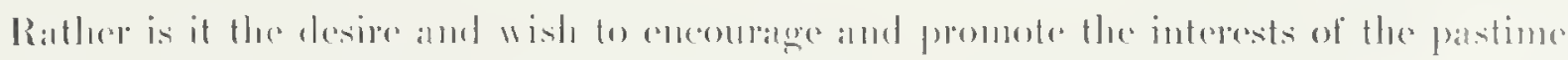

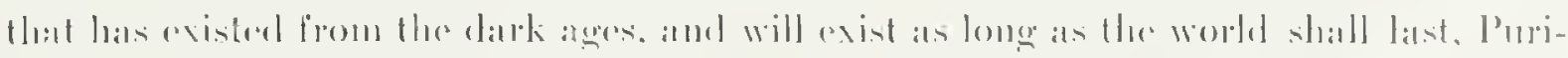

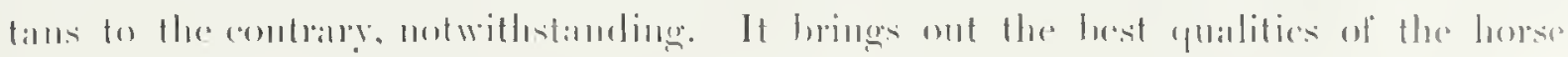




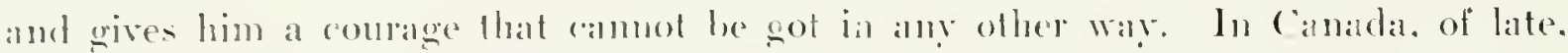
the sport has made tremendons progeress. Time was. indeed. when it was controlled culirely ly men whose first abject was money-making or money-getting. It is now. in Montreal. Toronto. (Quebere and other places. in the hands of men whose ohject

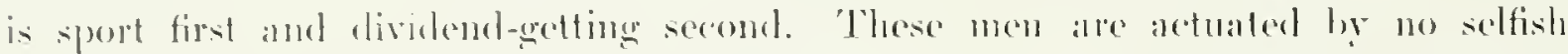
object. Hut with the desire to promote the sport of the people and to sive the comntry better horses.

All aivilized comntries in the world recognize the value of the "Thoroughbred. It

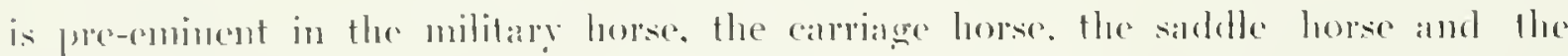

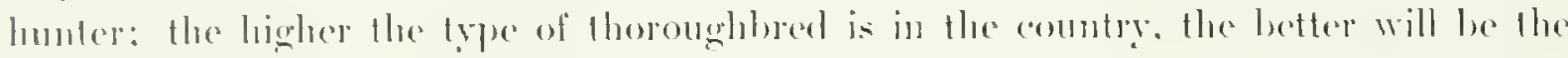
enencral quality ol the horse. Ile is not exactly ail the foumblation of the entire horse kingelom. lut he is a very larege portion of it. Ile is the root of the standarel-hred. of the trolter and paceer. and has not a little to do with the development of the hackney.

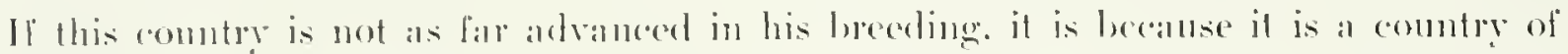
practically recent discovery. And yed when there were vallous British military sta-

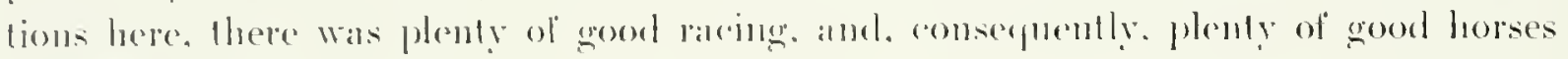
and handsome luorses.

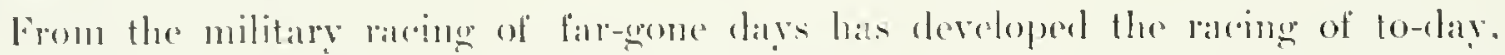

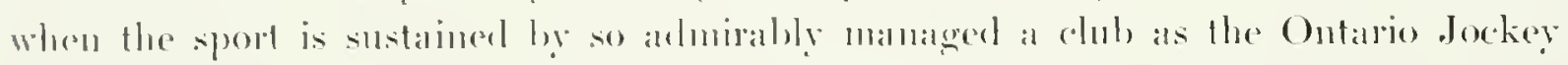

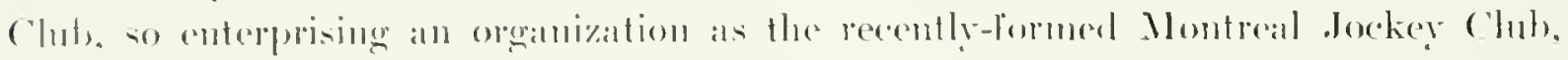

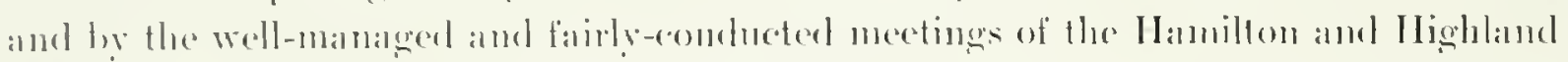

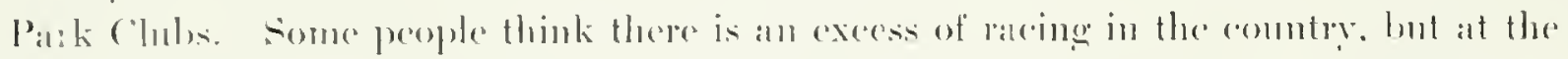
worst it labls to a latre expenditure of money and gives omployment to many men and

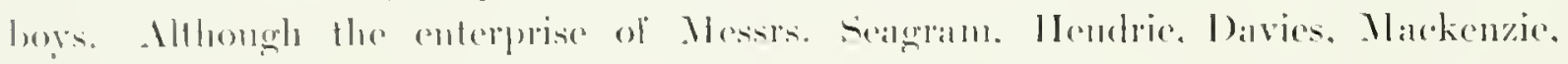

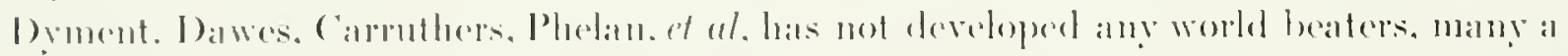

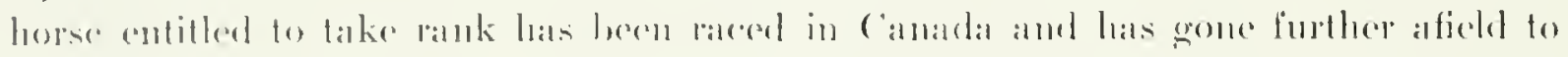

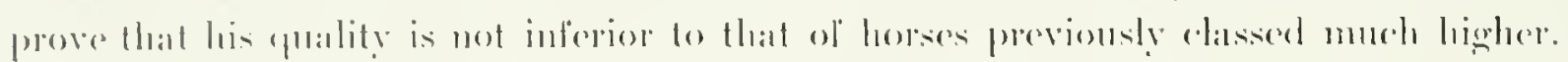

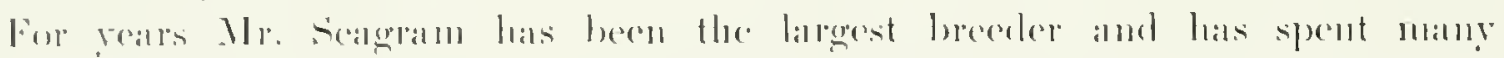

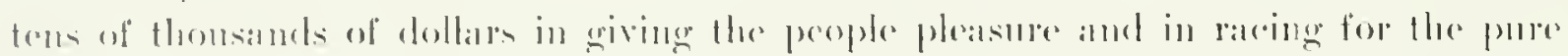
sport and love of the thinge. The late Wur. Ilendre did the same. and so are his soms

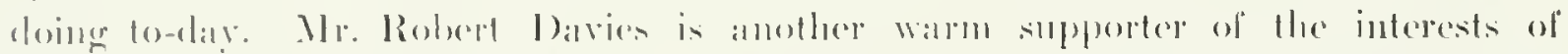

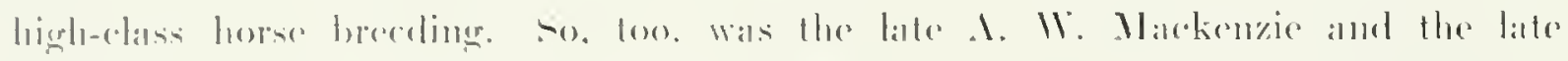

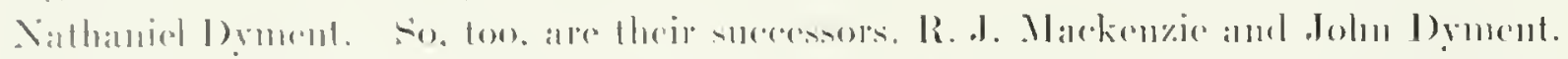

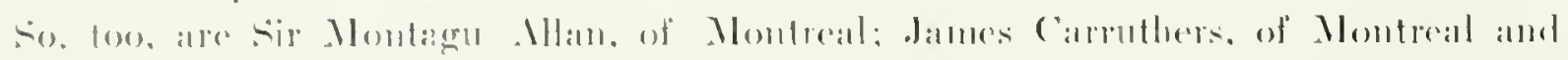

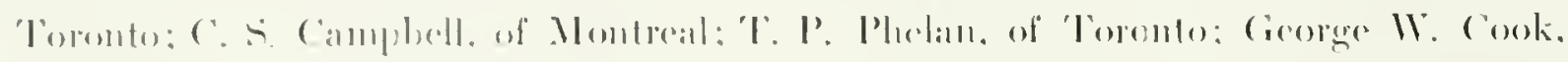

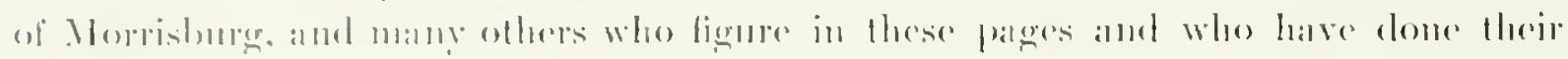

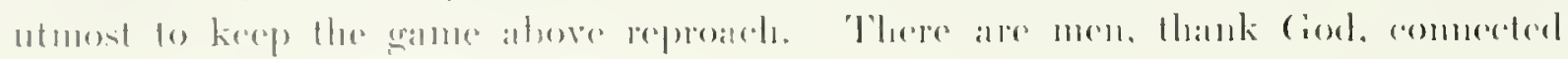


with the sport whom the most strict camot arecuse of taking any dishomorable advantage or of heing unwortly in thomght. Year ly yeall their efforts are bearing fruit and the gane is becoming reamer and more worthy of patronage.

Finamedally the sport was never stronger than at the present time. A few yearsang a thousand dollar purse or stake was comsidered extraordinaly: now, if three thousand and five thousand dollar stakes a pe not numerous. there are at least sufficient of them to Warrant the keeping of a good horse esperially to strive for them. If the Kinges Plate, pou off ammonlly at the Woodhine. 'loronto, and of the estimated value of five thousand dollars. has not done all that might have been expected of it. it lats at least elevaterl the "halrater of the sport and henefited, in so doing. hoth horse and man. It may seem an extravagant statement. hut it is more than probable that nearly lalf a million of money was raced for over the running and trotting tracks of Canatal during the year 1907. And there is every prospect that, with the gerowth of the population and eonseguent increase of the sport-loving community, that this sum. in the compe of a few yours. will be dombled and even trebled. It is ille to say that the sport that repuires millions of aprital to be carried on is of no value to the comutry aren the fact that it keeps such a vast sum of money moving is of itself a recommendation that (amot be overlonked.

We. Herefore, in dedicating this work to the lovers of the horse in cimalad take prick in trusting that their shatow may never grow less and that the sport will go on and proserer for all time The names of the ladies and gentlemen who figure in this look are sufficient progit that horse racing has got far heyourl that period when its patronage was bencath the dignity of any one. 



\section{INDEX}

The Right Hon. Harl Grey

PAIE

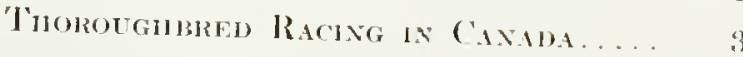

Wihliam IJendre...............

James Carrettifrs................ 11

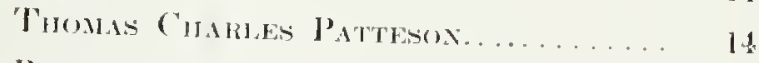

RoBert J. CHzisthe.

George Whilata Cook

Nathanife Druext

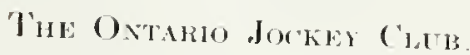

JoHn Macinoxals, J.1

Dr. Darul Kixg Surth

Mlsi Katheriag l. Whis

T. Mmbrose Woons................ 37

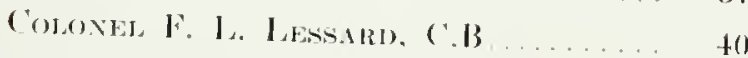

The Tonoxto HeNT ............ H

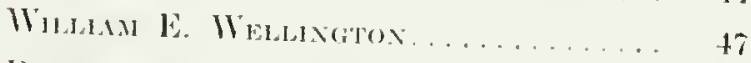

DR. AN1, Mks. S. H. MaCor ...... 48

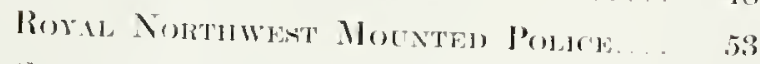

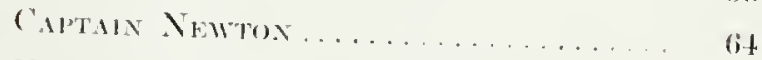

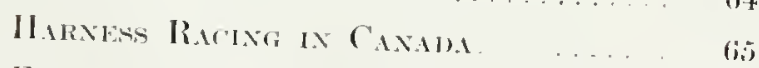

IOWWRD SELKMK SKEW

George W. Yhrral

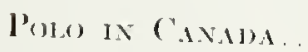

Sexator lobert Berth

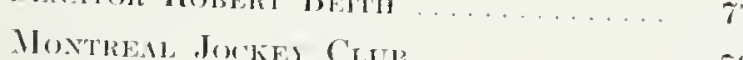

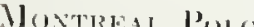

Jomx C. WATSON

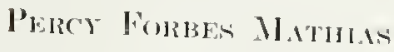

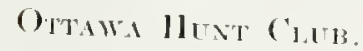

85

domx fie Rax

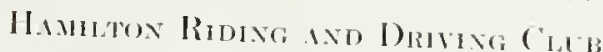

J. 11. MOORE

JoIN BoDas.

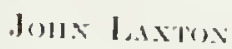

Kentue R. Marshille. 


\begin{tabular}{|c|c|c|c|}
\hline & PAGE: & & P.SEE \\
\hline T. I'. P'HELax... = . . & 163 & JOSEPH RLESELL. M.P. & 2119 \\
\hline 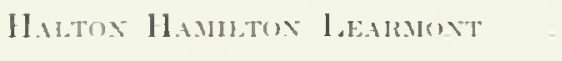 & 166 & The Qceiber ThliF Clatb... & 2013 \\
\hline Lothin RENHARDT & 168 & JohN Forster Smyth & $\because(16$ \\
\hline MYDREW SHEARER & 170 & P. II. FEeNEY . . . . . . & 907 \\
\hline 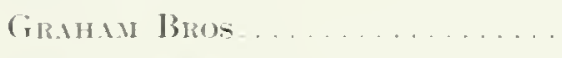 & 182 & II. G. Keflate $\ldots$ & $? 0 \mathrm{~s}$ \\
\hline 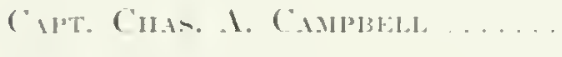 & 175 & 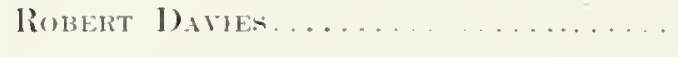 & $90 ! 1$ \\
\hline 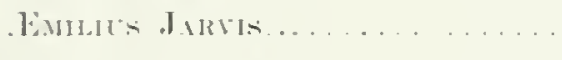 & 13 & Lateto-Colonel Doxila M. Rolsehtsox & 911 \\
\hline 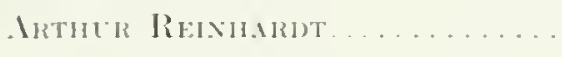 & 178 & Fraxcts Nelsow, M... . . . . . . . & 212 \\
\hline 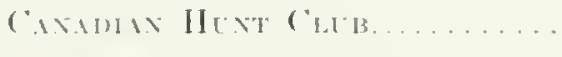 & $17 !$ & Hox. ID.M BECK $\ldots \ldots \ldots$. & $\because 1+$ \\
\hline 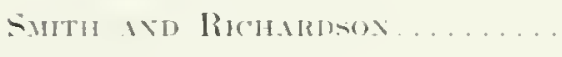 & $\operatorname{lsin}$ & 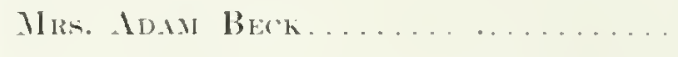 & 915 \\
\hline Nithasial D. Ra. & 181 & 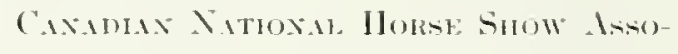 & \\
\hline 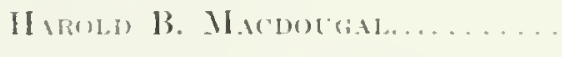 & 18.3 & ситы: ..... & 916 \\
\hline Rigit IIOX. EarL of Deximoxith. & 18.5 & Whllia d. StTaRk.... & 917 \\
\hline 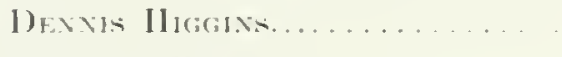 & $\ln 6$ & II. I'. Fraser . . . . . . . . . . . . . & 218 \\
\hline Frixk J. Merisit & 188 & 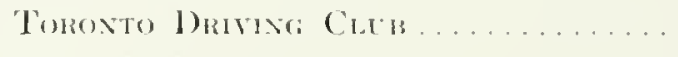 & 919 \\
\hline IEARY T' STOAE. & 189 & H. I. P. (inol) ..... & Q⿻日木 \\
\hline WhLLIM G. Whisol & 190 & MLFRED RoGERA . . . . . . . & 992 \\
\hline 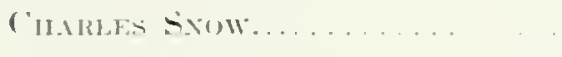 & 199 & Mlaster Alarein W. Rogems... & $9: 3$ \\
\hline E. II. $\operatorname{cox} \ldots \ldots$ & 193 & J. W. Rrax . . . & 294 \\
\hline ALERED RGMitra.... & [19.) & 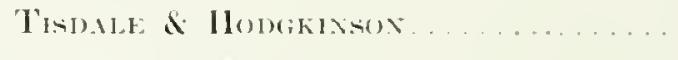 & 9.5 \\
\hline 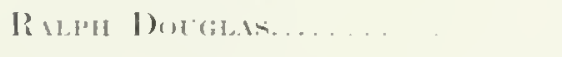 & 196 & 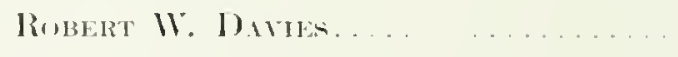 & 939 \\
\hline ('LOWE AND) MLRR & 198 & CHARLE I. MIRIRI. & 988 \\
\hline WR. R. Ю. WE WSTLAR & 199 & 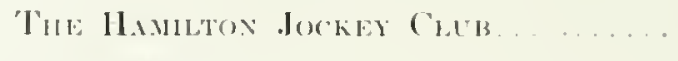 & s.9日9) \\
\hline 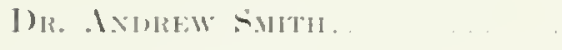 & 300 & 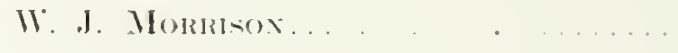 & 9301 \\
\hline
\end{tabular}




\section{Lovers of the Horse}

\section{THE RIGHT HONORABLE EARL GREY, G.C.M.G.}

$\mathrm{H}^{\prime}$

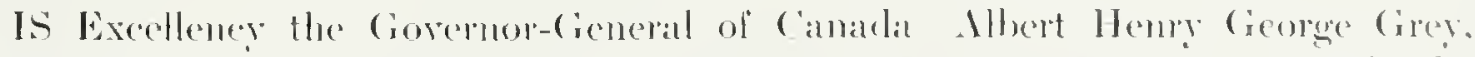
lourth Eand of his line, is well-known als al devotee and patron of sport in the highest sense of He worl. Ile comes of a distimguisherl family. Ilis ancestors remelered good servioe to the state. sometimas on the field of battle. some-

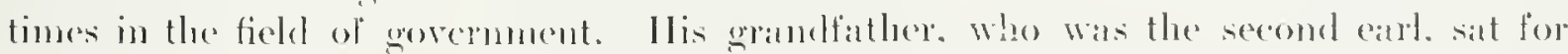

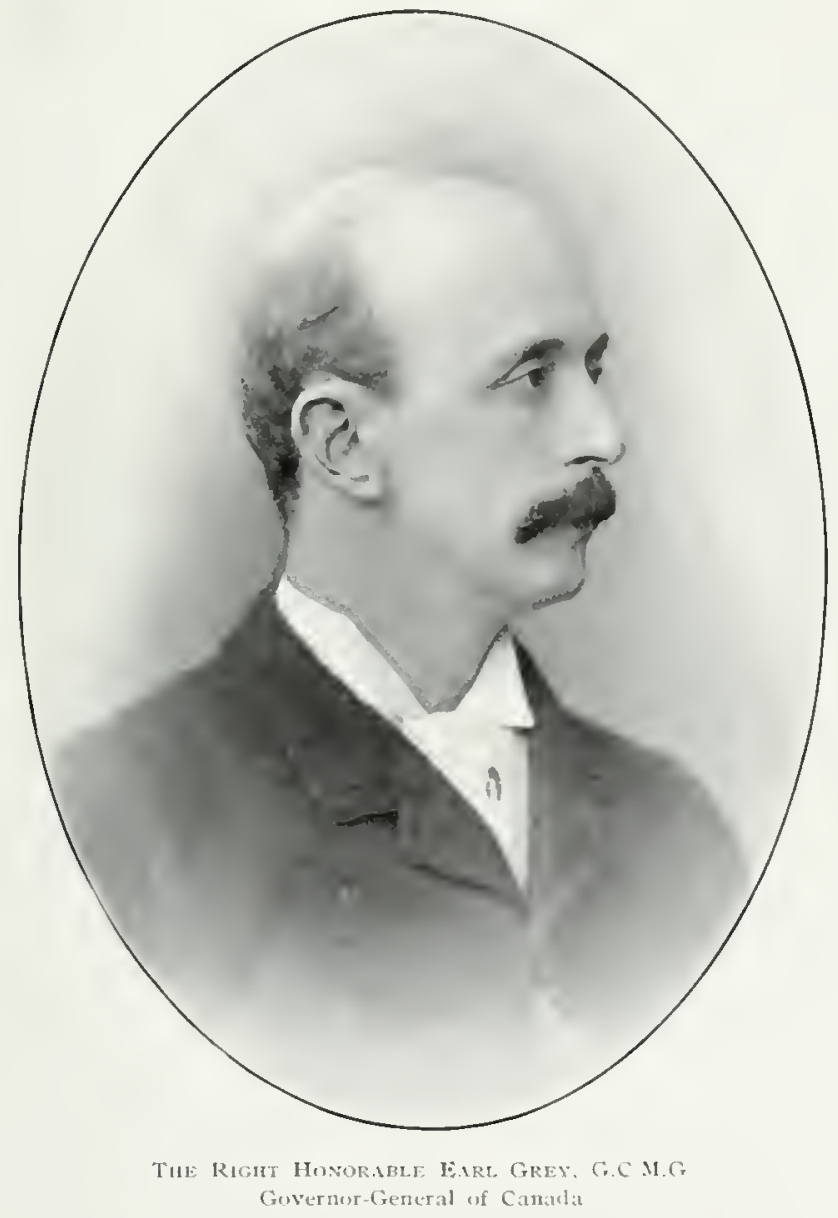
orer twenty years in the British Ilonse of commons. IIe was a laorel of the Armiralty in the Pitt administration. secoretary of Foreign Affairs, and afterMatrds Prime Minister. His uncle, the thimel Earl. Wast for six realrs 1846 to $18.52-$ Seceretary of State log the Colonies, and doring that perion his name ras a houschold word in C'anada.

On the death ol the third Eall without a direet suceessor, the title descomeled to the present bial Gres. Whose bather Was J Jon. Clantes Girey, al gencral in the alruy, and seeond son of the second Eatrl.

'The present Farl Grey was hom an Novemiler 28, 1851, andel educated at Harrow Sidool amd at 'Prinity Col-

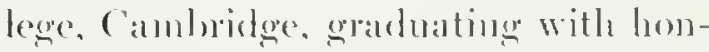
ors in 1873. In 1858 he becalle a anutialate in the south lovision of Northomberland in the liberal interest. and secumed a majority of the votes, but wats unseated on a technire ality. In 1880 he rall slleeresfully. and sat in Parliament from 1880 to 1 SS.jas a supporter of Mr. Cilardstone

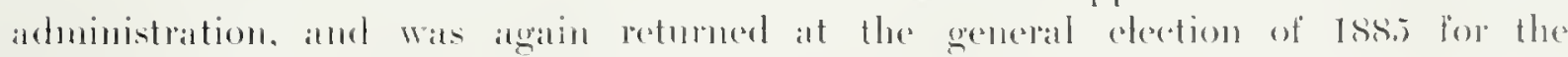

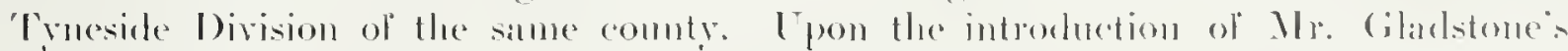
home pule bill he joined the ranks of the liberat-l nionists, and in ofl'ering himself for

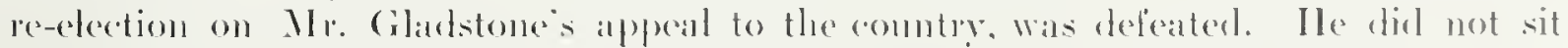

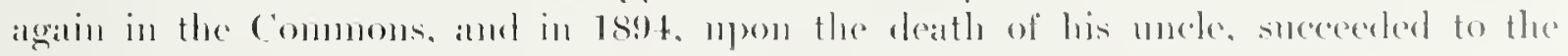
pecrigere.

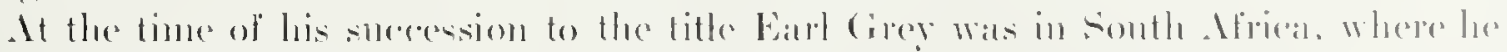

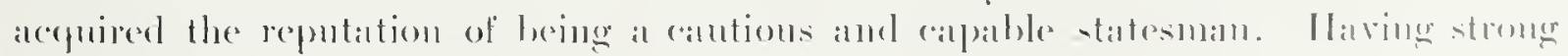




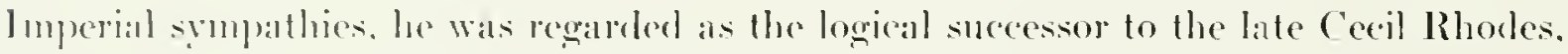
as administrator of Rhodesia, and in fadet during 1896-97 he acted in that capacity. It wats moler his regime that the Matabele rising ocemored. and was finally quelled,

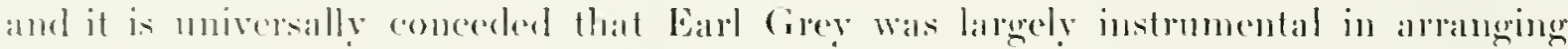
the hasis of settlement. Which hats resulted so satisfactorily to that important district

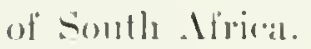

In 1904. Wpon the retirement of Earl Minto whose wife is Earl Grey's sisterEart Cirey was appointed Governor-Cieneral of Canada. It is acknowledged by all that he has diselatreged the duties of his high office to the entire satistaction of the Canadiall people. Ile has studied the comblitions of the comntry at first hand; he lass manifested a deep persomal interest in the concems of all its diverse sections: he has used las influence to promote geod feeling between the races and he has so aramered puhlie affairs that grovermment has proceeded along the lines of the wetlmolerstom wishes of the people: while his influenee has always been in favor of

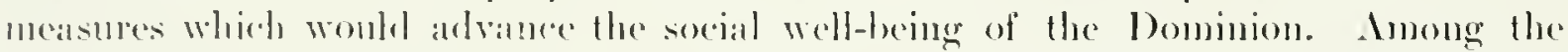
subjects altrateling his special altention are forestry. education. prison reform, the stampring ont of tuberenlosis. the beantifying of homes, and the preservation of ancient landurarks of historical interest.

llis bxaellency is not only a great lover of horseflesh. hut is a capplble jurlge of

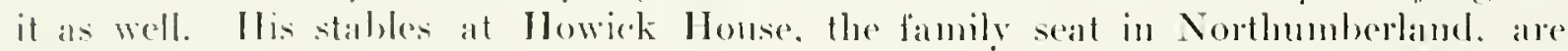
wirlely known. and the loxal hunt reeceses a generous measure of his patronatge. "The Earl first rode to the houmds will the ('ambridgeshire parck. and haviug a geosel seat. and beinge at all times well monnted, he was usually in at the death, althometh the aomutry is one ol the most diflicoult in Englanel.

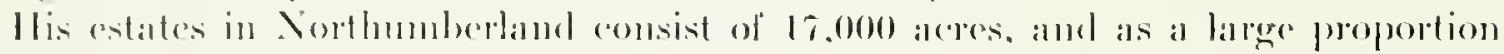

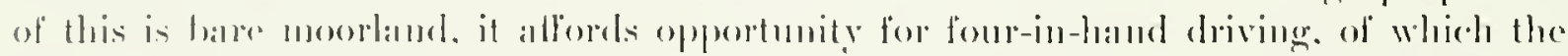

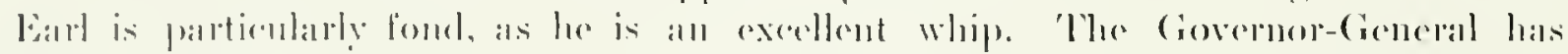

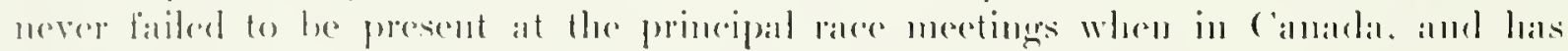

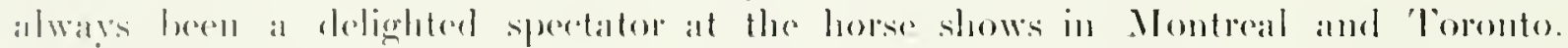
Ilis elese attention to the horse is often the sulpjert of eommente and he is always

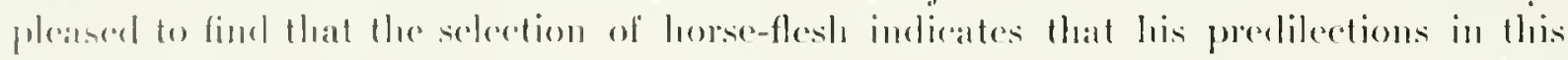

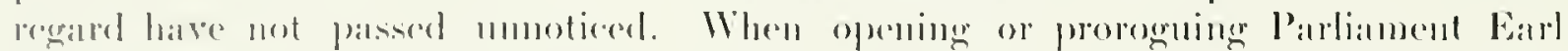

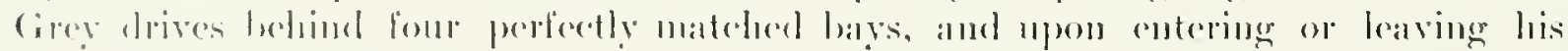

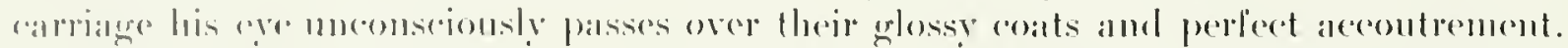

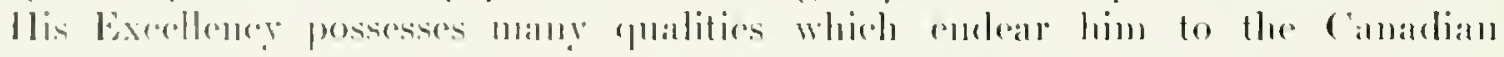

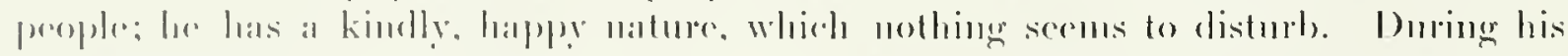

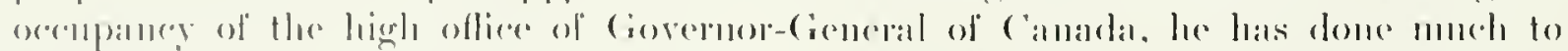

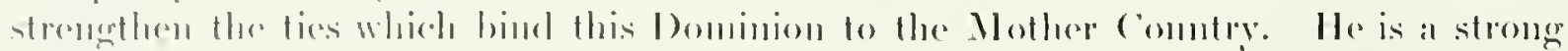

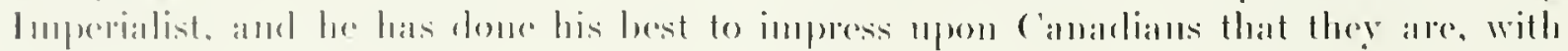

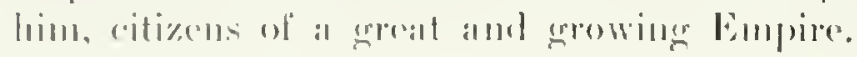




\section{THOROUGHBRED RACING IN CANADA}

$\mathrm{W}^{\prime}$

IIEREVER English-speaking people come together there will be sport, and in nine cases out of ten it will be racing. for there is no albolntely new combly opened mp without the man on horseback, and there is something invigorating in racing that does not pertain to any other form of sport. Baseball, lacrosse, ericket, in fact every other outcloor game, takes more than two to make an interesting contest, but put a comple of men on horseback, and there atre bound to eome moments when ther will try the merits of their steeds. In this way doubtless racing eommenced, mntil fually it became a matter of wagering. Anrl, speaking of wagering, history does not tell us of a single type of aborigine that has not some form of gambling. Even religionists, and the straightest-laced of them, have no doubt put their hand into the pristine grah-bag, or played the apparently ham less Lotto, the forermmes of the insidions game of Keno, that vagabondizing methoul with which nearly every man who has travelled the sonth is to a greater or lesser extent accuininted. Probably the promoters of church hazaars when they establish the lucky bag, or grabbag, or the fish pond, do not reeognize that they are sowing the seeds of a pernicioms form of gambling, which, in later life, they will expect the very children that they are enconraging to denomuce.

Is a distinguished dergyman has said, it is very difficult to discorer, either in musiness or in sport. where gambling eommences and legitimate speenlation leaves off. Inywar, it is eertain wherever there has been horse racing. there has been speculation as to the result. Wagering is inherent in the human system, and none of the laws, divine or human, that can be made, will ever antirely praticate the tententey.

Racing in Camada, it is tolerably safe to say, eame with the pioneers, althomgh probably as a recognized sport, it was the military who first set the game afoot on these broal acres. Whatever the beginning, it is certain that, as a sport, meing hat progressed and thriven. It may be that there has been at disposition to overto the thing, and that some individuals have manifested a keener inelination for the dollars, come whence they may, than they have for the interest of the sport or the welfare of the people. "That, perhaps, to a certain extent is mavoidable, for just as gambling. Wagreming, or speeulating is inevitable, so there will always be lower hmman stratil composed of peopte that will take alvantage of the weakness of their fellow-beings. In the ollen times in Canada, the officers attacherl to the garrisons, which were then stationed at different places in the comntry, got itp races for small wagers. or gifts given by the regimental mess, ol possibly the Colonel in command. This, of comsere was pure, madnlterated, legitimate sport, arising out of a desire for ammsement. As the geals went by a new orter of things sprang up, and people organized to carry on race meetings. Still, if reports are true. Alue methods pursued at the heginning to win were not always as gentle as they might have been, and bumping, thmmping and crossing were not inkmown to the offieers who, in many eass, contl traec their pedigrees back a great deal further than could the thoromghbreds they bestrode. 


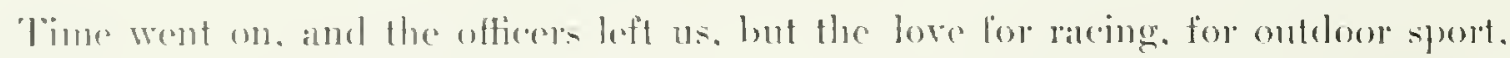
for the competition between living things. continued. and little by bittle racing pro-

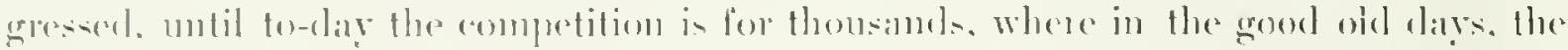

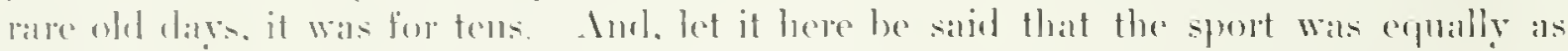

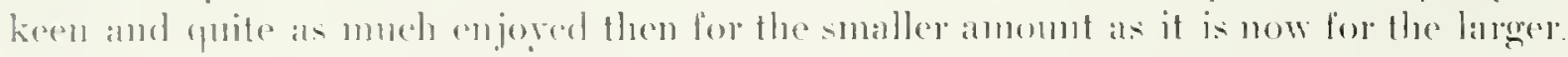
'The writer is oid enomgly to remember when he consilesed that these was no finer surt fortheoming than that given by the Hunt chul, of the elay, at which there wats no

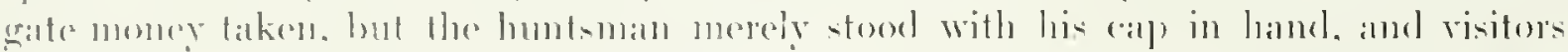
dropperd in whaterer they felt dispo-ed to give. The prizes to be won were com-

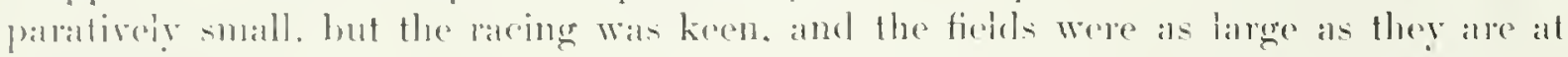

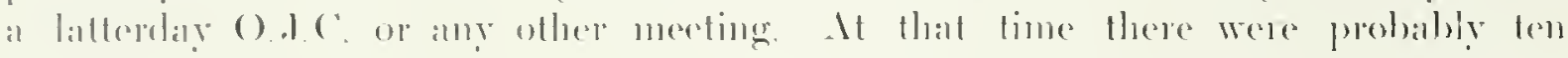

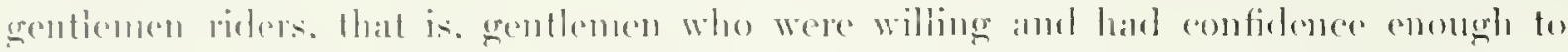

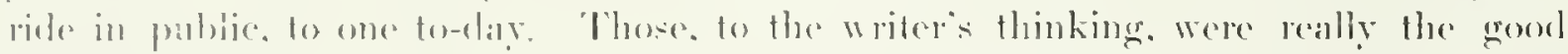
fimes of sout the limes when men rated just for the love of the thing. amel for the celibaration of flying throngh the air with a good substantial back beneath them.

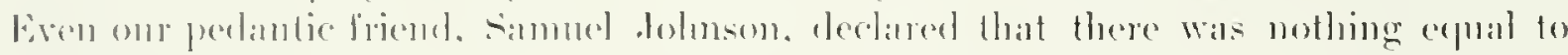

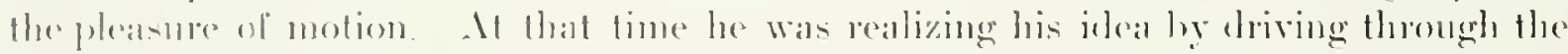
wilds of sootland. and. What the gereatest lexicographer of his own. or probably any

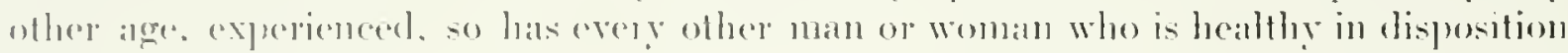
and broad in mind

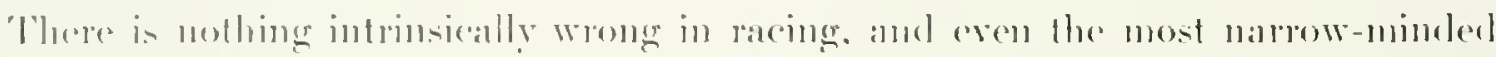

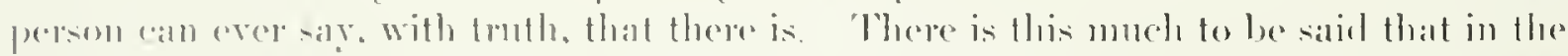

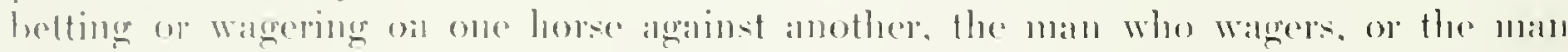

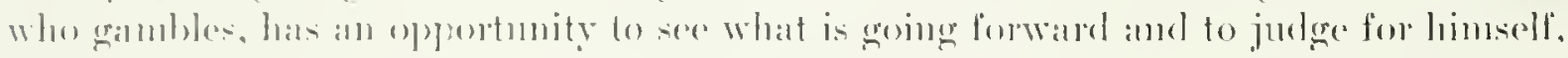

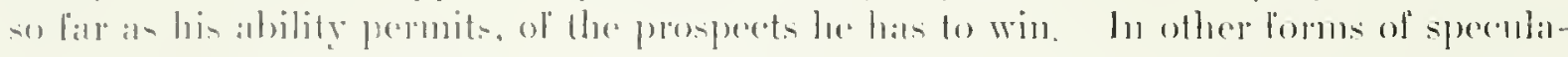

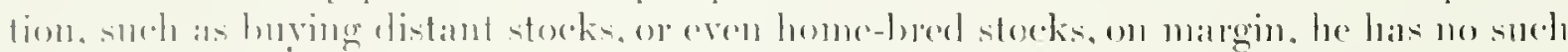

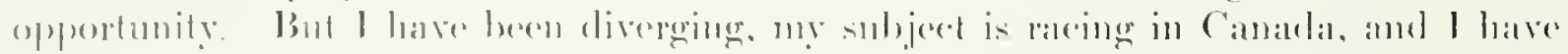

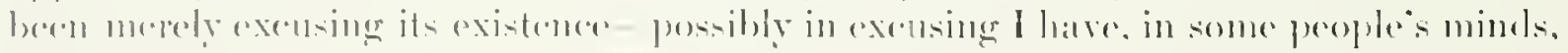

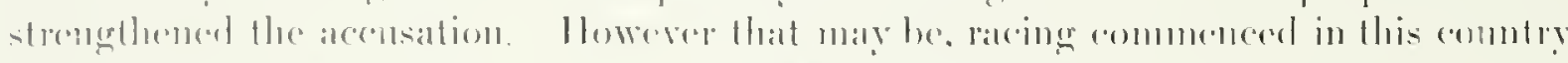

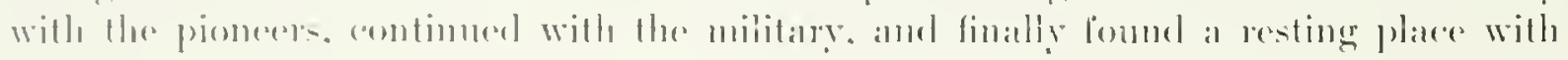

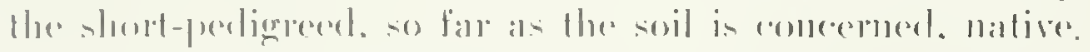

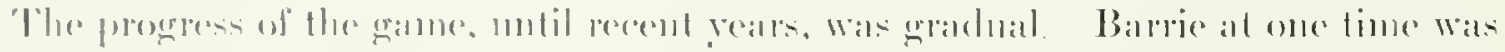

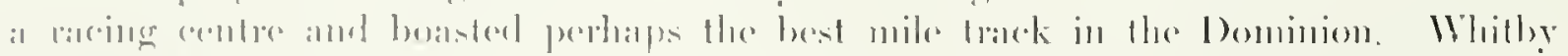

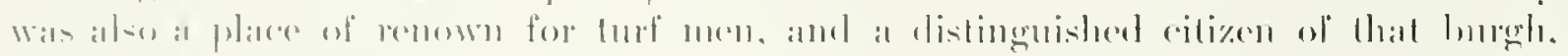

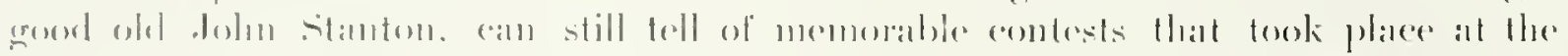

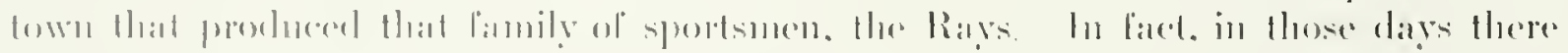

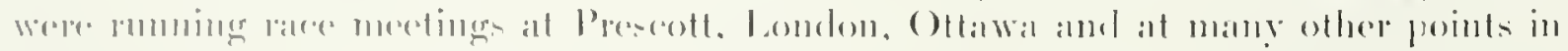

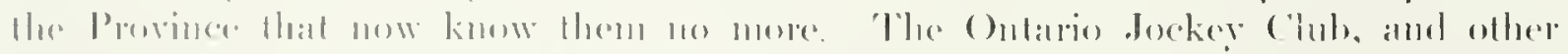

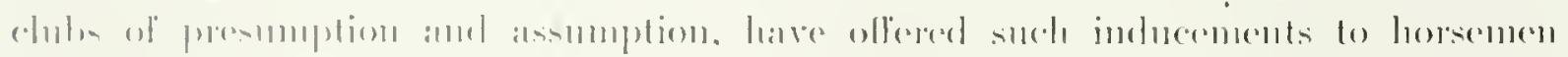

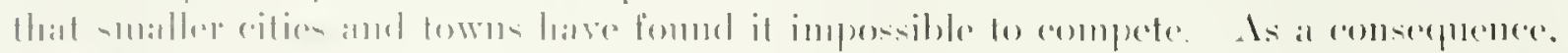

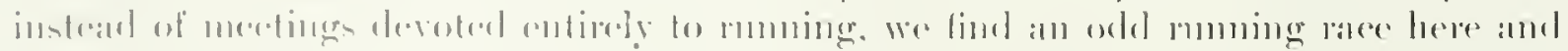

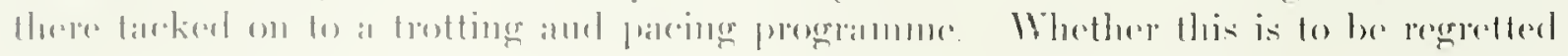


or not, it is not the province of this article to suggest. suffice it to say that racing has gone ont at many towns where it formerly flourished and has centred itself, so far as muning is conecrned, in the hig eities like Nentreal, Toronto, and Itanilton. Protracted meetings are griven at Windsol and Fort Erie. hut their strength and theil custom are latrgely from the neighbouring cities of the Initerl states, and as a consecpuence they are latrdly antitled to extenderl notice in an article devoted to the progrress of racing in Cimada.

Prior to the eoming of the Ontario Jockey Club, there were a munber of rake tracks in 'Toronto, one of the most notable being where 'oronto . Tunetion now stands. known in those days as Carltom. Another important race track was known als Newmarket, which is still in existence, although ratrely used, a mile or two outside the city limits. (On both these tracks some very famous races were pun, and some very promincut people took part thereiu. But, racing in its modern aspeet can fairly be sidid to have commenced with the ineeption or organization of the Ontario Jocker (Bul, 'That elub had the usual suall begimnings, less money being given per meeting than is now oflered in a single day. Purses angregating $\$ 200$, and extended over ten lances, were considered liberality indeed. In these times, a single day that does not see four or five thomsand dollars hung up, is seatrecly considered worth mentioning or patoniz-

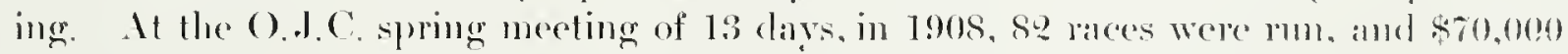
was given in added money. By added money, perhaps should be explaned, is meant the amomit of the purse adeled to the stake or entrance fee of the different horses en-

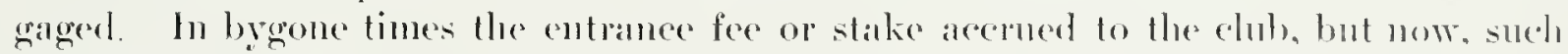
is the liberality of the mintagenent, it goes to the horse-owners. In fiet. the one effort of the O.J.C., next to the promotion of sport of the highest kind, has been to aid the horse-owner, to whom the public is really indebted for its pleasure. fn Encrand, lo this day, owners race practically for their own money. 'lake the eqreat Porloy, for instance, which is amomed as worth 6,500 sovereigns; of that probaldy six thoilsand poumds is derived from the fifty-pomed stake put up by the owners of starters, and from the forfeits of nominators who fail to allow their eolts or fillies to compete. In Canada, the (). J.C. las set the literal example of not only giving the stakes to the owners. but of also adding a generons smon. As a consequence, while the owner of the horse first past the post may not receive as much from the wiming of the Tomonto ("up as Chevalier Ginistrelli did for lamding the great Epsom event in $190 \mathrm{~s}$, the elul, it:elf is out quite as mueh as are the promoters of England's foremost classic. This marks the progress that the sport has made in Camada.

Following the Ontario Jockey Club, has come the IInnilton Jocker Chul, and

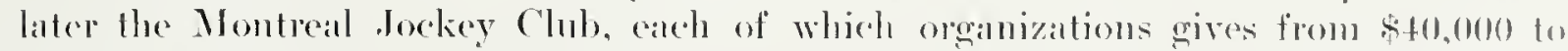
$\$ 50,000$ per annum to be raced for. These chubs have meetings extending ovor three or four weeks in the vear, hut Fort Evie and Windsor race longer, and undonbtediy

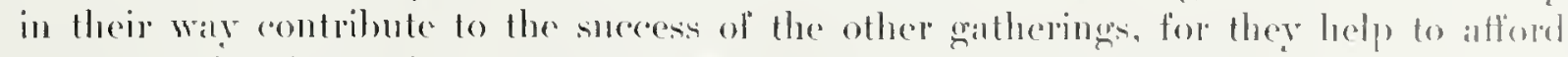
owners racing for an important part of the year, and thus emathe them to hring along larger stables and better horses. 
I contribulion such as this to so valuahle a work as " "The Lovers of the llorse " would be incomplete without some reference to the men who have fostered the sport of theroughtherl racing. The lowells, of Gatt: the Whites, of Halton. were mueh to the fore forty and fifty yars ago, and so, too, were the Hendries, who have lasted down to the present day. Then John and William Ilendrie the latter of whom was the first homorary member in Canada of the English Joekey (hub. only passed away in 1907 -rode their own lorses. So, also, did Dr. Indrew Sunth, the veteran ax-principal and foumder more than (io years ago of the (Mntario Veterinary College,

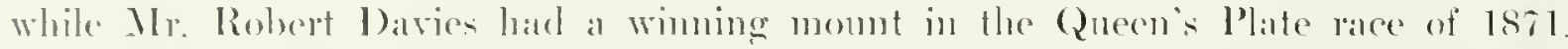
Thesc men have all contrituted hargely both to the mantenanee and progress of raeing

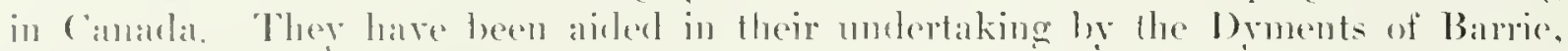

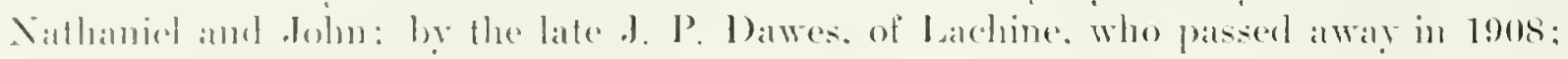

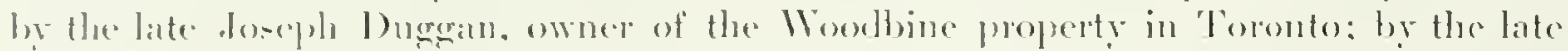

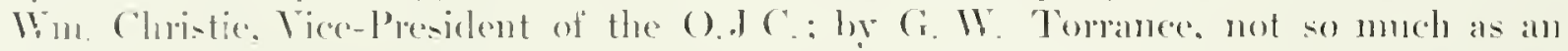

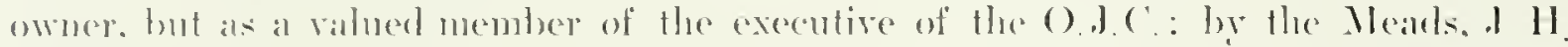

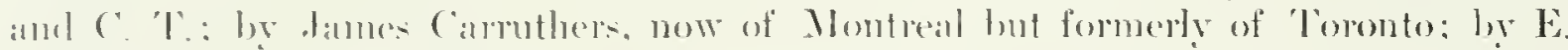

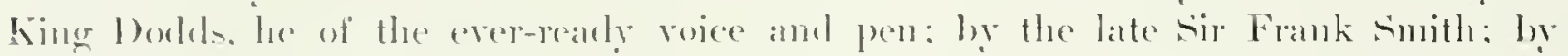
mally oflere men of rank and tahent. some of whom have fignred prominently and some of whom have uot, and more than all by the late Mr. 'l'. ('. Pattesom. al griant in sporting litelature, and a ome-time anner. with ambitions and aspirations: and Mr. Joseph

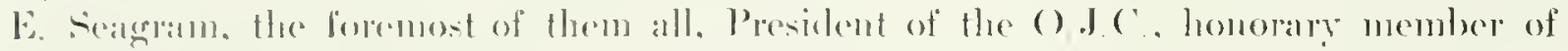
the English orekey ('luh, and a man entitled to ramk with the bignest-hearted, most

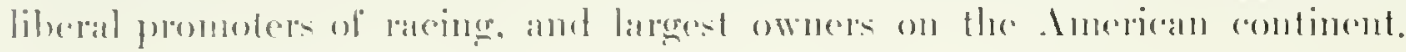

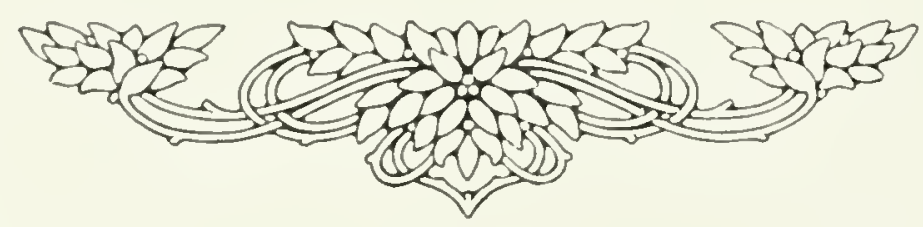




\section{Lovers of the Horse}

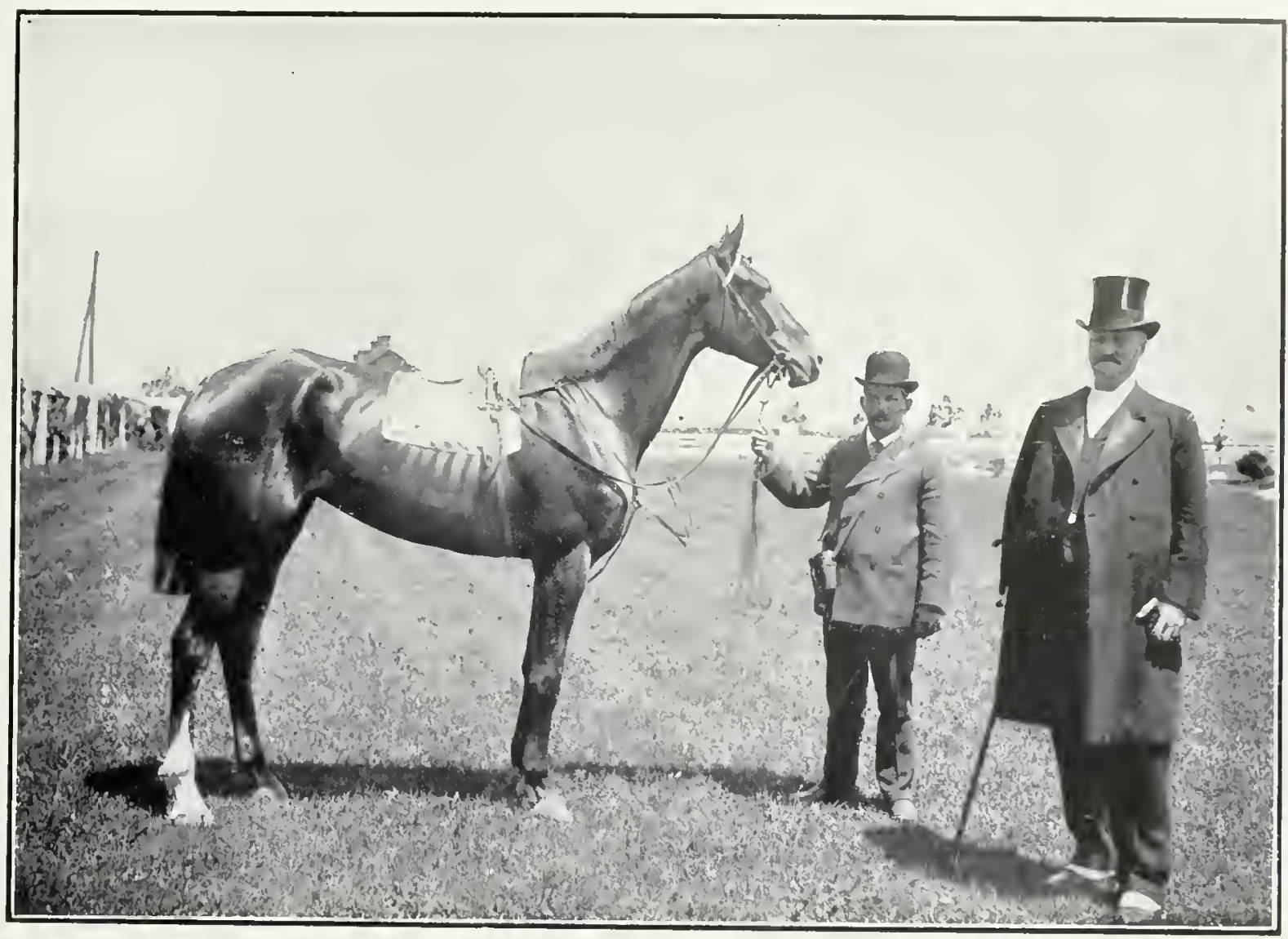

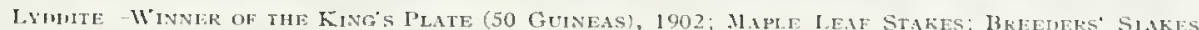

\section{WILLIAM HENDRIE}

Thas heen truy said that the late Willian Hendrie, of Ilamilton, ()nt., at the time of his death President of the (Ontario Jockey Club, was the deant of the Canadian turf. No man had done more to elevate what people are pleased to call the "Sport of Kings" than had the laimel of Villey farm. Ilis interest in the tull was solely beanse of his love for it, the financial returns not being commensulmate with the thomsands of clollars lee spent. He had all the equalities of at sportsman of the old school, the betting ring having no attrations for him in faret he never wagered money on a race, even when his own horses were rumbing.

Mr. Hendrie was the first Canadian to have the distinetion ande honor of be-

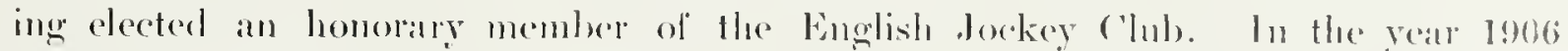

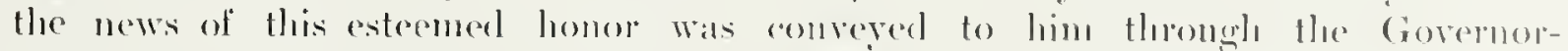
General, Earl Grey. Is a youmg man Mir. Hendrie lam the opprortumity of acequiring the love for riding which he retaned to the time of his death. His

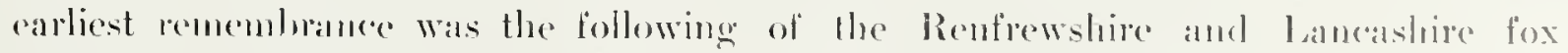
homeds and oecasionally Lord Eglington's pack in sicotland. 


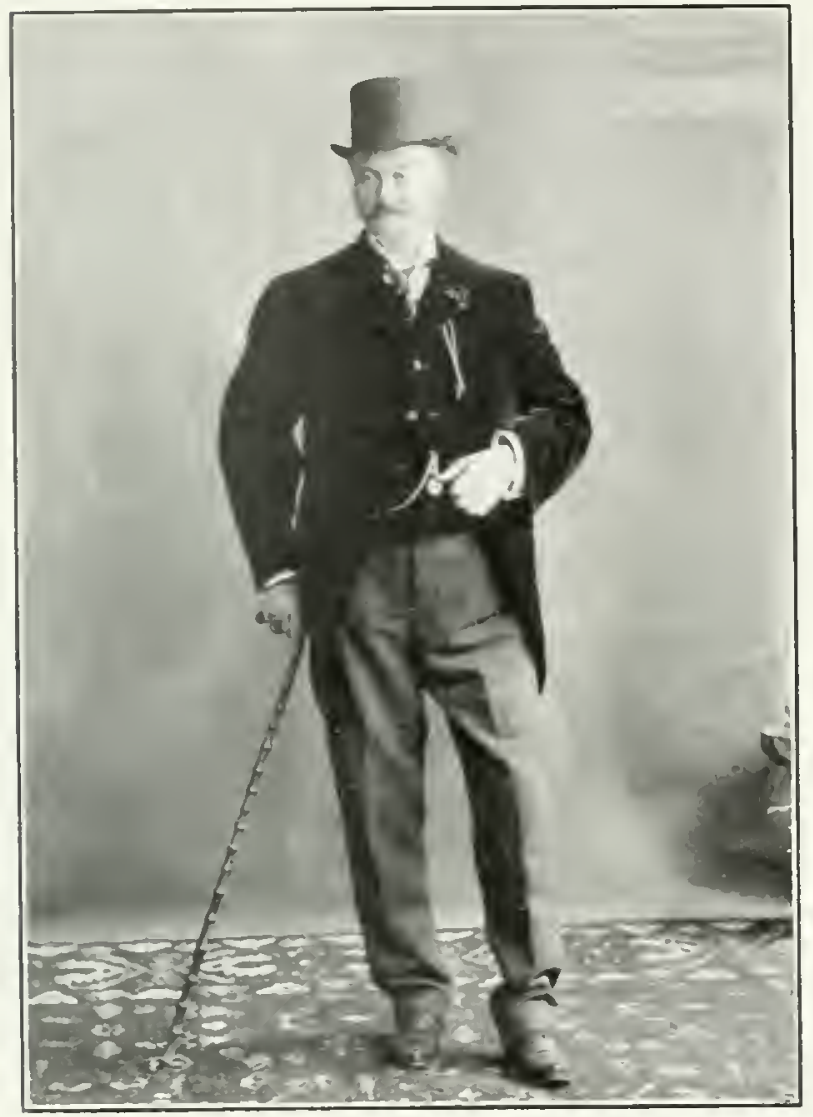

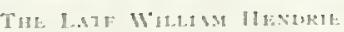

Mr. Hendrie's comection with the turf daterl barek many years. longe before the ()ntario bockey ('hll was organized: and the famoms colors, brown body yelbow steeres and calp. are well kmown. not only on the ('alladian tracks, but in the Inited states as well.

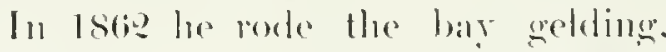
Mark "lapley. to victory over a stecple(hase course of twelve stifl jumps. () May ?1. 186it. great interest was taken in the mated race between Mr. Ilendries "Riffeman" and fames Whites " I bomal Maria." the former. who was ridders hy John Hendrice winning. Mr. Ilendrie was serectary-'Prasurer of the Hamiton Rarome Issocolation in 1867. Ile wals one of the litheres of the ()ntario Joekey ('lub, alme wats a jullege at its first meeting in 1ssi. Ile heosume President in $18 s !$ and laded the office for several rears. retiring in lavor of the late sir Jiank smitl. and surecerling again to the homole on the deatle of Sir Frank. Mr. Hendrie atso organized the eom-

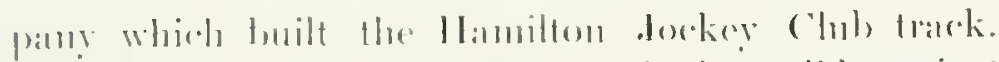

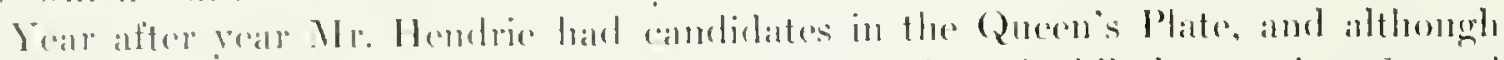

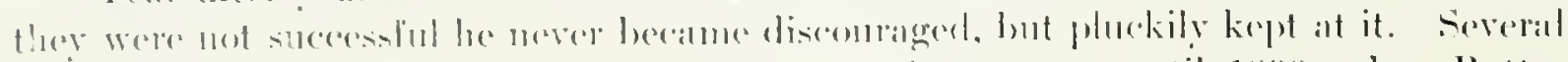

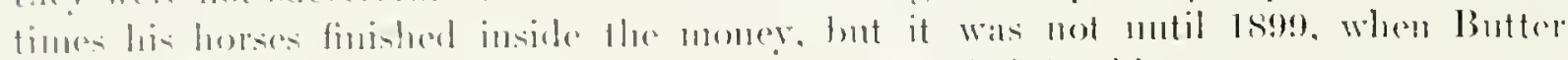

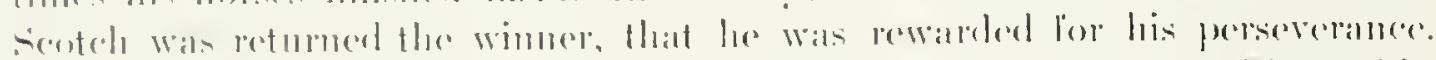

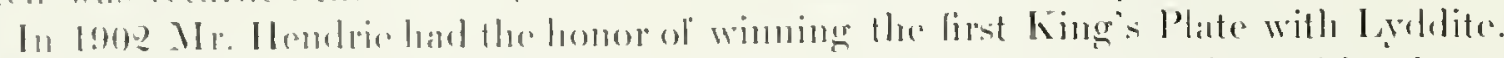

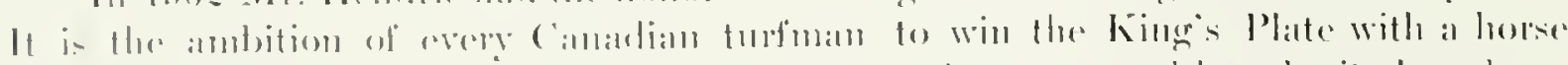

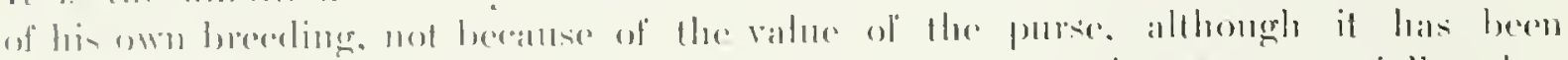

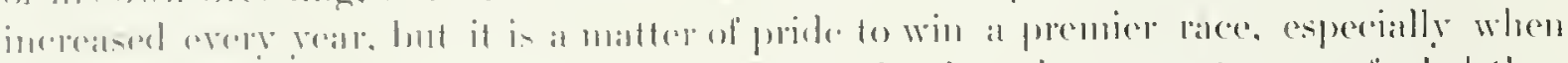

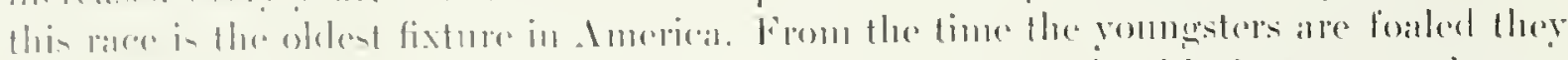

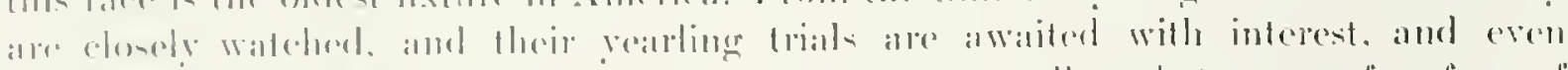

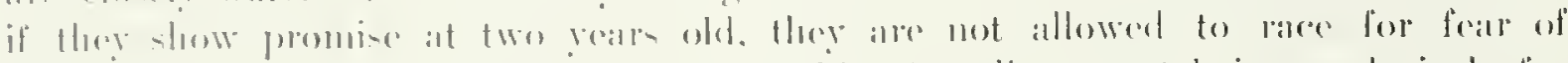

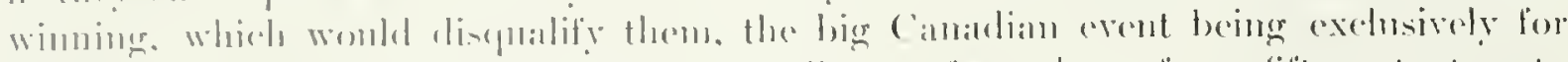

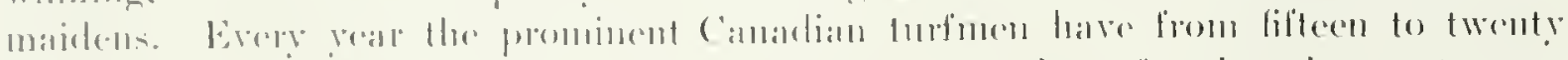

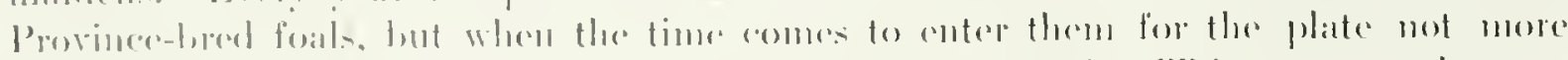

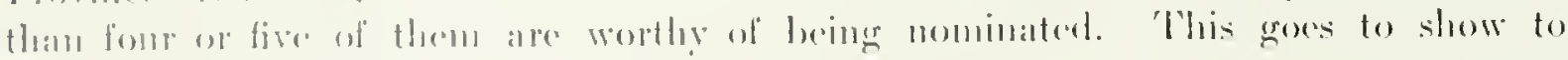

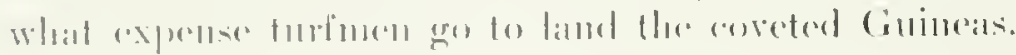




\section{Lovers of the Horse}

The Hendrie breeding establislment is Valley farm, abont five miles from Hamilton, on the Plans roal. It is a beantiful place, the lower pant of it orelooking Burlington Bay. There are lareand eommodious batrus for the brood mares, yearlings, weanlings, stallions and lorses in traning. Everything about the place is kept neat and in tirst-elass oreler. There is exeellent pasture for the horses, the farm-house is large and eomfortable, the walls of the rooms bejug adormed with pictures of famous laterhorses. There is also a training track of five furlonges on the farm. 'Mlac soil is dry and sandy, enabling the tramers to work the louses carly in the spromer.

Shortly after the deatly of Strathepey. Ml. Ilendrie bought the imported stallion Derwentwater, hy Doncaster-Thorwater, who was most successtul in the sturl, Butter Seoteh and Ixddite, the Plate wimers, both being sired by him. Jle was also the

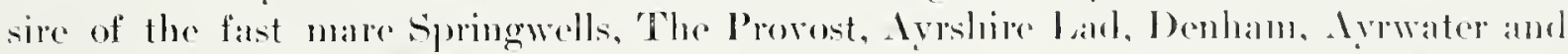
otler good horses. Siter being at the farm for a number of years, Derwentwater was shipped to Nashille, Tenn., where he died as the result of an alecident on the ears.

While the late Mr. Ilendric won many rales witle horses of his own breeding. his ereatest suceess was with American thoroughthreds. Pee Wrep won the Iropulois

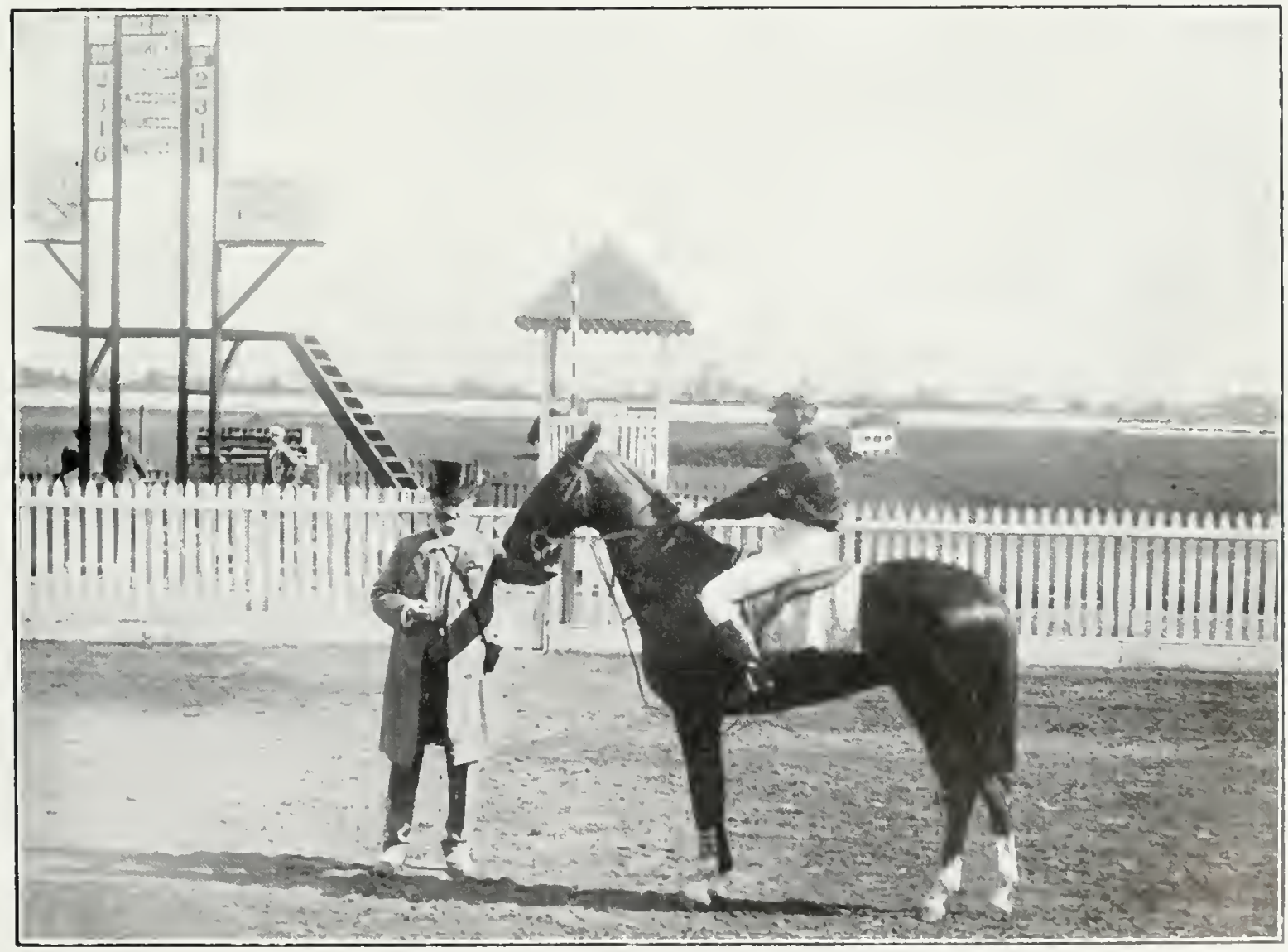

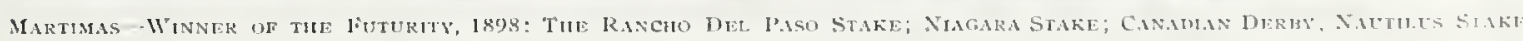

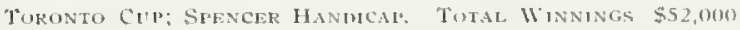




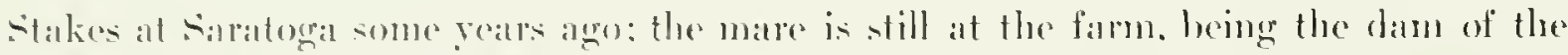

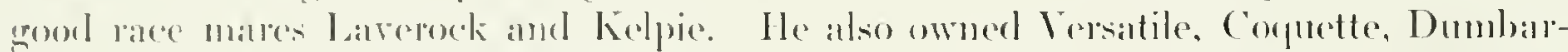

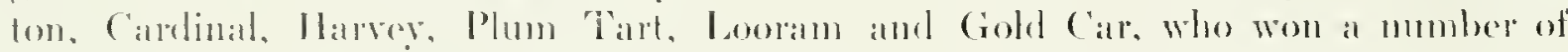

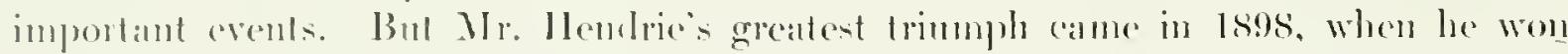

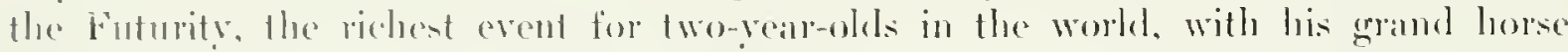

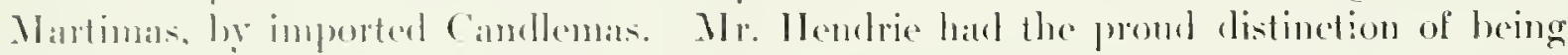
the first and only Canadian to wint this event. It was a matter of some prible to him. lhat he tought the colt himsolf at lle vearling sales in New York, paying $\$ 750$.00 for lim. Is a gealling Martimas showed lots of speed, and in thespring of 1898

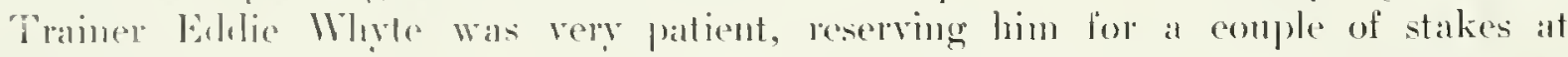

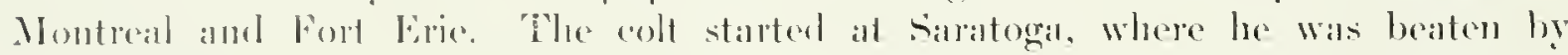
Sintucky colomel amol Kinley Mark. Then eame the Futurity day. There was a

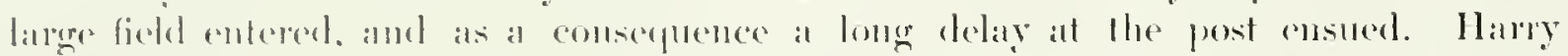
I.ewis harl the mome and, saving the colt ats much as possithe at the post, when

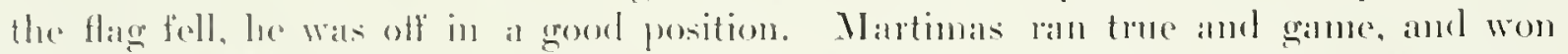

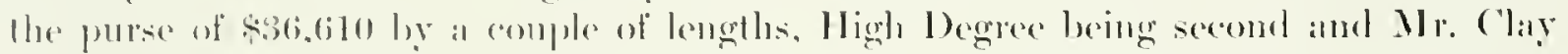

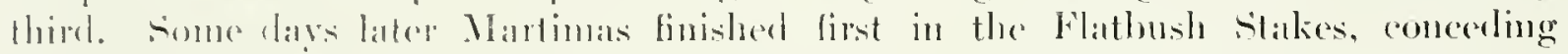

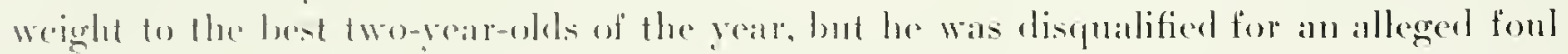

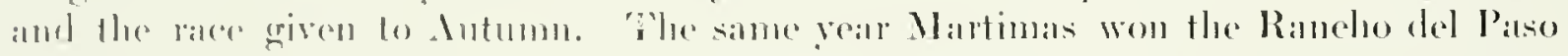

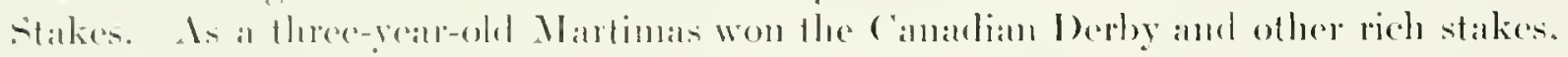

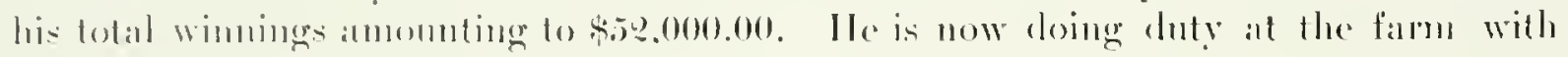

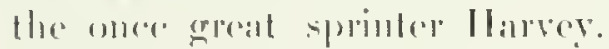

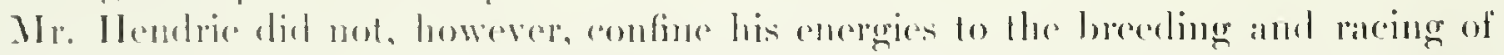

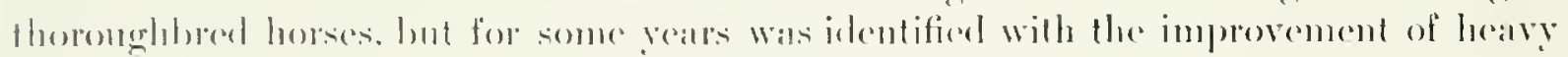

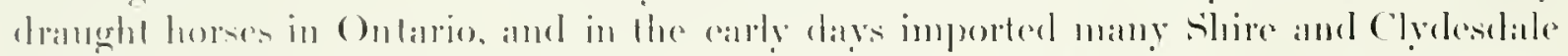

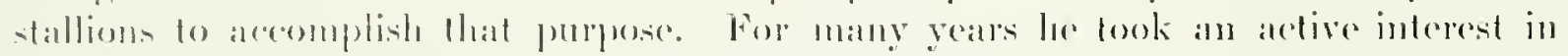

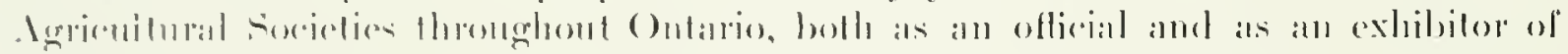

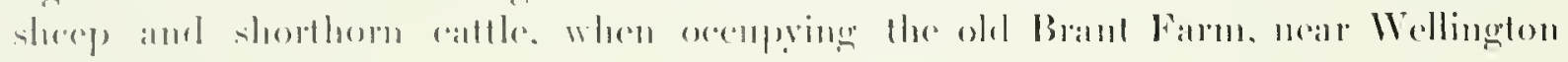
sipuare. Burlinglon.

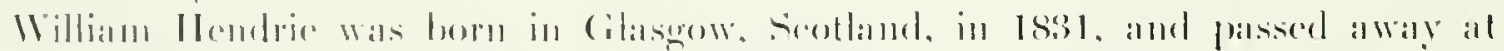

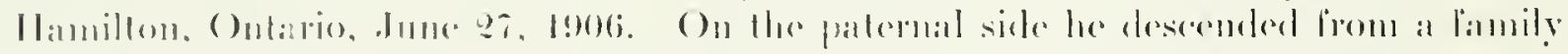

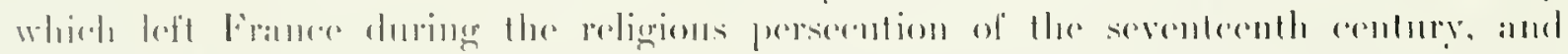

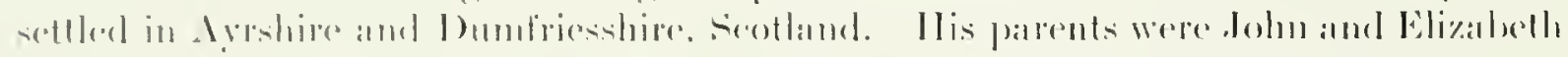

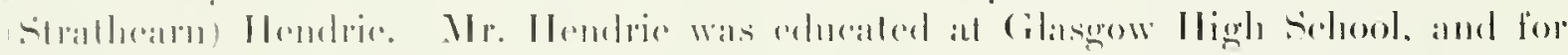

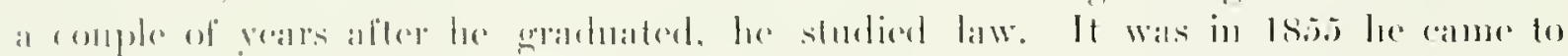

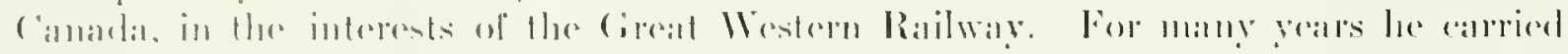

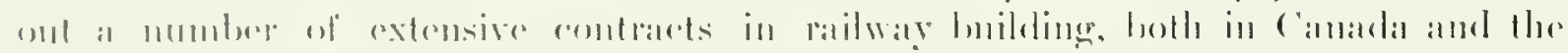

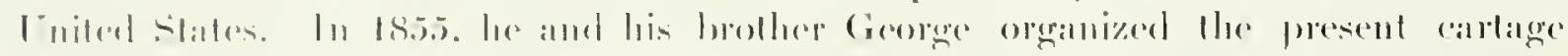

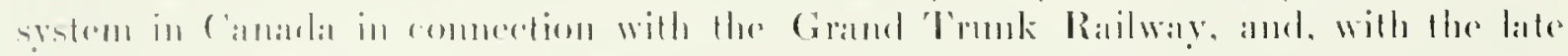

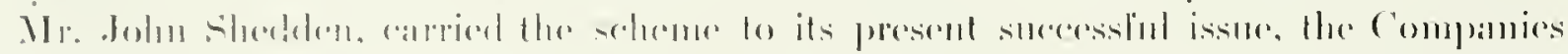

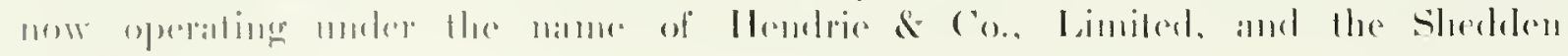
Forwitringer ( 0 . 


\section{JAMES CARRUTHERS}

V

ER I rare, indeed, is the man who can combine business with racing and make tootl pay. We have many examples in Cantala and the Inited states of ricll nen who, wishing for the relaxation which comes to the followers of the furf.

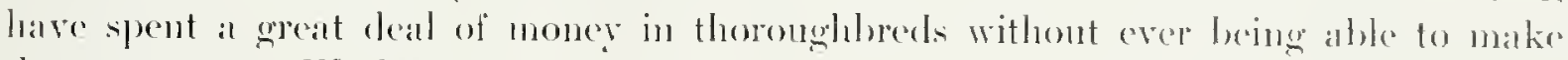
the sport pay. We have also natuy men who make a husiness of the turt, and who get al comfortalble revenue from the sport.

But the husiness man who gathers together a string of ralce-horses garts all the pleasure from racing them at convenient places, and still makes his pastime a financial sucecess, is not often foumd. Mr. ('arruthers, however, has been ralcing for a dozen yeats. and it is doubtful if he has erer hat a losing season.

fanes Camuthers was born in the City of 'Toronto in the rear 18.53. where he made his home for the andier part of his life, afterwards moving to Montreal, where he lass spent the last few years. He was educated at the Grammar School, Toronto, from there going into Insiness. His first renture was witl a grain exporting firm. ITe took advantage of (wery opportunity oflered to him. and sained a more practical knowledge of this partieulat line in the business world than the majority of nen. Ile started in business for himself early in life, and the firm grew so rapiclly that a company was formed, of Which Mr. Camuthers was male president, lookling this oflice at the time of writing. Being interested in the far west, a bramell office of the Iitumes

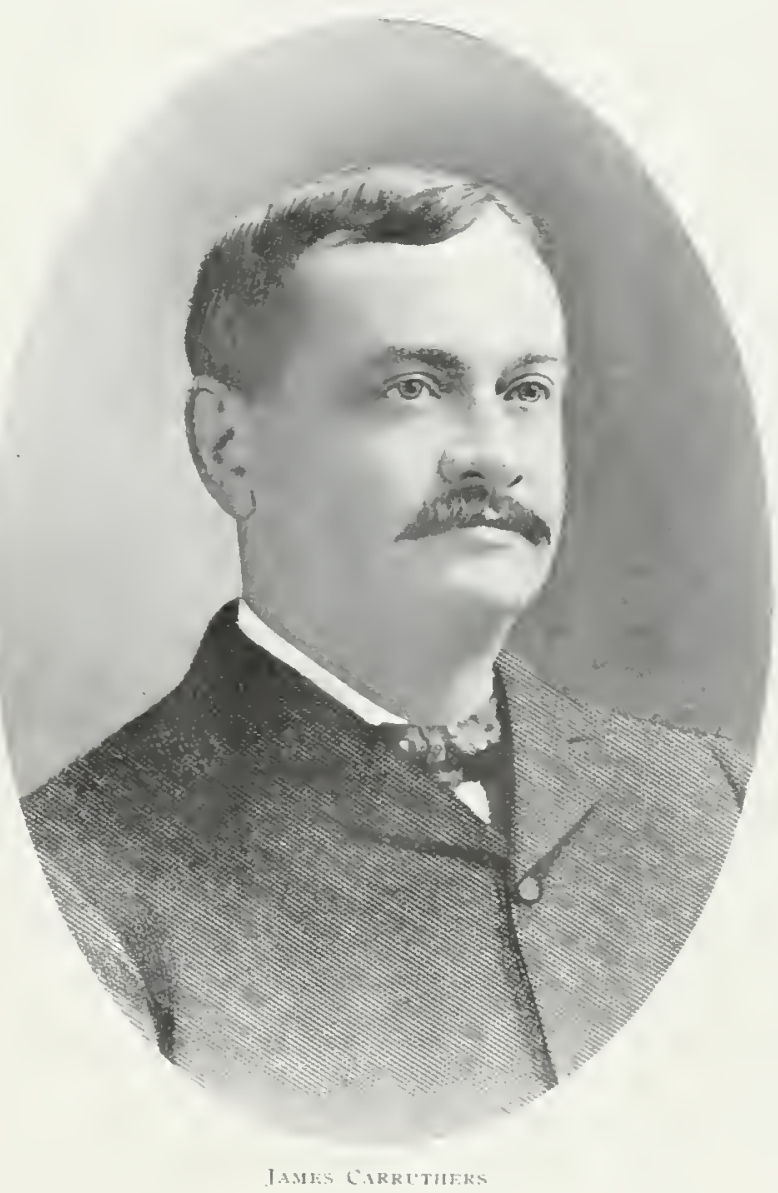
Carruthers (ompany was opened at Wimipes. and later at Montreal. 'There is probably no better known or thought of business man in the Dominion of (amala than the subjecet of this sketeh. who is interested in many latere concerns ontside of his own company. Mr. Carmtlers is President of the foronto and Montral stean-

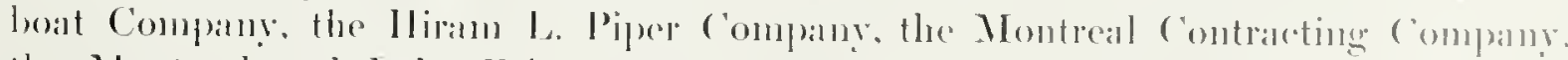
the Montreal and latke Erie Steamboit ('ompany a birector of the l)ominion

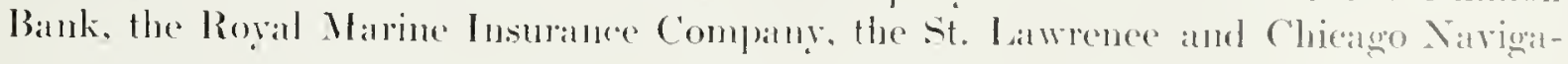




\section{2 \\ Lovers of the Horse}

tion Company, while he is a prominent member of the Montreal Board and 'Toronto board of 'Tratle. and an rex-President of the Montreal Corn Exehange.

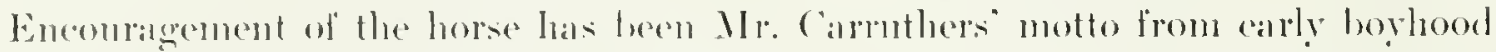
and he has always alpproved of his soms following his rample. Ile not only takes an interest in the thoronghtorerl. Lut in show horses as well, and has owned some good

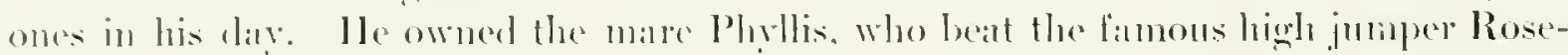

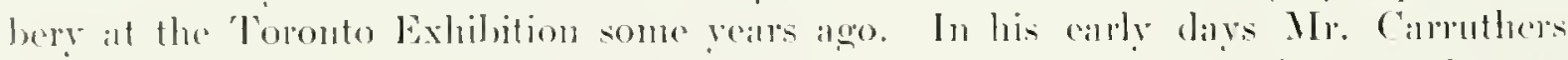
wais lookerl on as one of the lost gentleman riders. and was a regular attendant at

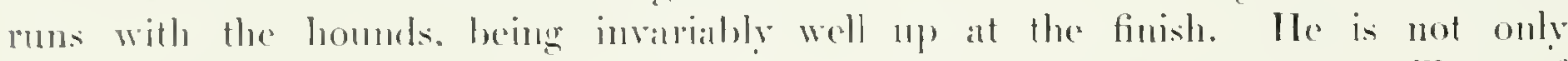

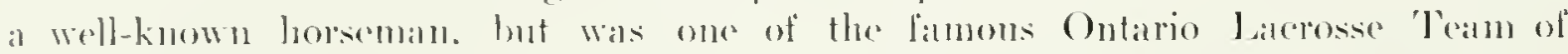
Foronto. He played witls the Ontarios for sereral seasons. and on retiring from active membership le hecame a referee of some standing. oflichisting al many noted games playerel in Montreal and Toronto, the two gereat laceresse centres.

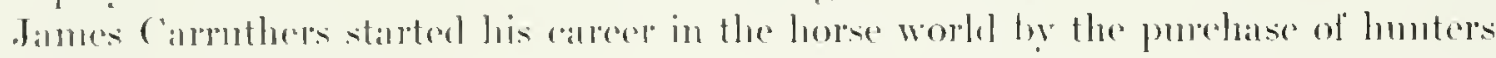
and saddle loorses for lis own nse. Ho was then persuaded to go in for radeing. his first start in this way being when he joined partnership with Mlex. Shields. the stable being registered as Carruthers and shields, its colors. red and black, being well kmown on the Ameriean torf for the many stakes won moler them. The first

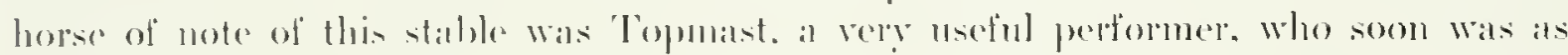

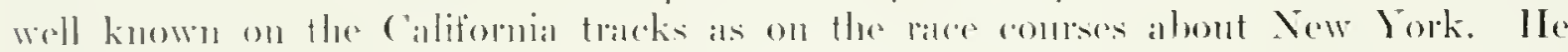
contld tratrel for a weres on a ralwilg train without losing his form, and was in many

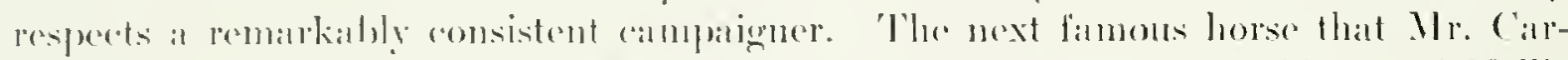

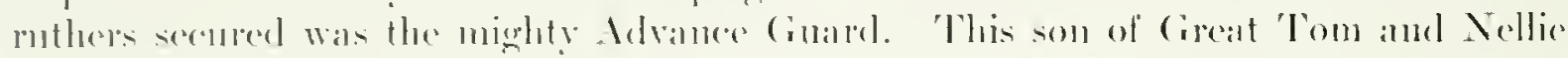

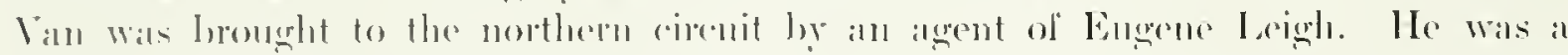

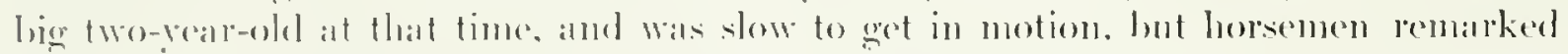

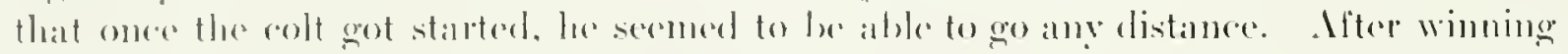

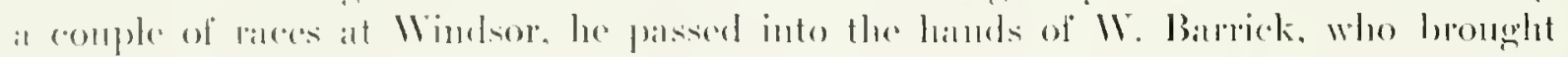

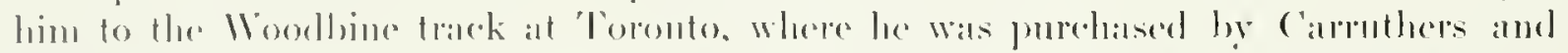

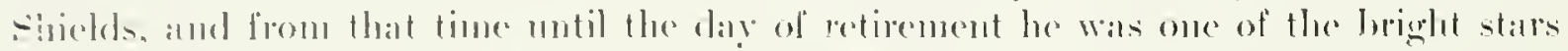

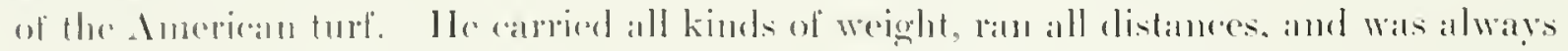
eithere in linout or lighting it out stromgly al the end. At one time or another he deferated neally all the horses of litis age in Ameriear.

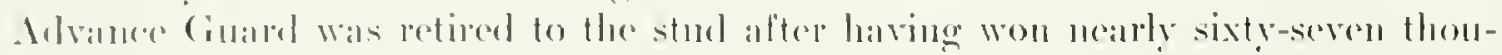

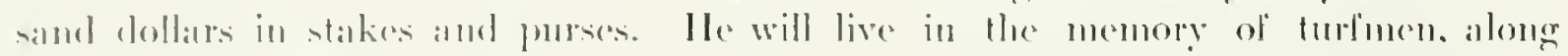

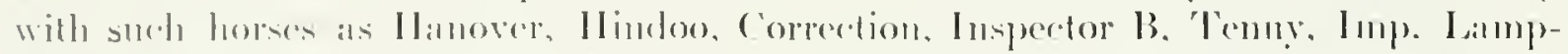

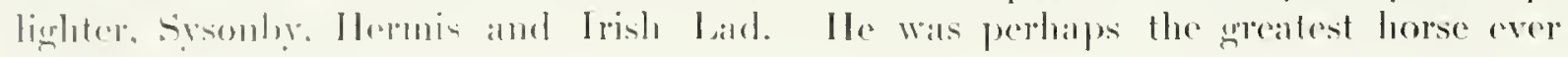
ownerl ly, a cimardian.

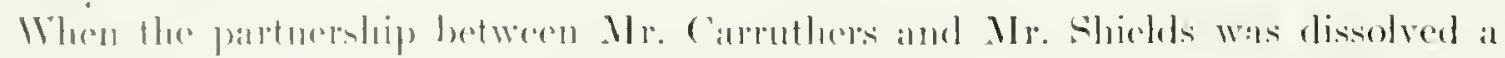

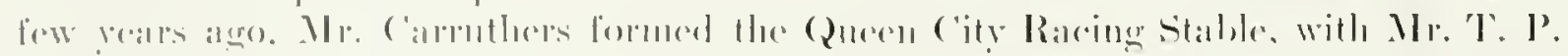

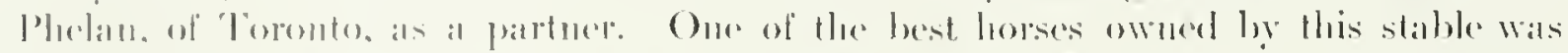

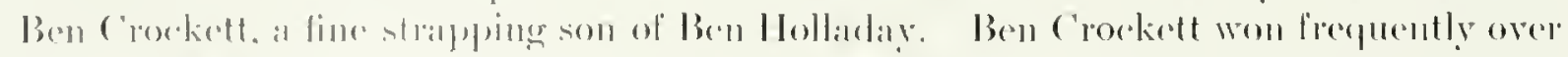

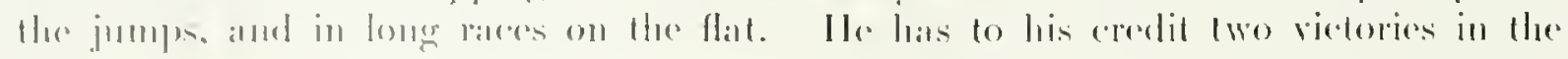


Maximum stakes at Washington, which, being at the trying distance of three miles. wals the longest rale of the veall on the castern turf, and one of the severest tests which could le given a rilce-horse.

Mr. Carruthers wals one of the first to realize the necessity of having a jockery chuh and an up-to-dlate racing plant in Montreal, and when the proposition was latil before him. he became a very wam supporter. On different oecasions when the new track was in its infancy and vastly different from the powerful oreanization conducting

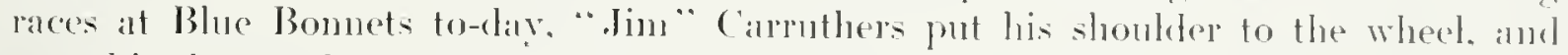
gave his time and money to finther the seheme.

He has heen a member of the executive of the Montreal Jockey cluts since its inception, and is one of the orignal seven charter members of the chub. Ilis pratctical knowledge of rancing and intense love of the sport. with his efforts to plaree the turt on the highest possible hasis. combline to make him a man of the greatest value to a jorkey chub. Mr. Carruthers is ako one of the ohlest members of the Ontario Jockes clut.

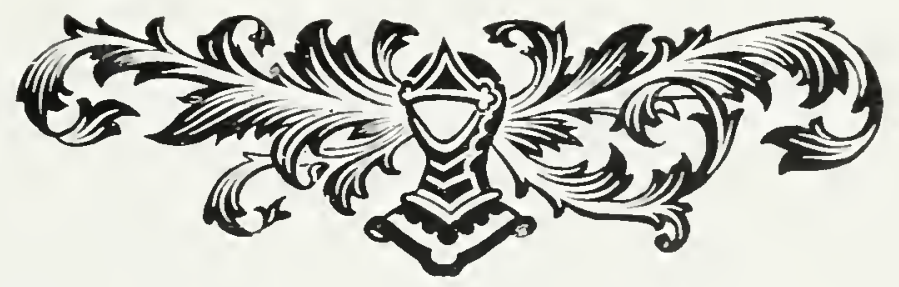




\section{$14 \quad$ Lovers of the Horse}

\section{THOMAS CHARLES PATTESON}

$\mathrm{W}$

lex 'Thomas ('hanles Patteson died, the Nestor of the turf in Canada, and the founder of the ()ntario Joekey ('luls, passed away. Although within two or three weeks of completing his ist year. laving been horn Oet. 5 . 1836 , ten dats before deatle came he was apparently in his usual health, and was taking lis costomary lively and intelligent interest in mmobne affiors. A week previously he was in the 'Torento Irorld oflice, and, after aseending the editorial

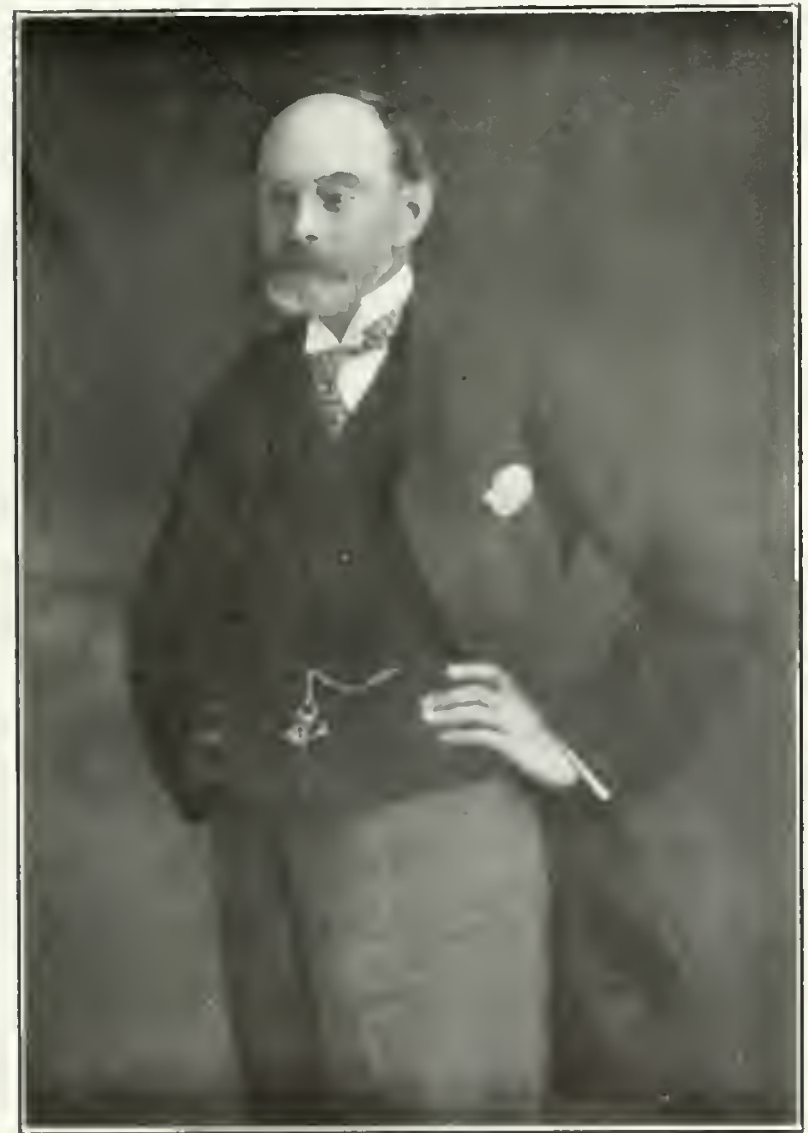

PHUMAS CHARERE PMTTESN stairs briskly, eonversed lightly and interestingly on the record achievement of the then new C'mander, the Iusitania, at the sane time chatting with knowledge of the performanee of other of the ocean greyhommls. Mr. Patteson s witle circle of acepraintaneess, it might be here noted, included ehiefs of the marine world, and it was primarily through him that the late C. I. Pipen. who met his death in a railway arevident near Bristol, England. beane agent for the White star line.

I man of rare parts went from among us when Mr. Patteson's spirit tonk flight at midnight on Friday, the twentietl day of september, 190\%. Mis memoly was marvellons, and his knowlcolge of ment amel pulblice alfairs, not alome in Camalda lut in Girat Brilan, Was prohably mexerllerl. No man eould die. hut, il lue were of any note, Mre l'attreson hall a good, or at least an inferesting story to tell of him. What he reatel or what passisel his way. he seemingly never longot. Ilis powers of olservation were illimitalule, and his thomghts quick and

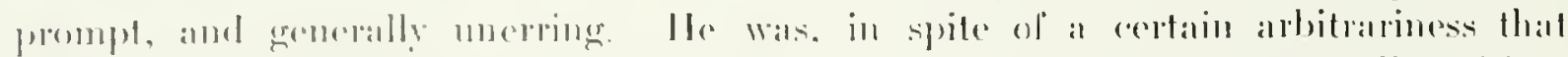
often provoked lostility. a man of generous, eomsiderate and kindly disposition.

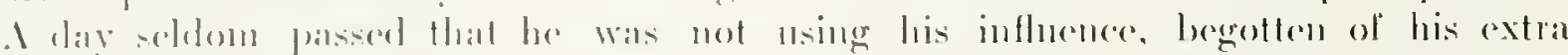

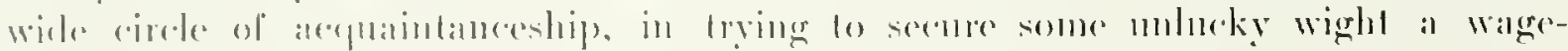

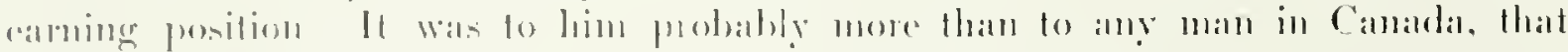

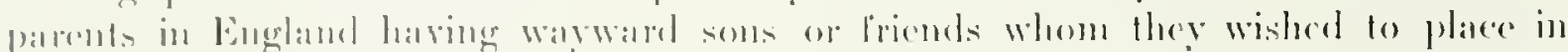

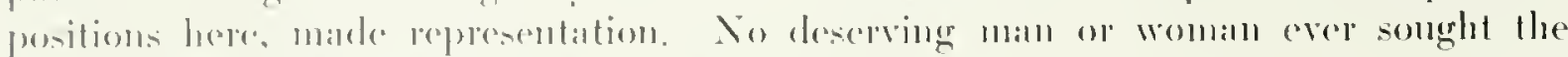
egool oflices of 'Thomals Charles P'attesen in vain 
In the good old days of the Great Western and Northern Railways. when Brylges and Comberland were the respective chicto of those roals. many were the linglishmen who seeured appointments through his aid. Aul so it wats to the end. Sommd. usoful advice and level-headed amosel were always to be had fom Toronto's Postmaster of that day for the asking. Thirty-five years ano the writer of this was aldef proofreader on the then recently established Mail. A year or two afterwards an ex-member of one of the learned professions was a member of the prooferenting statf. His habits were "a bit off," and a bottle of supposed tea molombtedly containcel something that inebriated as well as checred. Towards midnight this gentloman was flecpuently in an

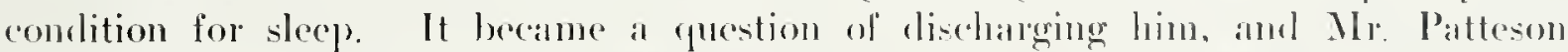
walked with the writer from the Mail office. which was the ald Metrenpolitan Hotel transformed, to the postoffice and hack, diversing the matter. That the place eould not be matle a refuge for incurables was certatum, "lutut," said the managing dirertor. "youll have to tell him. I can't." And that faily represented the kindly disposition of the mill.

It was not only by the seckers after employment that Mr. Palleson's sage eominsel was in demand. Newspapermen. masters of lants, promoters af various enterplises, were acenstomed to take advantage of his wide experience and extensive knowledge. He was heald to say once: "If I charged for consultation the customary legal fere, my official salary would be trehled." Ind that was an muldoubted fact. It was his willingness to help that led the late "Dcacon" or Joseph Duggim to gen to Mr. Patteson to sece ill something combl not le done towalds the improved utilization of his Woodbine property, and the placing of racing on a better footing and a higher plane. Mr. l'at teson, with no thomght of the valuable service he was gratnitomsly remelering, at once set to work to interest sumdiy prominent men. Having secured at pomise of their cooperation, he ealled a mecting at the Queen's lloted. wor which the hate sir Calsimir Gzowski presided, and subscribed \$.500 towarls the somght-for (appital of $\$ 10,000$, signing the stock book with the rematk. "There. that's all l expect you want of me," and then surrendering the ehair. However, Sir Casinir"s interest continued, and, uncler his auspieces and those of Colonel Cumbertand, William llendrie, l)r. Andrew Smith, Willian Christie, Rohert Davies, the Mlads, I. II. and C. T., E. King Dodals. and otlier men of the time, the Ontario Jockey Club came into existence and set ont on a somewhat checkered path, but still one that from its commencement has had hut a single objeet-the clevation of rading and the corresponding development of the thoroughbied.

Flood, frost and rain played plentiful parts in the early years of the O. J ( 2 in pre-

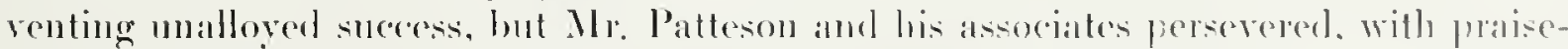
worthy devotion and self-salcritice. One hucky diy the P'ostmaster secured the promise

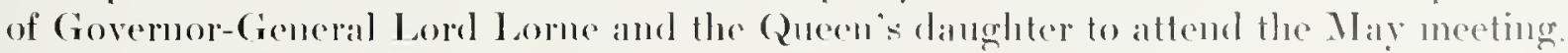
Racing prospects in 'loronto then and there received the stamp of social suceess which has never sinee left it. With wise management, the duh from that time has gone on and on, until to-day, despite the puritans who have simply lopought duass where order 


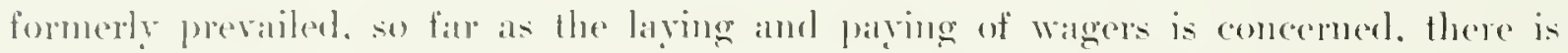
none on this contiment that stands in higher repute.

While the dispute that alrose in Ire Miller's reatr-that is, the veall 189t, when

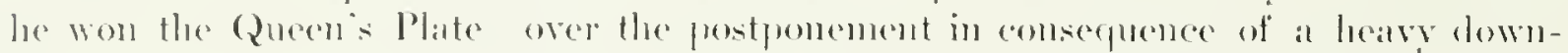
pour of min. led to reorganization and, in some pespects. to a changer of programme. and even of policy. the objects of the chut have remained the same; and whereals the

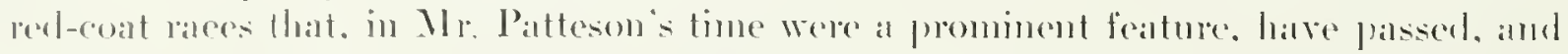

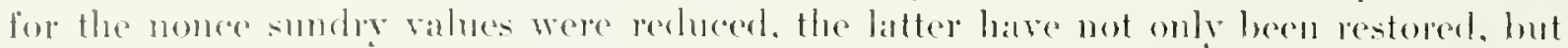

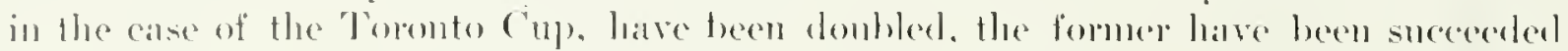

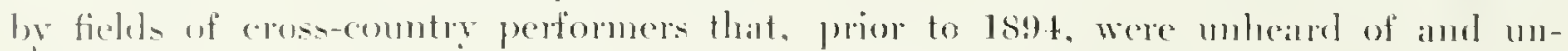
thought of. "l"hus the tree, that the wirlely amel sincerely lamented dereased planted. contimes to bear good frut and to retain the good-will of all rational amel reasonalule people.

But 1 lr. Patteson, in ceasing his active participation in rateing alfairs, alid not relinguish his love of the game or lis anduration for the thoronghbred. These he

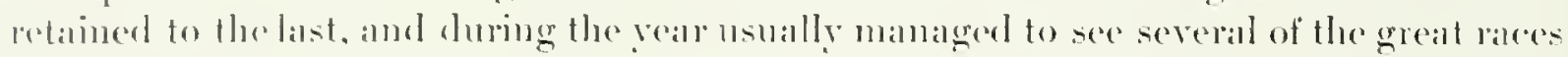
run in the Xew York listriet, and also to insperet the eracks of the day. Nor were his trips to Brooklyn or sheepsheal Bay the only way in which he maintained his interest.

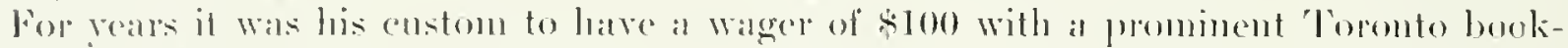

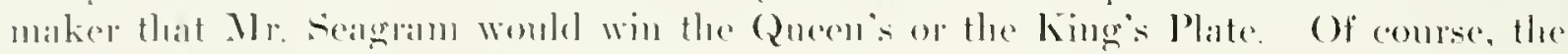

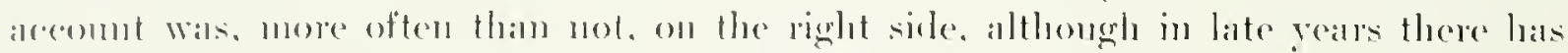

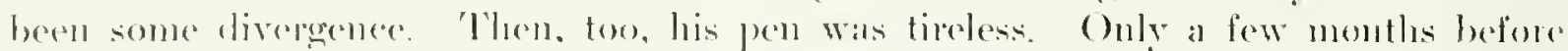

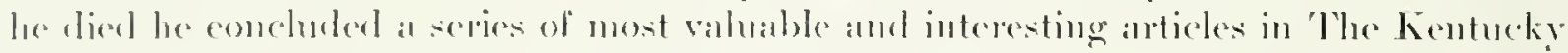

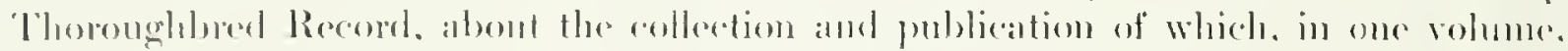

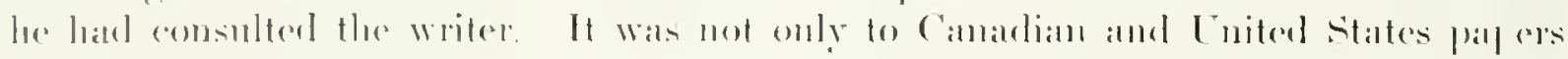

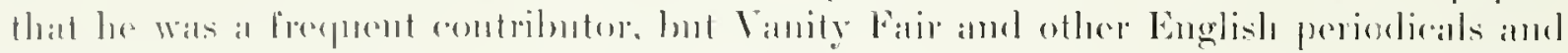

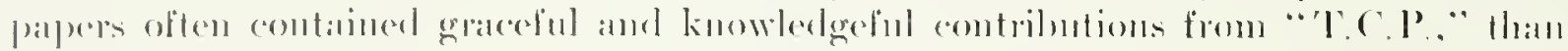

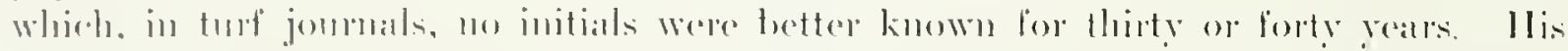

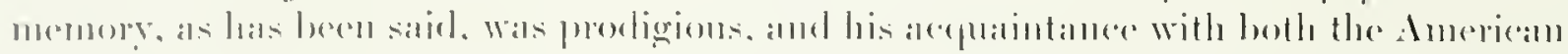

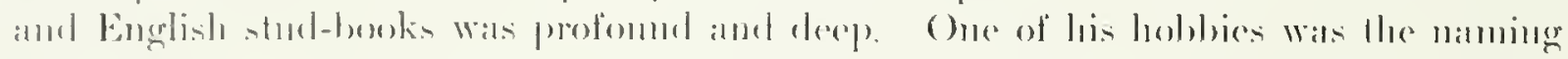

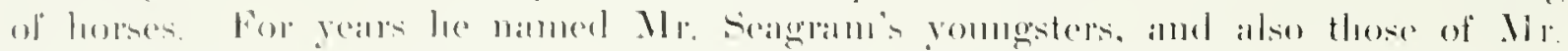

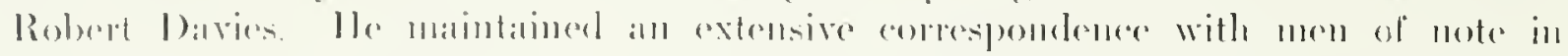

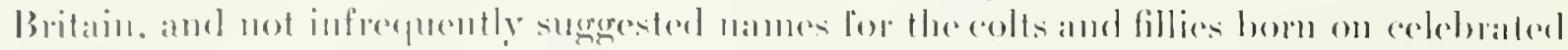

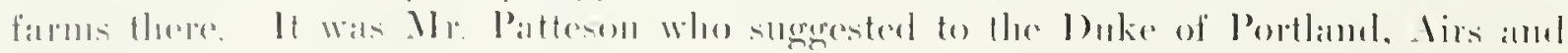

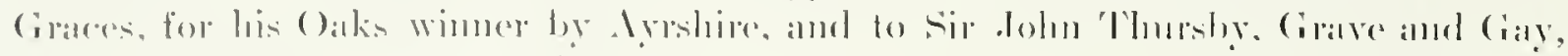

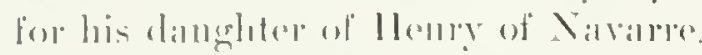

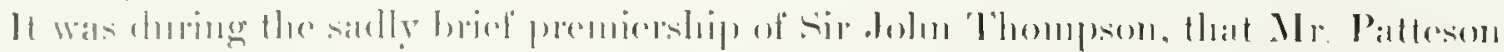

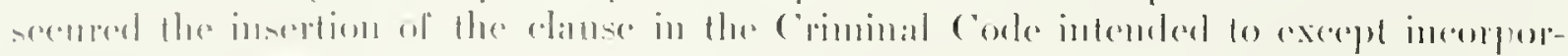

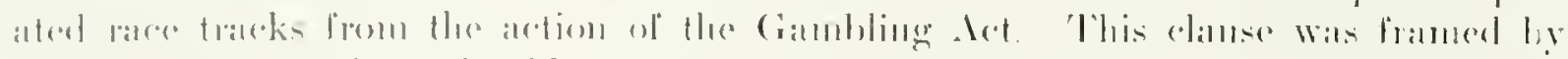

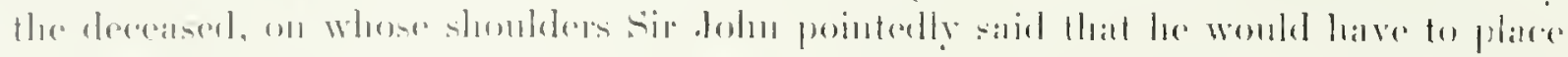

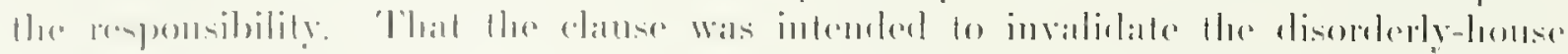

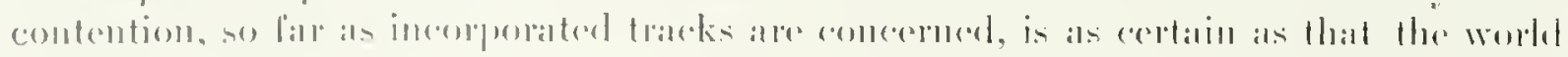




\section{Lovers of the Horse}

exists. Iufortunately it watis literal interpretation, not literal evilence, that goremerl the mullifying dereisions of the courts, both at Toronto and Ottawa, and it was the lestere, and not the spirit, of the law that it was somewhat inconsistently puled must prexall. Thus the eroorl intentions of the now dead Nestor of the Canalian turf went by the board.

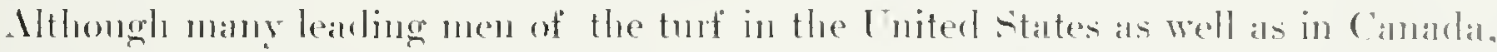

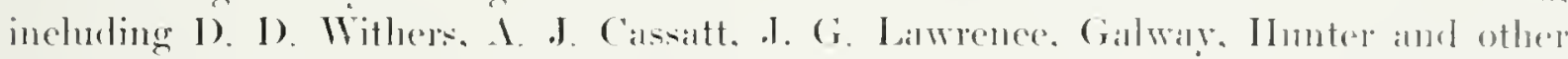
respected old-timers, were all pleaserl to comsult and chat on horse matters with the thesl Master of the Vansittalt Farm at Eastwood, raleing and race-lorse breeding were not the only sponts or pastines in which the deceared nanifested enthusiastic interest. It romning and jumping. in his college and university days, he was expert. He was allo al grood oarsman and an excellent anthority on rowing but it was crieket that, in onteloon games, was his idol. It one time he wrote as mamy anticles probaldy on britain:

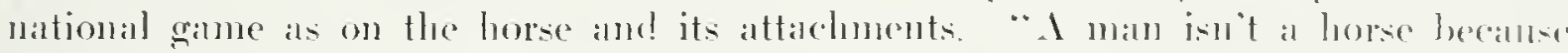
le is bolm in astable, but perhape the fact that I was brought up at Ilamblectom, in

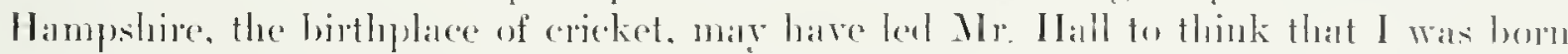

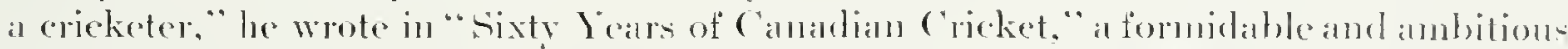

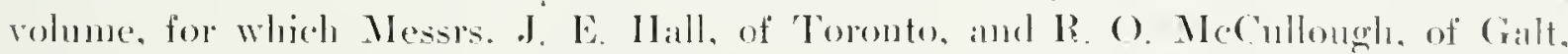
were responsible. "I eentury ago," Mr. Patteson went on to write. "Hhe llamblestom seren conld have beaten any twenty-two in England. In that Ilanushire village, full of sportsmen who ranked with the best in Britain, I played many a mateh." Ile then tolls how he was a postmaster at Mertom before he was postmaster at 'lorento. It wals in 18.5s that Mr. Patteson first played in Toronto. Ilis place was belliud the wiekets, and as a wieketkeeper no man in Camalal of his time was his expal. Ile eaptanined the

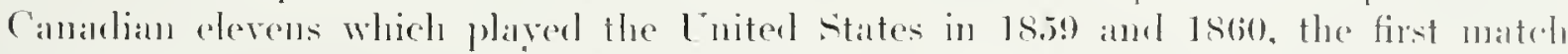

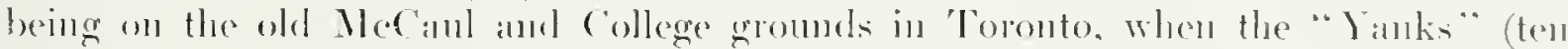

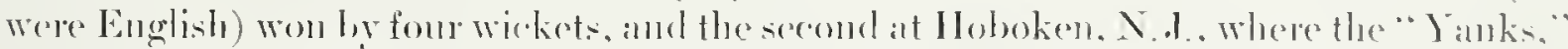
the only one of whom who was native-hom beinge of the iblustrions fandy of Newhath.

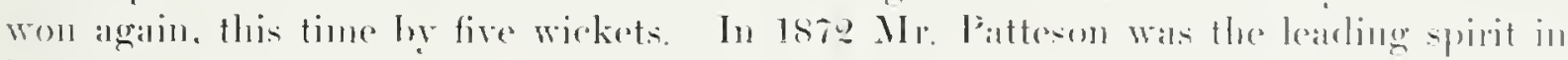

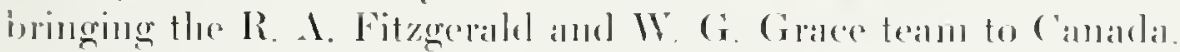

An mufortmate ruphure prevented Mr. Patteson from enjoying the sport of huntingr. but for many years he was a member of the llunt Chub, and to the last touk his daily

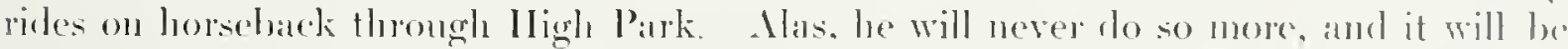
many years, it is to be feared, hetore his like will be looked on again, for so straightfor-

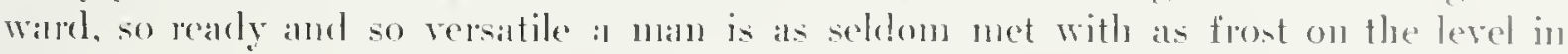
the tropies.

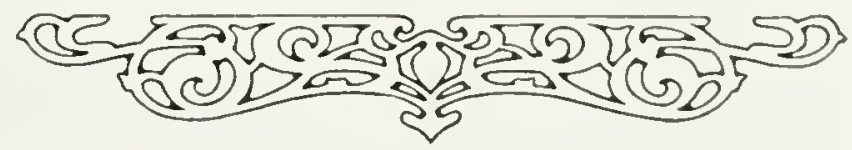




18 Lovers of the Horse

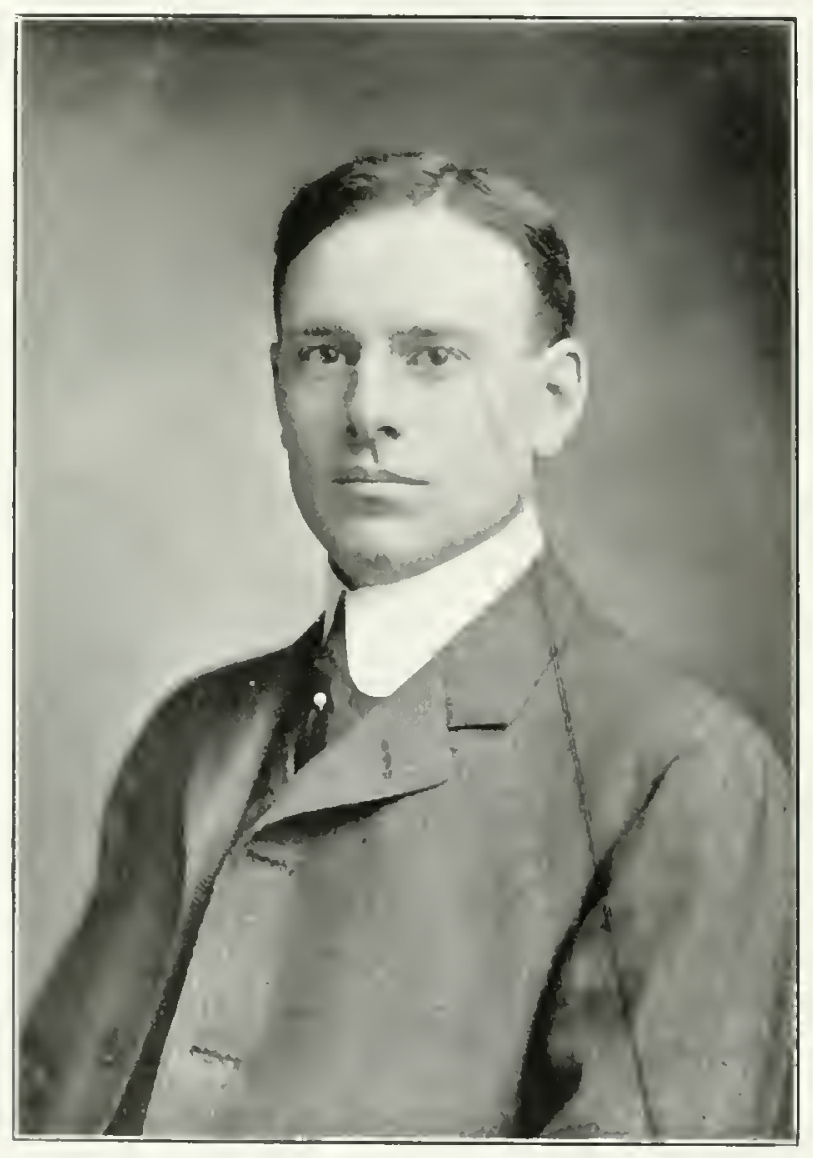

ROBI:RT J CIRISTIE "TORUNJU, 


\section{Lovers of the Horse}

\section{GEORGE WILLIAM COOK}

$\mathrm{O}$

YE of the most prominent horsemen in Camada is Croore W. Cook. of Westmonut, Montreal, Que. Ile has done much to encourage good sport. Ever since he can remember he has been intimately associated with the horse, and has bred quite extensively. Ile has been racing for the past ten rears, during which time he has owned such groorl horses as Orontas, Merriment. Benckart, M.I).L., 'Too Many, Mango. Factotum, ete. One year. with a statble of six loorses. Mr. Cook hearterl

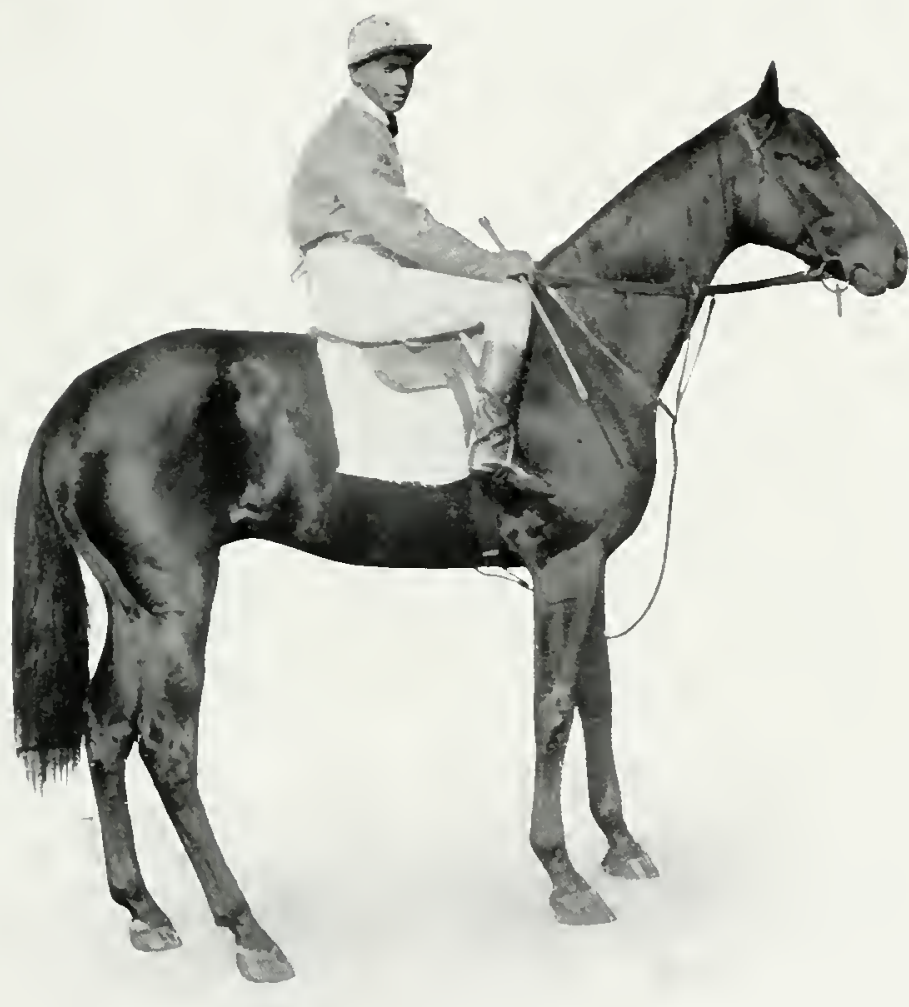

ORONTAS, B II , BY AZRA-STARLIGHT-KING, AlfONSO

the list of wimning camalian owners. His faiolite horse has probibly been Orontas. winner of the Livelpool Cup and many other good races. the next best being Merriment. Who was also wimer of the Liverpool ('up at 'Toronto, the spring handicalp at Washington in 1905.and who ats at three-year-old was only beaten by the great Machesney, by a nose. at chicano when the world's reaord for six furlongs was lowered. George William Cook is very prominently known in the lumber business. Ile was born at "Erlgehill," Morrishure. Ont. and Was exlucated at Montreal. Morrisbure and CPper Camada C'ollege, 'loronto. In 1905 he was married to Miss Willa O'Mlarar. (anghter of 1). D. O’Meara, Inspector of P'orts, of Quebec. Mr. ('ook comes of a widely-known

family of U.E. Loyalists, who settled in the County of I)undas and all of whom have manifested a fondness for gool horses. I Iis grandfather was the late (apt. Cieorge Cook. who as a young man fought at ('ryster's Farm, and in 1839 at the battle of the Windmill. The family lave always been stameh Liberals. Mr. Cook's great uncle and father having represented the Comnty of Dunclas in Parlianent for many rears.

Mr. Cook is President of the Cook \& Bros. Lmmber Company, and the Serpent River Improvement ('o. He is a nember of the Montreal Board of 'Trarle. Sorially he is commected with the Montreal IImt Club. Montreal Rachuet C'lub. St. Cieorec's Snow Shoe Club, Montreal Imatour Ithletic Issociation, and the Ontario Iockey Chub. He is also a member of the Mount Roval Club, Montreat. and the Reform ('ul). Mr. Cook's summer residence is his birthplace. "Lidgehill," Morrishurg. His city residence is $400 \mathrm{Ehm}$ Ave., Westmomnt, Montreal. 


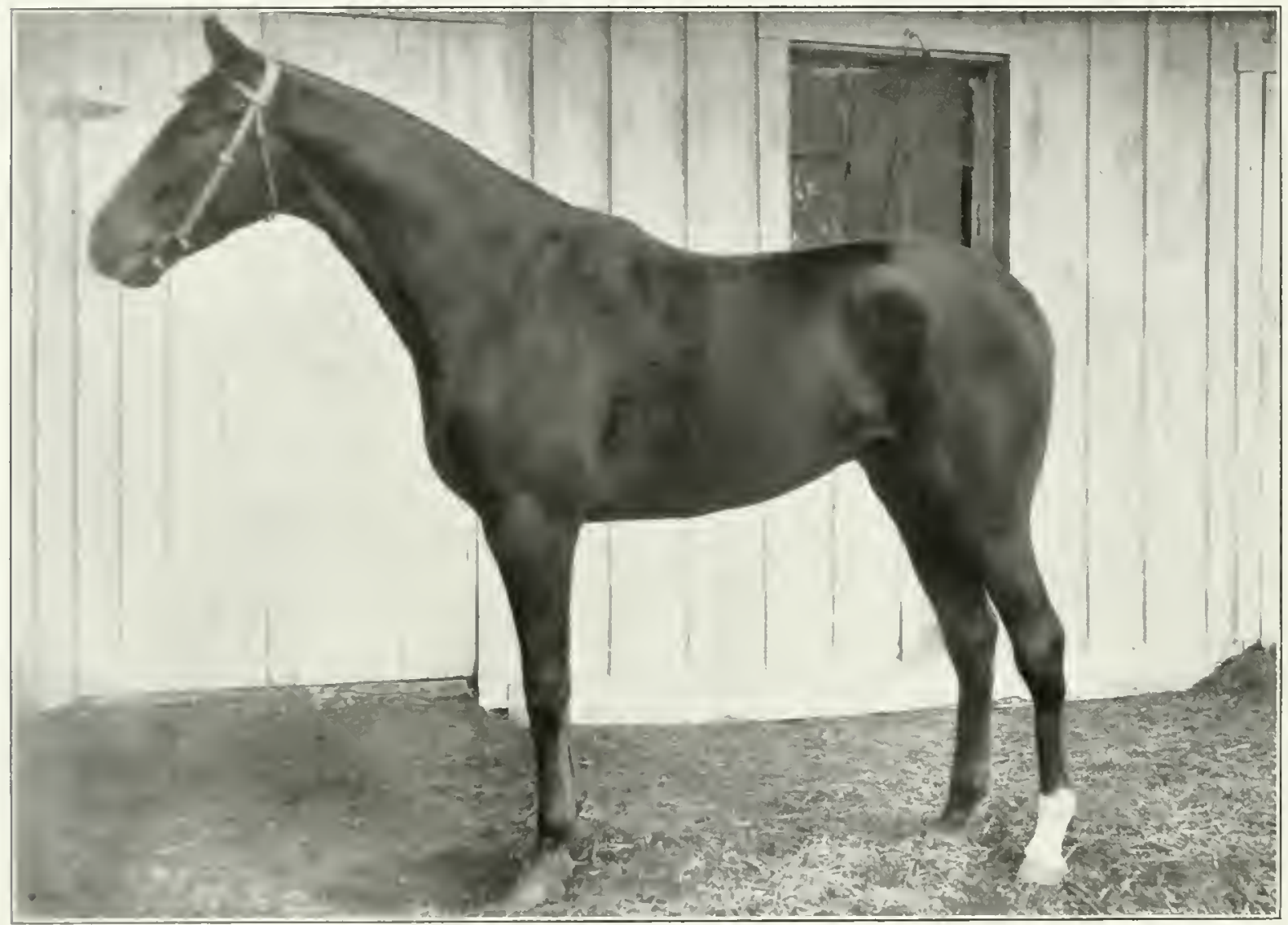

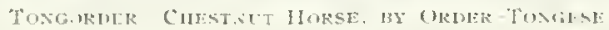

\section{NATHANIEL DYMENT}

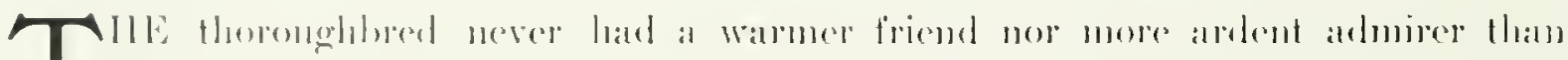

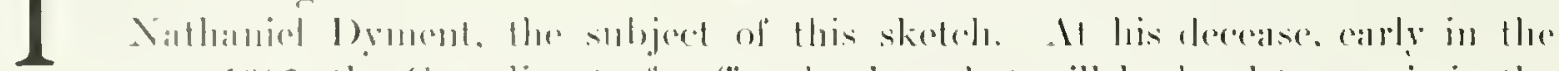

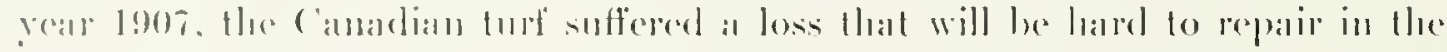

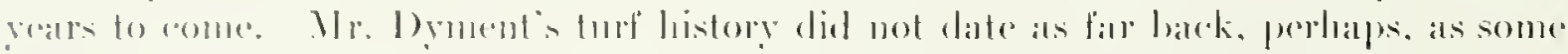

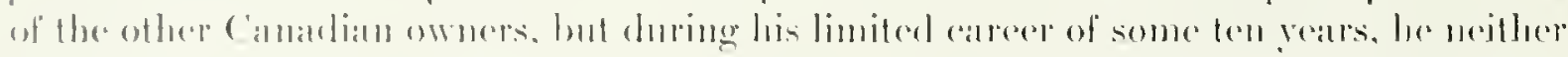

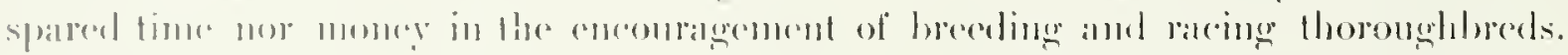

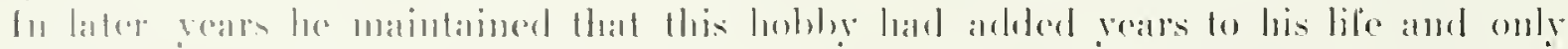

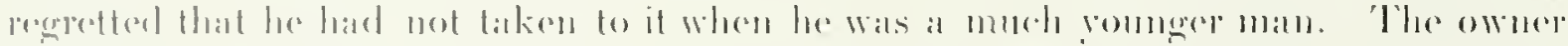

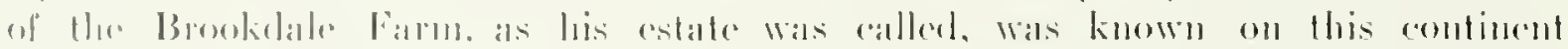

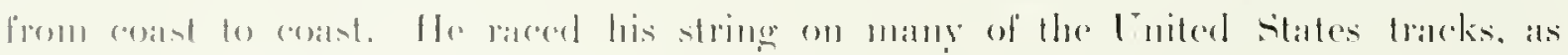

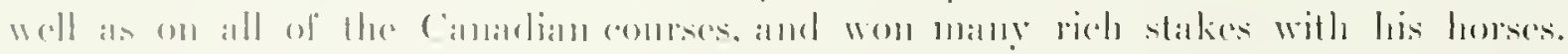

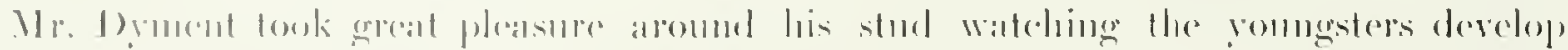

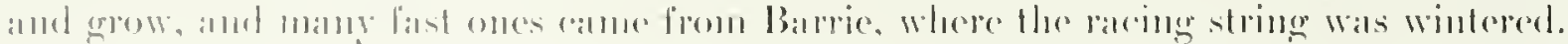




\section{Lovers of the Horse}

Mr. Pyment hat all the fualities of a sportsman: the hettimg ring had no attrace-

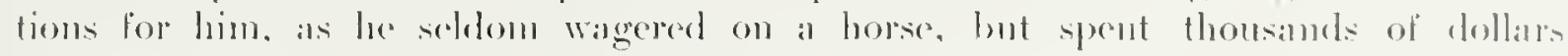
on foreign breds for the purpose of bettering his string; this being done for the pure love of the sport and not for the finameial benefit to be derived thereform.

Ilis bondest hopes were realized when he won the Kinges Plate twire in suceresion. first with Thessilon of his own breediug. and the secomel time with salpere sired hy his famous stud courtowm. and purchased hy him at at small figure. Mr. lyment"s commection witl the torl dated back for many rears. and the orange and green rotors of the stable were well known

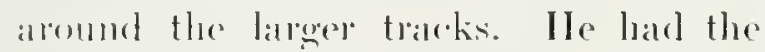
distinetion of heing one of two ('amadian (mones who latel a loorse fit to start in the Amerian Derles, which wals run at Washington lark Prack. Chicago, for rears. and was the richest stake for threereratr-olds on the Imericaln contiment. Ile wass a most enthusiastic mender of the Ontarie and I Iamilton Jockey ("lubs, and for two years won all of the more important baces on both tratcks.

The laresest purse evere wou by the owner of the Brookdate lam was the Buflalo berts. Which was worth some twenty-five thomsind sollats to the winner the year he wom it with Fort IInuter. 'the following season le finished second witl 'Tongoreler in the sime event, and witle a better risker would latre wom.

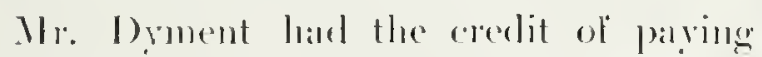
the latresest price that was ever paid for a

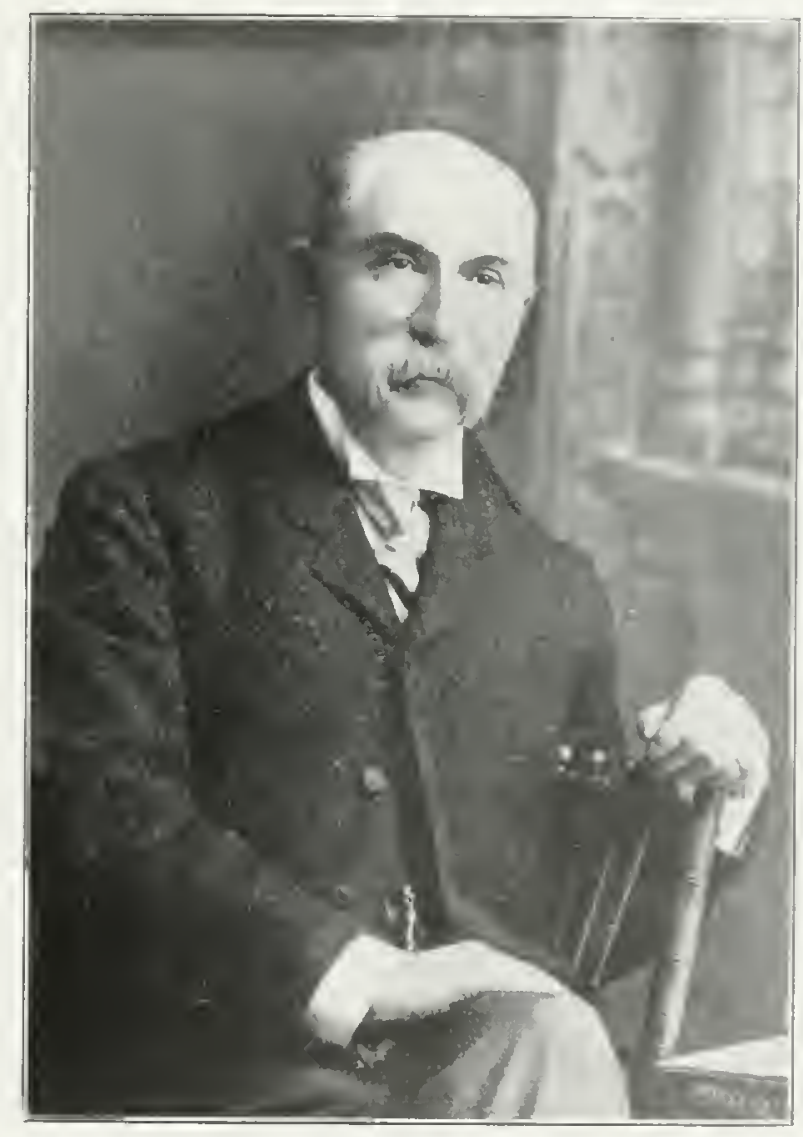

Xithaniel DYMTN thoroughbred by a cimadian, when he purellased Kinleytale, the som of Kinleymatek, lor $\$ 11.500$.

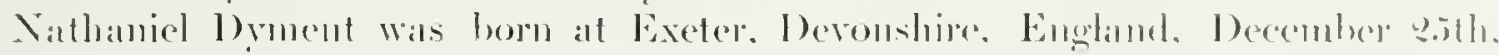

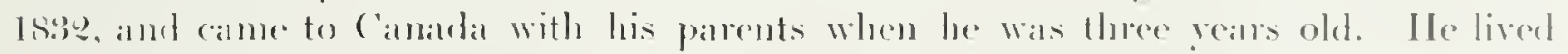

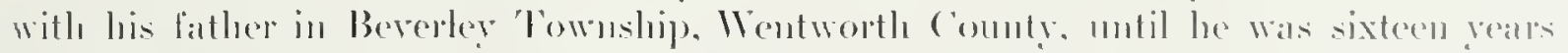
of ane. He begand business for himself at that age by purelasinge a hig pine trees. which he felled himself and had taken to the mill; as he mate memer he purehasod more pine, and from lumber amassed a large fortme and remained in this husiness up

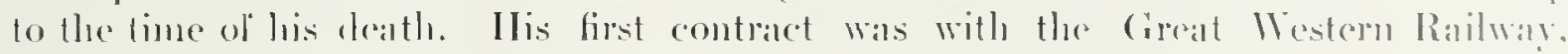
supplying them witl the entire output of his mill at Linden. 
In the rear 1850 he went to Barrie, which place he mate his home and where he pureluaned the timber lands at Vestra and Ilillselale. Vext eame the purehase of latrer timber limits in Algomil. He was the hearl of the firm of Mickle. Drment and Sons. Which is now one of the largest lumber firms in the Dominion of canadia. It one time Mr. I)yment was leresident ol the Barrie loan ('ompany. Which was alu-

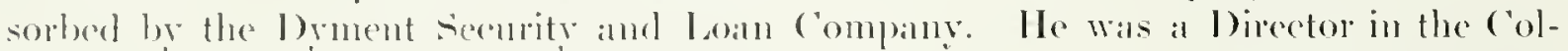
lingwood shiphuilding Company, the Coderich Elevator Works. The Barrie Carriage

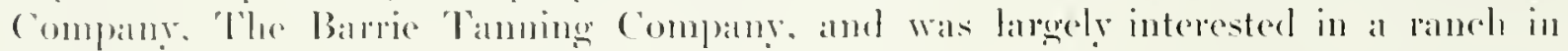
llinertis.

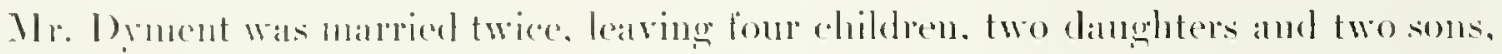

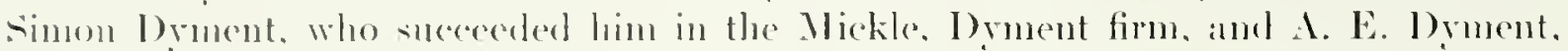
M.l'.. of 'Thessislon.

When Mr. Inment first took to raxing. le was langely interested in English stock. which did not slow quick results. Itis racing cancer really did not commence nutil after the purelasse of the famous stablion courtown. The first get of this sire to slow anything was the mare Flying bess. and it was a prond day when her owner salw

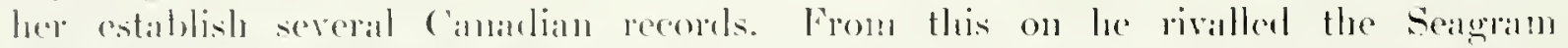

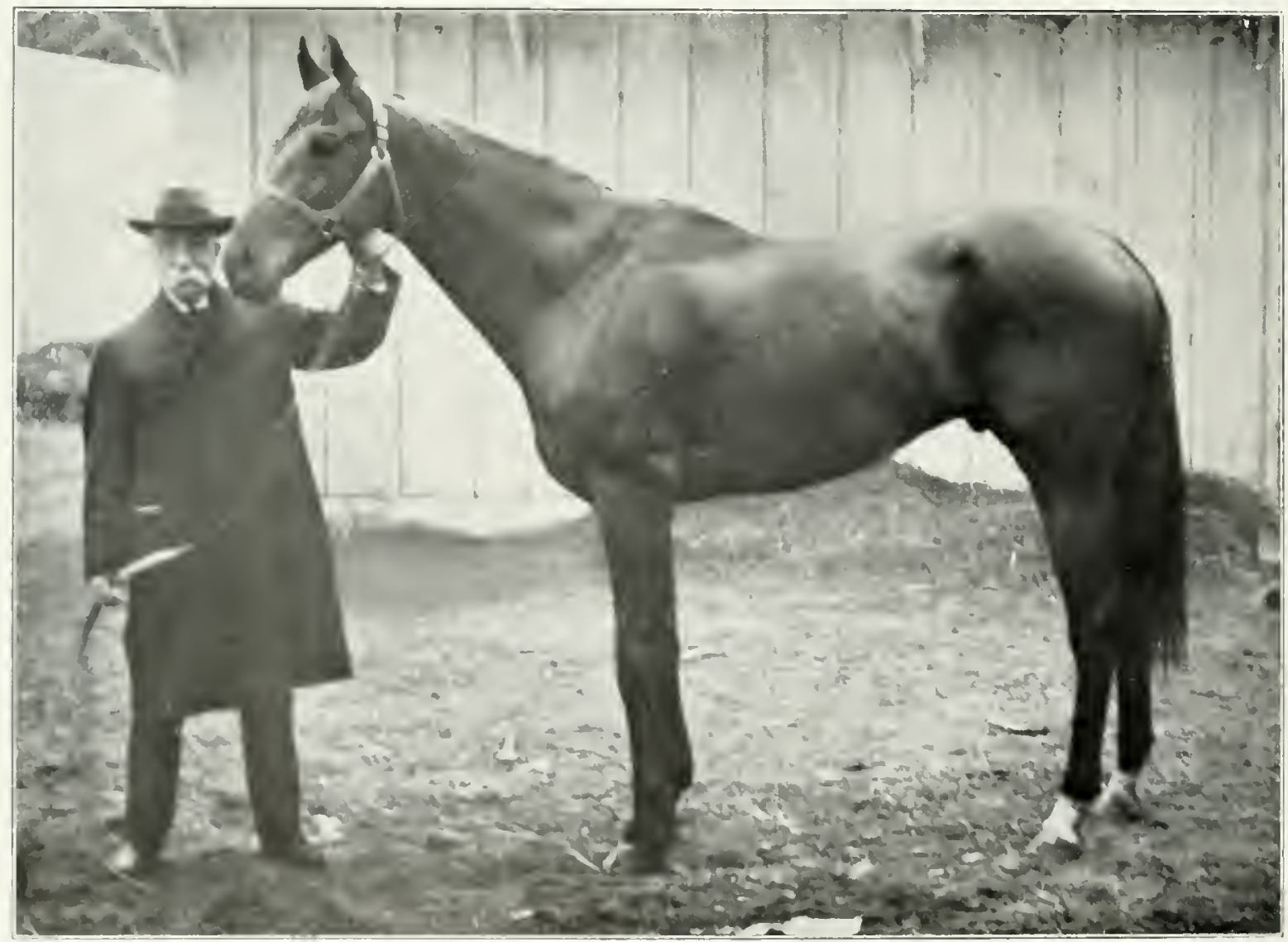


stalble, and it was a battle for supremacy between them for the honors of the Camadian turf. In 1903 the Brookelale stable won the King's Plate for the first time with Thessalon, sired hy Courtown. running second the same year with Xesto, another one breal at the farm. In $190+$ Mr. Drment saw his string hearl the list of wimning ('anarlian owners. 'This year he won the plate with silpler, a despised outsider. while he captured all of the principal open stakes in Canada with Fort Innter, who had heen purehased the previous fall at a cost of $\$ 3.500$. This horse won the buffato I) Thy and started in the last American Derby exer rum, finishing fourth after being in lront at one time. In 1905. 'Tongorder was the bread-winner of the stable: and althongh he did not ergual the record of fort Hunter, he won the majority of the open Canadian stakes and finished second in the Buffalo berty. It was in the fall of 1905 that Kinleyelale was purelatsed and when he failed to make good. contracting cold at salem, from which he died, the genial owner only remarked that another one must be secured. The next in line was Temeraire, which was hought for $\$ 9.500$, the fall previous to Mr. Drment's deatl. On the Brookdale Farm there is a mile trark over which the Queren's Plate was won hy Mignonette, owned by Mr. Rodely Pringle. in the geatl 1833.

Mr. Dyment was a great lover of home, and helonged to rery fert social alubs. Ilis principal delight was the entertainment of friends at his estate in Barre. where le woukl show them his string and talk of the raees to be run and the races won and tost. He had many friends and his loss was seriously felt all orer Canada.

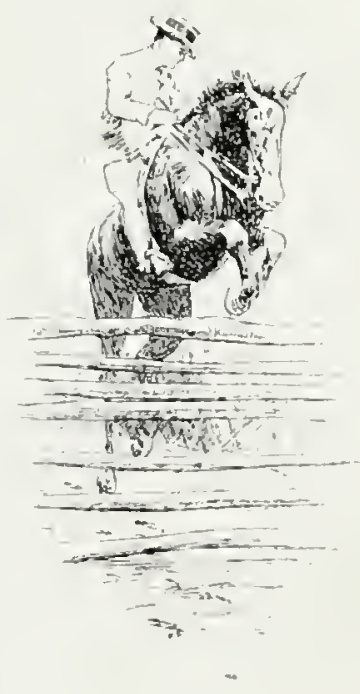




\section{$24 \quad$ Lovers of the Horse}

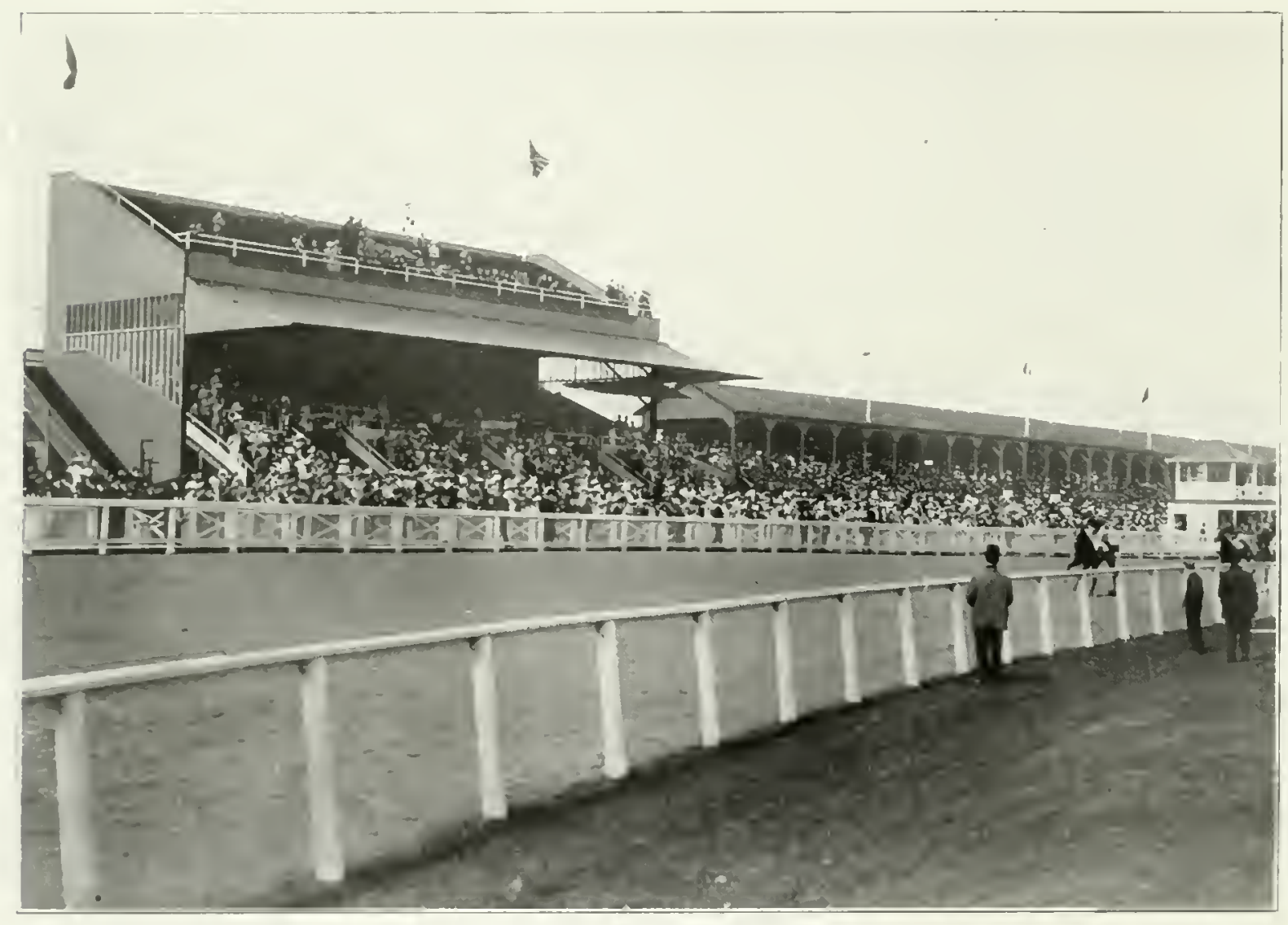

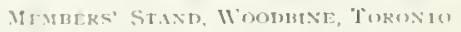

\section{THE ONTARIO JOCKEY CLUB}

W

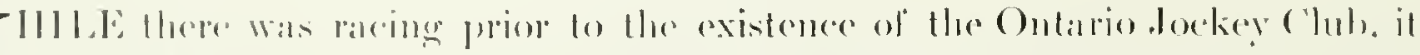

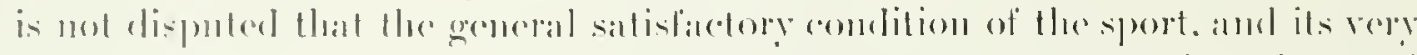

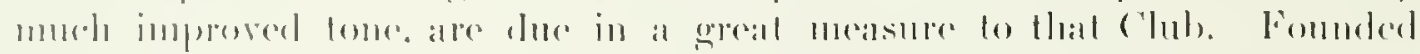

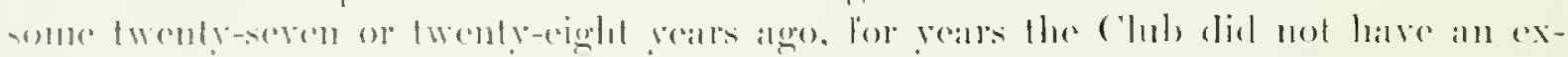

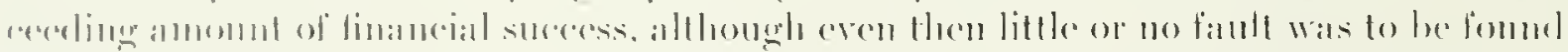

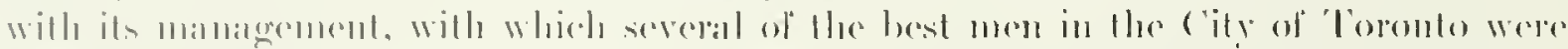

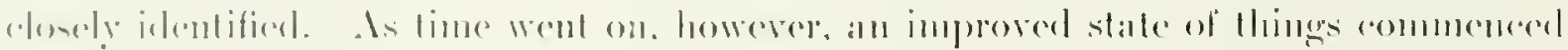

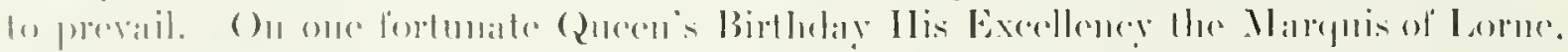

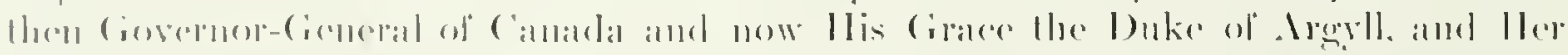

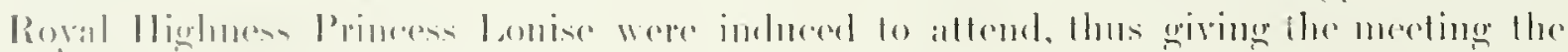

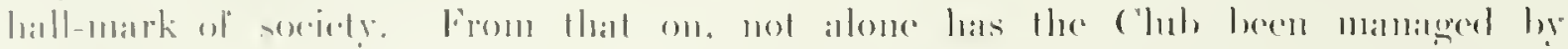

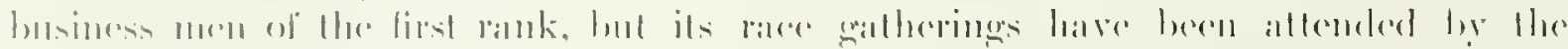

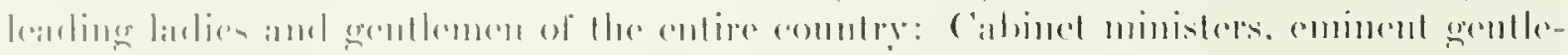

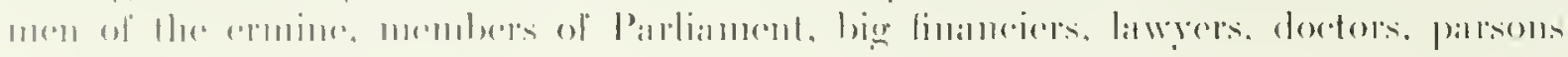


and nuepeluants, have net on a common level on the leantiful green swate in front of the stamds. 'Tley have chatted cordially together in the hoxes and seats. on indulged in little imorent hat-pools while in the engynent of sport as well and reputably mathaneel as ally on the broal face of the eartlo.

It was in 18 is that a few gentlemen met in a parlor of the Queen's llotel with a view to forming a . Jorkey Club with the moderate eapital of ten thousind dollars.

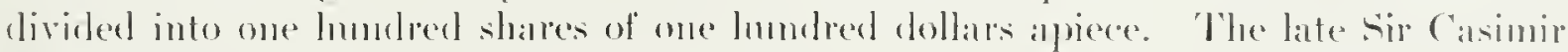

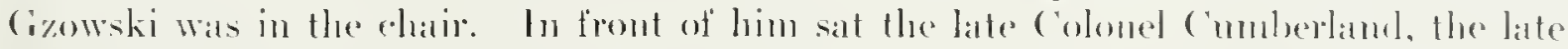

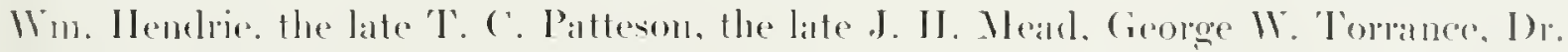
Andrew smith. 'T. W. Jones. E. King Dodels. Rohert Bond, C. 'T. Mead, Arthur (ionlsom, Joseph l lugeran, and perhaps one or two others who have escaped the writer"s memory. Previons to this meeting the Wowlhine track hat for six yeats heen used

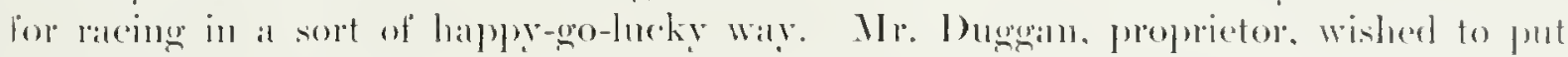
both the lrack and the sport on a better footing. and with that view interviewed the late Mr. 'T. ('. Pattesom, Who, after considerahle persuasion, consented to take the matter in hand and at once set alhout it in a husinesslike. practical way. The leanlt was

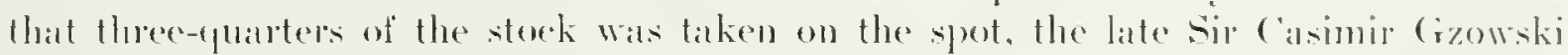

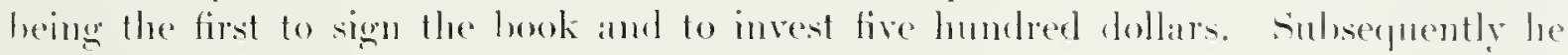
heecame President, and in the fall of 1851 the first meeting was heded. It is not necessalp to saly that, compalred with the present gatheringse it was on a very moderate scale indeed. In lact. ome stable eombl supply ats many horses, and of possibly a better

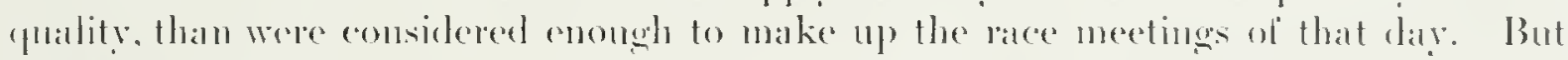
emerger and enterprise had its reward. Although the disposition at first was a bit cont-

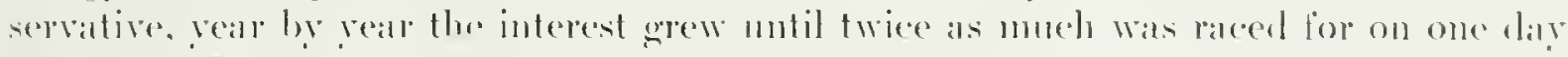
as was at first considered sufficiont to afford splemelid sport for an entire meeting.

colonel comberlandel was the first president. Mut was overtaken with sickness. and never had the pleasme of offiriatimg in that capraty al a meeting of the ('hul). 'The old Adam was. howerer. so strong in him. that on his teath-herd he commanded his family to go to the ratees, so that they conld tell him how they resulted on their return. "Even if I am dying." sild the andlant colonel, with true sportsmanlike and soldierlike spirit. "you should so to the meeting and tell me all allont it. I shall enjoy

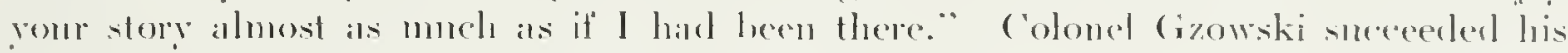
fellow-coloned and antinued in the position of l'pesident for two or three rears. when he was succeeded hy the hate William llendrie. who. on a little diverenence of opinion.

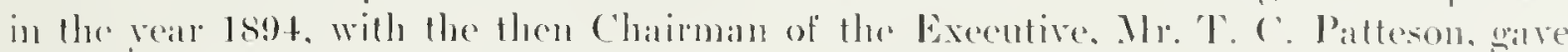

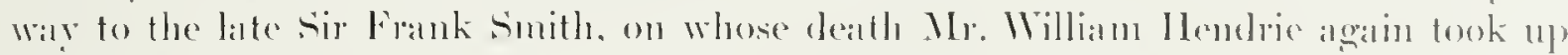
the reins. In this commection. it is interesting to note that the first list of f)irecolore Wats a somewhit long one, induling twenty of the most preminent gentlemen of the

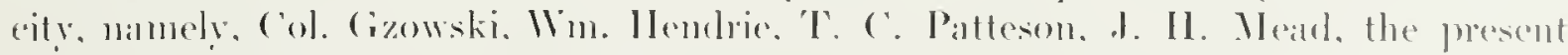

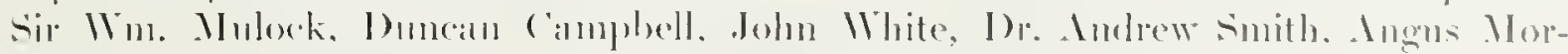

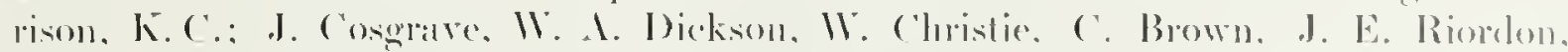

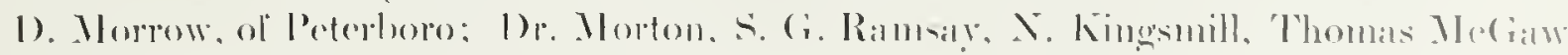


and 1)r. strange. "The present (1908) Executive are: President. Mr. fosephl Seagram. M.l'.. who suceeded the hate William Ilendrie on his death, in 1906i: E. B. Osler.

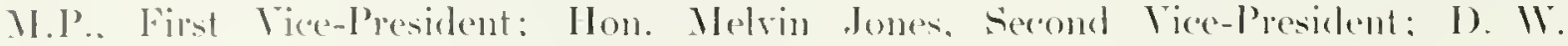

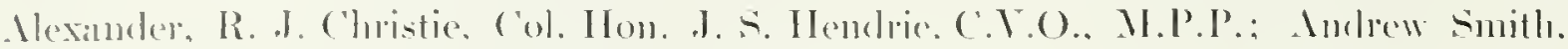

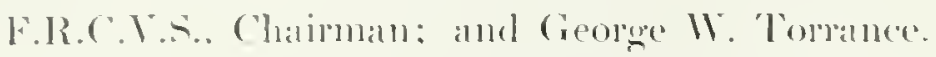

'The splendid enrowth and policy of the ().J.('. is. perhaps hest illustrated by the increase in value of the Kinges Plate. Is recontly ats 1890 (kmown as the (2ueen"s

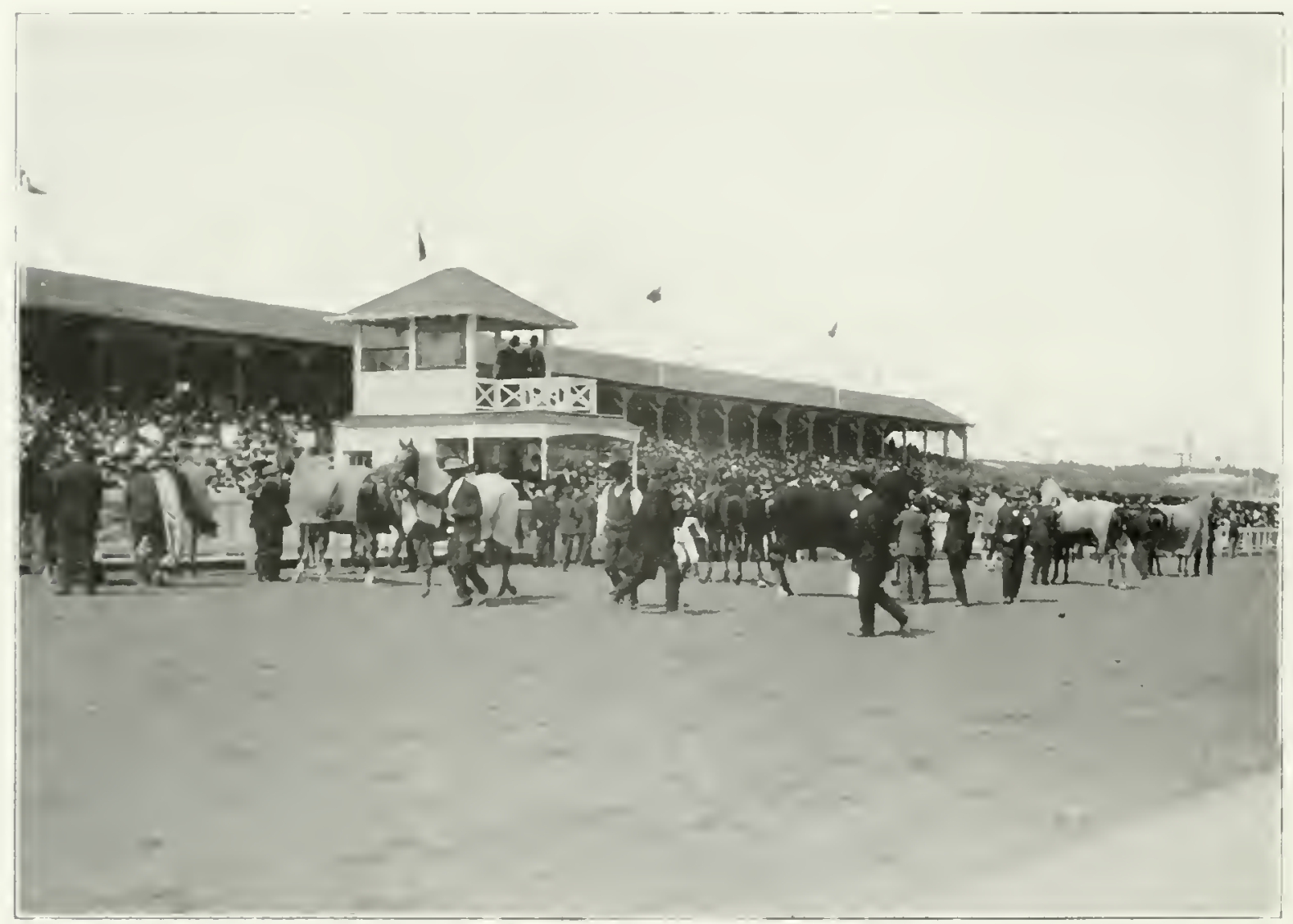

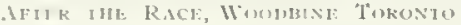

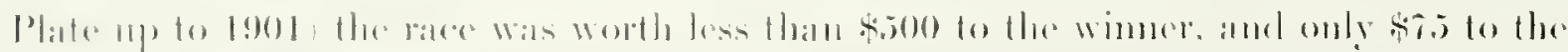

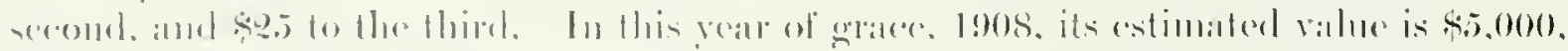

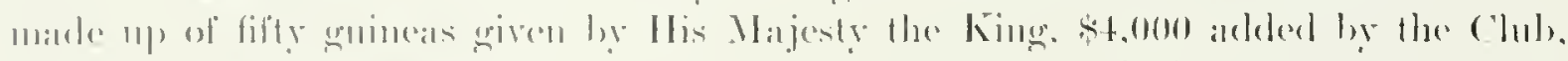

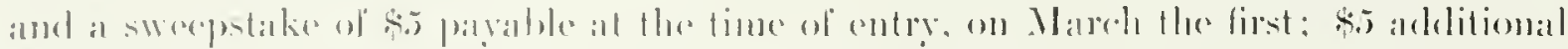

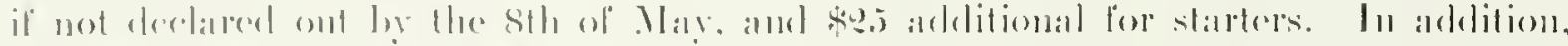

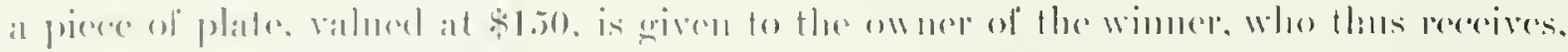

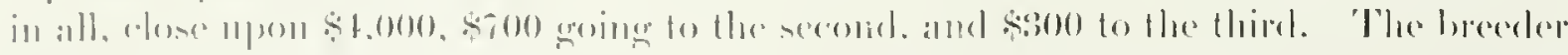

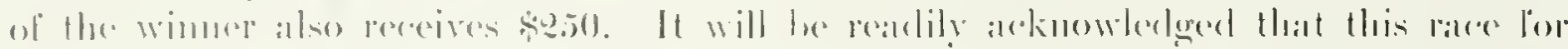

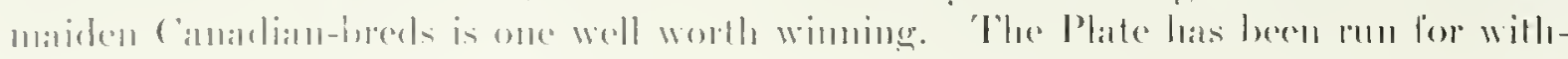




\section{Lovers of the Horse}

ont intermission since, and including. ts60, and is the oldest mee fixtme to-day in America.

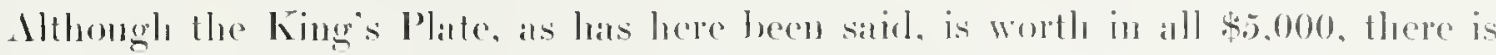
ret one other lace given hy the Ontario Jockey (Chb that is worth consideraluly more,

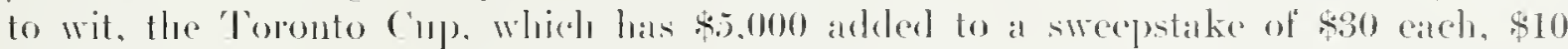

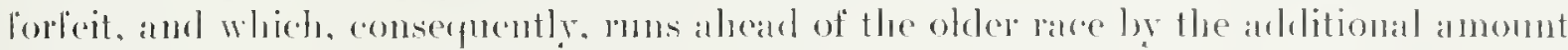
of the collected sweepstakes. While at the first meeting of the Ontario Joxkey Club.

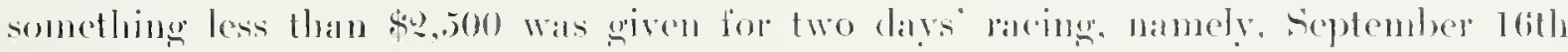
and 17th. 18si: On the days of racing in 1908, extending from Maty sespl to June the

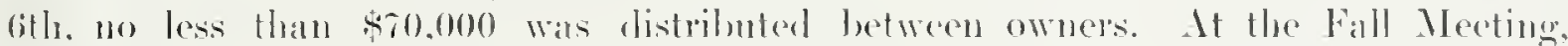
which nstally extemels from saturelay to saturday in the midelle of the latter hall of September, \$30.000 was given for the seren daps meeting. making in all $\$ 100.000$

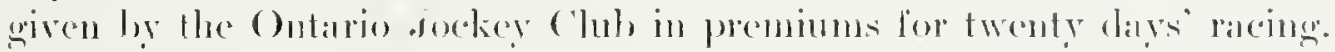

In 1881. the purses. as I have salid. amounted to $\$ 9.500$ : in 188.5 to $\$ 3.78 .5$ : in

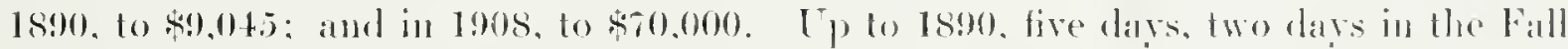

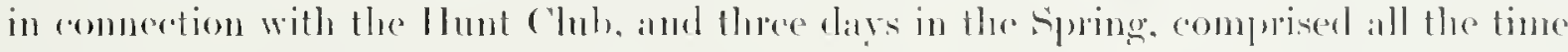
given to racing under the ('lub eolors. But the progress wats continuous nutil 1894. when the aforementioned dismption took plater in the Club, resulting in the fomeler.

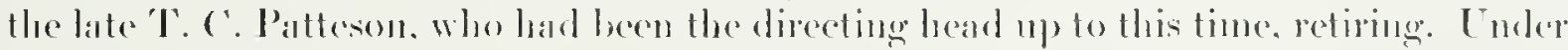
the new regime at the beginumg the tendency alpeared to be to greater conservatism. but time has proved that the ('hul, management was working up to new, wider ideas. Recently the ("luh has acepuired the Woodhine property, which for al quarter of al century it only leased, althomgly all the money made las heen continuousty fut into in-

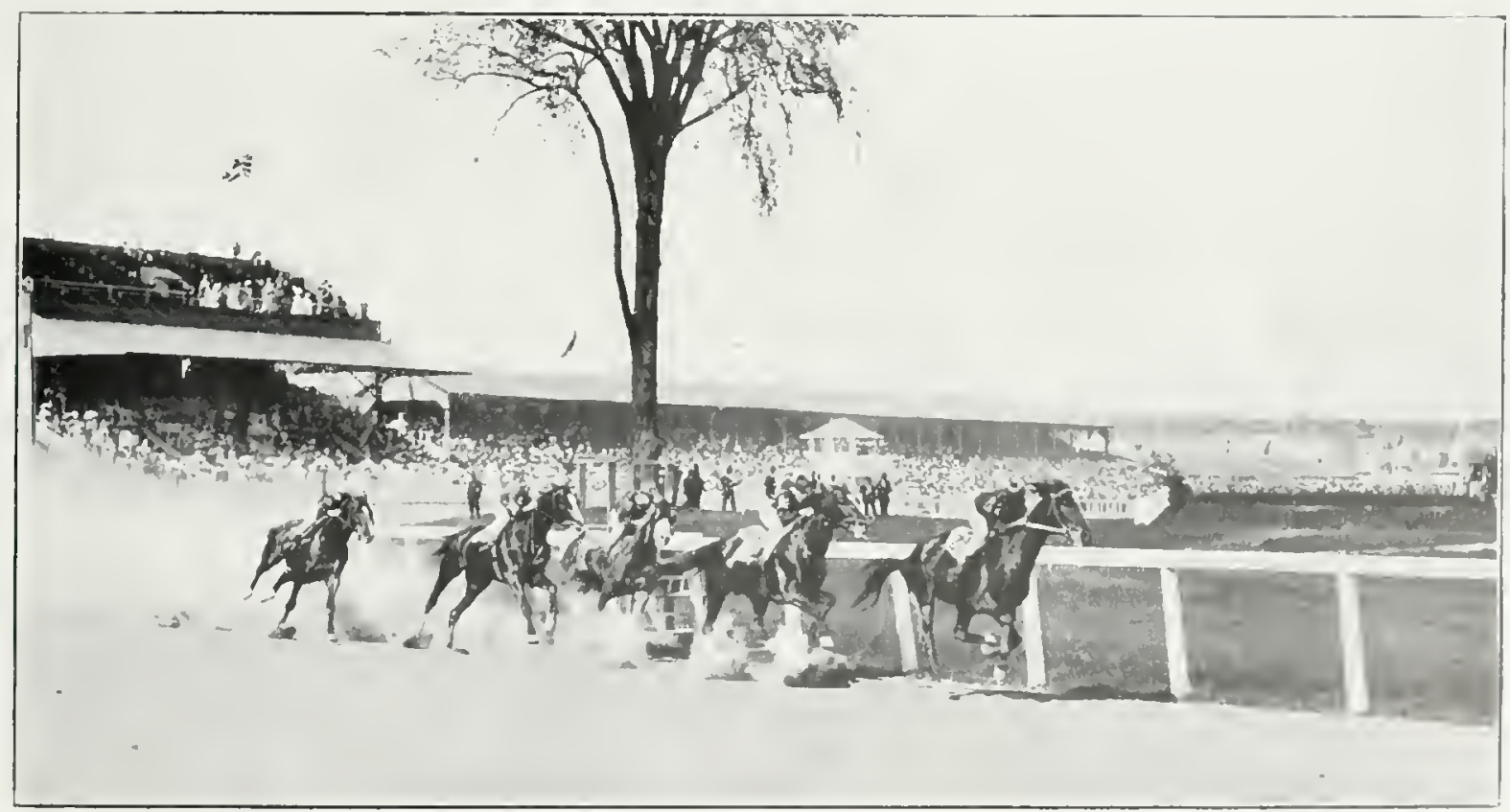

CLTBB IIUTSE CORNR, WUMUINE, TORONTO 
provemente. 'liwo or three years ago the track was entirely overhatuled. heing removerl

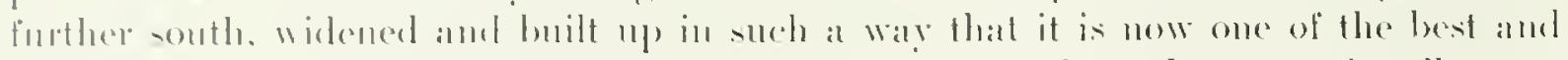

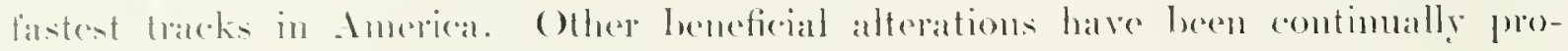

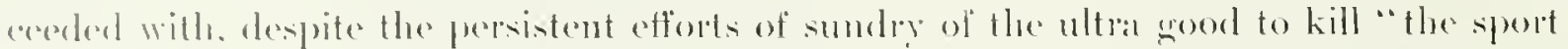

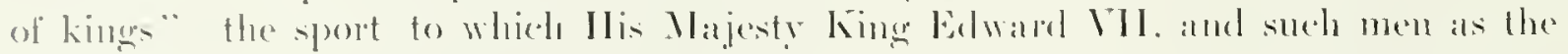

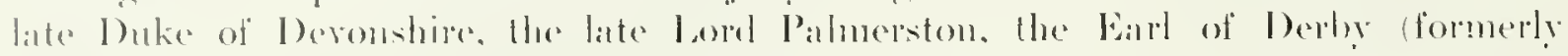

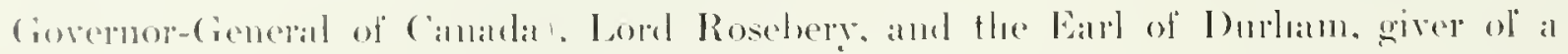

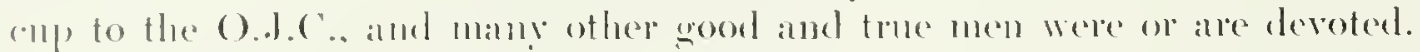

In 1906. shortly hefore the deatlo of Mr. William Ilemdre. senior, then President

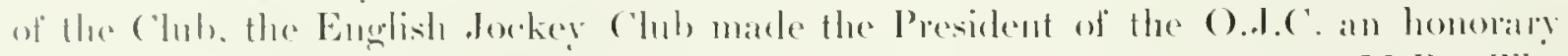

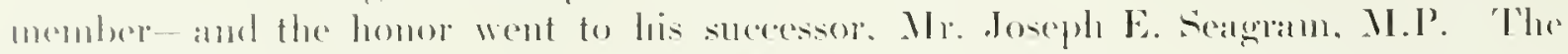

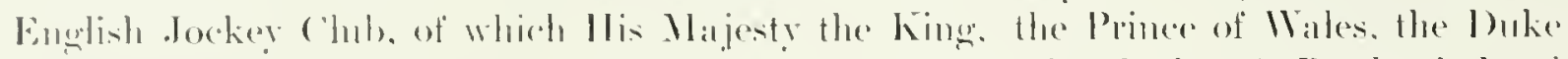

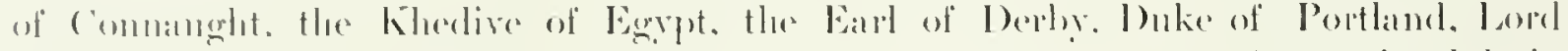

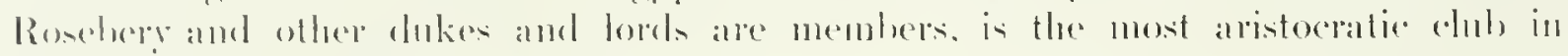
Enghand, and probatily of the workl.

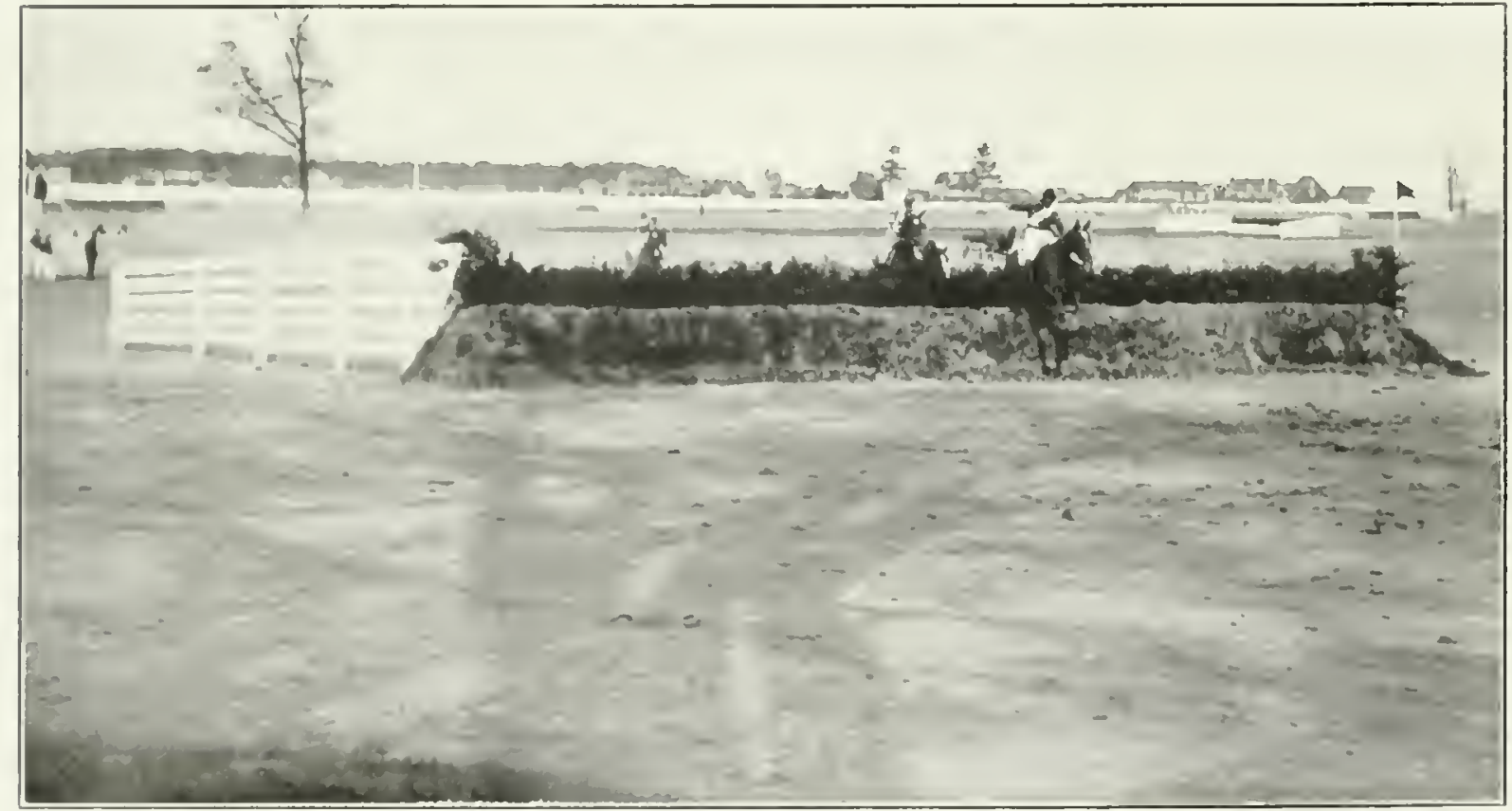




\section{JOHN MACDONALD, J.P.}

I

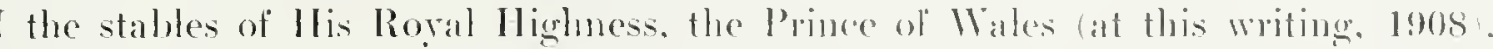
there are a heantiful pair of harness borses purehased for the prine in 'Toronto by a gentleman who is one of the most prominent resickents of the ( 2 meen ("ity and a most wielely known hevere of the horse. 'The patip mentioned were hought from Mr. John Macelomald. I.l'.. the head of one of ('analats leating wholesale homses. Who in adelition to the managenent of the vast fusiness in aly goods founded hy his hather, the late Senator Maredonatal, has foumd recereation in estal)lishing a premier reputation an possibly the best jurlge of a hamess horse in Camalat. and incilentally it might be mentioned that at least a thousand horses have passed through his hands. Some of the finest harness horses in any of the principal eities in Canada, amel. in fact. in all of the bigre cities in the Inited states, have heen sold by Mr. Maledonald, who since he was old enough to take an interest in anything. has been very fond of the horse, and lats made the high-class harmess horse his hoblyg -practically since ho had his first holhy horse, for when asked low long he had heen associated with the horse he reptied. "lrom infancy." His prize-wimers are many, ambl since the inaluguration of the (anadian Horse show at 'Toronto. he has captured very numerous trophies coreted by those less suceresstul in bringing forward the reat "arriage lorse.

For vears he hats been Judge in the ippointment elasses at the Horse Show, and three reals ago. when Mr. J. Ross Roherteon donatad special prizes for the Appointment dass, Mr. Robertson made a

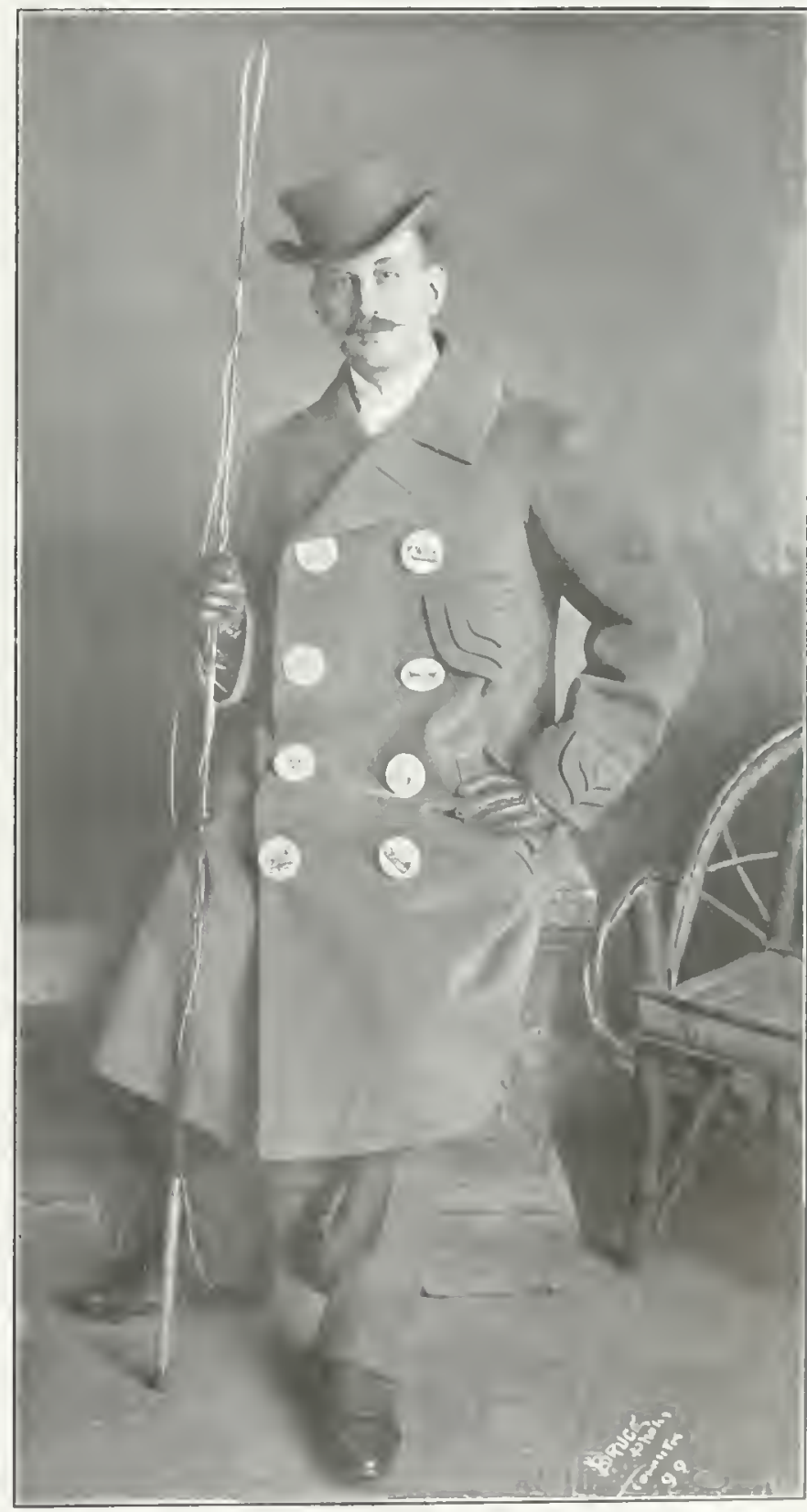

Jom Macounale J.P 
provise with the terms of the enift. and it was that Mr. Macalonald shonla be the solecetion as the Julge.

Ir. Iarelomalel's work in the interests of the carriage horse has been a hahor of love arowned with splendid suceess. He is a stiekles for detail on all points, and his spacrons stables on (umberland st.. Toronto, supplying ample and comfortable accommodation at all times for his horses, are always well filled. He has heen a consistent exhilitor at the Canadian National Exposition in 'Poronto. and has won many honors. It the 1907 fair his ehief wins were a first in the open four-in-hand and first in the pairs. Mr. Maldonalet levotes most of his leisme time to his horses. but is at all times a friend of sport. He is honorary presielent of athletic oreanizations lae does not know the name of. hust they have received from him liberal support in the nature of help that is of the substantial kind, and very necessary for the suevess of everything in encereral. and particularly for the welfare and promotion of varions athletic assoCiltions.

Iersonally. Mr. Macelonald is the sterling type of the energetic Canatian business man who looks upon punctuality in all things as an index to the suceess of the project. as well as thoroughly realizing the fact that to try to do too many things al once is detrimental to the proper progress of some of the things gou want to do. so he satisties himsolf with his commeredal obligations and his devotion to the horse. Ile is casy of approaleh, and husiness comes to the point on the initiative. The husiness he controls as president of John lacelonalel \& Co. Idinited. Was founded by the late Senator 1larelonald in 18t9, anel is still carried on undere the time-honored name of both father

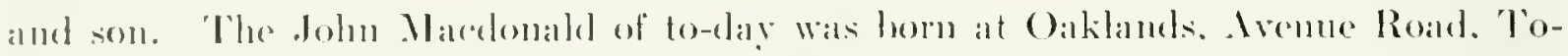

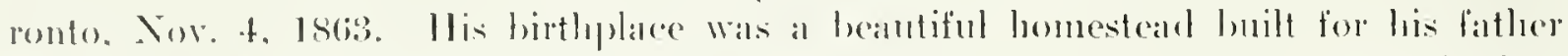

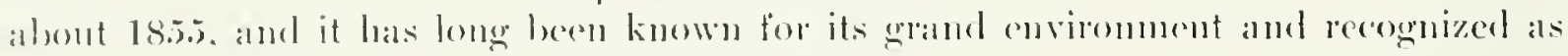

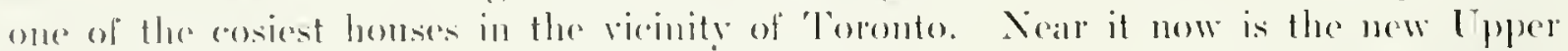

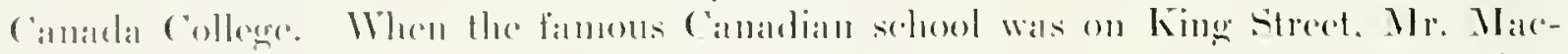
demald was one of its brightest students duriug the time he was being fitted with a

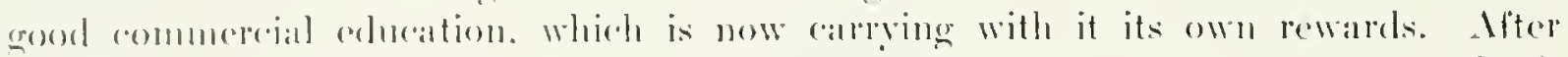
(anpleting this education he entered his father's husiness homse in 1839 . 'This lmsi-

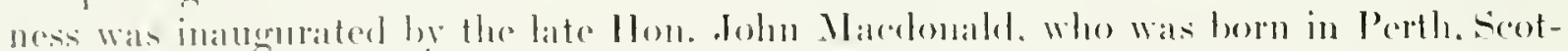

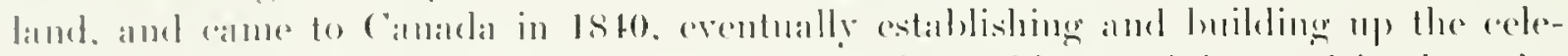
brated mereantile honse known thromgh the whote of this lominion and in the prin-

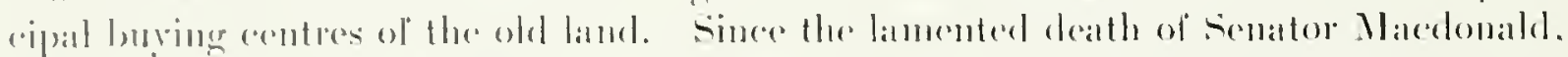

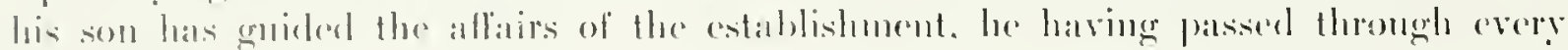

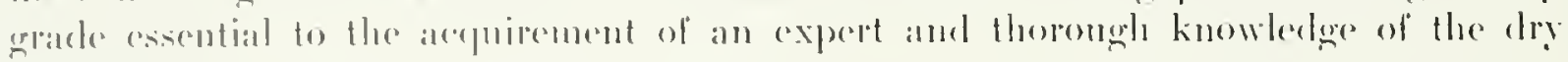
iroods triale.

Ml. Maredonalal is patriotice. But has elevoted his patriotism to the commeredal

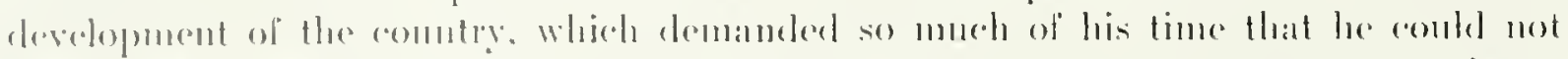
sere his waty to assume military responsibilities moless necessary. It is a mote of inter-

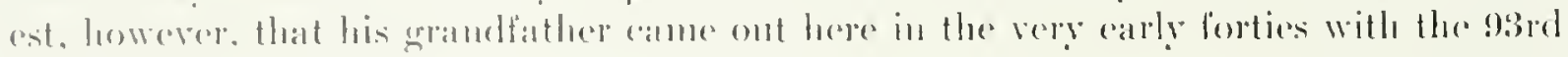
Ilighlanders. who were stationed in 'Toroute. 


\section{Lovers of the Horse}

Is a zealous supporter of the commercial interests of the city of 'Toronto. Mr. Macelonaled is a valued member of the Boind of Trade, director of the Bank of Toronto, and rlirector of the conferleration Life Assuranee Co. He is a Justice of the Peace for the county of lork, member of the National ('hub, and is associated witl the Caledonian Society. Commercial 'Travellers' Assoriation. York Pioneers, and the Incient Order of United Workmen. Ilis energy has been a factor in the development of the mereantile conmmity of 'loronto, while his etforts on belalf of the good carriage horse have been productive of equally satisfactory results. His characteristic traits are a mixture of modesty and husiness. which have earned for him an enviable popmlarity in all spheres. On August 5, 1903. Mr. Macelonald marred Miss claire IHungrerford, daughter of Mr. W. A. Hungerford, of Belleville. Ont.

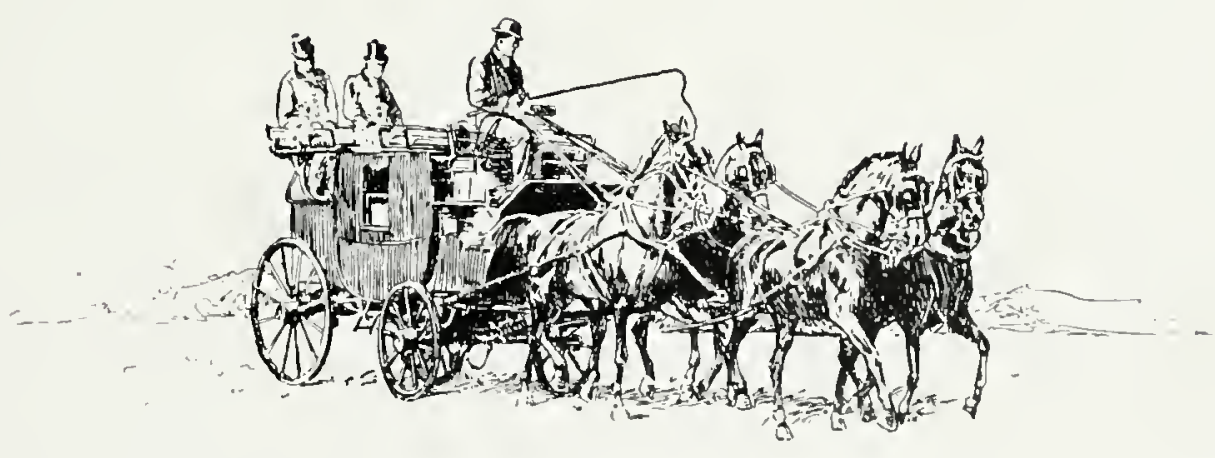




\section{DR. DAVID KING SMITH}

$\mathrm{D}$

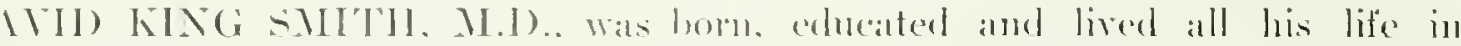

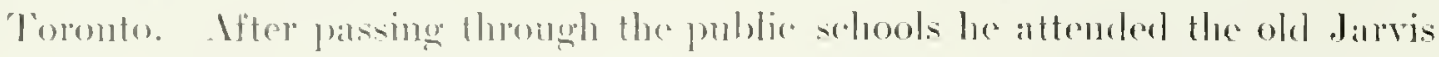

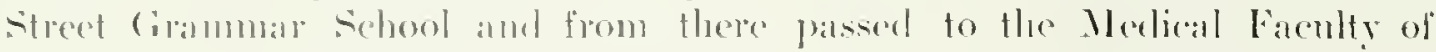
Turonte Iniversity. from which he enduated with aredit on the completion of the

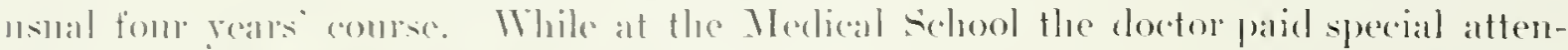

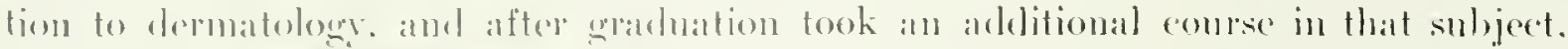

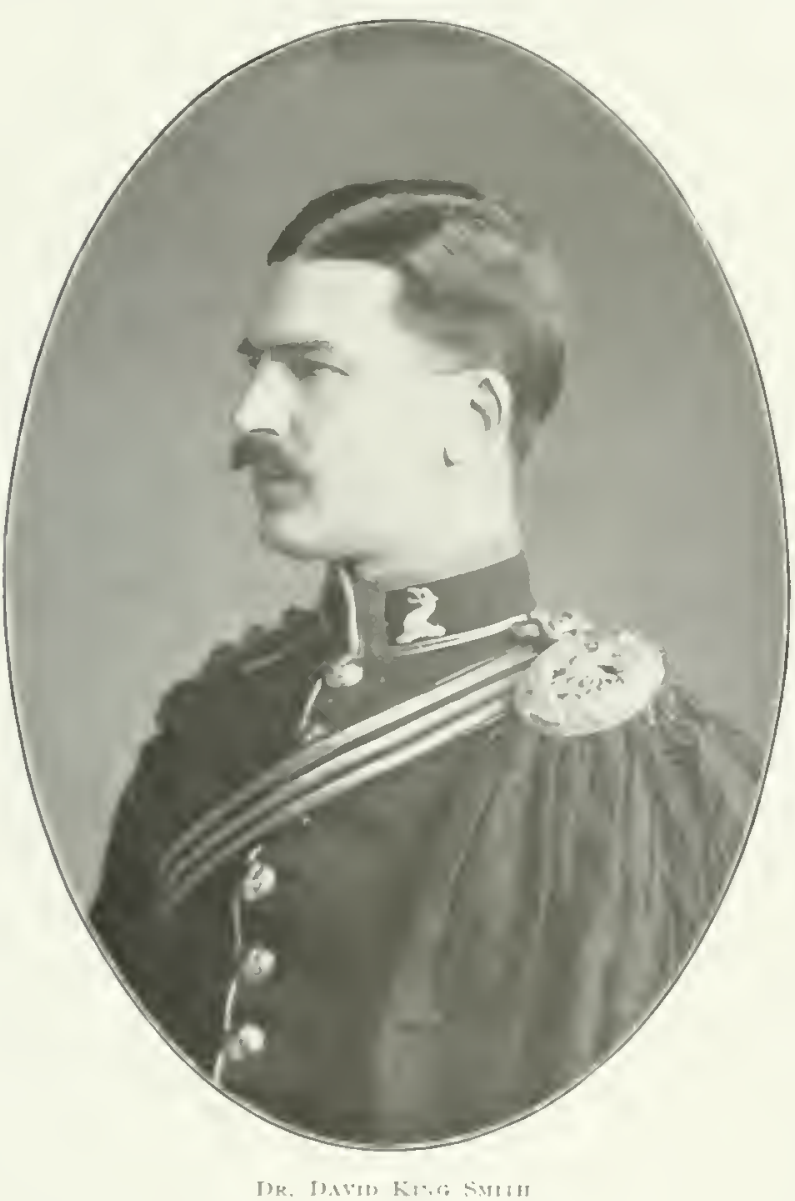
oll which lac is now a recognumed atuthority, as well as being an expert in practice.

1)r. smith's interest in lorses began very arly in life. He was tamght to ride almost in lis infanere and thomgh at the presont time only in the early thirties. he has leeen an enthusiastic follower of the homols for twenty yours past. and few members of the Ilunt ('luh have carried ott so many prizes in the ('luh competitions. "llae boetor lias owned mamy fine limuters doring the past len or twelve reals. lunt among them all his favorite was Athol. with whom le won the llalker ("iip) in the llunt ("lul, Sterplechase. 'The loretor, in lacet, is one of the memferes of the (lul, whe lase contributed largery to the improvement of humlers in (Ontario in recent rears. He lass spaleed neither time nor laber in lis

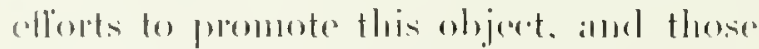

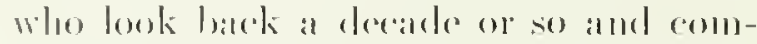
pare the mombts at the meets of to-elay

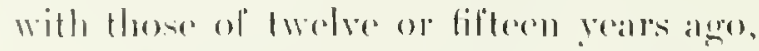
will apprereiate the deht of erratitude whicll horrement owe to him and those

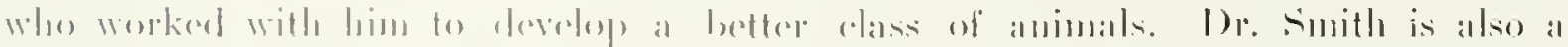

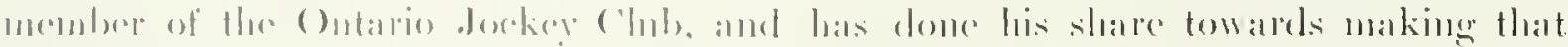

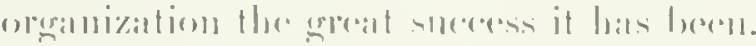

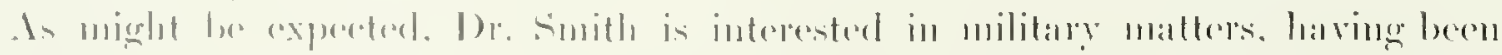

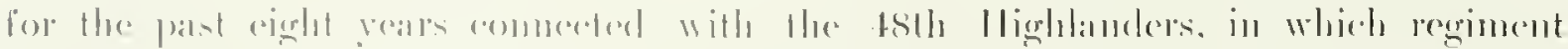

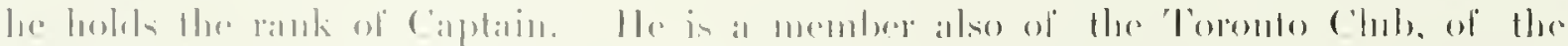

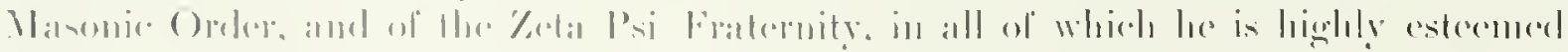
louth lor his abilition and his areial qualities. 


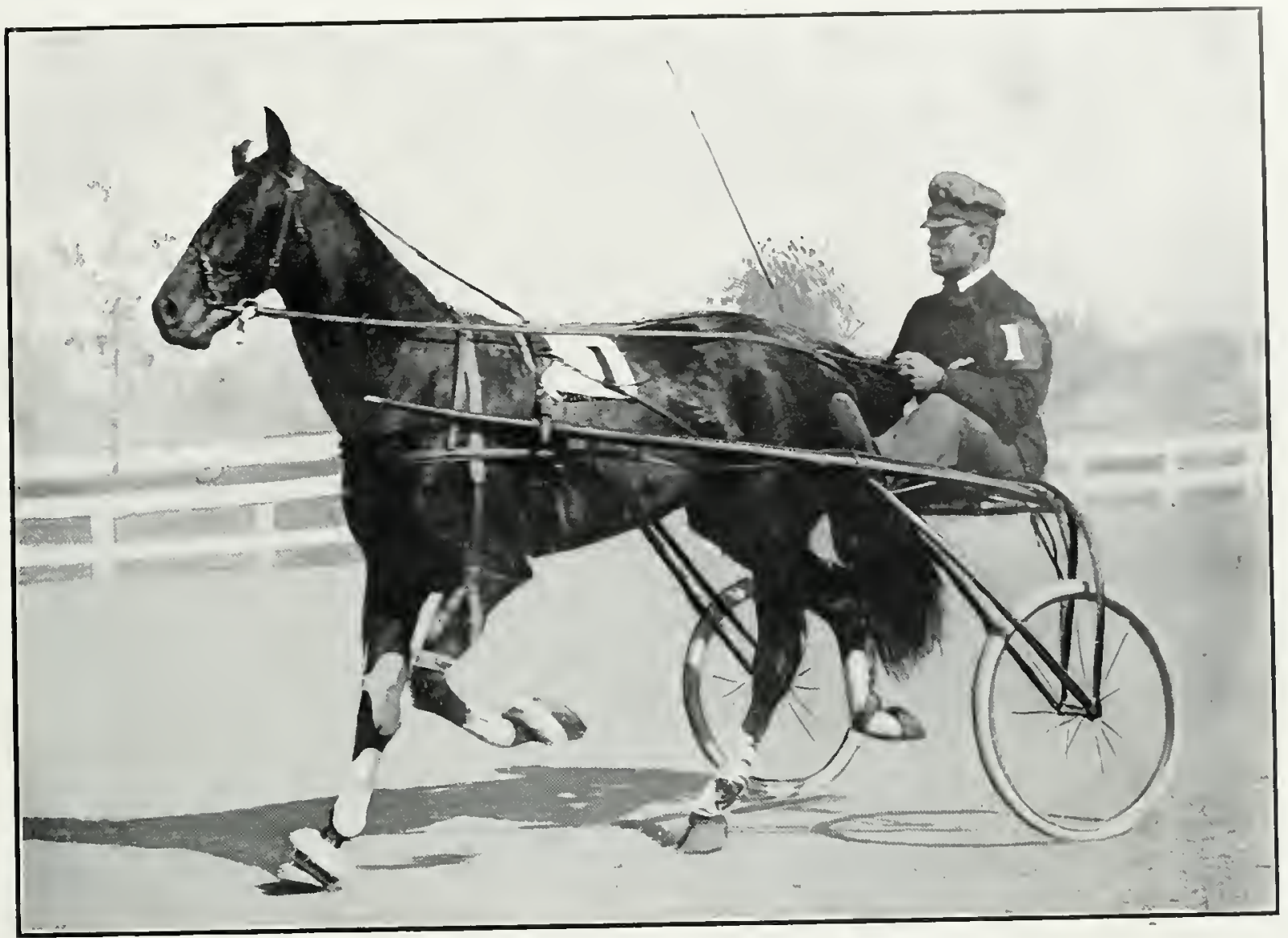

"Kentucky TODd," Property of Miss W11 ks, Crutckston Park, Galt, Ont.

\section{MISS KATHERINE L. WILKS}

$\mathrm{A}^{\mathrm{T}}$ LTHOIGH not altogether a rarity, it is musual to see a lady of such high social position as Miss Katherine L. Wilks, of Cruickston Park, Galt, interested in the breeding and racing of the light harness horse, or for that matter, of any other kind of horse.

To be sure, Miss Wilks, who has an ancestry of worth and wealth, and the entrec to the most exclusive society of America, being a member of the great Astor family of New York, adorns lier position with the most gracious and charming hospitality. She yet prefers the attractions of her Canadian estate to the all-absorbing pursuits of New York's "four hundred."

There are, indeed, feminine owners of lace-horses in both Great Britain and the United States, but Miss Wilks is exceptional in that she possesses a stock-farm of over a thousand acres on which she breeds almost exchsively light harness horses.

Within the last few years she has spent an enomous amount of money in further- 
ing this fancy. and althougl it has been a rock of destruction to many ambitious breeders, this lady. with extrandinaly hosiness acumen, has achieved gratifying success.

Miss llilks has consistently pursued that polieg which embodies the principle that it pay to buy the best. It wats this reasoning which induced her to pay fifteen thomand five lundred dollars for sadie Mac, the highest price paid for any mare during 1904. When the queenly sadie Mares former owner offered thirty thomsind dollars for her return the sheredest horsemen on the continent thought ond ('anadian

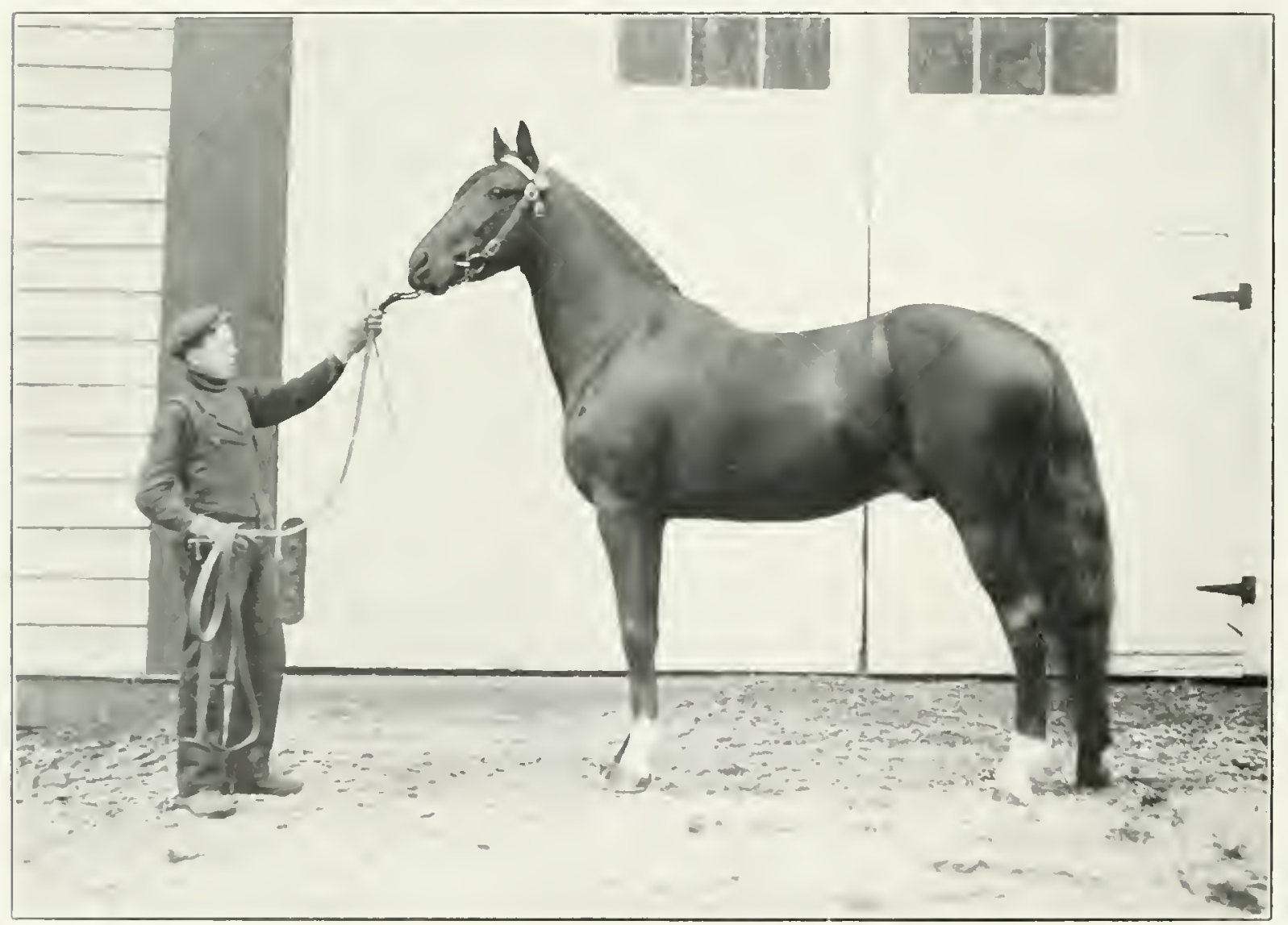

Mtss Whass" MonkM

horocemoman was labrlly justified in refusing sueh a princely sum, but her jurlgunent was brilliantly sustained in carly results.

Sarlie Mae ontshone all rivals on the Grand ("ircuit so easily that the trainers and

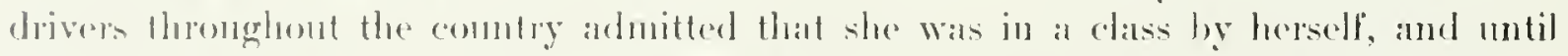
she dropped deat in that lateful race at llartford. she was absolutely invincible.

Comickston lark is becoming one of the great show places of Ontario. Situated

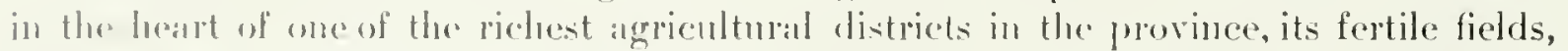
forestecowned hills, lovely vallegs and superd avenues, rival those of some of England's beautiful combly scats. 
There are orem a hundred horses in this equine paralise, and Miss Wilks is known to every one of them personally. She is a rare judge of harmess horses and is a fearless driver.

Some of her favorites ane: her beautiful mare, Lady Creseens, daughter of the

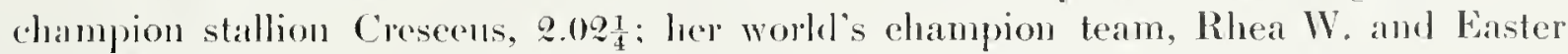
Bell: Katherine L., a beatiful male by Liberty Chines: Oro lambert, a level-

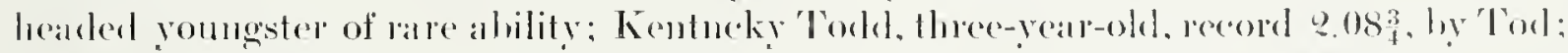
Mograzia, beautiful level-gaiterl National show champion trotter, by Moko, and the famous primer stallion, Oro Wilks.

Miss Wilks was mufortumate in her racing stables in the cally part of 1906 . 11though she sent out a string of good horses in the spring. bad huck seemed to pursue her, and, one by one, her horses met with misfortune, mutil it began to look as if the Cruickston Farm would for that year be coweded out of racing records altogether.

Miss Wilks has indomitalole pluck, however, and notwitlistanding lee persistent reverses she went on with her training of Kentucky 'Todk and entered him for the fall meeting at Lexington, where his phenomenal combination of speed and staying power won for him the enviable title of ehampion two-yeal-old trotter of America. As if this were not enough to redeem the stables. Mr. Wetherill, who manages the breeding farm, won more prizes with his exhibits at the Canadian National Exhibi. tion, Torouto. than were ever before eaptured by a single exhibitor, not only in the show ring, but also in the speed department, while at the famous exhibition in Madison Sipure Gardens le won three firsts and a ehampionship, Mograzia finirly carrying all before hinn. 'The sanc story has been repeated since with of her horses. the show-ring snecesses in 1908 and 1908 more than complaring favolably with those achieverl in other vears.

Miss Wilks owns more standard bred horses than any ladly in Anerica or Europe.

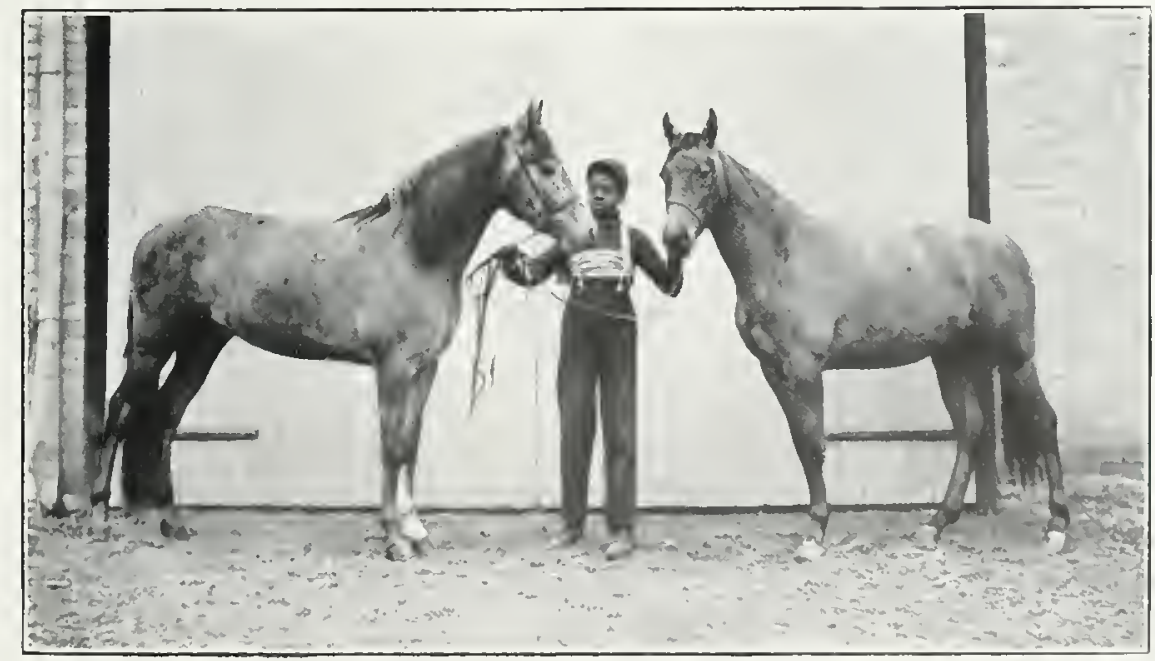

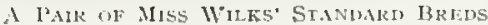


Among the century at the farm now are some of the best bred hosses in Anericun trotting history. whose records rimge from $Q$.08 to 2.30 .

One of the stars of 1907 , and a very promising yonngster, was a grey colt. by Oro Wilks, to whom was given the name of Oro Lambert, and who gained as a tworealpold in the year maned a record of 9.1\%. He is a trotter of the first quality, and is a particular farorite with his mistress.

There could searcely be a more interesting spot in America for a horseman to visit than the big Couckston breeding farm. It has eight hundred acres of magnificent pelsture land, and its stables are models of eomfort and convenience.

Of Miss Wilks herself, one can sealledy say too much in praise, for it is indeed seldom that we find a woman who has the pluck, the energy and the intelligence to successfully manage such an immense undertaking as this, undoubtedly the greatcst breeding establishment of stamdard-bred horses in Camarlat.

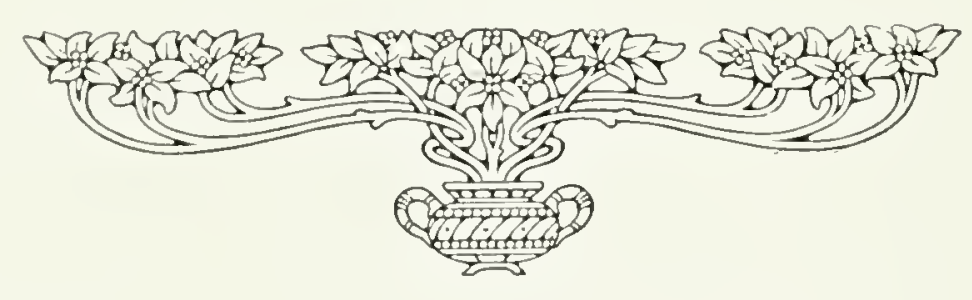




\section{T. AMBROSE WOODS}

$\mathrm{T}$

IIE love of the horse is an hereditary tencleney with 'T. Ambrose Woorls, ats his father, the late John Woods, pioneer wine merchant and proninent Toronto business mall, was also an mustally well-known horseman, and his son, who had every opportmity to develop his fonduess for horses. was not slow to take arvantage of his elanees in this respect. Although one of the youngest, T. Ambrose Woorls is now one of the most prominent horse-owners in Canalab besides having an enviable recold in the show-rings of the Cnited States.

Mr. Woods, who was born in 'Toronto, was edncaterl at Upel' Camada College, going into business with his father after lis graduation, and after his father"s death hecoming head of the business, which, established as it was filty years ano, is now one of the best known houses in Toronto.

Mr. Woods maintains his stable, not for finaneial gain, but for pure love of the sport, and derives his greatest pleasure in schooling and driving his own horses. hunters and hamess horses being his favorites, while in his ability to landle the reins he is suppassed by few.

In $1907 \mathrm{Mr}$. Woods was married to Elsie Belle, daughter of Mr. A. M. Orpen, of loronto, whose interest in horses is too well known for comment. Mrs. Woors is in perfect sympatly with her lusband's tastes, and is an exceptionally clever horse-woman, both in the sidclle and with the ribbons. She has driven

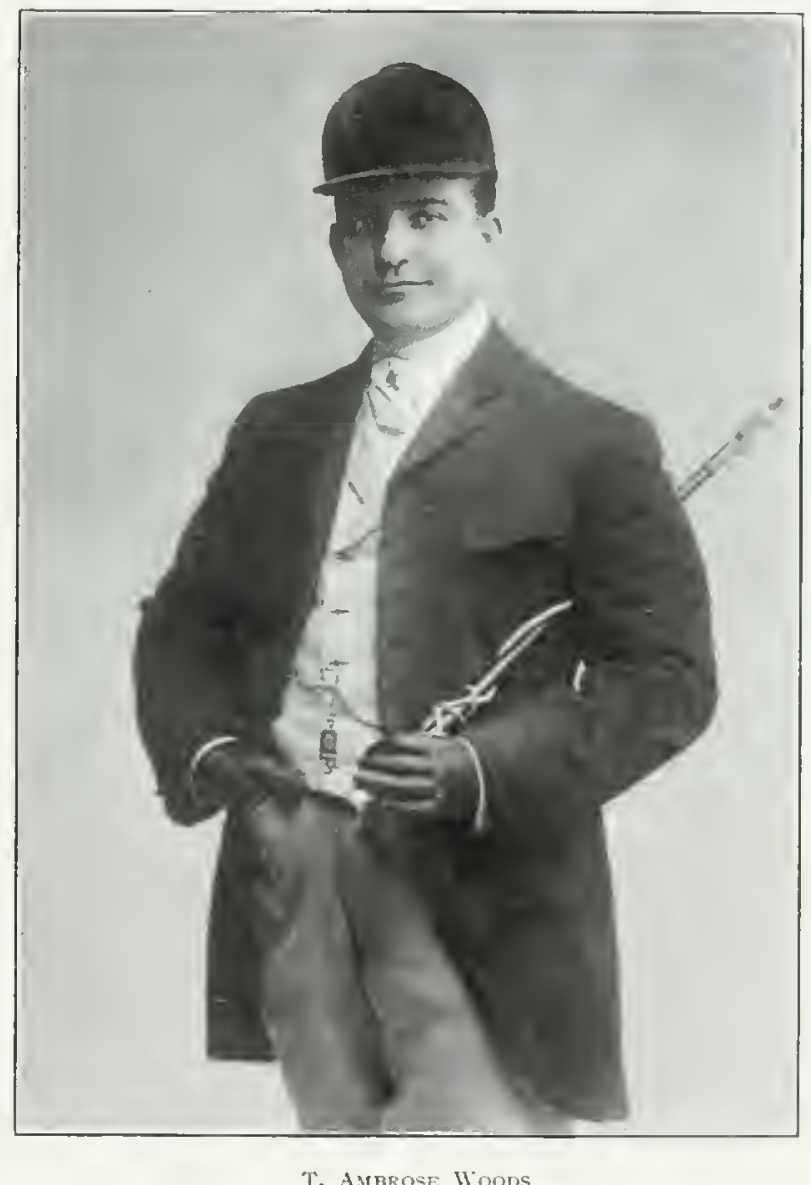
and ridflen her husband's horses with great suecess at many of the horse shows.

The sensation of the Spring Meet at the Woolbine. Toronto, in 1907 was the winning of the King's I'late, the biggest event of the Canadian turf, by Mr. Woorts' horse Kelvin, who galloped home in front of a big field, snatching the lanrels from all the big Canarlian stables which devote both time and money to breeding horses for this event alone.

Kelvin was purehaser by his owner from the late Willim Hendrie as a vearling, and is royally bred, being by Martimas, the only Camadian horse which has erer won the big Finturity Stakes. Mr. Wools purchased Kelvin nore for show purposes than 


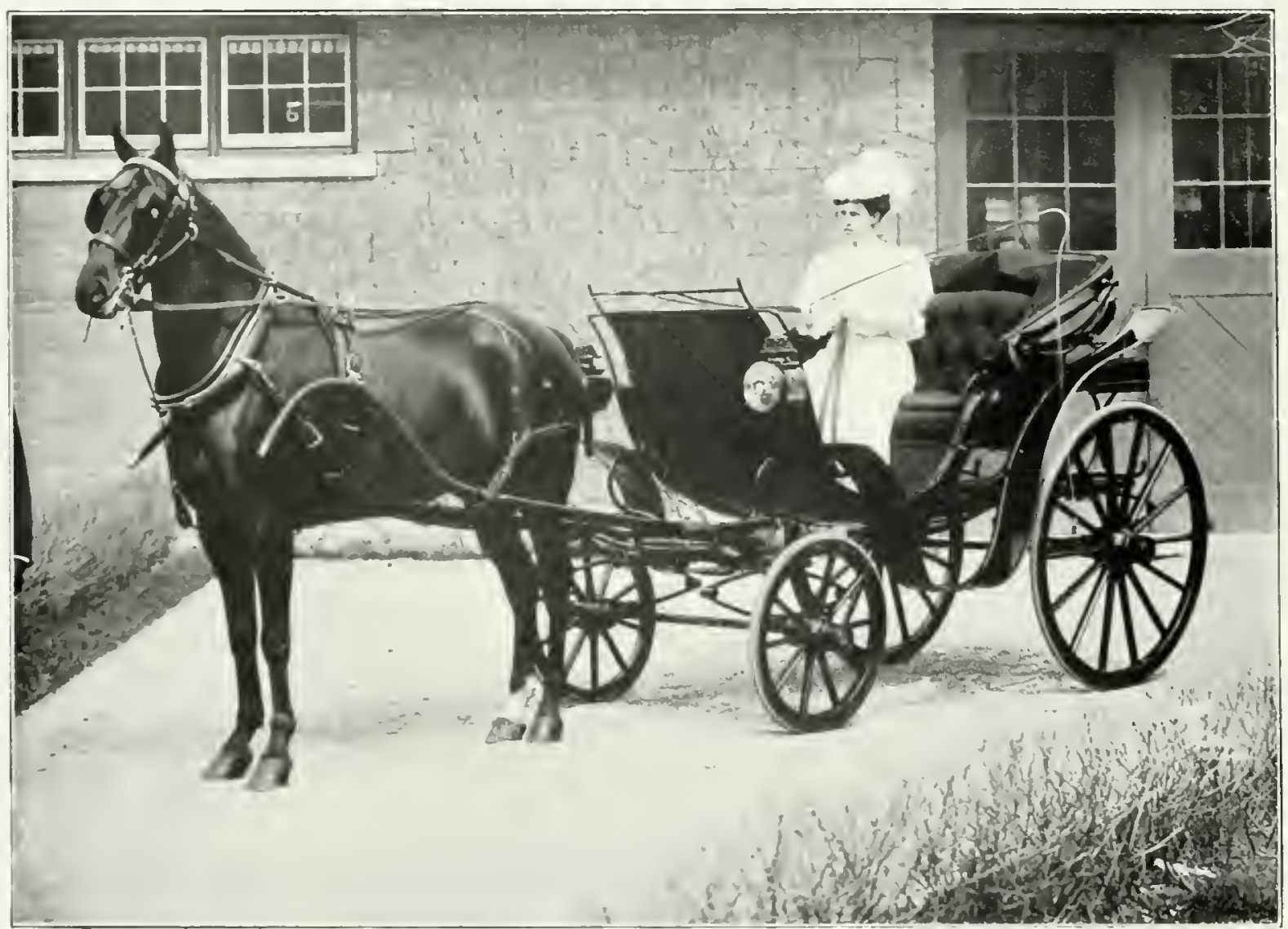

LUMD, DRIVEN BY MRS. T. AMHKOSE IVOM

lor raleing, as he has perfecet conformation. At the Canadian National Exhibition, as a rearling. he won the first prize ribhon for stallions and angan at two yearsold repeated

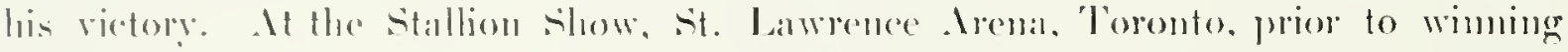
the plate he again won first prige for stallions. Showing some good trials as a pour-

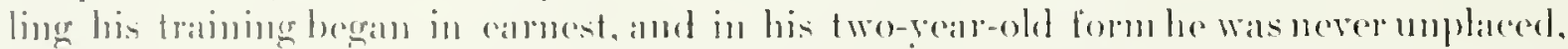
and when the memolable Plate lay eame in 190 a he male his owner the proudest man in 'Torousto by anmexing the groneas donated by IIis Majesty King Edward. Ile

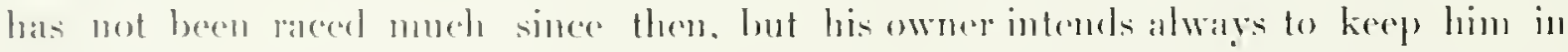

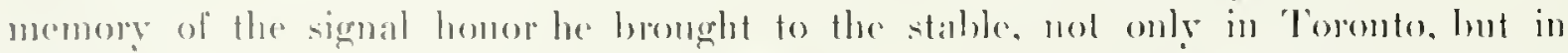
Montreal, where he easily defeated the winner of the Kinges Pate in the Province of (vilebere.

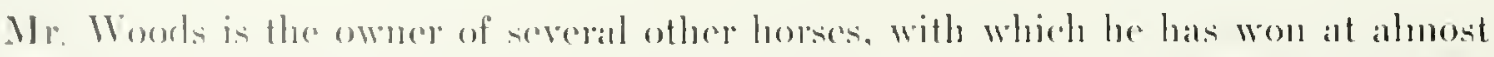

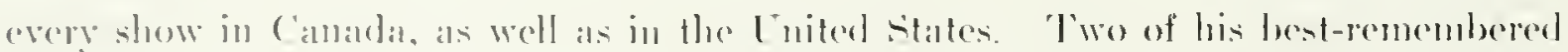

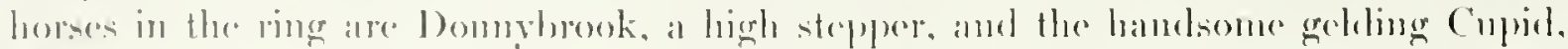

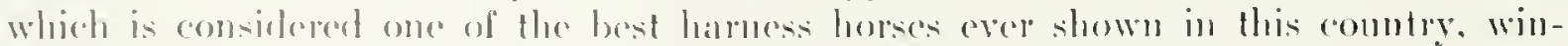

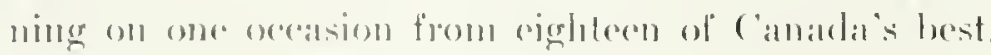

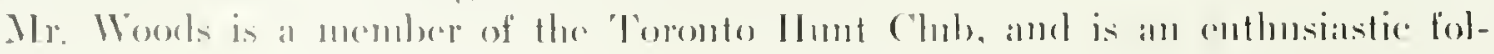


lower of the hounds. Ile is also a prominent member of the Ontario Jockey Club, and several husiness clubs, and has been an enthusiastic admires and promoter of amaterr sports of all kinds. Thromgh his activity in this regand he has manle many friends, and is well regarded by all those who know him in sponting cireles and ont of them.

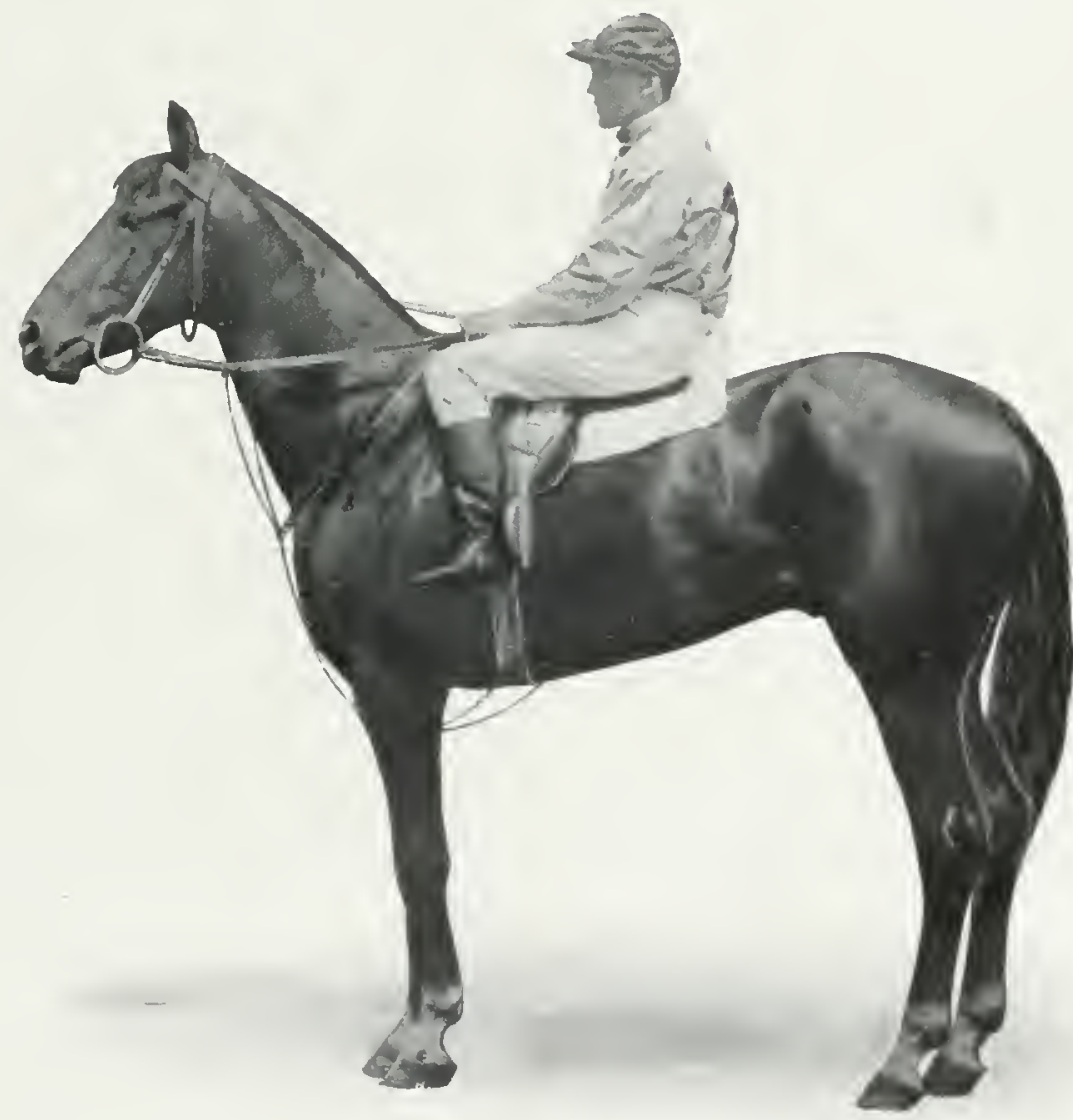

"Kelvin," lir, H. Martimas- Nancy LeE Winner of King's l'late, 1907. Woudbine, Torontu 


$40 \quad$ Lovers of the Horse

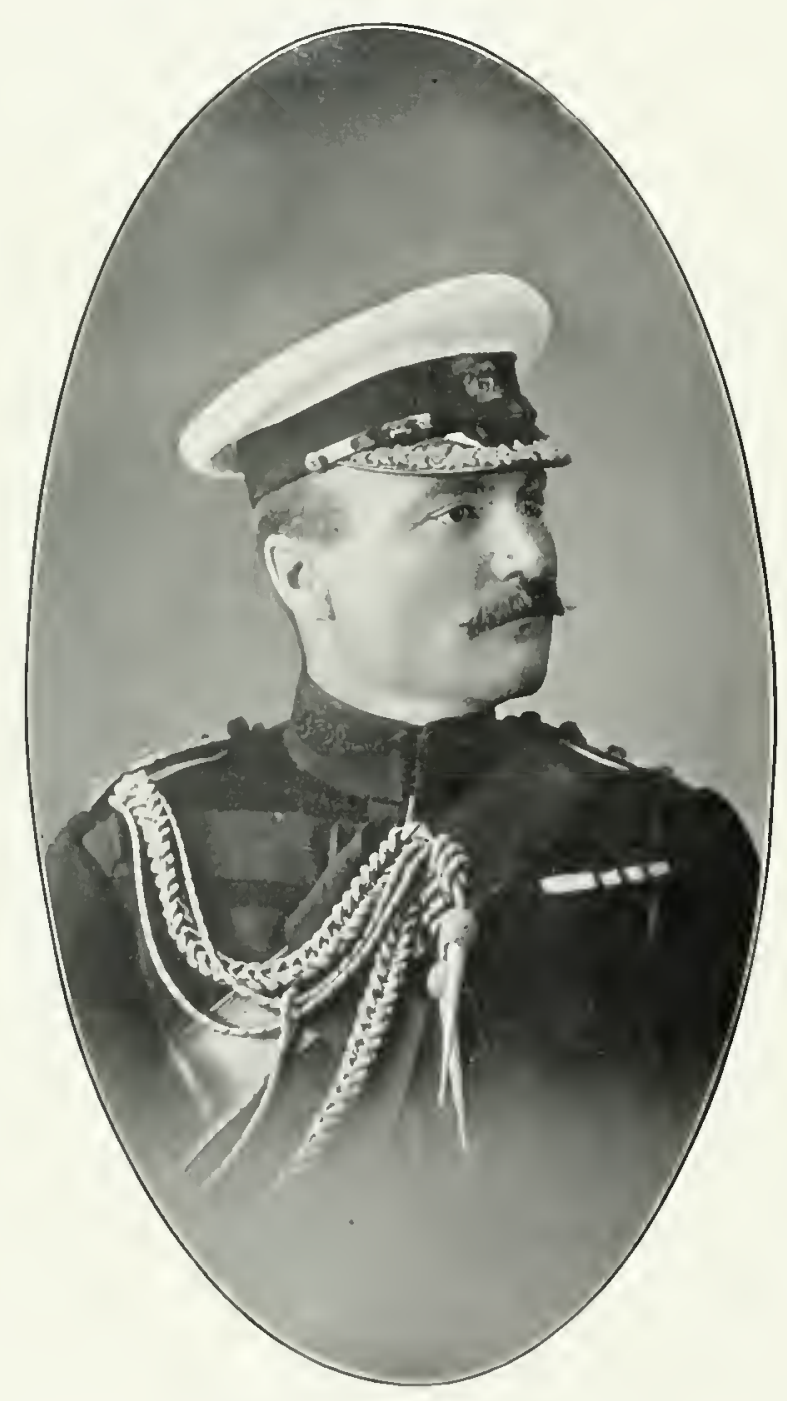

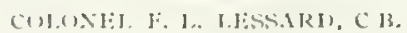

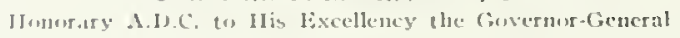




\section{THE TORONTO HUNT}

\section{$\mathrm{T}$}

CIIE 'Toronto Hunt is probably the most popnlar institution in the smart set of the Queen City. It was not until the year 1865 that Toronto, then a town of only about 40,000 population, could boast of an orwanized IJunt. There is. liowever, a meet of hounds on record held at the top of Bathurst street. on April 30. 1869 , at which history records that every available horse and saddle was brought into requisition. This was not a meet of the Toronto Ilunt, hut a meet of a private pack belonging to an Englishman named Steers, who had, during the few precerling years, kept half-at-dozen couples for the amusement of himself and his friends. No doubt, however, it was largely due to the enterprise of Mr. Steers that, in 186.5, a number of Englishmen got together and organzed the Toronto Innt. Anong the gentlemen actively concerned in the organization were to be found those having such wellknown names as Copland, Worts, Hendrie, Ciodson. Thomals, Smith. Ileward, Boswell, Leys, Dundas, Bond, Walker, Nordheimer, Dwight, Kiely, Donaldson, shedden, Gillespie and Crooderham. Most of these gentlemen have passed away, but there are several who are still active members of the IIunt. Nearly

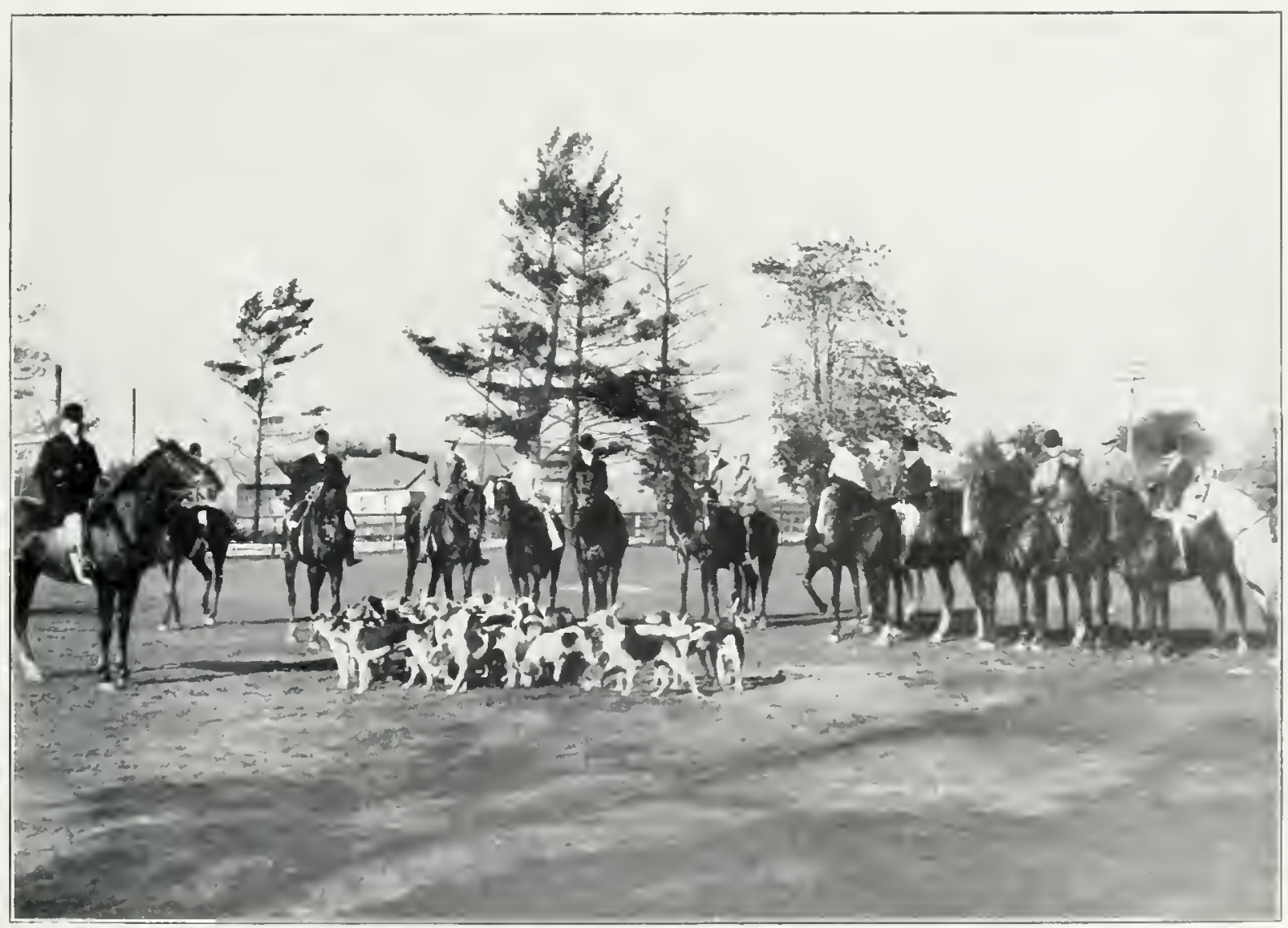

THE TORONTO HUNT 
all of them calme to Canada from the Motherlamed, and they met together for the purpose of perpetuating in the land of their adoption the sport wheh they and their forefathers had so long supporterl in the land of their hirth.

"To Mr. Copland belongs the honor of being the first l'resident of the Toronto Hont: that grool sportsman. Mr. John Hendrie, arreving the horn for the first two yeirs. with , Iohn Ilalligan as his first whip. A few rouples of homols were purehased ind the palck was strengthened from time to time hy presents from various entlusiasts. and by the time the Master called the opening meet in the autumn of 1865. a very presentalide palck was in evidence and from that day to the present the Toronto Munt has met two days cropy week - spring and alutumn.

Owing to the nature of the comenty it was seldom possible to lumb anything but the drig. but good sport was enjoged, and like all true sportsmen. the members conduded that if it were imposible to hunt the live fox. they most lave the next best thing, and. no matter what happened. they must bunt.

Adelitional strengtls wats given to the newly-fomed llunt by the ardrent of the 13th

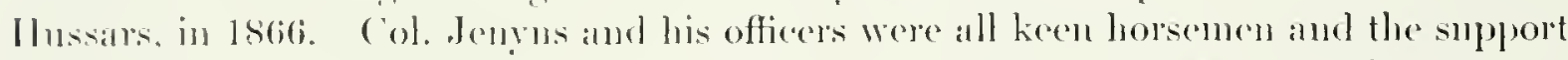
which the Chub received from them made it nore than ever certain that the sport of

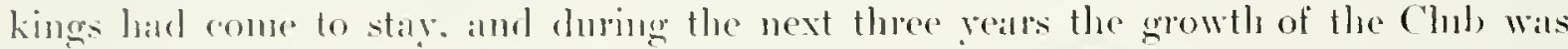

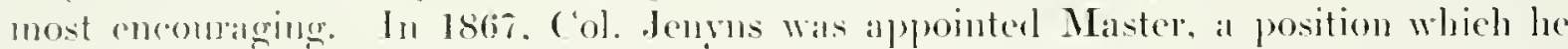
lield for two yeass. during which period the sport flomphed, and olten the saturday

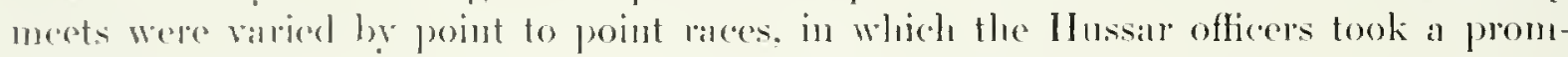
inent pirt.

An extract from an anticle in a 'Toronto palper of Xos.9, 1868 , written by an ling-

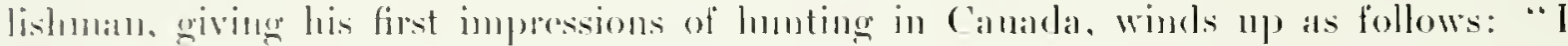

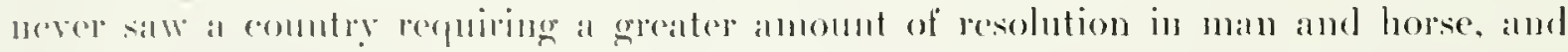
as to sllake fermes, I think I woukl almost rithere go at a stiff English fence, where the bullfuches are strong and thick, than lum lhe chatires of being spread-eagled in one of throm."

In the spring of 1869 the IInsials were recallerl and their horses were sold al auction. 'The prices fetched ly some of the lunters may lye of interest, showing lhat "rem in those dars a good humiter eommanded his price. Mr. Bieber"s " "itarlel" sold

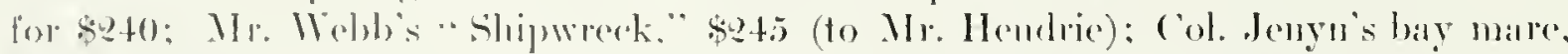

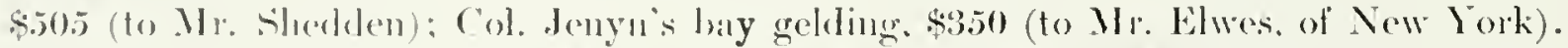
After (ol. Jemrol's departure. Mr. Hendrie aginiu assumed the Mastership. which posi-

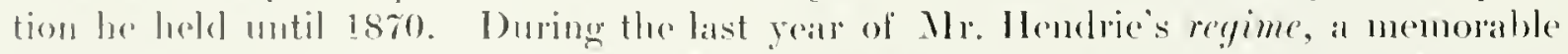
trip was malde hy the 'Toronto Ilunt Club to Ilamilton, lyy the Great IVestern Railway,

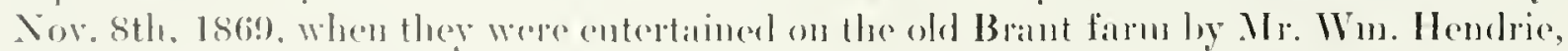
and an enjoyahle afternoon's mun was had on the farm limits. 'I'he meet was at Wellington Siquare, mear Hanilton, and many amusing incielents during the day's sport ilre still perorderl.

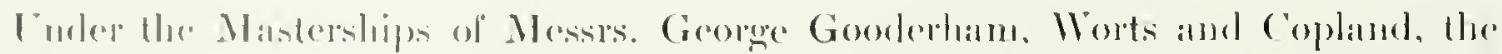
llumt ("hul, eontinued to flompish for the next ten years. The meets were always woll 


\section{Lovers of the Horse}

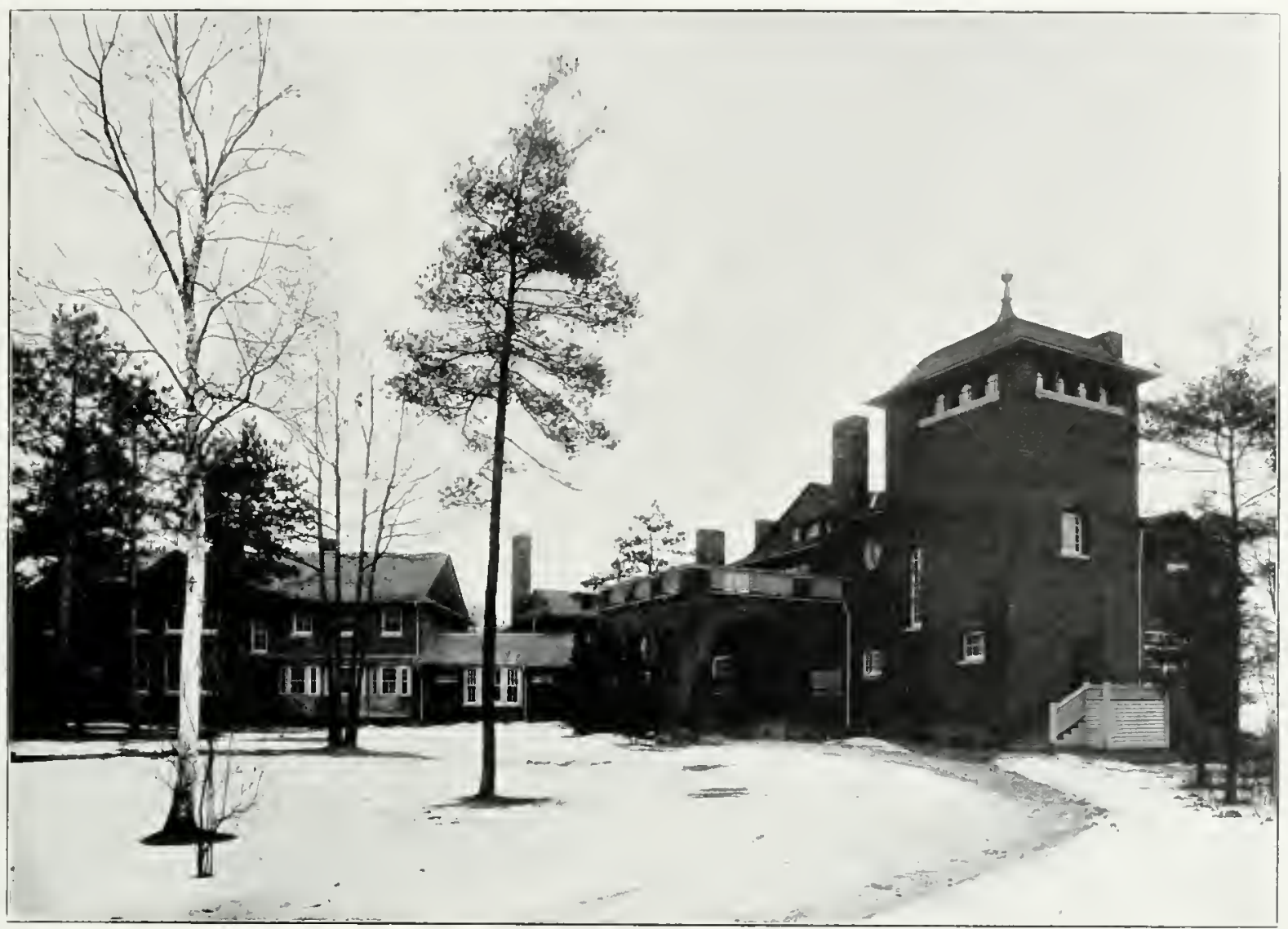

The Toronto Huyt Club-house

attended, there being seldom less than forty or fifty present, all well mounted. including, as a rule, five or six ladies. From time to time, the kemels, still muler the carchul management of John llalligan, with 'Tim Blong as kemelman. were replenished with fresh drafts of homuls from England and elsewhere, and gradually the 'loronto Hunt worked its way into public prominence as a sporting organization. Frecpuent hunt meetings tended to increase the interest in steephechases and ross-rountry races. and many keen and exciting contests were ritnessed on the impromptu stepplechase courses in and about 'Toronto. In 1883, Dr. Andrew Smith, one of the originators of the IIunt (and still a most enthusiastic and active supporter of it) was elected M.F.H., which position he retained until the reorganization of the Chub in 1893. 'Too much eannot be said of Dr. Sunith's untiring efforts in the canse of good sport, and too much eredit cannot be given him for the time and energy which he has devoted to the Chub from its ineeption and the interest which he still takes in it. Suffice it to say, that under this good sportsman the Chub continued to prosper and the meets became more and more popular, nutil the ('luh grew to such proportions that a complete reorganization wats necessitated in 1893. The late Mr. D'Alton Mc Carthy was elected President, and Mr. George W. Beardunore, Master. By the summer of 1894, drafts of hounds 
hat been imported from such kennels as the "Fitz William," the "Warwickshire," the "Cottesmore," the "Belvoir," and the "Ciraftons." not to mention the Master"s gift of six couples of lounds purchased from the Montreal Itunt. In extensive area

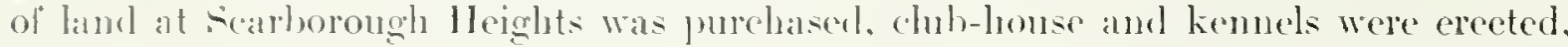
new huntsmen and whippers-in appointed. and ML. Creorge Beardmore, on the completion of the stables in the early antumn, furnished them from his private stables at Chudleigh with horses for the huntsmen and all the IIunt servants, which he has gracionsly continued to fo till the present day, although this fact is only known to a few of the members. With such determined spirit of sport hat the new blood entered into their work of reorganization that the opening meet of that year is recalled with pirdonable pride. It was a large and fashionable meet, and prominent among all to encourage Mr. Bearture was its ever popmlar former Master, Dr. Andrew smith. I thoroughly good opening meet was followed by a thoronghly good seasom. From reatr to pail everthing continned to flourish till the eleath of the chubs President, in 189s. Itr. Hec antly antinely and lamentable death was sincerely mourned. not only loy the lunting fraternity, hut by every true lover of sport in the bominion. 'The loss to the Toronto Hunt was irregarable. but fortunately for the Club. the Right Honorable the Larl of Minto. then Covernor-General of Canada, and ever ready to promote good sport. gracionsly anceeded to the reepuest of the dineetorate and honored the ('luts by becoming its l'resident.

Frem the inception of the foronto llunt. the one idea paramonnt has been to give spert in the hunting field and to encourage all ofher sports. Ilow well this has been carrief out in the last fourteen rears may briefly be put dow as follows: Complete reorgantization, 1893: furchase of valuable property, searborough Jleights: building (Chb-honse with all convenienes and sufficiently latrge to dine 100 people; building of model kennels: buikling of llunt stables: buikling of polo stables: preparing golf links; prepanting polo field; anmual rane meetings or gromkhanas: anmual lIorse show.

The spring houting lasts from six weeks to two months, the autumn three to four: the meets, counting the early moming lmus. thee times a week. 'The western

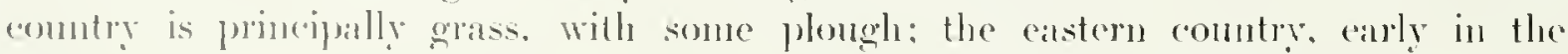
spling and late in the season, heary going. In both directions there are few ditches. and the ordinaly Canadian suake fences. 'The most useful monnt is a short compled hlood horse, imel it would he hand to imagine a better comutry to make a goonl chisser.

To the Ilunting Iaties of the ('Int) is due the organization of the first Race Meet-

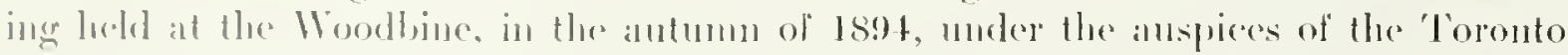
llant. The ladies formed themselves into a Raree Committere with Mas. J. K. Kerr

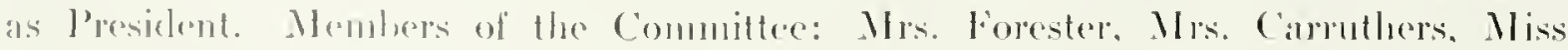

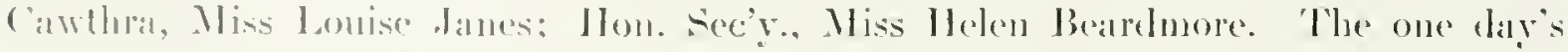

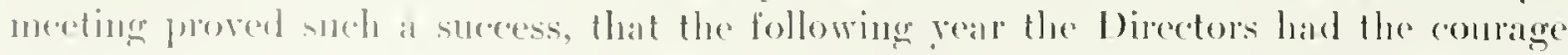
to follow in therir footsteps. 'Tlue meeting beeanne an anmual one for seven days until 
1902. When the Autumm Hunt dates were taken by the Ontario Joekey Chub. 'The same success, thanks to the Toronto Hunt, has marked the anmal Toronto Ilorse show. When the Hunt ('hul, was striving for an existence, the ladies worked with that spirit of sportsmanship which has done much to bring about the immense sueeess the Horse Show enjoys to-day. No association in Canala has done more to promote and eneonrage the breeding of the right kind of horses than the 'Toronto, or, as it is generally termed, the Cimadian Horse Slow, which las an enviable name all over the continent and which increases in popularity every year.

The Inriving Section of the Toronto IImnt Club is a most enthusiastic body. The 'Toronto Riding and I)riving (lub was organized many years ago. 'The first President was Mr. J. K. Kerr. K.C., and the first Vice-President, Brigadier-Cieneral Otter. K.C.B. 'Tlue Club at this time was composed of thirty or forty members, who net on every saturday afternoon during the sleighing season, and after driving around Queen's Park and through the city, would proceed to Earlscourt, some four or five miles from town. where they would all dine, have an informal danee and drive honte in the evening. 'The house which the Chb had leased at Eardscourt was large and beantifully situated, and the stable accommodation was commodions. 'The menber-

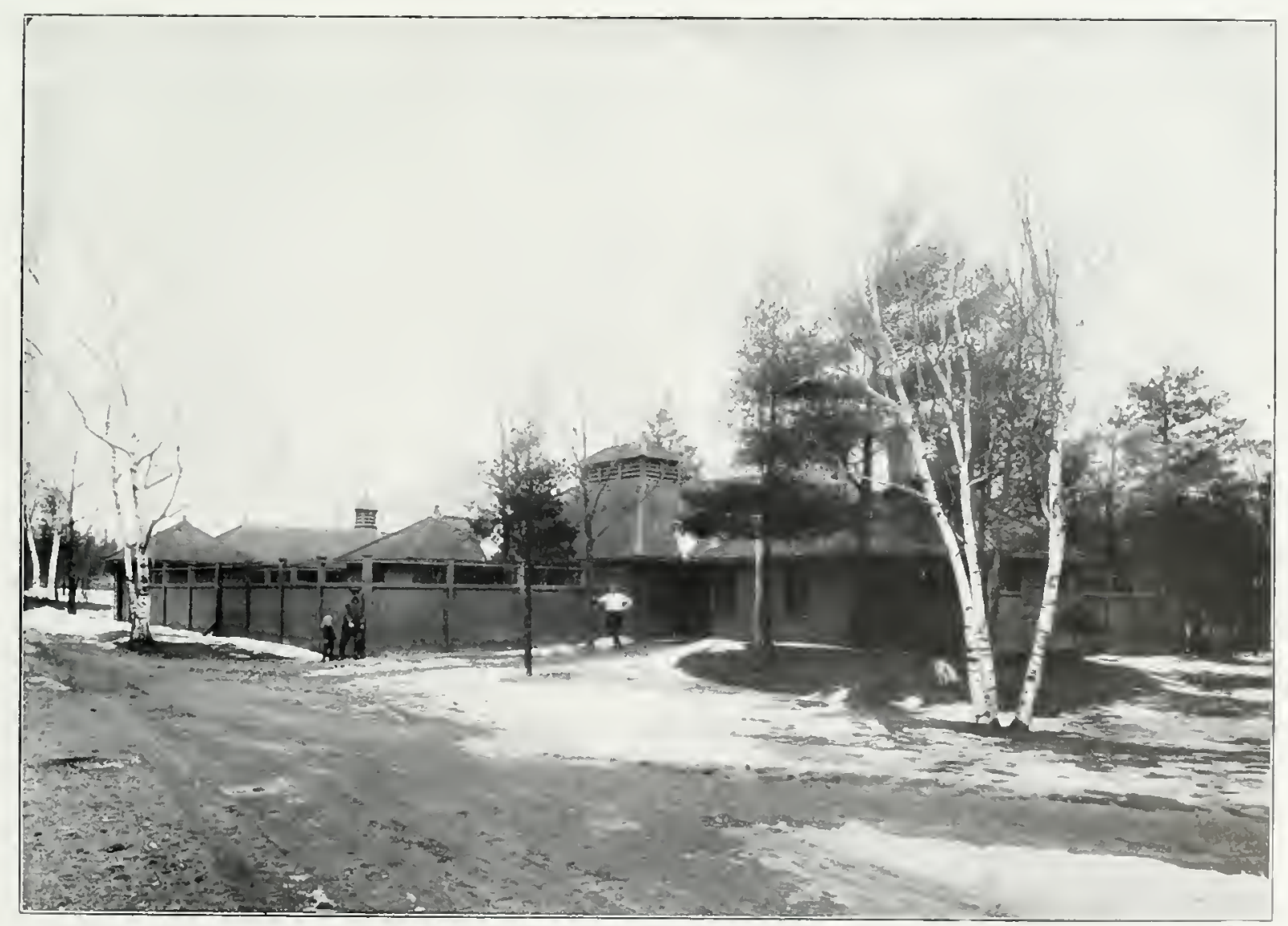

THE Tokonto HI:NT Ki:NSELS 
ship gradually increased to sixty-five. In those days many tandems used to tum out with these meets, as well as one or two fomr-in-hands and micorns, and a number of pairs. When the 'Toronto IIunt Club erected its leantiful elub-house at scarborough Heights. the Riding and Driving Club joined the Hunt ('tuls and becanse what was known as the I) riving seetion of the (lub. The drives are continued in the same way as before. only that they proceed to scarborough Heights instean of to Eartscourt, as previously: Some of the prominent early members of the ('lub were: Col. (i. 1. sweney, the late Major Hay, Major Sears, the late Mr. I) Mlton Macarthy, (aipt. ( . X. Shanly and Mr. Edwin Heward, Driving ('lubs in Canada were instituterl some forty years ago. when the English regular troops were in the eomtry. The officers took a keen interest in sleighing and enjoged the splendid sport of driving a four-inhind, unicorn. or tandem.

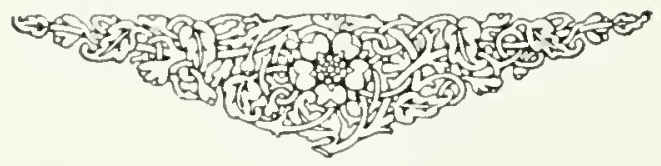




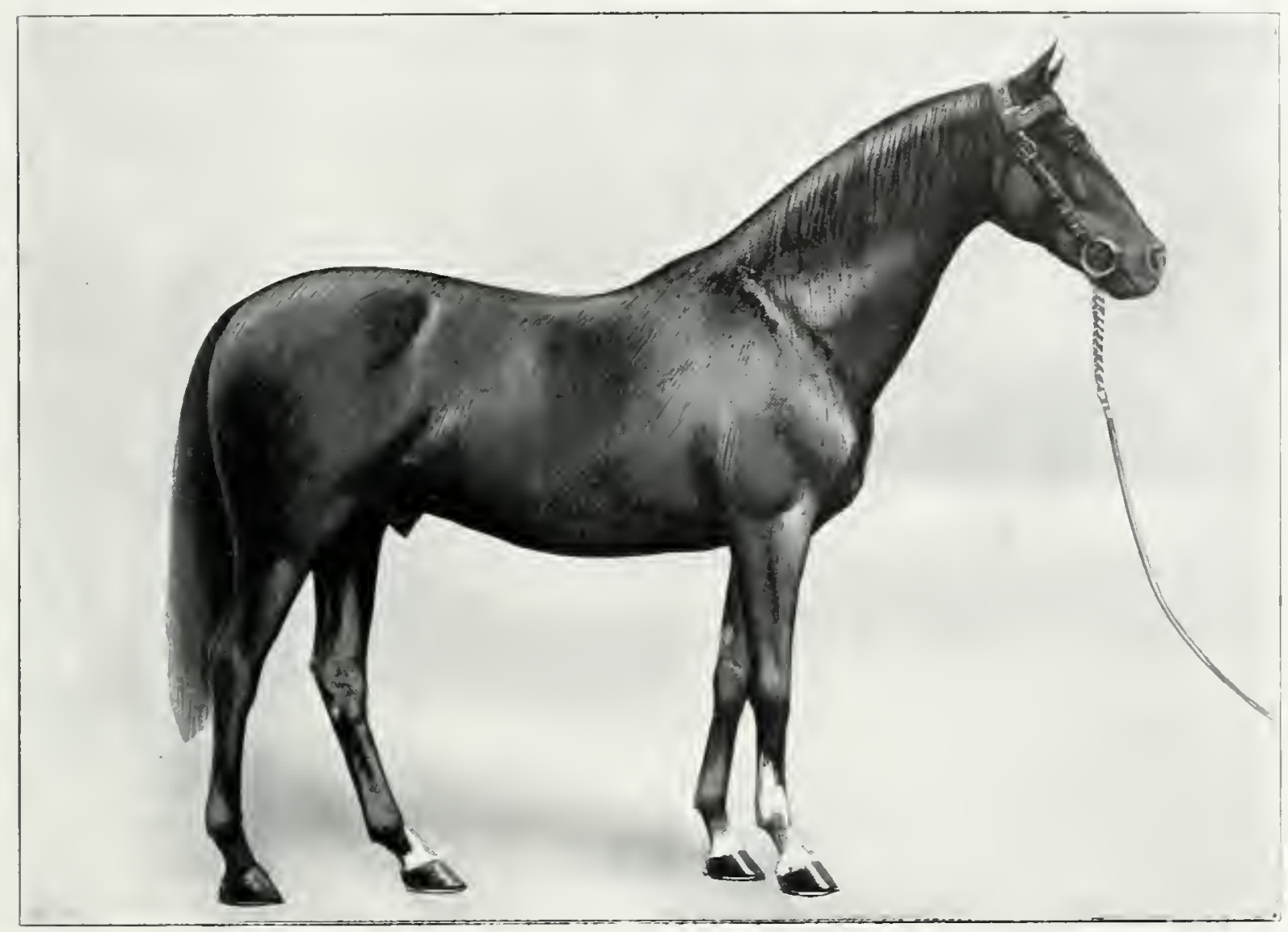

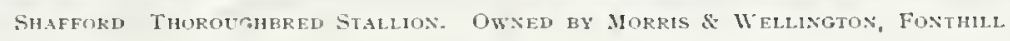

\section{WILLIAM E. WELLINGTON}

W

ILLIAM E. WELLING'TON is a Canadian by birth. having been born in the town of Oshawa in the year 1849. Mr. Wellington was edueated at the high school in his native town. From his boyhood days Mr. Wellington showed an interest in the lorse, and at the time of writing holds a prominent position in the breeding world. Ile has been associated with all of the horse shows, as well as the Nitional Exhibition held in Toronto, and his advice on matters of this kind is sought after throughout the Dominion.

Mr. Wellington took up horse lreeding for the love of it and as a pastime more than anything else. Coming naturally to him, he hats made a success of breeding from the beginning. First starting in business as a printer. which trade he learned in his native town. he remaned at it only three years. When the nursery business took his faney and he formed a partnership at the age of twenty-two with the late Mr. Stone. For rears the firm known as Stone and Wellington was only a small concern. but rapidy grew until the firm nomery bas now grown from one hundred 
alcres till it corers over one thousand. Afterwards Mr. Morris was taken into partnership. Shortly after the change was made. Mr. Stone died. Mr. Wellington huving his interests in the concorn. It was at this time that the horse business was taken ups and there is now probatsly not a better known firm in Canada. Their specialty is slive and thoromghbed crosses to obtain saddle and hunters.

Probably the hest horse ever owned ly Mr. Wellington was Slatford, who is royally bred, coming from Derby wimners stock. The won the first time he wats shown in the ring in two specoial classes agranst many gool ones. one being for best horse to get sadulte horses and lunters. Another good one in this stable is Brambope Calrdinal, an imported shire. Which also won the first time shown. This horse was sired hy the Duke of York ont of the mare Bomere. Shaffordls first sire and dam were Saraland and Iaty Imelia. they eoming from such stock as IIighland Fling, Doncaster. Iampton and larly llester. 'I'lese lines go back to some of the best stock in Eugland, making slattonel a nost valuable one for his breeding, an aequisition to the hest horses ever bromght to this combly. The firm have at the present time over sixty shire and half-bred saddle horses at their farm. Shaflorl's colts show the true saldlue elass and ane grand ones.

fior two years Mr. Wellington held the oflice of first viece-president of the board of directors on the Industral Exhibition. hesides being on the hoald for many years and frequently deaiman of the horse committee. Ile has heen connected with the Canaclian Horse show for yoars. heing looked on as one of the best juelges in the land. Ile is l'resident of the st. Creoreces Society. and was at one time a director of the Canata l'ermanent Loan ("o. $1 \mathrm{Je}$ is also Viee-President of the Birklneck boan ("o. of Toronto. Mr. Wellington has never taken any active part in polities, althongh ho has leeen oflecer the nomination for Welland on many orcasions, his business taking ne most of his time.

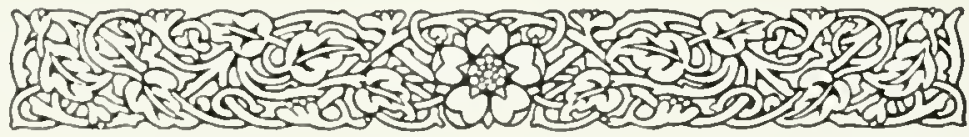




\section{DR. AND MRS. S. H. McCOY}

$\mathrm{N}^{\prime}$

work on the horse or on llase interested in the horse womld be complete, so far as Ontario at least is concemerl, withont mention being marle of I) and Mrs. Mecoy of st. Cathalrines. Nowhere is there a better eximple of mity of interest between husband and wife, and no two people bave dome more to make fire horses miversally arlmiled and popmlat than they.

For years their time and moner

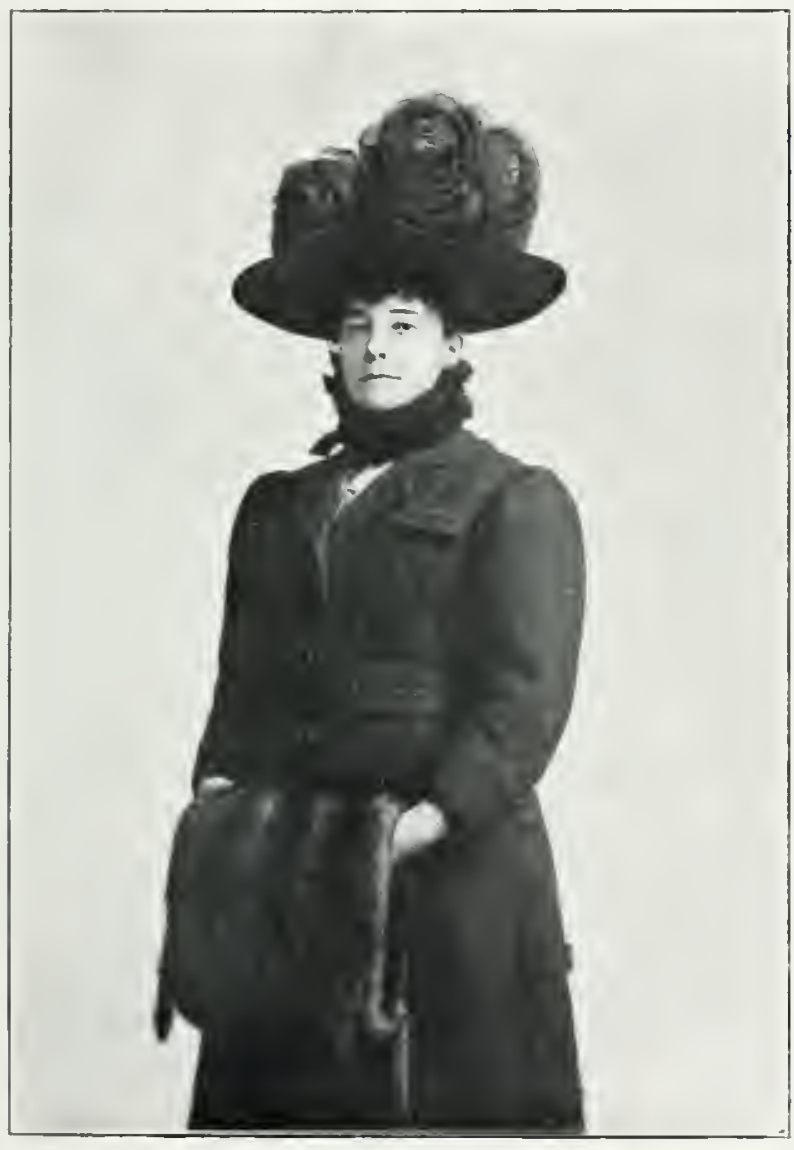

Mrs. S. HI. McCov have been freely spent in buying and exhibiting some of the finest horises seem in Ontario, and their stable. "Mearkowficedd," at St. Catharines, is a morlet of perfection in both elesign and equip) ment. D)r. and Mrs. Meceyse horses are housed with the greatest possible calle and attention, and nothing is onitted that conkl contribute to their confort and well-being. Dr. and Mrs. MeCoy are absobutely in sympathy in their lose of a geod horse, and their eflorts atre lirected with zeal and perfect knowledget.

Mrs. Macoy, formety Mrs. Florence Mamde Fraser, widow of tolun IV. Fraser of Port Ilopere and dianghter of the late Johur Cook, of C'ook Bbothers I mmber Company, was one of the first women

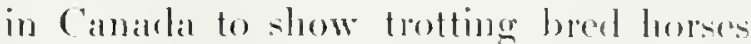
as high steppers at a time when women were but litte kuown as exlibitors in the ring. Iler initial rentures, hareked as they were by a wicle knowlerluge of horses, met with so minch suceeess that she was greatly encouriged. She and I)r.

MaCoy have exhibited with ereat success at all the important Camalian Horseshows.

Mrs. MeCoy first ereated a name for herself as an exhibitor with Vutcan allul Erebus. 'They were a team of remathably beantiful high-stepping blacks, and her appearance in the ring behind them was the signal lor something very like a sensation. Fulean became very well known latel on moter the name of 'The British lion.

The mamiage of Dr. Mecoy and Mrs. Fraser, both alrealy wedl known to exhibitors as factors to be reckonerl with in the prize ring. saw their individnal eflonts nuiterl, amel an even greater meed of suceess fall to their lot. Ther have exhibited 
hat 


\section{Lovers of the Horse}

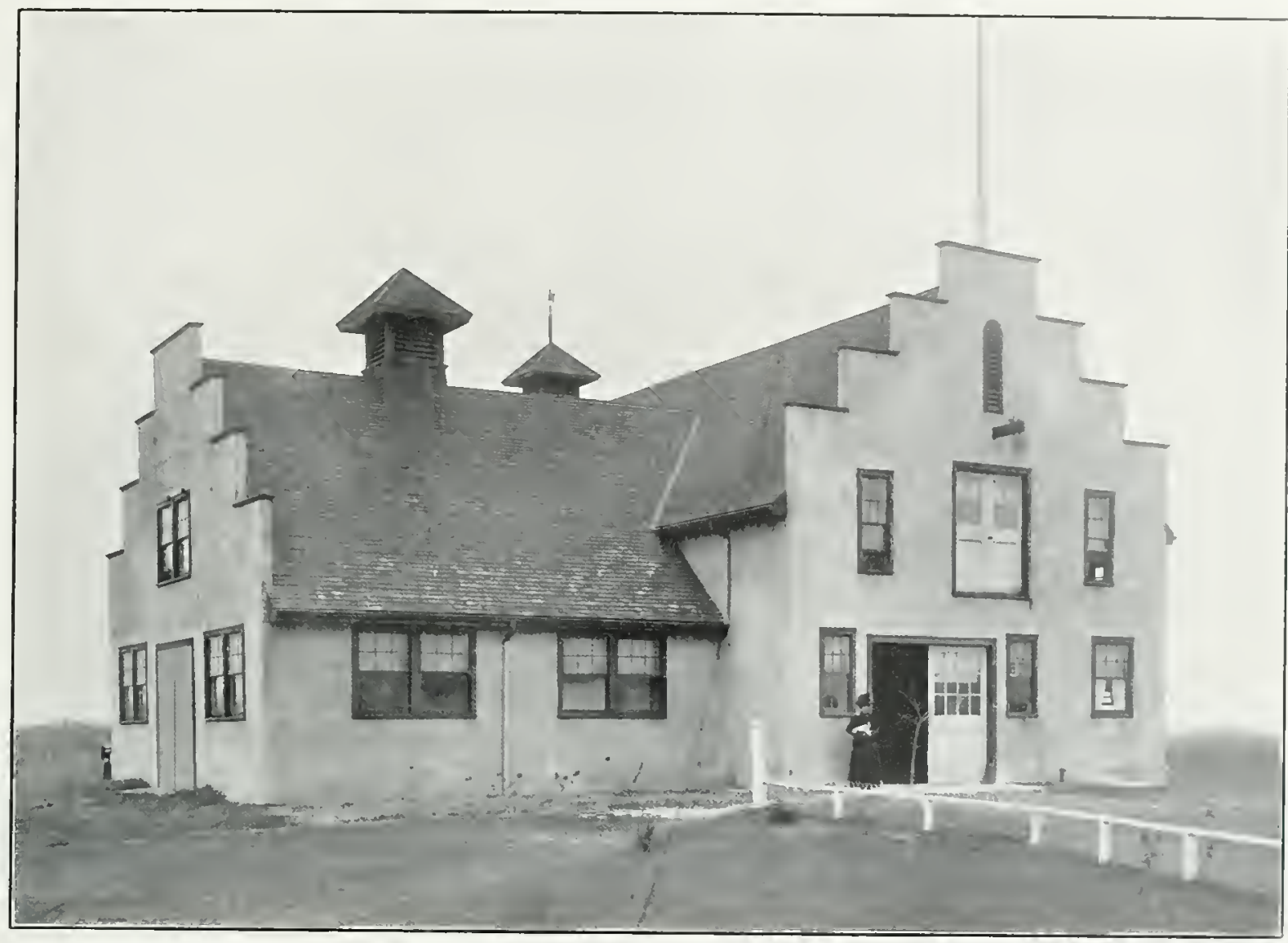

MradowhIElt, Starifs, St. Catharines

together principally in Toronto and Montreal. It would be impossible in the short spatee which can of necessity lec devoted to a sketel of this nature to mention all the superb animals shown hy Dr. and Mrs. Mecoy, but perhaps their erreatest trimmples have been achieved with Flyer and ()ntime. Mikarlo and Sultan, Cabin Boy and Fortume Teller. They have. however, not contented themselves with wiming the highest laurels in the driving elasses alone, but are also well known as no mean anthorities in saddle horses. Horsemen will not soon forget 'The Raijals and Nightelight, two bealuties which have hronght their owners many a hlue ribbon.

Dr. Mre oy is not, in atny sense of the worl, a man of but al single idleal, and hats not nexglected the more serions idlals of life in the pursuit of a holbly. Mledicine is his chosen profession, and in medicine le has won an enviable reputation.

Of Nortl of' Ireland ancestry, D). MeCoy Was born in Hamilton, ()ntario, anm received his early education in that city and in st. (athatrines. Ile entered the Iniversity of Toronto in 188.5, graduated in . Its in 1889, and finisherl his medical contra in 189. After lour yours of very successful practice in St. Catlatrines he went to lingland in 1901. There and in Scotland he sturlied for four rears more, and was andmitted to the Royal College of surgeons, England, in 190\%. In 190.5 still another 
lonor in his profesion came to him in the form of an appointment to a fellowship) in the Roval college of surgeons. Edinburgh.

1)r. Mrecoy came batek to st. Cathatrines and resmmed his practice there. His practice in a large one, but lae still has time to be greatly interested in things military, and holds a eommision as surgeon-Major in the leth Regiment of lufantry.

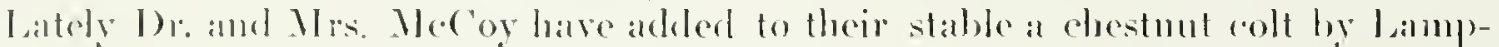
lighter- Cribhage, antly named cliblight. With this stallion they hope to adel a little warmer blowe to the half-beed stoek of their palt of the Peninsula, thus improving the strain and trying for better sadellers and hunters. Criblight is a grand-fooking colt and promises more than well.

We in ()ntario, where good horses ale becoming every day more and more appre-

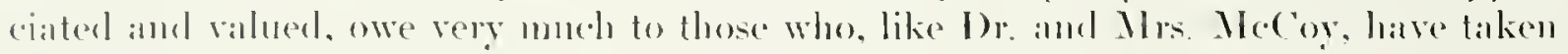
so prominent a palt in showing what ean be done by a liberal expenditure of time and money to inporove the breal of onl Camalian horses.

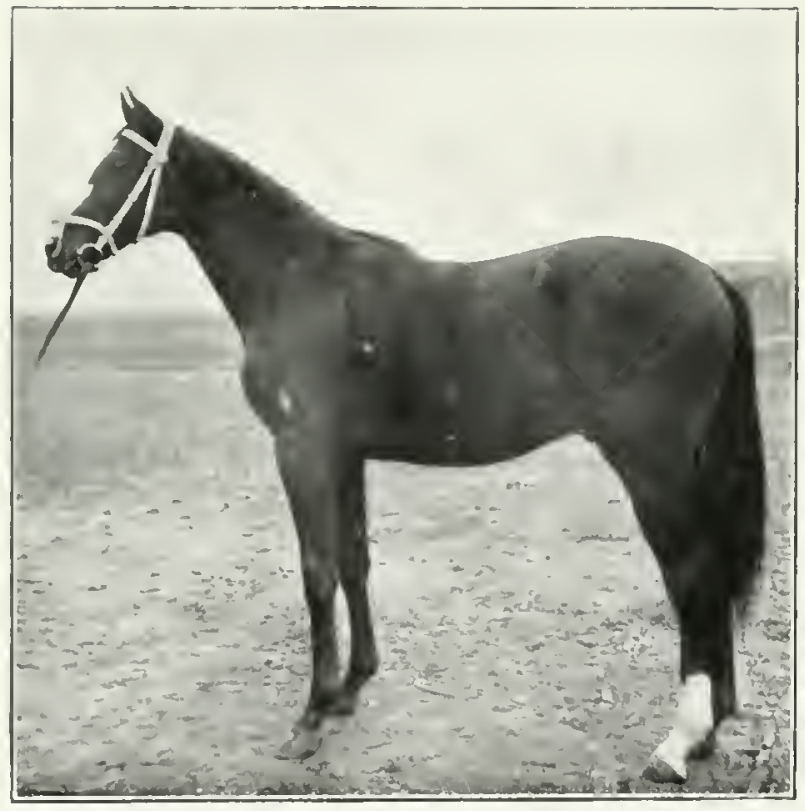

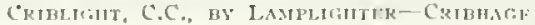




\section{ROYAL NORTHWEST MOUNTED POLICE}

I

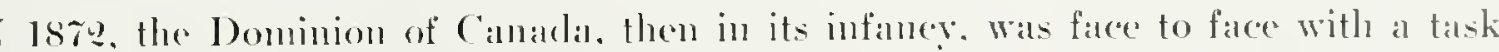
of stupendous diffienlty. Weak, besth in population and financial resonrces, the five-realr-old comutry had to provide for the exploration. development and settlement of a tract of land which covered s.300.000 sifure miles, a continent in itself, acpuired by the Dominion in virtue of the Rupert's Land Aet, passed by the Imperial

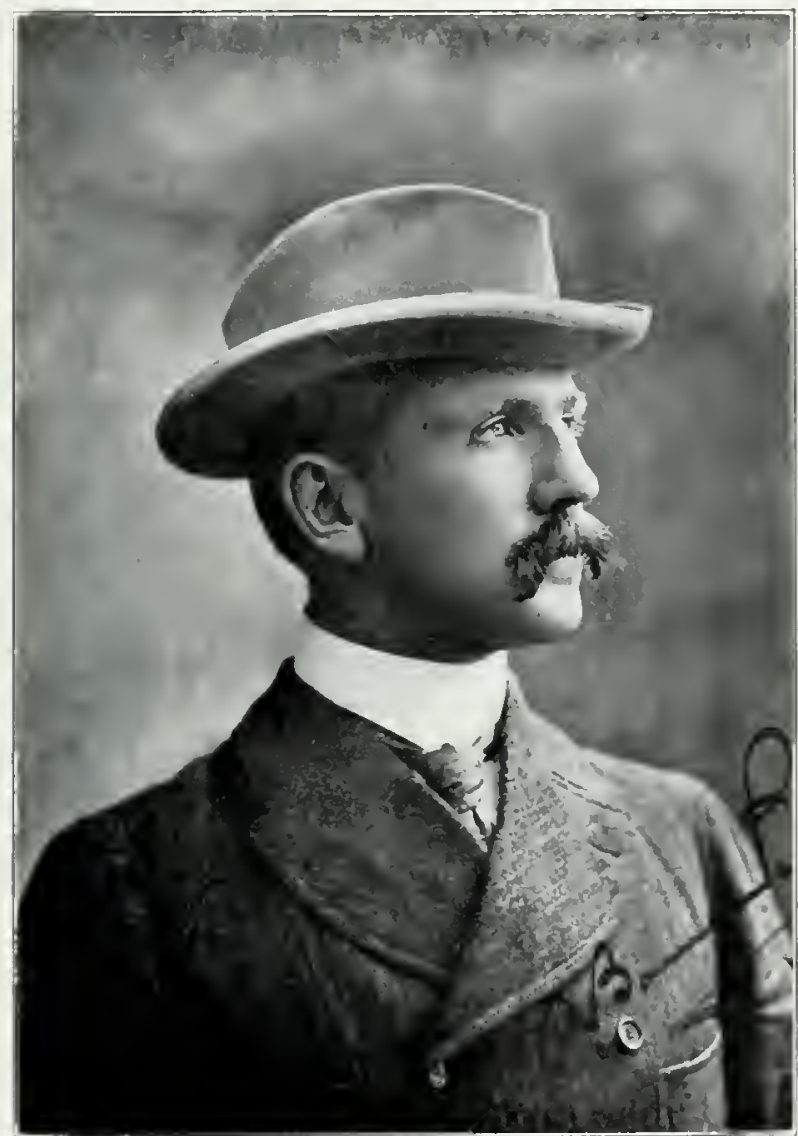

COLUNER A. 13. P'ERRY, CUMMISSTUNER, R.N.W.M.P. Parliament in 1868 .

Up to 1866 Vameonver Island and the manland of British ('olumbia, formerly called New Caledonia, were two separate provinces. but in that year, they were minted muler the mame of British C'olumhia, the new province entering the lominion in 1871, on the muderstanding that within two reals. work would be heegm on a railway to connect the province with Eastem Cinada.

It was obvious that to ensure the sate eonstruction of this transcontinental railway, no less than to proviele for the sottlers in this vast wilderness, it was necessiny to providesome efficient method to assert national anthority and enforee the latw.

"lhe ultimate solution of this problem was the creation of the Nortluwest Momut(a) Police.

The Riel uprising of 1869 had left the eomutry in al very msettled eomelition. and with a population of $1.5(6.5$ whites. ios Indians, 5.757 French half-breets. and t.0s3 English-spreaking halli-breeds, it an readily be understood that mumerous acts of lawlessness were reporterl.

It was to bring about the fusion of these janring elements and to restore law and order that the first momuted police foree in Western Camada was organized under the command of Captain Villiers, of the Quebec Battalion of Rifles.

'This initial organiation, however, was purely military, and was stationed at Fort Garry, going out on marehes only when necessity demanded.

Sir John A. Matedenatd, then Prime Minister, felt that this was not suflicient and asked in the Honse for a moderate grant of money to organize a momnted police force. somewhat similar to the Irish momuted comstabmbary, which, while laving the advantage 


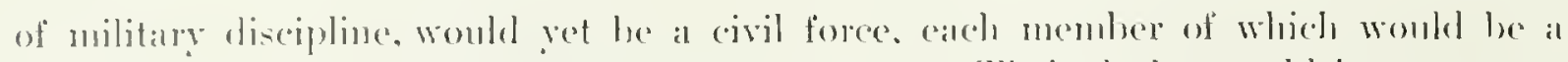
police constable. and therefore al preventive offices. Their duties would be to protect the frontice. look after the customms and put down sumgrghing, especially the smugrgling of liquor, which temled to demolatize the Indians, and also to maintain military onder.

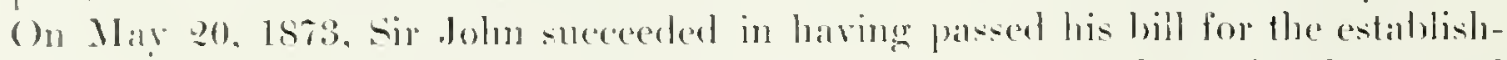
ment of a police foree in the Northwest Territories. the fores to be uncles the countrol

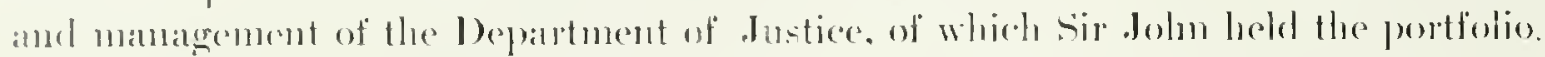

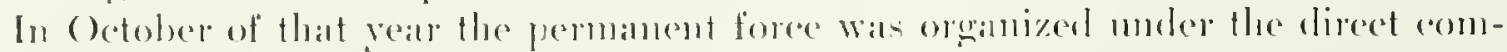

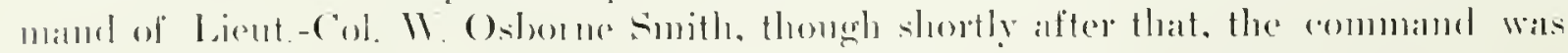

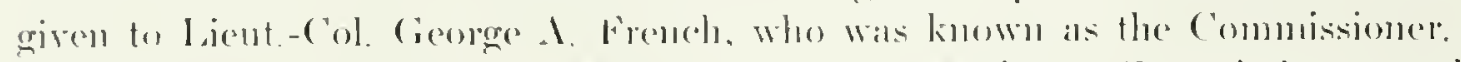

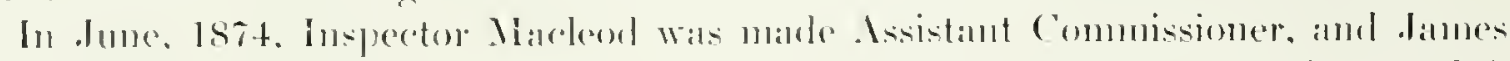

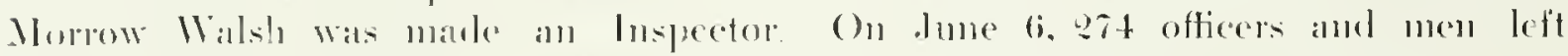

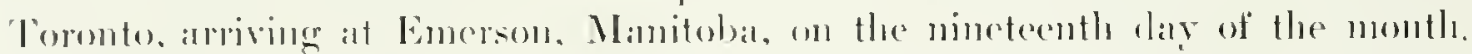

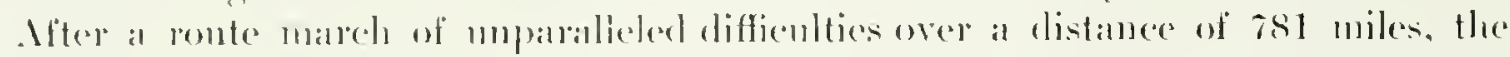
forese arrived at their destination. Buw and Belly Rivers, on september go. There divisions were left in the Bow River distriet meler eommand of the Assistant (antmiscioner, another division being left at swan River, while the remanning eompany.

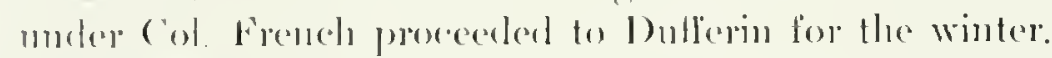

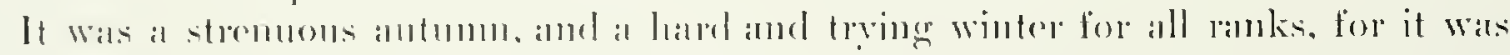

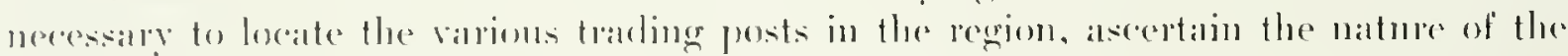

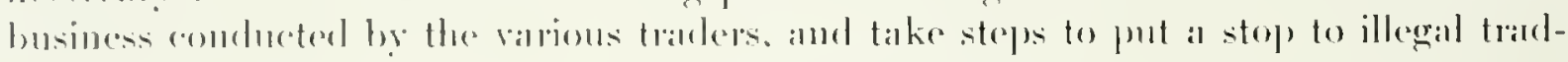
ing of all sorts.

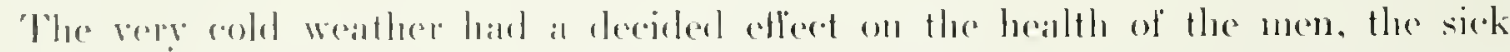

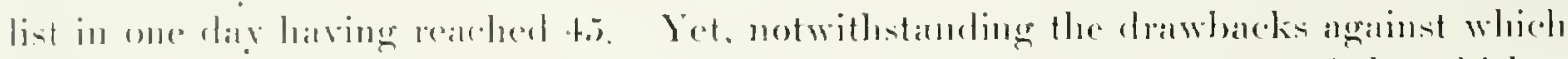

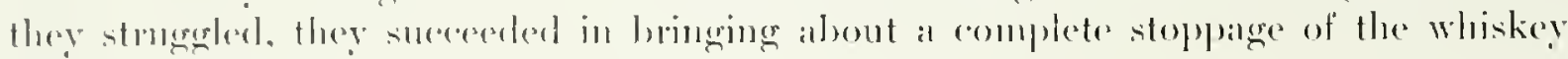
tracke in that soretion al the comoly

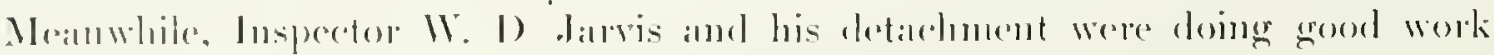

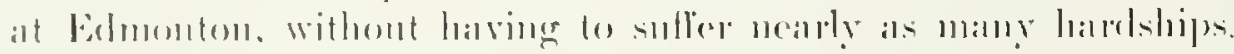

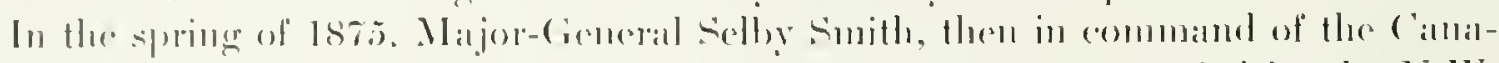

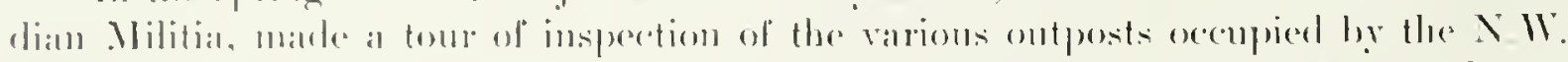

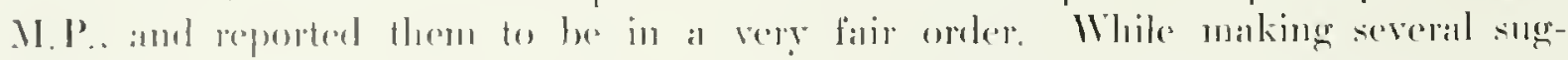

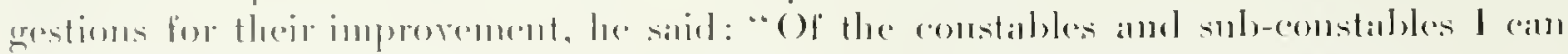

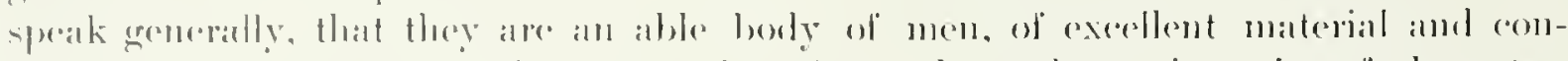

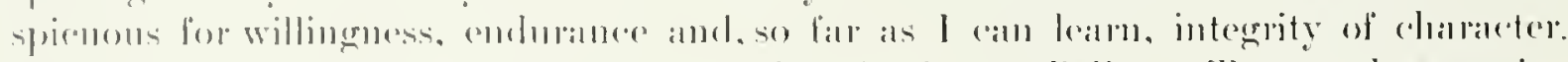

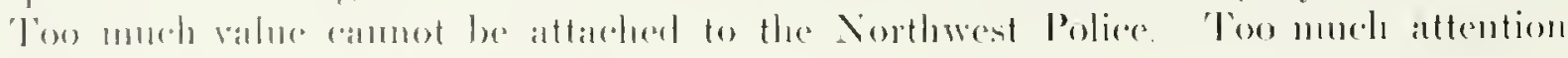

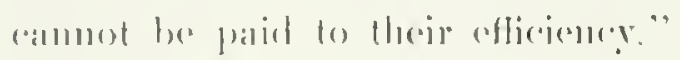

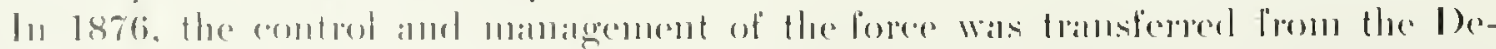

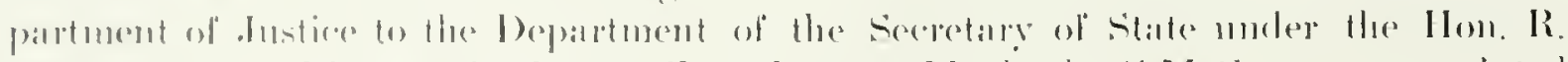

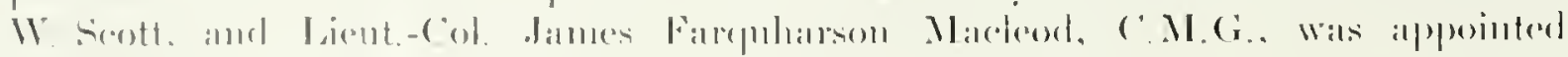

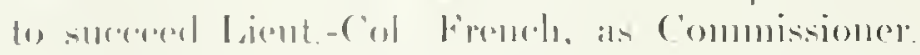

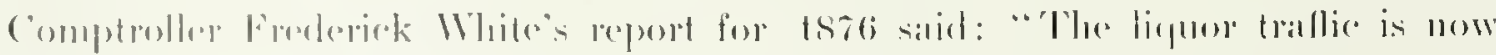

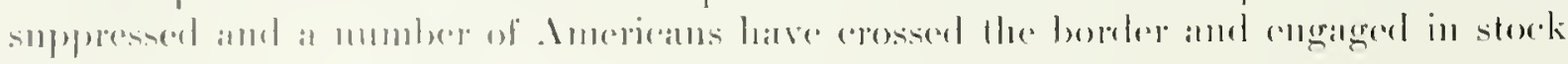




\section{Lovers of the Horse}

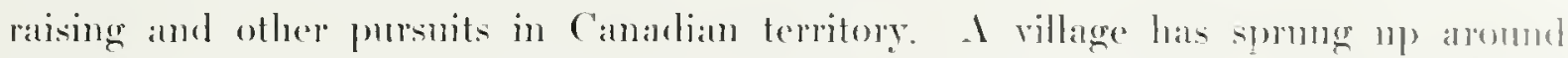

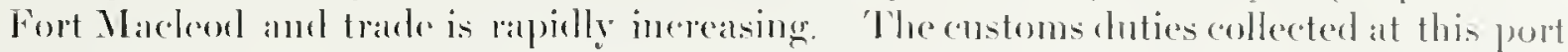
by the officers of the Bolice during the two montlis ended 31st (October last, amounted to $\$ 16,99+69$, and over 90,000 robes were shipped from there during the past sealson. It Cypress llill, the scene of the massace of 1873, there is also a settlement, at which the customs collections made dning the nine months ending soth september amomted to $\$ .5 .584 .98 . "$

Few more critical positions were ever fared hy a force entmoted with the preserva-

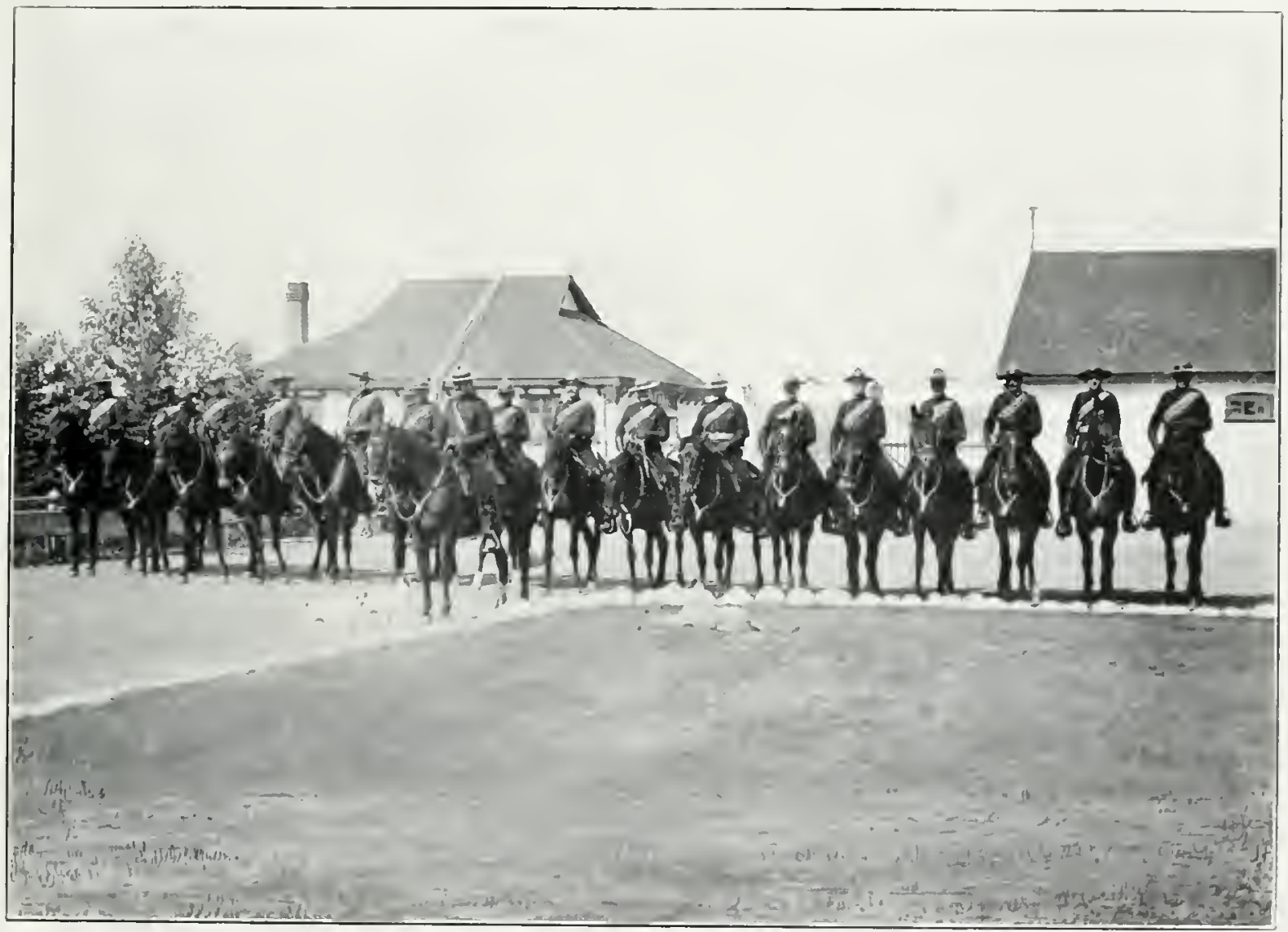

A Troop of Rotal Northwest Motnted lolice

tion of law and order in a country than that which ronfonted the Monnted Police when sitting Bull, the sioux warrior, with his whole nation, cossed the boundary line to seek shelter in Canalian territory after the "("uster massalere" in the Inited States. From 1870 to 1881 , the foree was compelled to maintain constant supeprision and control of the refugee sionx, and to exereise monearing patience and diplonale ln 1881 sitting Bull was finally induced to surrender to the Lnitexl states anthorities

Thetrace our steps. in 1878 sir John 1 . Matedonald formed al new Cabinet, tarking

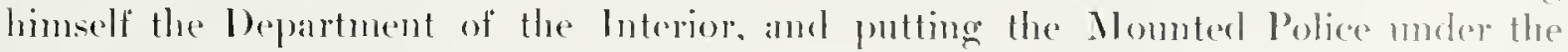
juristiction of that depantument. 
In 1859 there wats a great influx of population to the Northwest. and during that year the force undertook faming operations of an experimental and extenderl chatralcter in southern therta. Duing the rear Lient.-Col. Mareleod held sereral civil conts at Fort Walsh. Mareleod travelling ovel g.300 niles to perform his various duties

Sereral new important ontposts were established, and in 1880 lient.-Col. Mateleod was alppointed as Stipendiary Magistrate for the Northwest. Lient.-Col. Irvine heing promoted to the commund of the force.

The total amomut of anstoms duties rollected at Mardeod for the rear 1880 amounterl (1) $\$ 15.433 .38$.

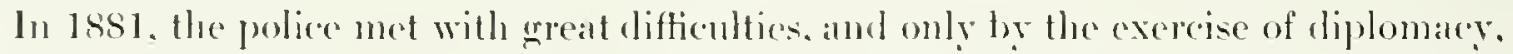

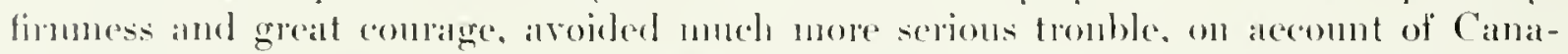
dian Indians stealing horses in the United states and hringing them aross the line.

In 1882. serous tromble arose with the Blackloot Lulians on aceoment of the arrest of Bull Elk, a Blackfoot. For shooting with intent to kill.

On arecount of the increased responsibilities devolving on the force. owing to the construction of the C'anadian l'acific Railway, and the influx of settlers, anthority was viven in 1889 for an increase of 900 ment

The Marquis of Iorne was the first Governor-(ieneral to visit the Northwest 'Perritories, and his visit bromerlat that region very prominently before the notice of the public, the Mounterl Poliec reereiving esperial attention because of the efficient fishion in which they assumed all the duties in connection with the long pratice journey of the Vice-Rergal jaity.

Ever since the establishment of the foree, there hate been uncertainty as to the best place for permanent leadepuaters, and it was the building of the Camaldian Pacifice Railway which finally decobled Sir dohn Malcolonald to establish hearlquarters al Regrina, whicle was finally dome in 1889.

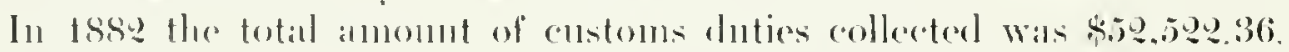

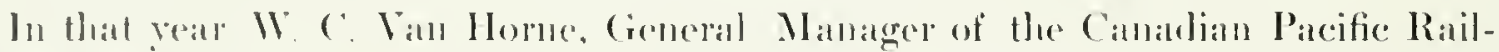

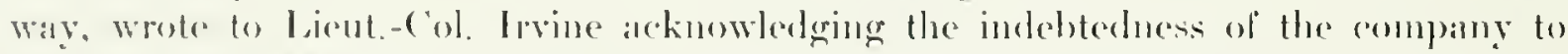

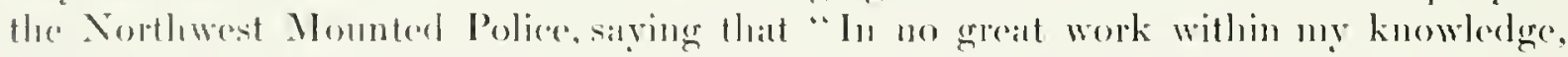
where so matry men hatre beren emploved, has such perfert order prevailed."

I wonderful illuntration of the power of the Monuted Police was griven in the

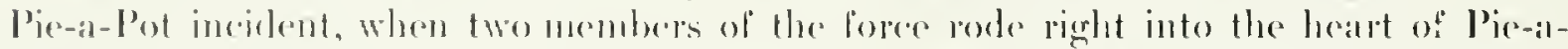

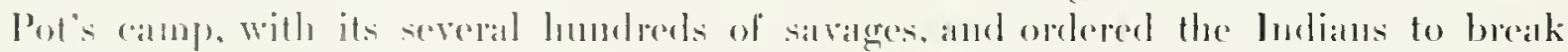
rallip immerdiately and take the trail for the north. When the hadians refused, the two

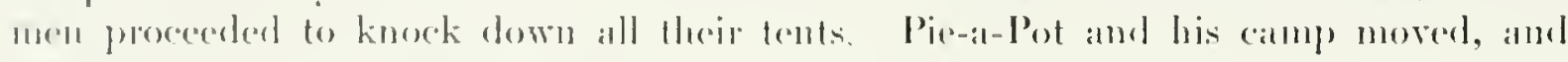

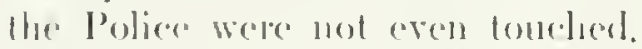

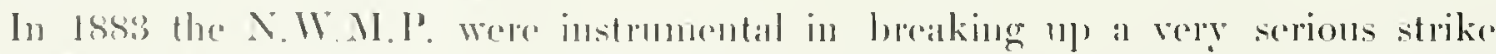

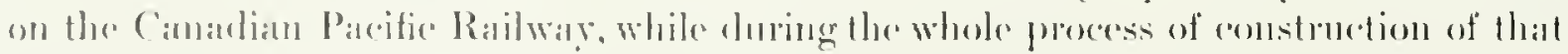

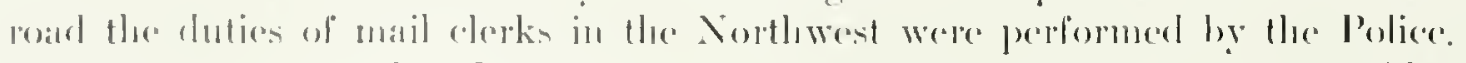

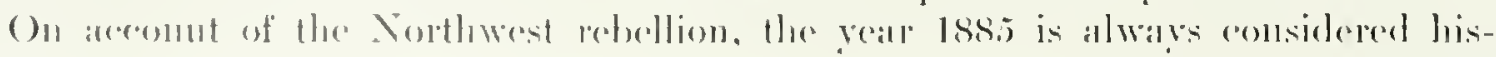




\section{Lovers of the Horse}

torical in Canada. The R.X.W.M.P. naturally bore the blunt of the campaign and acquitted itself well; officers and men reflecting the greatest credit on thenselves and on the country.

The ent of the rebellion left the Mounted Police with greatly increased responsibilities. First, there was the pacification of the half-breed settlements and the Indian tribes which had been in revolt. Second, the sense of security hitherto enjoyed by the white settlements had to be restored, and third, provision had to be made for the enforeement of the law in new settlements and mushroom fronticr villages, which sprang into existence as a result of the eompletion of the C.P.R.

Steps were taken to inerease the strength of the force, 608 recruits joining anring the year 1885, and to re-armange the distribution of the work. In the mirlst of this proeess or reconstruction the visit of the Governol-General, Lord Lansilowne, dirl mueh to allay exeitement and to emphasizo the fact that law and oreler had been restored throughont the Territories.

Writing at the ent of 1885 from Prinee Albert, which had been the centre of the disaffeeterl district, and where, sinee his promotion, the eommander. Supt. 1. Bowen Perry, reported: "The half-breed population is quiet, and the feeling amongst them, to a great extent, appears to be that of regret for the past troubles. Very few will aeknowledge that they took up arms of their own free will, elaiming that they were persuaded and forced into the trouble.

"They are now entirely depenflent on Government assistance.

"I have seen the priests of the different half-breed missions and they all tell al piteons story of starvation and want among their people. 'The Indians are very quict and peaceable."

In 1886 Lawrence $W$. Herehmer, Esq., succeeded Lient-Col. 1. G. Irvine, as Comnissioner, and that year the work in connection with the erection and reparirs of barracks, hitherto done by the l'oliee themselves, was handed over to the Departunent of Public Works.

During the years immediately sueceeding the rebellion, there was a matkerl development of the patrol system. Log cabins with stables and corrals were built at convenient places along the frontier, to afford shelter to the men in bat weather, and some full-blooded Indians were engaged as scouts, doing very good service.

The men of the foree at that time were of exceptionally fine physique, the average leight being 5 feet $9 \frac{1}{4}$ inches: chest measurement $38 \frac{1}{4}$ inches, the Commissioner aiming to make the standard rery high, so that it might be hard to enter and easy to leave.

In 1889 Lord Stanley, then Governor-General, visited the Northwest. During that summer an extraordinary drought was very had on the horses, and the patrols, under Superintendent Perry, had to travel on one day to miles, and on the next 4 ? miles without water. Great eredit was considered due supt. Perry for the splendid condition of the horses on arrival at Regina.

During 1889 much interest was taken in rifle shooting and many improvements were mate in the fore and in the method of working. 
In 1890 11 R 11. Whe l)uke of Comalught was porideel with escorts and transport through the Nortluwest, and His Royal llighness expresised himself as much pleaterel with the Yomuted Police, amel the services performed for him by them.

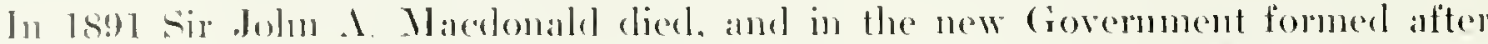
his deatle, the Premier. IIon. Sir J. J. C. Abbott, petained control of the Mounted Poliee.

buring this fear the force gave great assistance to the Calgary and Ealunouton. and the Calgary and Macleod railways, and also, in that reatr. al strict liquor license

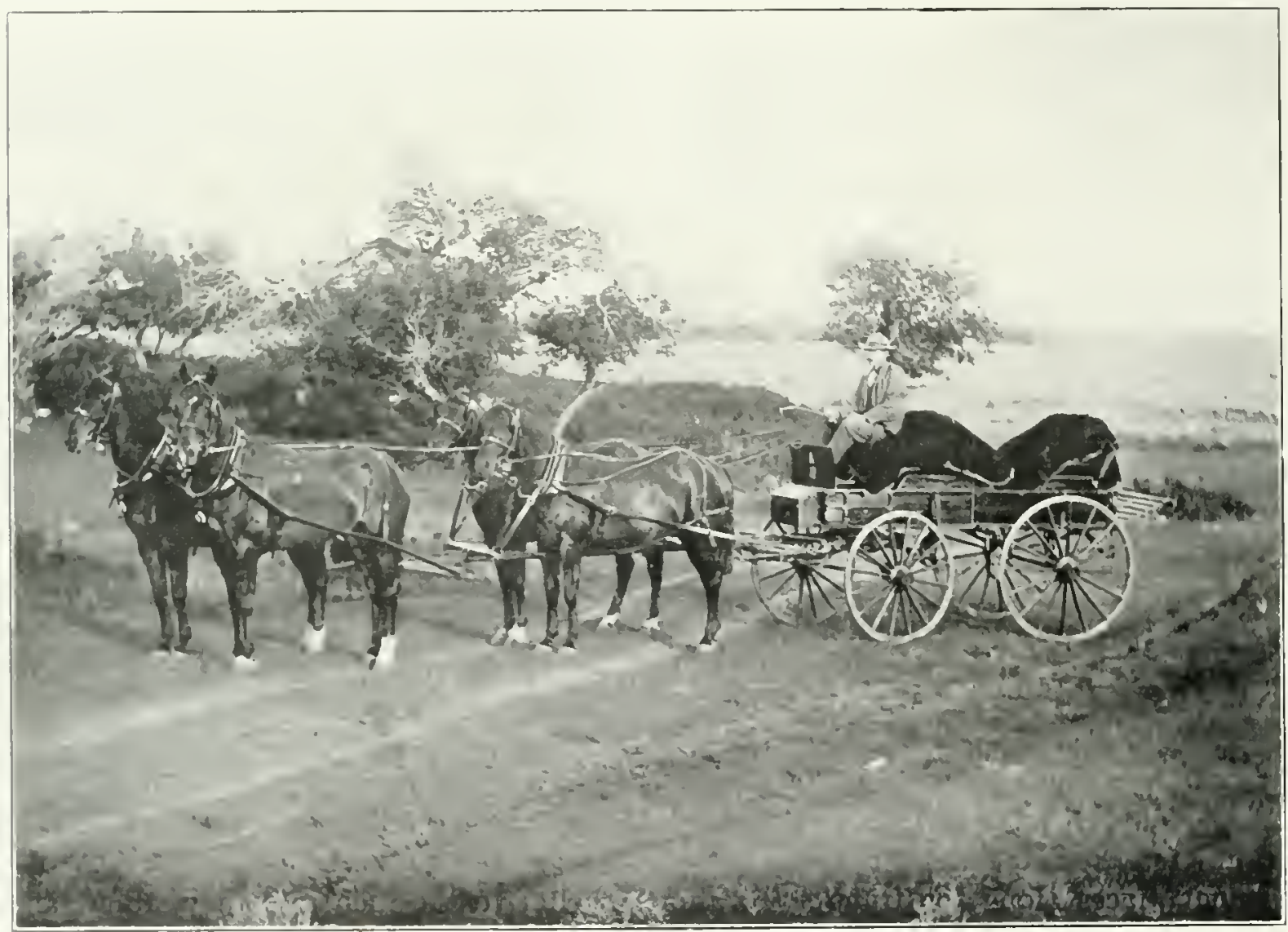

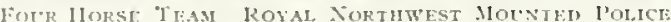

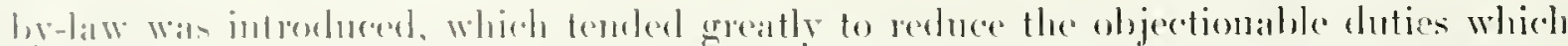

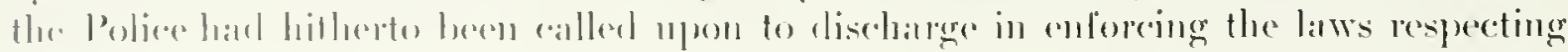
lipinol:

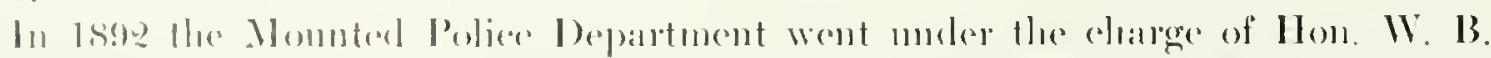

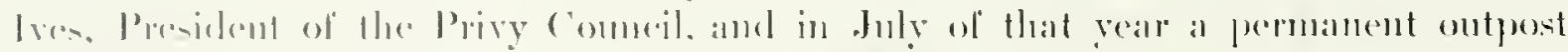

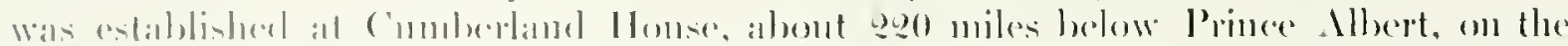
silstitrlemill River:

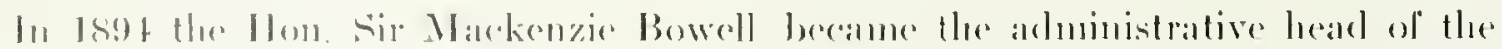

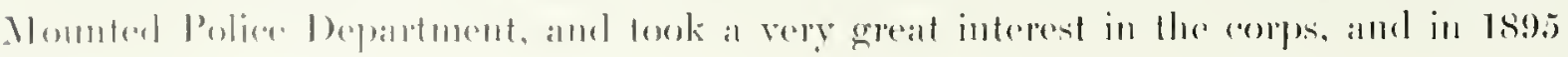




\section{Lovers of the Horse}

a detachunent of the Momited Poliee were sent to preserve law and onder in thes likkell.

In 1896 sir Wilfid Lamper fomed his first Cabinet, and since Hat time hals maintained the keenest personal interest in the foree and men.

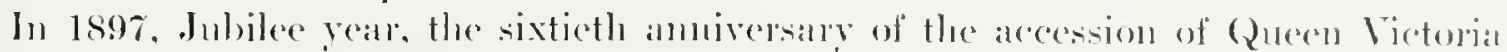
to the British Throne, was natred by a splendid demonstration in homol of that enteat sovereign. It was decinled to send a representative detadelument of the Northwest

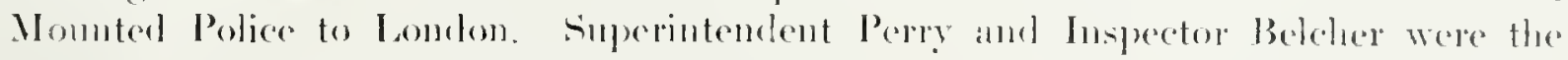

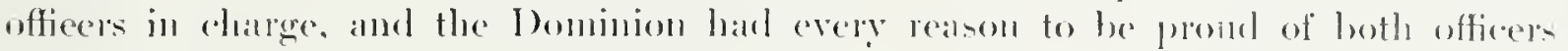
and men.

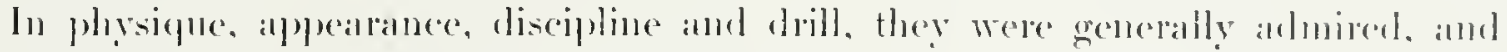
were comsidered equal to the hest troops present.

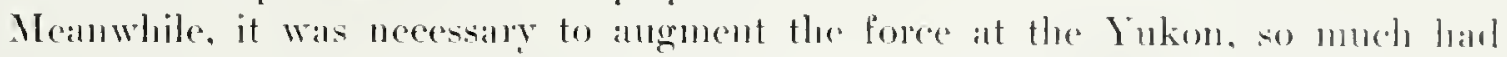
the rush to the gold mines increased, and a staff of eight officers with righty-eight men were stationed there, umber command of the Administrator of the district.

In 1899) Superintendent I. Bowen Perry assumed command of the Nolthwest Nomed Poliee in Sukon 'Territory, and during that winter the Poliee assumed the duty of carrying the Yukon mail, travelling (it,019 miles with dog trams. Suberintendent Pery recommended that $\$ 9,601.80$ be distributed amome the ment as axtrat pay lon this service.

In 1900 Superintendent Perry was appointed Commissioner to sureceed lient. Col Herchmer. The new Commissioner gramhated from Royal Military college. Kingston, in 1880, and served for some time with much distinction in the Roval Engrineers.

It the time commissioner Perry assmmed eommand, affalim within the foree were in a very unsettled state, owing to the recent heary drafts of officers. men and horses for service with the Canadian Contingent in Sonth Ifriea, the Mounted Police having supplied 945 men, all ranks. for South African duty, and the Commissoner thought that their strength would have been easily increased to 1,000. if the Goremment hat thomght it wise, by ex-members rejoming for the campraign. In his ammual report for 1900. Commissioner Pery remalked: "The great countries of the Peare. Athatbasca and Matekenzie Rivers ane eonstantly requiring more men. An officer is allout leaving Fort Saskatchewan to take command of that portion of the 'Territory. "The operations of the Ameriean whaless at the mouth of the Matekenzie will, ere lomger require a detachment to control their improper dealings with the Indians and to protect the revenue."

In that year medals were awarded to members of the force who had served through the rebellion of 188.5 , and in that yeatr, also, the Covernor-Gencral. the Eall of Minto, and the Combess of Minto, mate an extended tone thromgh the 'Perritories. the N. II.M.P. providing an escort.

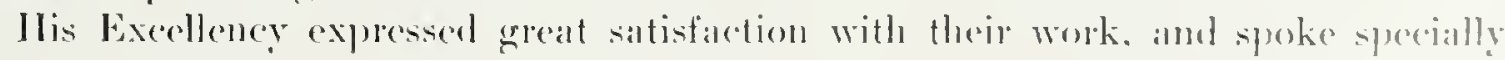


of their smatness and efficioncy, also sending, as a math of his appreciation, a gold pin to each nember of the escort.

In April, 1900. a census of the Yukon Territory was taken by the Police, and in lugust, il school census.

'The event of chief importance to the foree in 1901. Was the visit of their Royal llighnesses the Duke and luchess of Comwall and lork. His Royal ITighness expressing great sutisfaction with the alpearance of men and horses.

In his anmal report at the ond of the year. Commissioner Perry drew attention to the increased duties devolving upon the foree and to the need of inereasing its strength.

Ho said: "When the foree was organized, in 1873 , with a strength of 300 men. the 'Terlitories were unsettled, and the control given over to lawless bambls who preyed upon the ludians, with whom no traties had then been male. In 1885, complications with the half-breeds resulted in rebellion, which was sucessfully quelled. The strength of the forere was then raised to 1.000 . where it stood for about 10 years. when, owing to the pealceful state of the 'lerritories. the settled comblition of the Indians, and the

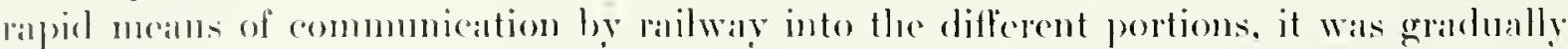

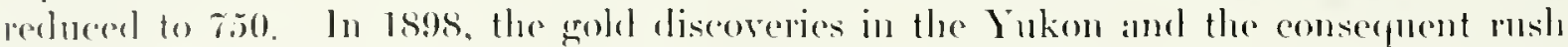
of gold-serkels calused the sudden increase of the force on duty in that territory to 250 men, thus reducing the strength in the Northwest Territories to s00.

"I forther decrease has now taken place by an addition to the Yukon strength. charged with the maintenance of order in the iukon. but the services of the Poliec

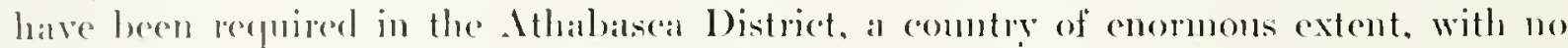
facilities for travel, hut where police work is ever on the increase.

"It may be thonght that the settled portions of the 'lerritories onght now to provide for there own police protection, or, at any rate, that the incorporated towns and villages should alo so. Some of the latreer towns have their own poliec forees, but the

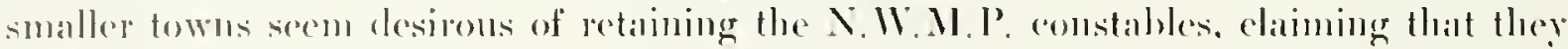
obtain better service, but dombtless they are latgely influeneed by ecomomical considerations.

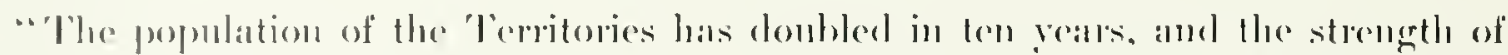

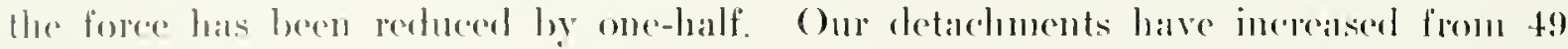
to 79 . Nethemgh we have only half the strength of ten reals age, still we have the

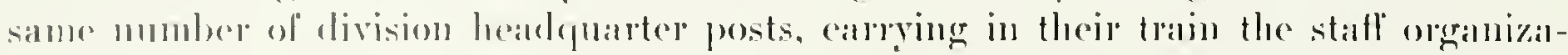
tion and mainterance of barracks as though the divisions were of their former strength.

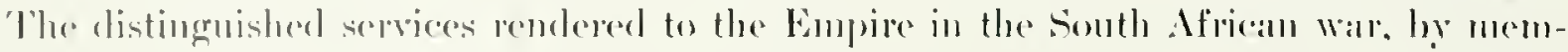
bers of the forere, rmphasize the faet that it has a very dereded militaly vilue and that in future mothing shomld he rlone to imparir its efficiency."

lu his ambinal report for the following reall, Commissioner Perry again emplat-

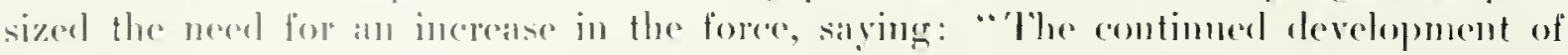
the combtry, the incerase of popmlation, the settlement of remote distriets. many new

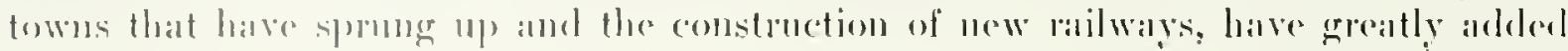


to onr work. In the train of the immigration has come a mumber of the criminal class. which, thomgh not latree, will probably increase.

"The new settlers are principally from foreign combtries. a great number being from the United states. The Imerican settler is much impressed by the fair and impartial administration of justice. Ile funds a constabulary foree such as he has not been accustomed to. Wut the advantages of which he is quick to acknowledge. and a country free from all lawlessness and enjoying freedom without license.

"The proposal of the Gand Trunk Railway to build through the l'alce River country, is sure to attract to that district in the immediate future a lot of people secking for the best locations. The police work is steadity increasing. We ought to increase our strength there. and establish a new police district, with headquarters, for the present, at Fort Chipewyar. "lwo of the districts in the organized territories could be combined into one, thus releasing the staff for the new district in the north. 'The northern trate is stealily increasing. Detachments ought to be stationed on Mackenzie River."

In 1908, a Pension Bill, providing for the pensions of officers in the Northwest Monnted loblice, was passed, the generous provisions of which were much appreciated.

In his annual report for 1908, Commissioner Perry says: "The increase of poptllation this year has been greater than in any previons yeall in the history of the Territories. I think 350,000 a rery conservative estimate of the present population. 'llis rapid development has greatly ine reased the work of the force, and I have hat diffieulty in unceting fully the requirements.

"On field of operations this year has heen tremendomsly widened. I detachment of five men. under the command of superintendent Moodie. Was selected to arecompany the Inulson's Bay expedition in that fartratistant region.

"Another expedition was despatched in May to the Aretic ()ean, consisting of five men under the command of Superintendent Constantine and was afterwats left in charge of sorgeant Fitzgerald, who visited Herschell Istand, so miles north-west of the montl of the Mackenzie River, and had the honor of astablishing a detachment. the most northerly in the world, at this point.

"I renture again to call your attention to the valuable work of the foree among the immigrants, who alre latrgely foreign-born.

"It is elaimed. and rightly, that we are a law-abiding people. that no new country was ever settled with such an entire absence of lawlessness. Why: Becaluse of the policy of Canala in mantaning a powertul constalunlary which hals for thirty gears enforced the laws in an inpartial manner.

"The Nortluwest Mounted Poliee were the pioneers of settlement. 'They carried into these Territories the work-wike maxim that, where the British flag flies. preace and order previll.

"llye force is now distributed from the international bondary to the Aretic Ocean. and from Holdson's Bay to the Maska boundary. There are divisions in the Territories, each with a headquarters post, and there are $8+$ detaclunconts. with 189 officers 
and men romstantly comployed on detached duty. Of these. is are distributed anomg

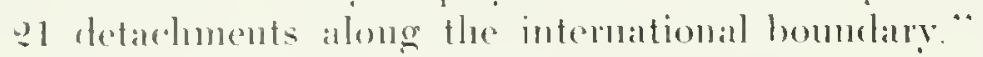

In his anmul report for 1904. Commissioner Perry wote: "'lhe Royal Xorthwest

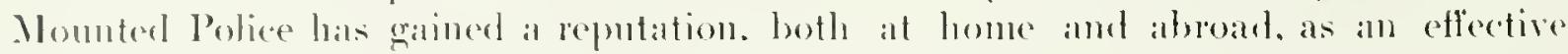
organization, whel has materially forwarded the progerse of the Territories. It is tortary dealing with all chasses of men-the law wess element on the border, the cowbors and ludians on the plains, the coal miners in the mountains, the goold miners in the Vukon, the American whalers and the Escpuimanx in lludson Bay and the fandistant Aretic soa. It is an asset of Canatal. and the time las not yet alrived in

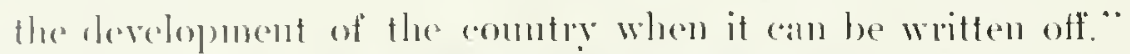

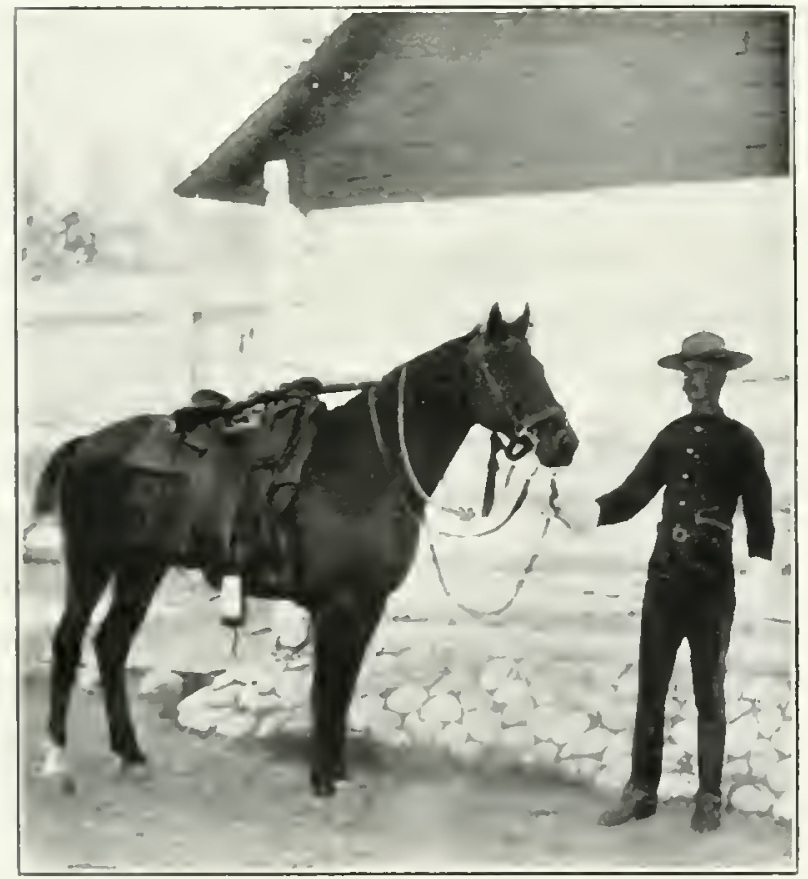

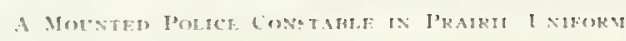

Four events stand out prominently in the histors of the R.X. W. M. P. for the reall 1905-the aceeptance by the Earl of Minto of the appointment of Homorary Commissioner of the fored the risit of their Excellencies. Lord and Laty Grey, to the Northwest, the establishment and inaluguation of the new provinces of Alberta and Saskitchewan, emblacing practically all the territory comprised within the original sphere of operations of the R.X.W.M P., and the lomgdemanded and much-needed increase of pay

When the provinces of Alberta and

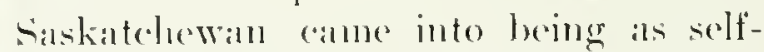
goreming proviness, with celeblations at Edlunonton ant Regina, the foree was

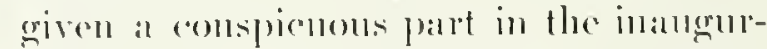
ation reremonies ats a fitting reacognition of the pre-eminemt services it hat lemdered in fostering and protecting the combtry in its pioneer days.

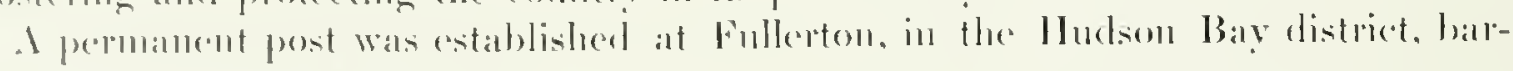
rateks bering built there in 1906 .

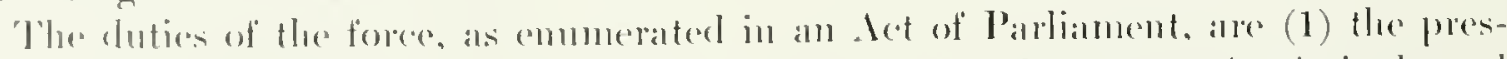
cration of the peatere and the prevention of crime. otleres who maly he lawfully taken into enstody.

(2) 'lle arrest of criminals amel

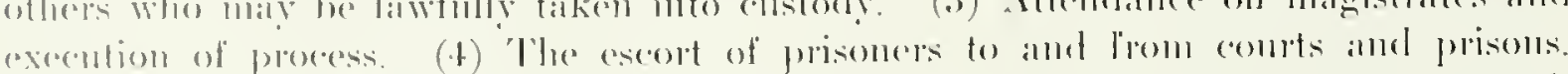

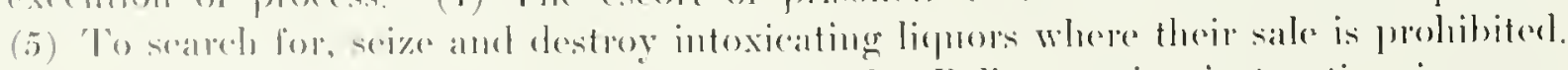

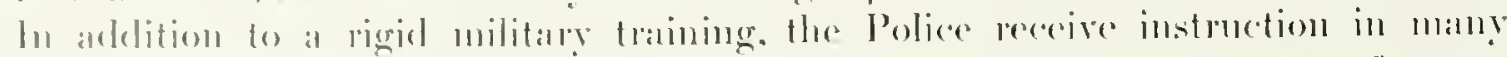

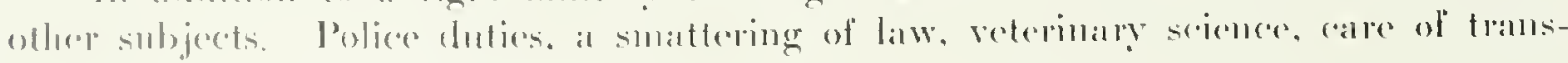
port and sabllary, all reeceive dure attentions. 
Bishop, Stringer, who was on mission duty in the Northwest, spoke of the Momnted Police as follows: "We are getting more particular as to whom we weleome to the great north now. The tomgh finds his row a hard one to live, and this in a great measmre is Wue to the excellent management of the R N. W.M. P., whose work in the wild secetions of the northand cannot he orer-estimated. It isn't the numbers of theme nor is it the force of their authority; it is a subtle something which enters the mind of the wrong-doer whenever he meets the eye of the man wearing the aed jacket. Why, an ordinary eonstable weaning no badge of office beyond his small batge and reel coat, strikes terror to the heart of the roughest. It is the dienity and determination of the Police, and the splendid esprit de rorps of the fores. The Momuted Police it may be asserted, lave been the sateety and pride of the whole north commtry."

In short. the Momnted Police have bromght British law into Western C'anada and established it there. The settler nowadars. even in the last West, doesn't even carry a hunting-knife. where once no man dared to travel without a regular atrenal.

The Indians, too, have fallen into line. Many of them are engaged as laborers in the construction of the new Govermment transeontinental line, the Grand Trunk Pacific, where once they did everything in their power to himbler any new work instituted ly the palefiace.

The mounted policeman has dome it all by his patiences and fearless, mnflinching courage, his readiness to do the thing which anue to his hand and do it well. He has been policeman, magistrate, soldier, letter-antrer, executioner, detective-anything that is in the daly"s work.

There has never been a buehing in Camada: nevere anything like the wass with the Indians that the Inited States has waged, and never a train robbery such als fignre even yet in the headlines of American newspaprers.

I farorite story ont II est is that of the troop of American cavalry who escorted a whole tribe of Indiais to the canadian border line, where they were met by one solitary momited policeman. A comple more appeared on the seene shortly and the troop of American cavalrymen sat there and wateherd the thee go off with thesir hand of bat Indians.

IIow greatly the Indians have come to respeet the justice and impartiality of British law is shown by the lacet that an Indian who had escaperl alter heing given al fair trial and adjudged genilty. was handed over to the anthorities again by his own tribe becanse they were convinced that his trial had been just.

At the recent 'lereentenary relebrations, a prominent oflicial sald: " llhey atre the finest thing in the way of trained men whom this comntry has produced-modern "entaurs. Men with the iron wrist, who ride as straight as knights." But nothing "an be said, nothing written, to embody the spirit of the foree as did that mesisage found scrawled on the orders of a policentan who perished in a blizzard while making his way with dispatehes to a distant post. hu his dying hour. with numbed hand, he wrote: " lost; horse dead. Am trying to pustr ahead. Ilave done my hest." 


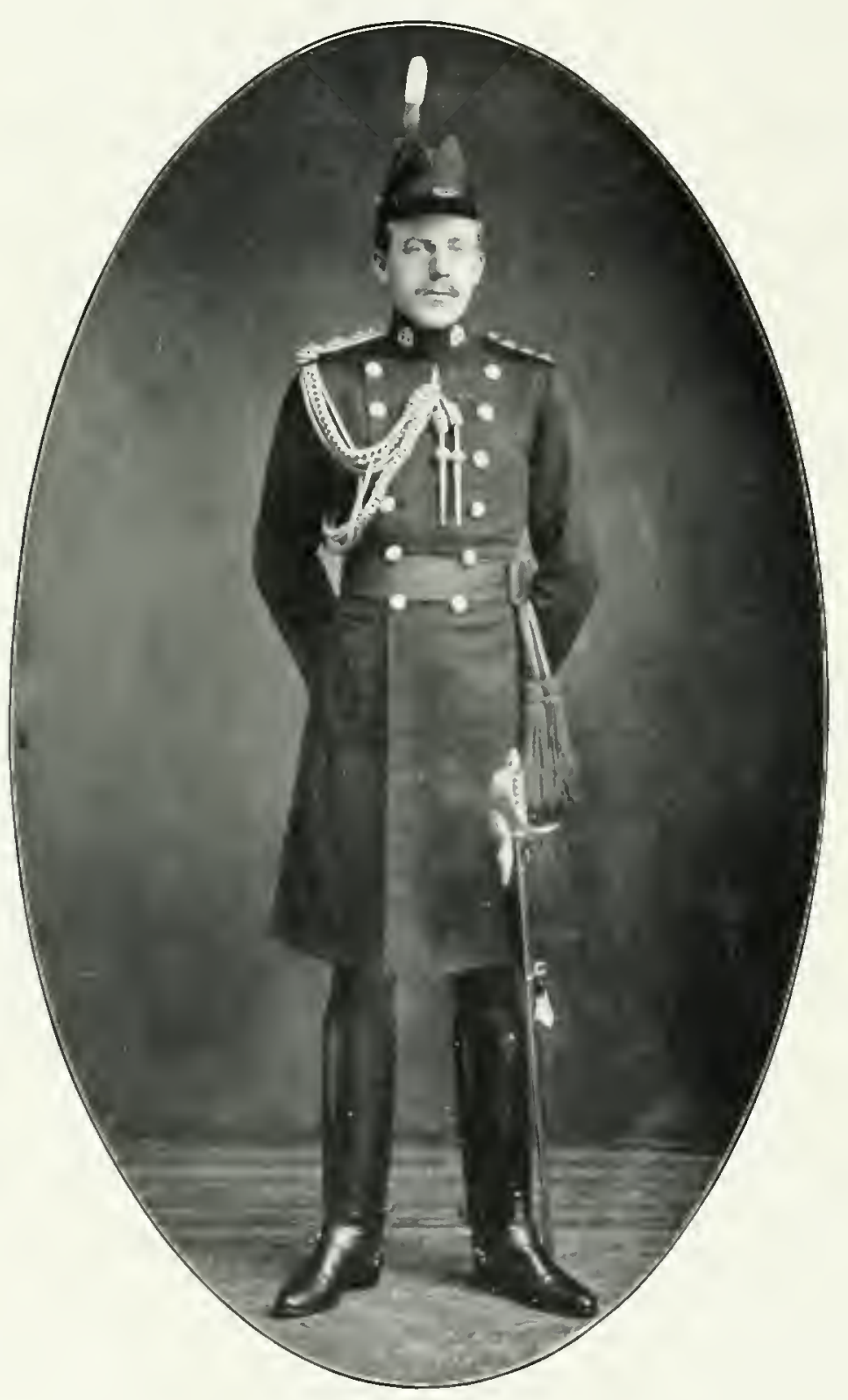

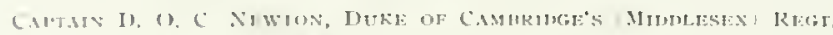

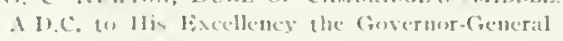




\section{HARNESS RACING IN CANADA}

$\mathrm{I}^{\mathrm{F}}$ we were to he asked which hreed of horses is the most populat in Camalat the mhesitating reply would be the light harness horse. The other hreals, such as the hackney, thoroughbred, heary-draught, etc., are excellent in their way, but their field of usefulness hardly covers the range that the light hamess horse does. 'The latter ean do about all that any of the others can do, and much more. The aldmirers of some of the other breeds will hold different oppinons, which, perlalps, is only natural, but at the same time it is doubtful if they eould advance arguments that would warrant their opinion. 'The standard-bled, or well-bred trotter or parer. makes a firstclass horse for the farm, as he ean work longer than any of the heavier breeds, although much lighter in weight. When put at heary hauling, he may make more trips on the job, lut his rapidity of action fairly eounterbalances lis lack of pulling rapacity. Is a carriage horse he has no equal, and in proof of this assertion it is only necessary to point out that nearly all of the champion heary hamess horses of the present day are standard-breds, or animals bred in trotting lines. While not equalling the thoroughbred or laalf-bred in performance under the saddle, he is, however, fairly good at that work. Is a gentleman's driver or road horse he is in a elass by himself, as he not only has speed and good manners, but can travel an extraordinary number of niles in a day.

While the trotter or pacer (we combine them for they are so neall alike) has many other qualities to eommend him, it is his ability to move fist on track and road thit hrings him most prominently in the public eye and the large inerease in the munluer of harness horse meetings griven anmually in this comntry, is ample cridence that this strle of racing is beeoming more popular each succeeding year. Not many years since meetings for harness horses were few and far between in Canada, while now there are hundreds, made up of circuits in Nova Scotia, Quebec, Eastern Ontario, Western ()ntario, Manitoba, Alberta and British Columbia, besides seores of independent meetinars ontside of the eireuit. In addition the number of entries in the early closing exents, as well as at the meetings themselves, shows that there are at least twenty-five por. eent. more horses meing in 1908 than in any previous year.

Here in Camada, while our opportumities have not heen of the best, we have produced some truly great performers on the track in the past, and, from the number of really high-elass horses in training at the present time, it is safe to prediet that we will continue to hold up our end with the cracks of the hig country to the south of us.

Within recent years we have turned out such good performers as Angus Pointer, a pacer that made a world-wide reputation eompeting against the fastest horses of America on the Grand Circuit, when he went through the sealson of 1909 with but al single defeat, and that in his first race on the cireuit at l)etroit, when he was hardly ready for a bruising race. Ilowerer, he turned the tables in his next race, when he handily beat Baron Grattan, the horse that beat him at Detroit. The Canalian-bred 
pacere alterwards went through the big races to the last meeting, which was at Lexingron, Ly. without losing a hast exeept at Columbus. where he lost the first heat of the freefor-all cliss to Gallingher. another Canadian-bred. The succeeding heats, and the race. fell to . Ingus lointer, as dicl the bign two-minute pace at Lexington later on.

The campatign made hy the unsexed son of Sidney Pointer was one of the best ever made by a lamess horse and stamped the product of Listem Ontario an a tuly great performer. He took a record of $901 \frac{3}{4}$ in $190 \%$ and his owner, senator George Whituey, of bermont, had crery reason te think that he would pace a mile in less than two minutes the following gear, but unlortmately the great paeces died during the wintere and the track lost an equine hero.

Gallagher, Q.03 $\frac{1}{2}$, is another paces beed in Canala that has attracted attention to this comotry as a producer of last horses. This well-known pacee is a produet of IVestero Ontario, and has a well-camed reputation as a great campaigner. Several

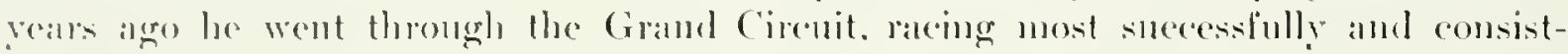
cotly against the best horses the leading horsemen in the Inited states romb pit against him, after which he was sold to ge lo Europe. lle remained abroad but a singrle sason, when he was returned to Ameriea and sold by aluction at Cleveland. (). When he was kneked down to the bid of Messis. Browa \& Wigle, of Windsor. Many of the cirenit followers thought the gedding had secon his best days as a racing propesition, and that the Canalians had bought a "grold brick" as it were. but the

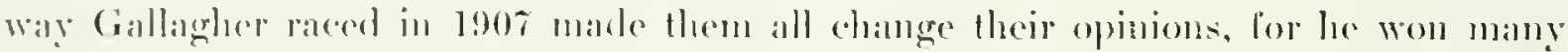

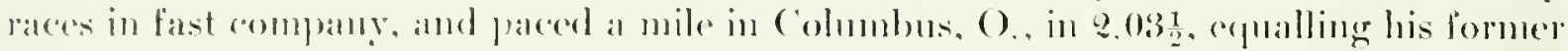
record. During the season he lowered many half-mile tratek records, and also the

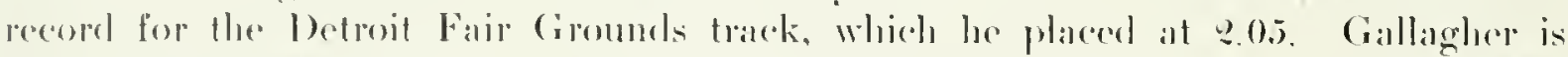
now owned hy Mr. Brown, of Lexington, (Ont., who bought out the interest of Mr.

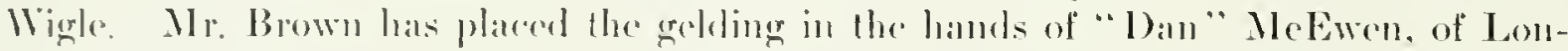
dom, who has been most stlecesstul with parers, having camplaigned such good ones

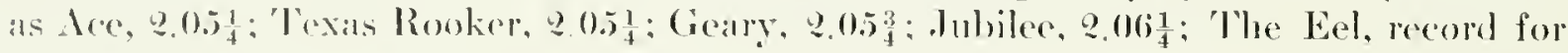
scasom near lo two minutes, and others.

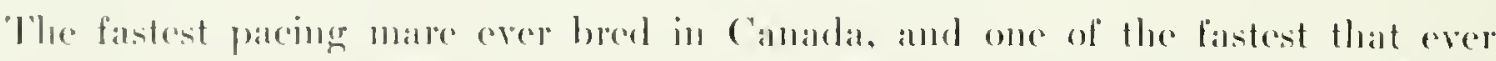

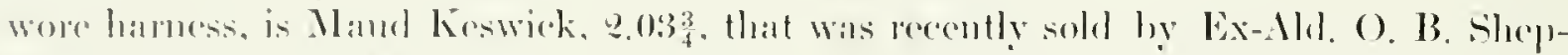
parel, of 'Tomonto, to Mr. Brown, of laxingtom. This mare stated the seasom of 1905: comparatively gerent prospent. and went into winter quaters that year with a record of 2.093 , a notahle aldieverment.

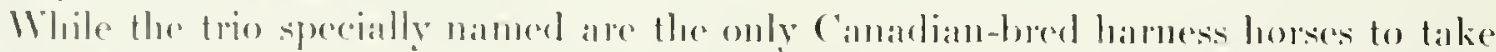

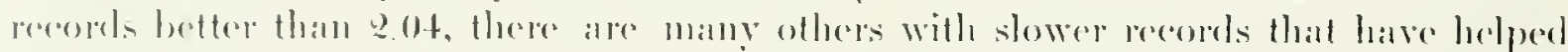

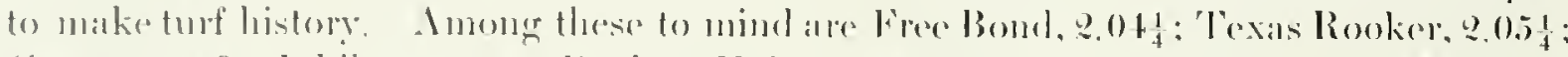

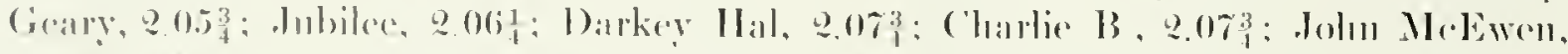

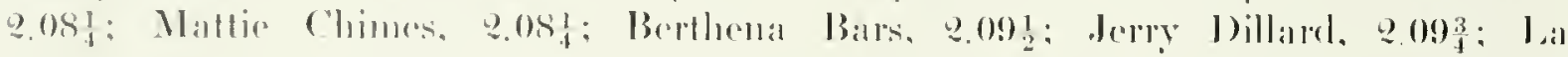

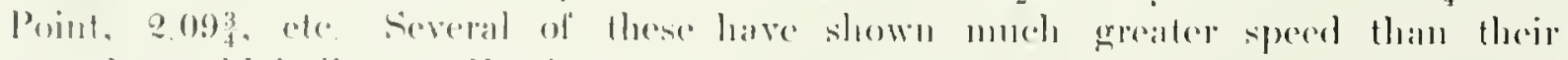

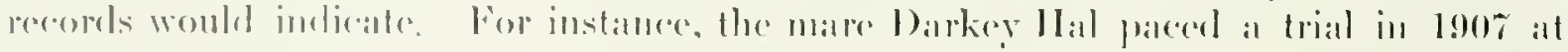

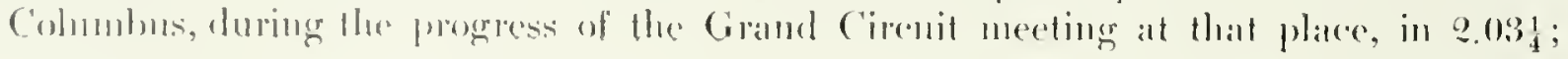


John MeEwen, owned by the well-known steeplechase jockey, Nat Ray, of 'Tomto, paced a mile in public in 9.04 at Ponghkecpsic in 1907, and as the track there is not considered anywhere near a fast one, it looks like Nat's pacer coubl have paced the Columbus track in its best condition in 9.09 or better. La P'oint has been many miles in lex work around 2.05 over a mile ring, and Berthena Bars has shown 9.06 for a mile.

Although none of the horses numed hare established world's records, if we except Ingus Pointer's waggon record of $2.03 \frac{1}{4}$, Canadia has the distinction of producing the holder of the three-year-old pacing record for a half-mile on a half-mile track. 'The

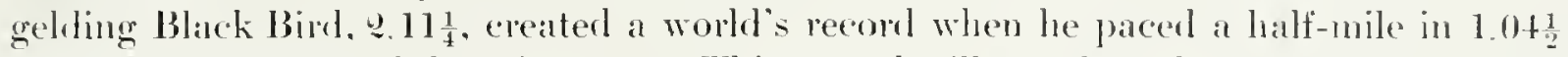
on the Exhibition track here in 1904. This record still stands, althongh it was exualled by the eolt lan Bar during the Canadian Circnit races at Stratford in 190\%. Mr. Pierce. who trained and raced Ian Ball in that year, had a two-year-old in his stable that conkl pace a half close to 1.05 , and he was eonfident there wonld be a new recond for three-year-olds when the yom gsters got to racing.

In vears past mamy trotters bred in Canala were able to go south and win on the big traeks, but only one was able to get into the chamed circle of select society, and that one is the gelding Wentworth, who took a reeord of $2.04 \frac{1}{2}$, the fastest ever obtaned by a Canalian-lored. Wentworth was foaled in the vicinity of IImilton, and was mbroken milil five years old. He was sired by Superior, a stallion owned by the reteran simon James, who, by the way, is still hale and hearty at his home below the momtain, althongh carring the weight of nore than fourscore years. It was Mr. James' son, Ilavis, now recognized as the leanling Canadian Linight of the sulky, that first brought Wentworth into the limelight, wimning many important races with the black gelding on the Gamd Circuit. Anong the baek numbers. Alvin, ?.11:

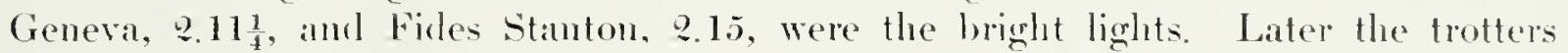

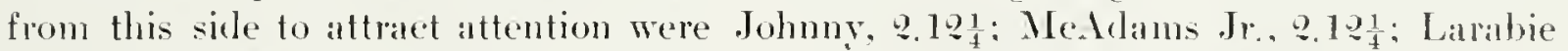

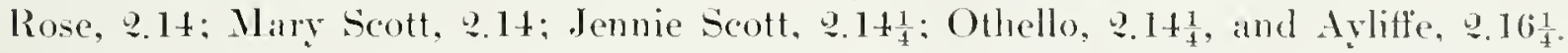
Of these, much was expected of the gelding Johmy, that is owned by the Brantford horsemen, Messrs. Hunt \& Colter. At the begimning of the season of 1906 it was conficlently thonght hy those on the inside that Johnuy would retum to winter quarters with a record of 2.08 or better, but mortmately the little trotter went wrong in one of his hind legs and did not get to race. The following winter he was started on the ice eirenit, and mate grood in all the races, and in $190 \%$ he was sent after the money on traeks in the Lnited States after he had eleaned up the trotting stakes on the Canatdian Circuit. Race after race was won by the Brantford trotter, and it was only when he measured strides with the fast flyers at Detroit, in the celebrated Merehants and Manufacturers Stake, and at Colmmbus, that he met with defeat.

Of the trotters in Canada to-day probably the fastest is the blaek gekling (othedlo. owned at Chathan. This holse has made but one start on the Grand Cirenit, hut in that he showed much hetter than a 9.10 trotter when he was seeond to Daniel at Colmmbus last fall in $9.08 \frac{1}{4}$. Othello continues to be laced on the big tracks, and unless all signs fail, another extromely fast trotter lias to be credited to Canadia. 
Another world's record that is held by a Canadian-bred, is that for trotters in a half-mile ice track. 'This is $2.19 \frac{1}{4}$, and was made during the winter of $1907-8$ by the gelding King B ryson, owned by Mr. Samuel MeBride, of loronto, when he trotted at Plattsburg, X. Y. in a winning rilee, King Bryson went through the winter's rieing with a phenomenal string of vietories, winning many important races, and, julging by the form shown in his early training, he is entitled to be considered one of the trotting stars on the Canadian tracks.

lnextricably concerned with the progress of the hamess horse in Camada is the "nterprise shown by her latgest breeders and owners, notably, that of Miss Wilks, of Cruckston linm, Galt, and Mr. A. C. Maclaren, of Puckingham, Quebee. A general anticle, lowerer, is not the place to deal with individual ventures. Still it is inpossible to arodel paying respect in dealing with the subject to those who stand out so pominently as do Miss Wilks amel Mr. Machalen. the former as the owner of the

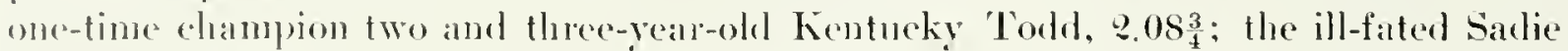
Hat, g.06 $\frac{1}{4}$ : the stallion Mograzia. Oro Wilkes, and a hundred others; and the latter as the foresunner in a lealling position primarily with the goon ralce-horse and mag-

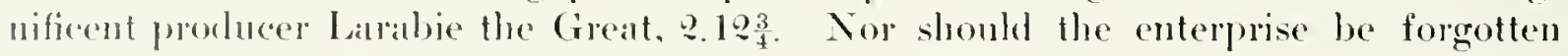
in by-gone days of stleh men as Angus sinclair, of Roslyn stoek farm, "Ansonia" Stewart. I. ('. J) Detricll, of Gilt, and other's.

If we mistake not. hamess racing has bright days before it in every province of Canalar, for in arery province both the trotter and the pacer are naking great hearway. While the thoroughbred is practically mknown in the Maritime Provinces, the trotter and palce alre ererywhere to be foumd. and no Fair is considered complete maless the hamesis horsemen make bids for victory. 'This is true also as regards Manitoba, although lere and in the Territories and in British Colmmbia the thoroughbrent is making considerable progress. But the great hold of the light hamess horse lies in mad rateing, and in the innumerable driving (bubs that have sprung up, and are still spromging up, all weer the land.

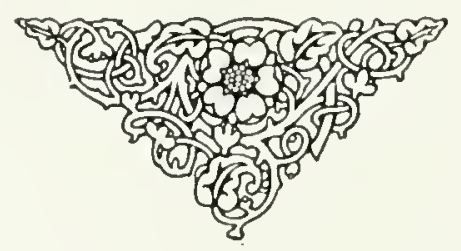




\section{EDWARD SELKIRK SKEAD}

$\mathrm{E}$

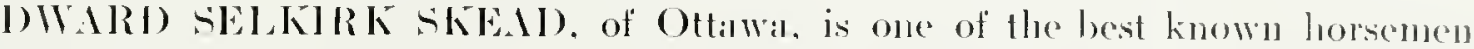
at the capital of Canadil. The son of the late Hon. James Skeald. semator, who was one of the pioneers of the lumber business in the Ottawa valley, he was born in Ottawa in 18.5.5. Niter a conse at Tpper Canatal Collexe. Toronto, he travelled for a year and them returned to Ottawai

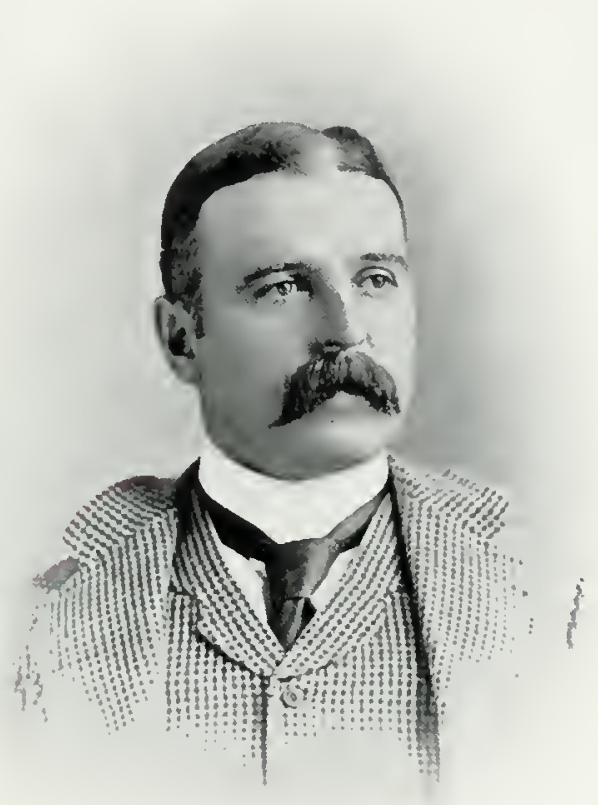

ENWARD SELKIRK SKEAD to enter upon his fither's business, which lue lats sinee conducted successtully.

Einly in life he showed sincere affection for horses. which was accentuated when on his ninth hirthelay he received the present of a shetland pony, which lived for thirtytwo years. and was a filvorite of two genelaitions.

Mis grantest pleasure in life has lween the following of the hommels. and even 110 w he maintains his custom of riding to hommes on every possible occasion. His favorite hunter was a mare, Titula, whicl, did yeomanls service, won matny stecplechlises. and was finally killed while going through at heary fickl. Mr. Skead was in his rommer tiys a noted polo pliyer.

Ile has been a familial figure at most of the leading horse shows. having driven many a prize-wimuer at Mardison sefuare Gialden, Philadelphia. Boston, Montreal amel Toronto He has also been longe regalded as an excellent jutge of saddle lorses and hunters, anul when an opinion as to the purcliase of a huntar is wanted he is looked to, owing to the repulation gained in judging this elass of lorses at the numerous shows on this continent.

llis stock-finlm "Riverview," on the Iyluner roirl. is one of the best expuipped in the Ottawal district. No lover of horses who groes to Ottawa retums home witlyout visitimg the skead farm, and all who have any regard for mans best friend alre

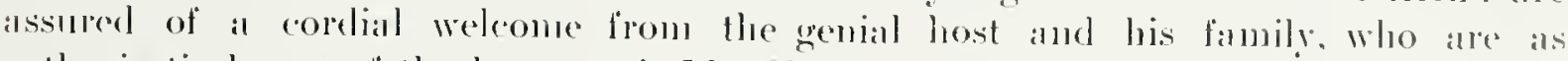
enthusiastic lovers of the loorse ats is Mr skearl himself.

Mr. Skead has always heen ambitious to have a race track established at the (alpital and has devoted considerable lime furthering the scheme, offering his property on the sylmer Road for the purpese at ronsiderably lower price than the properety was worth, and at time of writing it seems that Othawal woukl at hist have a race track for thoroughbreals. 


$$
\text { T }
$$




\section{GEORGE W. VERRAL}

$\mathrm{T}$

RLLY one of the most remarkatsly quiet men in Canada is George William Verral, of Toronto. Who. although almost an oetogenarian, appears like a man approalching his sixticth instead of his eightieth year, for he stands ereet, sees well, talks in a most entertaining fashion, and looks back with serene satisfaction upon a life characterized thronghont by that usetulness which has been snch a factor in men of his calling helping to make Canada a nation. Ilis contentment is empluasized ly the fact that the good lady he married over laalf a century ago is still his able helpmate, and the six danghters and two soms whell blessed the mion are all hale and hearty. Mr. Verral was the fomder of the business now so widely known as the Verral 'l'ranster Co., and the story of the old gentleman's career is one that is calculated to inspire the young Camadian and spur to emulation.

Mr. Verral was born at Seaford. Sussexshre. England. in March. 1899. His lather, 1)r. (Jarles Verral, was a prominent physician. widely known in England as the inventor of the Prone Couch, a cone for spunal diseases. which was of such benefit to the community that the existing Prone Conch hospital in London was ratablished

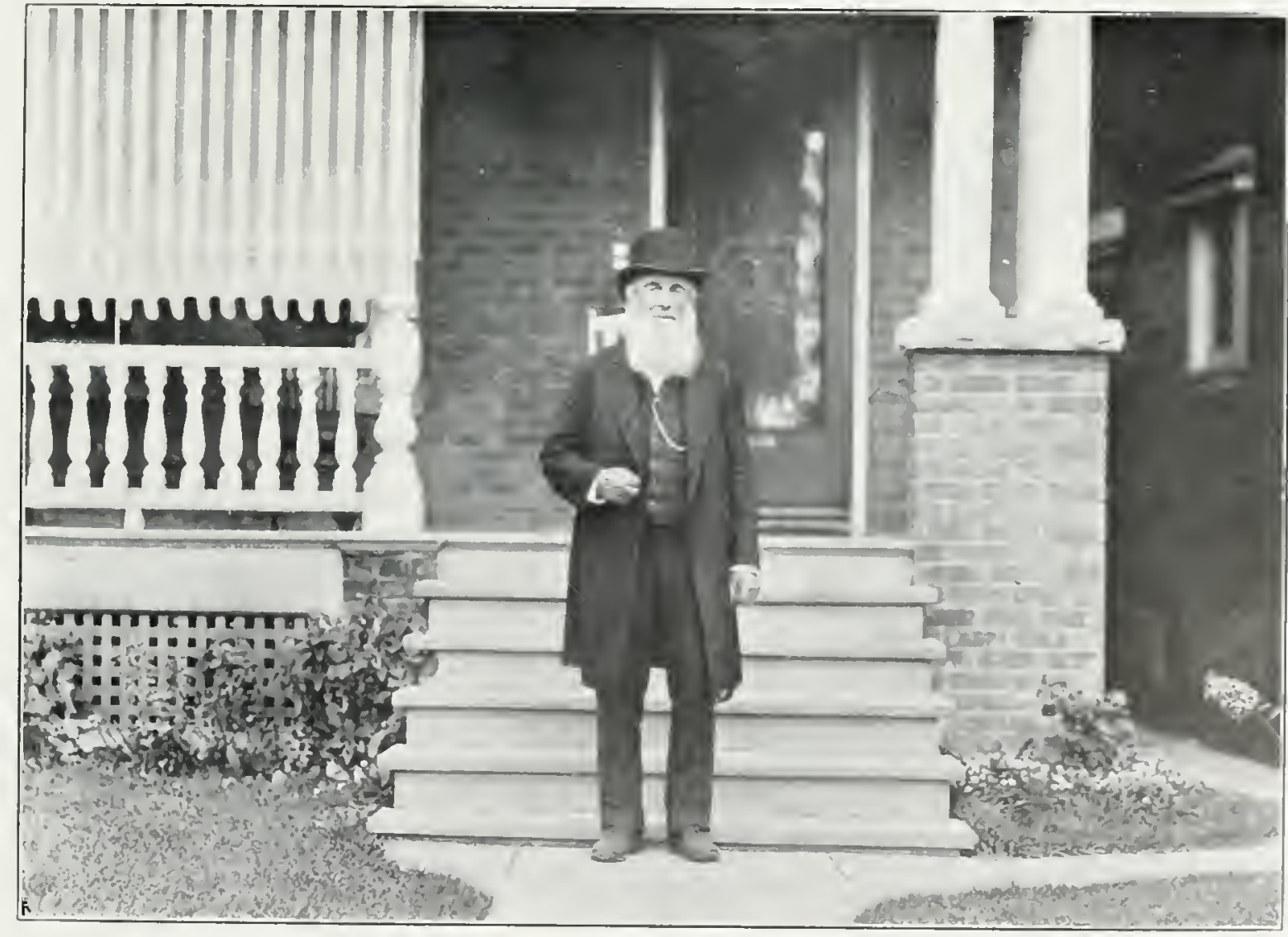

GEORGE IV. VIRRAL 
and was for a long time managed hy a brother of the inventor, also a eloctor. Mr. Verral's erandfather on the paternal side was also a medieal puatitioner. On the matemal side the grandfather was a cleregruan of the Chureh of England. One of Mr. Verral's prized posiessions in his pretty residence at 43 Kendal Ave. 'Toronto. is a framed aleeonut from a Brighton paper of 185 , entitled "Ilistory of our Anecstors."

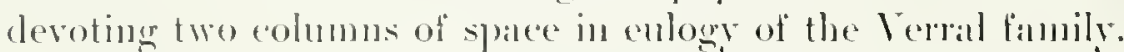

Mr. Vorral started out for himself in life early. Ile was some years at a boarding selhool in Lewis. Ilis lither died when the latl was fourteen veats of age. The ex-

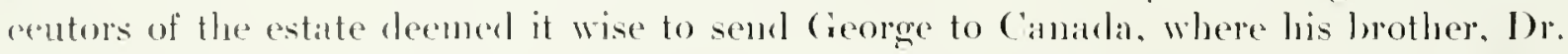
Henry Verral, Was pratetising at Goderich: so in 1843 the boy came acress the Atlantice in a siling vessel. a "packet ship," reaching New York after a long and meventful prissigere. It took him a week to gret from New lork to 'Toronto. The New York Centrial Ry, was then in course of construction, and roung Verral. to get to Poronto. lade te take a small steamer up the Hulson as far as Mllany. Then he travelled hy canal boat to Rochester. and from there came acooss Lake (Ontario, on the little steamer liochester. to 'Toronto. 'The lad was of a comrigeons nature and decided to depenel entirely upon his own eflorts to mould his future. Ilis first oceupation was gardening, whicl did lim good, and is probably responsible for his lusky frame and bright intelleret to-day. 'Then he went into the employment of a Mr. Sams. who conducted a store on King st. Toronto. Mr. Sanns was a fimons English cricketer, from Brighton,

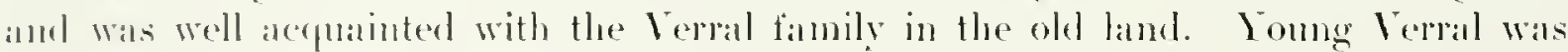
very satistactory. but the end of his carcer as a store assistant came muder tragie anspices. Mr. Sims went to meet the steamere at the old whatre foot of Yonge St., to get some goods. Ile stood too close to the edge of the doek, and the fender of the steaner struck him, cansing his death. It this time, Mr. Verral was about twenty years olel and. seeing the opportunities ofern for the suecess of a livery husiness. he went into partuership with Mr. Farley and opened an establishment on Sork St., a site now ocempied by a portion of the Rossin House. In connection with this lusiness. he beeane inti-

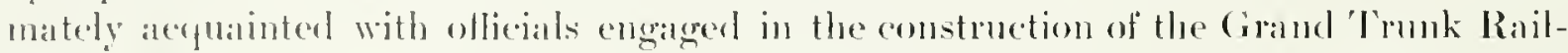
way. Mr. 'Tait, superintendent of the lunilding of the line east of Toronto, was inapressed with the younger man's ability, and induced him to aerept a position on the smrveys. Ho was engagerel in railroad work for about five years, when the work was completerl. It the conedusion of the fourth year of this servie he was offered the position of station master at Whithy, hut declined it. on the representations of his friends in anthority, who said that when the roal was completed there wouled be lar better positions which Mr. Verral womld be alpilble of filling. However, changes were mate in the managenent, and the new faces in elatrege were strangers from the Olal country, and the senes joh did not materialize. Then Mr. Verral weat batek to the livery hosiness. Ile was alwaly fond of horses and loy this time was well known in

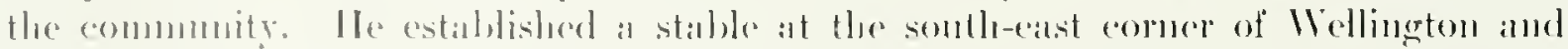
lork Sts., but the property was sold and is now the land npon which the Torouto Club stands. 'Iluen Mr. Verral moverl to Front st., opposite the custom House. 
but funcied getting further west, so le bought property on Wetlington st.. between Simcoe and John Sts. He built large stables on Mereer st. and also erected a confortable residence near by. 'lhis property he occupied for nearly forty vears. About fourtecu years ano he sold out to the Verral Co., of which his two sons, Cieorge and charles, are the guiding spirits of to-day, and are in control of an enormous husiness.

Mr. Verral was for years active in municipal polities. Ilis fellow-citizens appreciated his energy and ablity to give the municipality good service, and for ten years. continuously, honored him by retuming him as Alderman. For seven of these vears he sat for old st. Creorge's IVard, and then, when that district was inrorporited in the new system of wards and was part of Ward Four, he was elected for each of the next three vears. For several vears he was chairman of the Market amel License Conmittee and also sat upon the Bourd of llarbor ('ommissioners. 'Though now out of all kinds of polities, he is yet an ardent champion of every matter he considers in the Welfare of the city and comintry, and he still has a fondness for his old friends, the horses, and the livery business in particular. Mr. Verral says that he never had time to go in for show horses. His fancy was a good, strong livery lrorse, and there is no better judge of such anywhere. Mr. Verral has been an enthusiast in Masonic circles and is a nember of the Sons of England. Ile is an energetic atherent of the Churele of Enerland and was for several years a member of the Inglican syorl. He was married in Toronto, fifty-three years ago, to Miss Anne Farley, and the union has proved a most happy one. It is a source of congratulation that the hand of death has not mate any galps in his large family. Mr. Verral mentions with priele that he was himself one of a fimily of twelve-nine girls and three boys. Only two survive, himself and a sistel eighty-nine yeal's of age, pesident in Lonelon. England. Mr. Verral's eldest son, Creorge, is well known in Ontario political circles. In the Provincial election of 1904. he wis the Liberal canditate deteated in West lork by the late Ilon. J. W. St. John. Speaker of the Local House. Both he and his brother are bright business men, with an inlierited capacity for work and keen business instinct bound to culninate in success. Recently they have added to their facilities half-a-dozen fine motor tallyhos. which are very popular with tourists on the rounds "Seeing Toronto." Mr. Verral is justly proud of his boys, and their wish that the old gentleman may still be spared for many yours is echoed by thousands of people who have enjoyed his aequantance. Ite siys his working days are over. but, nevertheless, he always finds something useful to do somewhere.

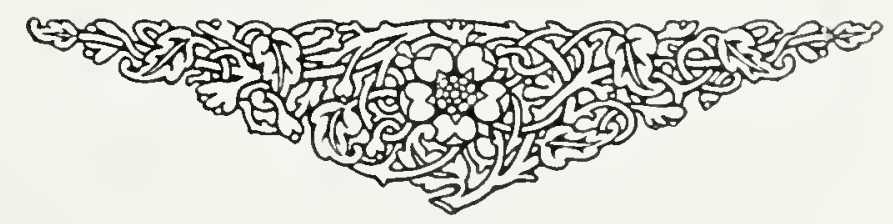




\section{POLO IN CANADA}

A CrlEXNT a game as l'olo is, it has not as yet taken what might be called a very emphatic hold upon Camada. It made its appearance in the West somewhere around 1859. When some offiecrs and young Englishmen took the game up and astablished teams at High River and c'algary. Ciradually more teams were organized, among them one each at Sheep ('reek. Cochrane and Pincher Creek, the advance guard lecing usually roung Englishmen who had gone in for ranching. Before long Canalims took kindly to the game and at this time Alberta alone can boast fourtecn strong teams.

Lientenant-Colonel Willians, at present Commander of the Royal Camalian 1)ragoons. was one of the earticst to exhibit a penchant for the game and when. in 1900. he foumd himsell in Wimnipeg. he at once proceeded to organize a chub there. Infortunately, this chuly was not of long duration, but a couple of years ago another elub was formed in the Prarie ( ity, and this year it is proposed to hold a tourmament. if not on as anbitious a scale as the bonspiel held in the winter anmually, at any rate in a manner more liberal, and eren generons, than has characterized any tommament in Eastem ('analat. 'leams are also to le fond at Qu'Appelle. Indian llade and one or two other plates in Manitoha. The Western chubs have hedd a tommament ammally since the introduction of the game. New blood is continually groing in aud. the country heing wedl arlapted for the sport, young men of the territory soon acquit themselves well and, ats we have sech on several oceasions. have rather the hest of their friendly

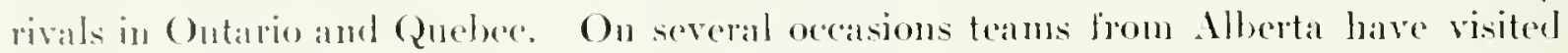
Forente and Jontreal and the high standard of play shown by them has greatly

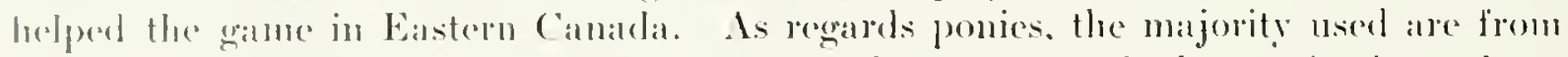
oul own Northwest, and although some have becon imported the native-born have mallally proverl the best.

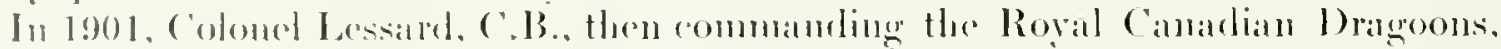
fetermined to oroanize a clul, in 'Toronto, and having a pronounced disposition to put his ideas inte practieal and businesslike elfect. proceded to the west in searrel of the

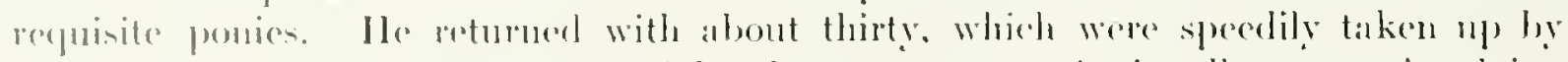
enentlemen who hat been attracted by the new gane. As in all matters involving

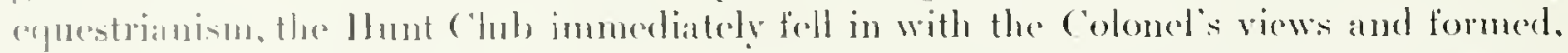

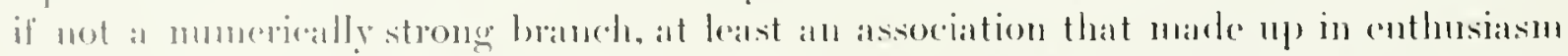
any defiedeney in mombers. Mr. J. Kerr Osborme berame the first President of the

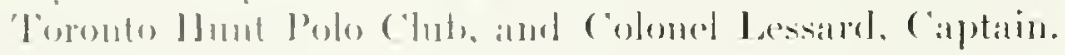

In the same year Woutral omanized a chul, with lientenant-coloned Meighen

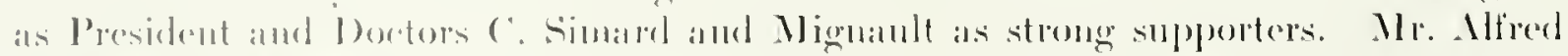

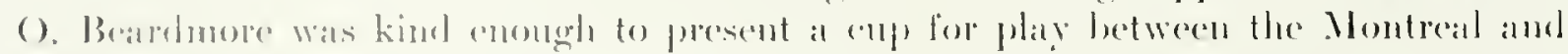

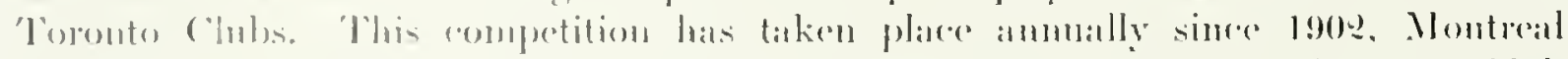

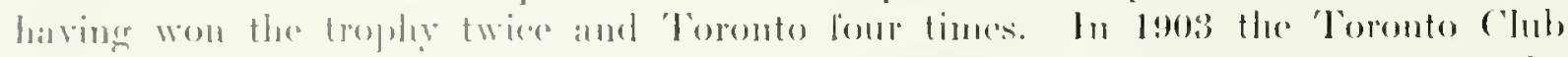
oreanized an huternational Tommanent, and presented a trophy to be known as the 
luternational ('up. 'This cup was played for by Anerican and Canadian teans anmally, but Rochester, N.Y., proved the best by beating 'Toronto thee veatrs ruming and wiming the (up outright. Another godel (enp was presented by the late Mr. J. G. Ireril, of Rochester, N.Y., to be competed for on the same combitions as the International cup presented ly the 'Toronto Cluh. This trophy has heen won two yeals in succession by the 'Toronto Hunt ('hub teann and it is now in their possession.

In the 1902 tournament, held in 'Toronto. High River, Rochester, Montral and 'Toronto competed. Iligh River, the members of which team played a spanking, resolute gimne all through, won tolerably easily. In 1905 the second tommanent was hedel in 'Poronto, with the same team competing and Buffinlo as an addition. 'The IIigh River quartette again proved themselves expert at the game and again won. During this tommament a match was made between Eastern and Westem players, and the litter won. In 1906 a tommament was held in Montreal, the competitors being ( algary. Montreal, 'Toronto and Kingston. The Limestone City team, it should be mentioned, organized by that ever mwearied enthusiast, Lientenant-Colonel Williams, made its debut at this tommament, and althongh the gentlemen of the team gave a creditable arcount of themselves, 'Toronto came out victorious. It shonld hatre been mentioned that prior to this, in 1905, the year the Kingston C'luh was formed, a second elul, called the Back River, was orgamized in Montreal, Major George Hooper being the moving spirit.

In 1908 Montreal bait the 'Toronto Club and won the Bealdmore coup, making thit eity's team a second time wimmer.

In $190+$ the Eastern Canadian Polo Association was organized, with LientenantColonel Willians as the first Presiclent. The Montreal and Toronto Clubs were the sole members at first, hut since they have been joined by Back Rivel and Kingston, and have some hopes of IIamilton and Ottawa coming into line. All Polo tommaments in Eastern Canada are held under this Association, of which Lientenant-colonel Witliams is still P'resident. I ientenant-Colonel Meighen, of Montreal, being Vice-President, and Iajor Ehmsley, Secretary-Treasurer. An Executive Committee is formed of two members firom ealch tean.

Colonel Lessand, whose removal from 'Toronto to the Military Headquarters at Ottawa, everybody in the former city greatly regretted, at latest advices wats taking an active part in forming a club at the Capital. In organization is also in progeress at Quebec.

Up to 1906. Quebec, although a strong military centre, had not seen the ganne played, but in that year two Montreal teams went to the anclent capital and played an exhibition match before two thousand people.

'Toronto's first experience was somewhat after the fishlion of Queluec's. In 1902 a couple of teams, muder the direction of the late II arry linmlin, visited the eity and played an exhibition game humer the holding of the Exhibition in the old horse-ring.

It is rather singular, eonsidering the enthusiasm that wats manifested then, that eight years slonld have been allowed to elapse before anything was done to oreanize a 
Polo Club at the Capital of Ontarjo. Howeves, now that the game las got a firm lookl there, and is in the hands of men like colonel Williams. who are indefiatigable in anything they undertake, the game is boumel to push rapidly ahead. A Polo Tommat ment is ladel in 'Toronte in the latter part of septentere. In adelition, other matelues are arranged for a beantiful cup, presented hy Lient.-Colonel Meighen, of Montreal. to the 'loronto llunt Clab for ammula competition on their grounds, whelh, by the way, experts dectare are among the best, if not the resy best. on this continent. The 'loronto cluh presents pewters to the wimniug team.

The Outario dockey ('ub has also shown an interest in the game by laving a ground made in the astern seretion of the enelosure formed by its splendid mile track. Un-

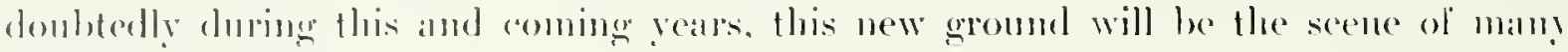
imbertant matelies.

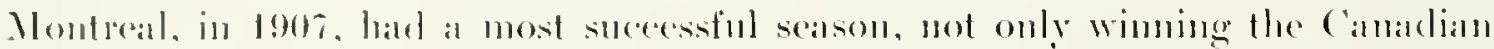

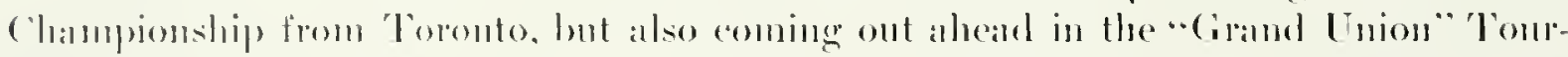

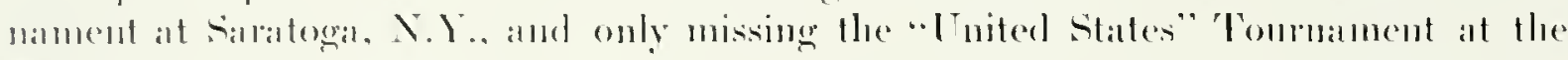
same place hy three-quaters of a gabl. Montreal. however, hand the grood luek to

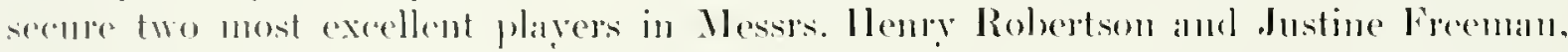
erentlemen who alepuired their knowledge of the galme in the west, and who had

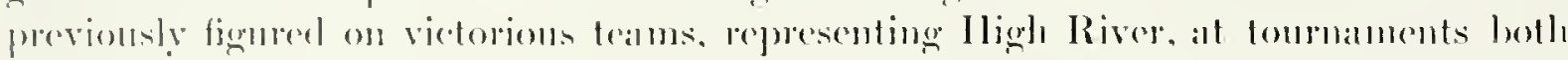

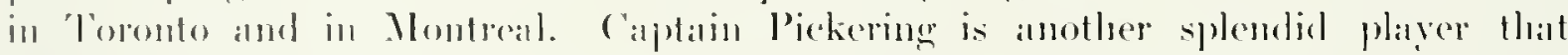

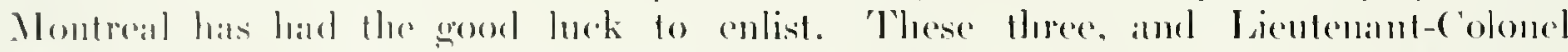

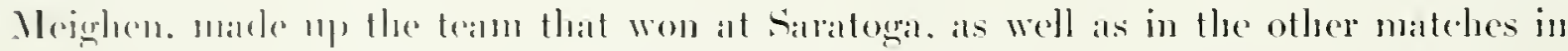
which Mlontreal suceresthilly compeled in 1907. As respards the general history of the

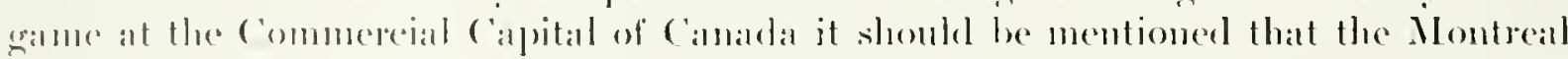

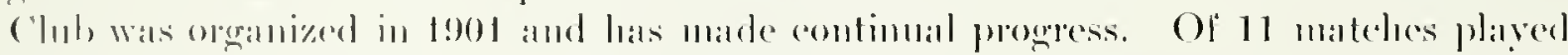
in 1908 the ('lul, won 9. It was the first Camalian Club to send a team to take part

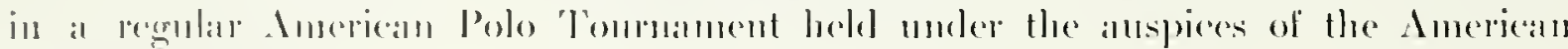
lolo. Assomiation.

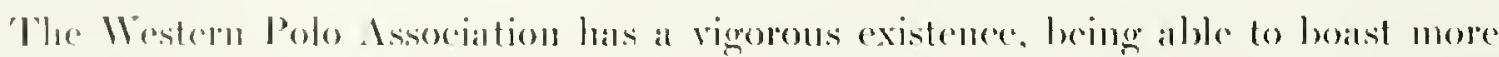
clubs thall any other lole Association in the lominion. Its membership is fourtern

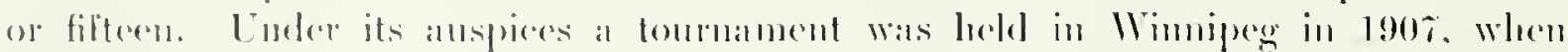

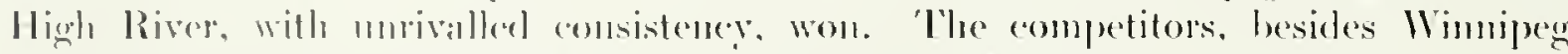

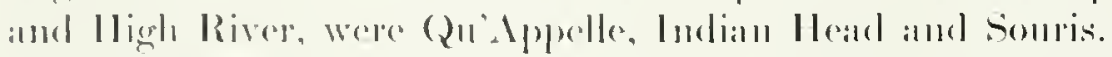

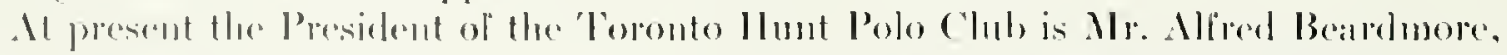

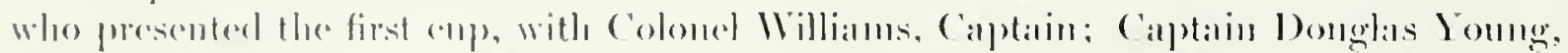

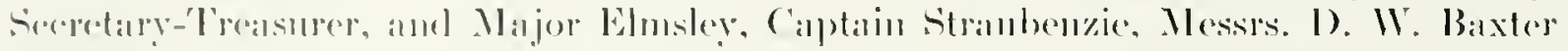
and bivart Osborne. members of the lixerentive. I moving spirit in the progeress of

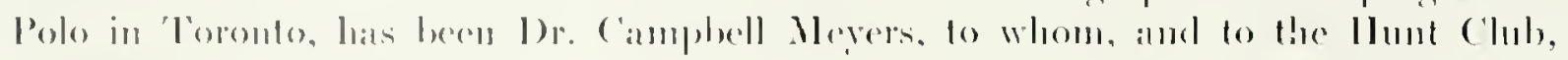
admirers of the ancient game in the (2ueen City of Calladal owe al great deal. 


\section{SENATOR ROBERT BEITH}

C

ANAIDANS have every reason to be prond of Senator Robert Beith, who is probably one of the best known horsemen on this continent. Senator Beitlo has to his eredit more prize ribhons than any other hreeder of Itackneys, as well as having the distinction of being the only Canadian to win championships at the World"s Fair shows, both at chicago and st. Louis.

He has paid particular attention to the horse the greater part of his life. Having a stock farm, which is known as "Walverly," at Bowmanville, Ontario, he not only pary

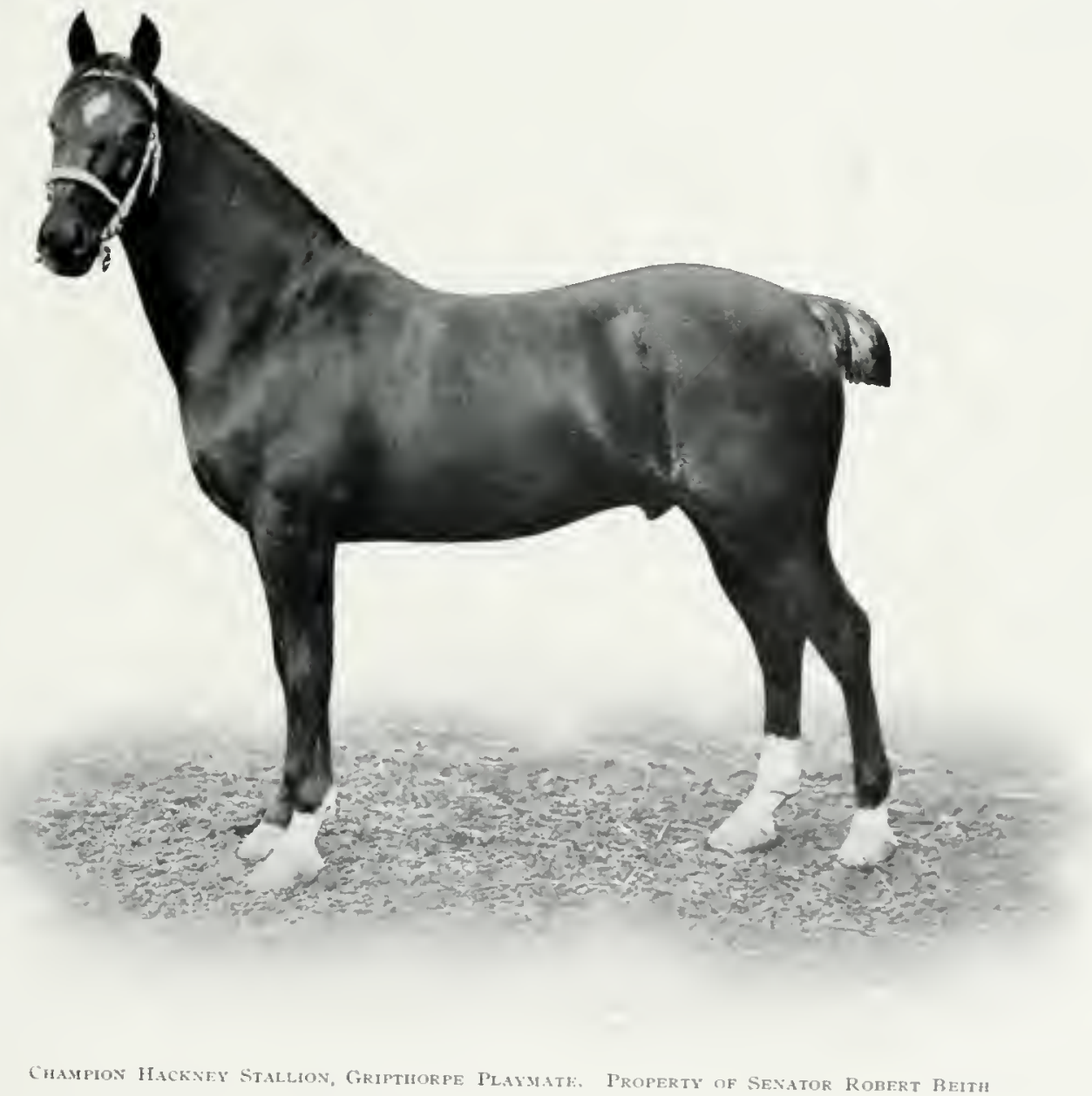

attention to the breeding of Hackneys. but in a small way to Clydestales, and has also won prize ribhons with this elass of horses.

Mr. Beith has never taken up any other business than farming and stock raising. In this he has been most sucessful. even from the beninning. He has raised many a prize-winner at his farm, and is more prond of this than of winning with his importations. 
Rolvert Beitl was hom in Darlington Township in the year 1843, being the son of Alexinder Beith, of Argeleshire. Scotland. Aiter taking a prominent part in polities for years. he was appointed to the senate in the year 1907. and is now looked on as one of the stalwarts of the Liberal party.

When Mr. Beith was about twenty years of age he branched ont as a horseman. The ereatest victory ever scored ly Mr. Beith was when he won the ehampionship at the

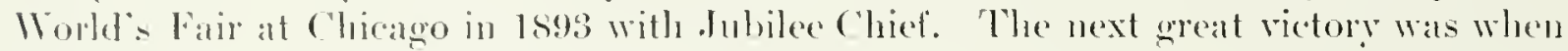
saxon. another IJackney stallion, won the same honors at the Workl's Fair at st. Lours. 'This parle won innmerable ribbons, and were sold for a big price to Americans. Two other nood ones owned by Mr. Beitl were Ciripthorpe llaymate and Robin Adair. 'These were also great prize-winners. The horse saxon bronght the largest price ever paid for" a Canalian-owned horse sold at puldic anction. as he lorought the sum of five thousand five humbed dollars. Mr. Beith manages his own stable. and makes all his own selections when he imports English-hred ones. Ile is of a genial disposition, but very morlest in his manner when speaking of himself or his many victories in the slow rimg.

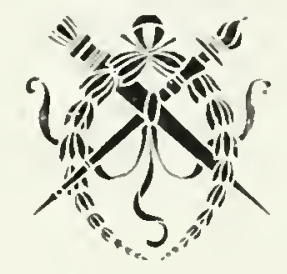




\section{Lovers of the Horse}

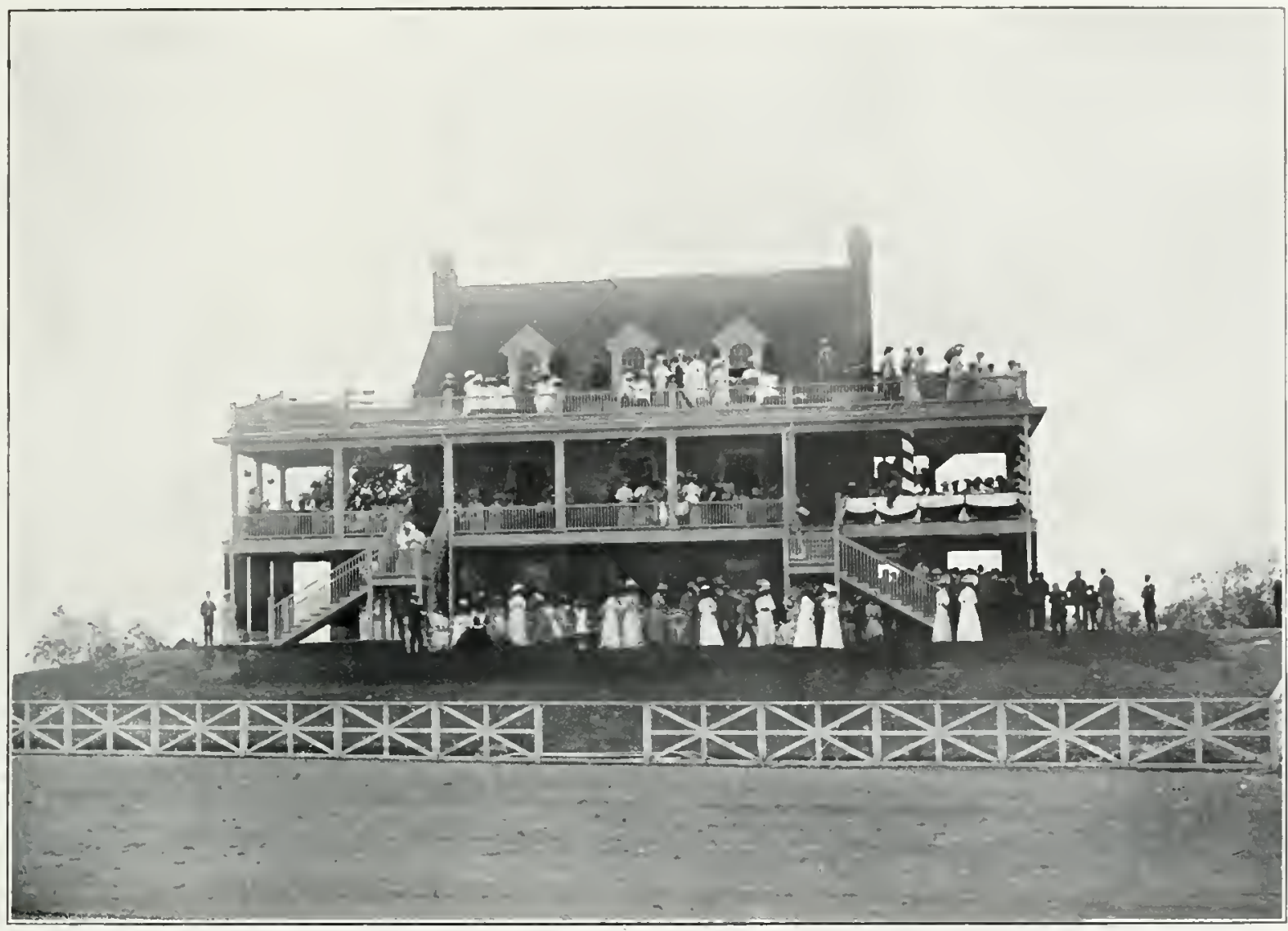

IHE CIUB-HOUSE OF THE MONTREAL JOCKEY CLUR

\section{MONTREAL JOCKEY CLUB}

$I^{1}$

is no stretch of imagination to say that the new race-comrse at Bhe Bomnets, the lome of the Montreal Jocker Clul, is the finest and the most np-to-date in the Dominion of Camada. Nature, money and brains have been united into a combination which has given the public of Eastern c'anadal, and Montreal particularly, an ideal resort for the "sport of kings." Of all its improvements that have marked the progress of the Province of Quebec and the City of Montreal, none will prove of more benefit than the formation of the Montreal Jockey Chuls and the building of such a first-class track. Its benefit will be felt more in the years to come than at the time of writing. 'The plant is beantifully situated west of the momntain, consisting of one humbed and seventy acres of most fertile gromd, being conveniently accessible to the city, and reached either by the street cars or by raibay. The circumference of the track is one and one-cighth miles with two chutes, one for the mile, and the other for the seven furlongs races. The home streteh is a particularty long one, being nearly three-eighths of a mile in length, which is beneficial 
to racing from erery standpoint. The width of the comse is over a hundred feet. which does away with all possible danger of aredelents so common on the turns of nalrow trateks. It the finishing wire there is a first-chass stand with a seating calpacity of four thomsand. and a most up-to-date chub-house and lawn for the use of the memhers. At the other end of the stand is the rotundia. While directly hehind the club-house is the saddling padlock. which affords accommodation for as many as twenty horses at a time. 'The sarldling parldock consists of an L-shaped hmilding with twenty stalls. 'The stabling aceommodation hats been inereased until there is now accommodation for at loast six hundred horses.

The race track proper will in future years make the platere fimons. The soil is of such a mature that great speed must necessurily be the onteome. and what with its

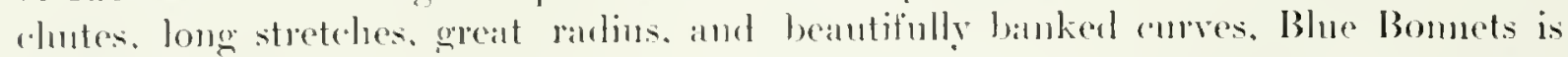
rertainly made to order as a sife and speedy track. This also applies to the steeplechase course. Which is as level as the provertial billiarl table. Those who have pidden over it. and who shonld know, claim it is unsurpassed.

One of the grond features of the place is the electric light plant which hats been installed, doing awal with all danger form fire aromel the stables and bublding. A telephone system was also installerl. so that the stewards in theip official capacity can communicate with erery portion of the park. This also applies to the starting points, no matter from what portion of the grounds the thoroughlueds line up.

Whe citizens of Montreal and rieinity are to be comgratulated, not only for having such a splendirl phare for testing the speed of the noblest of all animals, the

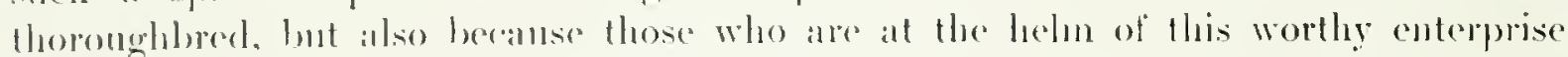
are gentlemen of such gemuine enthusiasm and moloubted probity as must compel

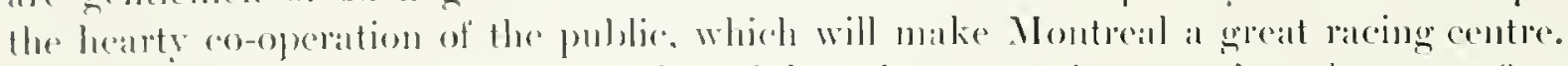

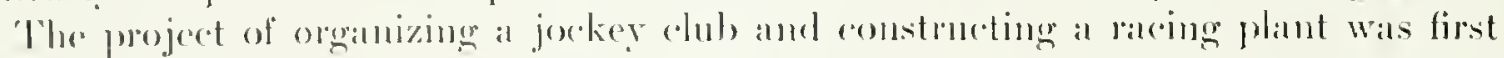
taken up by John P. Ryan in september, lo0.j. The first month was devoted to in-

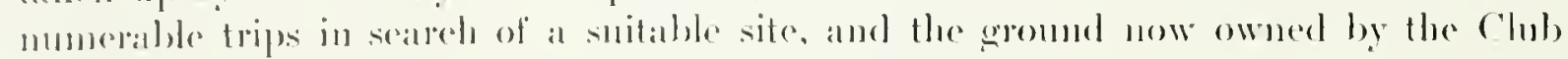

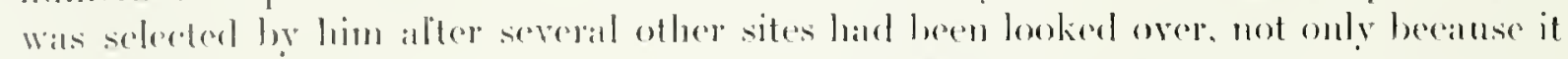

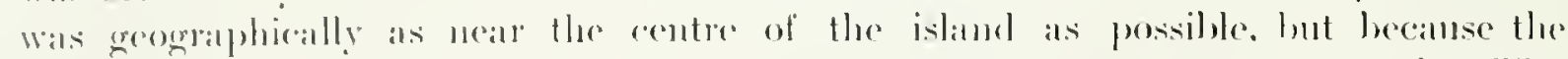

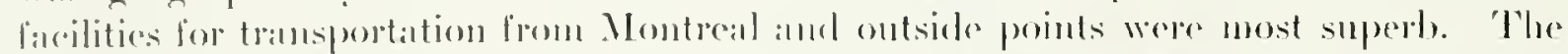

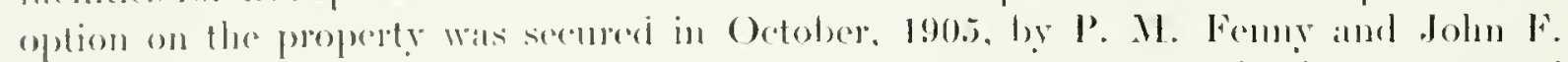

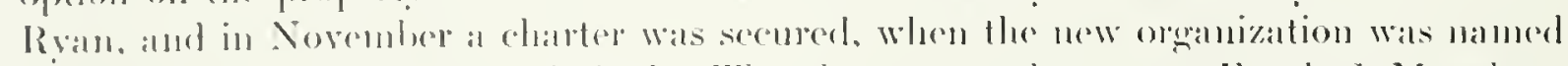

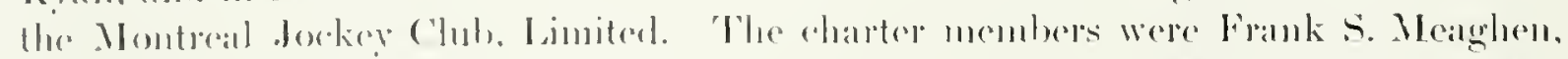

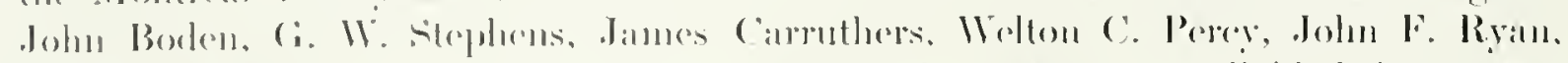

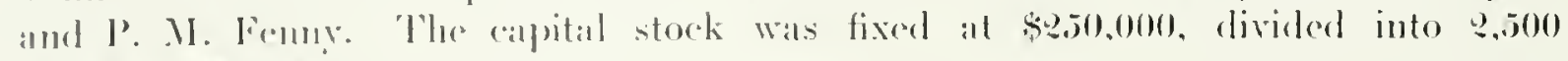
shares at $\$ 100$ (10illo.

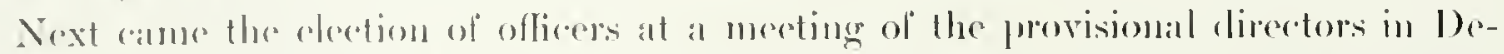

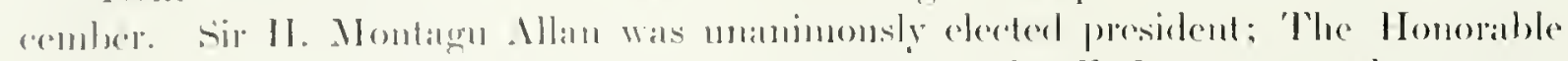

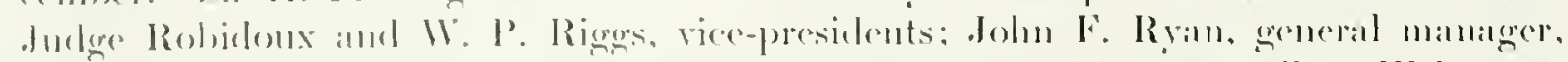

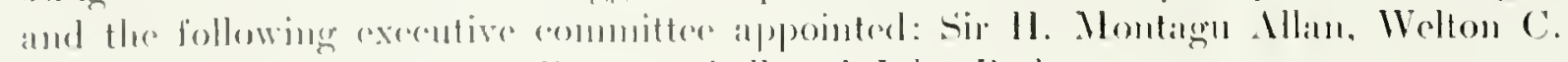

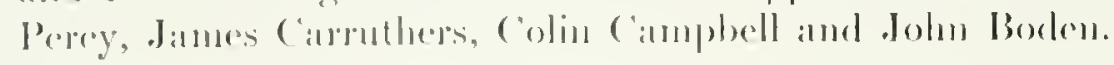




\section{Lovers of the Horse}

During the same montl the land heded muder option by Mr. Ryan was turned over to the Montreal Joekey Club, a prospectus was issued, and sulsscriptions solicited. with such suceess that Montreal was admitted to the second circuit, and it was decided to race mudere the rules of 'The Jockey Chuh of New York. In June, 1906, operitions were commencerl on the plant, and thronghont the summer the weather was so favorable to progress that by October of the sime year the Montreal llunt cluh and the Foxhunters" Lssociation were able to hold their hunt meetings at the new rourse.

A complete waterworks system was installed, by which artesian water is now distributed to ali of the luildings, including the stables. Splendid roadwalys have been constructed to the comrse, making it accessible by anriage or antomobiles from all pants of Montreal.

The new course is most pleasing to the eye. "There are trees in abundance, of ank, chm and maple, an attractive grove of these being immediatedy in the real of the glamb-stand. Mount Royal looms up beyomb the latek stretch, with the city creeping up its terraced sides. The paddock and lawns are extensive, white the spalce in front of the stamd is banked up, giving an unintermpted view of avery rater by those preferring to stind on the gromend.

The luildings are of the old French and Colonial style, with spacions balconies looking on to the track as well at the padflock. 'The club house is luxmrionsly furnished and decorated, and is hy far the most complete structure of its kind in Cinada.

The first meeting of the Montreal Jockey Club wats letd during June. 1907, with the following officials and directors: President, sir II. Mlontagu Allan; vice-presidents. Ilon. J. E. Robidoux, William P. Riggs; direetors, James Camuthers, Colin Camplxyl, Ingh P'aton. Major Geo. Iooper. Bartlett Malemm, Ilugh A. Mllan, O. E. Ogilvie, Welton C. Perey, John Borden, I)r. ('harles MeEachren. Hon. J. P. B. Cissgran. Martland B. MeDongall: executive committec, Sir II. Montagu Mllan, James Carrutlacrs, Colin ('ampledl, Welton ('. Perey and John Boden; Joln F'. Ryin, general manager: II. Nortly, secretiny-treasurer.

The inangural meeting proved a marked success from every standpoint, and for a new track it was surprising the time that was made in the ditlerent trials of speed. The attendance was much larger than was anticipated by the most sanguine of the directors or shareholelers. The purses were most attractive in size for an opening meeting, and brought horses to Canada whose owners had never raced here before.

It wis decided to hold another meeting in the lall, which was even more suceessful from a racing standpoint. in this first year of its existence the Clut, paid out in stakes and purses to owners \$76.975.

A word must be sald about the officials and directors. 'They spatred nothing to make the first rear a snecessful one, and their work will long live als a monnment in the raving wordd. Eareh and every horseman left Montreal lond in maise of the conrse and the treatment recedved. A remalkalde feature was that Montreal paid financially the first yein. which was never known in the history of raeing before. 


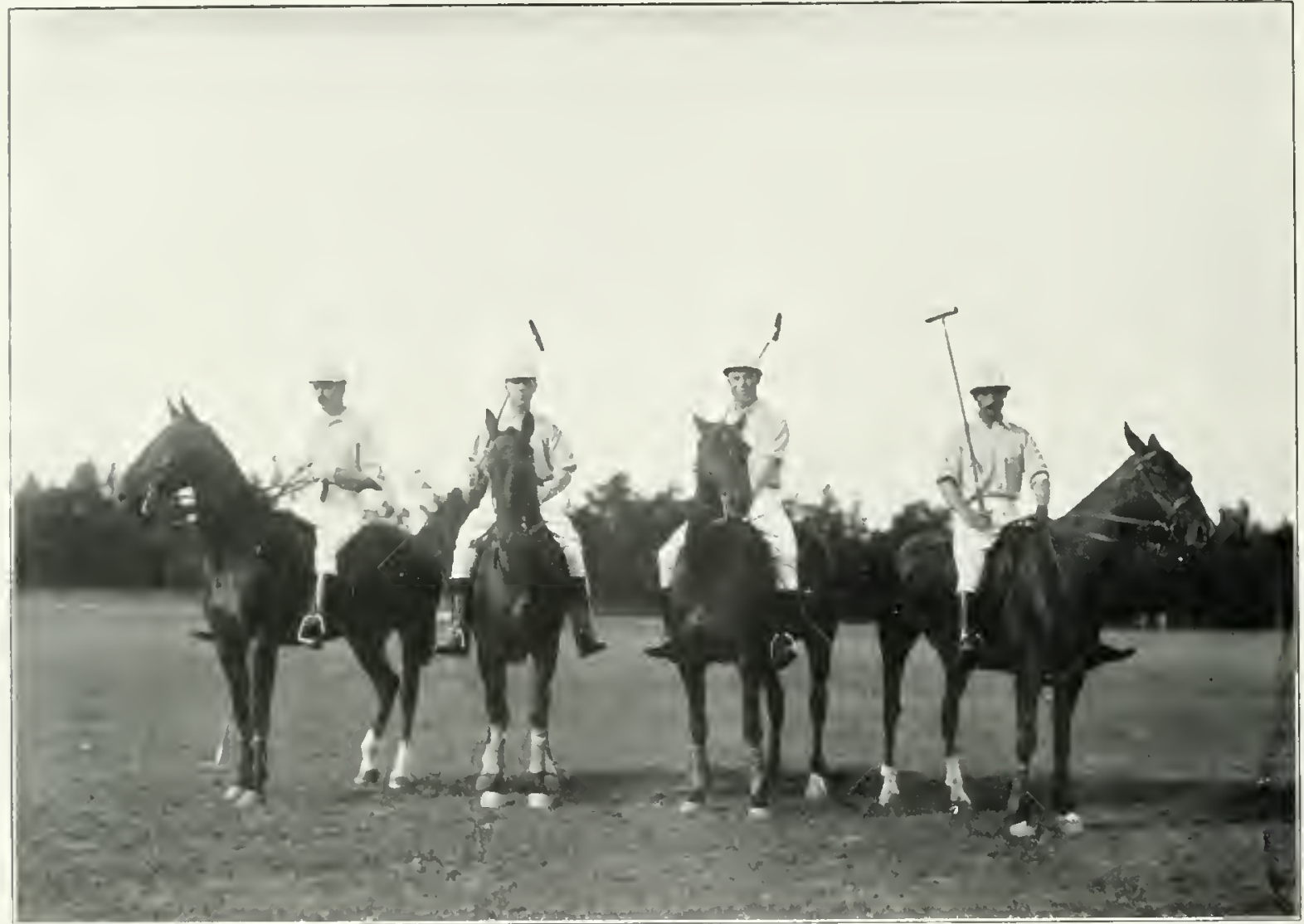

MONTREAL POLO TEAM

\section{MONTREAL POLO CLUB}

$\mathrm{P}$

()1 () is a grand game for the development of dashe vigos and daring. It is

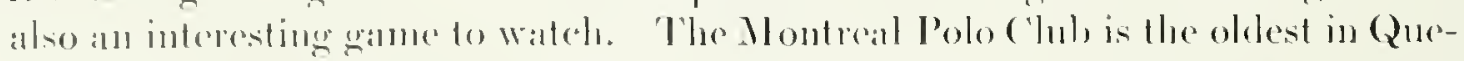

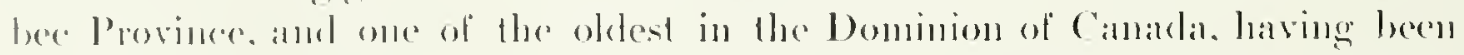

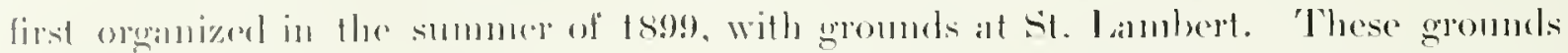

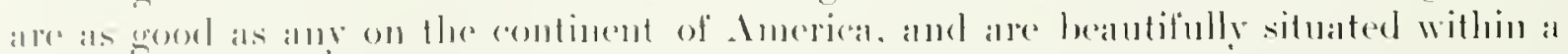

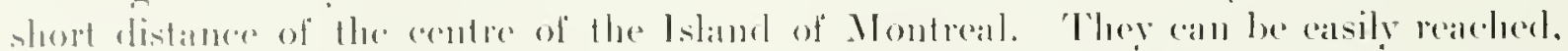

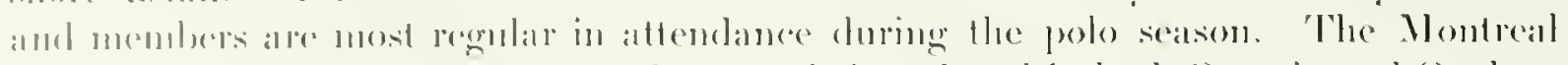

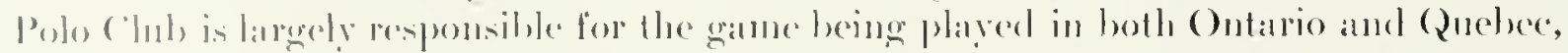

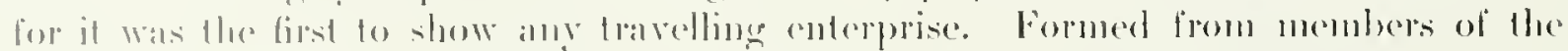

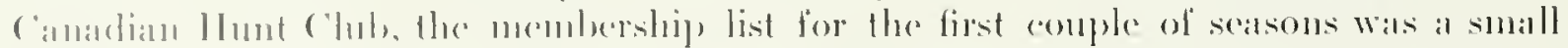

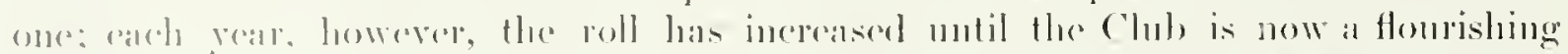

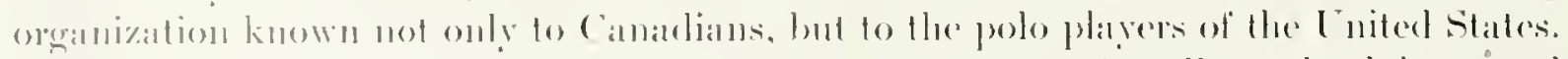

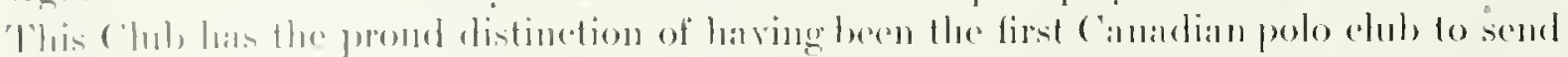

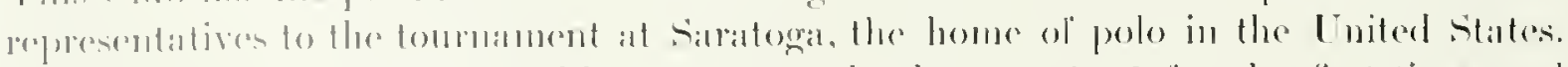

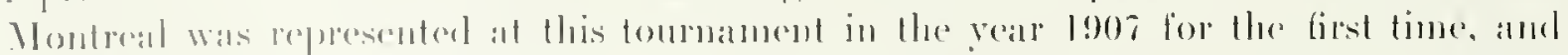

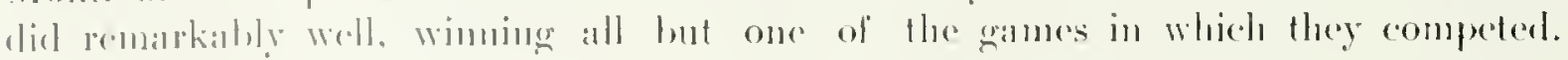


Many matches are played eated season, and in 1908 the Montreal men proverl thein

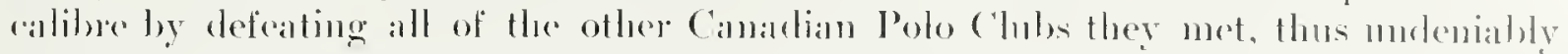
establishing a chain to the title of Camadian ehamplons for that season.

To Mr. Cieorege A. Simard must be given aredit for the existence of the Montreal l'olo ('hub. Ile was the first President, and the first matehes wepe platyed all his farm. In the summer of 1899) Mr. Simand imported a calload of polo ponies from the lan West that had not exen been halter hoken. They were lowgengt to Montreal and the most likely selected and given over to a breaker for coducation.

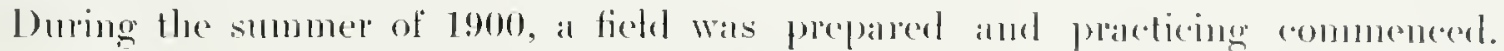
This eontimued, and by the end of the season the players were reatly to make al reditable showing for a new organization. Officers were elected he the (tul), with Mr. Simand as the President.

'The original memters of the ('lul, were: Geo. 1. Simatrd, I)octor Mignault. P'. 1. Beamdoine, Arehilnald Allan, and Col. Meaghan. These gentlemen marte up, the team from gear to veat and have phayed the majority of the matedes. The enreatest

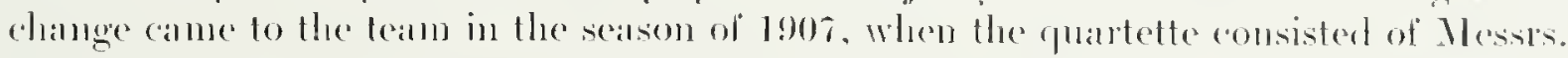
Rohertson and Freeman, Captan Piekering and Col. Meaghan. The ('hub hats alwalys been noted for the good ponies owned by the mentuers. They are wedl lowked atter.

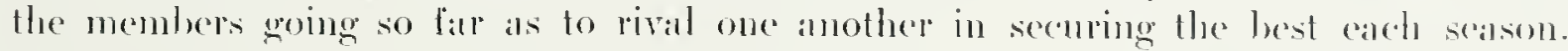

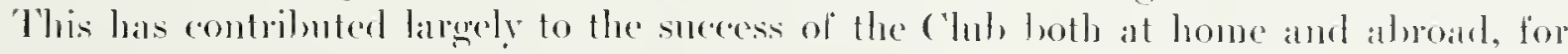
a hamely, clever pony is as necessilly as a grood man.

Messis. Frecoman and Rolertson and Captain Piekering learned to play Hae game leefore coming to Montreal, white the other members of the chuls learned to play it on

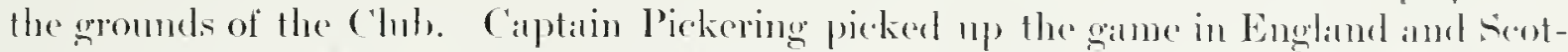
lamd, while both Mr. Robertson and Mr. Freeman learned to play in the far West. they at ome time being members of the fimmous IJigle River Club. Col. Meaghan and Mr. simald, the two oldest members of the Club, are taking an active part to-day. All are well-known horsemen and slow great skill at riding. 'Ther ale members of the ('anadian IIunt (lul), and take a gleat interest in the wedfare of the horse.

Out of the Montreal Polo Club sprang the Back River Clul, with grounds at cartierville, and which is now a well-known organization.

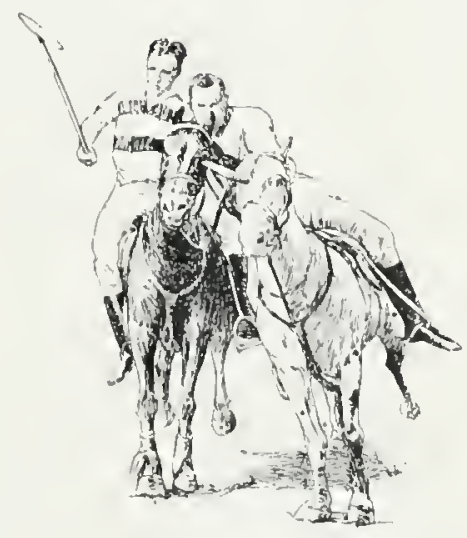




\section{$84 \quad$ Lovers of the Horse}

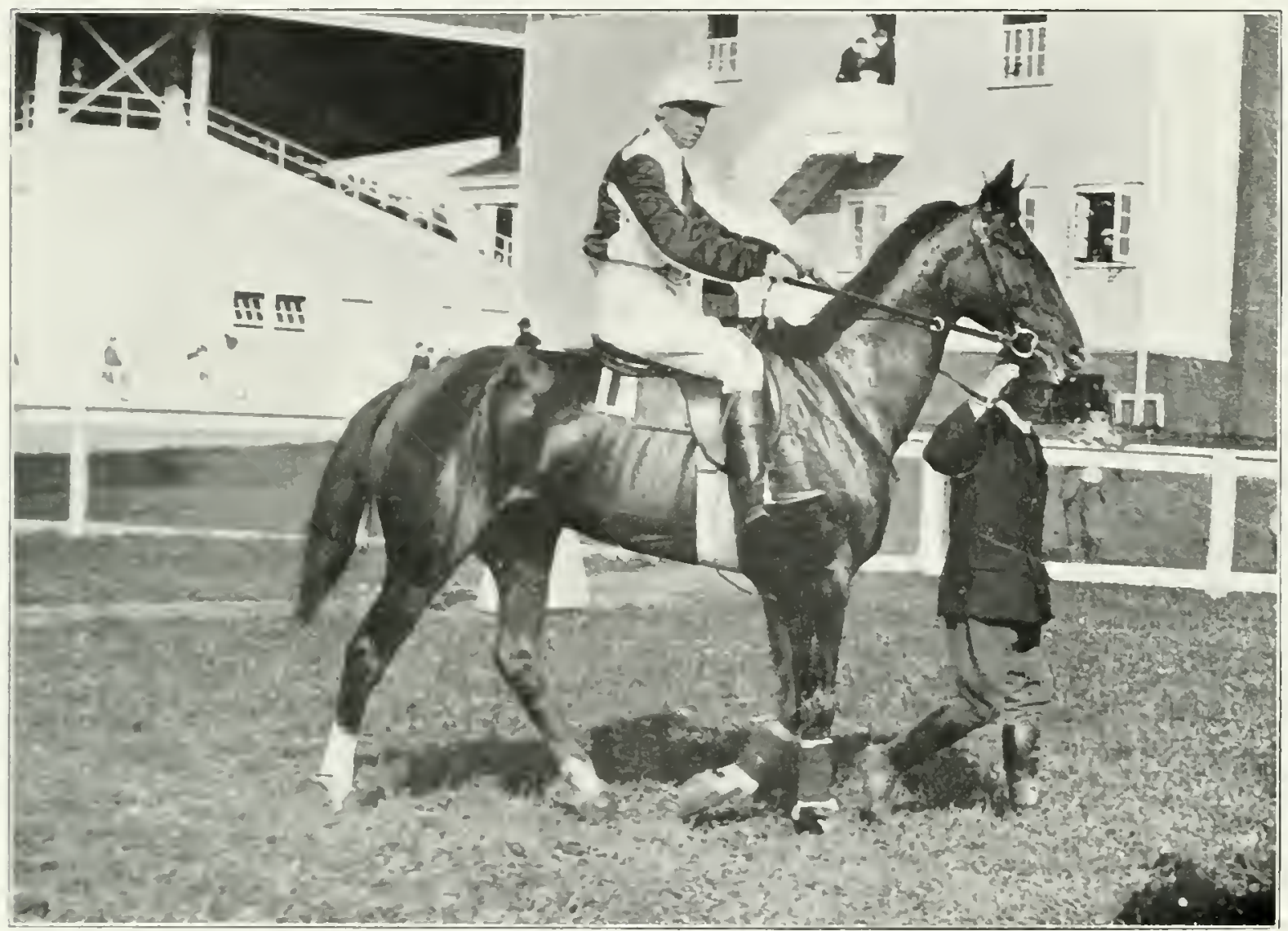

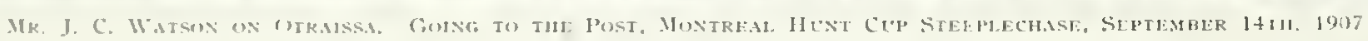

\section{JOHN C. WATSON}

$\mathrm{O}$

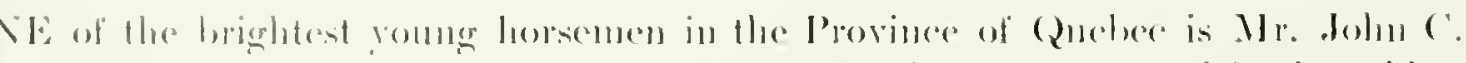

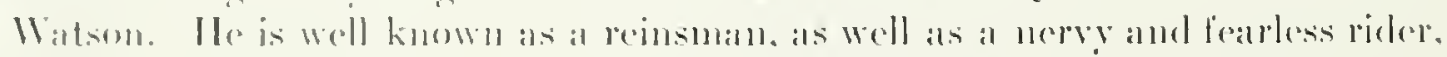

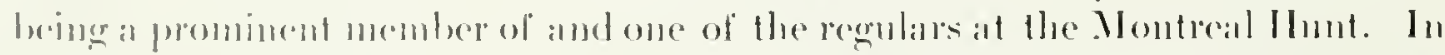

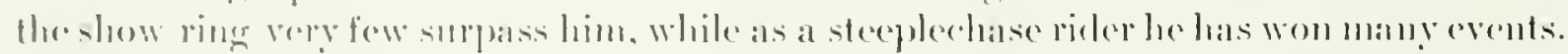

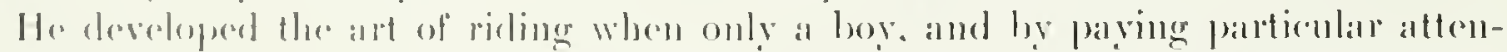
lion to it has heerome a master ecfuestrian. He was one of the origninal members of

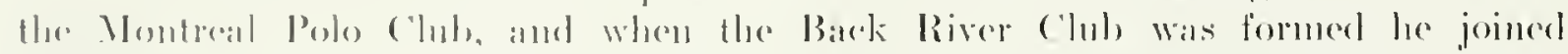
Hrom, and is one of Hroil best players. He has becol associated with the horse mere of less all of his lilo having his initial momb at har first horse show held in

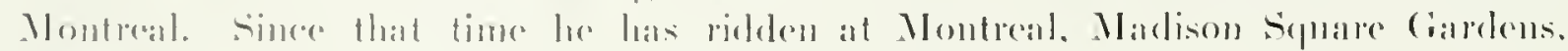

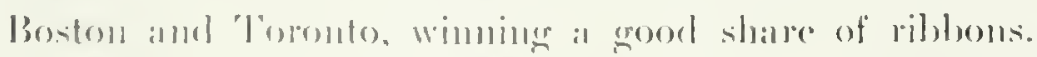

Born in Montreal, Mr. Watson has always made his home there. He coll-

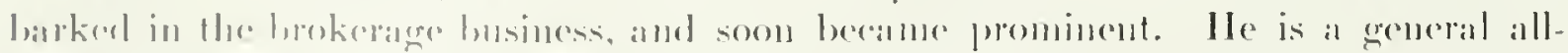

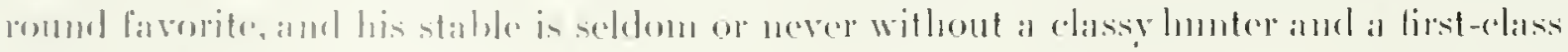
string of polo ponimes. 


\section{PERCY FORBES MATHIAS}

DIIE honor of wiming the first race orer the new Blue Bomnets coulse at 1 Montreal foll to Mr. Perey Forbes Mathias. There is probably no better known or nore almied gentleman rider in the Provinees of (Ruelyes or (Ontario than Mr. Mathias, who has shown an interest in the horse for many years. Ile hats done all within his power to further the sport, giving up a great cleal of his time to it. He is not only known in Canada but thoughout the United States, and has ridelen on the majority of the tracks for the love of the sport, and not for any financial gain.

I recond of five victeries out of serent stats on the Montreal Club's contre at Bhlue Bonnets is one tlant will not be equallext in some time to come, and this is helel by the sulpject of this sketch. The first race won on this track by Mr. Mathias was with the mate Katlideen. owned by Mr. C. S. Camplell, K.C., it being orer a distance of a mile. The next was at the inamernal meeting of the Montreal Jocker Cluh in the spring of 1907, on Peter Knight, owned by W. Keating. This victory was repeaterl later on with the sime horse. 'The next was on Kinmshaw, ownerl by 11. Iligginson, while the other victory was on Briek 'Top, owned by Dr. McEachien. Mr. Mathias also finished seconel with Peter Knight at the same meeting.

Mr. Mathias" first start in the racing world was when le owned The Bahsifuarla. It was on this mate that lee rode his first race, and finished secomel in a field of seren stanters, being the only gentleman rider up. Ile is one of the oldest members of the Montreal Hunt. anel can be found rogularly at tlee puns.

Mr. Mathias is the son of Major

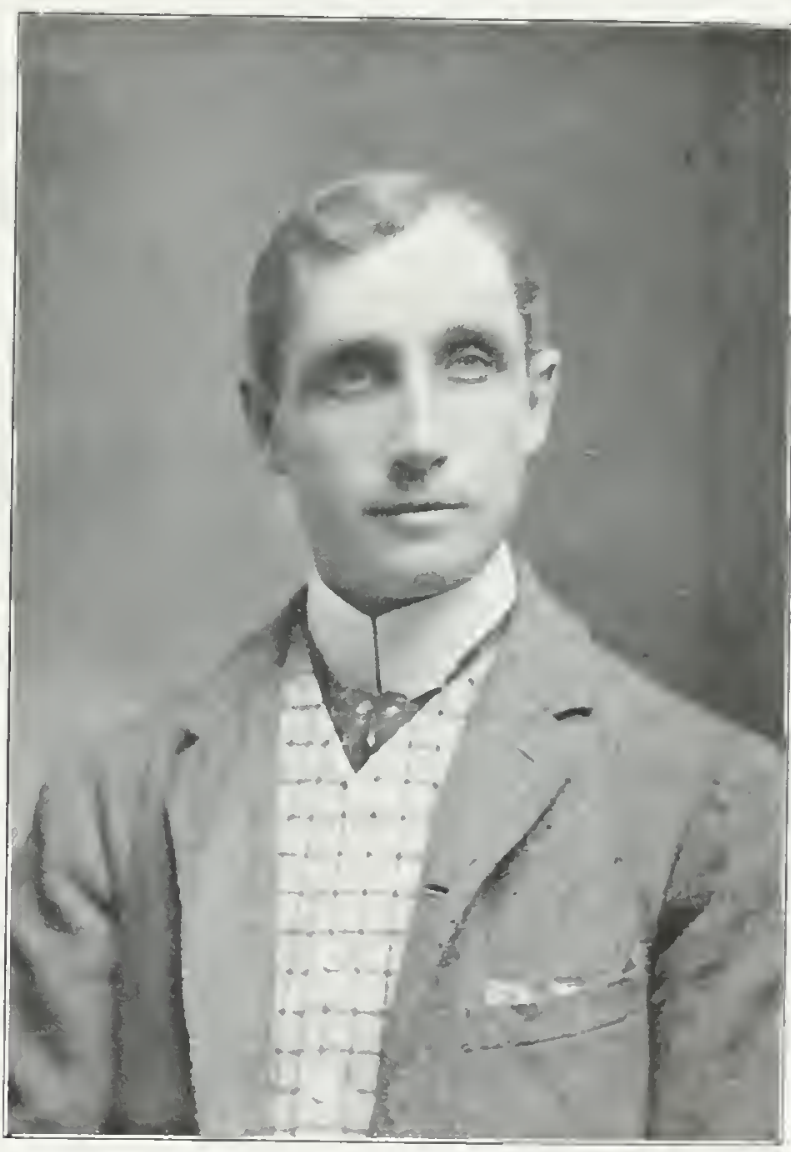

PFRey Forbes MathIAS Mathias, of Mellbourne, P.(2., having been born at Mokd, Wales, and coming to Camala thirty geals ago with his parents. He went into the insurance business in Montreal some years ago and at the time of writing is one of Montreal's brightest business men. Ile has heen comnecterl with the Norwich Thion Fire Insmance Society for a number of geals, being one of the socicty's special agents. Mr. Mathias was matried in the fall of 1907 and makes his loome in Montreal. Ile is a member of the St. James Club, as well as of many of the other oreanizations of Montreal. 


\section{$86 \quad$ Lovers of the Horse}

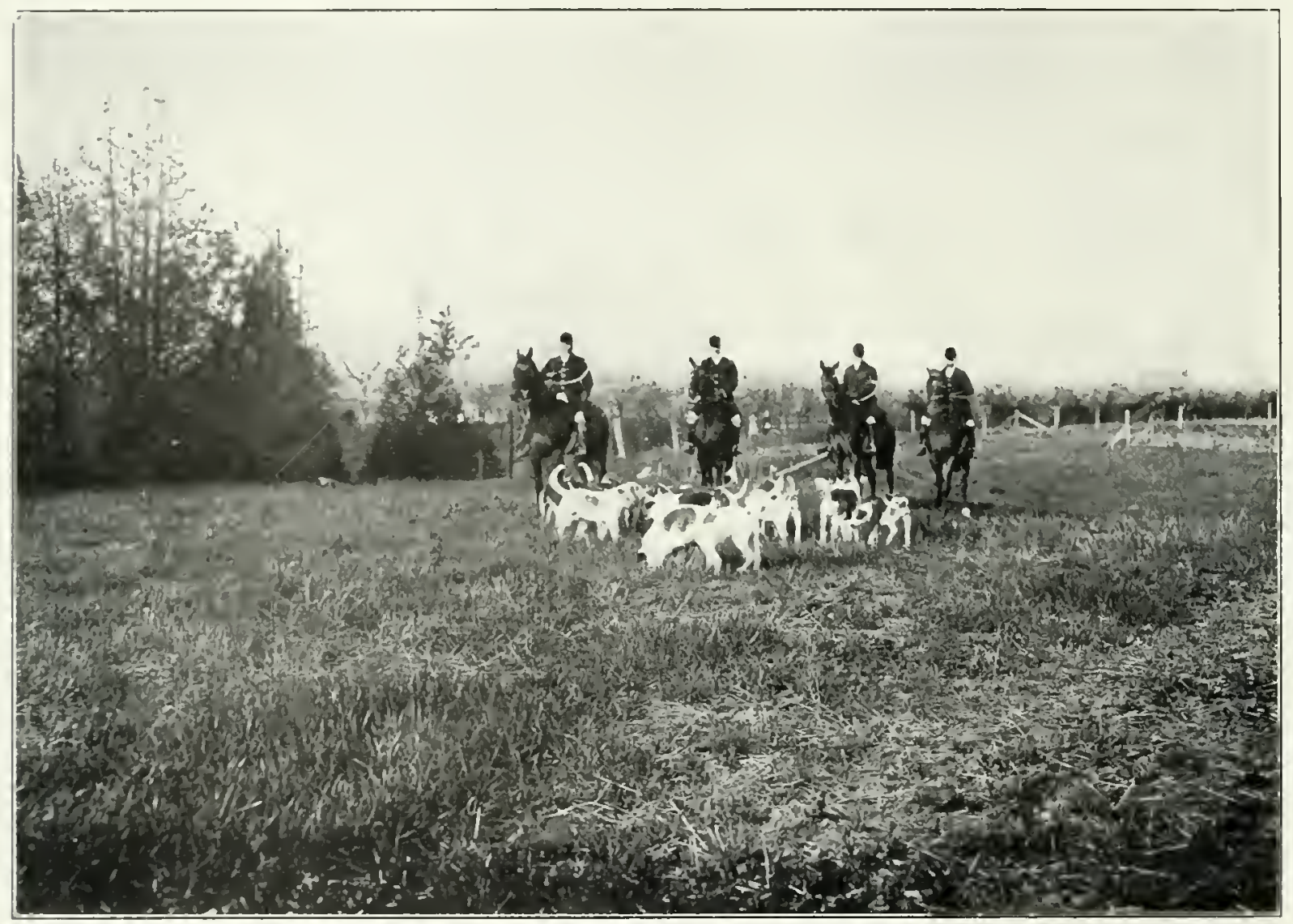

OTTAWA HUNT CLEB PACK

\section{OTTAWA HUNT CLUB}

$I^{T}$ ma! he salut without feall of contradiction that few organizations in Camala have met with mole prosperity than the Ottawa IImut Club. Even though it is scarrecly old emough in realls to possess what might be called a history it is alrealy thriving and thriving well. Vears ago there was an organization of a similar character formed suring the regime as Governot-(ieneral of Earl Dufferin, and remembered still for the particular latet that at that time Earl Dutferin domatert one (an) and the Rirlean (Chb anothere for the annual competitions. Even yet the cups ane eagerly sought for, hut as the condition attached was that earde one shonde be won three times conserentively, it is semerely necessary to say that they are still in the possession of the ('/ut). Sincly is the meneptainty of horses and of riders.

lintil a fro years ano, as has been intimated. the horsc-lovers of the ('apital were without an organization. It was in the spring of 1906 that Dr. Welsster, the pres-

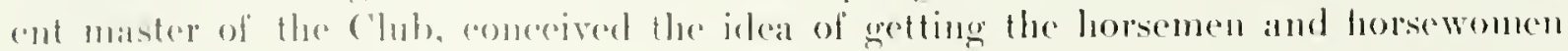

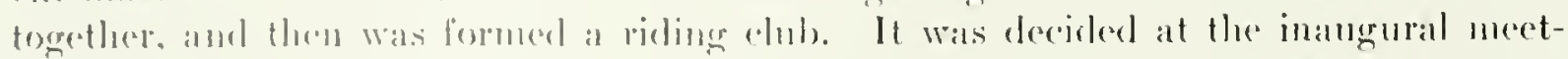

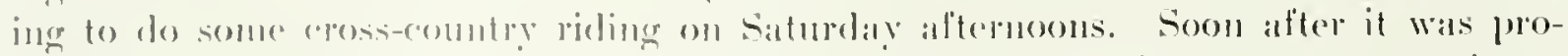
posed to buy some hounds. and the farmers in the surromeling country were inter- 
viewed with the object of securing permission to ride over their lands. This, needless to say, was soon secured, and the Club settled down to business.

At the moment, Earl Grey, the Governor-feneral, was in Western Canadat, but upon his return he irlentified himself arctively with the Club, and gave it a great dral of encouragement. The pack was increased to seven comples of hounds, and the ('lub was organized shortly afterwards on a regular basis with Earl (irey as Ilonorary l'resident. Mr. J. W. Woorls as President and Mr. W. G. Charleson as Secretary. The hunts were held regularly on Wednesdays and saturdays. and gradually the field was increased to thirty riders. In 1907 it was decided to buy a permanent home, and the

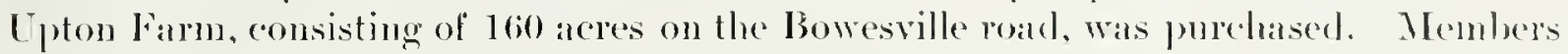
of the Club were solicited to take stock. and within the almost incredible time of two weeks the smm of $\$ 10,000$ was raiserl. The Club las since erected an extensive

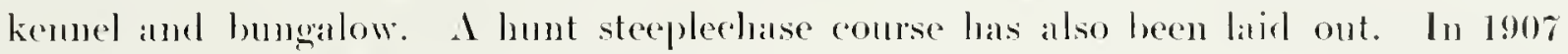
the pack was increased to twenty eouples. and more gratifying still, the membership roll has heen increased until it is now 180 . It is believed that the hunts are attended by the laresest fields in Camadat at the present time, since it is selkom that less than filty riders tum ont.

The ('lub certainly is in an enviable position at the present moment. and the interest is contimully on the increase. 'Tle membership is growing steadily, and the sport, to express it mildly has taken a firm hold. Farl Grey is one of the keenest supporters of the Club, and all the other officers are expally energetic. Ontside of those who are personally responsible for the conduct of affairs, the private members are keen enthusiasts, and, so far as they are called upou, do everything to promote the interests of the ormanization.

In 1909 the officers were: Patron. Earl Grey: President. Mr. J. W. Woods: Master, D). R. E. Webster; Seeretary, Mr. W. C. Charleson; Exeeutive Committee, Colonel J. Ianhury Williams, C.M.C.; C. Berkeley Powell, E. S. Skead, J. L. Garland, J. K. Paisley, Major Vernon Eaton, Major I. II. Panet. 1)r. I). 'T. Smitl, Ilugh Carson. llector Verrett, J. B. Dutord, and R. B3. Simelair.

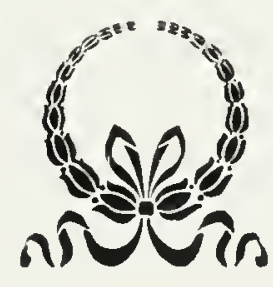




\section{JOHN F. RYAN}

$\mathrm{T}$

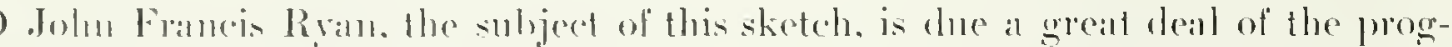

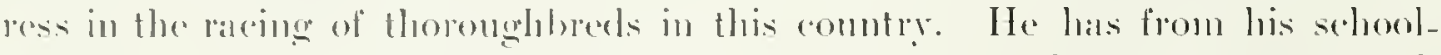
hoy disy patid more or less attention to the thoromghbred, and it was throngh lis efforts that the Montreal Joekey ('hub was formed. That it will hereme famous in

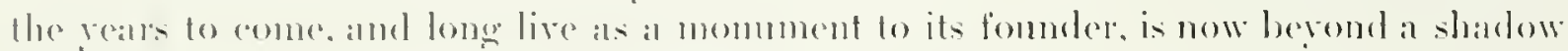
of dembt. It was thromeh Mr. Rian that the newspalpers of Tomolo first paid partice-

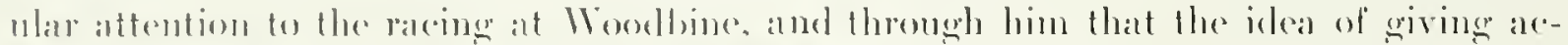

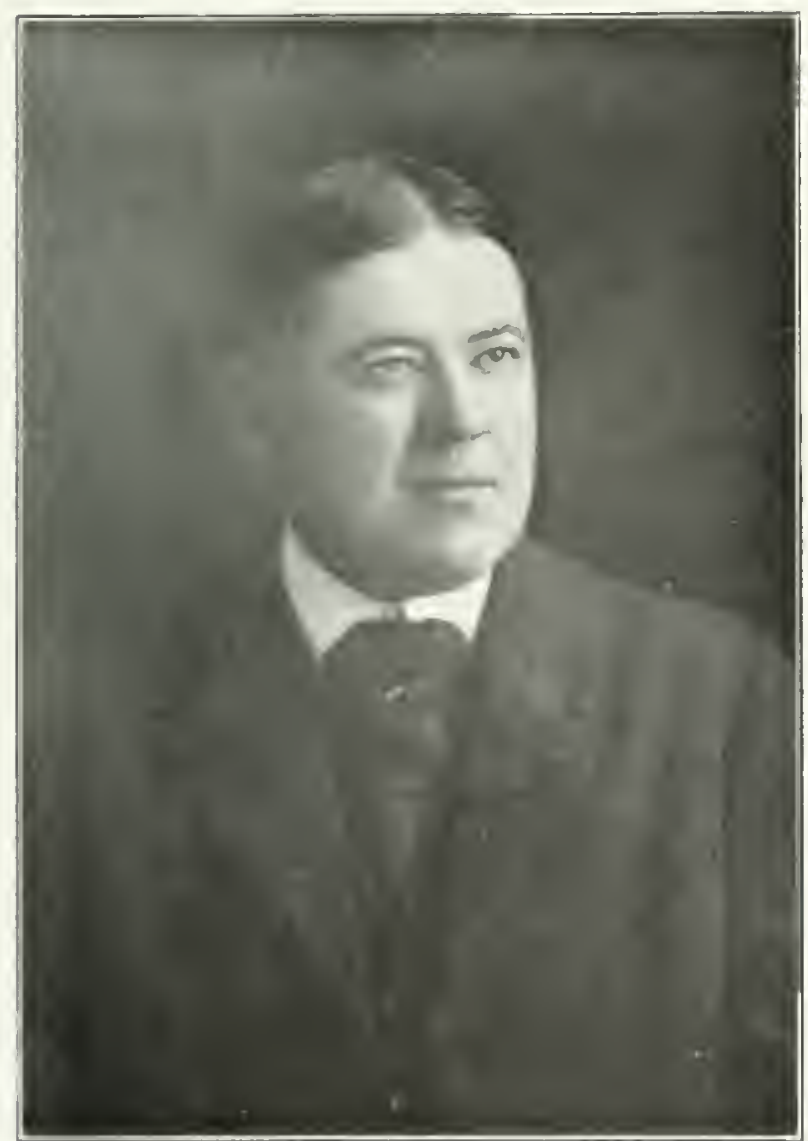

Jols I'k.1NCrs RYin counts of the early moming trials at the tratek were taken mp. This was solely and purcly his original idea in Camallat. and in eretting the publice interested in Here actual doinges of lorses it is still pere hapes the greatest magnet in gaming patroms tor the sport.

Mr. Rivall alwalse atered to the lorsement and is looked on as one of the careatest of lunf anthorities al the present time. Ile has devoted mally years of his lile to this work, leeing most suenessful in all of his rentures. the ereatest of all berimg the fommeling of the Montreal Jocker (luls,

Mr. Ryall is a camalian ly hirtla. amb is prourl of the faret. IJ. was borm at frergetown, Ontario, in the rear lsit. hemer edueated at the Bbamptom

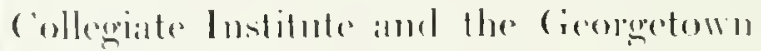
Higl selomel. Ilis tirst step) in life for himselle was when he areerepterl a position ont the reporting staff of the Toronto llorld. where he priekly slaswed his

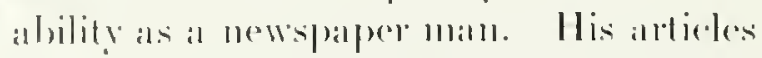
were all of the brightest. while he prover

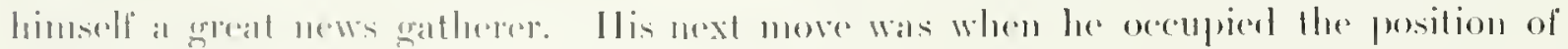

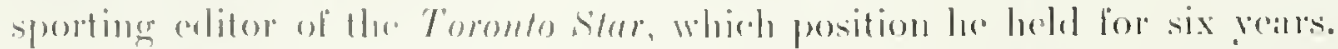

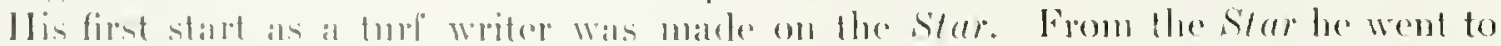

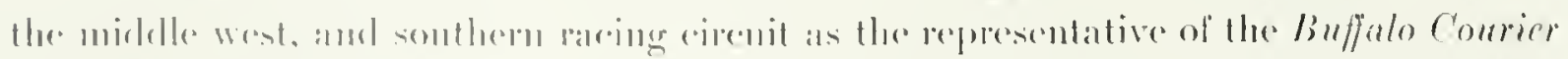

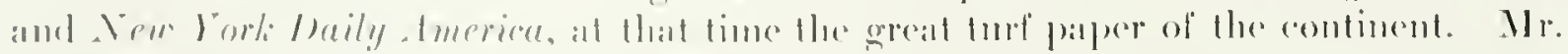

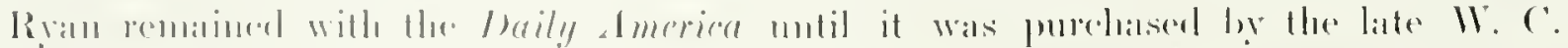

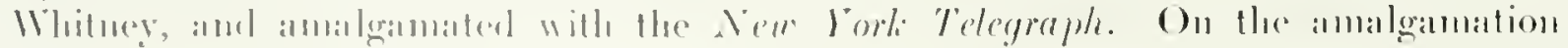


of these two palpers. Mr. Ryan was sent to the south again to do the turf work for the New Forl: Telegreph, with whieh paper he remained until he went as assistant to Iohn Boden. who holds the position of racing secretary of the Brighton Beach Racing Ascociation. the Maryand Jockey Chub, the Montreal Jockey ('lub, and the State Racing ('ommission of New York.

Inring a meeting at Providence the matter of forming a new jocker club to fill up time hetween the elosing of the C'anadian tracks and the opening of the Imerican tracks was discussed. and Mr. Ryan immextiately saw a chance and suggested Montreal as the plater. The iclea was not any too well thought of at first. but he decirled to go abead alone.

In the vear 190:5 Mr. Ryan came to Montreal for the purpose of organizinge a jockey (dub). Montrealers took hold of the ielea readily, and proved so anxions for the chance that Mr. Ryan's venture proved sucessful. He worked hard to secure the land and the chalder, and after the ('hul was organized, floated the stork among Camalian and American sportsmen, croming limself with ghtory.

Ile was elected fieneral Manager of the new Chub, which position he now holds. Mr. Ryan was never given to riding. But spent his energy in encouraging the breeding of thoroughberels, and has the credit of putting many a horseman into prominence on the American continent. Mr. Ryan is of a genial disposition, and lats many lriends in the racing world. Ile is a hamdicapper of some repute, and knows the executive part of racing thoroughly, having heen an apt pupil nuder such woll-known men as John Boden and Christopher Fityerald. His work as a newspaper correspondent gave him a wide acpuantance among turfmen, and he is expally well known in Vew

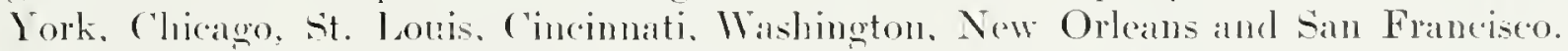
It is owing perhaps to this that he has always been able to gather latge mumbers of horses to the meetings of the Montreal Jorkey (lub. In New York Mr. Ryan is perhapes hest known as a story writer. He is the anthor of "Mammela," "( "hophus." " The Race that Won a Bride," ."The Land of Mespua Ukee," . The Legend of the Lotus." and other elever fiction, and when the more strenuous work which now oecupies his time has been completed. he will, no donht, return to the field of literature. Ilis plans for the futme include the building of two more tracks and the establishment of a National Breeding Burean. He has extensive mining interests in northern Quebee.

II hobby is music, and he can sing the tenor solos of eleven gramd operas. In the early nineties lur was a singer in St. Michatel's Cathedral. Toronto. and in later years saing in the Jesuit Cathedral, New Orleans, and st. Patrick's Cathedral, New lork.

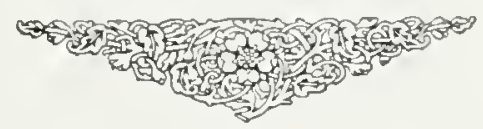




\section{HAMILTON RIDING AND DRIVING CLUB}

$\mathrm{A}^{1}$ l.TH()LCill the (ity of Hamilton has not a IHunt Club. the lovers of the horse are looked atter in this way by the Riding and Driving (bub, which fills its phace in an able way. This organization has only been short-lived, but it is recognized by all of the older bodies of this kind throughout ('anada, and its members are well known to the hunting public, they taking part annually in the point to point events of the numerous Hunt and Comutry Clubs in the Provinces of Ontario and Quebec.

The IIamilton Riding and D) riving (luh is noted for its clever horsemen and nervy riders, while the members always make a creditalbe showing with their horses. 'This (Jub has been well bepresented at the many horse shows in the past six years, and lats laat its share of honors in the show ring. The ('lubs menlership grew faster than. perlalus, many of the others. owing to the encouragement given to the members he the bite William Ilembre and his som William Hendrie. jumior, while to Mr. Alfed Rogrers. now of 'l'oronto, is due the existence of the Association. It was through him that the club was first formed, and during his term of offiec as Presilent, which lasted some there years. it was put on al solid foumdation.

It was through the llamilton Riding and Driving (Jub that many of Hamiltons romer men ame women came into prominence in the horse world. for as they hecame members they took up the sport in a more enthusiastie manner, which meant the derelopment of elever riders and drivers.

'The ('lub has nevere owned a pack of houmds. so that the outing days are spent in paprer chases, which attords just as much excitement and often gives faster rms than when the houmds are nsed. It each meet of the Chub, two or three of the younger men ane selereted and sent ahead, being griven a few mimestestart. making a trail with the paper which is prepatred lor this pmopose. 'The others start out after them and

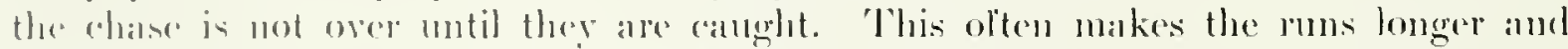
much more exciting than drang hunting with the houmds, as the canimes are sometimes known to lose the serent. The smounding country and on the top of the mountain is a splendial one for the sport, the lams being post and rail fenced, with little or no harbed wire to rontend with. This makes it better not only for the riders, but for thes

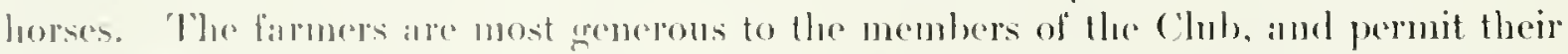
ridimg over the lams al all times, and seem to enjoy the sport as much as the horse-

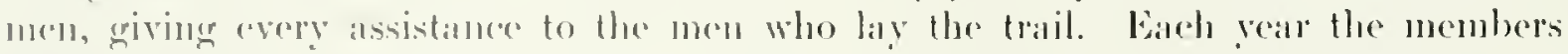

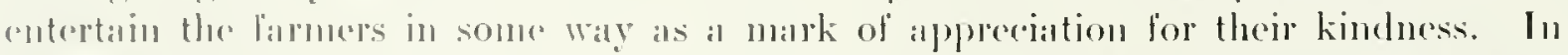
the andy alass of the chob dinners were tendered them, while battery the anmsement hats been in the way of a grymklatal, which anables the lammers and their soms to lake part.

It was during the sumbure of 1900 that Me. Alfred Rogers, then President of the

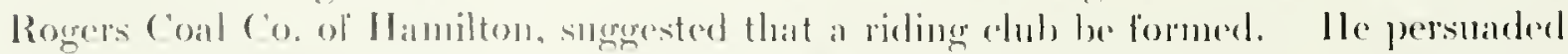
a number of Ilanilton's young members that the idlea was a good one, and the first 
meeting was held in the offiee of Mr. Willam Hendrie, with only halt a dozen in attentance, the original members of this Club being: Mr. Alfeed Rogers, William Ilendrie, junior, Mr. C. Ballour, Mr. D. Osborne and Mr. Combon IIenderson. Mr. Rogers was selected as the President. which office he filled for the first three years of the club's existence. In 190+ le was fored to resign, ewing to his moving to 'Toronto. Mr. Rogers' departure was keenly felt by the members and he was malde the recipient of a handsome silver service. Mr. Ciomlon llenderson was the next President in line, and filled the office in an able manner for the years $190 \mathrm{t}$ and 1905. when he was succeeded by Mr. George Hope, who still fills the office.

When the IIamilton Riling Cluh was first organized there was a membership of only half a dozen, which in two years had increased to over fifty, with a goodly mumber of ladies. 'This, in the past few seasons. has shown a wonderful increase. giving the organization a membership, list of over a lumbed. The first year of the Clubs existence only a few runs were held, hut the following season recognition was asked from the Ilamilton Jockey Chub and Mr. Alfred Rogers was elosen as the representative on the boand of directors of the Iamilton Jockey Club. At the spring meeting of 1901. the llamilton Jockey Club put on the first of its events for gentlemen riders, and from that time they have kept it up, for the purpose of encouraging the purehasing of thoroughloreds by the members. This has proven a suceess and many good horses have been purchased at the ammual weeding-out sales held in 'Toronto, to be used as hunters for such races. All of the jockey chubs of Canala now recognize the IIannilton Riding Club and accept their entries in events for gentlemen rielers, the loorses being qualified in the paper chases, while other Chubs are qualified with the hounds.

In the year 1902, the Ricling ('lul) held its first gymkhana, which wis most successful, some twelve humbled dollars being made clear of all expenses. Half of this was given to the city for the old boys' remion, white the other balf went to the Chubs treasury. 'Through events of this kind a neat little club-house was arranged for, afforeling every comfort and enjoyment to its patrons.

Each fall point to point races are held at which the attendance grows rearly, the members of the other hunt clubs throughout Camada being well represented, making the rivalry much more keen. The members of this Chub can be fouml among the competitors at the anumal grmkhanas of the 'Toronto and London Clubs, while often they are to be found as far east as Montreal and Quebee with their horses. For many years Mr. Rogers came to the point to point race of the Toronto Club, wimng it with his horse Revelstone, who has won so many ribbons for him. Nearly all of the original nembers are still taking an active part, giving encouragement to the new ones coming in, and thus kecping up the interest in the association. 


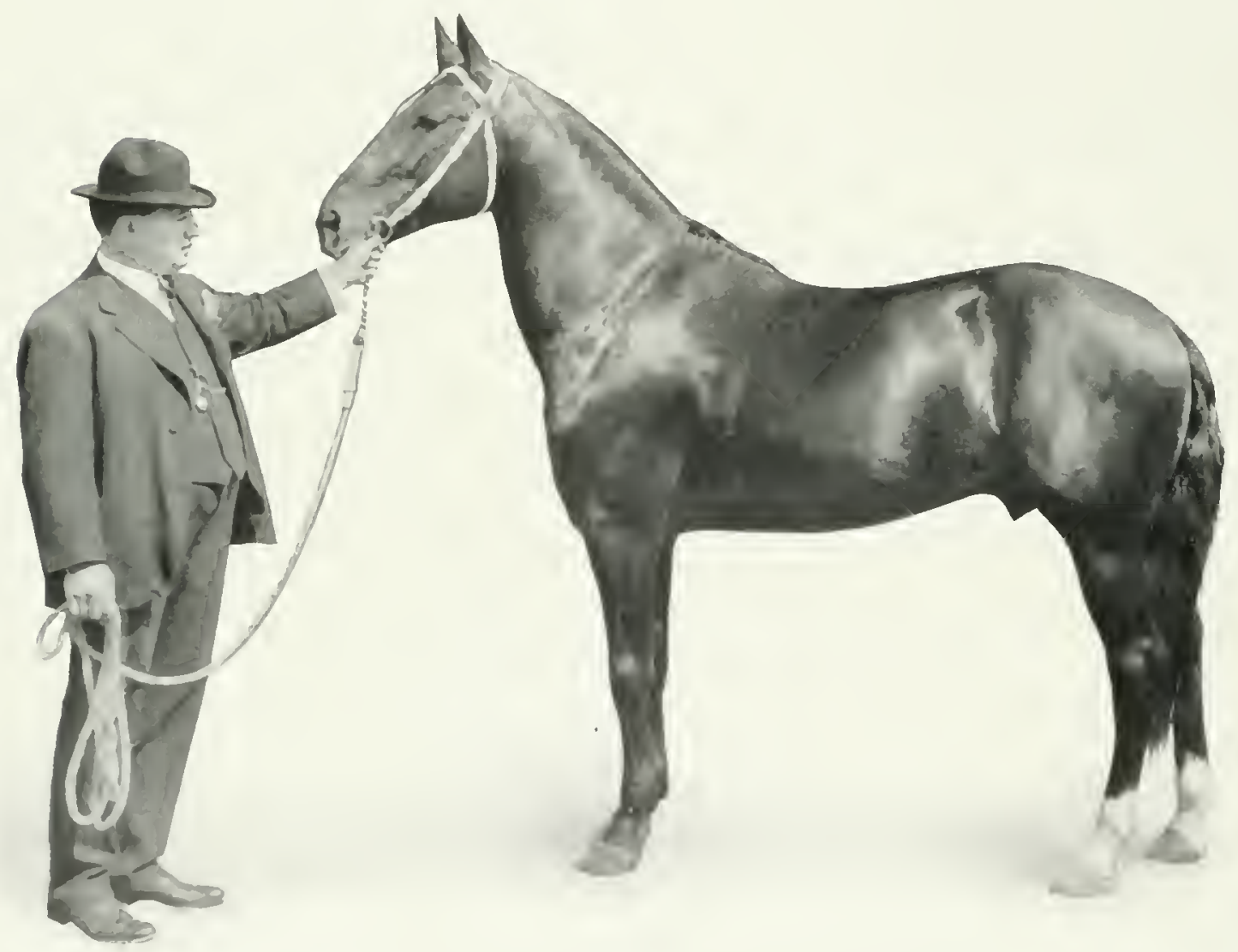

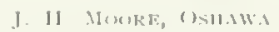




\section{JOHN BODEN}

$\mathrm{F}$ EW Cimadians have had the proud distinction of climbing the ladder of suecess in the turf world as rapidly as Jolun Borlen. Ile is now lookerl on as a racing anthority of the first matgnitude. and his advice is sought by nearly every lateing association previons to its making a venture. His judgument lass selfom or ever fanled to turn out for the best. Mr. Boden is responsible for the organization of more than one jockey club, and in each atse he has put them all on al paying hasis. his latest venture being the Montreal Jocker Club, which is one of the very few ('hus known to bate paid the first season of their eareer.

When Mr. Boden, with the assistance of Joln F'. Rvan, another Canadian, told the camadian public that the time was lipe for another jocker chu in Canada. he got little or no corromagenent to start with. Is the time went along. he persuated a number of Montrealers to fall in line and the stock was floated with surpmising results, fin beyond even the expectations of Mr. Boden. This venture. like many others. will stand as a monument to his memoly. When Kenilworth track at Buffalo was opened for the first season. it tumed out to be a dismal failure. and the directors and shareholders lost thomsands of elollars. The following season it was purehased hy a New lork spondicate and Mr. Boden was given control of it. Thlorough careful and juclicious management he was able to make it a paring venture.

John Boden has not only great exerutive ahility, hut has a love for the thoroughbred which he acpuired when a boy attending college, and which he hals developed ats years have gone by. Ile has owned. raced and bred horses, knowing arery particular of racing and breoding thoronghly.

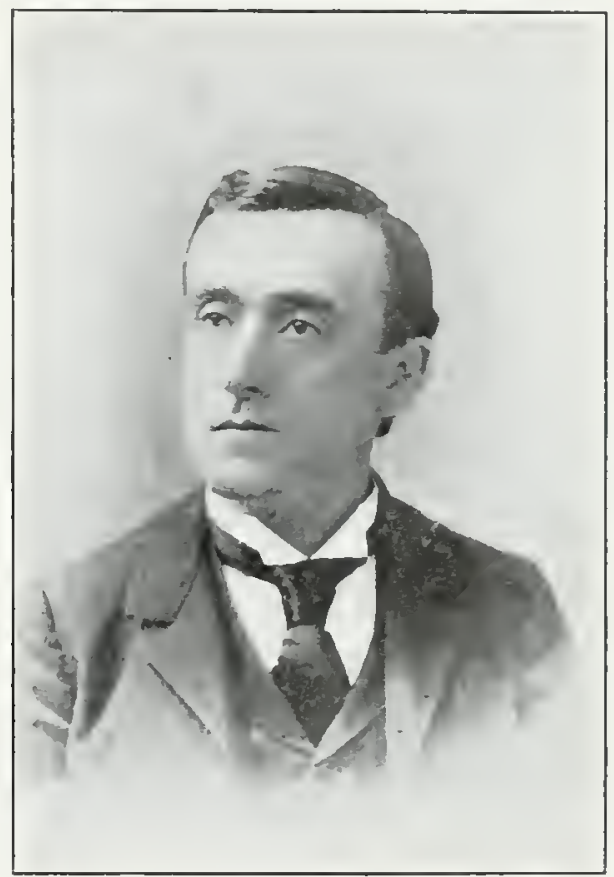

JOHN BULES

Joln Boden was born in St. John. New Brumswick, in the pear 1860. He Was educated at the grammat school of that place. afterwards taking his degrees ats a hallrister at the Jesuit College in Montreal at an early ange. He first practised law at lis hipth-place, and afterward songht a wider tield in New York City. When learing ('anala le was looked on as a most promising young lawyer. On lis arrival in New Jork he was told he must pass another examination there. Which lie did not try and gave up law to take up newspapel work. Mr. Boden spent many rears on the New lork press, holding almost every position from political reporter to manlaging editor, gathering a thorongh knowlerlge of journalistic work in general. For several years he was prominent in polities at Albany, N.Y., calrying on his newspapel work at the same time. 


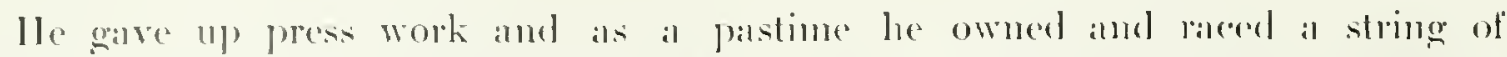
famons thoroughbreds on the American tracks. Ile met with al great deal of suecess in this waly and becante well known in the turf world. Frem owning. racing and writing performances of the thoroughloreds. John Borlen ganed a more pratedical knowlerlge than the majority of owners. 'Though this he was male secretaly of the Racing Commission of the state of New York. unter whose laws lateing all over that state is ampred ont.

Neter retring from newspaper work. John Borlen was induced to take it up again

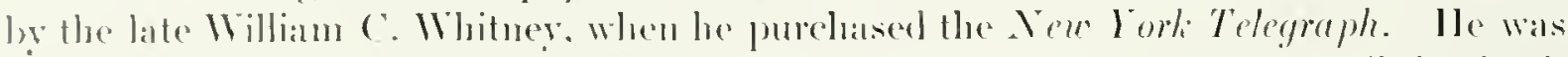

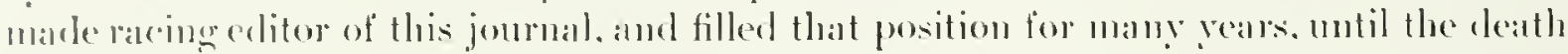
of Mr. Whituey. When the pressure of other rateing husiness eomperted him to retire. llis anticles on racing were greatly missed by the puldic and indeed, many of them are

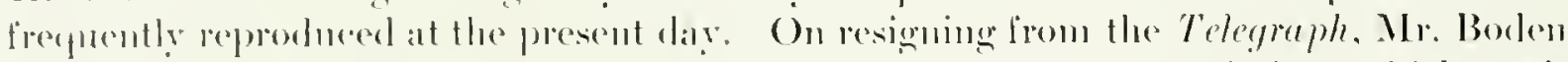
Irass selected as the fereretally of the Brighton Beach Racing Issociation, which position he still hosks. He fills the position of seretary of the new los Angeles dockey ('luh and spencls a gereater part of his time in the south after the elosing of the New lork tracks. Ilis best appointment was that of Secreetary of the Narragansett

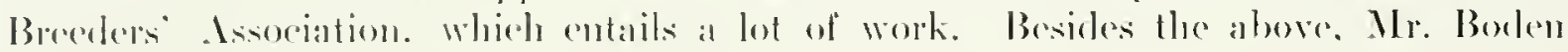

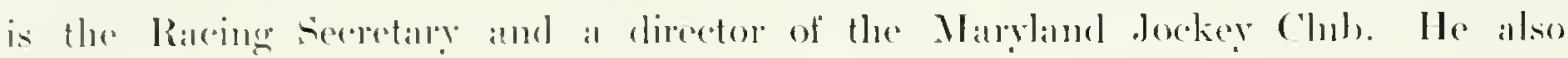

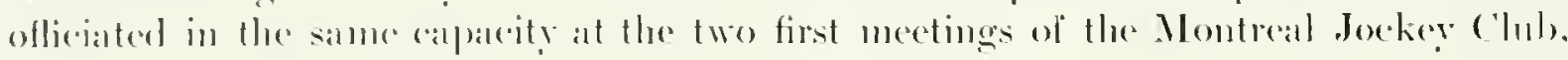
helel in the city of Montreal.

Mr. Borlen makes his lome in Brooklyn, X. I.. where lar lives with his hoother.

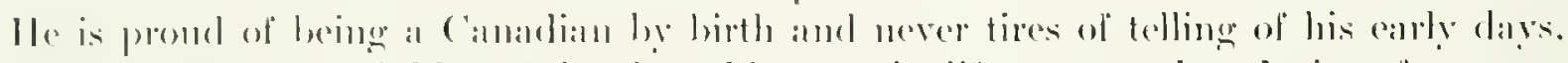
spent in and aremel Montreal. Where his start in life was mate. It is salfe to saly

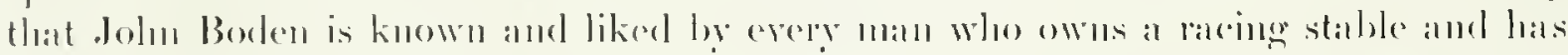

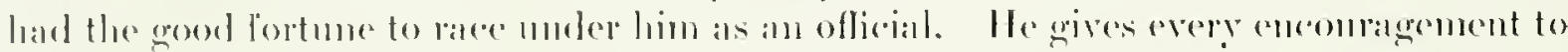

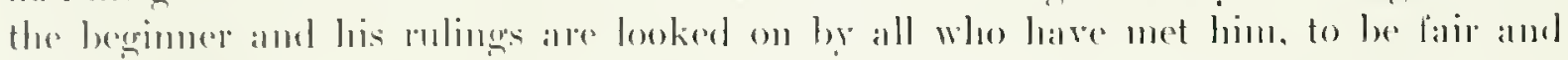
just. Hhe smatler onver and the latrece ones all looking alike to him when rateinge.

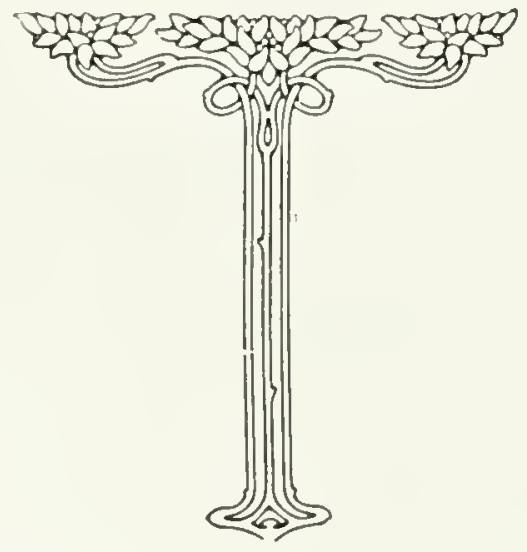




\section{JOHN LAXTON}

$\mathrm{T}$

I1E jovial disposition of Jolun Laxton is known far and wide. and his cheerful comntenance wonld be missed from any lunction where the horse is the attracetion. IIe is a keen judge of the noble equine, and lats owned at varions times some beanties. Imong lis farorites he singles ont Kinney. Nenbury. Mar Paint. Gold Sote. Aberta Lady. and Bedlington.

Mr. Iaxton, who is Superintendent of the Consumers (ias Company, is a familial figure in 'loronto, and he enjoys an emvialole popularity in business, sporting and political reircles. He has been suceessful and has acepuired a confortalsle competence through hard work as well as good fortune. He was born in Huntingelonshire. England, November 5th. 1848. his parents being Johun and Jane (Clark) Laxtom, both natives of IIuntingdonshire, who were hlessed witl seventeen children. The father was a coutrictor of public works in England, principally in the gats eonstruction and railroad lunilding his first bige job being in commection with the construction of the Great Northern Railway. Mr. Iaxton has followed in his father"s footsteps, ant lais had a rery wide experience. The parents both passed away during the year 1880, the fiatler at the age of 71 and Mrs. Iaxton at $l i j$.

The public sthool at Laxley, Englint. was where young John I axton seenued his early education. Ile was only fourteen realls old when le set out upon a career of hard work. After leaving school he went to I donton to arequire the details of gats works

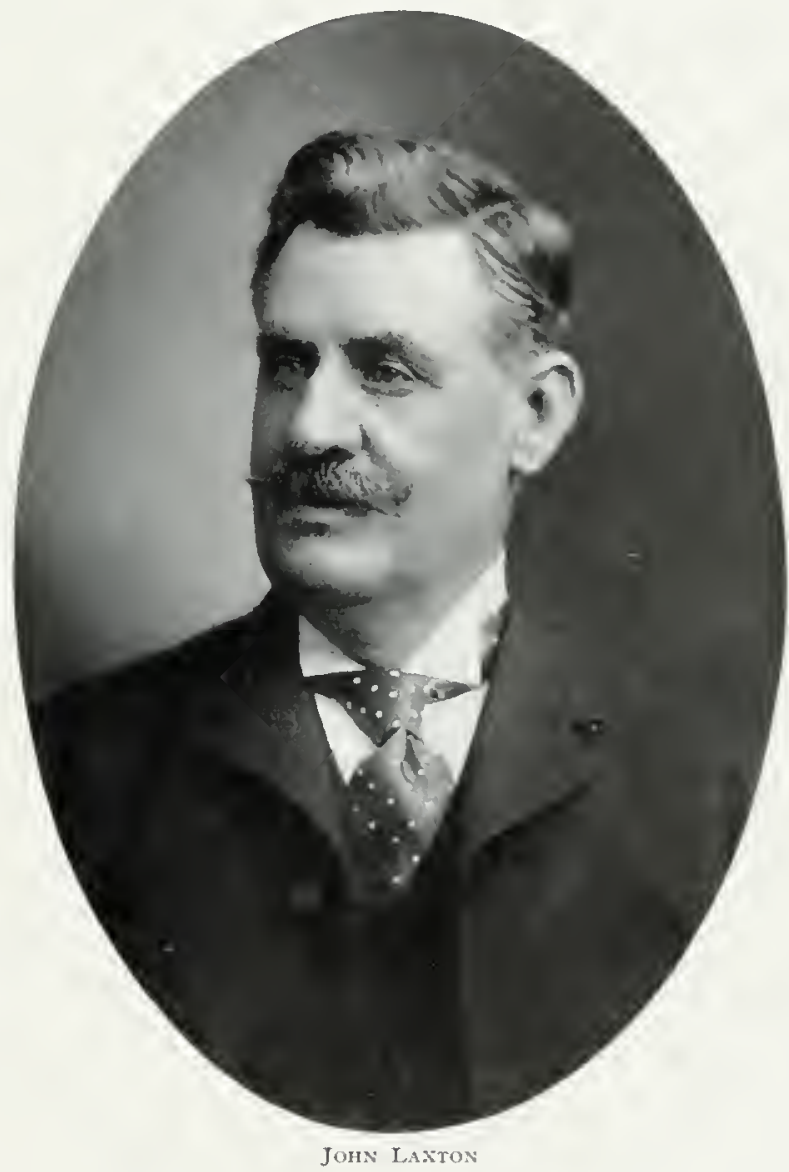
construction, with such marked success that the firm with whom he was emplored, John Aird \& Sons, Belverlere Roarl, Limbeth, sent him to Moscow. Russial, to work on the construction of the largest gas works ever undertaken in Russia. As this was in 1867. Mr. Laxton wats barely twenty years of age when he was trusted with so important a mission. Many interesting experiences are told by him in eonnection with his stay in the East, lut spare will net permit of relating them in this short article. In idea of the extent of the work can be saluged from the fact that the mans covered 100 miles of the streets of Moseow. Mr. Iaxton had only been there for six months when he 
Was given genelal supervision of the work. In the same year. after a nine months" stay. the work came to a standstill owing to lack of funcls due to the failure of Overend $S$ (imber. and he returned to England. The high falure was attributed to the GermanAnstrian Wal which Was then in progress. Mr. Iaxton was not destincel to remain long in his native country. however. for early in 1868 he was sent back to Moseow to complete the work. and he returned to Englant when it was finished in 1869 . 'Then he was dispatched to similar work in Edinhurgh. Scothand, and after heing at that for nine months he was recalled to England. By this time the ability of the young man hand so asserted itself that he was placed in chatrece of a number of important mudertakings in valions parts of England. and he so rarned the confidence of his employers that they made hin gencral superintendent of their outside construction work. Ifter nine years of experience. which hat heen of mutual benefit. the necessity anose for the tirm sending a man of Mr. Laxton's capabilities to Frankfort-on-Mains, but life was erowing too strenuous and he decider that it was in his own interest to take al rest from work, so he came out to Canada. landing at (Quebece 'This was in 1831. Ile went on to 'Toronto and has resided in the Queen City ever since. He wils just the man the ('onsumers' (ras company wanted. and he is about completing his thirtyfive veals's of service with that corporation. and is apparently good for many more vears of activity in the interests of his company. At present Mr. Laxton with his family resictes in Parkidale, the fashionable portion of the west end of 'Toronto.

The populatity of Mr. Laxton in his atopted city is attested hy the fact that he has served as a priblic school trustee for the old town of Parkinate, and for the city of 'Toponto aftere the amaleanation. Ile has on many oceasions been asked to become andiclate for the City Council. and for the Provincial and Federal l'arliaments, lunt he prefers to be a worker. and has for years been president of the Conservative Association of his distriet. as well as a prominent member of the Albany (lub. Doung lis carere of usefulness he has shown marked ability as an inventor, having brought out man! mureh-nereder improvenuents on olel styles of lighting. He patented the combinat tion gras and hot water stove in 1885. Which followed up his patent of a combination mats and roill store a eomple of yours previonsty.

Mr. Laxton is interested financially in a number of prominent instatutions in

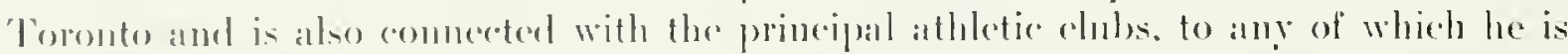

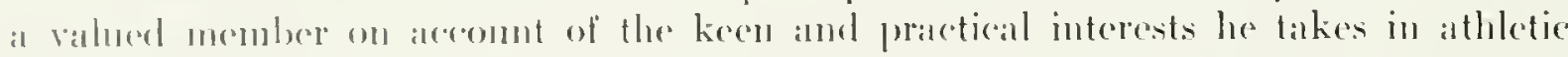

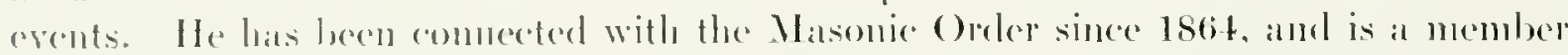

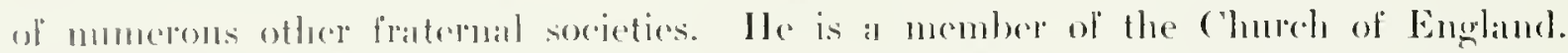

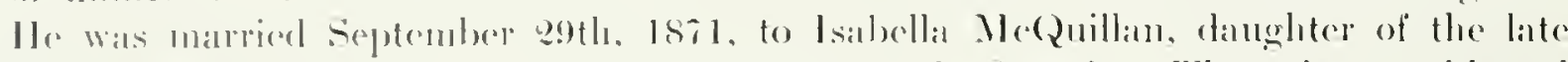

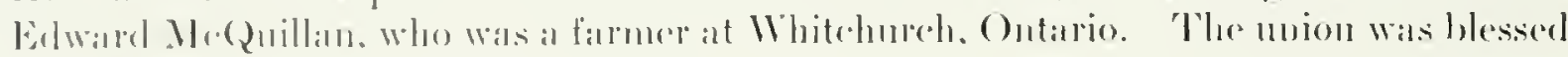
with nime ehilktere, two of them troys.

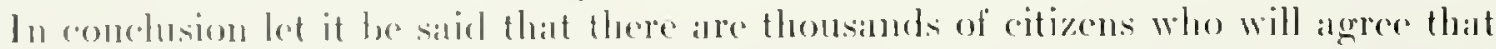

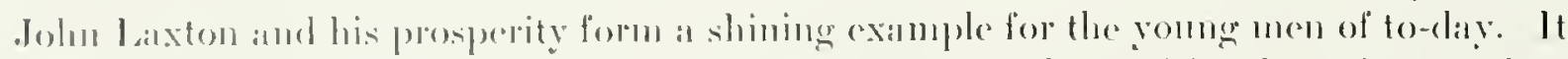

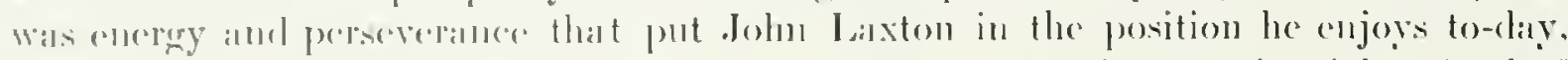
and is it any wonder that at man of his personality and attamments is mighty fond of the wohle horre: It rould hatrdy le otherwise. 


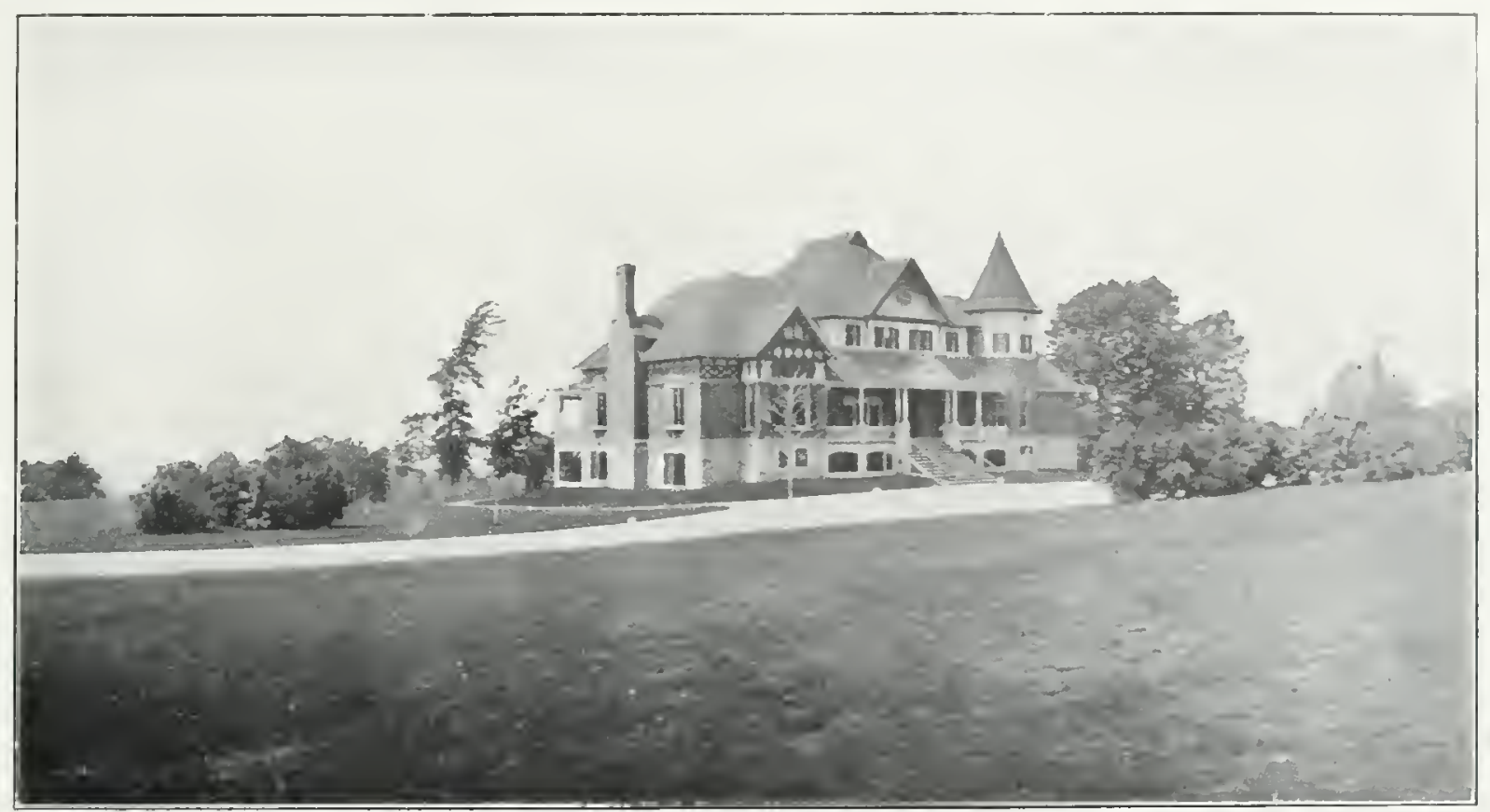

ClUb-hOUSE, MONTREM. HUNT Che

\section{MONTREAL HUNT CLUB}

$\mathrm{W}$

Hex the Montrail Hunt Club was organized in the year 1896 , there were very fow organizations of its kind in Imerica. Its object was the encouragement

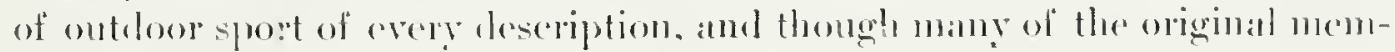
hers of the Clul, have long since departed this mumblane sphere, those who remain have always allhered to their plans. as laid out in the first charter.

'Theor" Chul-house, which is situater on one of the most beantiful spots on the Lstamel of Montreal, has been rebuilt and aldeder to, antil it is one of the most condortable and ing-to-date houses in the country.

since its organization, the Chub has becu particularly haply in its aclection of Masters every individual one of whom has done his shatre fowards making the (luble at streess, both from a material point of view and from the point of view of the puality of sport provided.

It was in the summer of 1896 that Mr. Willian Forsyth fommed the Montreal

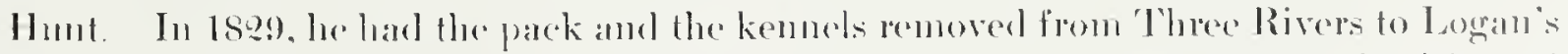
Farm. The majority of the mus in those days were in the region of La l'marie and Chambly, where there were enomgh foxes to give the members all the sport they condel posilily desire.

Indeed, it wats said that killinge were too numerous, but, as one of the older memlues said, "the houmds like it, he horses like it, and we like it." whiche decisive statement seemed to alose the discussion. 
The Mastership descended in this instanee from tather to son, for in 1834 . Mr. Inlm Forstly, a son of the founder of the Club. beame Master of the Hounds. In 1839. (aptain Walker held the office, and was sueceeded the following real by William Storkley. Sentor. It was during $M$ r. Stockley's term of office that the llumt stecplechases were inangurated and trophies presented. 'This ereated a new interest and encontragert the purchase of better horses. for in such events as these. speed, als well ats endurance, is needed.

The military men then stationed at Montreal took gareat interest in the life of the Ihunt and many of the officers held the position of M. F. II. In the realr 1St? the

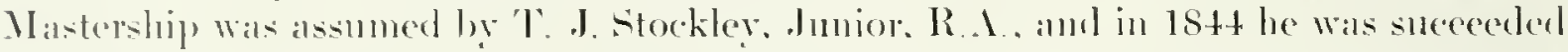
W (alptain, the IIom. Mr. Keene, R.E. Then for the first time in the history of the liunt the lack of financial support beeame a matter of serions anxicty to the members and afficess. In 1847 Captain Keene retired and the pack was solit to Mr. Ilubert, but when he retumed to the Ohd Comutry in 18.51. the pack was retumed to the Montreal IIunt as the property of the more enthusiastic nuembers. Who elected lient. I utyens, of the goth Regiment. als the Master. Lient. Iutyens lats since become famous as at painter of animals.

'The yeall 18.52 saw the Mastership pass inte the hands of Capt. Cox. R. E. muder whose gundanee the chab flonrished for two years, when the Master was called away to the Crimeat, and the ofliee was passed into the hands of D). Lom Maledongall. Who, through his rigorons efforts, saved the Hunt from suffering severely through the withdrawal of the military support. For six years Mr. Macelomgall bore nearly the whole

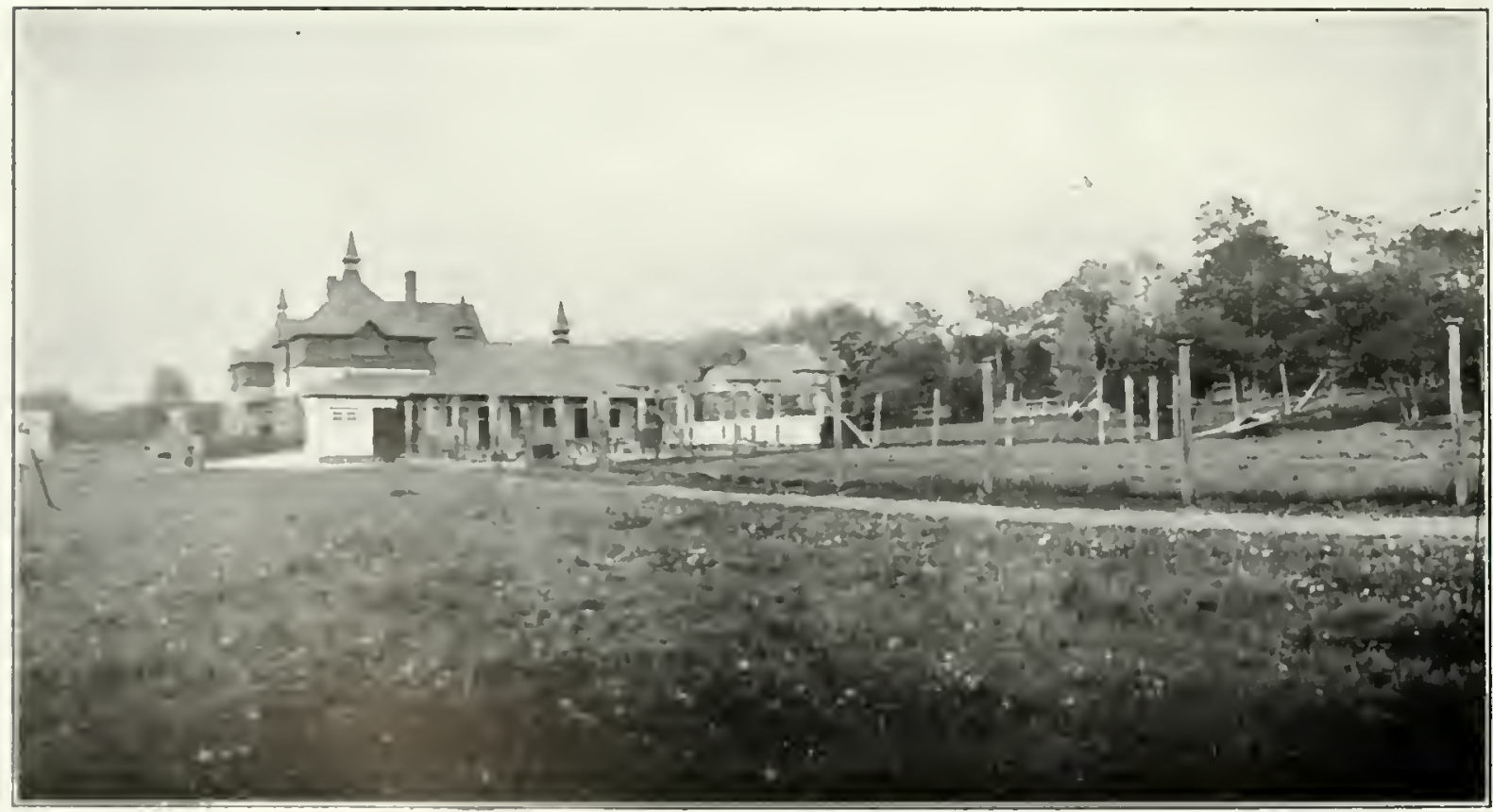

KFNNLL, MUNIREAL IUNT CLUH 


\section{Lovers of the Horse}

financial support of the Hunt. In 18.59). C'aptain A. W. Alloway came to the atsistance of Mr. Macelongall and relieved him of a great deal of the responsibility, beconning practically the acting Master. In 1860 . D. A. Bellouse wath the Master, retaining the office for only one rear. Major Burk was his snecessor lor the season of 1860 . and in 186 , Captain de Wintom assumed the responsible position.

1) ming the season of 1858 the kemels were moved from the Papinean Roal to the comer of Guy and what was called st. Joseph St., where they remanned until the spring of 1860 , when the guarters were again changed to the rear of Metealf Terrace. Cote St. Antoine, and agrain in the following season to logan's Farm, now l'refontaine l'ark. In 186.j Captain A. W. Mlloway was chosen as Master, which office he liceld lor two years, doing a great deal to further the interests of the Chub. Ile was suceeded hy Mr. John C'anford in 1867 , and for thirty years $M$ r. Crawtorl was a prominent fignre and moving spirit in the social and official life of the (thl.

From the year 1874 matil 1876. Mr. Amber Mllan helel the position of Master. amd althomgla seldom apprearing in the tiekd, get by his interest and patronage he did much to stimmlate the affatirs of the llunt. He was suceeded in 1870 by his preslecessor. Mr. John Crawforel, who in turn, after two seasons, gave place to Mir. J. R. Mutchins. The year 1879 matied an epoch in the sporting history of the Club, when captain camplofl, of St. Ilikire, was elected Master and, supported by a committer consisting of Messis. J R. Ilutelins, H. Bonthillier. Ingh Paton, I. Bammgarten and 1. Galarnean, determined to make the llunt second to mone on the continent, and to make it eompane favorably even with the best English Clubs. Captain Campluell was untiring in his eflorts to abolish everything that appeatred unsportsmanlike, especially the reprehensible chstom of humbing what is kmown as "elrags."

Tneler these conditions the character of the sport attained a higher state of excellence, which has since been continned. Doming this period it was desirable to and materially to the pack, and in response to a liberal subscription for the inportation of new hommls, the entire pack of Lord Iluntington was purchased. being bronght forom Dublin in 1889. This season Mr. 1. Bammgarten was selected as Master, which office lee retaned until the year 18s7. It was principally through his encrgy that the ('lubhonse on Delorimier Irenue was crected. It was well adapted for social wants of the Chb, and the memories of the gay Humb balls held there during the ten years of its oceupation, mutil the premises were abandoned for a more pieturesepue sitnation, are still fresh in the mints of the members.

On the retirenent of Mr. Bammgarten in 188\%, Mr. Hugh Paton was chosen as Master, while in $1888 \mathrm{Mr}_{\mathrm{r}}$. John Crawford for the thind time assmmed the office. Dnring the last term of Mr. Crawforl's office, he was ably assisted by Col. d. Dlexander Strathy, who was then secretary. In 1891 the Mastership fell to sir II Montagn Mlan, he being replaced the following year by Doctor Charles Mckateleren. I)uring the year 1896 Major Hooper was the Secretary, while Mr. 1. E. Ogilvie filted the position of Master, he in tmm being stleeerted hy Mr. W. R. Miller, who wats followert by Major Frank Meighen. 


\section{$100 \quad$ Lovers of the Horse}

lu the reale 1899 the present chuh-homse on Cote st catheriue was huilt, alomg

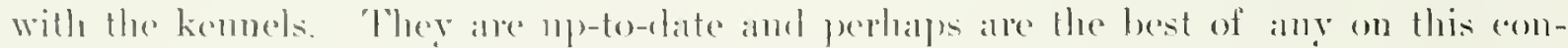
tinent. Jir. I F. (O)ilvie, a most enthusiastic member of the (Chl) for many years, assumed his secomel term in lous. Doring the last few gears there has been a great

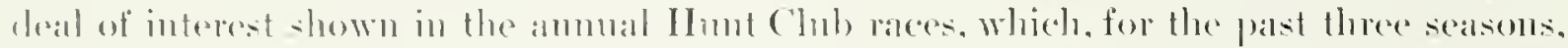

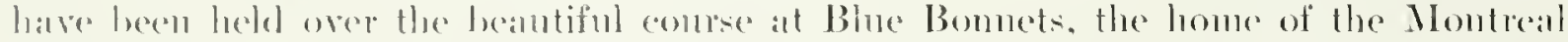

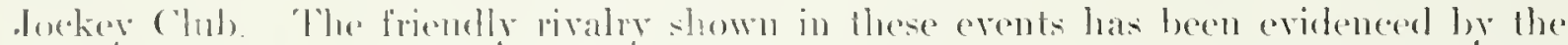
purchasing of a hetter ebass of horses. This has heen the means of developing better

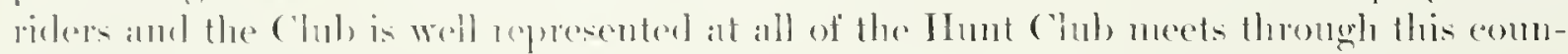

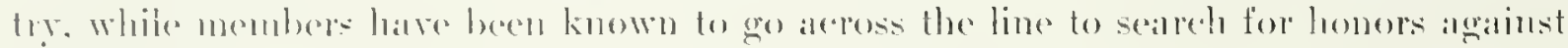
the members of the Hunt chuls of the luited states.

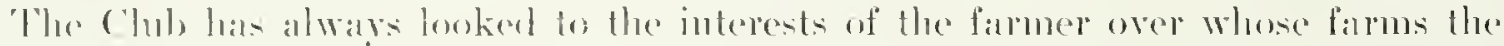

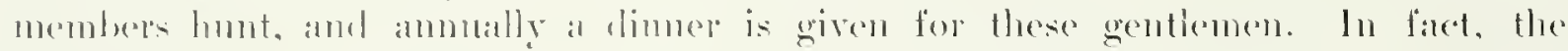

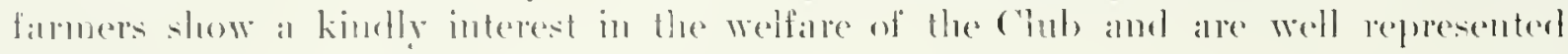
eale reall at the fall liaces given for theme

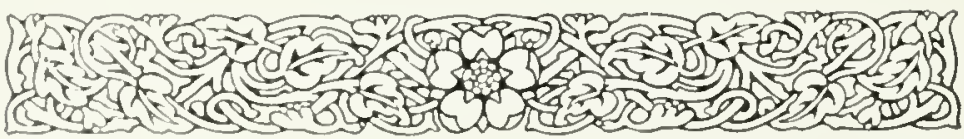




\section{CAPTAIN C. T. VAN STRAUBENZIE}

$\mathrm{N}$

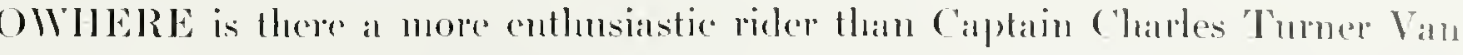
Stranbenzie, Royal ('anatian D)ragooms, Stanley Barracks, Toronto. Ile was born in Kingston, Ontario, in 1876, and is a som of the late It.-Col. Van Straubenzic. who, as Deputy deljutant-( General. Was for many years stationed at Kingston, Moutreal, and other points in the l)ominion. After completing his educition at Ridley College, St. ('athatrines. Capt. Van Strambenzie took a commission in the

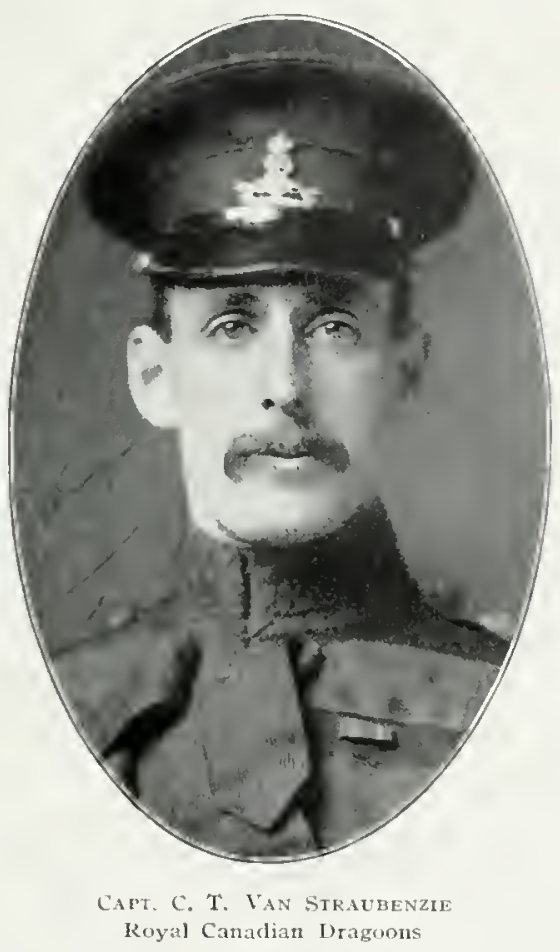

Dragoons at 'Tomonto in 1898. Eally in the following reall he wats transferred to the detachment of his regiment stationed at Winnipeg. When the call ane for active service in Sontl Ifrica. Capt. Van Strauleuzic was appointed a Lientenant of " B3" Sipuadron in the 1st Camadian Monnted Rifles (remamed in South Africa the Royal (amadian l)ragoons). This regiment was composed nostly of western men, and it made an enviable recerd on the fichd. On the retum of the regiment to Camala in Jamuary, 1901, le rejoined the Toronto detachnent of the loragoons. hut in the spring of 1902 he returned to South Africat with the 3rd Camadian Momnted Rifles as Adjutant. with the rank of Captain. The regiment returned to Camaldat in Dugnst of the same year. when it was formally disbameded. Capt. Van Straubenzie retumed to the Dragoons. He wears the south Ifrican medal with five dasps- Calpe Colony, Orange Free State, Johameshurg, Diamond I Iill amd Belfist.

All his life Capt. Van Strambenzie has heen an ardent friend of the horse. Soon atter joining the Dragoons he came into prominence as a skilful and daring rider, and to-day lie lanks ats one of the most alecomplished polo players on the American continent. llis apartments are ornanented with a score or more silver cups which he hals won in the past few years. Possibly no other rider can boast of such a collection. His first prize came in 1902, when he won a steeplechase at the Toronto Grublama, momted on Mle. George Beardmore's Laddie. At Wimipeg he was very suceesstul on his own horse Billy, a half-bred he took to the west from 'Toronto. In 1909 he bought Enghurst from Mr. (. M. IIarris. and rode hin to vietory in the Hunters' Flat Rare and other races at the Antumn meeting in 'Toronto. 1903. At the 1904 Spring mecting. Enghurst again acquitted himself most ereditably. Ile is a consistent pertomer. Capt. Yan Strabenzie rode him to victory in the IJunters Flat Race in 1906 , was second for the Stanley Barrateks ("up), and won the Walker ("up) in Itamilton

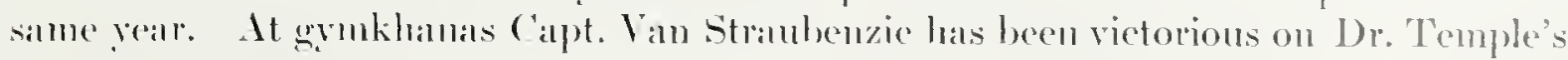


Major. and capt. Hambottes Joc Ociraly. Ile is rery fond of his polo pony

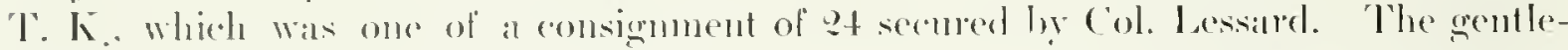
men interested drew lots for choice. and 'T. K. turned out ho be the best of the bunch.

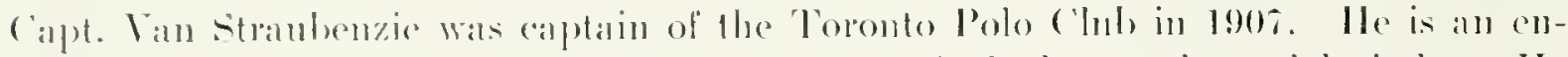
thusiastire member of the 'Toronto llunt and is widely known in social circles. IJe

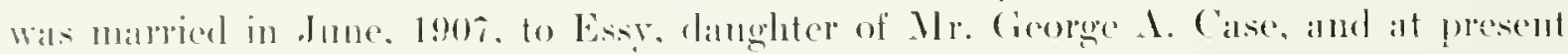
resides at No. Splodina Gardens. Toronto.

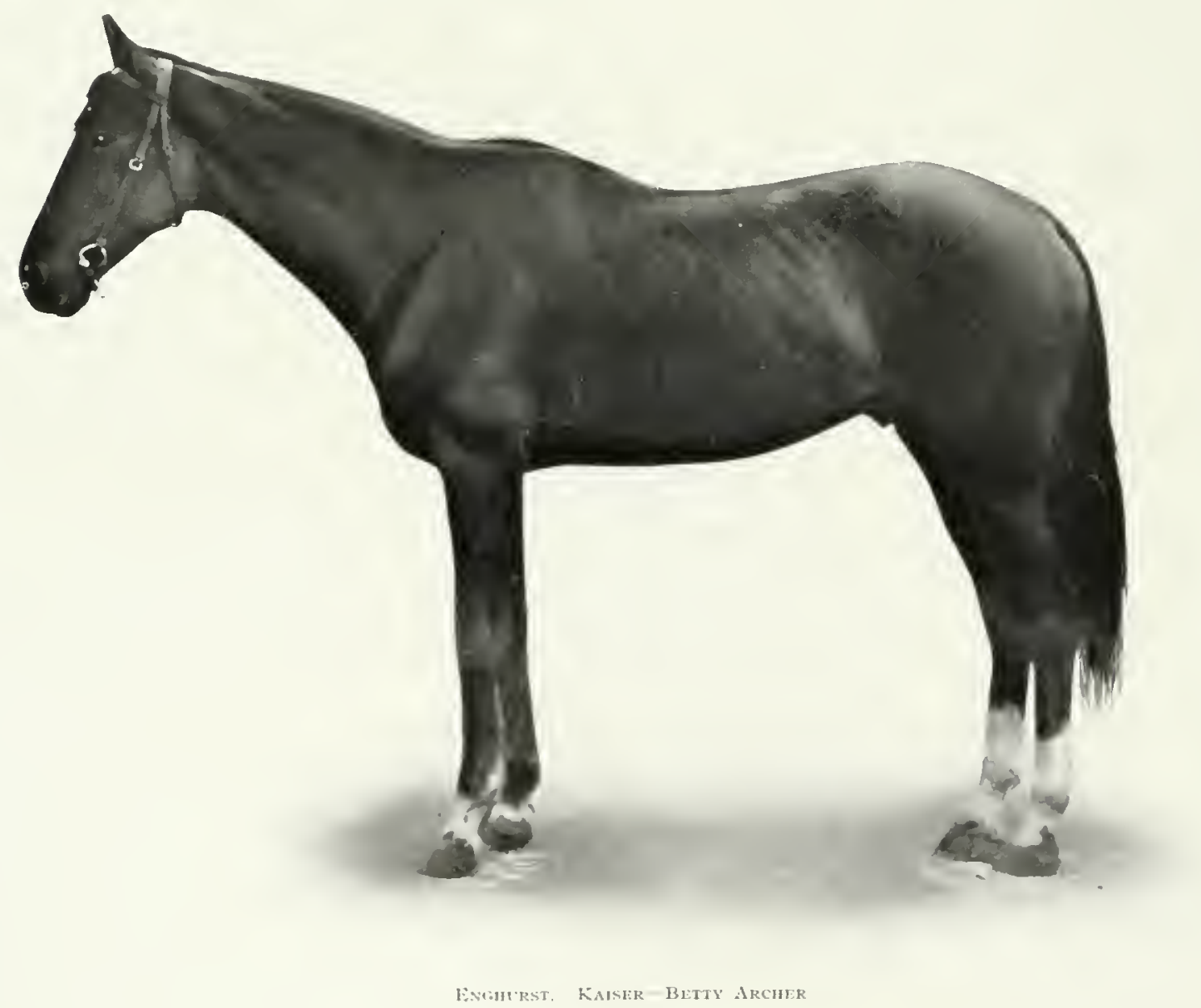




\section{Lovers of the Horse}

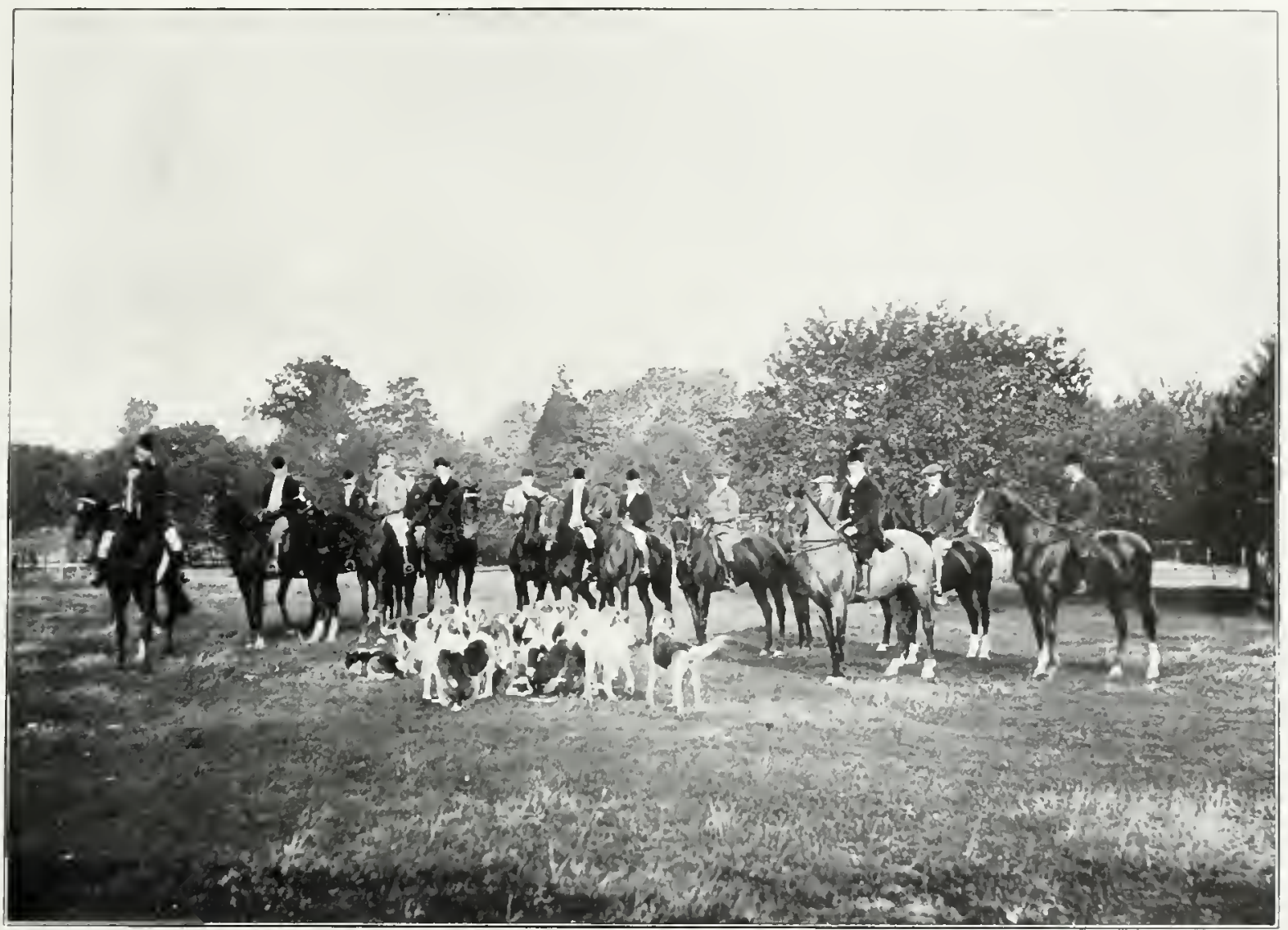

LONDON HUNT

\section{LONDON HUNT}

$\mathrm{T}$

IIERE is probably no more picturespue spot in the l)ominion of ('anada tham the home of the Lombon Jlunt and Comntry Chub, which is beantifully situated at the end of Richmond strect. just across the north branch of the Thames River in London. Ontario. (ilemnore. as the chln-luouse is known, is not only at familiar name to the people of London. hut to all who take an interest in the horse in this comotry. No Jlunt or Country (luh has a wider reputation for its hospitality for visitors are rovally entertained while there.

'This Chub has come into murl more prominence than the majority of organizaltions of its kind in Camada owing to the suecess of its Master. Ilon. Adam Beck. Hrongh his racent suceess at the horse show in England. where he won so many ribhous under the colors of the london Hunt. From its earliest days the Master's. one after the other. have emeleavored to place the ('lul on the highest standing with more or less sureess motil to-day it is one of the langest on this continent.

'lhe ('Mub-lionse stables and kennels are of the most up-to-rlate style and al re risited 
hy many who are always loul in their pratse of the suromulings. Cilenmore is situated in the centre of a clump of trees: on the one side of it stancls an olel orcharde while on the other side are two first-chass temis courts. which are sedelom or ever idle during the temis season. "lothe batek of the house alre well-latel-out goll links. well bunkered and hanked. miking them difticult to play over. The approath is through a long avenue of fir and lilac trees. Which adds to the beatuty of the place. Cilenmore is built on the old colonial style and from the hroal haleony eam be seen the temis games as well as the golt. The nembers take great delight in spending their afternoons in this way while not in the saldelle.

The lomelon lHunt and country chub was first lannched in the rear 1885. shortly alter the elosing of the rebellion in the Northwest. It was due to the efforts of the late John Fulelaer, who at that time was the riding and driving master at the Ilellmuth Ladies" (ollegere that this ('lul, was organizerl. 'That gentleman was always an contlusiastic lorsentun, and owned a first-dass lot of hunters. On retuming from the Northwest he suggested the forming of a hunt chuh, which met with a great deal of suceess and as the yeals have gone ly it has grown so that twice they hand to move to larger premises mutil the present location was chosen.

'The original nembers of the Club were: the late Col. Peters, who was the first Master: Doetor Niven, the lite Henry Beecher. Col. 1. M. Smith, IV. T. Strong, Col. 1)awson. Robert Wallare, and the foumder of the ('luh. In the year 1885 there were only al bout twenty memhers. anel in the original patek of homuds there were only four to he used at the first seasonts meets. 'This. like the Club. lass been increased from season to season until now it is known as one of the best packs on the continent of Ameriea, owing to new blood being imported to this kemel earels rear.

The first meets of the ('lub were liekl at the old rice-contse in Eist Lonelon, of which place many good lunting stories are told even at the time of writing. For the first eouple of seasons there was no encomragentent for the original members. but after the soeval element was adeded to the Club in the year 185 it branched out and has been

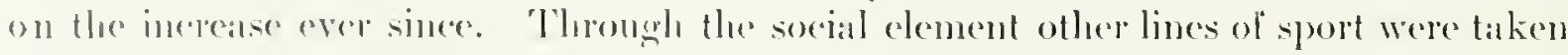

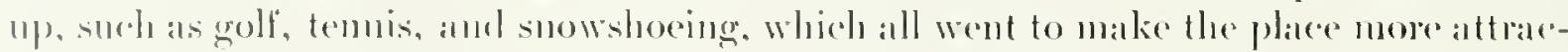

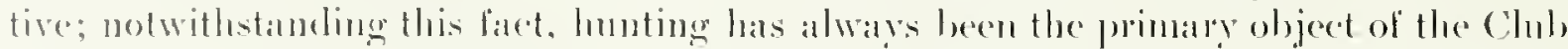
and a mere idral country than the township of lomon combl not be found for the sport. 'The beantilul lindsealye, the rolling country, with the hedges and waler-jumps. (go) to matie it perforet. Fox hunting is mext to impossible. Int trail hunting, as in most

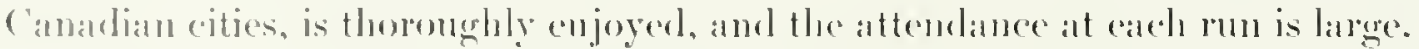

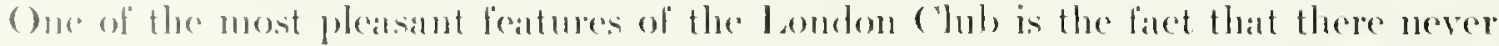

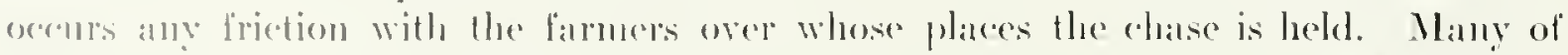

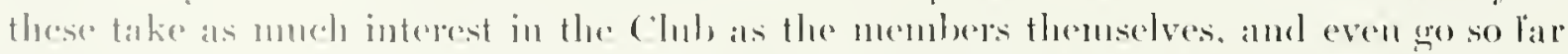

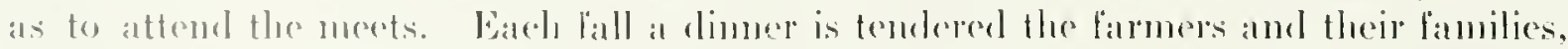

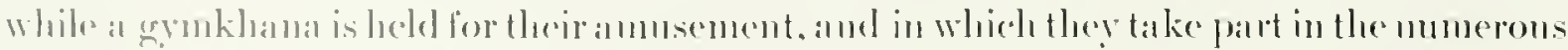

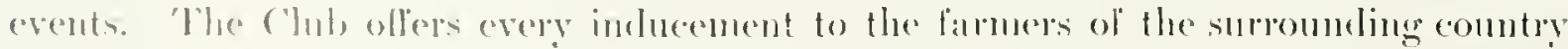
to hered saddle horses and hunters by purelasing loom them when gook ones are oflered for sille. 
'Tlue first Masters of the ('lub, to whom must no the eredit of its surcess, were all well-known husiness men of the liorest (City, and all spent time and money to carry out their olsject. They were: the late ('ol. l'eters, the late I)avid skirving, the late Ilenry Berecher, I) Niven, I)r. IIarry Abhott, Mr. George C. (iibhons, C'ol. A. M. Smith, and the present ineumbent of the office, the Hon. Adam Beck. 'To those who are leceased the ('hl, will live long to their memory, while those who are still living still take an active part in the executive working of the Club, while some of them even attend the meets.

'The Clul, has been just as successful in the selection of its presidents and secrertaries as in the ehoice of its Master, as the office has always been filled by men of great executive albility. Mr. T. R. Smallman, who at the time of writing holds the office and las held it for a mumber of years, is most enthusiastic in his work and is ably supported by Mr. Cimmpell Beecher, who succeeded Mr. I. B. Kilgur to the office of secretary.

There is a section for ladies in eonnection with the ('hub, and in the past few rears several branches, making the place attractive to those who do not rille, have been adeled. 'There is a ladles' golf chub, tologgan chub and temis elub, while a driving ehul, also gets their warmest support during the whole year. During the winter months meetings of the driving chul, are held with Glenmore as the destination.

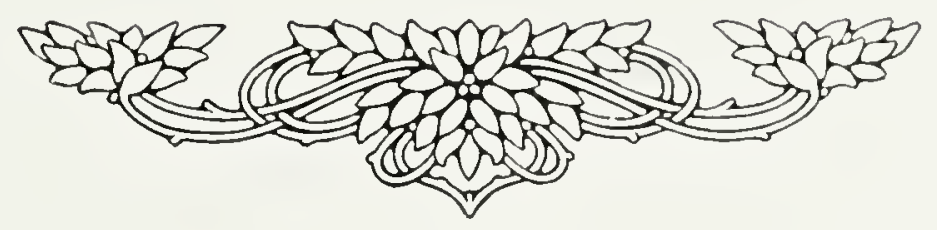




\section{$106 \quad$ Lovers of the Horse}

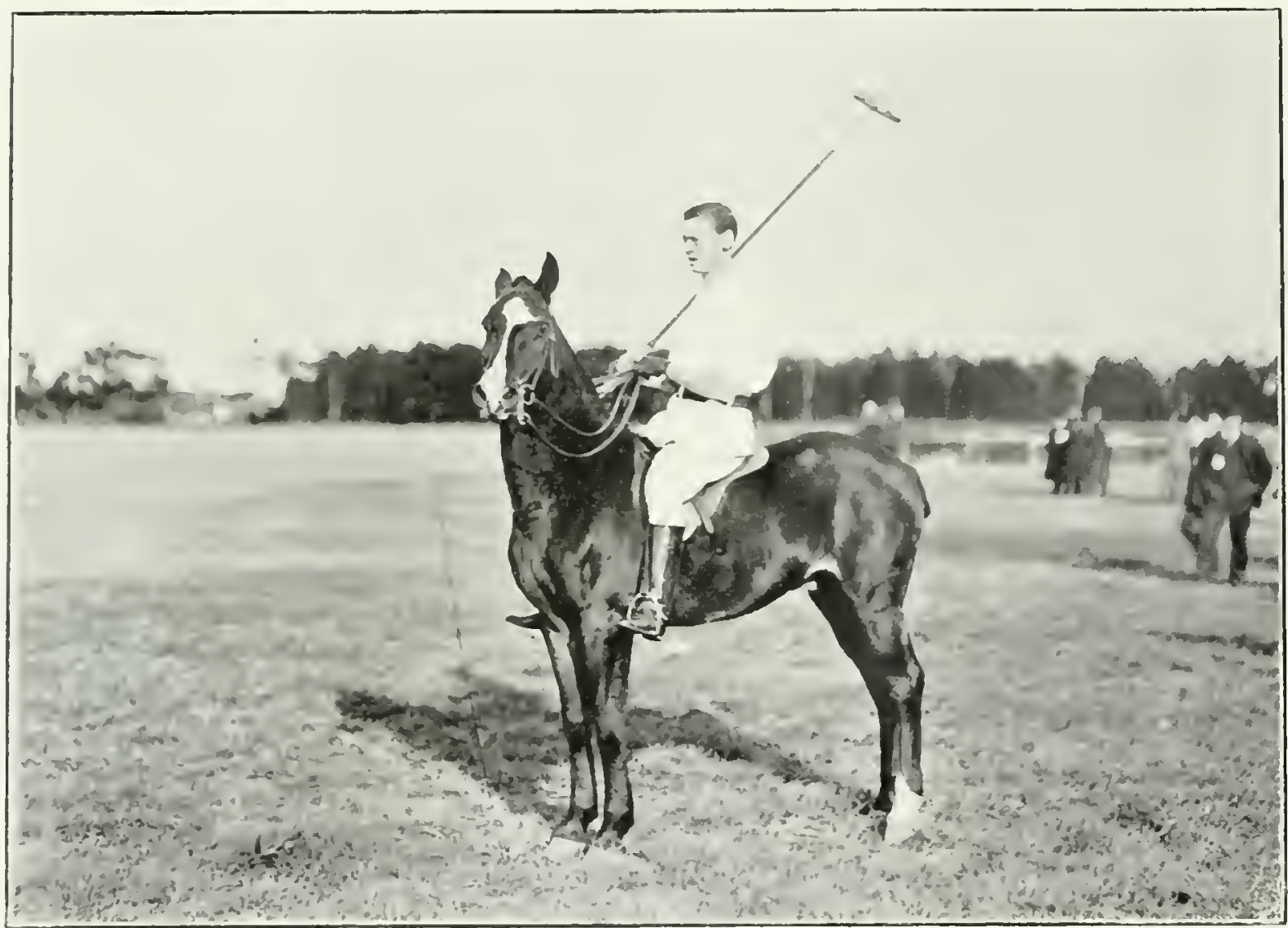

\section{CAPTAIN J. E. K. OSBORNE}

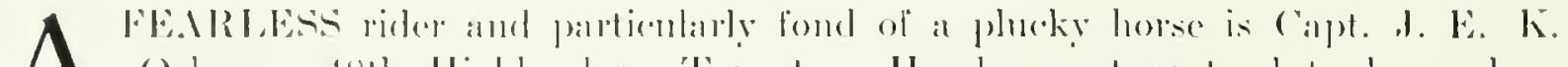

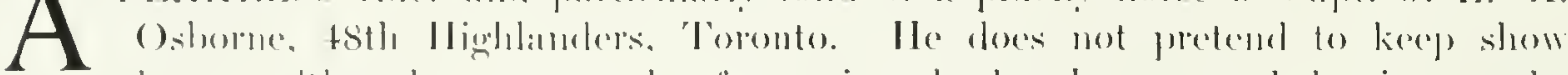

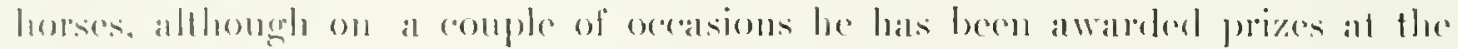

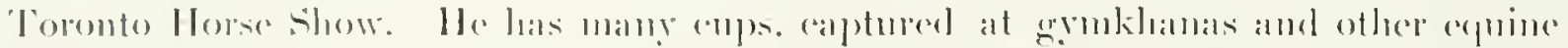

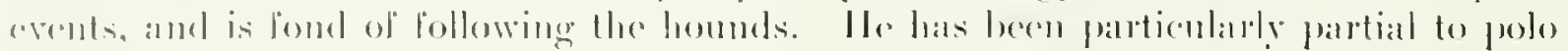

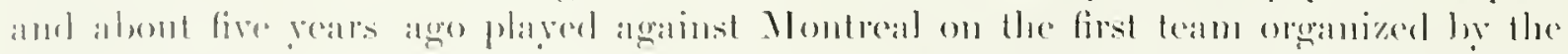

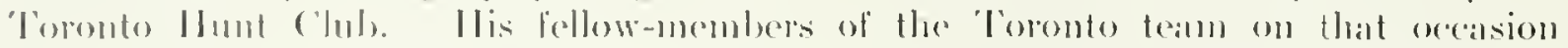

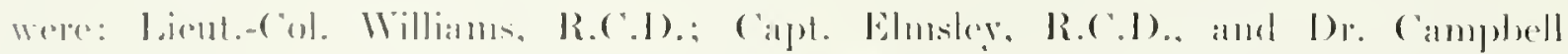

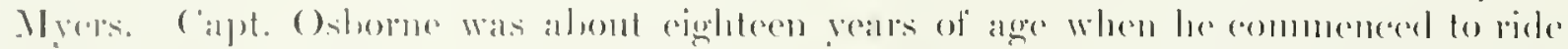

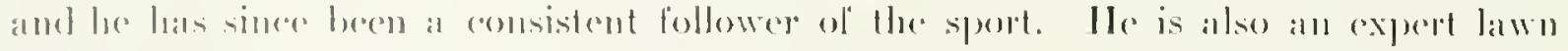

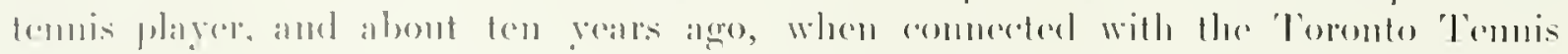

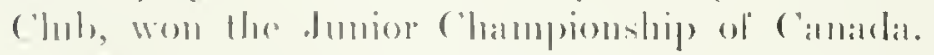

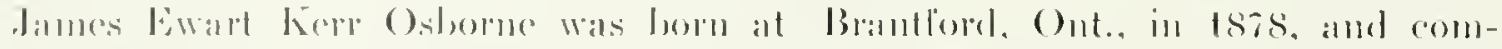

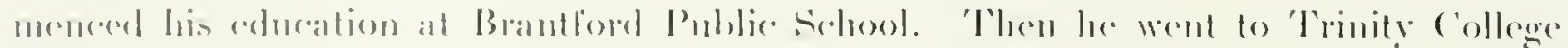

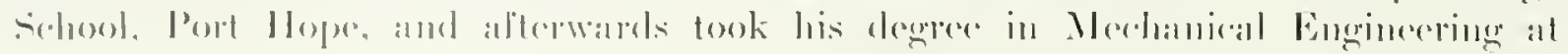


Mecill Cniversity, Montreal. He is now comected with the firm of Oshorne \& Francis, stock hobkers and financial agents. Toronto, and resides at jo crescent Road. In Octoher, 1900, he married Miss Eileen Amuette. daughter of the late Walter Barwick. K.C. He is a son of Jimnes Kerm Oshorne. "Toronto, who serverl in the Fenian Raid as Major of the 19th Regiment. Calpt. Oshorne entered the service of his comntry hall a dozen pears ago as a Lientenant in "I)" company, 4Sth llighlanders, and was subsergently promoted to the command of the company. He is widely known in social circles. Jeing comnected with the 'Toronto ('Inb. "Toronto

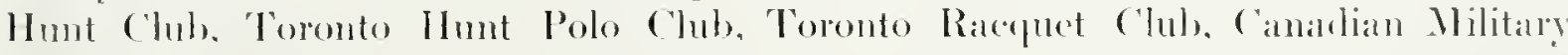
Institute, the creek letter fraternity. Mplat Delta Phi. Ile is popmal in financial (rireles. being one of the brightest of Camada's young linsiness men. and one who can make healthy exereise and pleasure go hamel in hand with work.

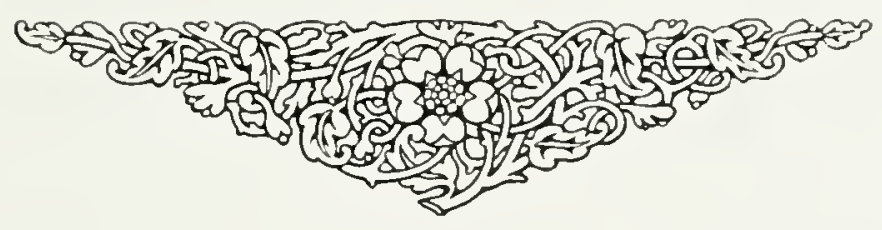




\section{$108 \quad$ Lovers of the Horse}

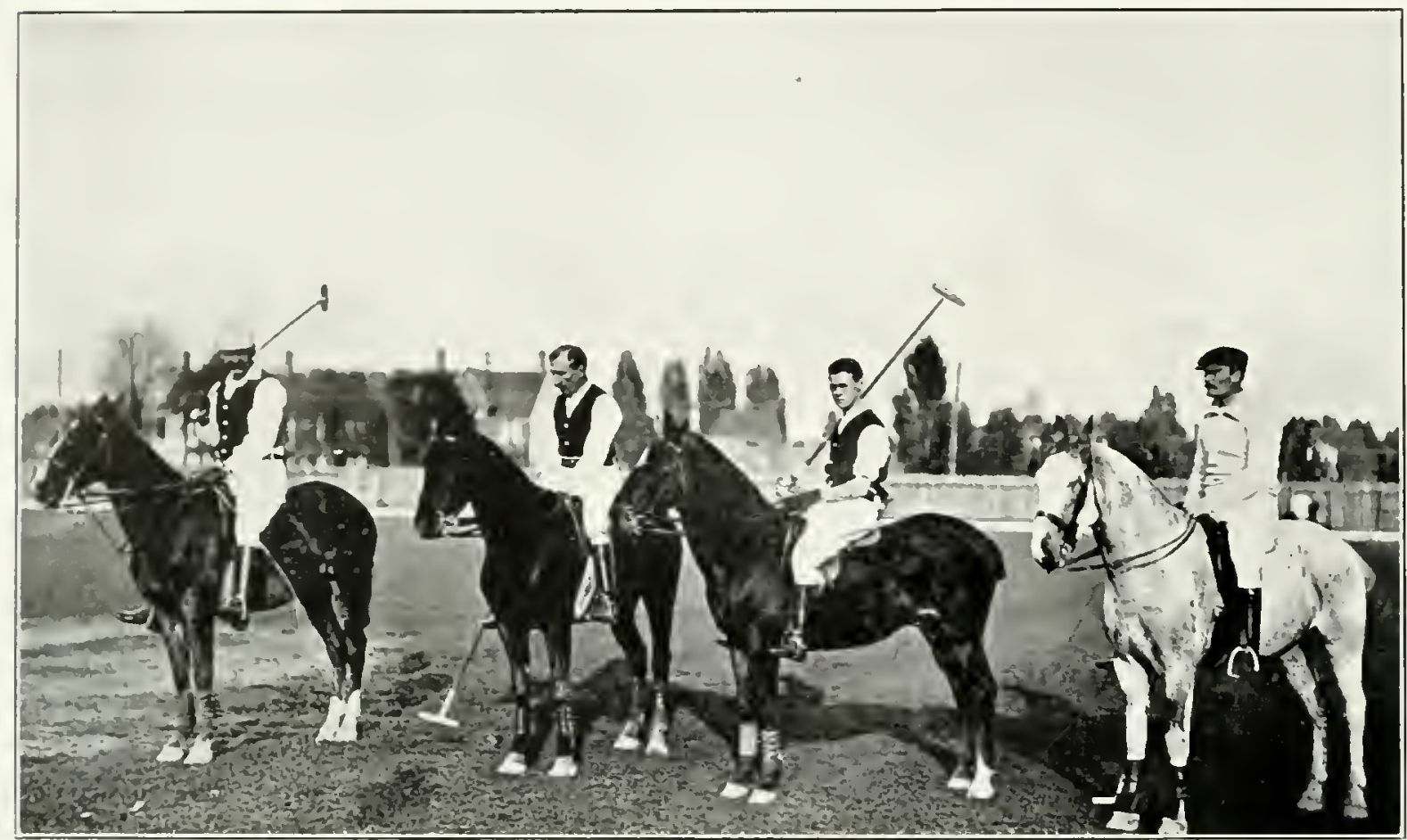

TORONTE PULO TEAM

\section{TORONTO HUNT POLO CLUB}

$\mathrm{T}$

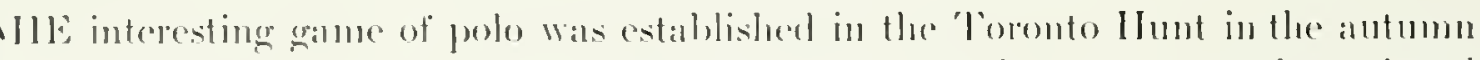
of 1901. and it soon assumed a solid tooting. 'The game was then played on a fiede in the vieinity of the llunt chuh, He undulations of which at times marle the contests intensely interesting. Early in 1909 additional grommel was purehased

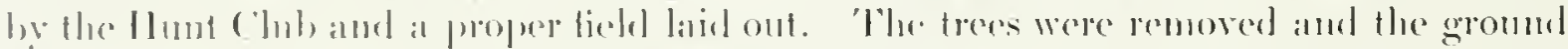

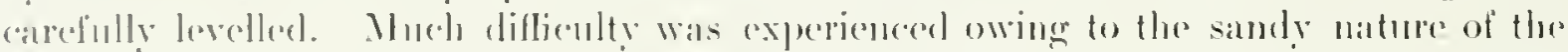
soil. Wut this was he constant improvement eventually overeome. "The lieded is 150

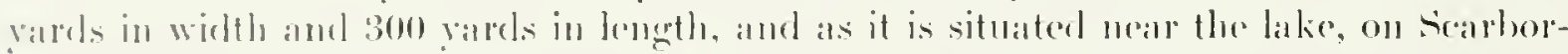

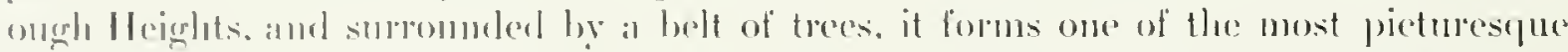

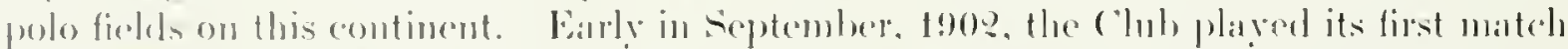

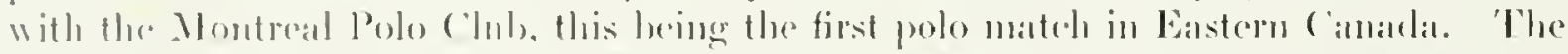

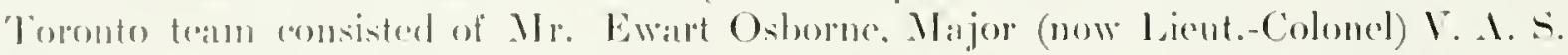

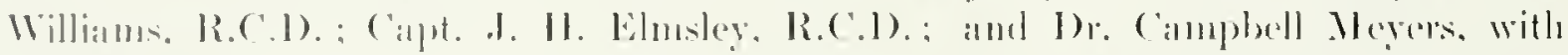

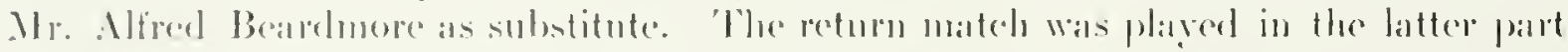

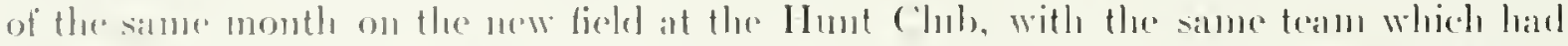

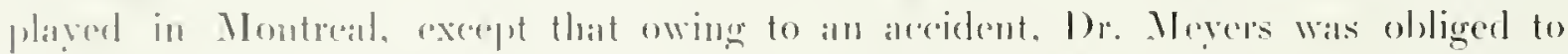

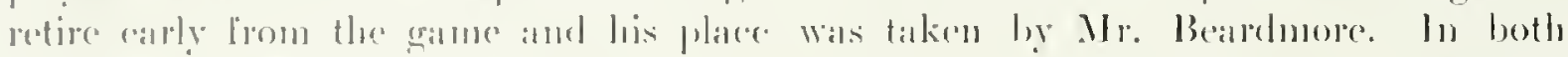
matedes the "Toponto teitur was vietorions. Sime then the development of the sport

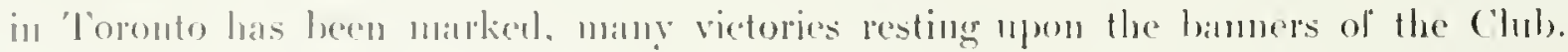




\section{Lovers of the Horse}

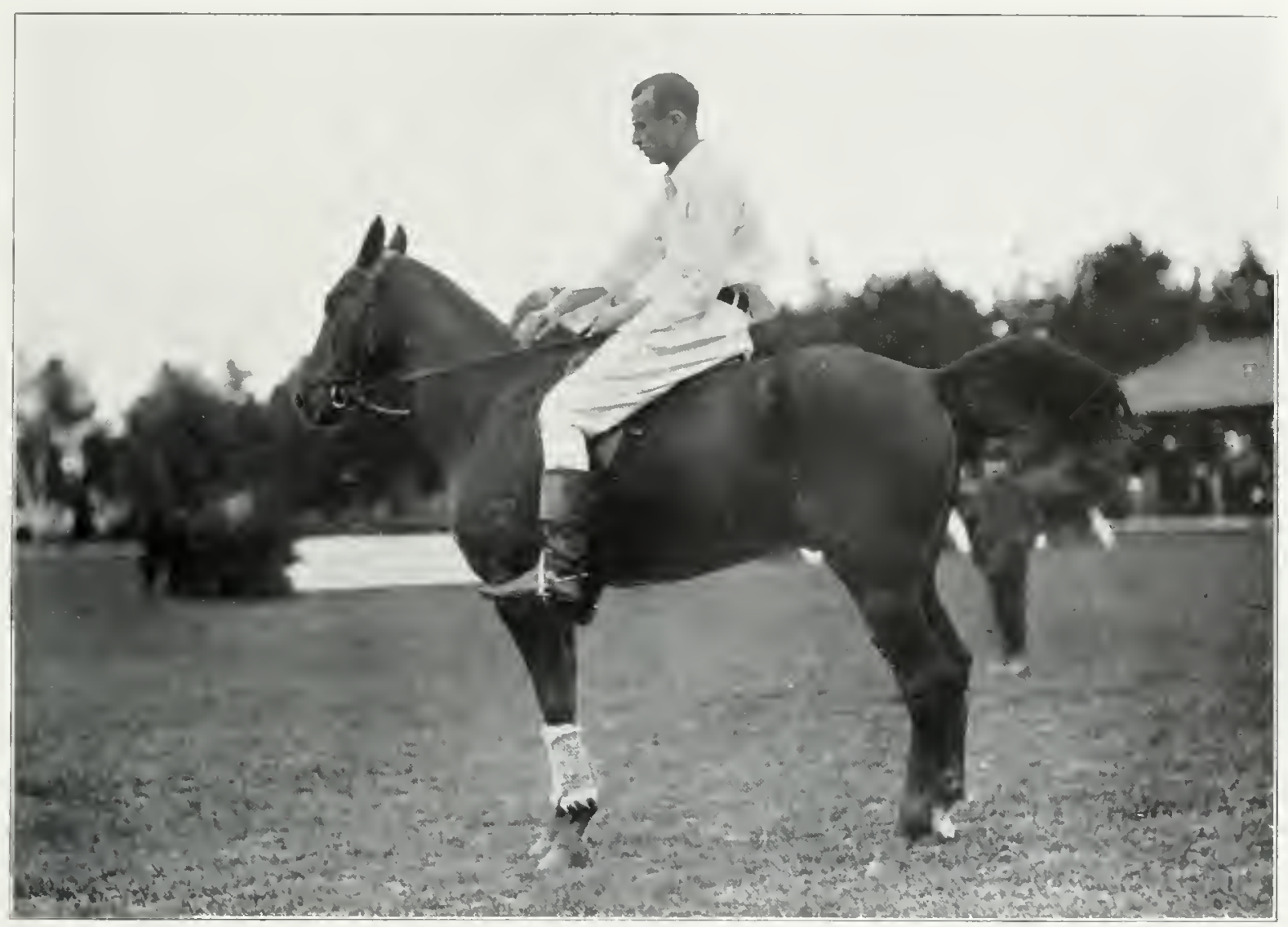

\section{KENRIC R. MARSHALL}

$\mathrm{K}$

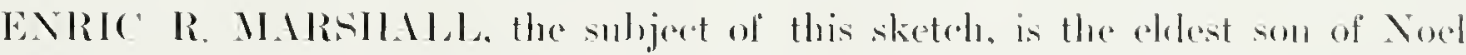
Marshall, a prominent Camalian. and was born in 'Poronto. on October the

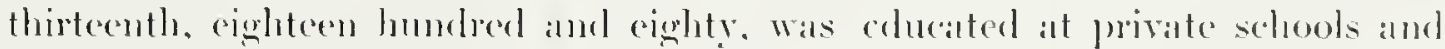

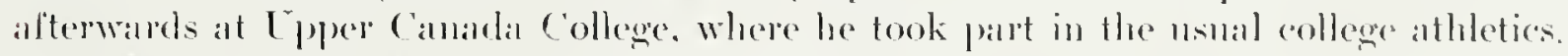

Mlr. Matshall has travelled extensively ahmad. and has had the advantage of secong spout under many different eonditions. Ile commensed following the houms at the 'Torouto Ilunt when only twelve vears of age, and has hunted regularly avel since.

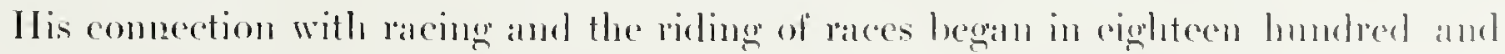

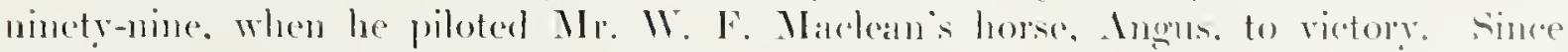
that time Mr. Marshall has owned and ridelen several well-kinown latere-horses, anome

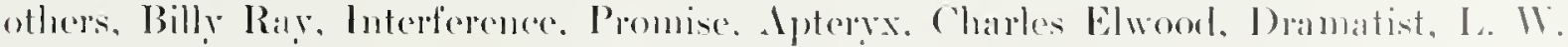
and Golden Wiay.

In commeredial life. he is at present Viereleresident of the Standard finel company. and assists his lathere in ofher husiness interests. Inereasing weight and the ohligid- 
tions of husiness prevent his being seen in sidclle very often now, although he rides an aceasional race where the weights permit it.

Mr. Marrsall is well known als a polo player and owns a string of light-chass ponies.

In nineteen humdred and three he joined the 4Sth Jighlanlers as a subalterm, and at present holds the rank of Captain in that Reginent. Ihe is liked socially and is a member of the following chuls: The Buffalo, the 'Toronte Ilunt. the Ontario Jorker, the National, the Vietoria and the Military Institute.

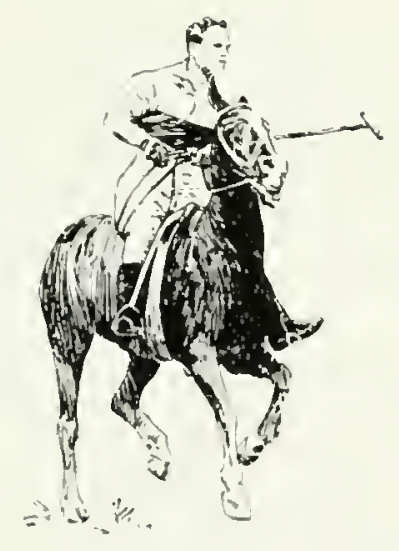




\section{THE CENTRAL CANADA RACING ASSOCIATION}

$\mathrm{T}^{1}$

IlE Ammal loe Races held on the Ottawa River each winter, muler tle anspices of the C'entral Camada Racing Association, are, frerhalps, the most unique and noteworthy racing events in the Jinness Horse World, and have done a great deal to advertise Ottawa as a centre for racing sport.

It was away back in the early seventies that the first ice meeting was helal, and during the succeeding years races took place on the Ottawa River. I deamy's I alke. St. Louis Dam, Melay's Lake and Aytmer. but it was not until 1887 that the first chub was formed at IIull, under the name of Leamy's Chub, with Eid. Cherrier, Georese

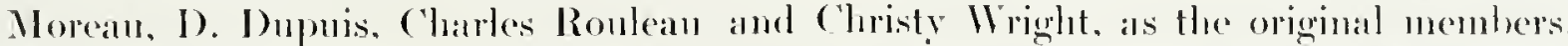

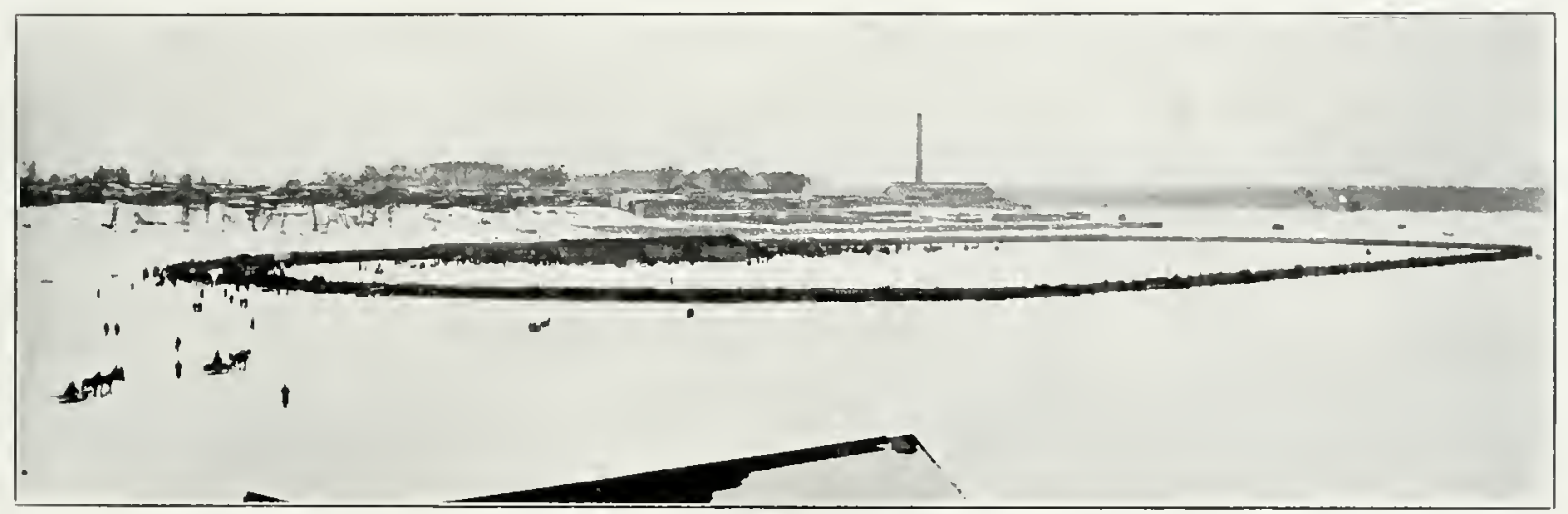

Winter 'roack of the Central Canada Racing association

This Chub heda races for seren years, after which the present Association was formed, with Mld. Lauzon as President, Ed. Chevier as Secretary, and Fred. ('herrier as Treasurer. From that time the Association las met witl marked suceess, areh season bringing faster racing and better fields, for the stakes are high and have attrated Ameriean, as well as C'anadian, horsemen, although cimada contimes to hold hel' own. Sammel MeBricle, of Toronto, getting more than his share of the events in t908. with his horses King Bryson and Jolnuy K.

Every possible armengenent is made for the comfort and comcenience of those attending the races. The track, a half-mile one. is built on the (Ottawa River, al little to the (Quetere sicle, with well-built portable stands that can be removed after the meet. 'There is a large room for the sale of pools and refreshments. white on the opposite side are the judges and ladies stand. It is a most expensive plant, the eight foot fence surrounding it costing a large sum alone, while the work of keeping the track dear of snow is also vely eostly.

Sone very last records ane mate on this track, a specially noteworthy one being that of lanty May, who, in 1908, in a fomp-mile ratee, went a mile over a half-mile tratek in $2.17 \frac{1}{4}$.

'This is, practically, only the tenth geall of the Association's existence, als it was 


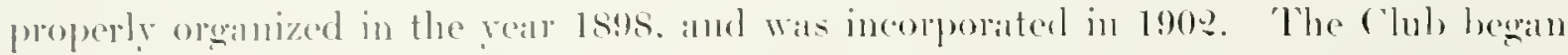

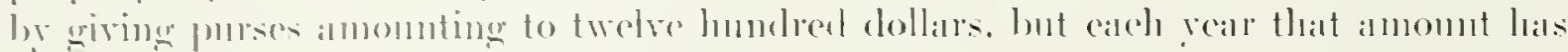

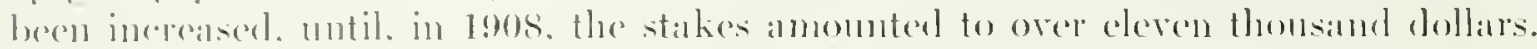

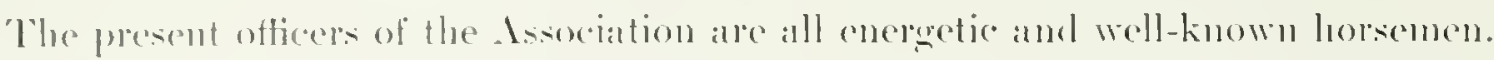

P'. H. Wall. the President, is a man of greall husiness ability. Eil. MoMallon,

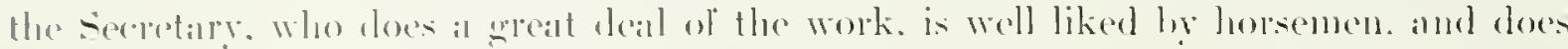

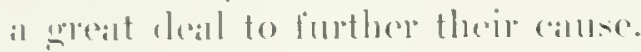

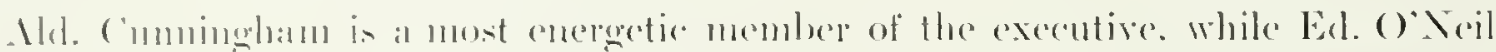

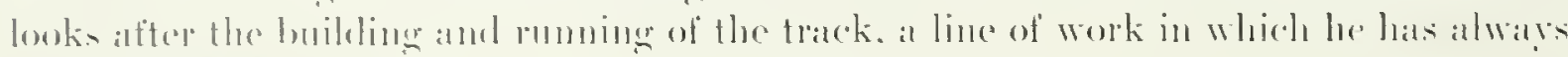

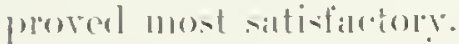

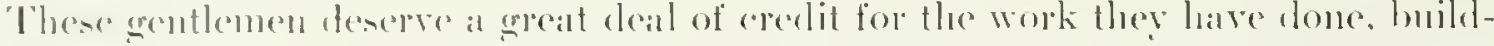

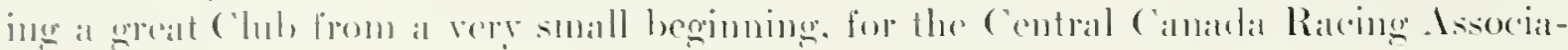
tion, of ()tanta in one of the most notewopthy institutions of its kind in the world lo-1lis.

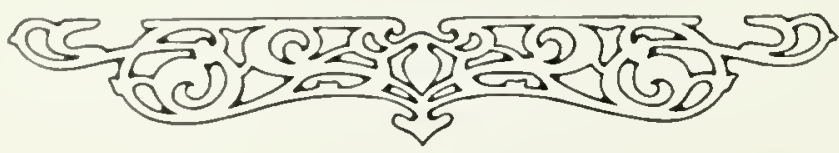




\section{WILFRID SERVINGTON DINNICK}

$\mathrm{A}$

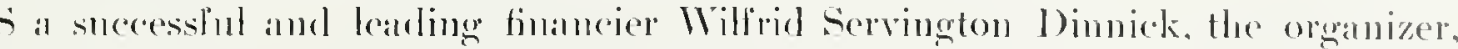
Vire-president, and Managing-l)irector of the standard Loan compuny of 'Toronto, has won for himself a deservedy high reputation for keen foresight. excellent and somel judgment, and unerring firmmess of decision. Which fits him specially for the thorough fullibment of his arduous duties. Ile was born on July 19. 1875, at Ciulford, surrey, England. llis father, the Rev. John Dumn Dimick. wass one of a family of which no less than seven members were chergymen. He came with lis own fimily to Camarlat in 189). Wilfrid Servington Dinnick was erlucated at some of the best schools and colleges in England, and alter completing a thorough course of study entered into the financial world as an employee of the Birkteck secorrity and savinges ('ompany of 'Toronto. Sulsequently lie became an Inspertor of the Dominion Permanent Loan ('ompany.

Finally. Mr. Dimnick organized the sitamelard Lam ('ompany, with loarlquarters at Equity Clambers, at the colner of Adedaicle and Vietoria Streets. 'loronto, assuming his present position of Manager. 'The suceress of this institution is latrely due to the enterprising yet conservative character of Mr. Dimnicks organizing abilities, comprehending as they do the strongest and most approved modern principles. Its appital stores is all permanent, fixed and non-withdraw-

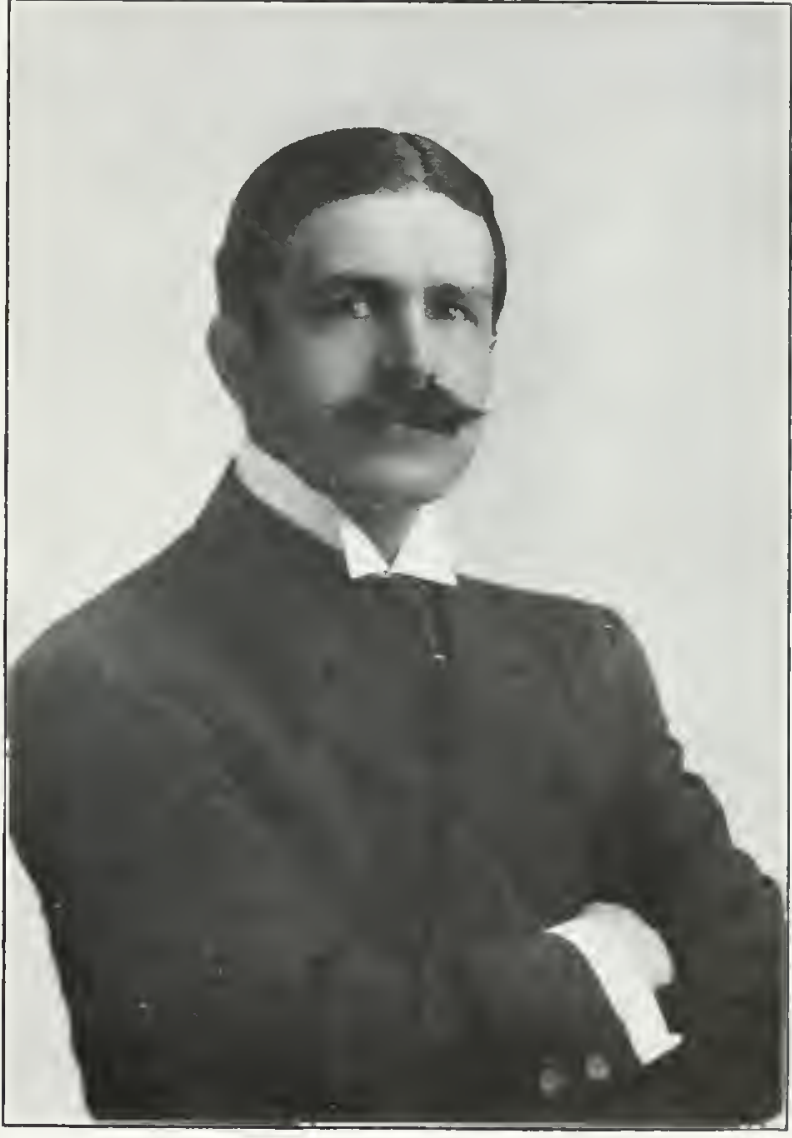

WIILRID SIRVINGTON DINNILK

able, features which place the Comprany on the firmest possible hasis, and attord it a large borrowing power. Mr. Dinnicks management has heen one with a most angressive policy, and through his encergy and diplomacy he has successfully negotiated and completed the absorption by the standard Loan Company of the did Salyings and Loan ('ompany of 'Toronto: the Ontario Industrial Loan and Investument company, Limited, of 'Toronto: the Hurou and Bruce Loan and lnvestment Company, of Goderieh: the Canadian Jomestead Loan and Sarvings Association.

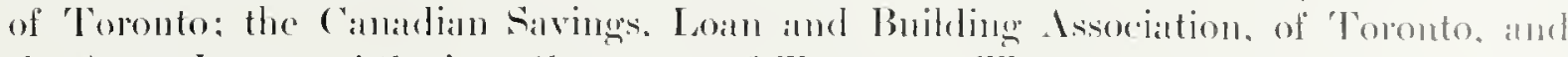

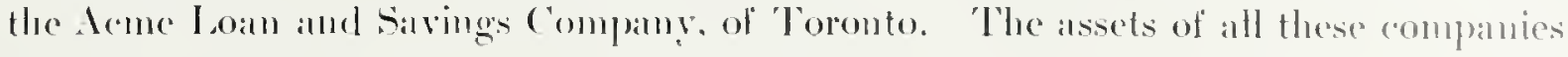




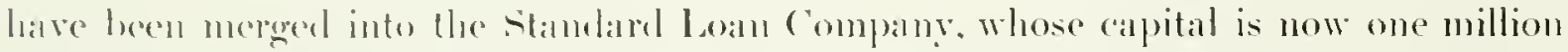
and a pualter (\$1.850.000). the total assets of the Company being two millions and a hall alollars $(\$ \$ 2.000 .000)$.

Mr. Inmiek devotes puactieally the whole of his time to the mamagement of the Stamball Loan company, hut gives a portion of his time in fulfilling his duties as VicePresietent of the C'analian ('alsulty and Boiler lusurance Company of Toronto, in which comprany he has a lange interest. Mr. Dimnick is also Vice-Presiclent of the Cirmel Valley Railway (ompany, the Brantforet Streed Ralilway. and the Woodstock, 'I'hames Valley and Ingersoll Electric Railroad, and is one of the loirectors for Cantala of the Gencral . Iecident. Fire and lite Assuranee ('orporation, of Pertl, scotlaml.

Mr. Dimnick is a prominent Freemasom, a member of the National and Albany

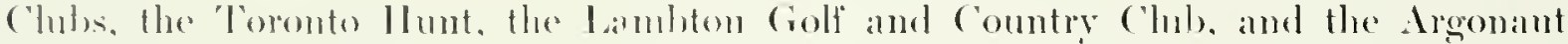
Rowing ('lul, Ile is an enthusiastic follower of the hounds, and is very rarety missing from a meet of the 'Toronto Homme. He spends most of his leisure time in riding

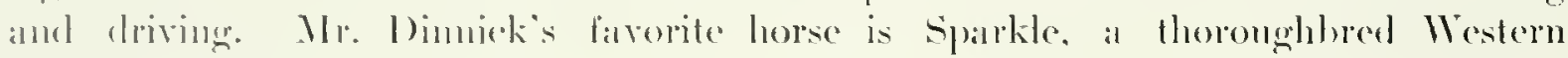

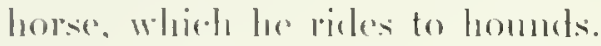

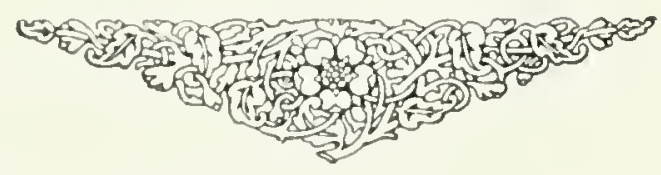




\section{ALLEN CASE}

$\mathrm{A}^{\mathrm{T}}$

TORONTONIAN thromgle and through, born, eflueaterl and bromght up in the Queen City, is Allen Case, only son of George I. Case, the well-known financier and real estate man.

Commeneing his Imsiness career with the Imperial Bank, Mr. Calse then went into business with his father, afterwards becoming associated with the Dominion Brewery Compiny, of 'Toronto, where he now holds an important position.

As a horseman, Allen Case achieved his first suceess at ten year's of age, and bas gone on so enthusiastically in his active eareer that he las won the reputation of being one of the most wonderfully suceessful devotees of the horse in Canada.

In 1895 he rode and drove at the first Canadian horse show held in Toronto, achieving stellar honors on the late Major Forester's pretty pony Judy.

This success hats been consistently maintained at all of the subsequent horse shows, and also repeatedly at the Toronto Industrial Exhibition, while in the red coat events of the l'oronto llunt Club lue has also been a frequent wimner.

Mr. Case is a strong, fearless rider. and is particularly expert taking the hurdles. As a rider in the show ring, he has few peers, while he rides regularly to hounds, and has schooled many hunters, and it is not only in Camala that he has demonstrated his ability, for he has

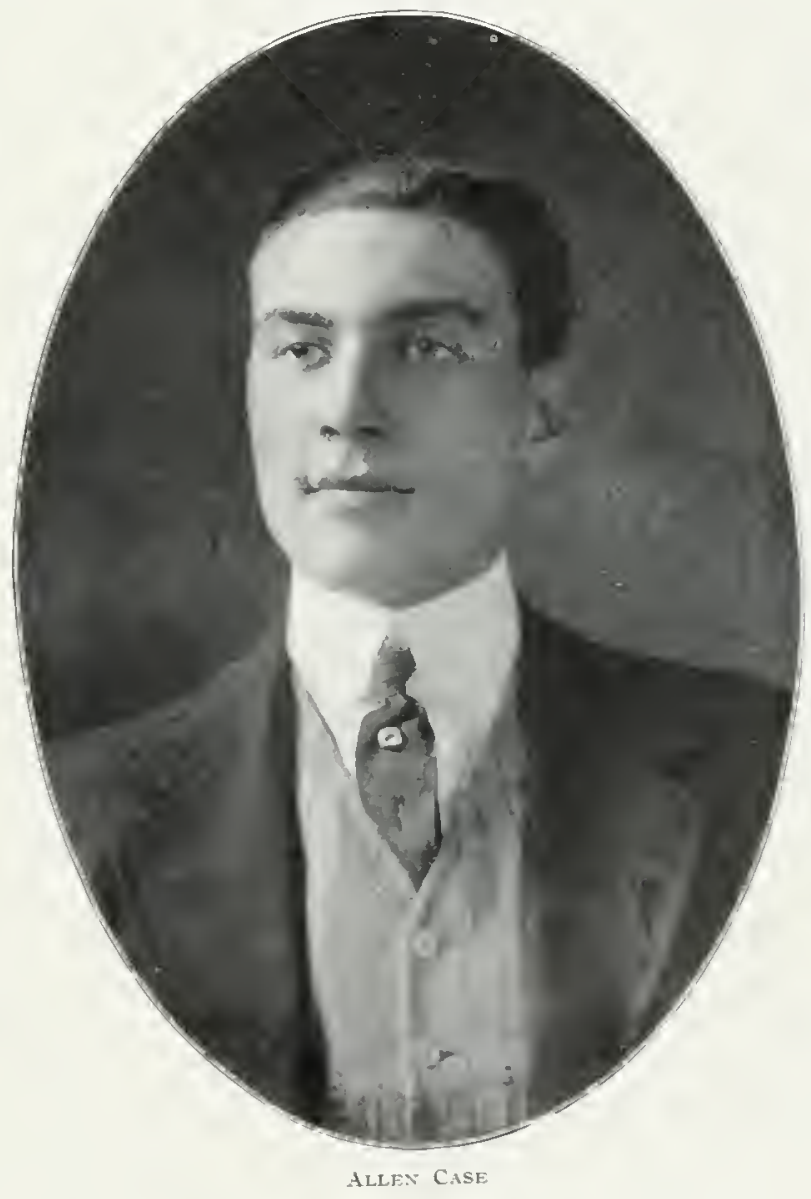
been most suceessful at many of the large slows in the Inited States.

He uses specially good judgment with all his momints, as wats proved by his ride on Purslane at the Blue Bonnets conrse, Nontreal, when he was an odils on choice, which established $\mathbf{M r}$. Case's popularity as a gentleman ricler throughout the east He had many mounts during the season of 19)8, heading the list of gentleman riders in Canada. Mr. Case has won more ribbous in the show ring, induding many championships, four of which were won on the smart hunter Othello, orrued by Mrs. J. J. Dixon of 'Toronto. during the past ten rears than any other anaterir. 


\section{$116 \quad$ Lovers of the Horse}

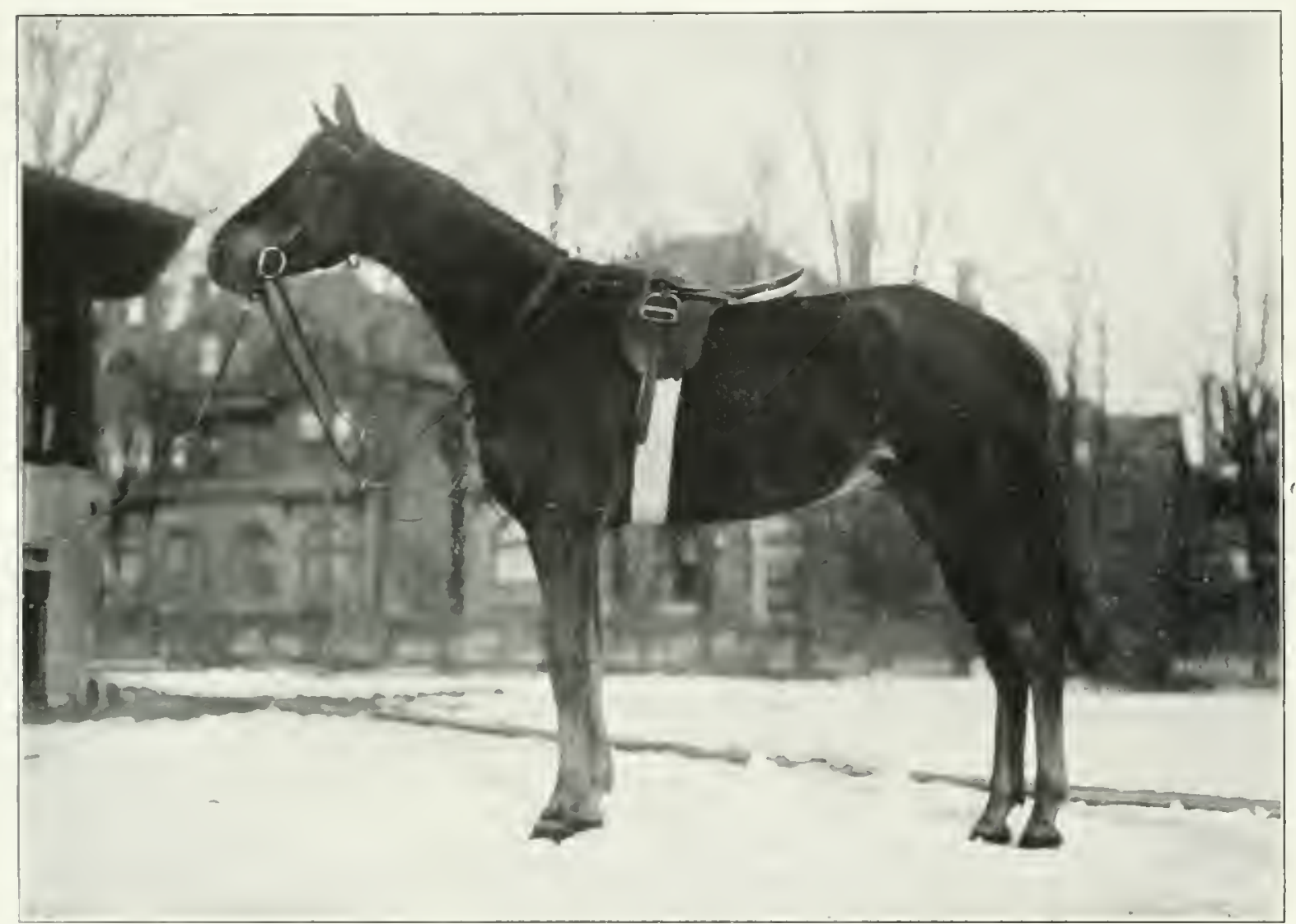

STEVE LANE

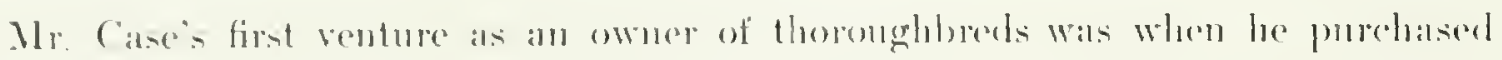

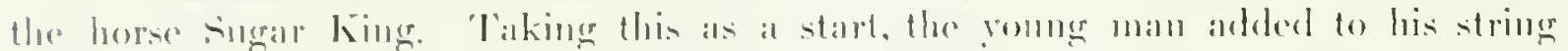

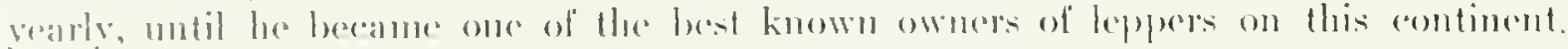

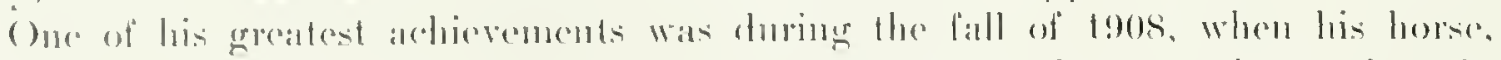

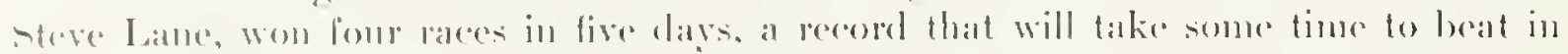

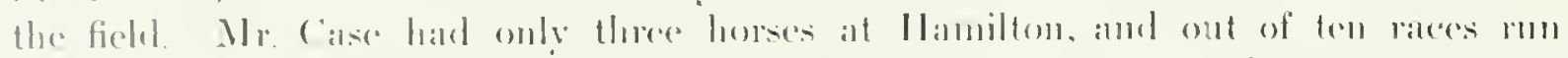

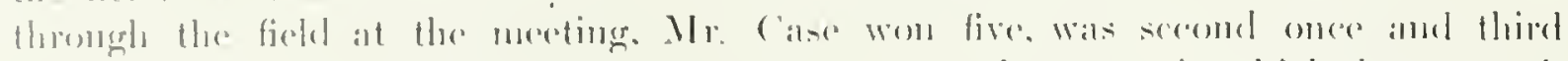

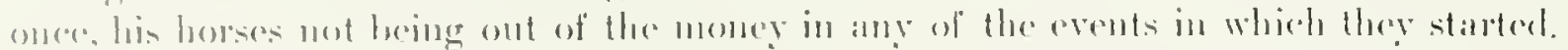

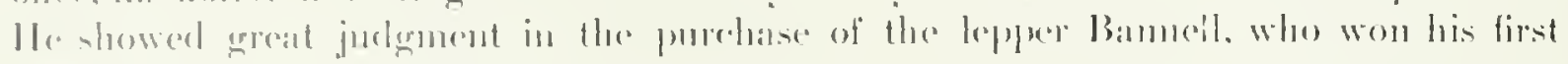

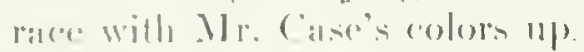

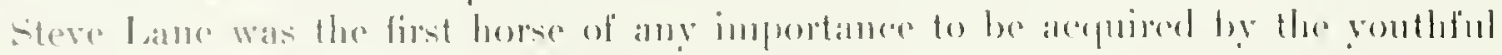

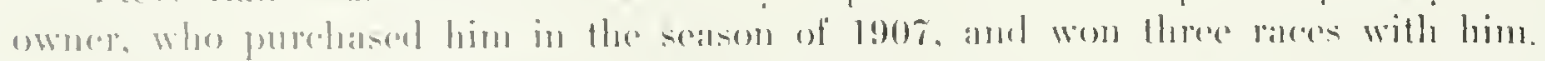

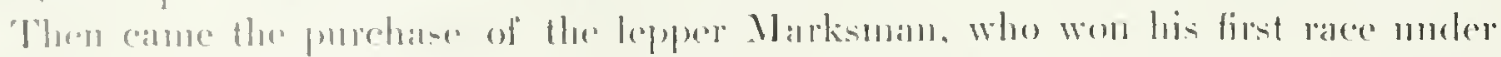

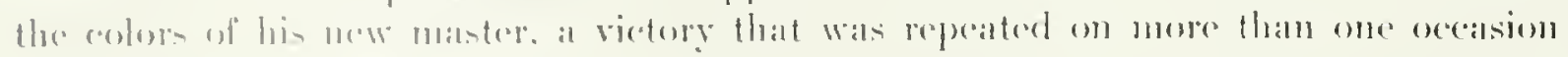

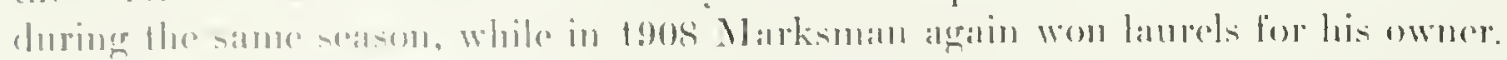

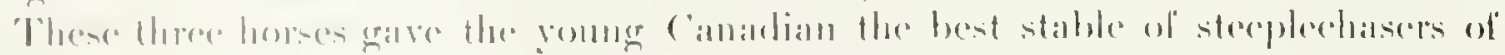

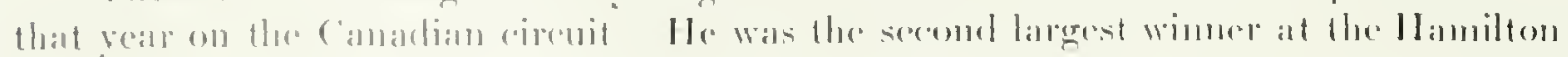




\section{Lovers of the Horse}

meeting, and would have hearlerl the list had he not sold the good rolt Demus stafford, who was also a winuer.

It is rale to malke a suceess both in the show ring and in racing. Int Mr. Case lats aceomplisher the difficult feat, Dame Fortune being edpully grateions to him in the racing field.

Like all enthusiastic horse men. Mr. Case is of a halpy disposition, mentally and plysially active. With youth and fortune in his faror, he bids fail to retain his prominemere als an expert rider and bliver for many years to come.

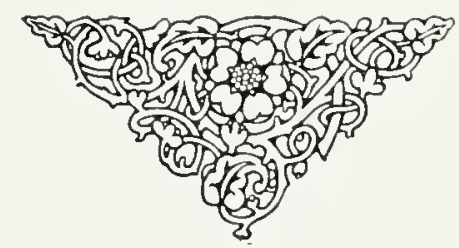




\section{$118 \quad$ Lovers of the Horse}

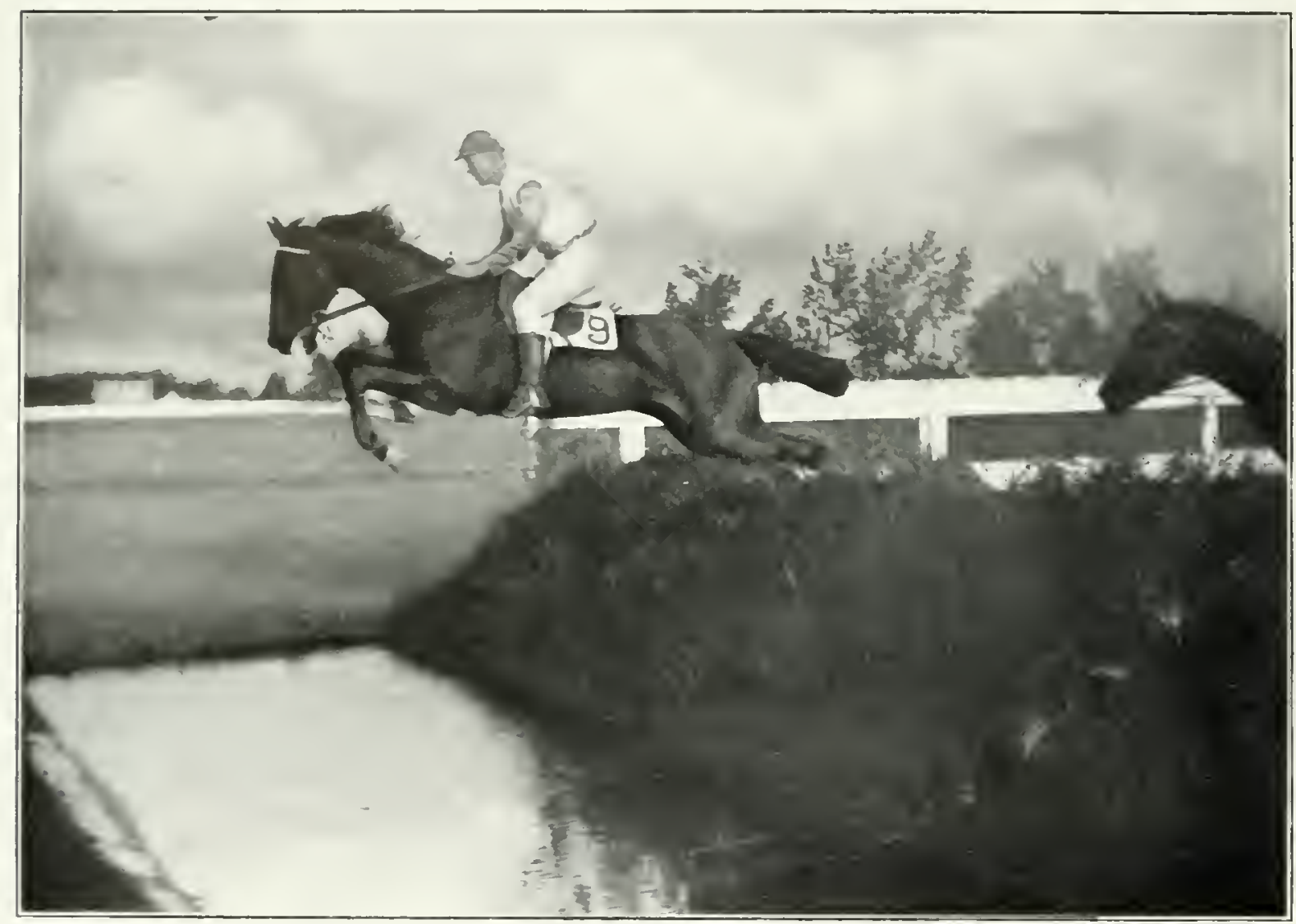

\section{MURRAY HENDRIE}

$\mathrm{T}$

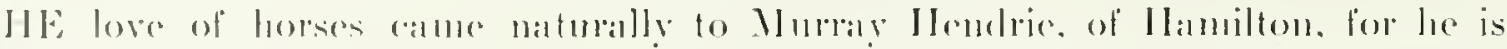

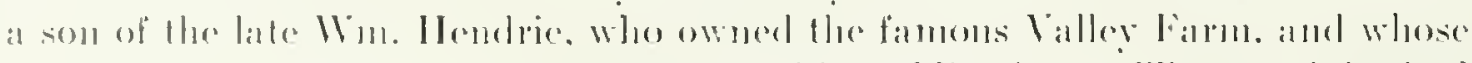

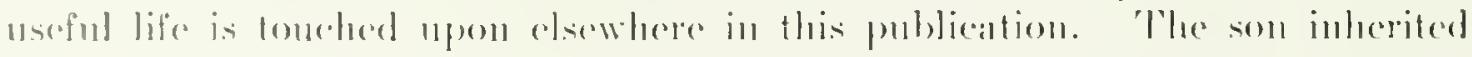

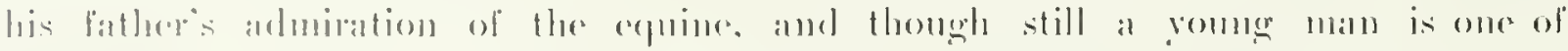

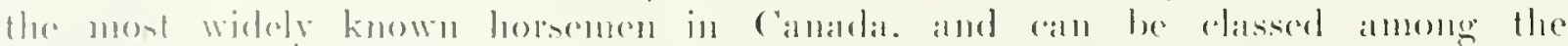

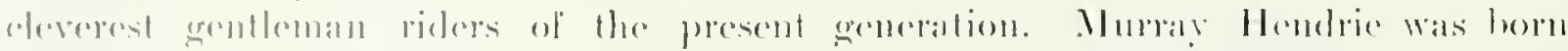

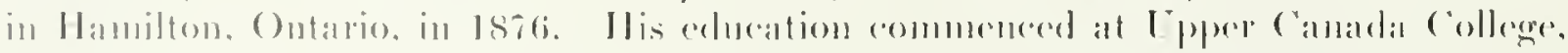

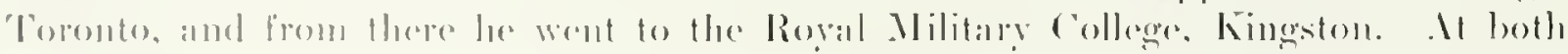

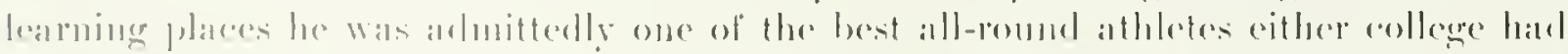

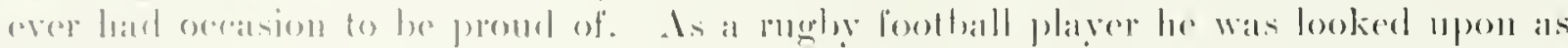

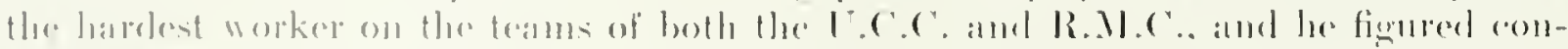

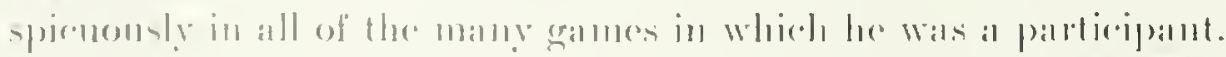

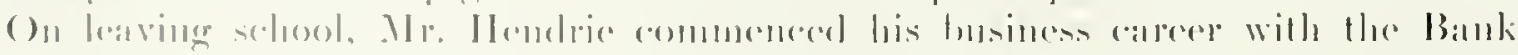

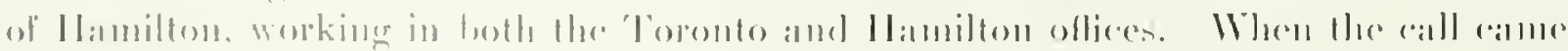

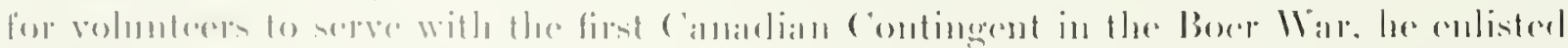

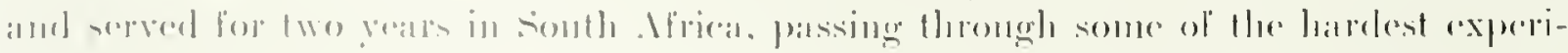


ences of the war. I pon the death of his father he commenced a brokerage business for limself, hut erentually abandoned it and spent a year in the Canadian IVest.

Ilis love for riling was acquired rery early in life. and it inereases an he grows older. When he was about nine years of age loe won his first race. This was at Intmilton Exhibition, and his momnt wats the Ilendric pony Magie. He rode his first jumping race in 1893 . and since then hats faily demonstrated that he has but few equals in camada. having skilfully handled rery many winners. Ilis riding is so well thomght of generally that whenever Murray Ilendrie accepts the monnt the horse becomes the latrorite in pullic opinion. and will win if riding can help at all. The first horses he owned were leen Below Kero and 'The Kiltie. For some time he was in partuership with Burton Ilolland, their stables inchuding leading Laty, Jim Lyles and sweden. Mr. Hemerie is of a jovial disposition, witl an eve ever to the bright sicle of things. He is popular in social cireles, and takes an artive interest in all outcloor sports.

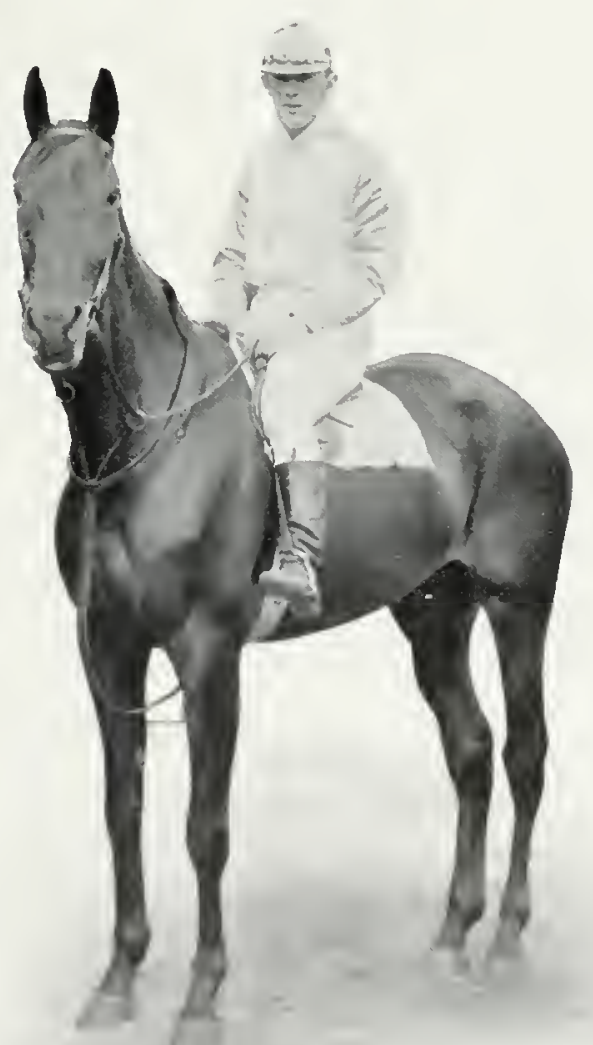




\section{FOX HUNTING IN CANADA}

$\mathrm{T}^{1}$ IIE eyes of the wortel are direceted to the North American Continent as the greatest hunting domain of the ghobe. Its magnificent forests, stretehing from the pine forests of Manne to the vast wooded region of the Puget Somml eomutry

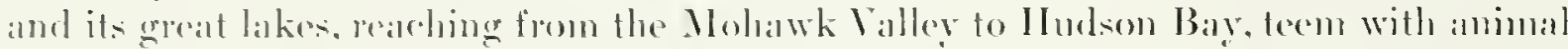
anel fiomy life. Muel has been witten, and deservedly, about the moose, cantrom, and

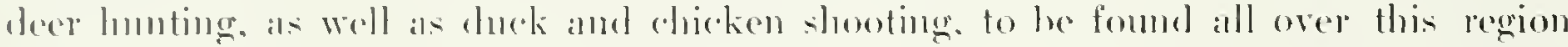
and the Nortluwest 'lempitories, which ledight the heart of the sportaman, but little has lecen said about the prines of sperts. fos humting

It is not berallse of its recent introuluction. lor since the vear 1896 the coverts of

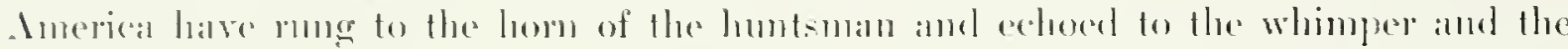
griving longue of the hounds. It has been truly ealled the "sport of kings." and cer-

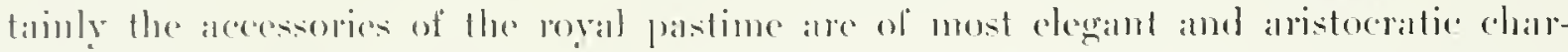

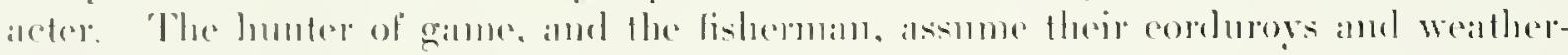

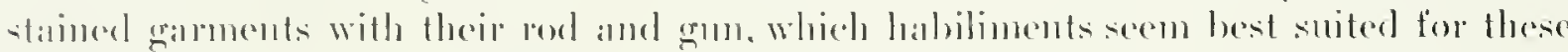

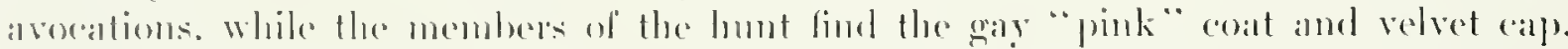

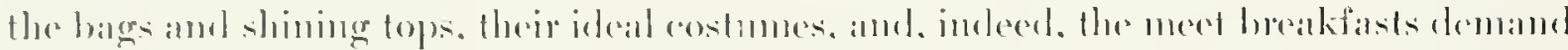

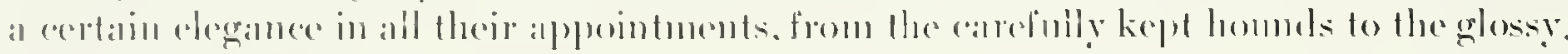
high-lured motlines of the humber.

lolike mam othere kimls of spom, which an be atried on in small parties of

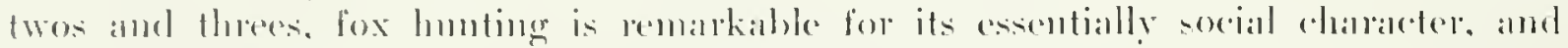

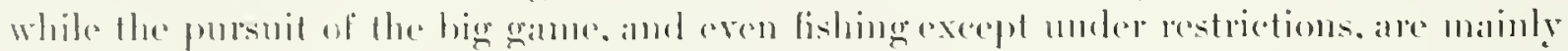

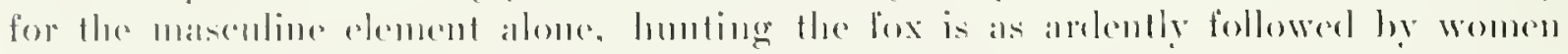

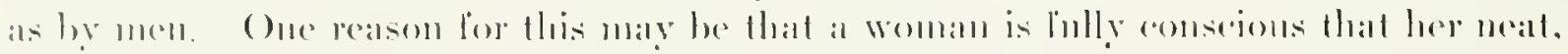

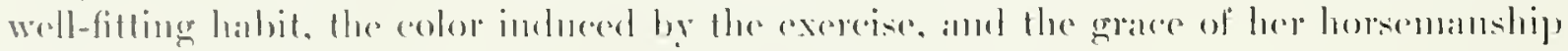

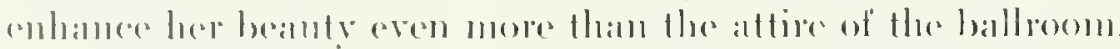

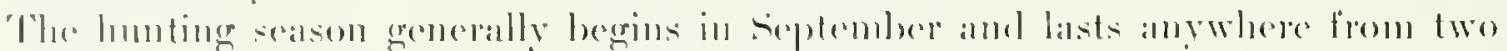

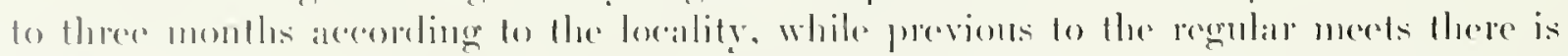

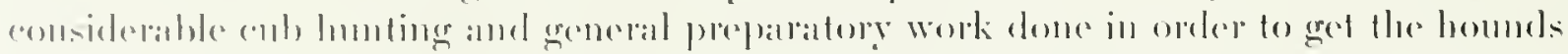

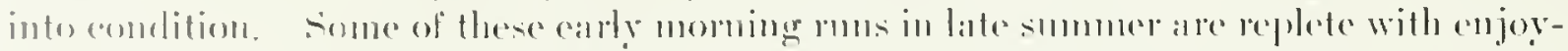

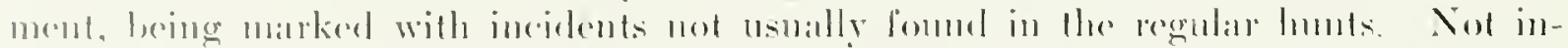

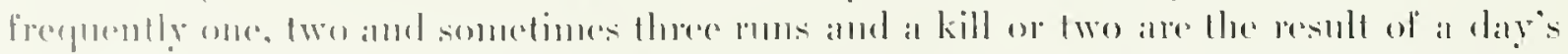

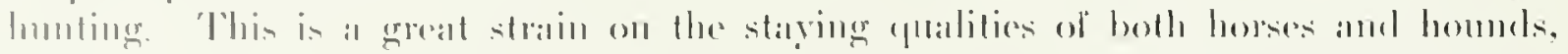

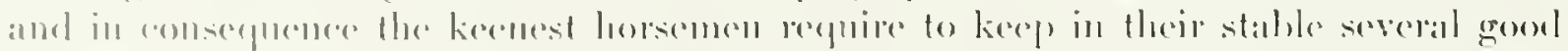

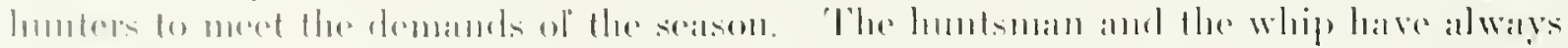

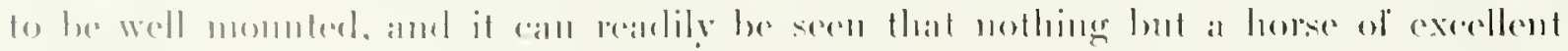

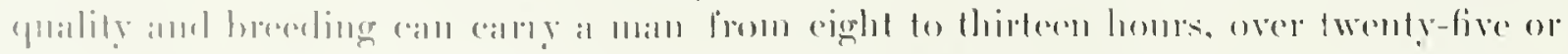

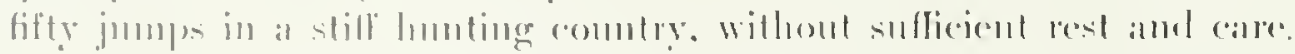

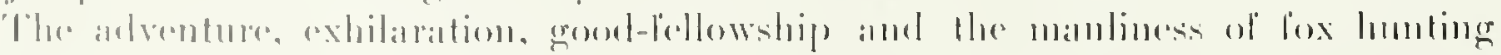

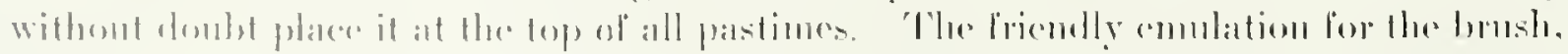

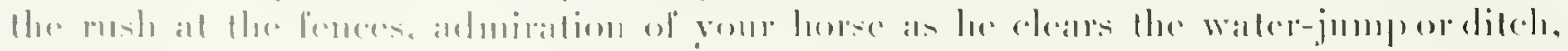


all dashed witl a suspicion of risk and danger, mako np a tomi ensemble which perthaps no other sport call ever alpproach. Ipart from the merely pleasurable side there is also the very imusortant one of the extreme healthenluess of the pursuit, and so it is that when on the back of your favorite hunter, with the homels in fromt, your friends aromet rom, and the fox in the distance. you feed that it is incleed the sport of kings.

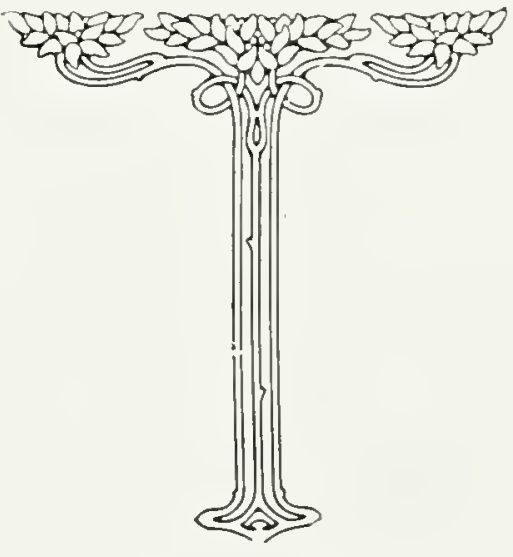




\section{COLONEL COLIN SEWELL}

$\mathrm{O}$

NE of the most promising men in turl circles in the ancient city of Q Quebere is Col. Colin sewell. who is also an eminent physician. He takes a great interest in the reltine of the thomoughbred. and hats owned many good ones doming his callere as a derotere of the sport of kings. Col. Sewell learmed to ride early in life, and has never lost his lose for the elase. heing one of the regulats at the meet of

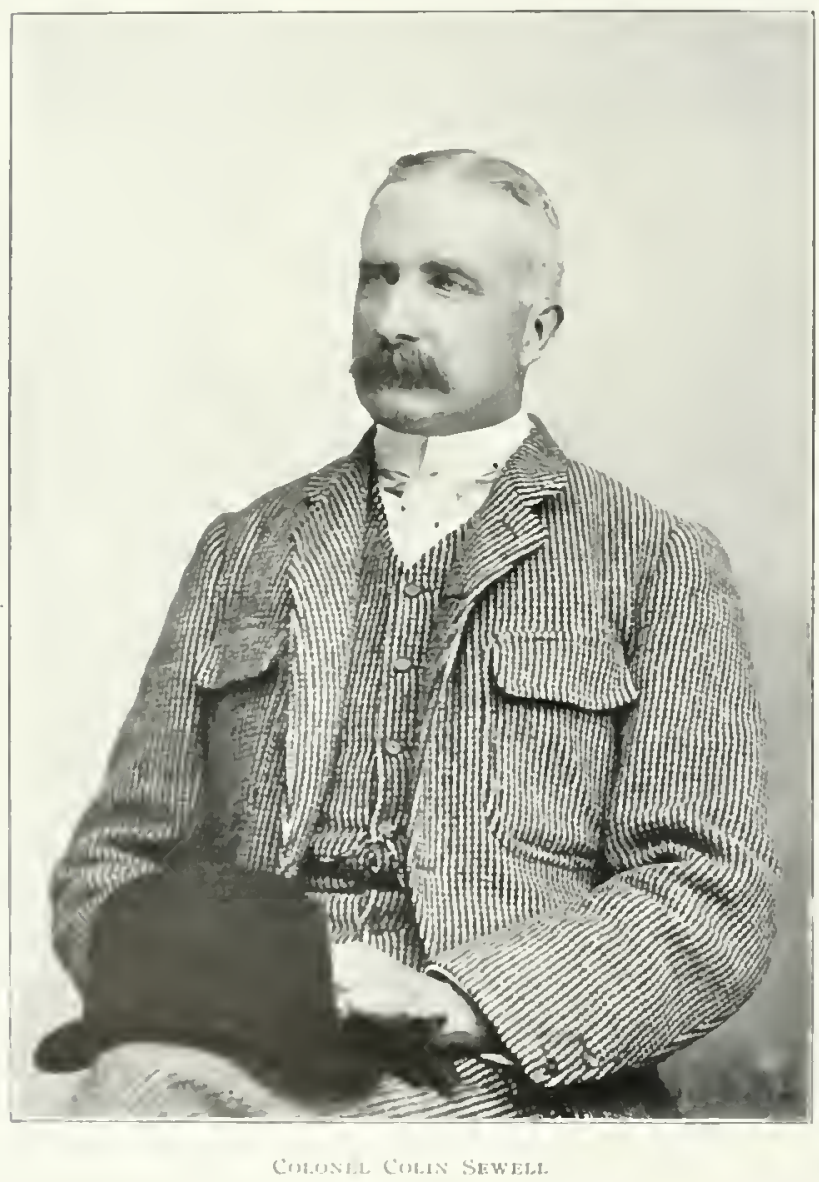
Hor hounds.

He commeneed lis racing calreer in the reare 1881, and since that time has selelom been without a thoroughbed in liss stable. Ilis first race-horse wats leatlere stocking. Which was afterwands renamed 'The Rake. With this horse the colonel won many coveted enjes and stakes. Diter the retirement of The Ralke. (obl. Sewell purchased several but diel not meet witl much sulecess mutil he secoued Krawals and Blar ("oit: with them he wom many races, only disposing of the lattere during the seatson of 1900\%. Ballyeastle was anothele in his stathle with whom several amps were

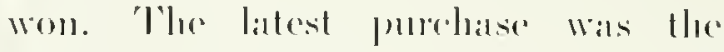
loome Andy Millianls. Who was raced moncere the serwell colors for the limst lime in 19017. meeting with limiterl star-

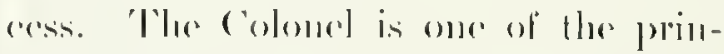

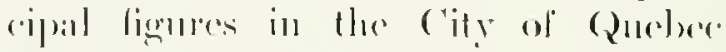

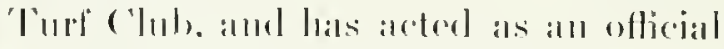
at all of therir ammual meretinges.

('ol. Colin sowell wats horn in the

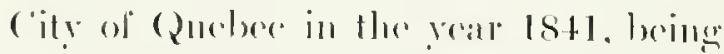

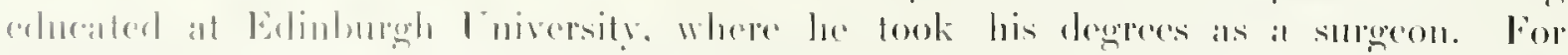

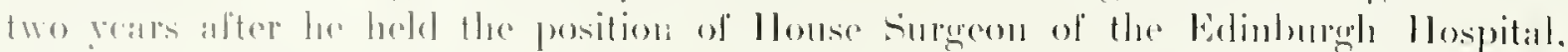

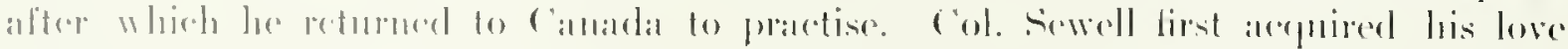

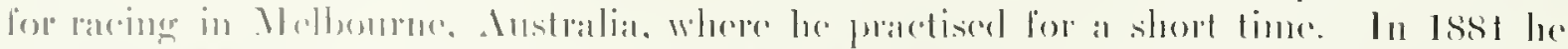

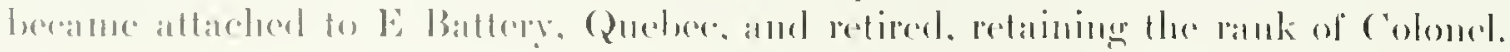




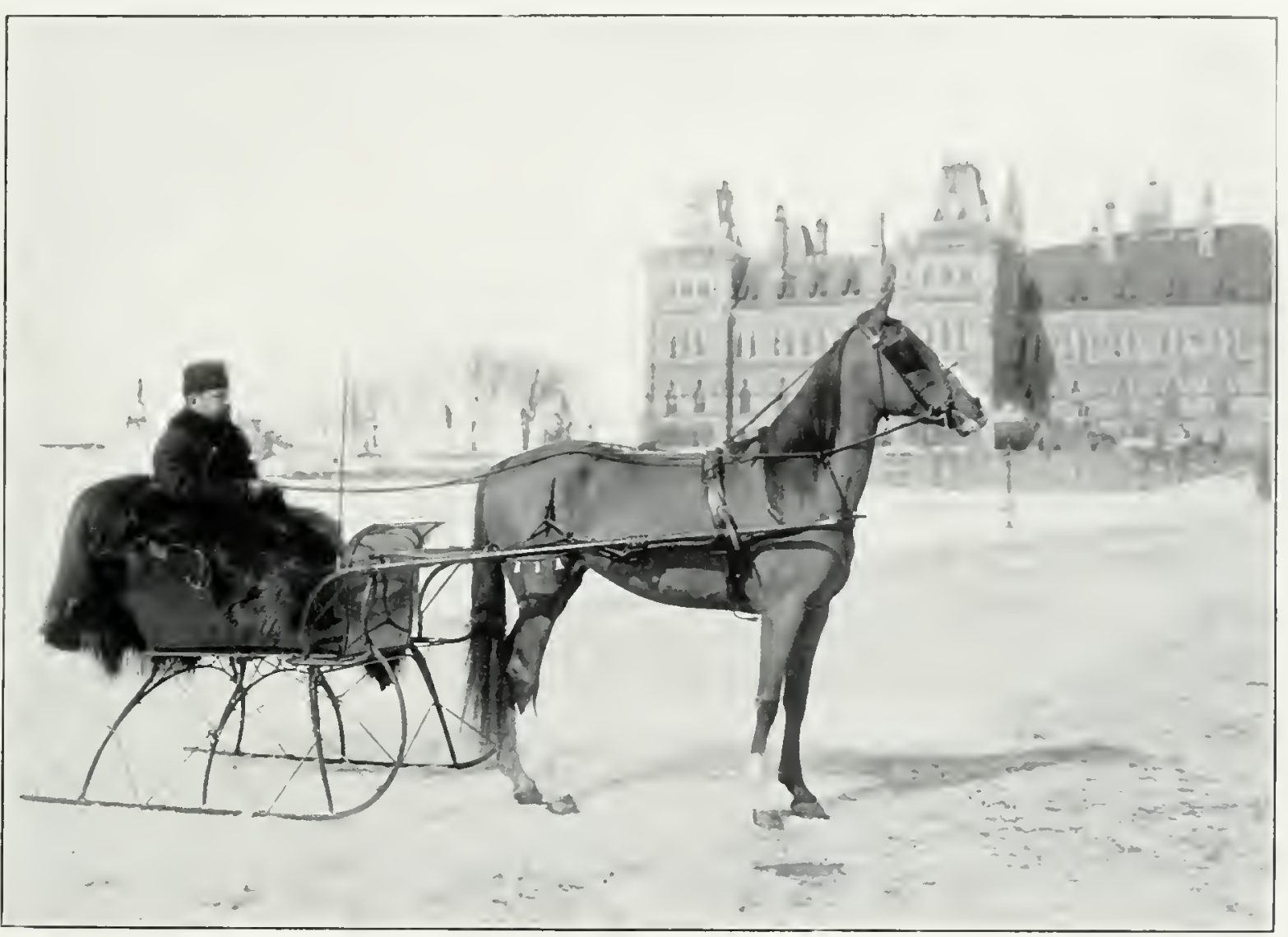

Betty kingsmere. Pap Larabie-Miambrino

\section{JOHN GRIMES}

$\mathrm{O}$

NE of the hest known horsemen in Eastem Canada is John Gimes, proprietor of the Windsor IIotel, Ottawa. Born and educated in the capital city. Mr. Gimes began his husiness career as clerk of the Grand Lnion Hotel. Ottawa, afterwards filling the same position at the Walker House. Toronto, where he remained for many reals, only leaving the Walker. Iouse to go to the Rossin, with which hotel he was connected until he purchased the Windsor at Ottawa. which he has remodelled and built up until it is consiblered one of the best houses in Eastern Ontario.

Mr. Crimes has for rears been one of the prominent figures in the Ottawa I)riving (lub, and, indeed. Was one of the prine movers in its first organizaltion, holding office in it for sereral years until pressure of husiness compelled lim to resign.

He is a big contributor to every movement to atrance interest in the horse, the annmal ied mecting. one of the many things which he takes under his patronage. being enriched each reatl by a stake named after the Windsor Ilotel. In the reall 1907, he donated a coup to be held by the ownere of the horse establishing a new ice track record.

Mr. Cirimes is a splendid husiness man. owns a beantiful residence in Ottawal, and divides his time between his home, his business and his horses. 


\section{$124 \quad$ Lovers of the Horse}

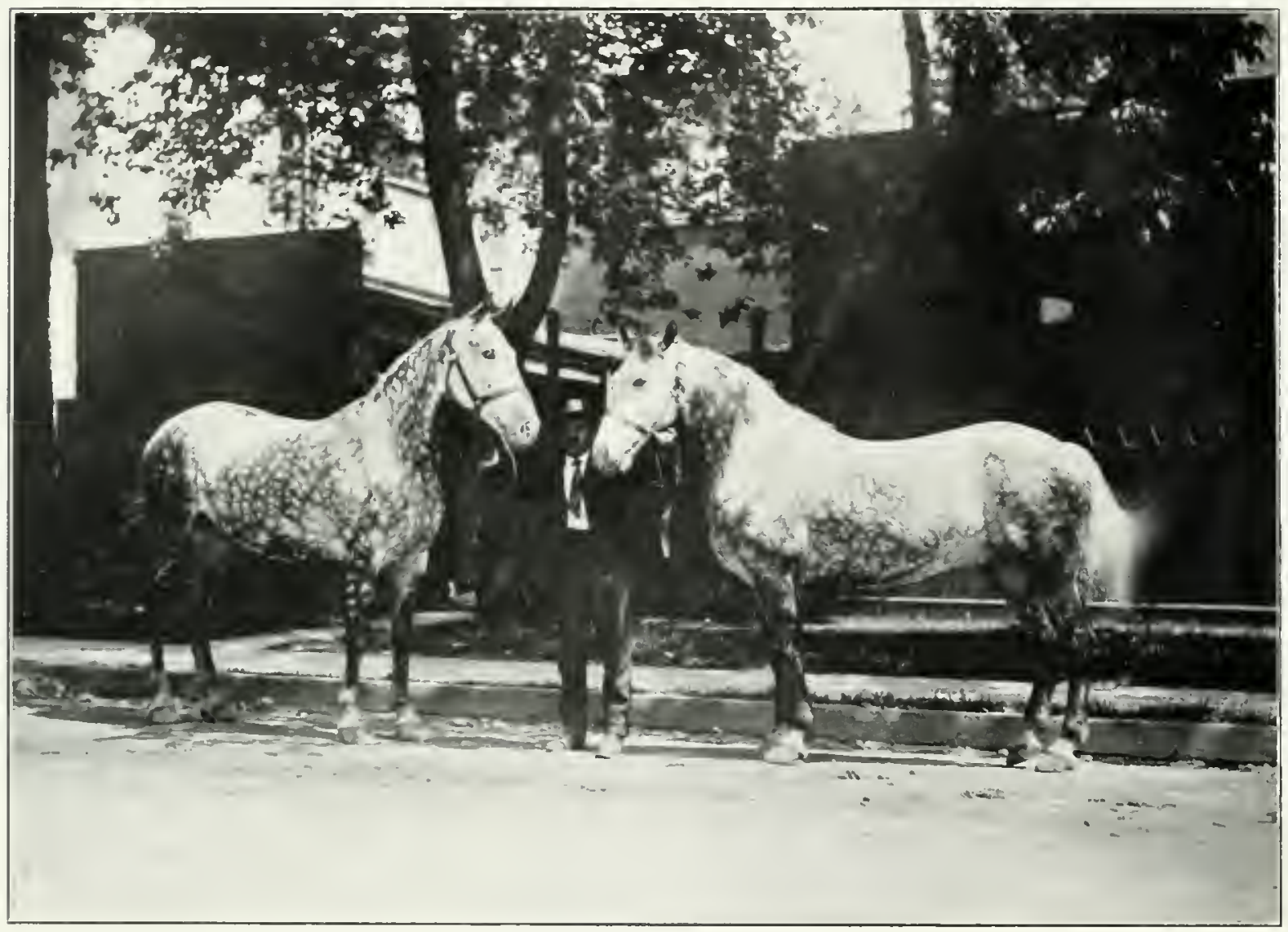

SIMPSON GREYS

\section{THE SIMPSON GREYS}

$\mathrm{T}$

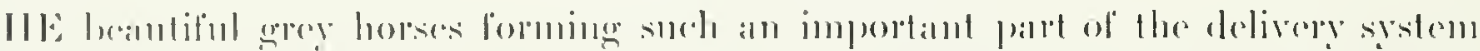

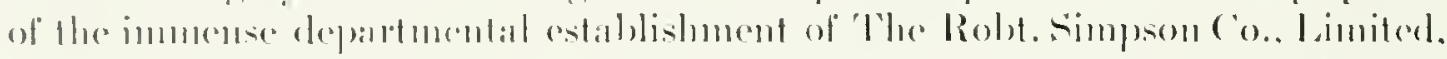

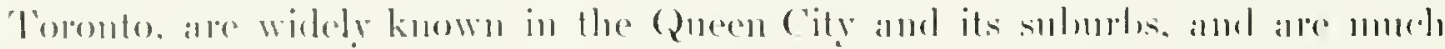

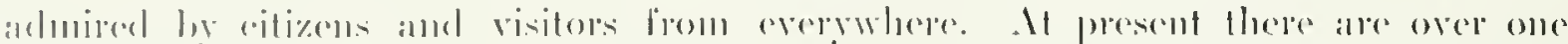

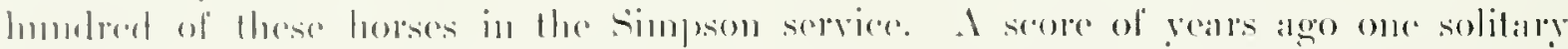

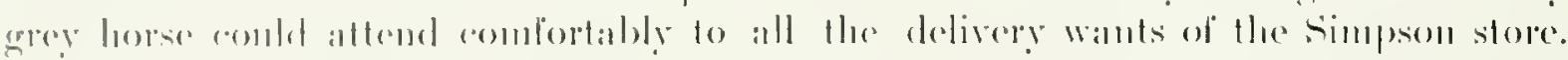

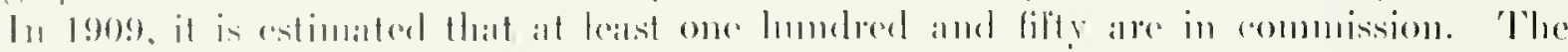

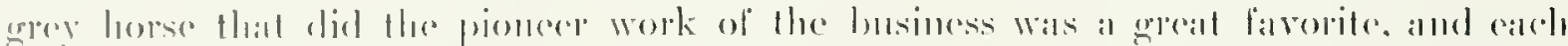

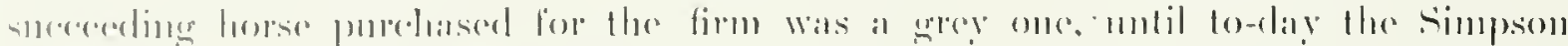

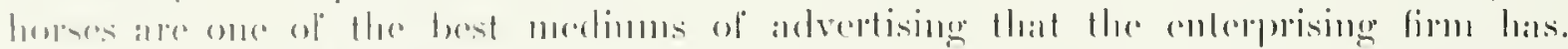

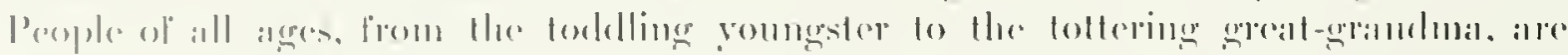

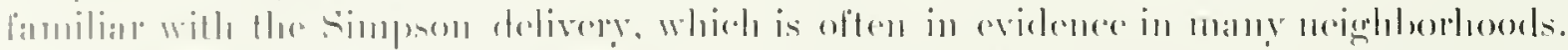

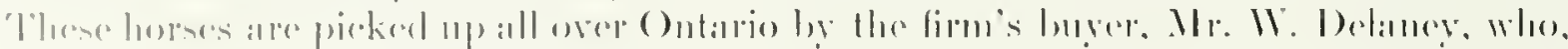

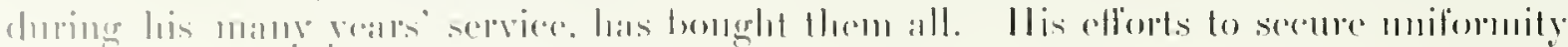


in color and size lave met with the signal sucress that romes of sincerity and experience. His standand is a horse about 16 hands and weighing 1.900 to $1.950 \mathrm{lbs}$., and he firvors a pounge horse because it retains its color longer. Some prersons who will read this are possibly not aware that a grey horse gets lighter in color as age increases, and eventually turns white, long before its usefulness has ceased. Mr. Delaney has been in eharge of the simpson horses for 17 years. Ile presides orer the stables on Mutual st. and Dallousie st. Toronto. where there is every acommodation for the big equine family, and the situation is within easy distance of the store. but the rapidly increasing necessity for more horses and. conseguently. more room, is being acted 11 pon he the company. and plans are now being prepared for new stables which will be the equal in modern equipment of any on the continent. Nearty a hundred men are at present enganged as drivers. or in looking after the lorses. There are some sixty wagons. about a fourth of that munber being the large sizes for team loads. I stringent srsten has to be employed in the assignment of the different wagons to their respective territory. There are three trips a day to all points within the city limits, and the suburban places are covered once erery day, and in some cases twice. In addition to this, there ane special wagons in rearliness to wait on trains and hoits. Sotwithstanding the precision involved, the system works to a nicety. Each nan knows what he has to to and is considerate of the welfare of his horse. some of them boing much attached to their nseful pet and taking personal pride in laving it look its very best. 'The suburhan delivery extends as far west of 'Toronto as Cooksville and Lorne Park; north to Richmond Ilill, and cast to Scarboro Jet. The wagons are of a miform color. as faniliar to the Toronto eye as is the simpson grey horse. 'they are the up-to-ulate. rubber-tired. roller-bearing vehicles: different from iwenty years ago, when the sole simpson delivery vehicle was a two-wheeled cart.

The many advantages that customers living outside the City may derive have been amply demonstrated by simpsons. Who are now handling in the neighborhood of 1.000 .000 mail orters per amnum. C'areful and prompt shipment and honest vahe have cansed a marvellous growth in this branch of the lusiness. which is just as strictly looked after as is the immense (ity delivery.

The history of the simpson husiness is of decided interest. It was established by the late Mr. Robt. Finpson. who ame to Toronto from Newmarket in 18i?. and opened a little store on longe st. north of the present mammoth huilding. Which is a monument to a comageous. progressive man. In 1880 the store employed thirteen cherks and the horse particularly referred to aloove. In 1881 . Mr. Simpson moved to a lareer building in the block which is now entirely ocenpied by the business he created. purchase and extension having continued until the whole hock has been acquired. In $189+$ contracts were let for a i-storey huilding to occups the site of his old stores. The building. when completed, was the finest of its kind in Canadal but scarcely before three months had elapsed it was reduced to ashes. 'this dreadtul calanity did not break the spirit of $\mathrm{Mr}$. Simpson. who set to work to rebuild on a

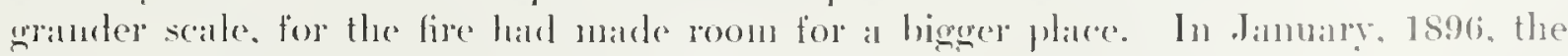




\section{$126 \quad$ Lovers of the Horse}

new store was aecupied. but shortly afterwarls. in 1897. the death of Mr. Simpson occurred, and though the business was continued in the same name, the cappital stoek passed into other liands and was materially increased. The cormer of Richmond and Yonge Sts. Was acepuired in 1900. and a large addlition similar to the main entrance was erected. The husiness grew with the building. and instead of the modest mumber of thirteen hands employed in 1880. there are now 9.500 . and the buildings are being more than doubled in size on the site just to the west. Which was purchased from Knox ("hureh. and runs through from (Queen to Richmond sts. I private street. 45 feet wide. is to be opened along the western line. and the store will have a street on each of its four laces. which will not only he of great adrantage for show windows. but will give an abundance of light and all for the upper floors from four fairly wide streets. When completed, simpson's will he by liar the handsomest and hest equipued retall establishment in the l)ominion, and will have a floor space of over 11 acres. It will be exeelled by only two or three retail stores in the whole world. There is alrearly every conceivalble convenience for the thousands of eustomers who visit the store daily, and this calreful consideration is highly appreciated. The system andopted by the firm so successfully positively prevents orestocking. and consefuently all lines of goods are the newest. "lo facilitate the luying in Europe, the eompany have an offier in London and another in l'aris. The London oflier is headquarters for many (anadian visitors.

"The simpson ("o is a large exhilitor at all the horse shows ledel in 'loronto, and

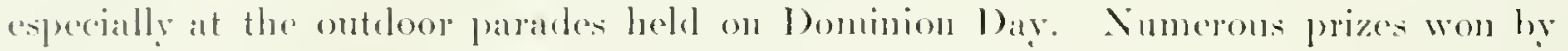
their turnouts signify the interest they take in all matters appertaining to the hor:se.

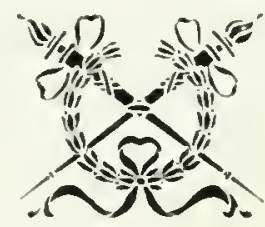




\section{HUGH S. WILSON}

$D^{\prime}$

URING twenty rears of active association with the hest of the jumping horses Jugh s. Wilson, of Toronto, has well earned his reputation as the pluckiest Cantalian rider ever seen in the arenas of the principal horse shows of Canala and the Lnited States. and no rider of the jumper's has more victories to his credit. Gameness is his characteristic, and when all his competitors have had enough of it lie is always out to take every clsance a man and a horse can take. Consequently, he has been the vietim of accidents a score or more times. some of them very serious, hut he has been fortunate in quick recoveries, and at this writing is in splendid shape, and a model of a vigorous young Camadian who loves a gane horse and possesses the utmost confidence in himself to achieve victory, no matter what odds are against him. For many rears he role Mr. C George Pepper's horses at all of the principal shows with magnificent success.

Ilughie Wilson, as lue is familiarly known all over America, was bom in Pickering. Ont.. in 1876, and when a couple of years of age went with his parents to Mimnipeng. Eight years later he eame to Toronto, where he wombl up his schooling. He is a matural horse lover and at eleven years of age he was an accomplished rider. In $190+$ he established his present husiness as a dealer in 'loronto in good horses and has arducved remarkable success. Ilis splendid stables on Pears Ave. Toronto, are a solid testimonial to his husiness acumen and his relialility. Ile marred Miss MeCormadk, of Torouto. in 1904, and their pretty home is at ts Rathnally Ire., Toronto. On the ammal three months cireuit of the American horse shows, stanting at Lonisville, Mr. Wilson has been time and again the most successful of the competitors. Ile olutaned a remarkable record at the New York show in Marlison Square Ciarden, 190t, securing the three championships, light, middle and heary weights. Ile won the former on King Juvenal, owned by Mr. Ilitcheock, Jr.: the midlle weight on Mr. Pepper's Sweet Lavender, and the heary weight on Ilon. Adam Beck's Dublin. Away back in 1891, in Chicago he rode Charlie, the pony muler twelve hands which made the record jump of 5 ft. 5 inches. He considers the hest jumper he ever rode was Mr. Pepper's Pearl, a most consistent performer of prize-wimning proclivities. lle made a world's record with her at Des Moines, la., in 1909, the jump being 7 l't $6 \frac{3}{4}$ inches. Ile quit riding the mare that year or would likely have at least equalled the present record of $7 \mathrm{ft}$. 11 inches. Ile is undoubtedly the most successful rider of jumpers representing this country. Some of his stellar performanees are Malnd, 6 ft. 10 inclies, at Toronto Exhibition: The Bard, $7 \mathrm{ft}$. $1 \frac{3}{4}$ inches, at Jes Moines, and Rupert, $i$ ft. $1 \frac{3}{4}$ inclies, on the same night: Sure Pop (Crowe $\&$ Murray), $i$ ft. $+\frac{1}{2}$ inches, at Nashrille, T'enn., and also sensational jumps on Myopia, one of the most successful performers in the world, and Bloomington, another of his stars. Mr. Wilson is a most useful member of the 'Toronto IInnt ('lub, and his quiet disposition and mufailing nerve have made hin decidedly popular with the anmy of his associates in the equine world. 
128 Lovers of the Horse

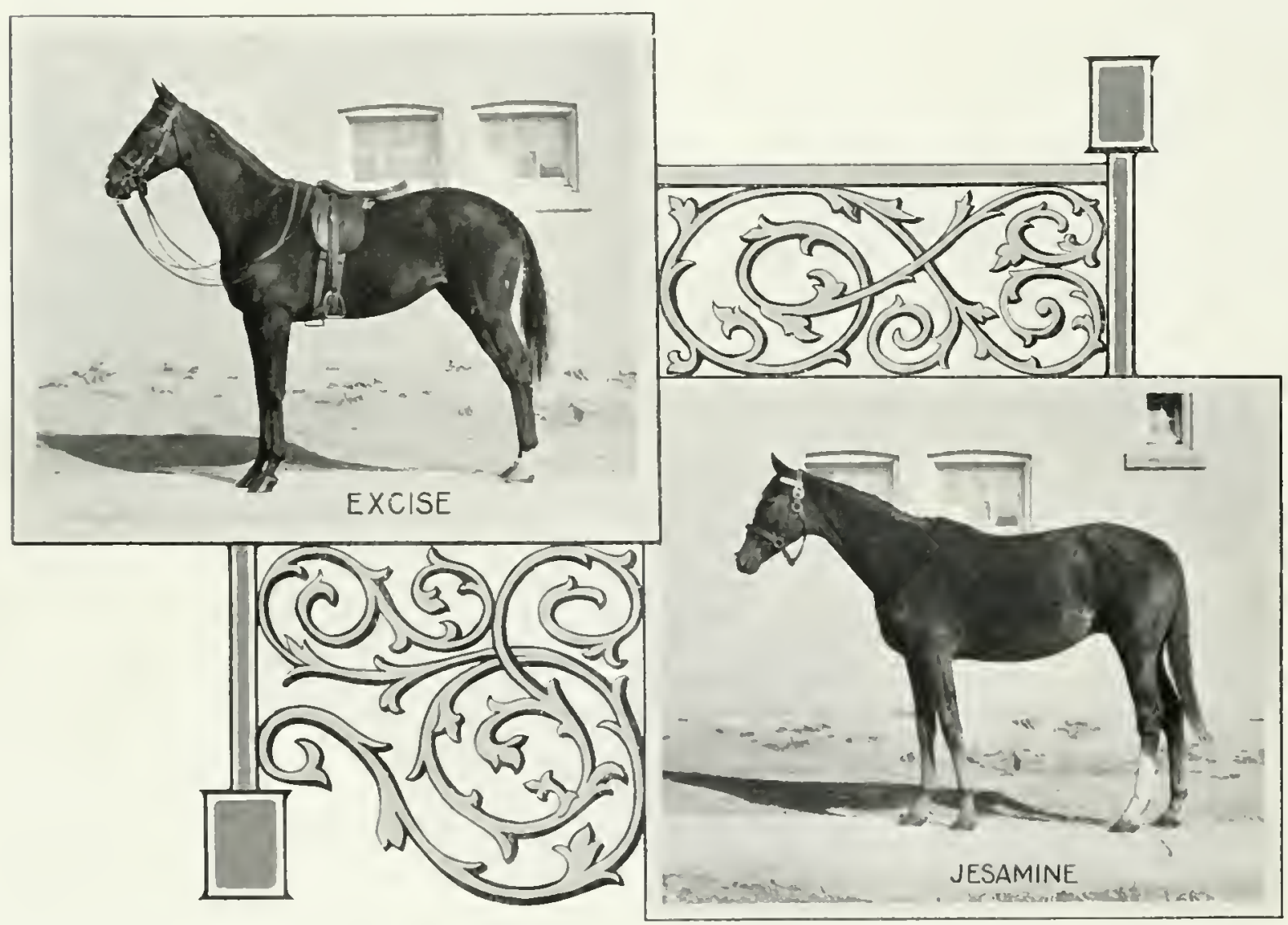




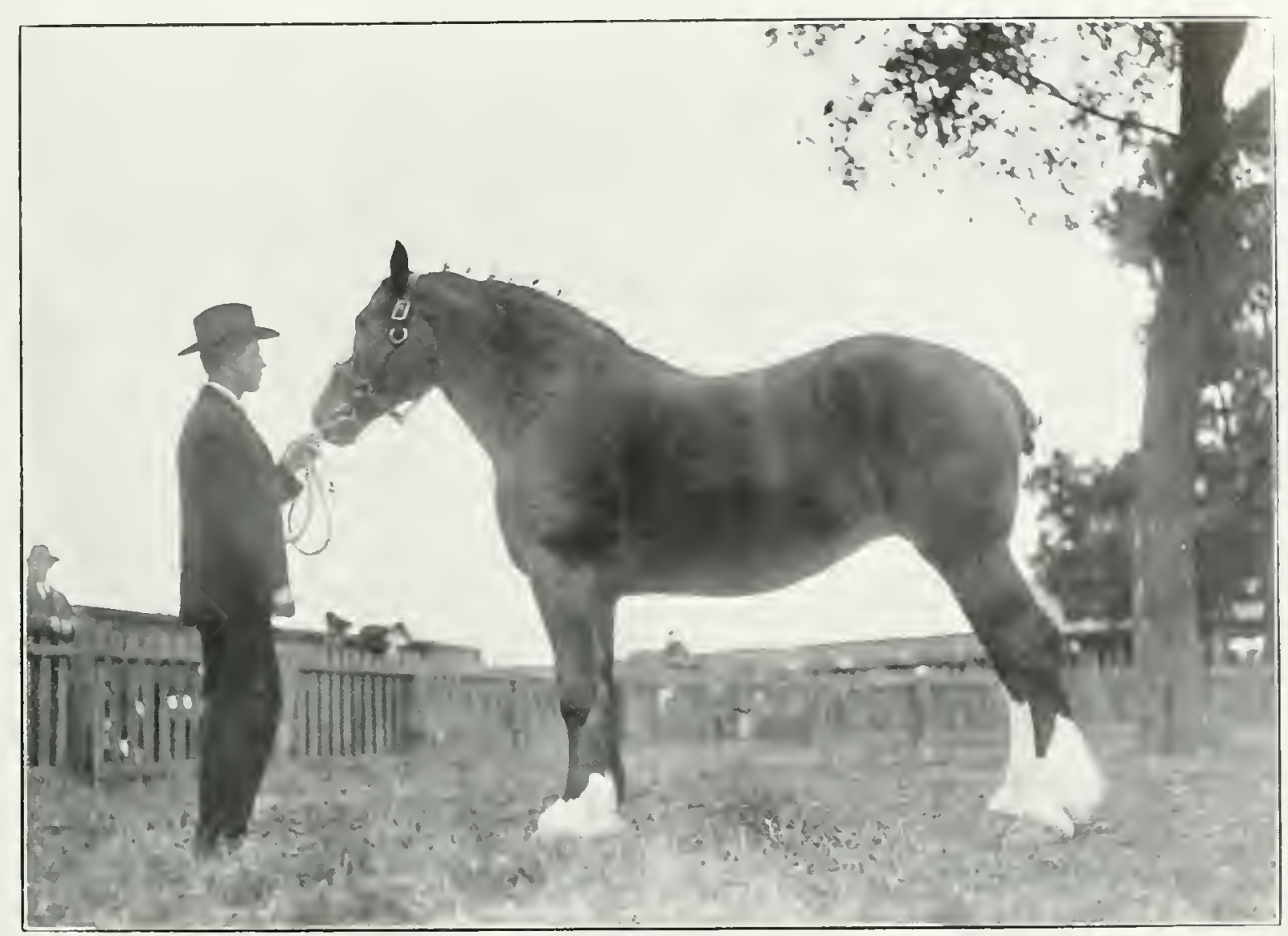

Chupion Clydesdale Mare. I'roperti of Graham \& Rexfrew

\section{THE GRAHAM-RENFREW COMPANY}

A Limoucill not so old as some of the other fims in the equine world, the sultA jects of this sketch, who are known from sydney to Victorial as the firm of The Grahann-Renliew Company, limited, are envied by many of the veteran admirers of the horse for their successful catreer in the breeding and display of fine speeinens of the steed. They lave not only won personal triumphs in this fiekd, but lave contributed materially to the success of others. The Gimham-Renfrew stoek farm, known as Bedford lark. Which is situated at a beantiful spot on Yonge Street. is famed for the winners which it has breed and ratised.

This firm is concerned with not only the hearier diass of horses, but also with those of the laicliney and hamess class. Success has been the result of the mentrers" efforts and experiments in all classes they have handled. Is a financial proof of their excellent results, may be cited the fact that they sold one of their champion hackneys for the largest price ever paid for such a horse learing ('andada. This was Hial watha. who was sold to Mr. Clapp, of Virginial, for the sun of seven thousand dollars, thus 


$$
M
$$




\section{Lovers of the Horse}

until it now ranks anong the first stock farms in Anerica. From time to time the stock firm has been increased in order to accommodate the demands of a rapidlygrowing business. Mr. Renfrew is a Canadian by birth, a native of Toronto, in which city he makes his home. Ile is regarded as an authority in the show ring not only for the hearier, but also for the light luaness horses. He has held rarions oflices in the lorse associations of the conntry and has always believed fimly in the improvement of the Camalian hreed of horses.

Mr. Robert Graham, the other member of the firm, dates his experience from an earlier perion than his partner can chaim. Ile has been an ardent adnirer of the horse

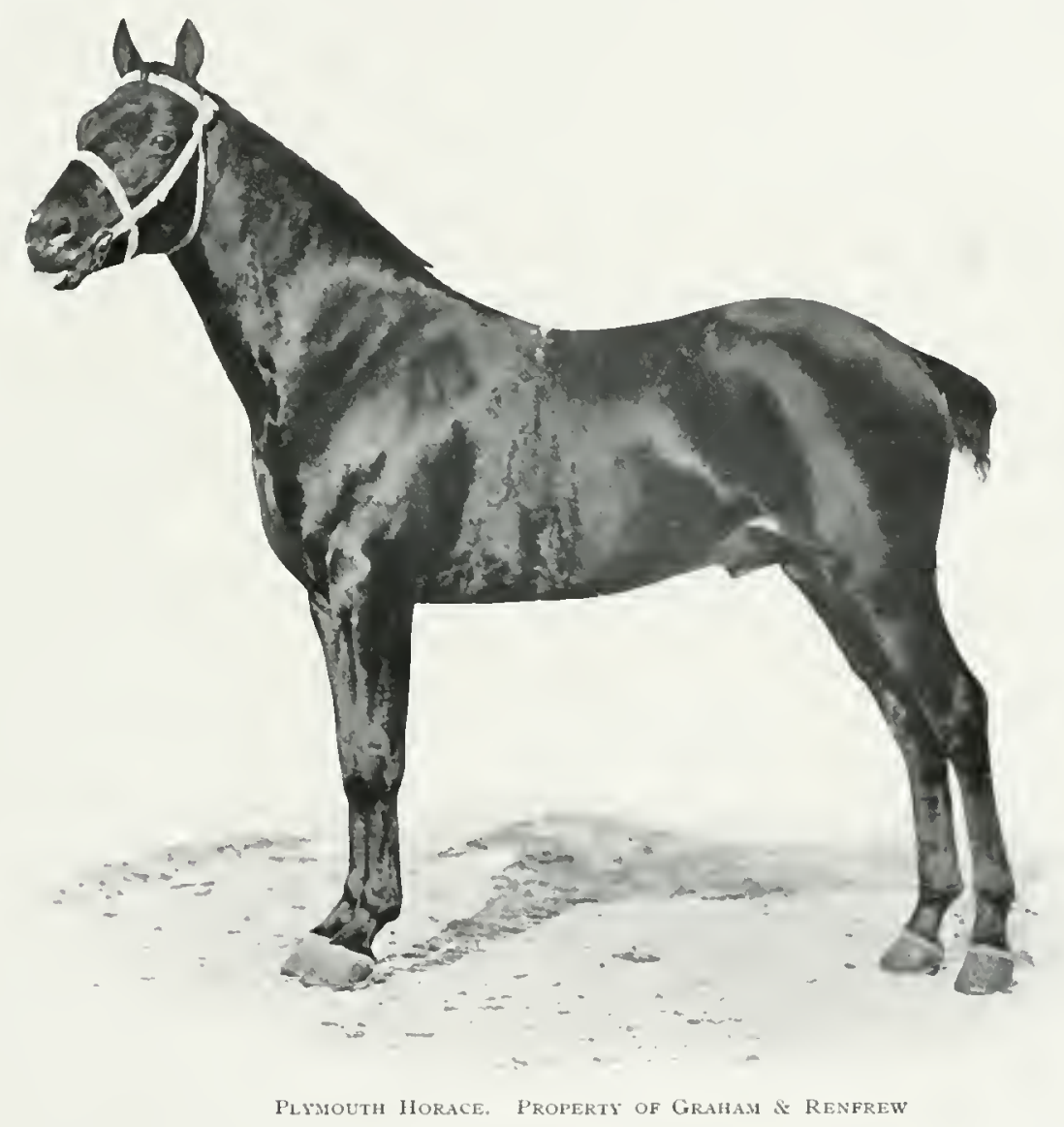

since 18iti, when he made his first trip across the Athantic with his lather, Richard Graham. who carried on the business betore hin. With a hereditary fondness for the horse, Mr. Robert Grahallu went into partnership with his father at an early age, and, on the demise of the latter, took sole change of the business. He was responsible for the firm of Graluan Brothers, of Claremont. After following in his fatther's footsteps tor sereral years, he took his brother William into partnership, and as soon as Thomas was old enough, he also was made a member of the firm. This triple alliance lasted for many years, in fact, mutil 1905, when Robert united with Walter Renfrew, leaving William and 'Thomas to rum the olel firm. 
Robert Graham was horn in the town of Markham, where he received his early oducation. making his home at (lanemont until his (change in business. During his caleer. he lias bought and sold many champion horses in almost erery chass. dealing, in the early dars, more extensively with clydestales. One of the best of these that he crer imported was Royal Exchange. who won great renown for Robert and his father from tsig mutil hought hy sentator Beith in 18is. Olel Prince Arthur was another horse that helped to make the Graham farm famous, alwas winning in the ring in this connty and siring many a brilliant winner. Mr. Robert Graham is one of the oldest importers of horses on the continent and is among the foremost judges. Ilis advice is always in temand and his julgung, at all prominent shows in the country, has calned for him an enviable reputation for discretion and fairness.

Both Walter Renfrew and Robert Craham are reinsmen of the first class, and many times have driven their ow horses to vietory. Bothenjoy a ride on a good hunter, hut devete more time to other interests in the horse world than to riding or driving. They are always highly gratified by suceess of others to whose stables they have contributerl. Mr. Robert bavies is an instance of one of their fortunate "ustomers, as the Renbew-Cimlan firm bronght to camalat the clyelesdale mares with which . Mr. Daves male such a clean sweep at the Industrial Exhibitions held throughout cillialis.

The (hampion ('nps and ribhens won by this prosperous firm at the many shows all orep the conntry would make a silver exhibition in themselves. white their humedreds of hanlese form a lisplay which tells its own story of breol and traming.

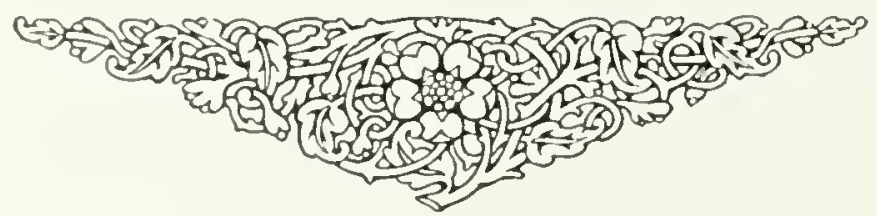




\section{THE CANADIAN NATIONAL BUREAU OF BREEDING, LIMITED}

$\mathrm{T}$

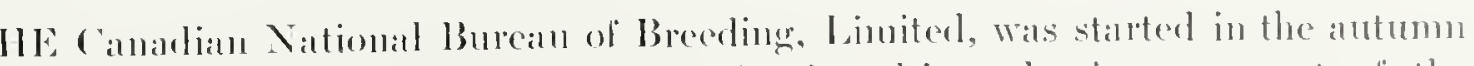
of $190 \mathrm{r}$ ly John F. Ryan. having for its ohject the inprovement of the breed of horses in Canadis. It was incorporated moler Dominion Charter in 1908. and its growth has been so rapid and its influence so far-realeling that in al slort time it has come to be perhaps the most important institution comected with lorse breceling on the continent.

The working of this Burean is simple. Thoroughbed stallions atre secenred by purchase and donation from owners all over the continent. and alde placed with re-

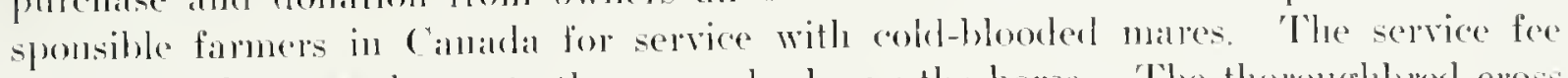
is a nominal one, and goes to the man who keepe the horse. The thoromghlored cross

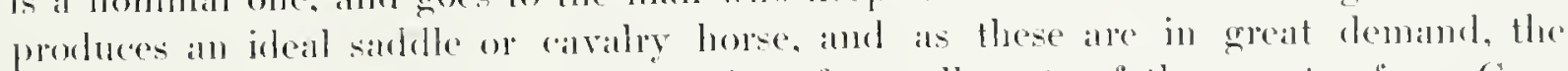

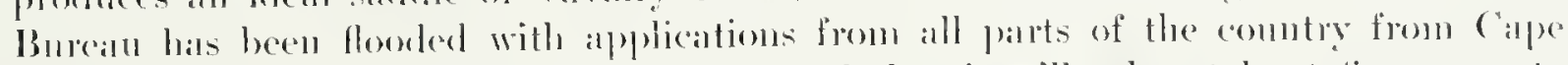
Breton Istand to the Yukons. It is estimated that it will take at leatst live gears to eomplete the work of the Burean, which by that time should be the finest in the world. and a national asset which will bring millions into the combtry every year.

A tremendous inpetus was given the Burean by the eamest support given it by the War Oflice. In fart. the Burean was hailed as a solution of the calvalry remomt poblem, and is now booked npon as the only feasible plan of securing an luperial cavalry reserve. The War (Othe buyers are travelling thoughout the country inducing lanmers to breed their mates to the Burean thoroughbreds, and showing them that there is a really malket awaiting them. England pays $\$ 200$ for a troopere and $\$ 300$ for a charger delivered at Liverpool, and as horses cam be rabed rery elieaply in Cimatal, especially in the western provinces, the breeding of these remomts is al profitable business for the farmer. The west is the natural mursery for the nations cavalry. Dlbertal is latger than either France or Germany, saskatchewan is twice as latre as Great Britain and Ireland. and British Colmmbia is twelve humdred miles

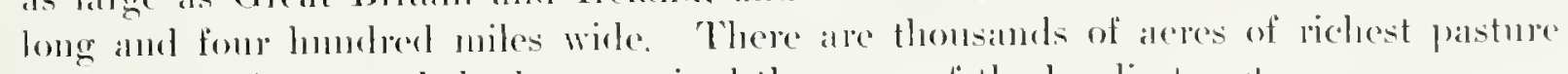
in these provinees, and the horses raised there are of the handiest sort.

But the work of the Burean is not eonfined to that pint of Camialis. New Brumswiek, Novia scotia, Prince Elward Island. (Queber and Ontario alle just as enthusiastie, and apart from the business of it, there is strong national sentiment behind the new organization.

It is in the interests of Cimaldal to secure for England if posithle the best cavilly in the worlel. It is recalled that during the Boer wall, the Mother Comntry was at her wit's end for cavally horses. She hall to get twelve thomsind horses from the Argentine and sent them to the Cape of Coonl Hope. and she had to pay top prices to the Ilmogarians for seven thonsind five humbed horses. It is estimated that huring that war, Engand spent seven millions of dollars for horses, and only the smallest fraction of this immense sum fommel its way to Canada, simply becaltse there were no suitable horses to be hanl here. The Burean is changing all this. and should there 


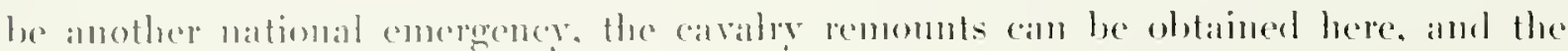
momer will remain in the Empine.

'The same ean and will be fome in cambla ats in framce. There, the covern-

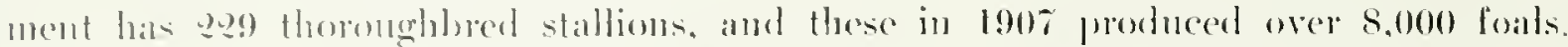

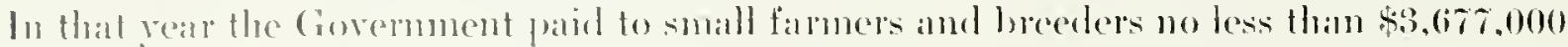

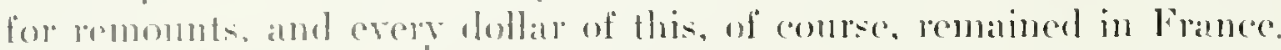

The Rusian. German, French, and Austrian Governments spend great sums for thomonghbeds to go to their humeans. Twenty thomsind pounds is not consid-

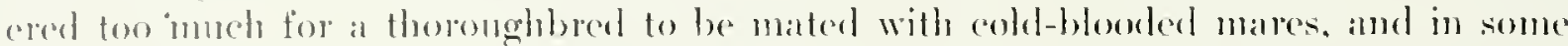

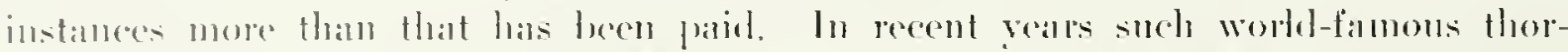
onghbreds as Fying Fox, Galle More. wimer of the Triple Crown: Clever. wimer of the firends bethy: ( pean breeding horeans.

The ("antalian Burean lats selected only the hest stallioms. Jorses of roval breedingregod conformation and free from all hereditary taint. In the lot are: Masterman.

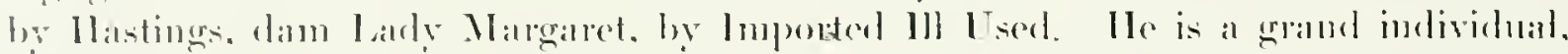
and was the Ameriean dhanpion in both his two and three-year-otd form. His sire

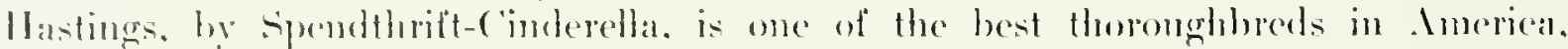
and has beren three times at the head of the wimning list in America. Rosemomnt, another Bureall stallion, is also by Hastings, and his dam, Lady Rosemary, is by st.

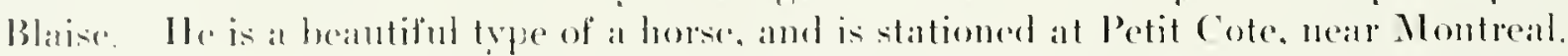

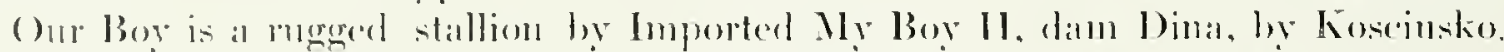

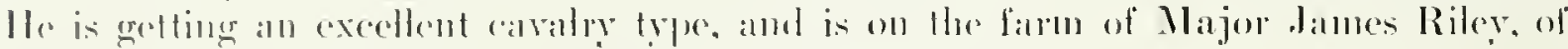

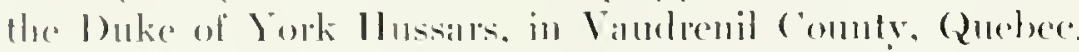

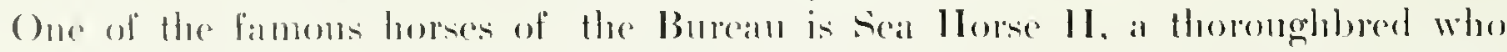

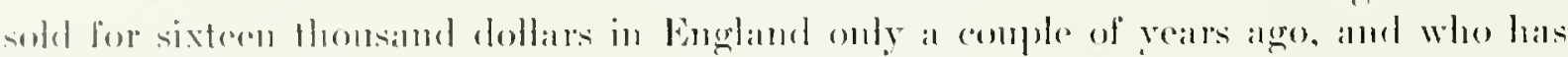

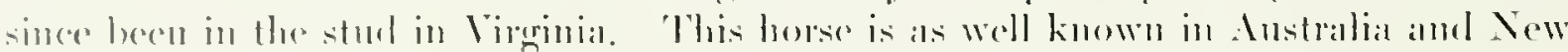

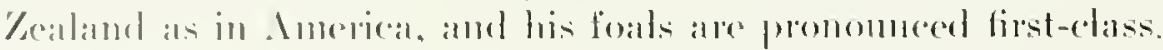

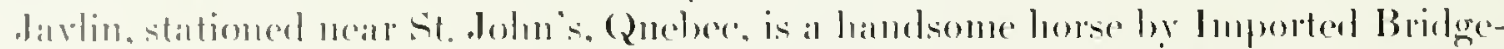

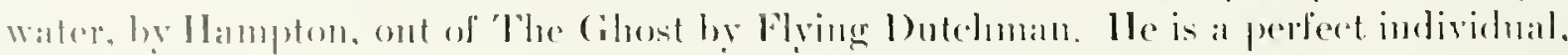

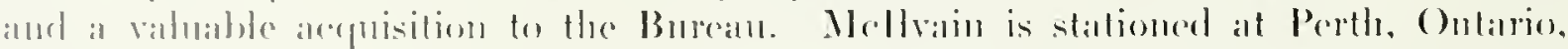

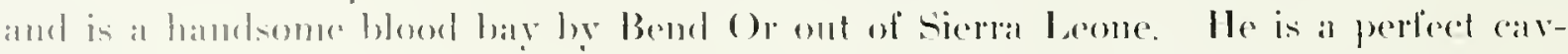
alry type.

Stallions ale being solut ont as fast as they alu be secured, and there will be no

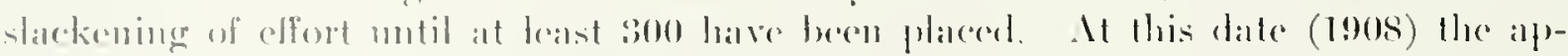
polications for stablions number over sevell hrmbled.

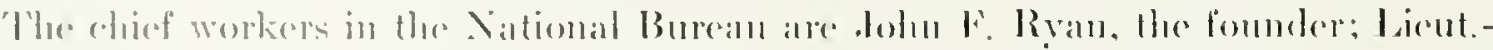

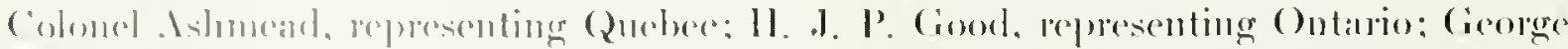

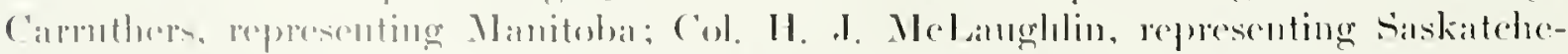

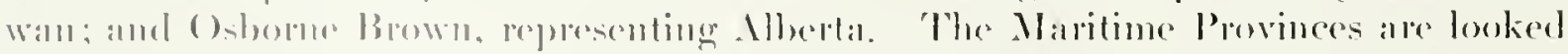

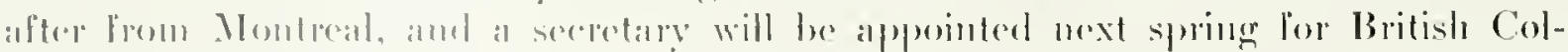

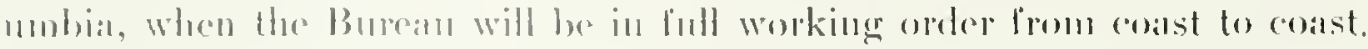




\section{CAPTAIN H. C. OSBORNE}

A I cuthusiastic follower of the lomuds is Captain H. C. Ostome, Toronto, and A althomgh lae has recently become an ardent admirer of the antomolile. he has not lost his kind reand for his friend the horse, panticulanly the hunter. Ile is a diligent worker in the aftairs of the 'Toronto llunt Cluh, being one of its most encrectic directors. and to his efforts much of the sureess and popmlanity attained by the Club is muloubtedly due. Ile followed the Toronto hounds first in 189.), and has been devoted to the sport constantly since. In 19003 his horse Codden ('rest (rolden Badge Straightaway) ran third to 'Thessalon in the King's Plate race at the Woodhine. Ife was one of the founders and the first secretary of the 'loronto Polo (luJ), and was repy arctive in procuring a suitable polo field lor the 'Toronto followers of the sport.

llenry (ampledl ()shorne was born in Brantford. Ont.. in 185t, and received his reducation at 'Trinity College School. Port Ilope, and 'Trinity College. I'oronto. Ile is a son of James Kerr Osborne. Toronto. In 1909 he married Mrs. C. L. Bath, daunghter of the bate (i. C. Francis, of 'loronto and London, Eng. (aipt. Ostrome is a member of the firm of Ostrorne \& linucis, stock and houd brokers and financial agents. Toronto.

'Though business demands much of lis attention le finds time for military matters. Capt. Osborme beame connected with the Camadian Militia in 1899. when he took a commission in the Royal Grenadiers, Toronto, and he is now in command of " B" compramy of that clack reximent. IJe inherits his liking for mili-

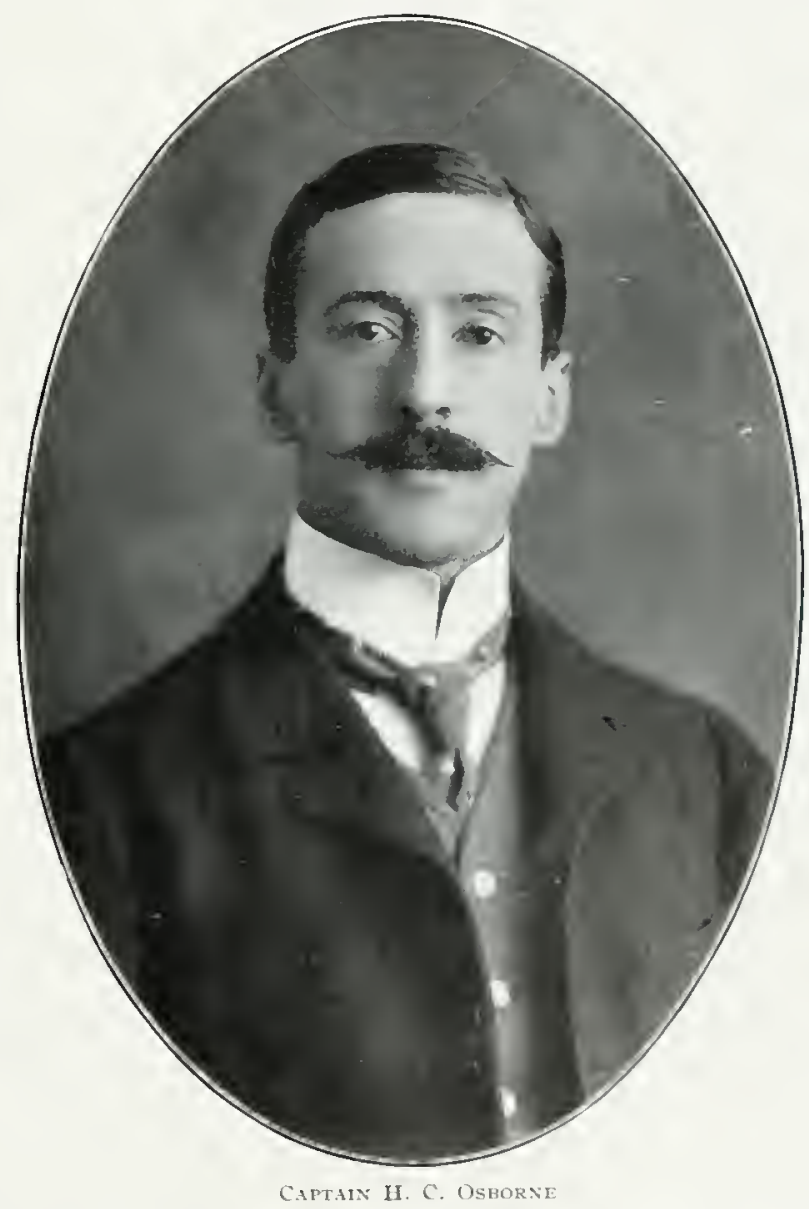
tary pursuits, his father having servel as a Majol of the lath Reginent during the Fenian Raid. In addition to his comnection with the 'Toronto Ilunt ('lub he is on the management committee of the 'Toronto club, and is a member of the T'orontes

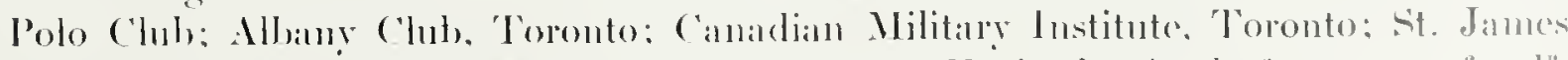

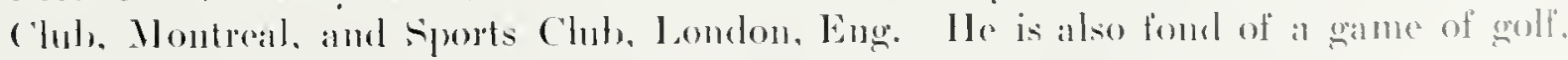
and was for some time a member ol the 'Toroute ciolf chlol. 


\section{SANDFORD FLEMING SMITH}

$\mathrm{S}$

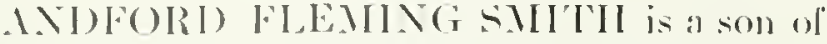
the late Alexander smith of Peterborought. Born in Peterthorongh. lie graduated from the Iligh sedrool of that town andel entered a private selood to prepare himaclf for the school of Practi(al serence in Toronto. where he hall a most

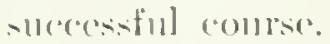

Ife hats made his home in Toronto for ser(ral vears. his handsome residenee in Poplan Platus Road becing a centre of open-handerl hospitality.

He joined the lirm of Bond s smith in 1909. one of the most prominent areditectural firms in the comoly.

Mr. smith hals always taken an aldive interest

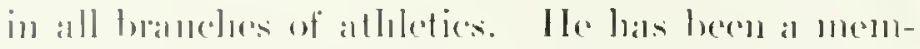

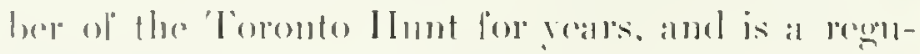

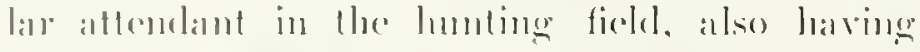

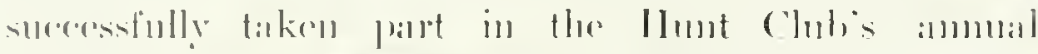

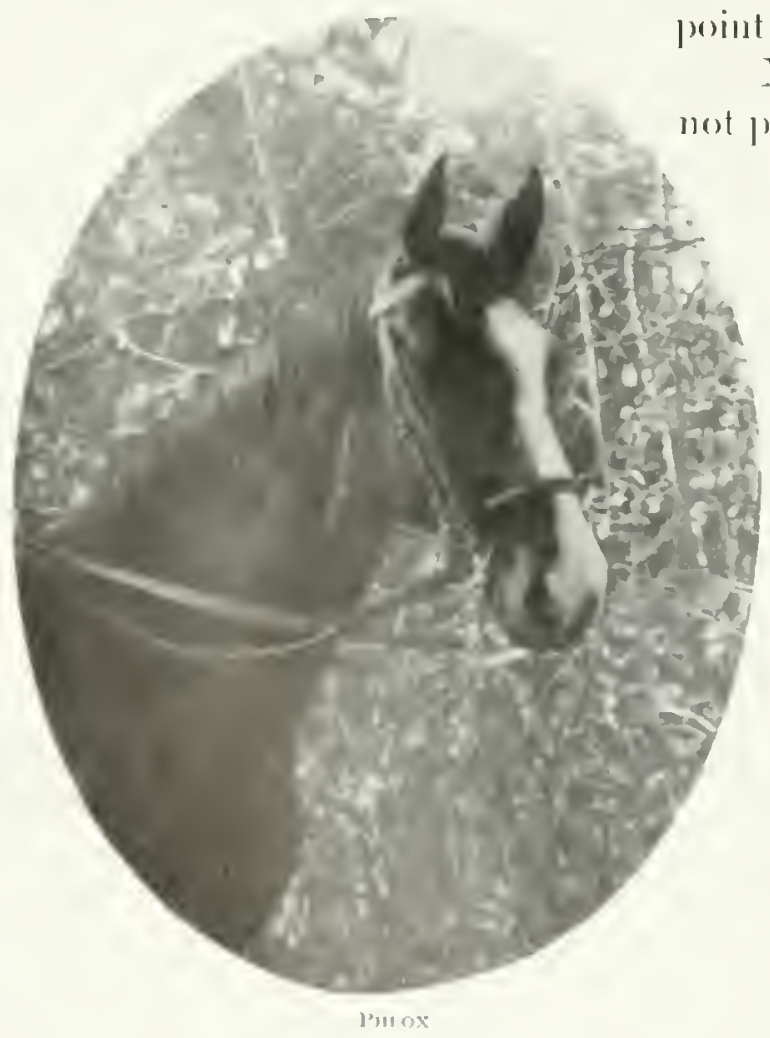

IIr. smitl does not particulanly calre

for the hemors of the show ringe thought lae hals won sereral enps in this way. Ile takes gereat pleatsure and pride in having a grood lominter.

In his stable alre to be fomel two

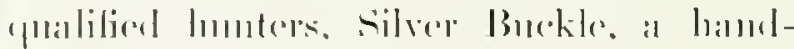

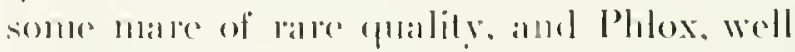
kmown to all followers of the hommes ats

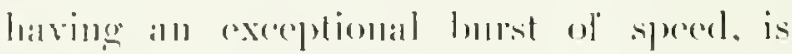
ilsor) al (:ilpital jumper.

Mr. Smith loldes a commission in the Govemor-Gomerial's Body Gilard, and hats for veals laken an aldive interest in all military matters. II is well know in both rocial and lonsiness circles. lor he is of a anenial spirit and loright disposition, and well clualified to win botl liking and asteem from all who know him. 


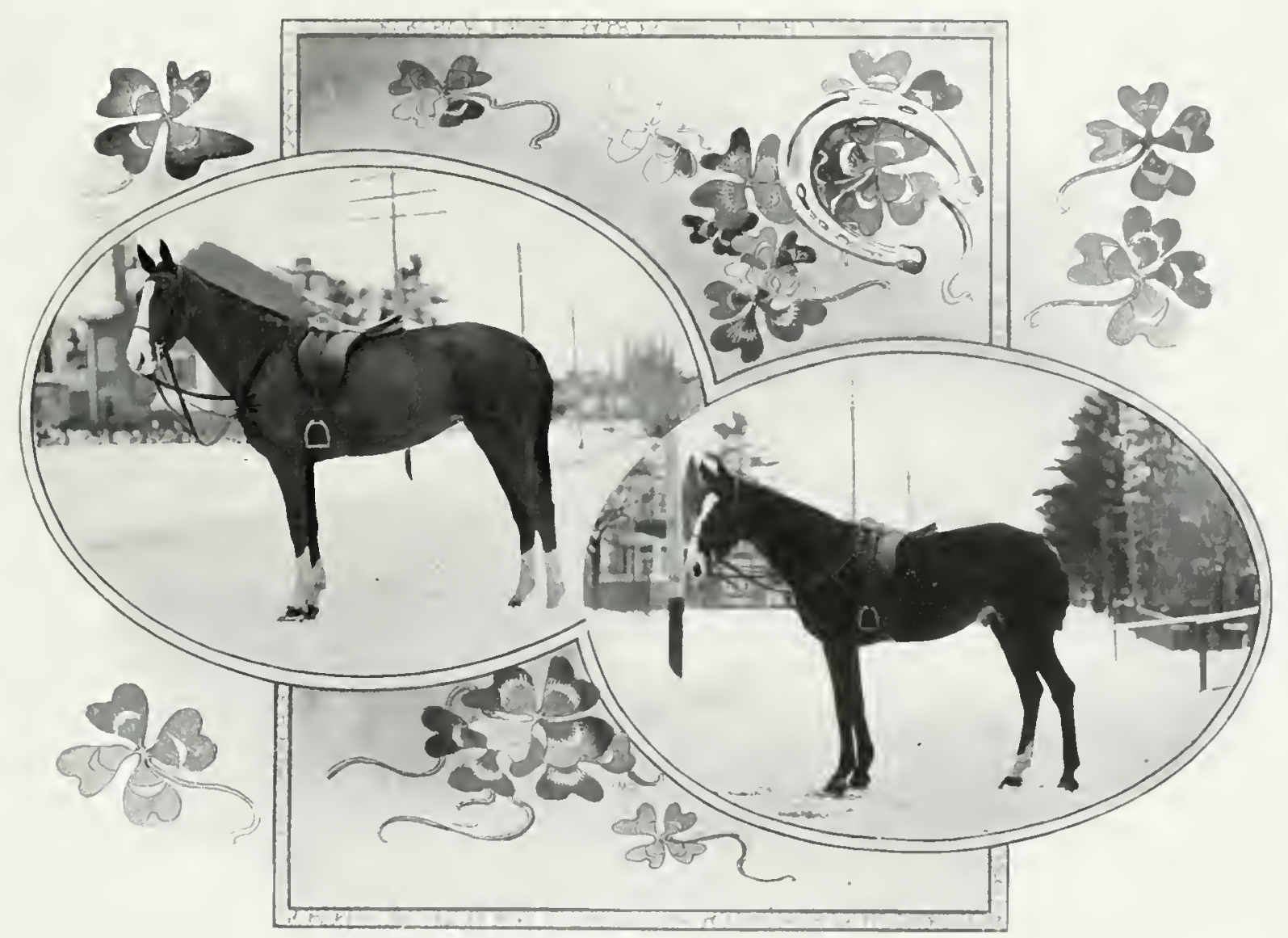

Silver BUCKLE

I'Jux 


\section{JAMES K. PAISLEY}

$\mathrm{O}$ NE of the most enthusiastie lovers of the horse in Othama is Mr. James K. Pais-

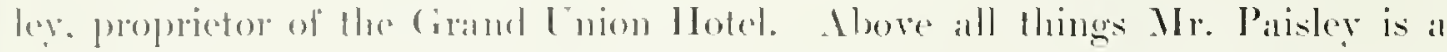
(amadian. his molest hoast heing that his life hats heen spent on candelian soil, and it may he sald that he is as welely kmown in the east as in the west. For many reals. he was a resident of ('entral Ontario and the farther west, and for a

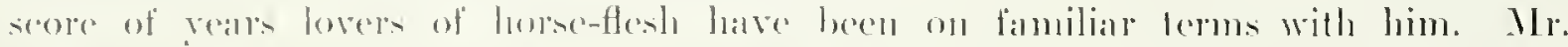
Paistery is now the proprietor of the Grand Lnion, one of Ottawas learling hotels.

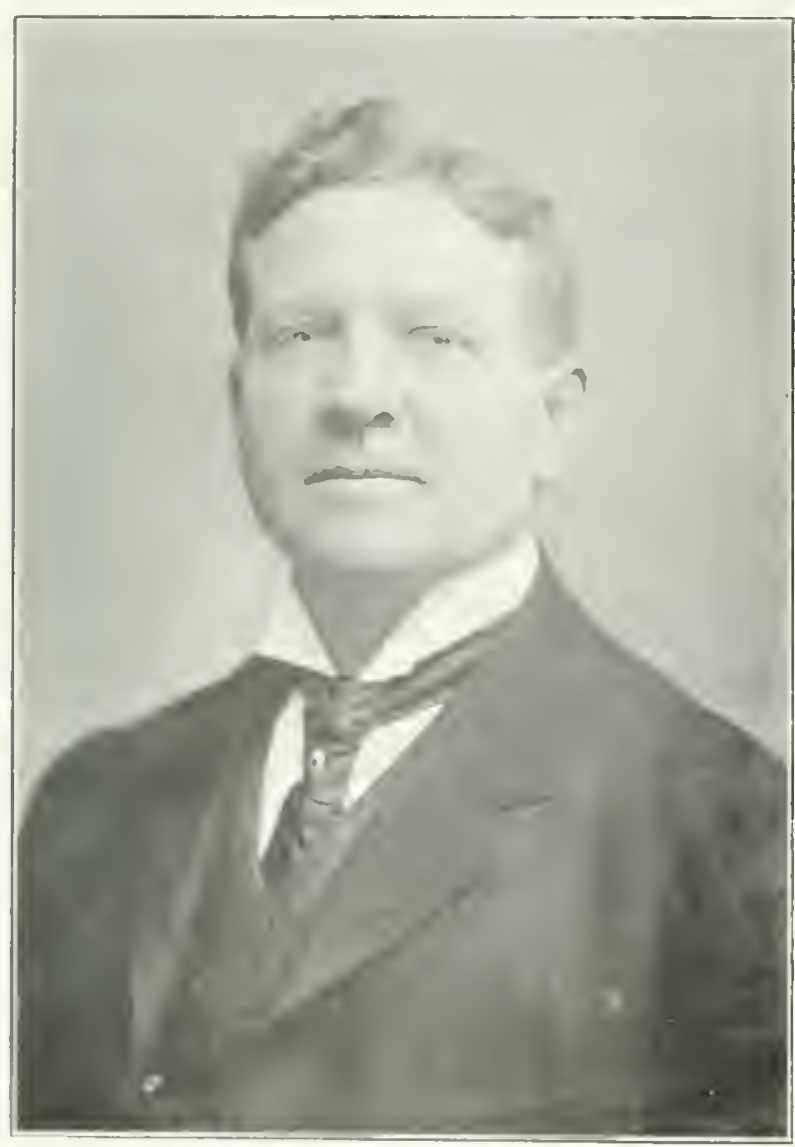

JAMES K. I'AISLI:Y

lle is a native of P'eel ('omuty. Ontario. ambl has hatd a rather remalrable and most roviable experienee as a host. Before enoing into business at Otlatwa in lyog he was owner of the New Roval in Hamilam, amel was responsilhe for the remorlelling of that hotel in 1897. the

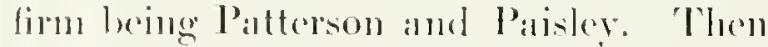
also the firm had antrol or management of the Penetanenishene llotel in Perretann. tlue Sans Somed at Moon River, and the Belvielere in Parry somme.

Mr. Patistey was eathier of the Wallier Honse in 'Toronto for a number of

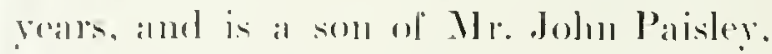
who was the owner af a popular hostelry in Orangeville for a quarter of a century.

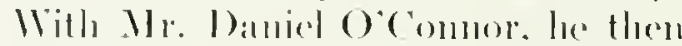

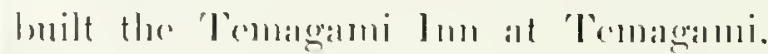
(Outario.and a year or so also purehased the liretoria Ilotelat Aylunel. Ile was also for some timse proprietor of the leseperis llotel in loomento. Ilo is an active membere of the Eillin, the Kuiglats of Pythias and the foresters and an exerutive member of the Ilotehonen's Mutual Bonelit

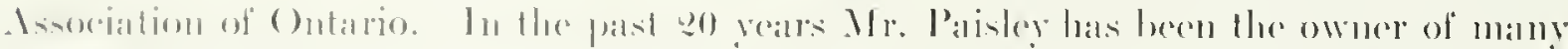

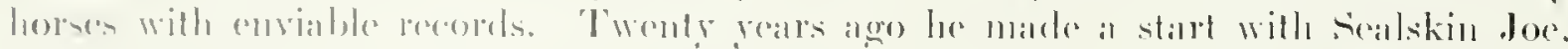

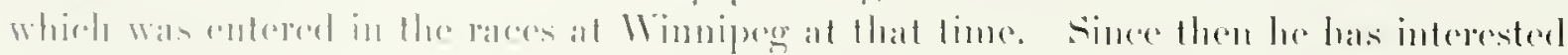

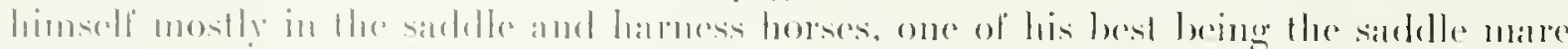

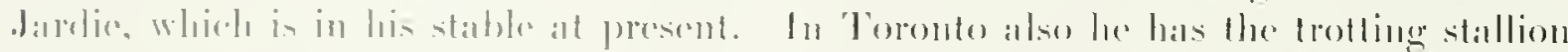

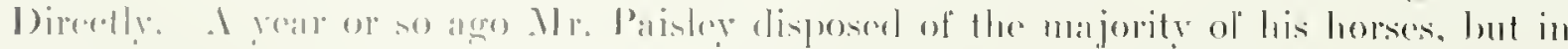

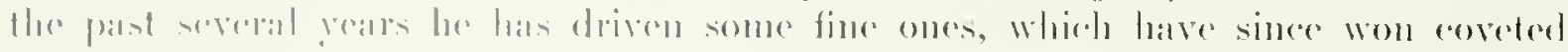

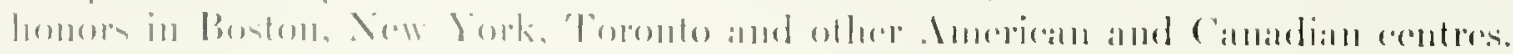




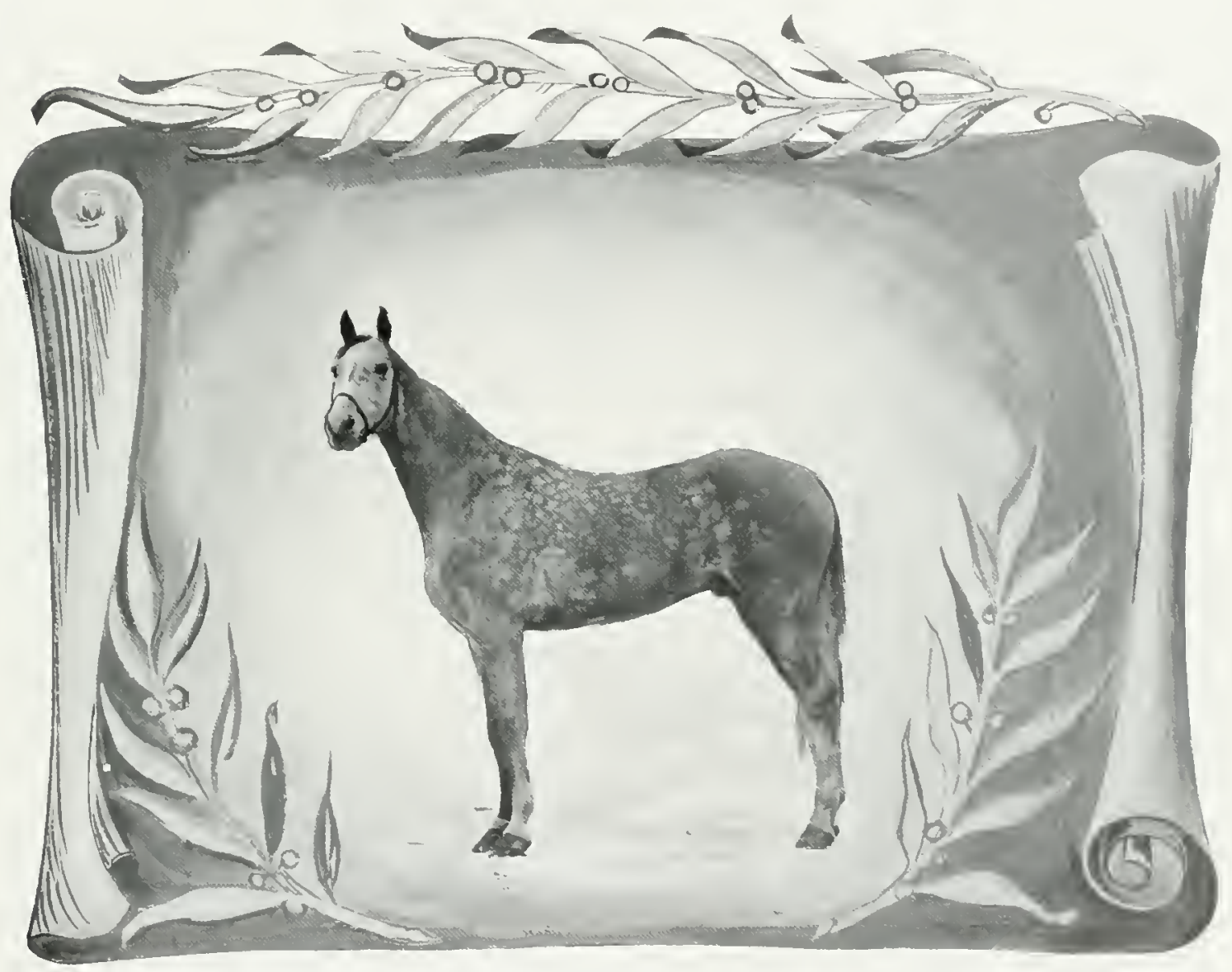

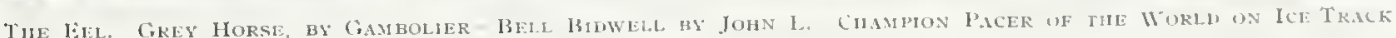

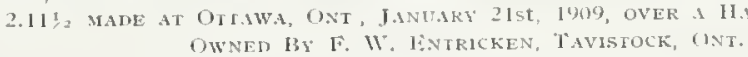




\section{JOHN DYMENT, JR.}

$\mathrm{T}^{\prime}$

IIL name of "I pronent" is known on the Smerian continent wherever there are lovers of horses and alean sport. One of the best known bearers of the

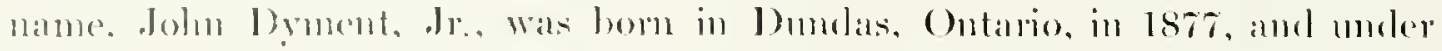
the gundance of his fathere. Who was remowned as one of Camada's prominent horse-

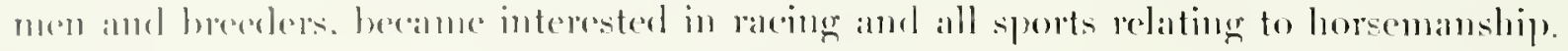

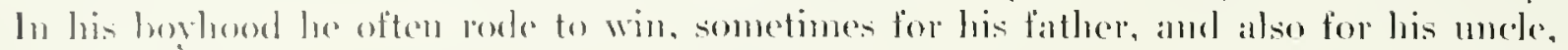

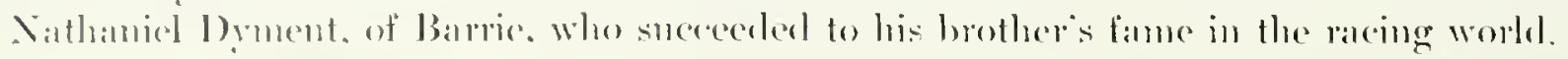

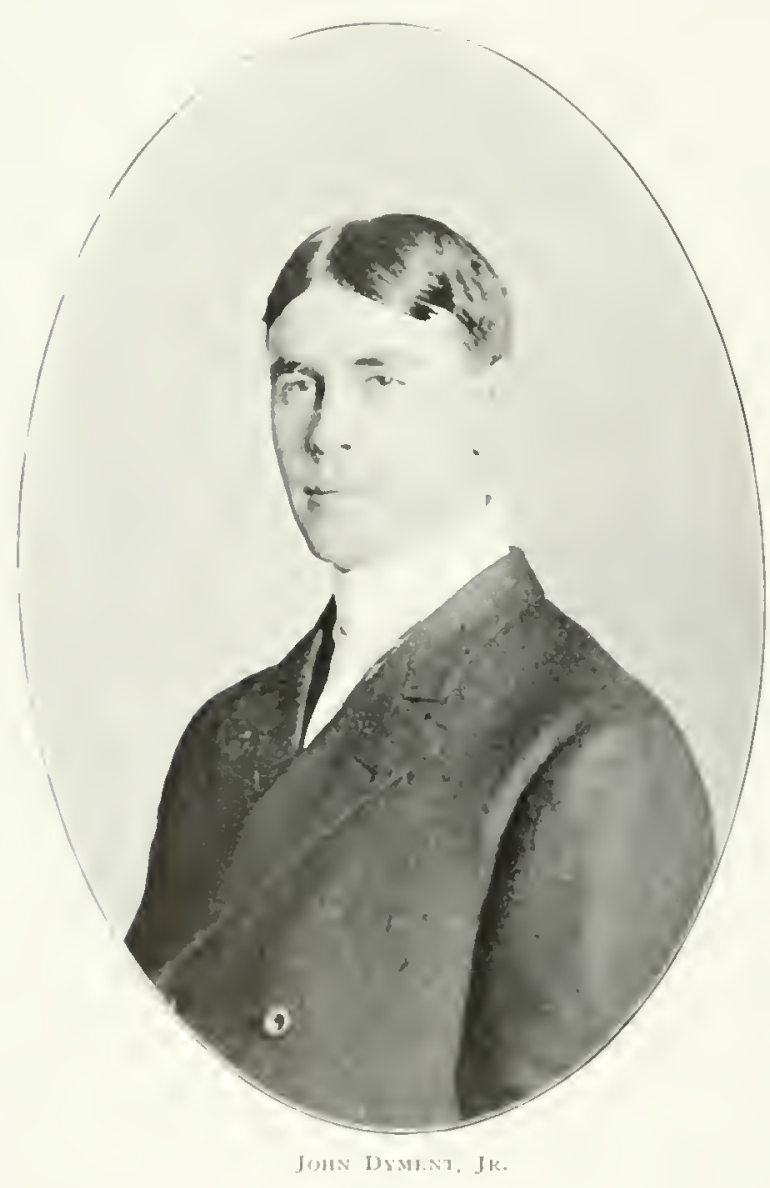
The ability of Johm, Jr., as a trainer was recognized eally by the discriminating grance of experiemeel horsemen, and he was soon cot risterl with the supervision of the stables it the fanmons Brookilale Farm, everything pertaminge to the borses being placed moler lis a are. Ilis carly arlvalutages, in recenving the encenragenent and henefit of the loroal experience of Nathaniel lyoment, the ownere of the Brookilale Stable. were quickly tumed to alecomb by the yommen trainer, who assumed his heavy responsibilities with the pride and pleasure of one "to the manor bom." The choice Was justifierl by its results, for Mr. Myment has

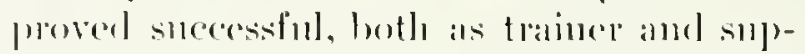
ervisor, to a degree most erratifying to lis sportsmen contucetion.

Mr. Dyment has been fortumate in the wimning of many stakes. Int this has leeen due laregely to Hare kuowledge and geourl jurlement of the main who knew that "lack" is not the laldesest element of ficld success. Mr. Dyment has known the grood points of his farorites and lis faith in their prowess

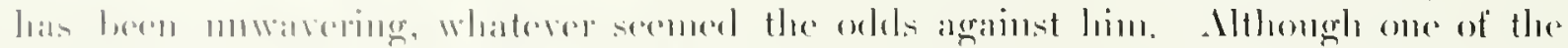

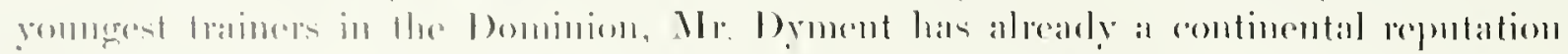

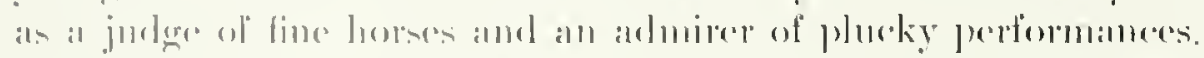

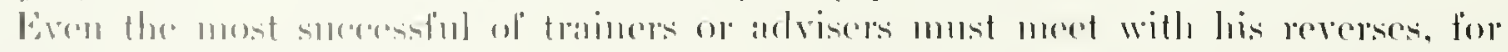

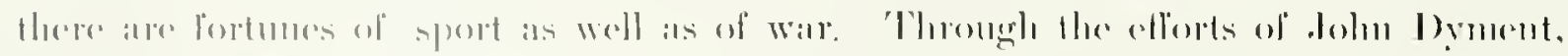

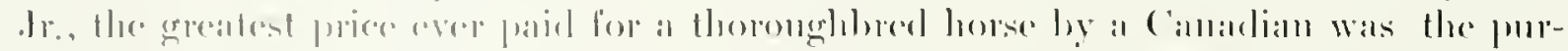

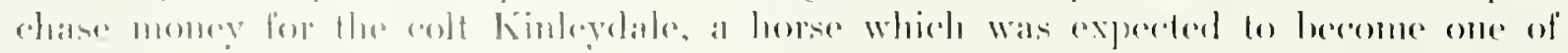

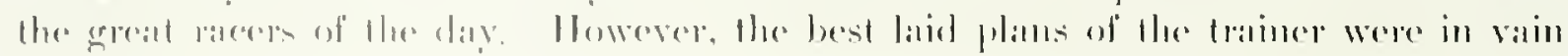


in this ease, for the promising horse died as a result of colkl, leaving disappointment to his admirers. But the enterprise which bad secured this thoroughbred is none the less to be commenderl. Mr. Dyment has been highly sucecsful in selecting twoyear-olds to race on the Canadian eircuit as three-year-okds, and with them he has won the majority of the stake events of Camala in the past few yoalrs

llis first great suecess ocenred in 1903, when he won the King's Plate at the Woorbine, Toronto, with 'Thessalon, muning second the same year with the horse Nesto, while the spectators thumbered their applanse over what proved a most popular vietory. He returned the following May and won the much-coveted roval Guineas with Sapper, a racer which he had picked np for a low fignre, and han bonghlit because it was sired by Courtown. Mr. Dyment is known as a vigorons trainer, and eacl pear. on his arrival at the Woodbine, his string of horses is fomm to be in fit and handy condition for the strennous days ahear of them. In 1903 he won the majority of the stakes at the Woollsine with the colt Fort Hunter, now in the stud at the Farm. With Fort Inunter he also won the Buffalo Derby, and tried for the great Ameriean Derby, at which, however. Fort Innter was beaten, to the supprise of the Canalian batckers.

In the following year he had conspicnous sneeess with 'longoreler. a winner which he had selected as a two-ycar-old. This eolt won the best stakes on the Camadian circuit, and to-day is one of the fastest horses owned in the combry At the Buffalo berby he was heaten by only a small margin on a heavy track, and showed by his pace and form at that event the thorongh training he had received.

The sncessor in the string was Uncle Toty, who was not all that his friends might have desired. During the season of $1908, \mathrm{Mr}$. Dyment had a fair degree of success with the smallest string he had trained for some years. Of eourse. the glittering prize luring the ambition of every Ontario tramer is the King's Plate, and with that object in view, Mr. Dyment has kept adding to his string in the purchase of many valualule brool nuares diring the autumn of 1908. One of the most noted dams of Amenieat was included in this lot, The Elf, dam of Broom Handle. Whisk Broom and liltal a trio of the greatest winners on the turf of the Ameriean Comtinent. Probalsy the best eolt ever bed at the Dyment Farm was Contown II. the farored racer loo the King's Plate event in the spring of 1908, who unfortumately gave ont the week betore the great day, leaving him eligible, however, for the following yeall. Stromeland was another favorite in the string that earried the Iyment coloss to the front on severai oceasions in the two-year-old events of 1908. Many yearlings have also been adeled from year to year, and from among these some firstedass race-lorses have been developed under this expent trainer's careful handling.

As Mr. Dyment is only in the andy thirties, he has, in all probability, many yasts of successful business and sport aluanl of him. In 1901, Mr. Dyment married Misis Grose, of Barrie, a lady who inherits a fonduess for the sports in which her hushand delights, and his whiter home in barrie is one of the handsomest residenees of that

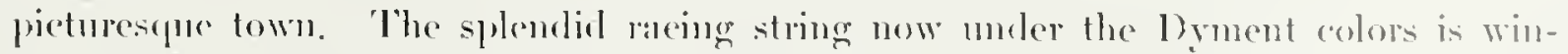
tered at brookilale Farm, which is a fow miles from sinnoos's connty town, and is famous for the many winners which have heen foraled there. 


\section{AMATEUR ROAD DRIVERS` ASSOCIATION, OF LONDON, ONT.}

$\mathrm{S}^{\prime}$

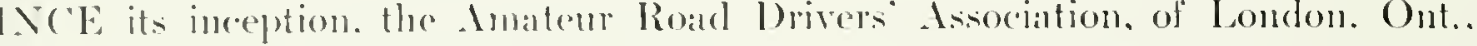
hals hecome one of the most suceessful matinee rlubs in Anerical. It hats al history of uninterrupted progress. reaching larck over a period of several pears. with erery promise of a prosperous future. In many features this . Association contducts its crents along unigue and noved lines: and through fair and sportsmanlike dealings, and the elimination of certain objectionalile features. which too frepuenty mar the strecess of surel organizations, lats woul an enviable reputation for gentlemanly sport.

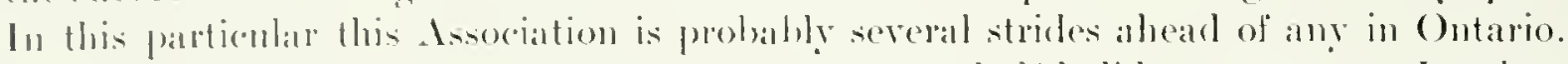

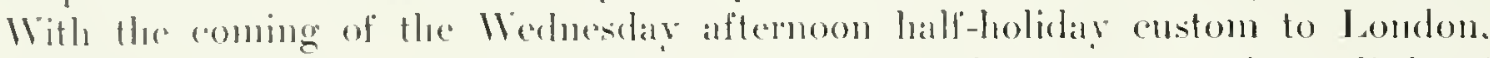
cance the opportunity for London's race-horse lovers and owners to enjoy a little of

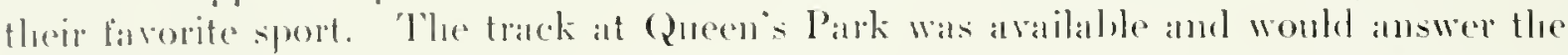
purpose admiraldy. There were plenty of horses and any mumber of drivers ready to entere conpetition. But there was still something lakeking. The racing events must be comblucted in an orelerly and sistematic mammer if they were to be a suceess, and with this purpese in riew the london Amateur Roat l)rivers Association was formed. Mr.

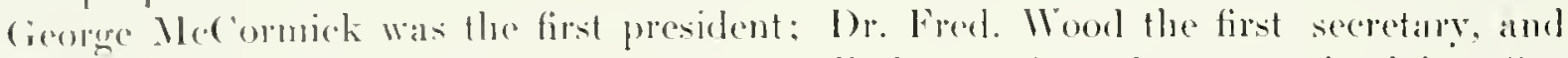

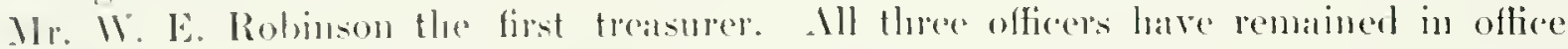

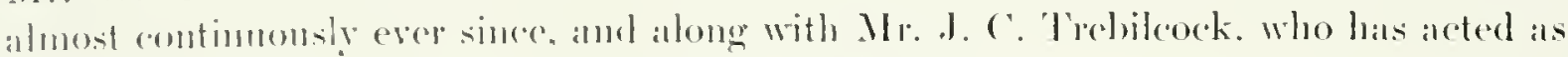
oflicial stalling judges all have grivens splemelid satistaction.

Before the inception of this association. othere oreanizations of a simian mature or with a similate end in view were formed. None of these, howerer, was long lived, and

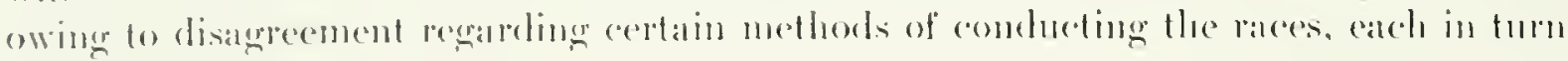
provert:a filiture.

Bookmaking and the sedting of pools were allowed hy these associations, and it was

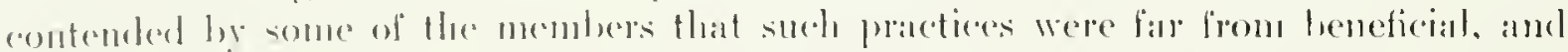

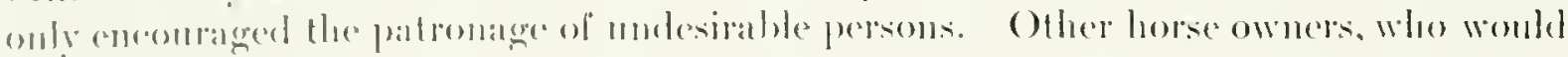

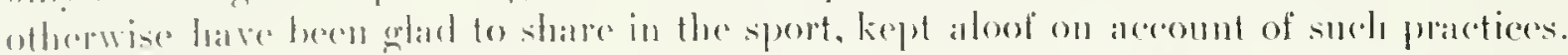

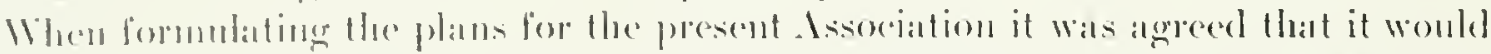

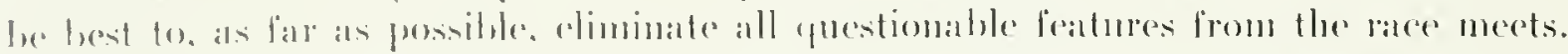

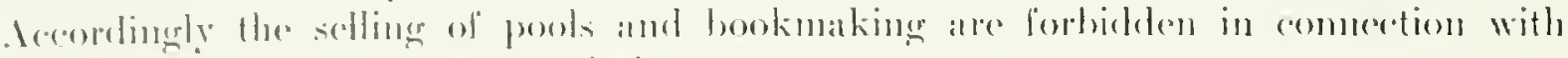

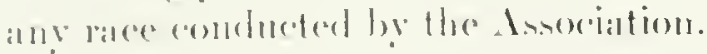

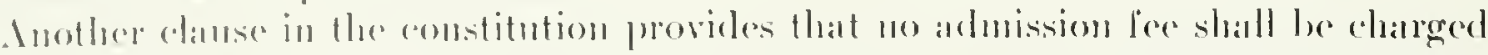

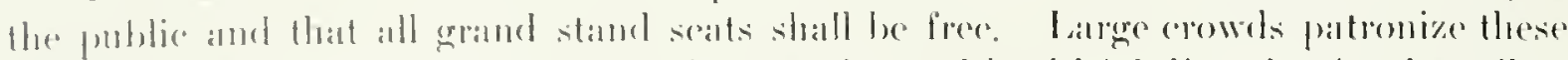

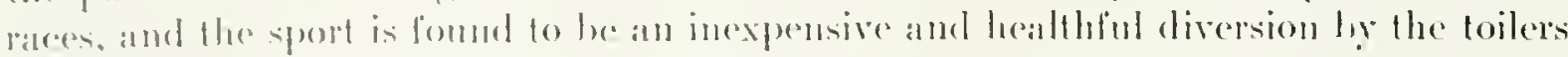

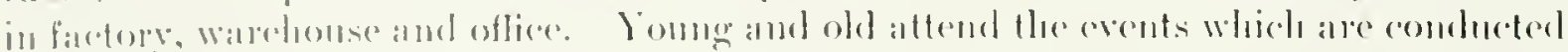

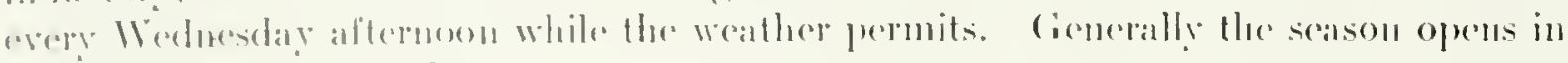

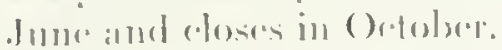

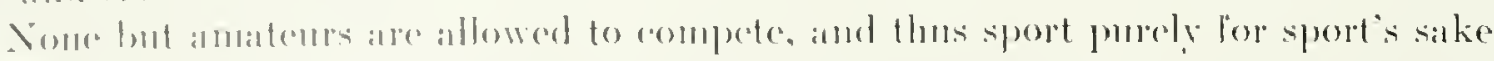

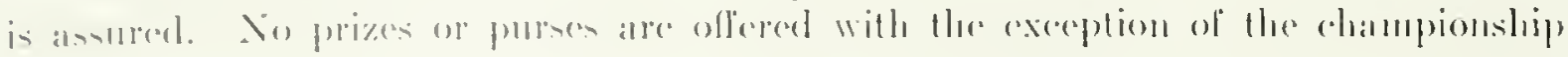


(aup, which is competed loor anmmally. 'This trophy was presented to the Association

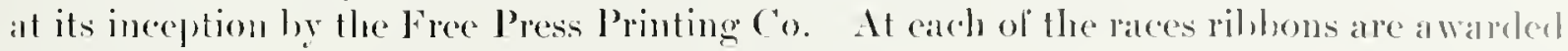
the winters.

The Association dees not include horse ownels alone, lout many lovers of the sport. whothromer mufavorable eireunstances are prohilsited from keeping a horse of their own, contribute financial aid to the organization, and keep the treasury at all tines well fillal.

Ilaness horses alome are allowed in eompetition, and the use of hobbles is strictly prohibited. The rehicles used must be of the four-wheeled type, and the Association owns all these wagerons hut allows the members to biteh to them at will.

There ane from twenty-live to thirty horses entered calch afternoon. (owing to the events lasting as they do for one altermoon eatel week only, it is almost impossible to make room for more than that number of horses.

In the matines has been fomml a splendial opportunity for testing green material, and also for showing horses with a view to their sale. Thromgla these races many London horses have found their way to the best racing stahles of the country. llorse burers from lan and near attend these events, and on several oceasions have purchased horses which have afterwards proved to he very fast. At almost every matinee promising young horses are brought out. Some are bought up immediately upon being tried out. while others have to give way to the speedier.

Imomenthe notable sates made through the matinee races of this Association during the past few years have heen: Walter S, formerly owned hy Norman Maldeod \& Sons,

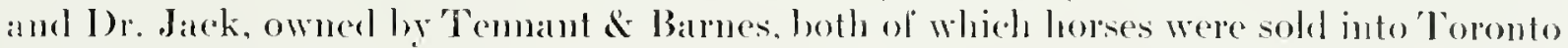
statbles for latre sums of money. Solstome, formerly owned ly Mr. (icoroc Mrecormick, is now one of the champion horses of the New York speedway, with a record of $2.13 \frac{1}{4}$. Ile was the eup winner in 1907. 'The Dentist, I aly Black, Madge W' ('lipper, and many. others have also found their way into the hig stalbles from the london matinee races.

Membership in the Lombon Amateur Road 1)rivers Association lass not been confined to residents of landon, and from tine to time amatenr lorsenen from neighboring towns have taken an aletive interest in the ('hul, 1)r. el. A. Hughson, of Buffinlo, who was at one time a prominent member of the matinee chuls of that city, has now taken up his lot with the Jomdon Association. IIis horses apprear regulany at the Wednestay afternoon matinees.

Sinch prominent business and professional mon as R. J. Mood. 11. S. Wilcox, IJ. A. Brownlece, Dr. R. Barmes, Dr. 1). ('. Temnant, Dr. S. W. A. 'Thompson, S. 'Thompsom, Wm. Collins, C. (i. MeCormick. Norman Meleod and Soms, Geo. Campluell, Robert Nixon, Frank Sage, James McCartney, Fred. Paisley, J. S. Sherloek, Alex. Henterson,

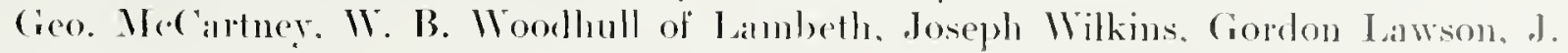
Il. Brooks, and inumerous others. have from time to time been anome the aretive members ol the Issociation. 


\section{PHILIP McGINNIS}

A BEAEFAC"TOR to the camse of the thoroughlored, and to the alevotees of the 1 royal sport of racing. is $\mathrm{M}_{\mathrm{r}}$. Phil. MaGinnis, who wats born at Huntingalon, Quebece, and who is one of the few Camadians to bave elimbed to the very top of the ladeler of suceess in the racing world.

Mr. Nechinnis's great contribution to the king of sports has heen his invention, the starting machine. In the ealy days of racing in this country, no barrice was used, and there were so many. Wretehedly mequal and unfair starts, that Mr. MeGinnis

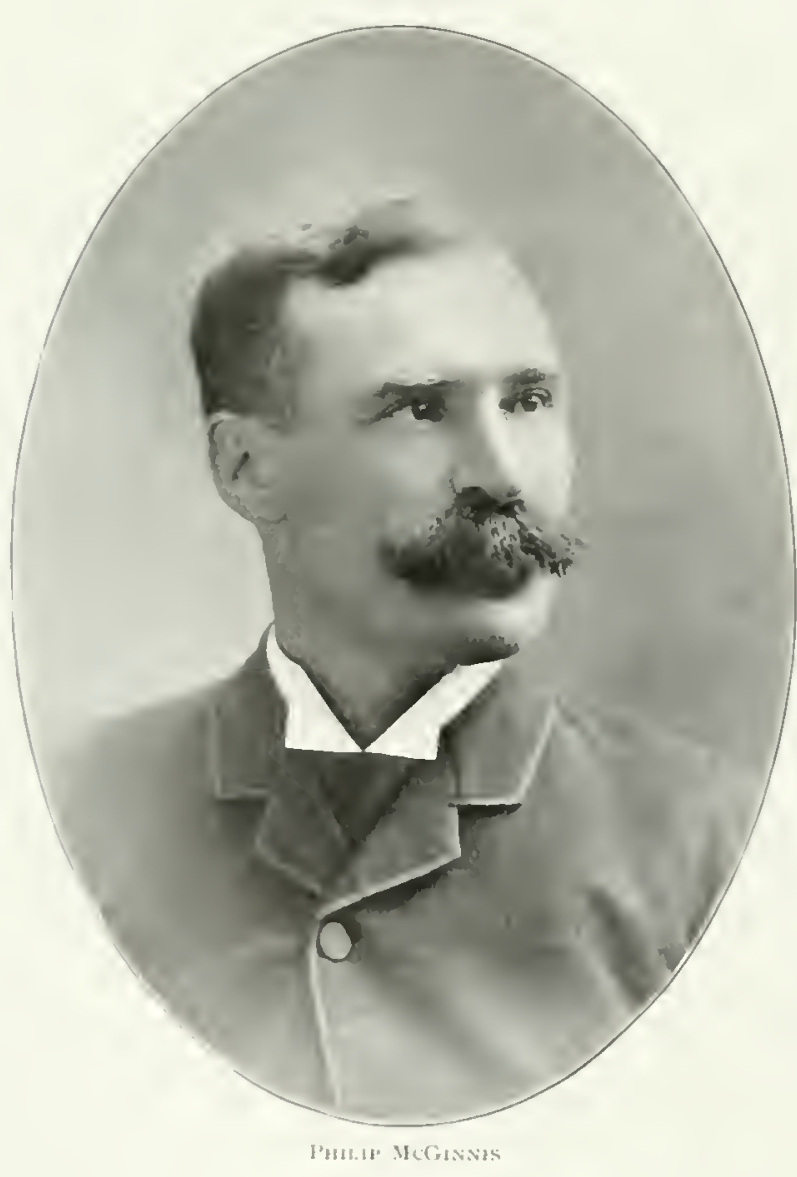

leegan to reasom out a waly to put things on a more equal hasis.

The result of his cognitations was the invention and perfection of the barrier, as it is known to-day, a machine which lats proved so suecessful that it is now being nsed on ahmost every race-track in Americia.

To start horses away from the post with an equal chance is something to have lived for, and this most desirable condition of affairs is what Mr. MeGimnis has areomplished. The public owes him a debt of gratitude for this one acherement.

Always a lover of the horse, particularly of the thoroughtored, Mr. Me( immis was a regular attendant at many of the tracks on this continent, beginning his aretive career as a starter in the eity of (Quebere, when he was askerl to fill that position at a meeting of the (vuebec 'l'url' ('lul).

for several years he fulfilled lis duties there so ably that he became very well kmown to horsemen, and then commeneerl his stecess. Mr. MeGinnis has

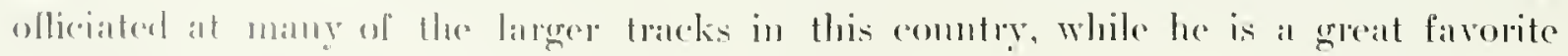
in the sonth, where he now does most of his work.

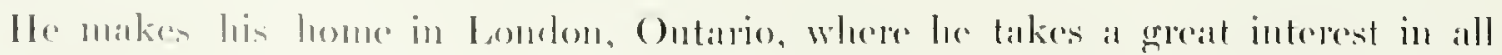
classes of sport. He has great skill, both as a lider and driver, and is woll known onl revery tratek in Imorian. 


\section{JOSEPH E. SEAGRAM}

$\mathrm{M}^{\prime \prime}$

R. JOSEPIl E. SEAGRAM has for many years been the principal supporter of the turf in Camala. He rarely has fewer than 100 thoromghbreds int one time in his stable at Waterloo, and each veall he spends thomsands of dollars in securing new blood. Ile hats brought to Camadal some of the best pedigreed horses the word has ever known. Ite has invested large sums of money in securing goonl American horses. In short, than Mr. Seagram, there has been mo greater benefalctor to the thoromghbred horse industry of Camala. His stable hats representatives in all parts of the combry, and wherever there is a race meeting it cam be tependal 11 peon that a representative of Mr. Seancians conterprise will be among the winners. Hlis success. first of all in the (2ueen's Plates, and afterwards in the Kingrg llates, is of sufficient renown to make umecessary any extembed referente to it in this sketeh. IIe has won no fewer than thirtern times, eight times, from 18!1 to 1898, successivety. While many of his pliste winners latre not gone on and raced. several of them have distingruished themselves subsequently both at lome and abroat. Among these might he mentioned Victorions, one of the last sons of that noble old sire 'lerror; toe Miller, who ran one of the fastest laces erer lum on the turf, at Coney Island: Bon Ino, a winner herself, and the tam of Inferno, winner in 1905: and of Seismie, the wimner in 1908. (of the other's none have done anything to distinguish themselves atter wimming the one race. except, possibly, to carry off two or three province-bred races.

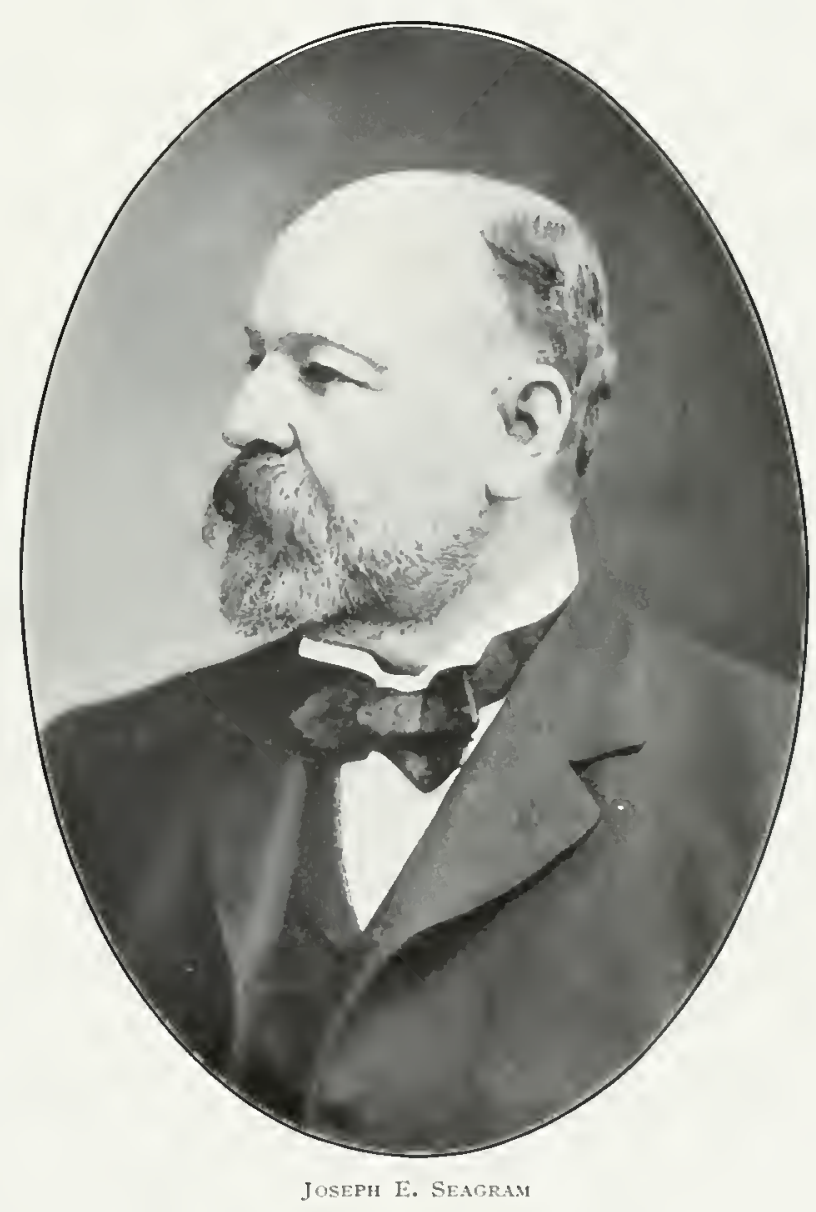

While Mr. Seatgram, greatly to the advantige of the horse interests of Camalia. has devoted the larger part of his attention to the breeding of province-breds. having imported many mares with foals in utero both from Great Britim and L nited sitates. at more expense than any other man in the Dominion has felt inelined to incur, he has also brought into the comutry many a good ralce-horse, but for whose presence the valuable stakes given by the Ontario Jockey Clmb and other ('anadian meing associations would have gone abroad. In brief, IIr. Seagram has truly been a pillar of the 


\section{$146 \quad$ Lovers of the Horse}

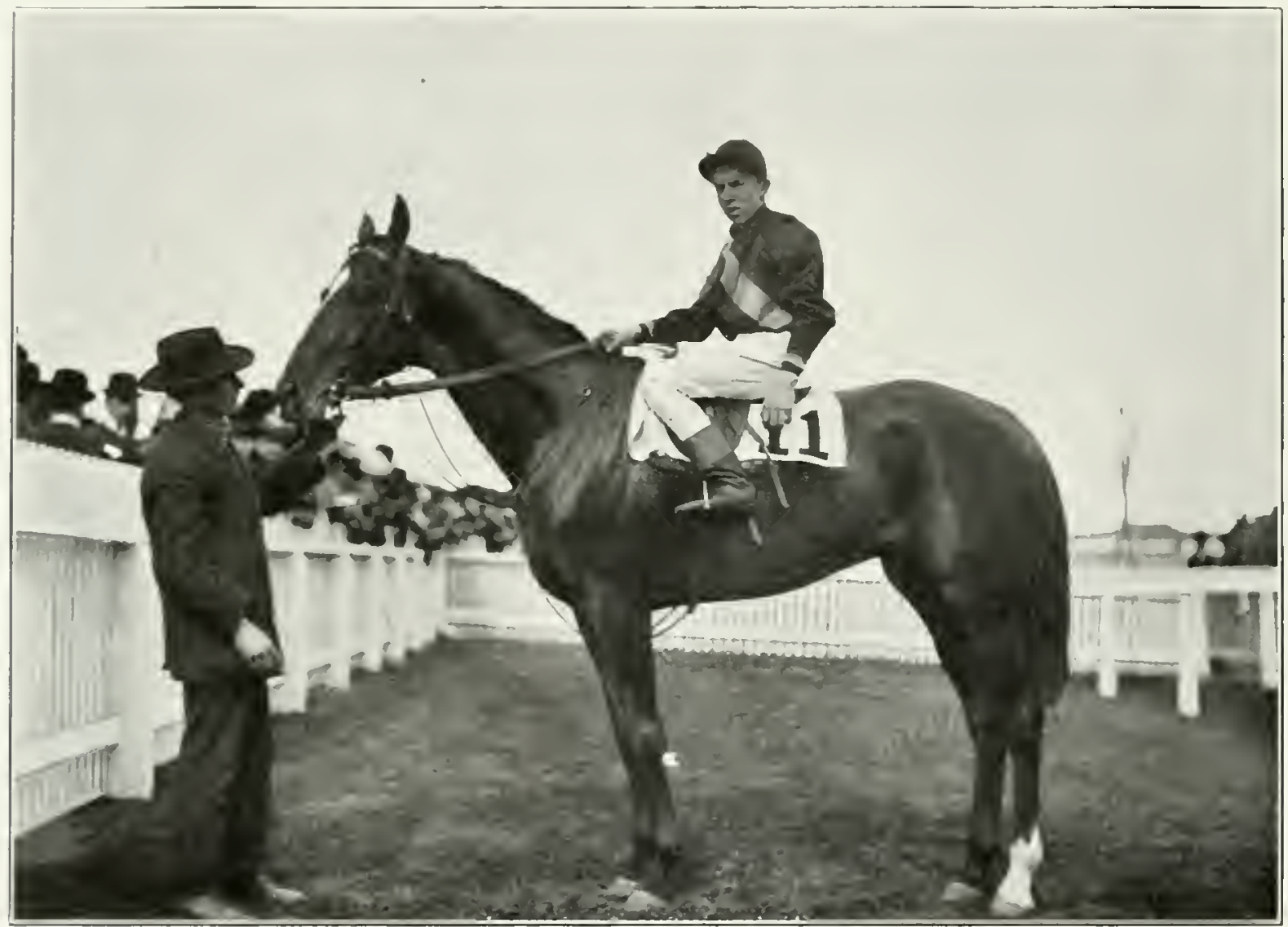

ISFERNO, BH. IIAVOC- IBON INO

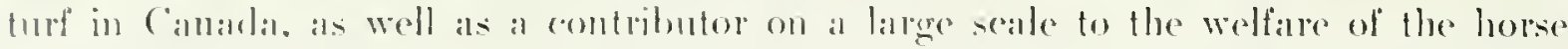

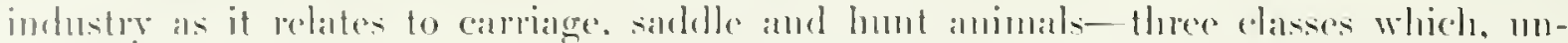

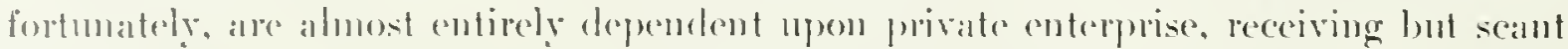

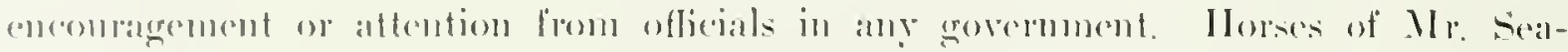
gramo bereoling have won racess after they have left his hands, not only in all parts of canada, in the Maritine Provineess als well as in the lan western Provinee of British

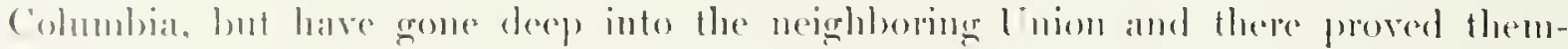
solves captithle of carrying ofl mally prizes.

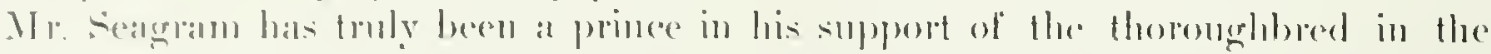

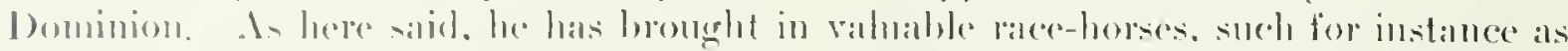

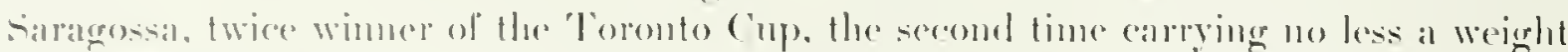

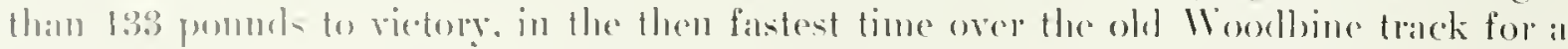

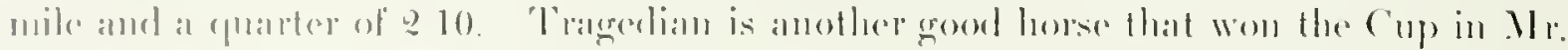

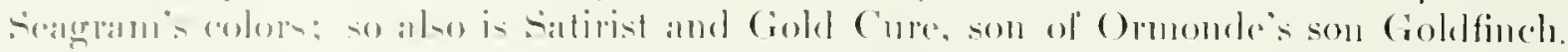

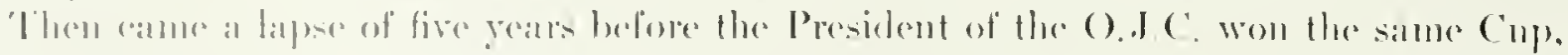

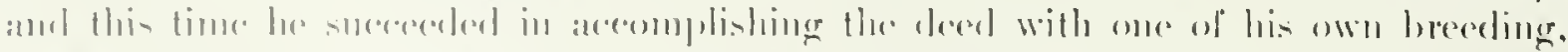

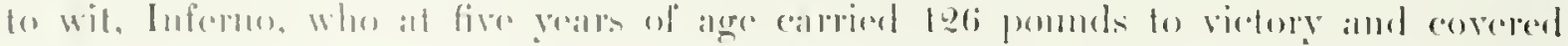




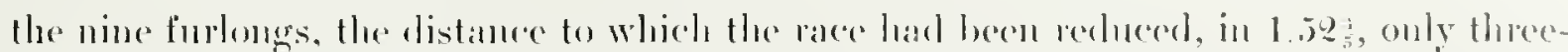
fiftls of a second mere than the best on recoml for llee distance over the new and fast track. In the Woolstock Plate Mr. Seagram has also had his suceesses, his last being in 1907 , when, with $\mathrm{M}$ an Chance, he won in the fastest time on recorl for the race, in 1.59\%. Inother important avent in which Mr. Seagrams stalble las distinguished itself is the King Eelwarl Ilotel (up, which tle province-bred Infermo has thrien won, against all comers. first in 1906 as a fomprear-old, calrying 117 pounds, and corering the distance, one mile and a quarter, in the fastest time on reeorl for Camada, namely,

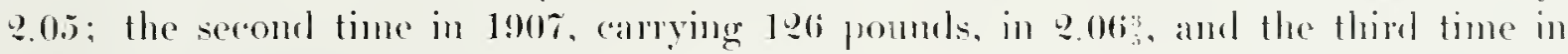

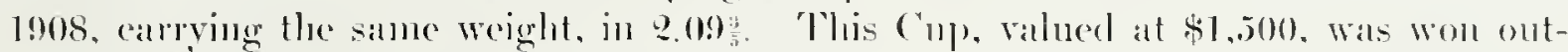
right by Mr. Seagram with his vietories of 1906 and $190 \%$ and in the following year the proprietors of the lotel having given another ('up of the same value, he won, als alescriberl, for the third time. Mnother race of prominence that Mr. Seagram has twiee landed with the same horse is the Iiverpool Cup, which the American-bred Procession won for him in 1900 and 1901. Perhaps one of the most startling performances that ever the Wombine saw was that of Mr. Seagram s Persistence II, an imported horse by the Kinge's Persimmon, that after rmming absolutely last in the

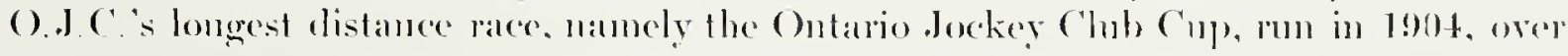

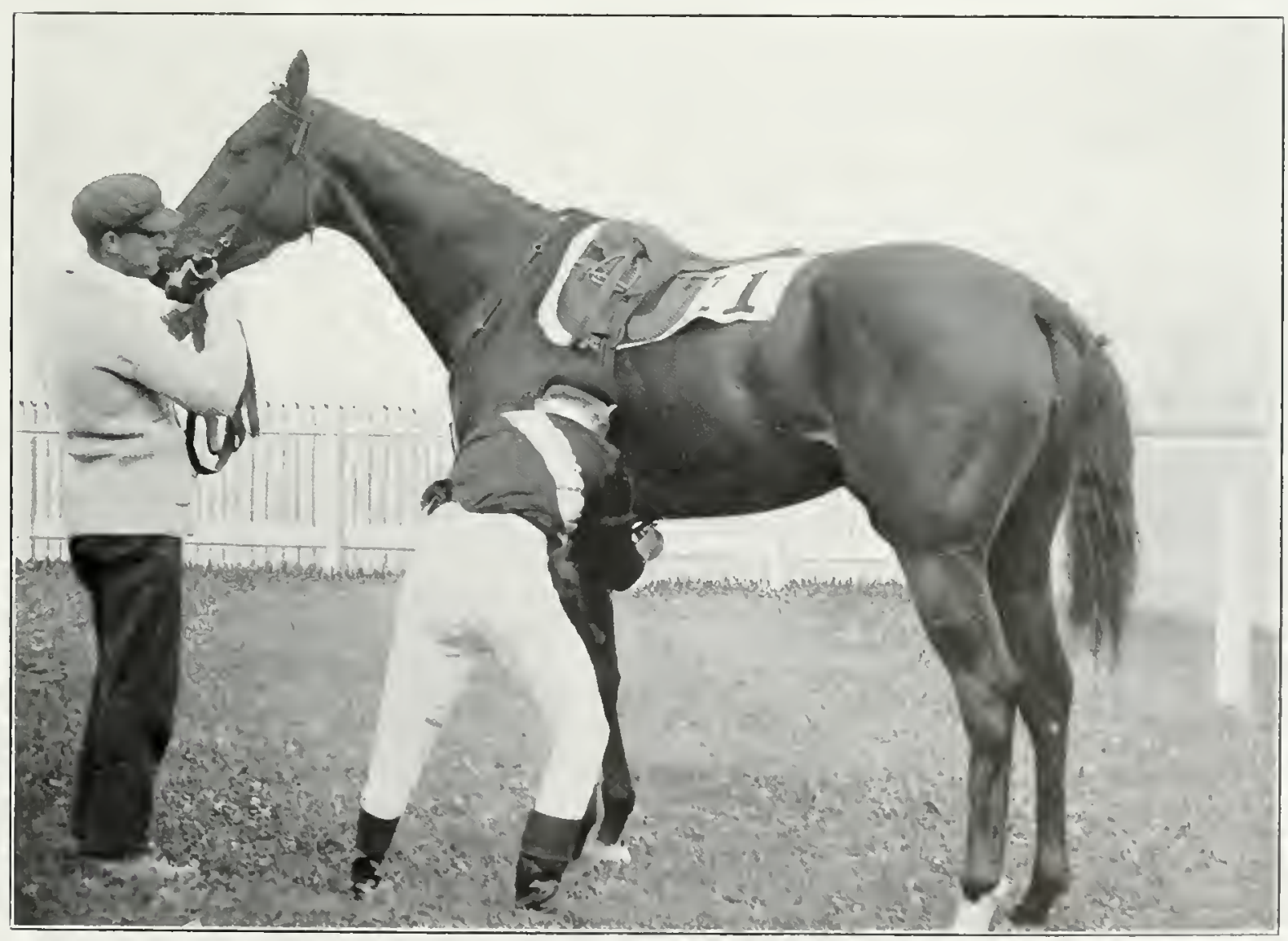

BUVQUET, B.M., KINLLY MACK-BRIAR SWTET 
two milen:and one-sixterenth. won with a marvellons hurst of speed in the last half-mile,

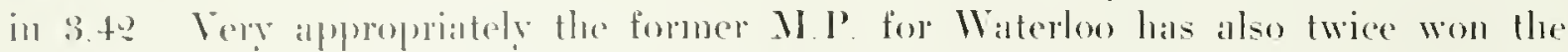

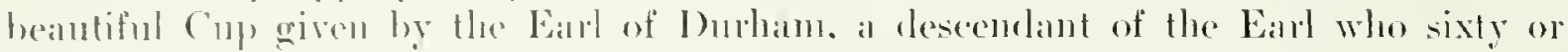

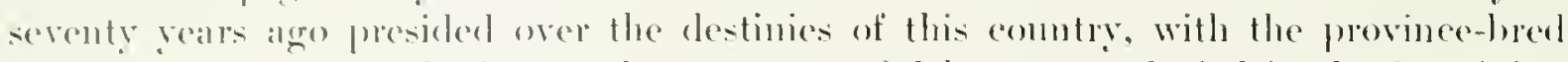
Infermo, mudombtedly the hest and most suceessful horse ever foalerl in the Dominion of Canalat. It is a tribute to the breeding sucess of the Presilent of the O.J.C. Alat this grand horse should be a lative in his perdigree for sereral generations batek. In

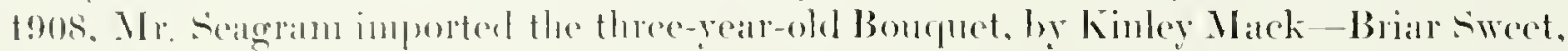
who lambed two impromtant races at the ().J.C. Fall Mecting. One of which was

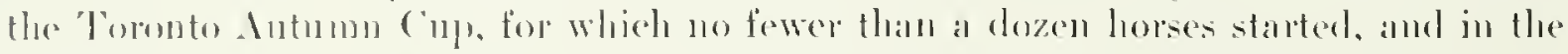

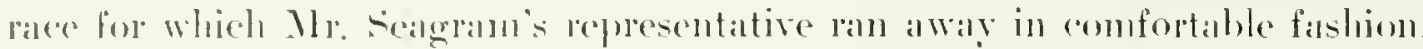

'llhe ownere of the Waterlon stable has neitlele eonfined his vietories to the Wood-

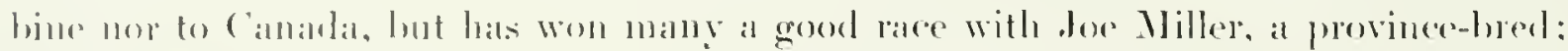

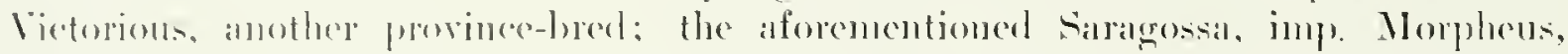
Ilavore, al son of llimyar, sire of the immortal bomino, imp. (Objection and others, at the hest meetinge in the Tinited states. To emonerate all the suceesses that Mr.

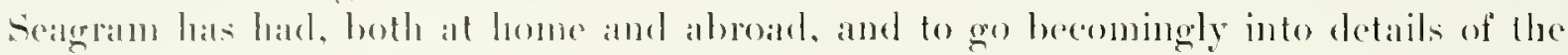
horses he has bred that haw areomplished deeds worthy of note, would he to fill this ('utile volumer.

Mr. Soagram is President of the Ontario Joekey Club and an Honorary Menber of the Einglish Joekey Chab.

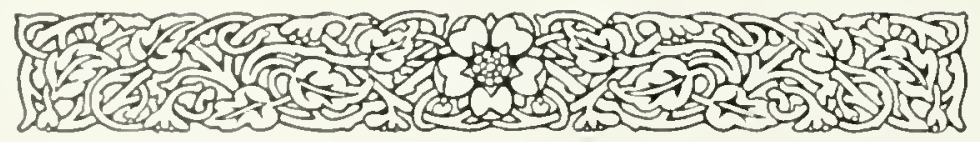




\section{MAJOR JAMES HAROLD ELMSLEY}

$\mathrm{M}$ A.JOR EIAMSIE T helomgs lo an English family of military and true sports-

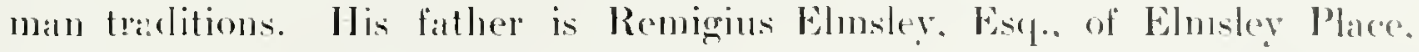
Toronto. whose pieturesque residence at the head of a quiet little avemese off St. Joseph street is like a gabled Old romotry reteat rather than a home in the buss. commeredal rentre of Ontario. The son, James llarold Elmsley, hats always heen at home in the siddlle, a fondness for the pony teeing manifest as soon als the sumbll loy Wats able to mount. The Elmsley family, like several of England's historio lonselookls, alle attacherl to the Clmireh of Rome, and it was to Carelinal Nemman's ('ollege in England that the future Major was sent for carly instruction. It was soon evident that he was destined for a militalry catreer. and his attention becaluse directed to studies pertaining to soldierly life and. incidentally. to all sports assoriated witla a horseman's activities.

In 1898. the young andidate for military honours obtaned a commission in the Covernor-(ieneral's Body Cuard, and then in the Royal ( analian Dragoons. When the war loroke out between Briton ind Boer. he went to South Afriea witl the first contingent from Caualas as lientemant in "A " squadrom, Royal Canaldian Dragoons. In the strenuous ampaigns of that conflict. he diel splendid service, acting for some time as 1.1).C. to Major-cieneral llutton, a lormer cieneral Officer commanding in Canada, who co:munanded a Mounted Infantry Column. In that stubbornly-contested strife, good loorsemanship was of the utmost value. and this young officer's skill and effieiency

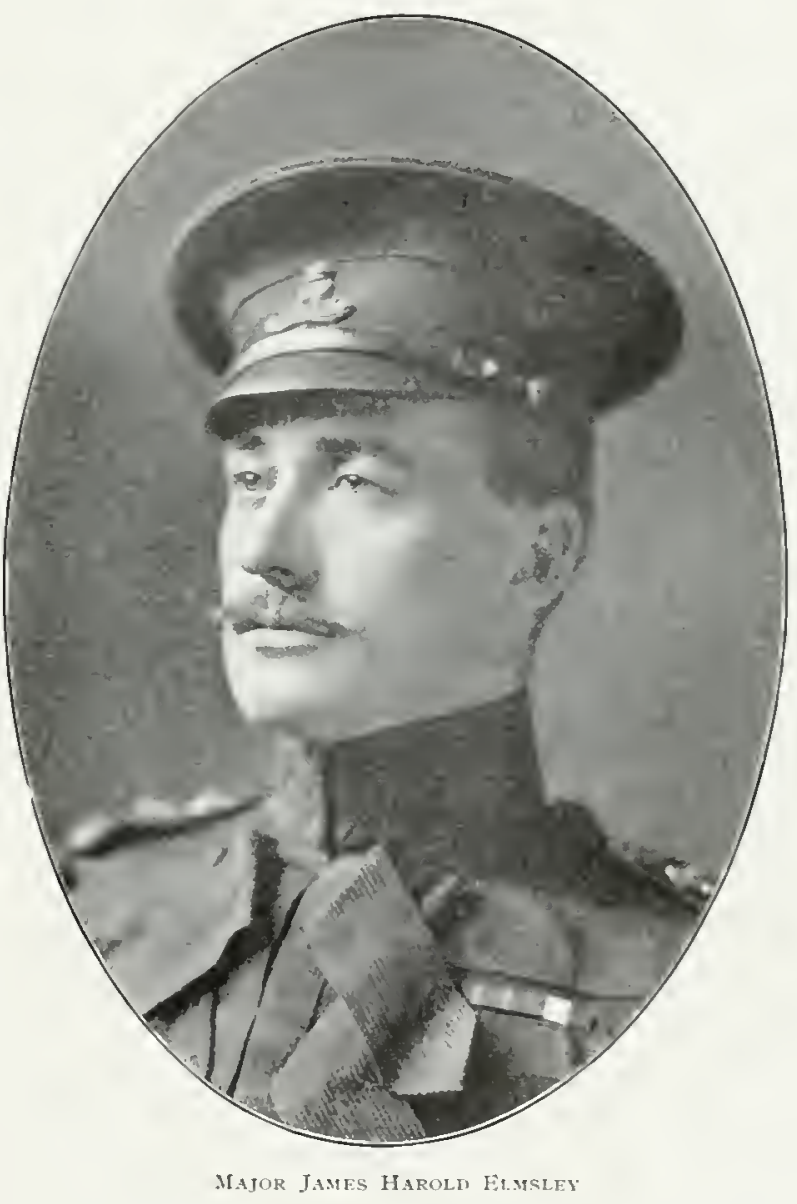
in this respect was of grood service, loth in the personal and patriotic sense. Ile was not without experience of the disconfforts and dangers of actual watratre and wats woumded in one engagenent. However. the honons of heing mentioned in the despatcles, and reeciving the (Quecon's Medal with five clasps. Was militaly distinction worthy of suffering in the sorrier.

Promotion eame rapidly in the days which called for prompt aletion, alud the sereas

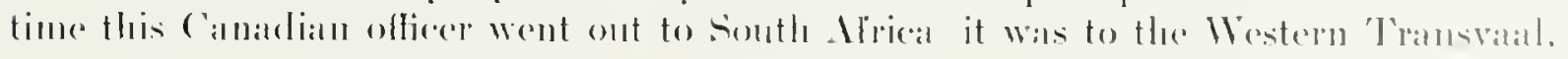




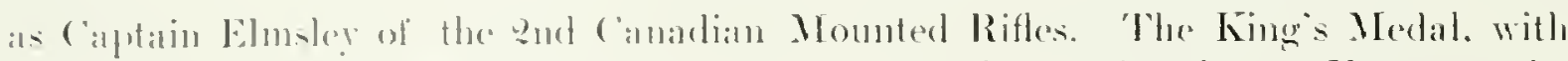
two displs. Was witnen of the geost work done in the service there. Howerer. the troubled times in sonth lfrical were nearing the dose and, cre long. Captain Elmsley was at liberty to return to the lominion. in whose militia he had proved so valiant an ofticers. In civil. combined with military service. he proved an aceeptable A.l).C. to

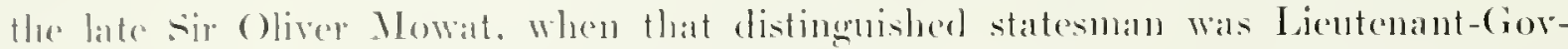
ernor of Ontario. resiling at Government Ilouse. Toronto. The position now helat

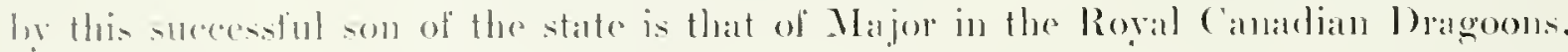
amel it is mere justice to say that he is one of the most caplalule oflicers in our Canadian militia erery inch al soldier.

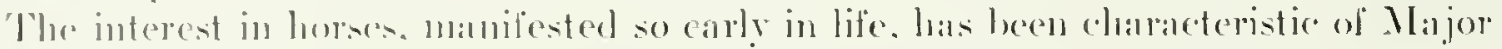

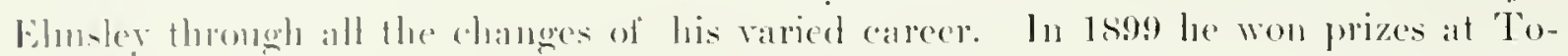

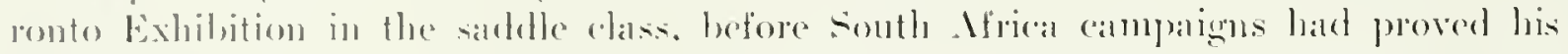

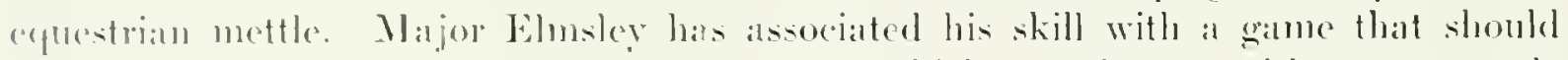

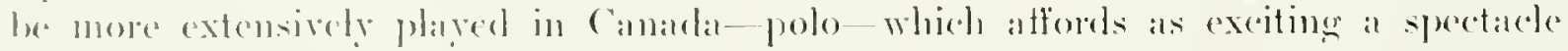

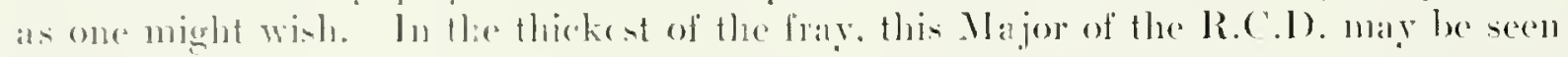

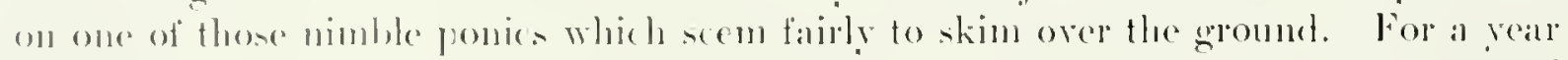
hesered in Judia, in achange with an oftiec from that lat British dependency, and

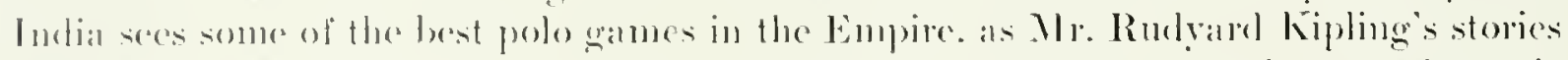
"and tentify. It the polo games. played in Mentreal and Toronto. the attendance is as markedly Britiah an at ericket itself. and the enthusiasm for the game has been steadily erowing. 'lowalds that inceresing interest such spipited and fearless players

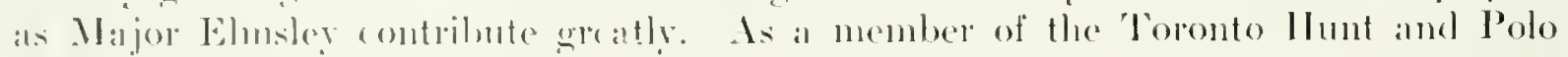
('hul) he has shown himself a suppenter of the finest sport in the community. Among

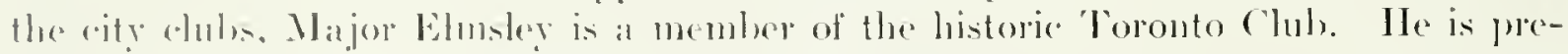
aninent in all spopts of lealthful and rigorous nature and has won temnis and golf

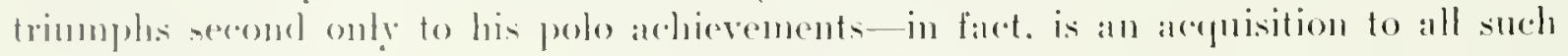
rinceles.

It is likely that Majol Elmsters future career will mean lurther military homours,

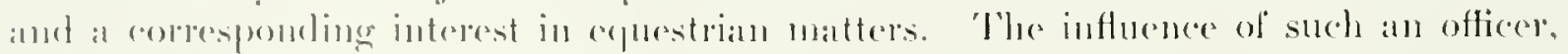

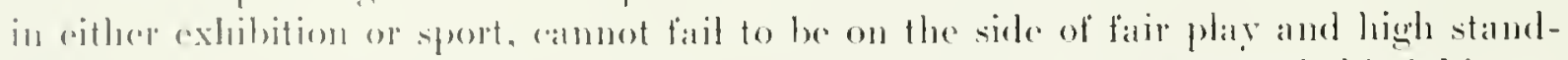
ands. In his marriage, Majol Elmsley has strengthened the ties which bind him to

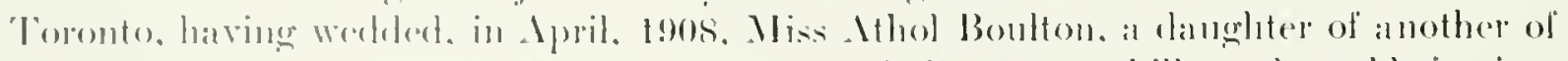
Torentos historic fandities. As les has proved his horseman skill on the velelt in times

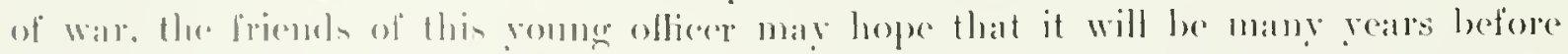

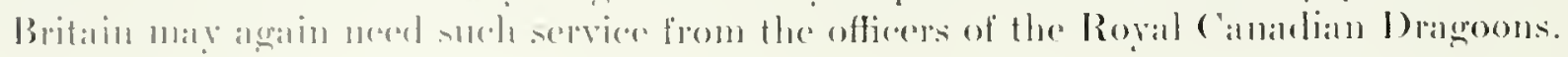

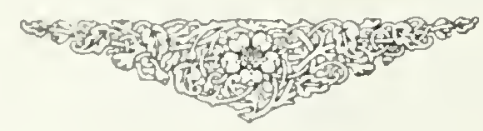




\section{CAPTAIN D. DOUGLAS YOUNG, A.D.C.}

$\mathrm{O}$

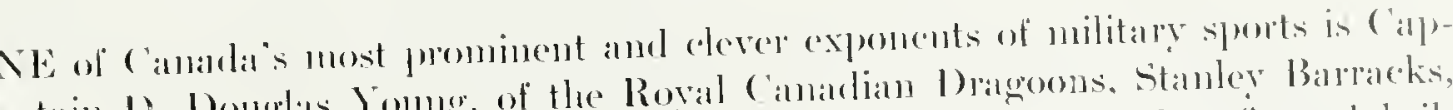

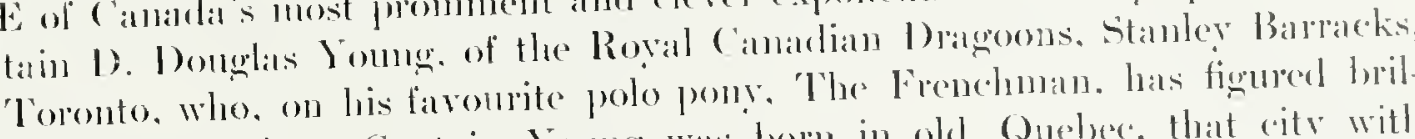
liantly in many vietories. Captan Jomg was horm in old Quebere that rity with traditions of military valome, in 1881. and is a son of colonel Jomg. now stationed in Kingston. The youngere offieer's love of the horse is a herestitary instinct, and he comes honestly by a devotion to all equestrian spouts, as his father has always heen ansidered one of the most enthusiastic lorsemen in ('anadal.

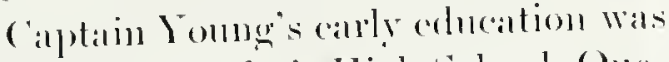
obtamed at st. John's High Sihool. ( Quebere, and he afterwats attended Lipere ('anara college. Toronto. the "Etom of Camarla," many of whose graluluates alle well known in military service. Ilis sol diesty catreer commenced in 19000 , when he went to south . Ifrica as a trooper with the Roval (alladian bougoons. The almpargens of that year were a trying ordeal for the youme volunters, but this Camalian soldier. like many another from the 1)ominion, retmrned with a geood receord of thirteren months service, and. in 1900. secureel a commission in the bovcruot-Ciencral's Bosly Cinarel. 'Toronto. 11e then entered the permanent anps as Lientenant in the Royal Canalian 1) ragroons. and a ana in went to South Africas as an offices in the (ith Camadian Momutad Rifles. selving seven montls in the trombled comutry on his second trip.

On his secend return from south

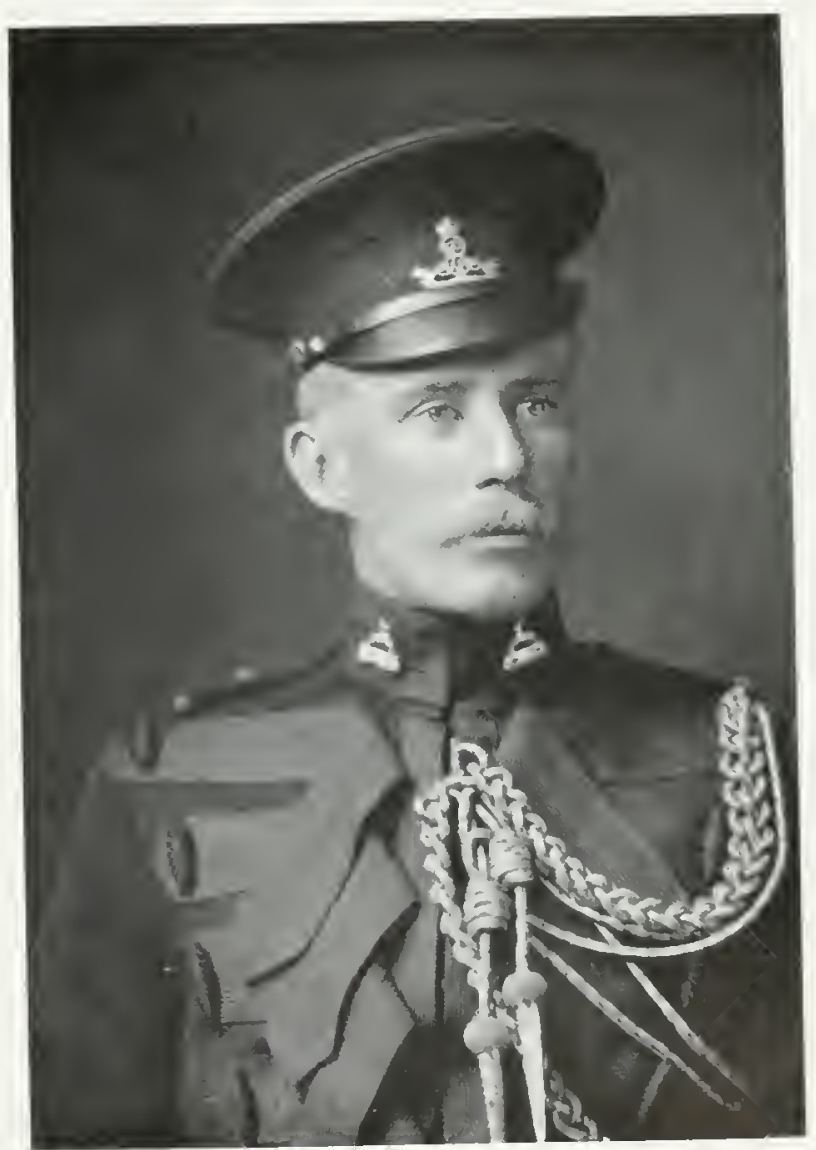

Ciptain [1. DOUglas YUUNG, A.IBC Alrica, he lesumed his dutices with the

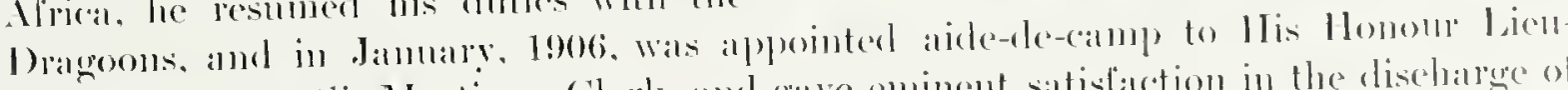

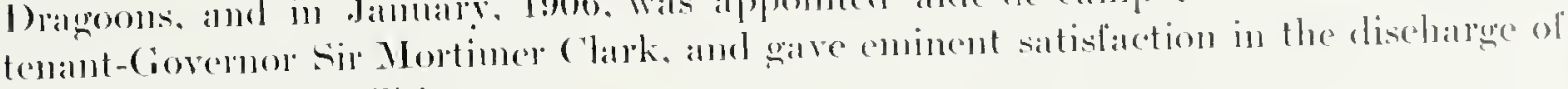
his official responsibilities.

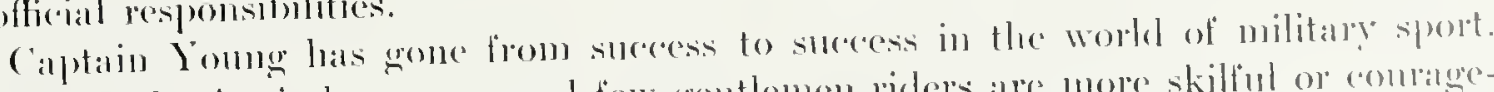
He is an enthusiastic horseman and few gentlemen riders are more skilful or andiageons. The polo ponies and the hunters claim his andmirat ion, and he has loesm a brilliant

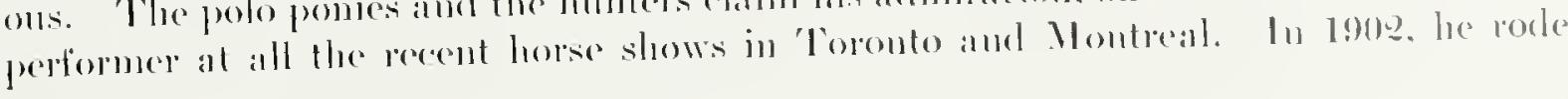




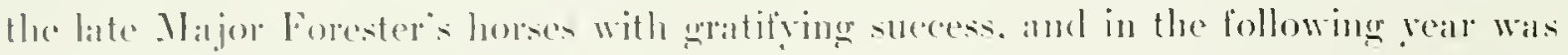
crpally fortunate and atpalle in handliuge licutenant-colonel stimsons horses at

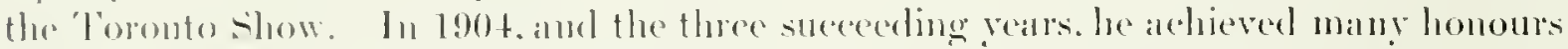
with the hornes of that gallant sportsman. IIon. Arlim Berk. and rode the Beck horses al Montrail also.

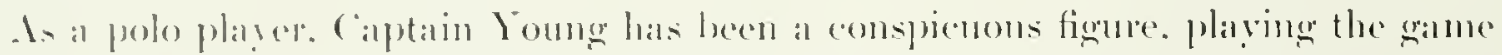
with a kerenters and athanclon whieh make him a highly valuable member of the teann.

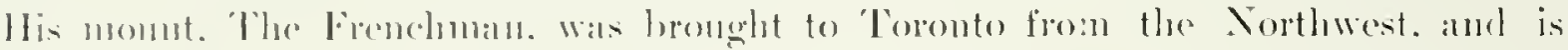

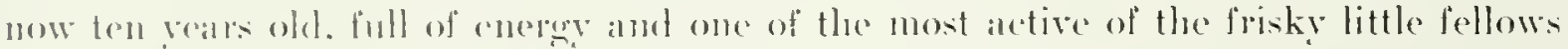
almost the cepual of The Maltese (ait. in the hest polo story evere witten.

(applain loung is an excellent atlalete. not narrowing his interests to one depantment of spolt. Ile is an export fencer and an aldept at tent-pergering. He won the

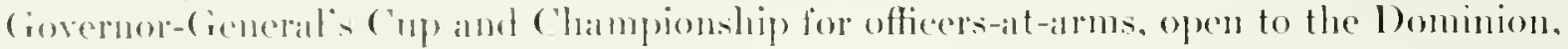
comprising six eompetitions. Ile is a skilful temnis plapers and is a member of the

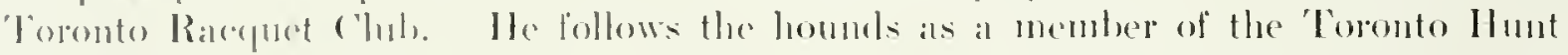

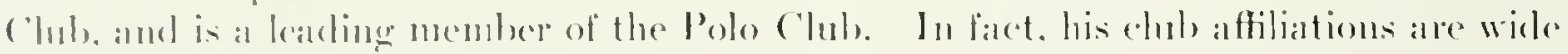

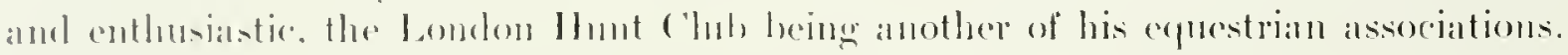

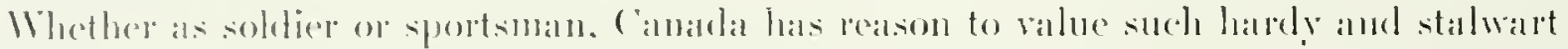

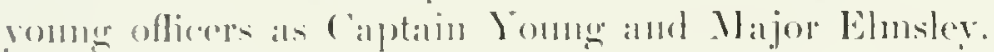

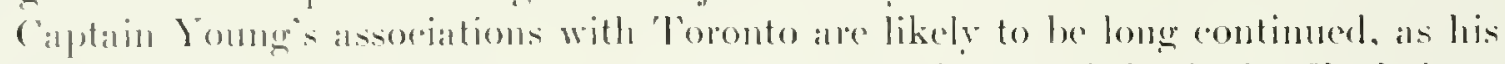

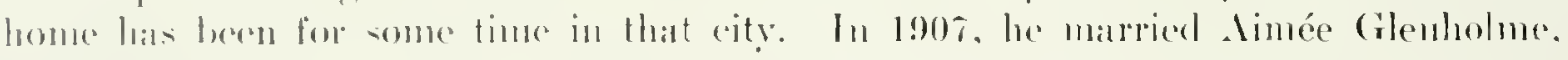

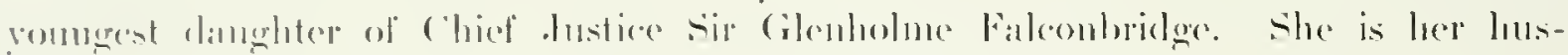

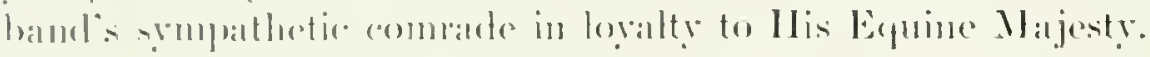

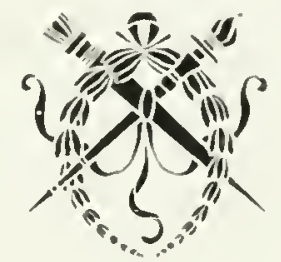




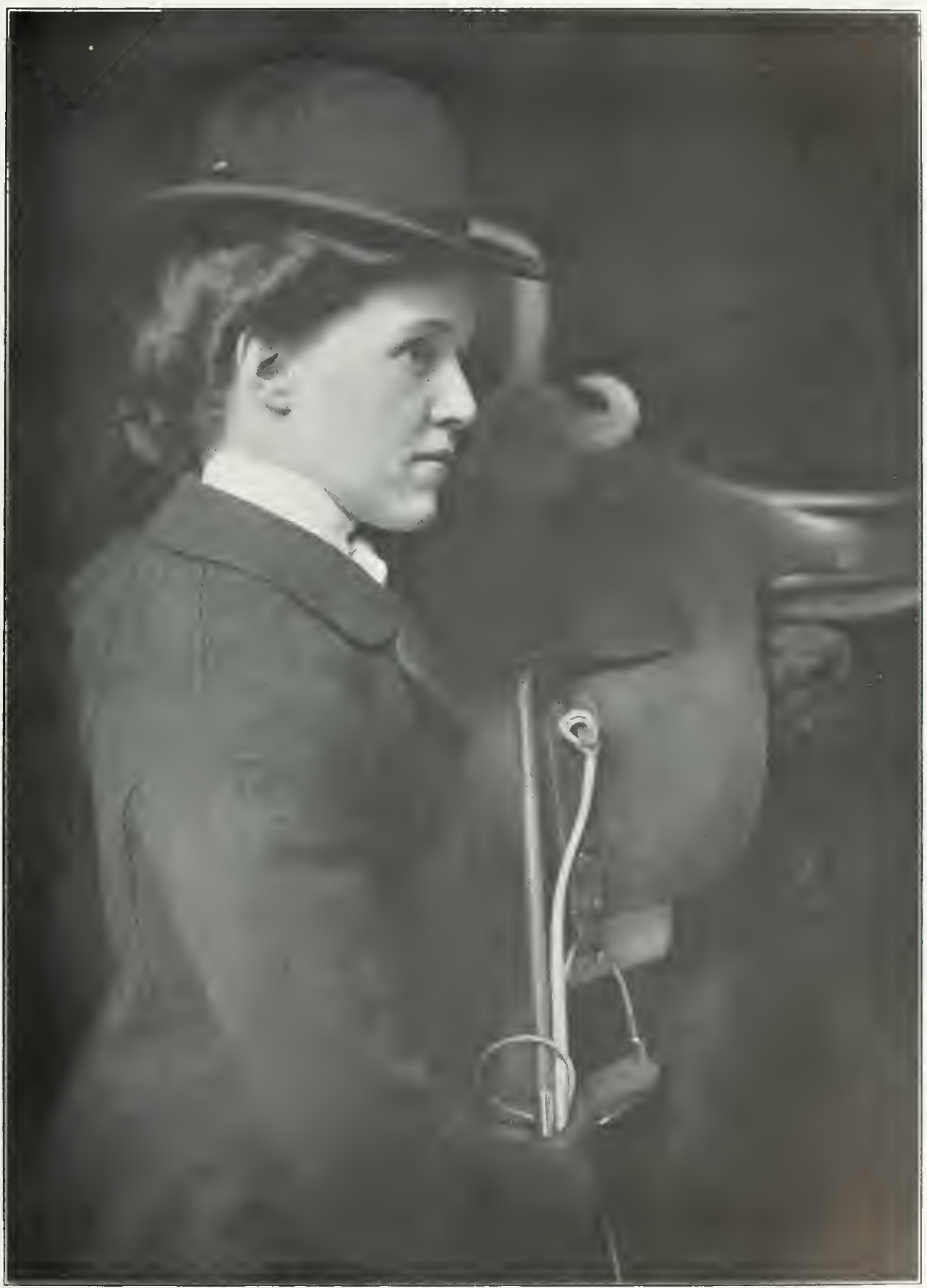

Mrs. Davan Douglas vuung 


\section{MRS. DAVID DOUGLAS YOUNG}

$\mathrm{M}^{\prime}$

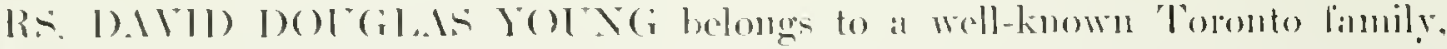

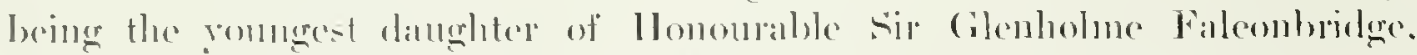

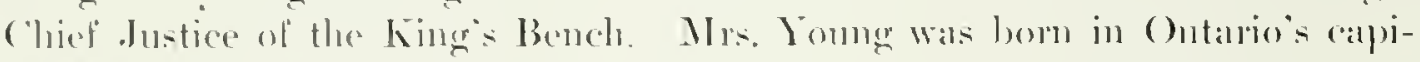

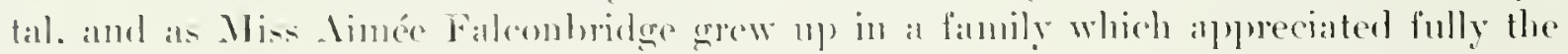

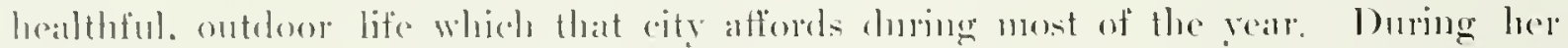
rarly girlhoul she showed a fonduces for horses and an ability in managing them more chatrateristice of English or Irish than of Camalian femininty.

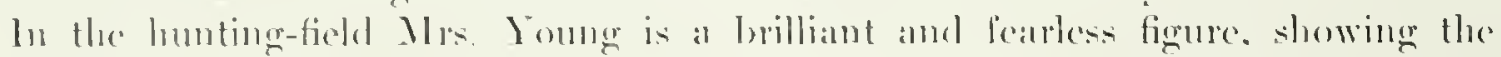

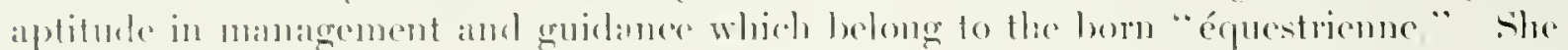

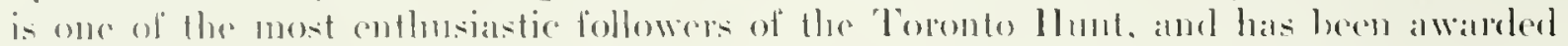

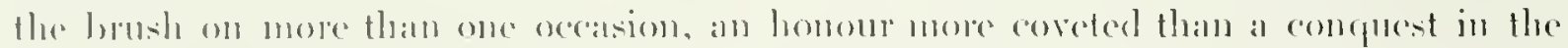

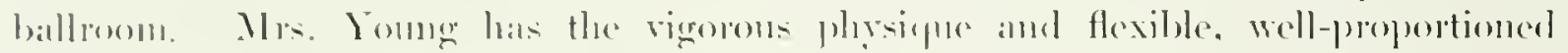
ligure which anduce to trimmphe on the hmoling-ficds.

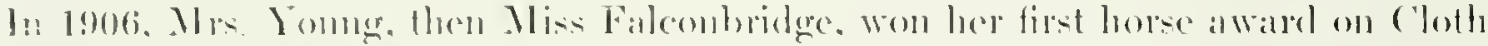

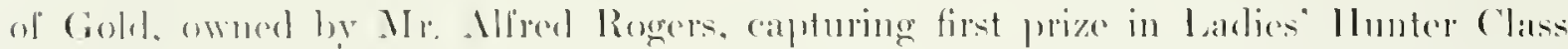

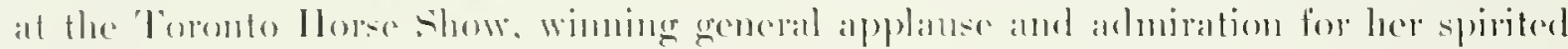
bearing. I second prize with sir Robert. owned by Mr. Herderson. of Hamiltom,

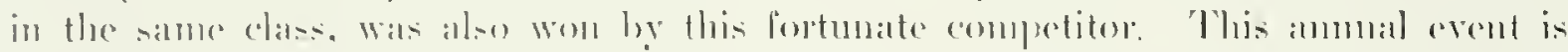

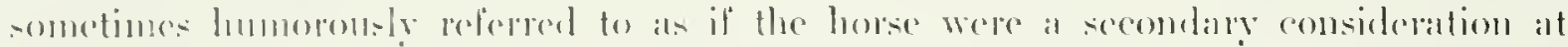

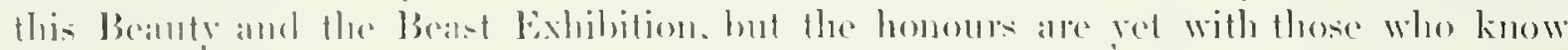

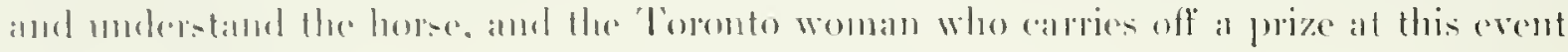

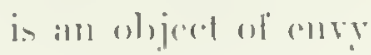

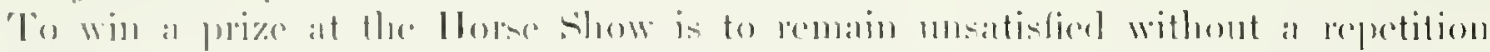

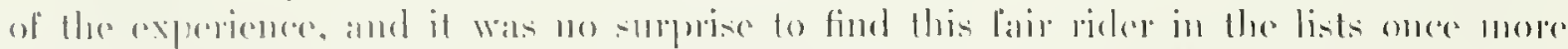

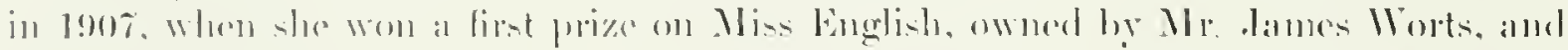

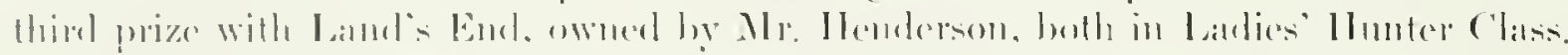

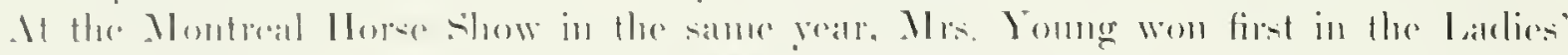

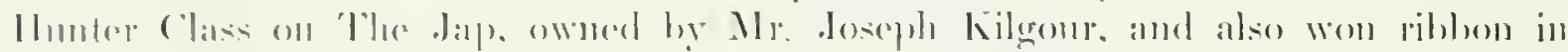

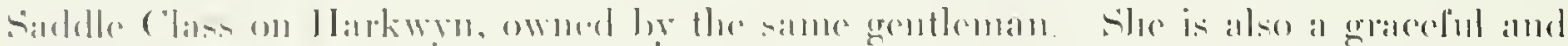

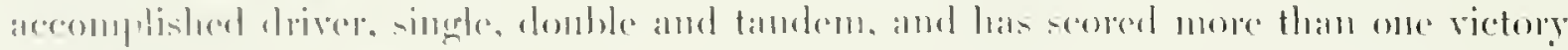

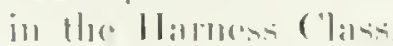

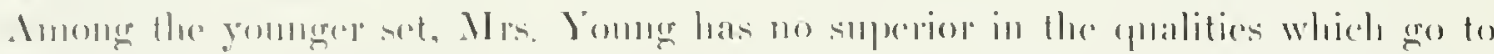

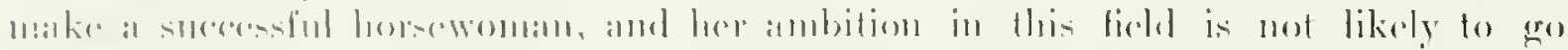

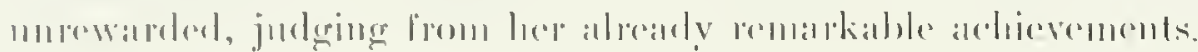

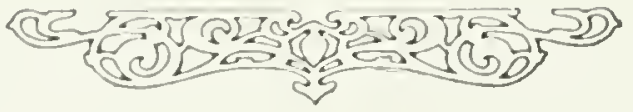




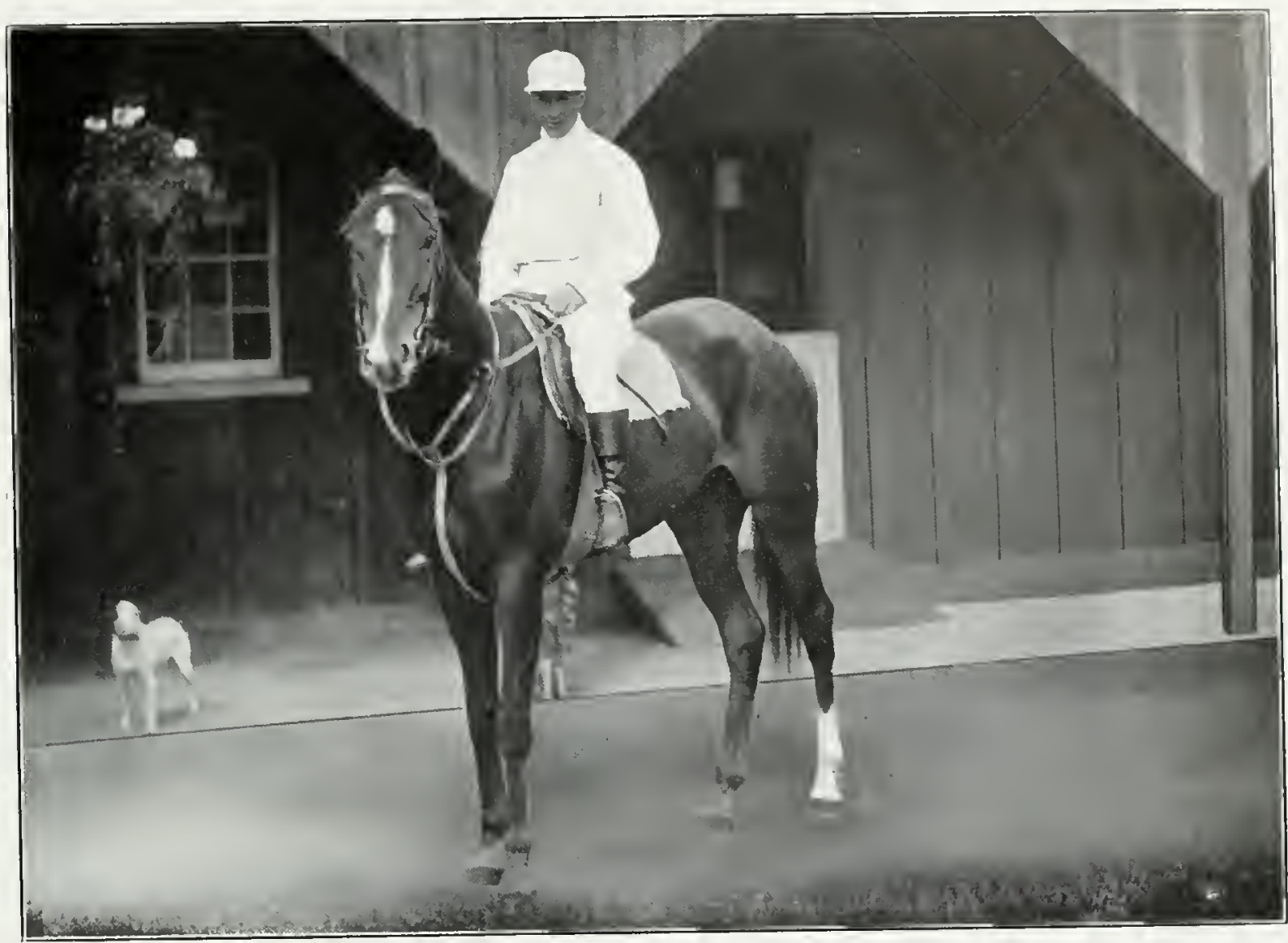

\section{BURTON HOLLAND}

A VERT good record as a gentleman rider is that of Burtom Holland. IJe is a A thoromgl Camadian, amel his father before him, Rolph Burton llollame. He

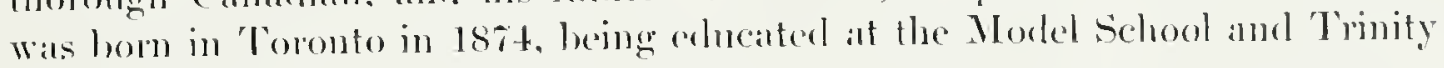
College school, Port llope.

In the fall of 1898 he roule his first race on .J. Stratelan Johnston's Ronlette, it the Comtry and Ilunt Chbs meeting at the Woolbine. Toronto, finshing third in a

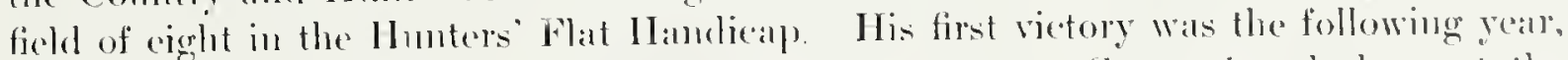
being his first steepleehase, riding Dnmont in the Open Gien steeplechase at the Wooblune: also winning the Ilunters Flat with Leading Ladly at the Nontreal Hunt

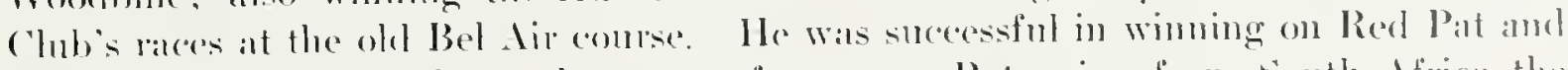
lapuring, both steeplechase, the same aftermoon. Returning from sonth Africa the following year, with the first contingent. he won with Muraly Hendrie s Barley silgall

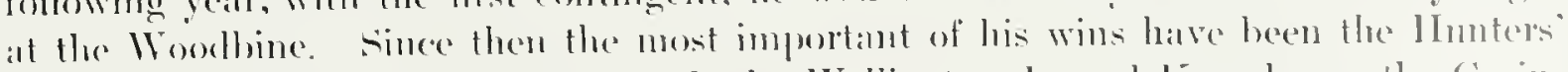

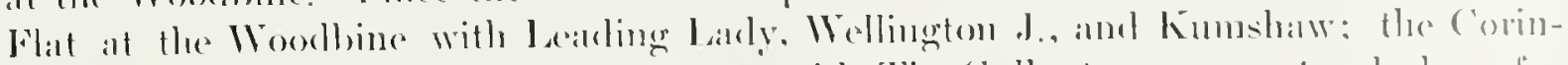

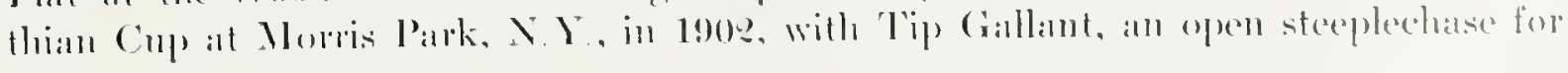




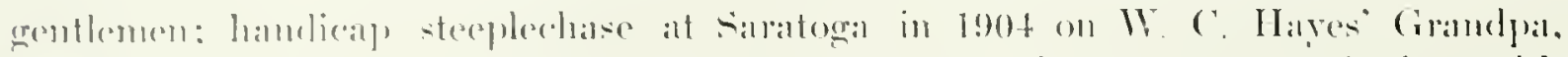

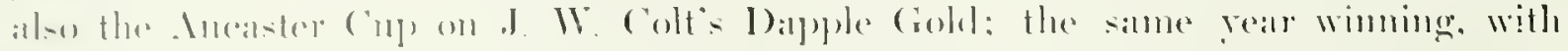

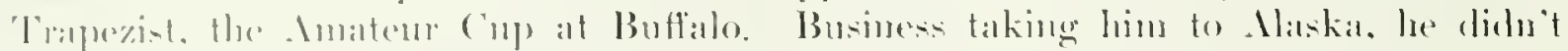

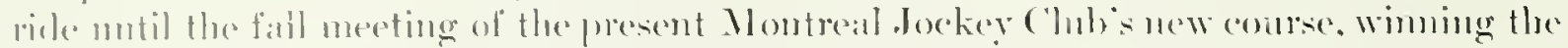

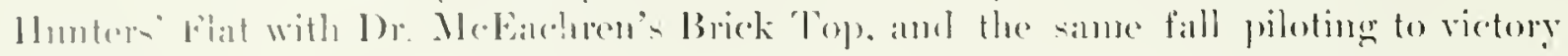

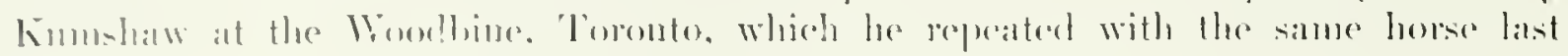
yeill:

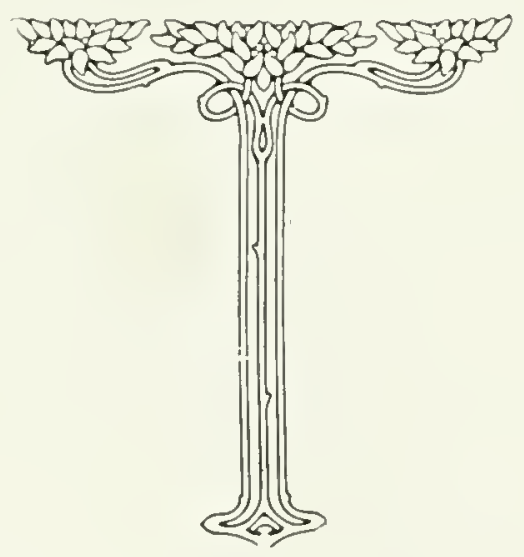




\section{ALEXANDER W. MACKENZIE}

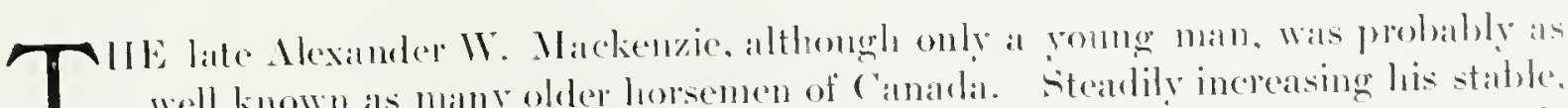
well known as many older horsemen of ('anadal. Steadily increasing his statsle. it hat beeome one of the best known on this continent. Mlex. Mackenzic Was the seeond son of William Markenzic. Whe is one of Canadia's most prominemt railroad men, being head of the Camalian Northern amb mamy other ratroat enterprises, also largely interested in the street Railway Companies of several Camadian and American cities.

The Kirkfield stathle started in the racing game in a molest manner. and as the sport grew in favor they increased their stable from time to time. gromg into partnership, with his older brother. Rodriek Mackenzie, and reaching a stromg position in the turf world. Mr. Mackenzie had always heen a lover of athbetic sports, and extablished a reputation during his college career as a first-elass all-aromad athlete.

It the time of his death. Mr. Maclienzie held the responsible position of Treasurer of the ('anadian Northern Railroad, a concern which gives promise of becoming one of the largest railronds in America. On his leaving the University he went into business with his fathere and brotlere and rapidly climbed the ladder of stleress.

Mr. Mackenzic's first start in the racing world was when the mare Ladry Berys was purdhased at a modest smom. She was an entry in the race for the Queen's Plate, the teature event of the Canadian turf. 'This mare was not very snecesstul as a race-horse. and was soon

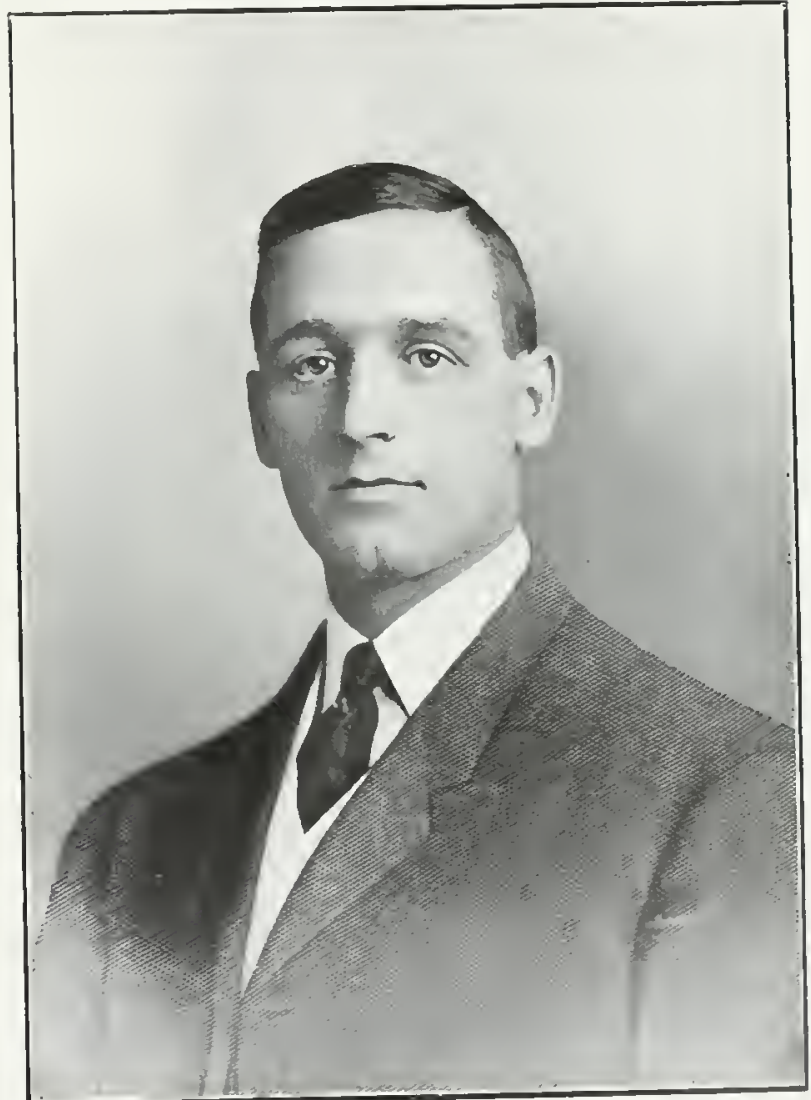

ALEXANUER W. MAKENZII replaced by the horse Heather Bee. which earried the colors of the Kirkfield stahle to the front in more than one event.

This was the commencement of what promised to be, and was. a most suceesstul, although lamentably short, eareer. After Ileather Bee had won one or two rares. a racing stable was in reality established, and more purchases were adeled. 'l'he stable was registered as the kirkfield stable, alter a town in camada. at which phace hoth Mr. Aleximder IV. Markenzie and his fither were born. 'The next purchase was made 


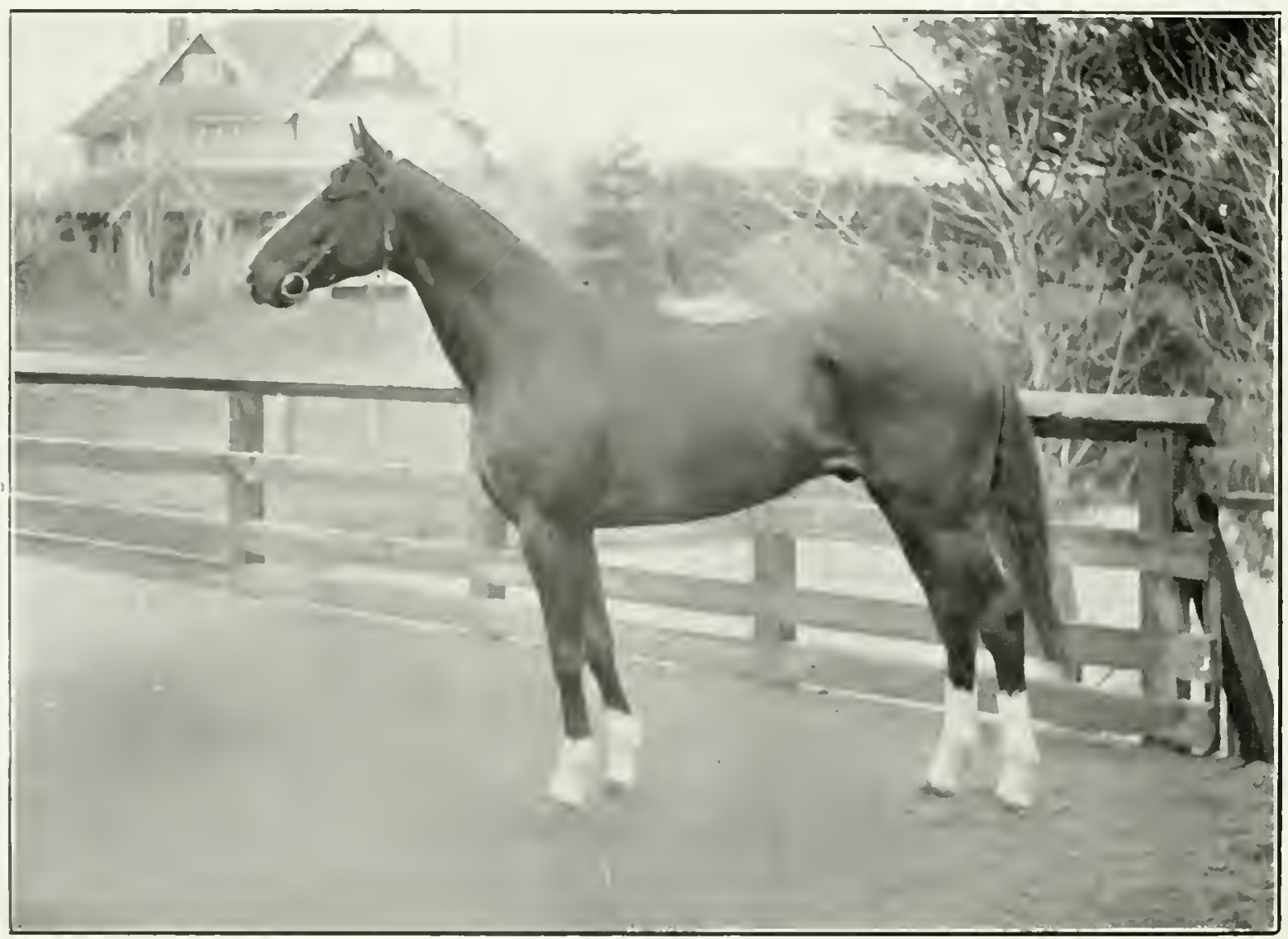

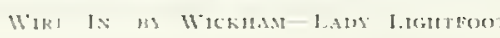

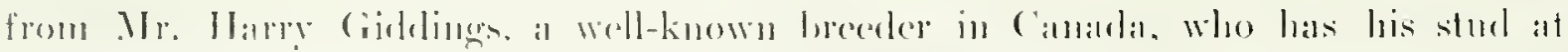

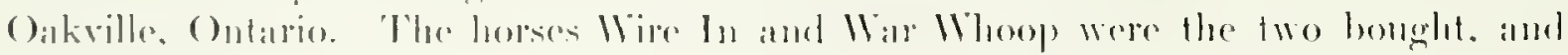

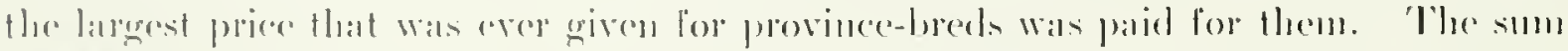

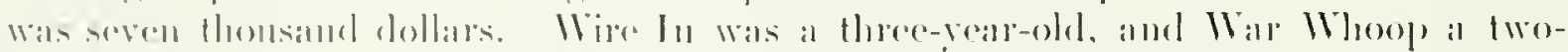

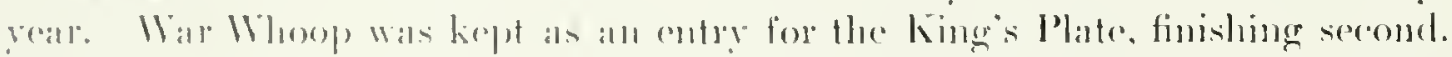

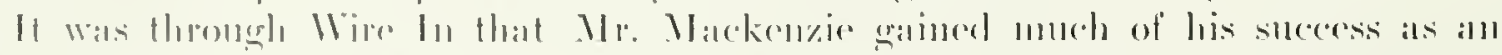

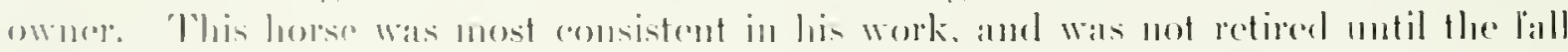

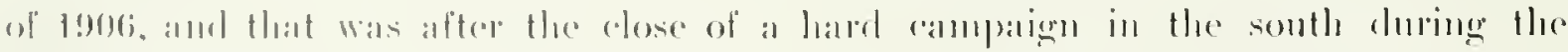

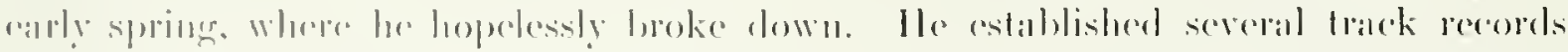

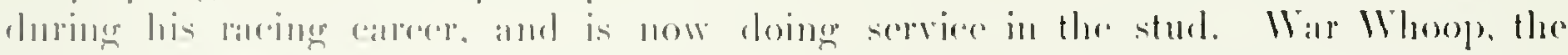

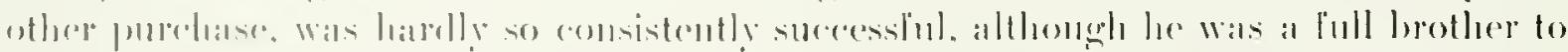

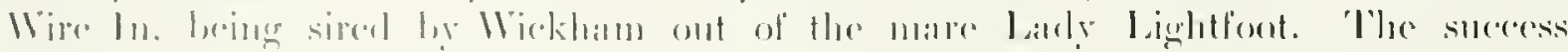

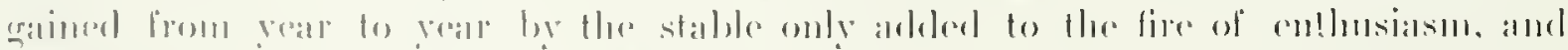

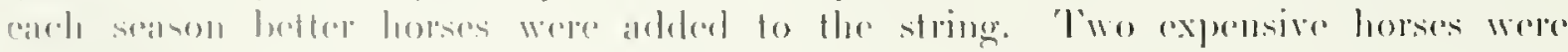

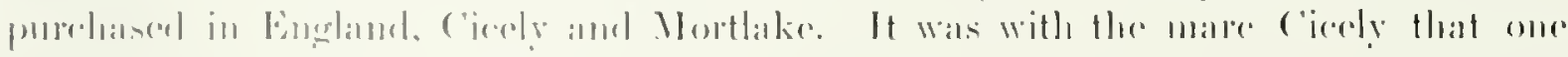

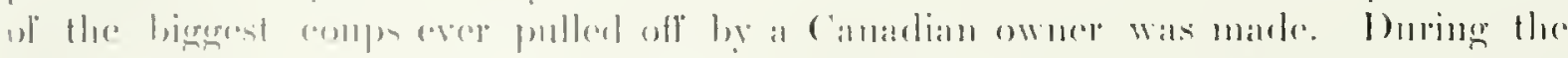

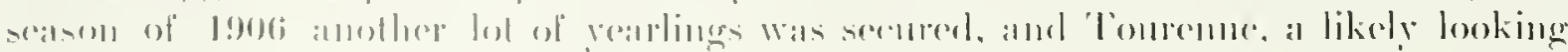


two-year. for which the sum of tem thomsand dollats wat pail. Although Toureme did not altogether fulfil expectitions he proverl himself a horse of much chass, with a silperior show of speed.

Mr. Mackenzie Was horn at Kirkficld in the yealr 1857. and afterwalds came to live in 'Toronto with his parents. He was married to Miss Kirkland, the daughter of Angus Kirklanel, the late manager of the Bank of Montreal. Mr. Martienzie's home in Rosedale was regareled as one of the most beantiful in the city of toronto.

lle was a horsenan of some ability and his figure a well-known one at the spring and fall runs with the hounds.

Mr. Mackenzie was a prominent member of hoth the Toronto and Albany two of the strongest and hest known clubs in the Province of Ontario.

Mr. Mackengic always took a great interest in military aftalirs, and held a commission in the Forty-Eighth II given him by his hother offirers of the garrison amel his regiment showed in what esteem he was held in military cirelos.

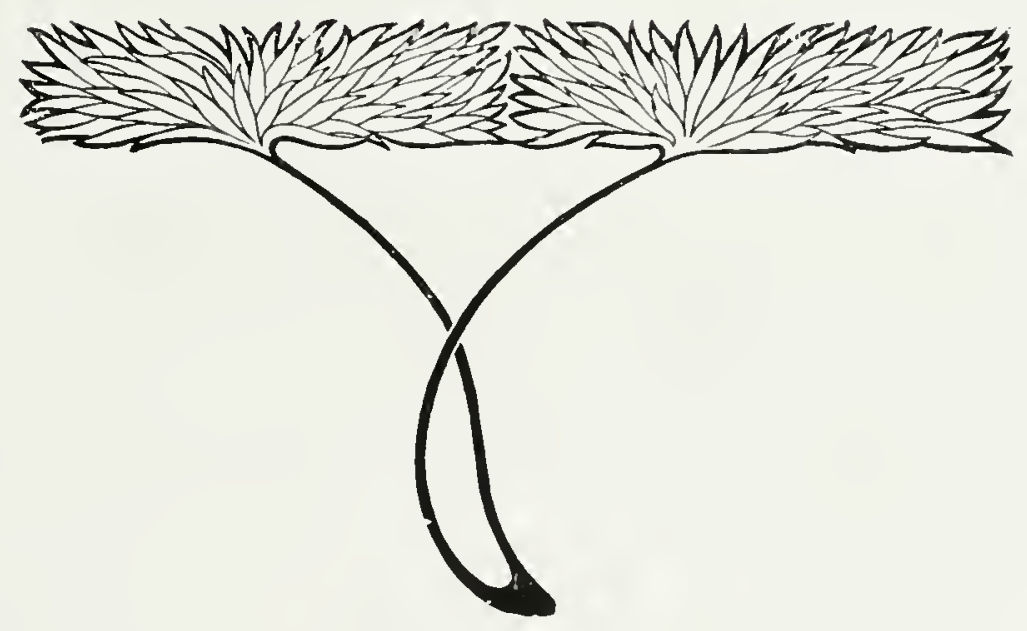




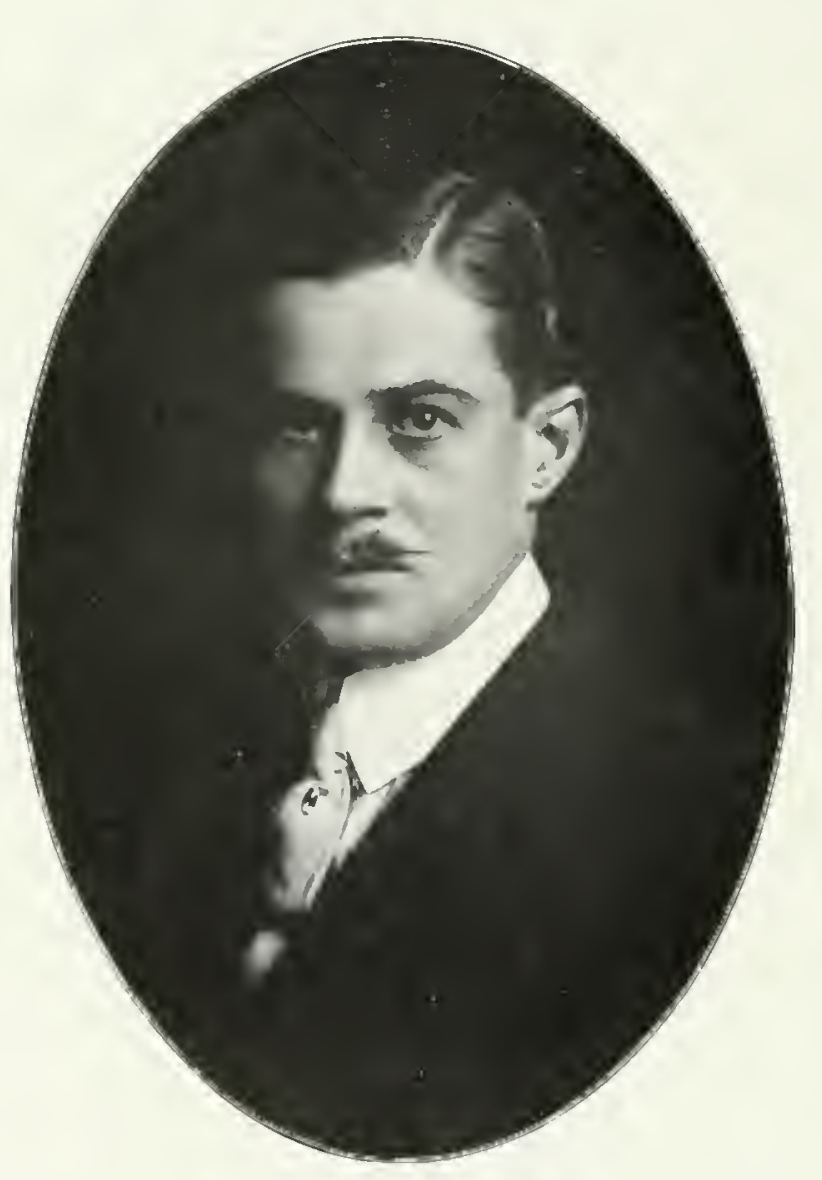

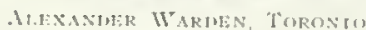




\section{SIR HUGH MONTAGU ALLAN}

$\mathrm{T}$

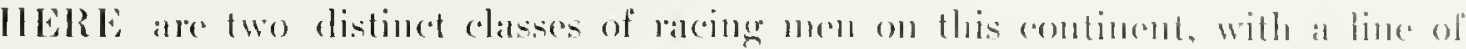
deavage, not always cleatr, but still dolinalde enomgh lo make the student of human mature and real lover of sport rearet that so few ment will reallize that

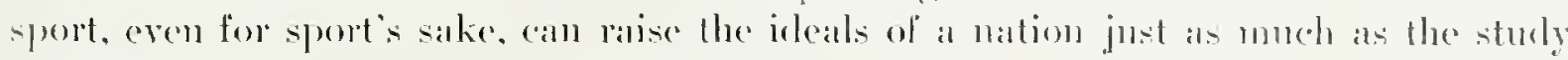
of the lareger problems. On the one hamel we have the owner of a string of four on

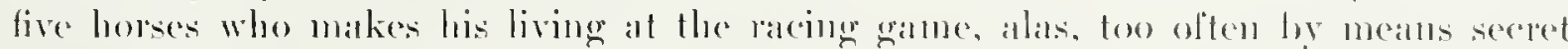
and devilish, which even the vigilanee of the officials camot always penetrate, and there are aven men of goose finameial positions, who go in for racinge just as they ero in for other specolations. Now these men ane no creslit io the game, and anumot by any stretele of indagination be termed sportimon.

On the other hatud we have gerentlemen of soreial and finameda position, who grive their time, influence, amel money lo not moly keep sport aleam, but to laise it to the stamblard that is set in Europe.

In the latter category can be platerel Sir Montarna Mllan, the Presilent of the llomtral. Jockey (lub a man who wats determined at the ontsed to make the Montreal Meet a credit to Camallian sport. Jlow weell he sucerestert we all know, but not many realize the diffientties he hat toovereome the shoals of religions prejuelice, ancl racial ignorances. he had to sail through withont striking at rock; the machinations of alever and raparcions racing sharks he had to fight all these sir Montangu diel, with the result that the Montreal Ratee Meeting is

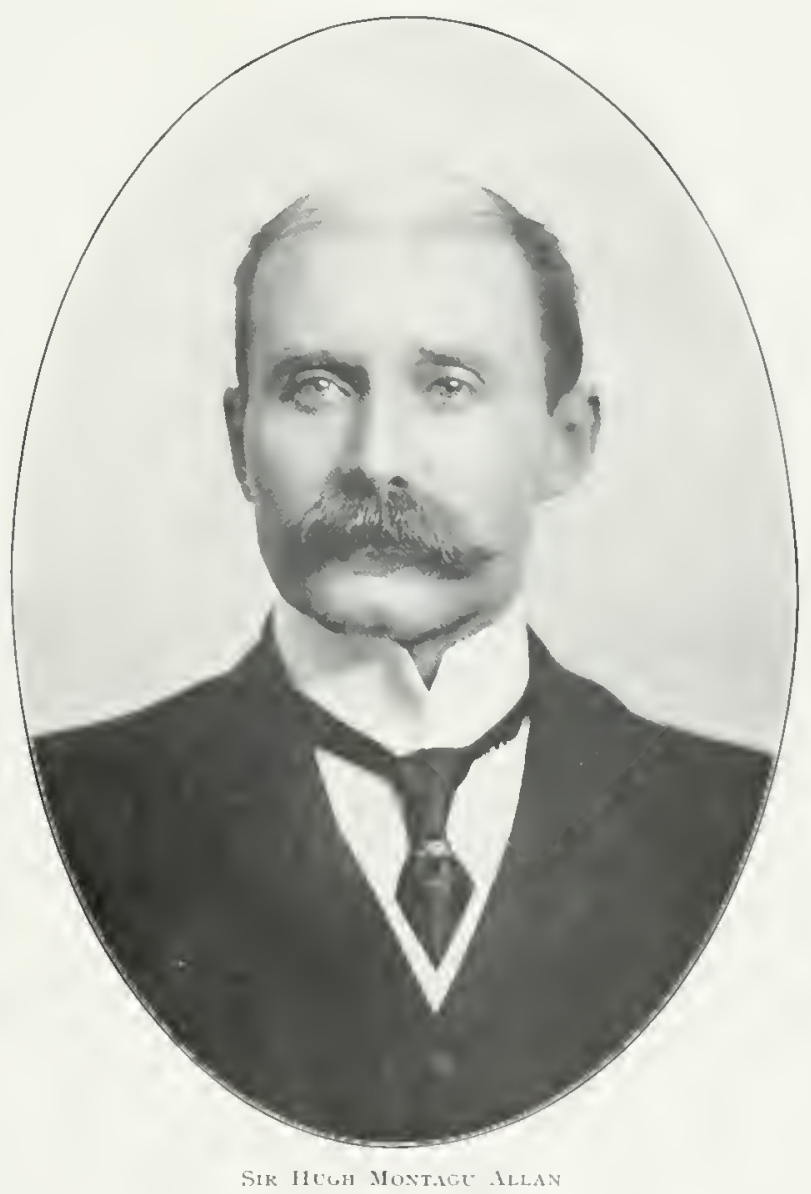
helel, and rightly so, as an ieleal place to see the finest sight in the worlel a horse race

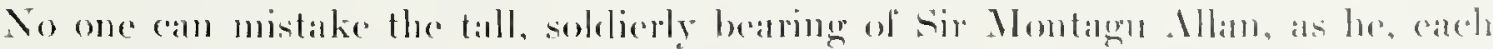
spring and fall, dispenses, with rale lace Hat hosputality at the Mentreal Meet which has not been the least to make it famous.

With a talent all his own, what one might term a mixture of seoteh shluewaluess

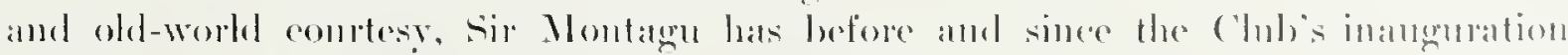

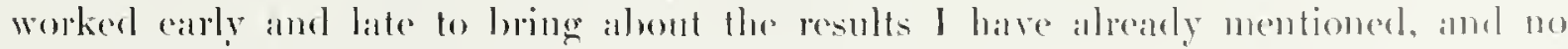
more litting and appropriate homor conld be matle than his chection als president. 


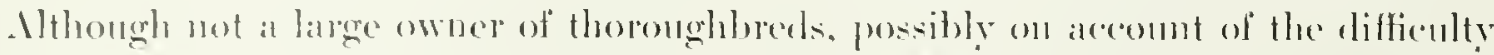

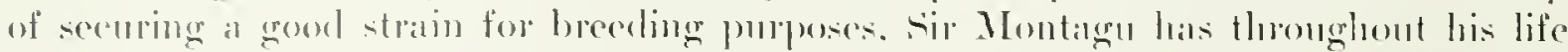
been a kecul lover of horses. having been for many years a member of the Montreal Fox Hunt ('bub- the year 189) being a memorable one inasmuch as his fellow-members presented him with a portrat of hinself, by llapris. R. C.... on the oceasion of lis marriage. IIe ledel the eoveted prosition of Master from 1s9s to 18:9s. Sir Montagn takes a spectial pride in his barcks. and the antomohile is not ret built that will take precerlence of his beantiful harmess horses. Wonld that Camadil hat a tew more such sprited men who take a real pride in their horses, who alre proul to take theid friends romed their stables pointing out the bealuty of this malre. the perfect bearing of that loorse. Too many of our wealthy men alle really ashamed of their stables, but are too mean to rephace the sorly weeks for horses that would be a pride to this f bominion.

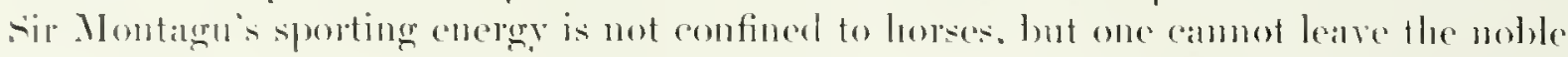
animal without mentioning that this real sportsman is on the fixedentive Committed

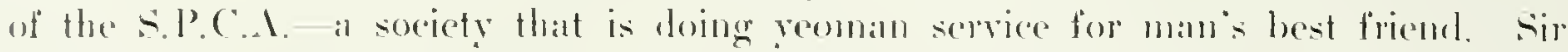
Montagu takes a great interest in the Amatenl skating Association and in racepuets. buingr Vice-Presilent of the Racepuet Club.

'This sketreh of sir Monfagn . Mhan is more or less confined to his interest in sport. and horses in particulals. Get no story would be eomplete without a few words of him als a business man

sil Hugh Montagu . Mlan (to give him his lull title) is the second son of that domgrhtr

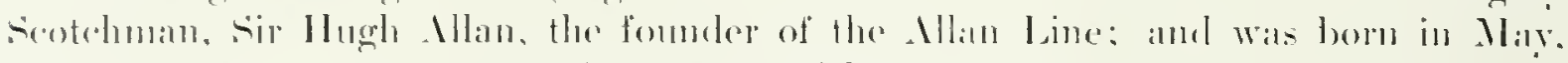

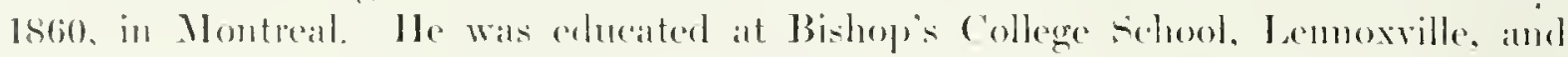

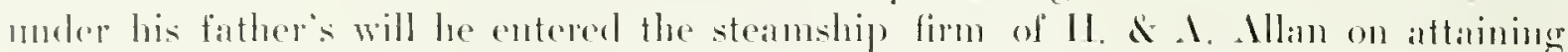
lis majority, and is now one of the semor members of the ('ompany. The firm in

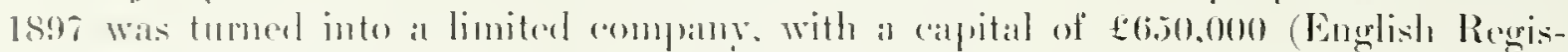

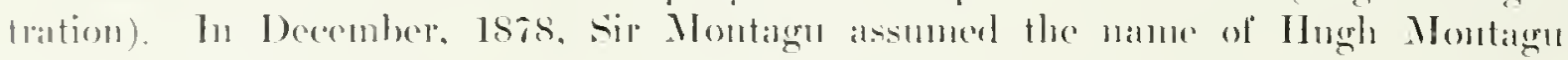
insteand of IJugh Audrew.

Is his business experience grew, sir Montagn went into other projerets, and is mow, to mention a few, dipertor of the following companies: Areatial coal co. Montreal Manufacturing (o.. Montreal Rolling Mills, Camarlal Palper Co. Cilladal

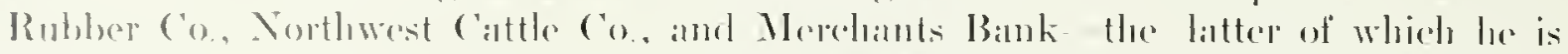

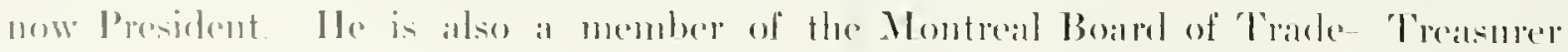

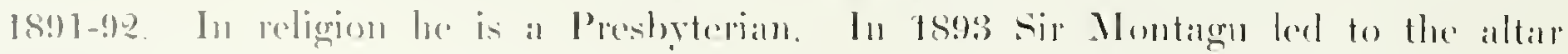

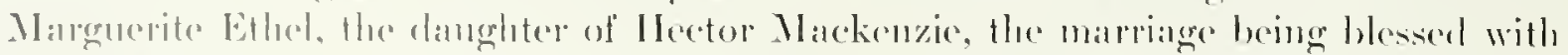
there children.

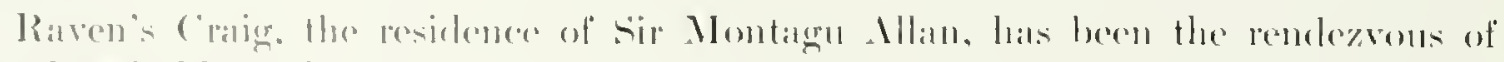

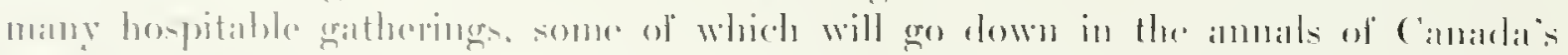

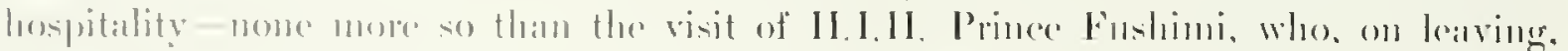

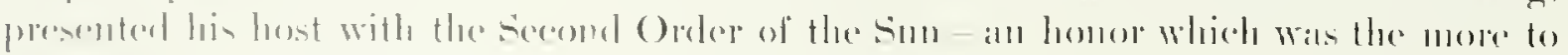

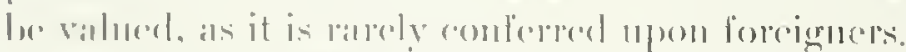

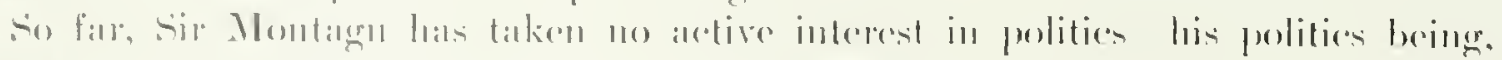

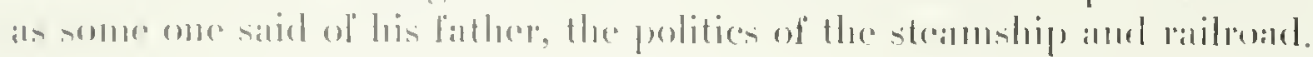




\section{Lovers of the Horse}

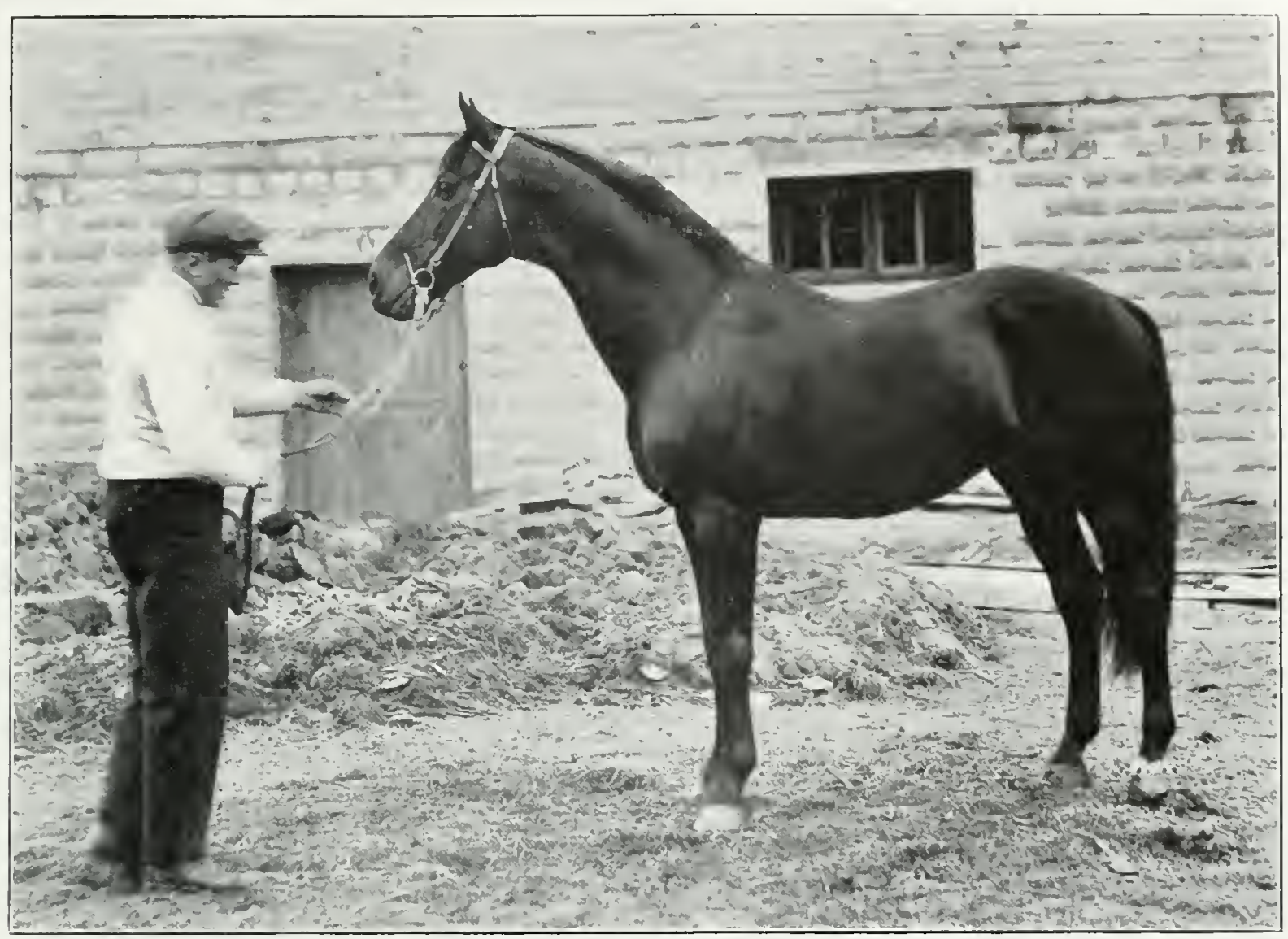

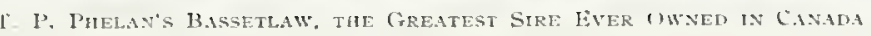

\section{T. P. PHELAN}

$\mathrm{O}$

YE of the old hrigate of hunting nen in 'Toronte is Mr. T. P. Phelan, who still heartily enjoys the great sport as much, if not more, than ever. although he has consistently followed the homme since the early 80 s, and has always been distinguished on a breedy looking horse. for in his dhoice of any kind of an equme he is fast in his fondness of a thoromghlored. Mr. Phelan has been al useful and enthusiastic membere of the Toronto comntry and llunt ('lub for at quarter of a century, and during his career has owned and raced such estimable performers as Herenles, Highie. Woolgatlerer. Crelone and Driftwool. Herenles was the champion steeplechlaser of his rear. and found much favor with Mr. Phelan. who. however. strongly maintains that his stal actor. Driftwood. Was erer his fir vorite mount. and his enlogies of the now departed pet are endorsed hy Mr. Pledan's associates. Who cam call to mind the many goor quilities of the great horse which won thee cross-comntry events at Saratoga hefore being reoggnized as a homter. Mr. Phelan won nany a cross-country hunt on this fine horse. Which eleerfully earried him to victory witl a malnifest shatre in the enjoyment. 


\section{$164 \quad$ Lovers of the Horse}

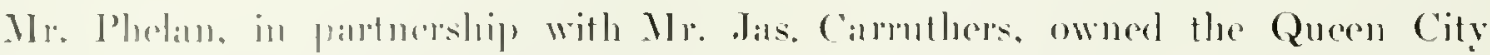
stables, with heallefiarters at the Woodhine. Toronto, and rated such goorl ones as

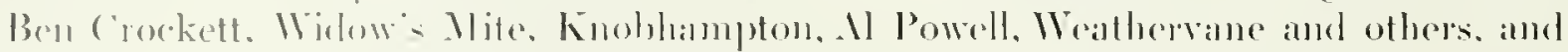

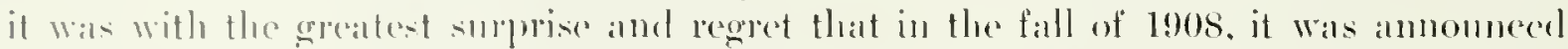

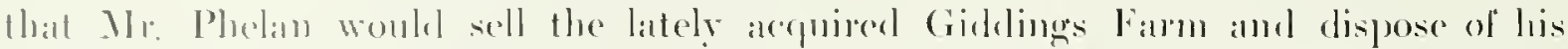
stathle. While evervone almired the sentiment which led Mr. Plichan to take this step. one and all hope that at some future time he will retum to the turfe for at the time ol

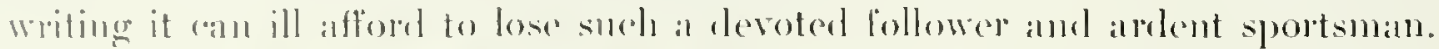

In eomertion with the firrol-

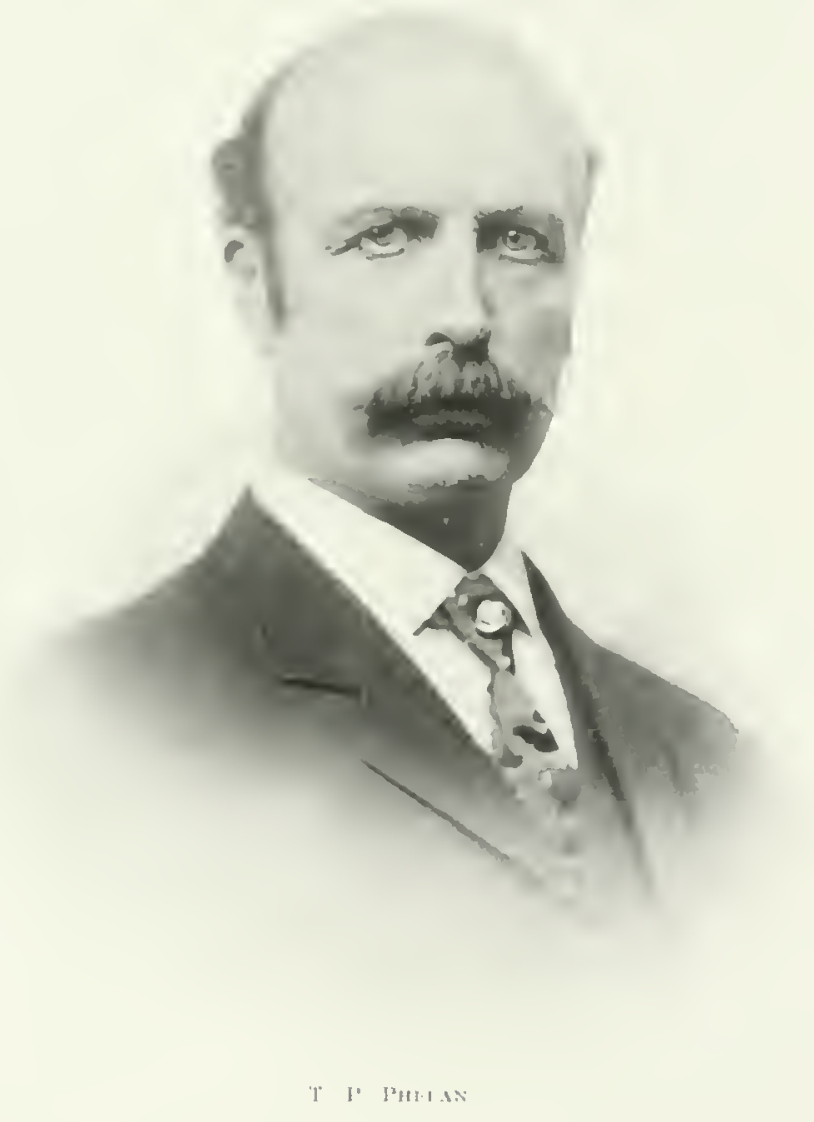
ite hunter I)riftwood, the writer alled to mind the pasticular racese at 'lomonto, years ango. in which Mr. Phelan ocempied a most mingue position. inasmucle as lo owned the horse, trained and rode it himself. and also sent inte the letting ring so much money on his horse, that the bookies deenoed it wise to tum their slites. 'This.

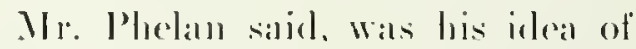
doinge a thime thoroughly. Mis ralre, lorsemanships and ronfidenere were not without hlueir jerward, for the race was wom alfter a desperate finish with C'lamdos and lambloroker. pidelen resperelively he Allio Lomdon and l)r. ('anpledl. Mlthough lhis event

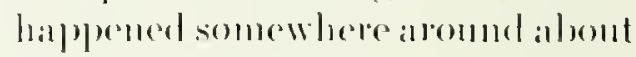
1sss, it is still fresh in the memory of those whose pleasure it was to wituess it. Mamy pleasant

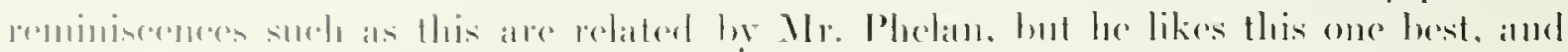

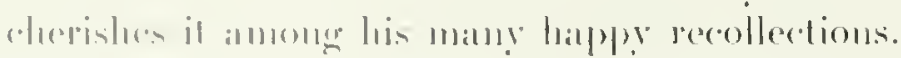

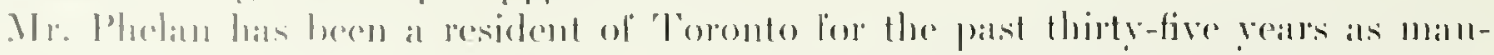

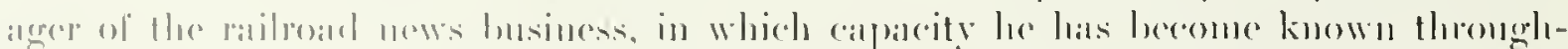

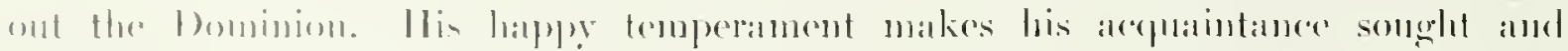

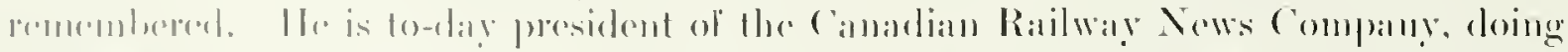

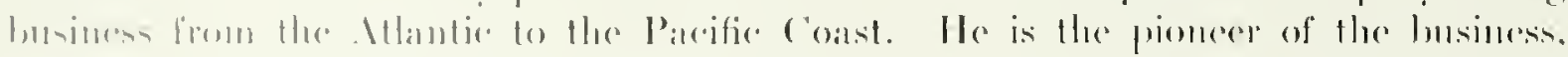

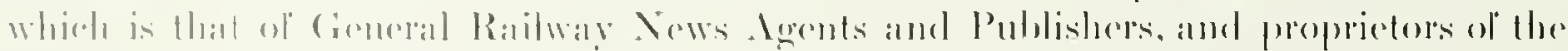

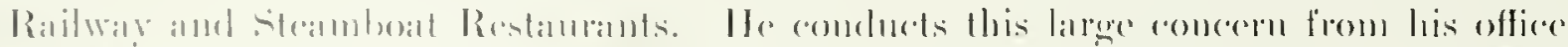

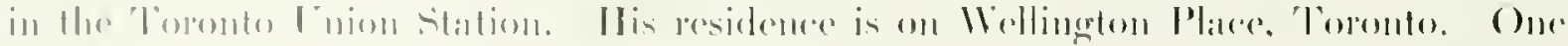


of his favorite receations is knockinge down the ten pins, and amonge the valued tro-

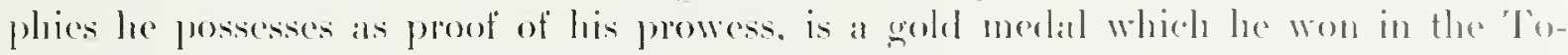
ronto Bowling ('lut tommanent early in 1907. 'The contest was for all conters orer

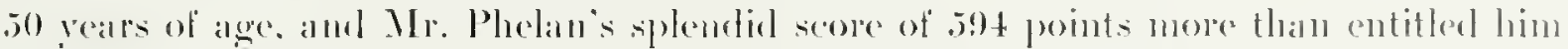
to his victory. Ilis son lived is widely known as at skilful amatenr saldor. who las competed strecessfully in intermational contests. Ilis secomel som. IIarry M. Mhelan. holds the important office of aeconntant of the ("analdian Railway News company. Ile is a member of the 'loronte llunt ('hal), and has demonstrated his ability to follow his father's footsteps as a clever horseman. having ridden the horse I Iarrold lawis to victory at the Woodhine races. Toponto. in the fall of 190.5. He is an all-round athlete. and is particularly fomel of haseball. heinge comsidered the best andente pitelere in Toronto, if not in the Dominion.

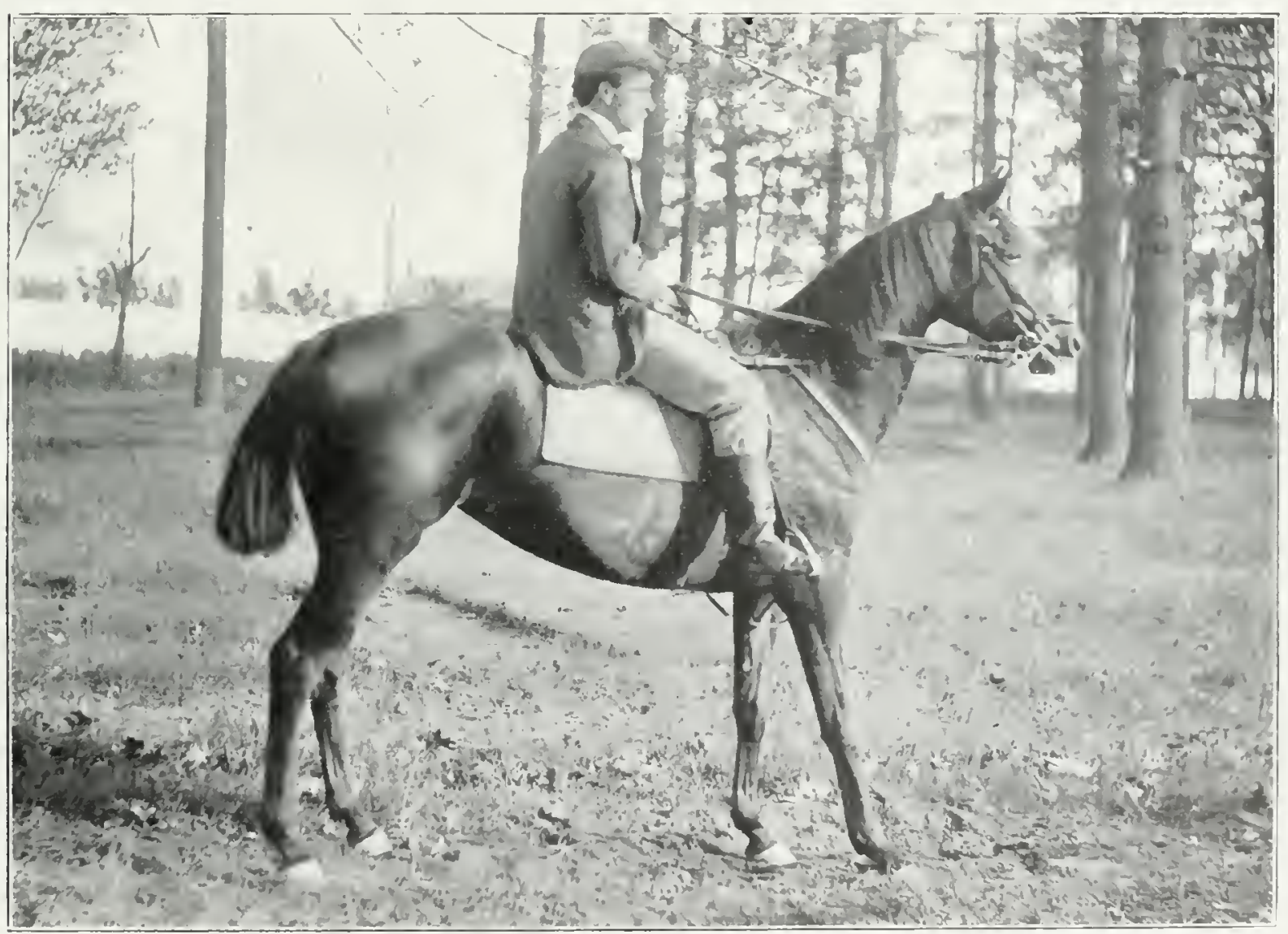

HARRY W", I'HELA: 


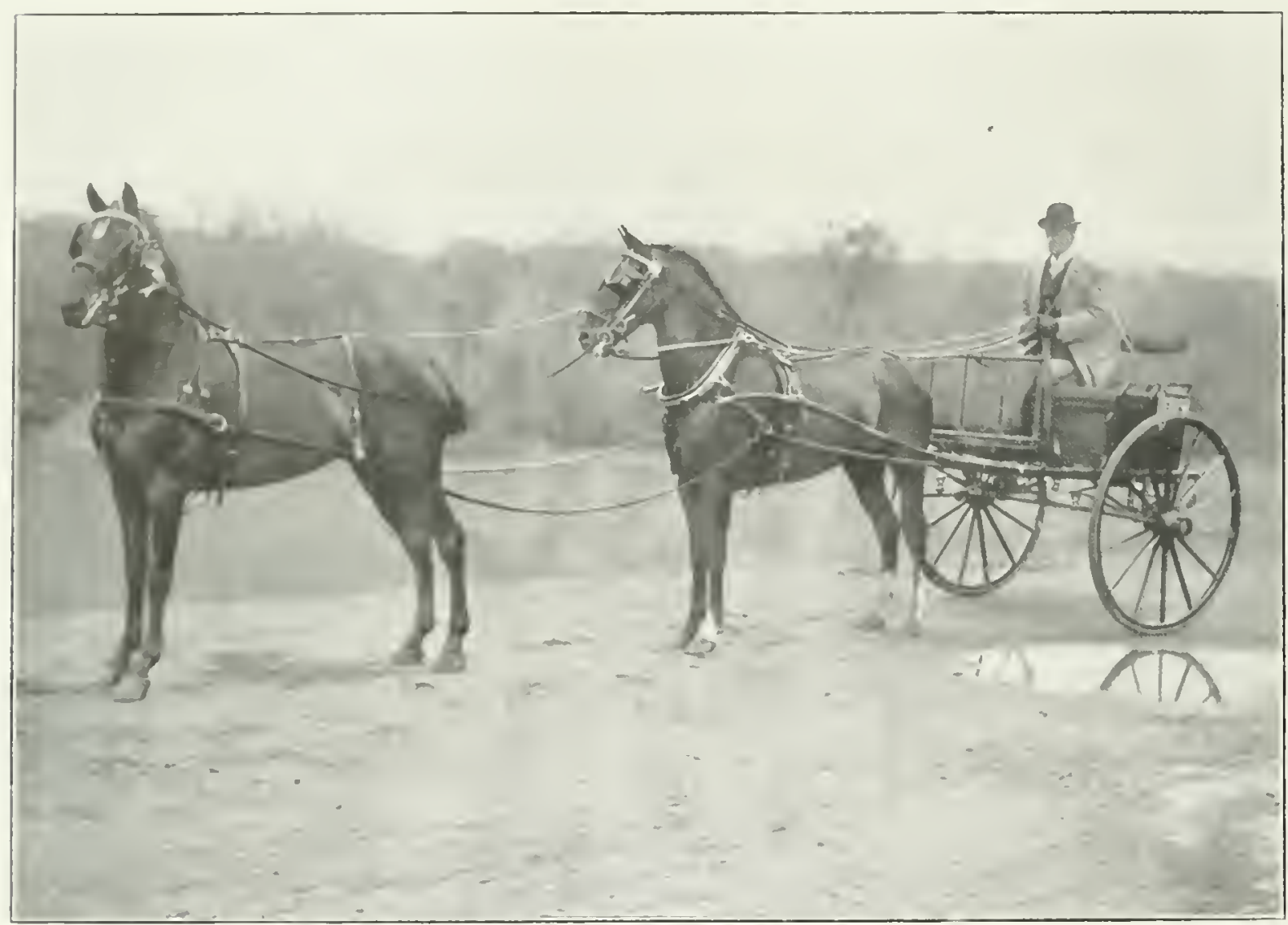

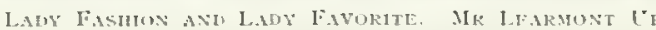

\section{HALTON HAMILTON LEARMONT}

$\mathrm{T}$

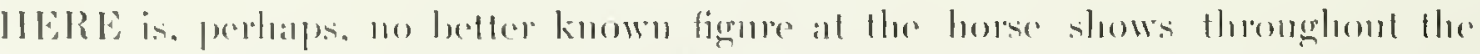

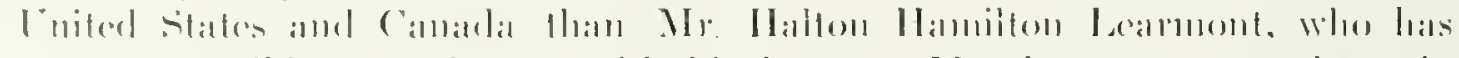
wom mally ribhoms amel colps with his lomses. Mr. Leamont was born in

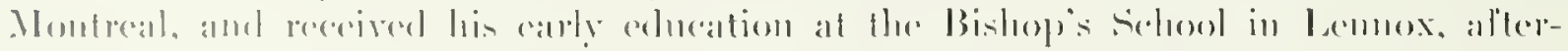

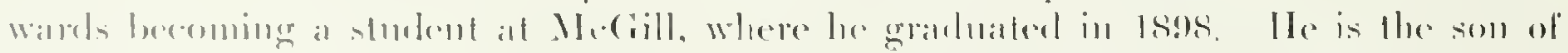

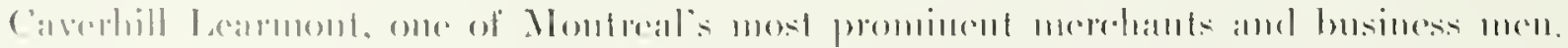

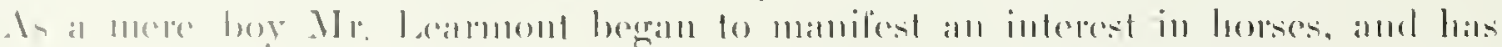

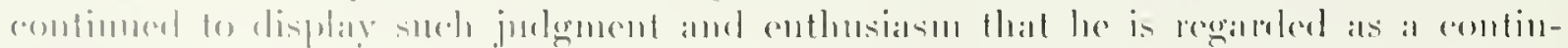

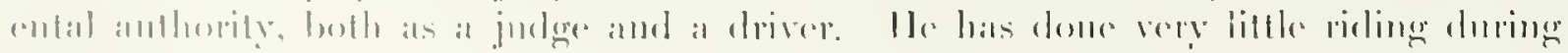

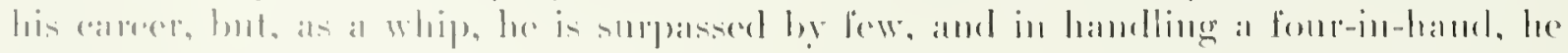

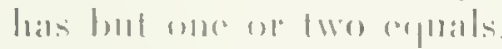

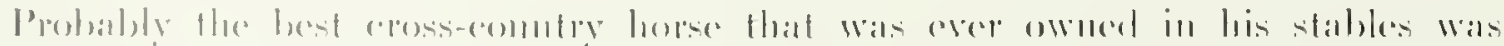

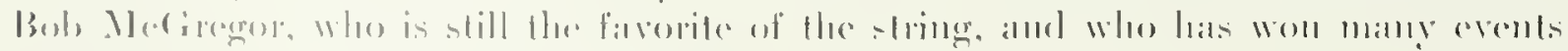

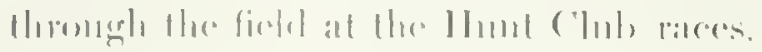




\section{Lovers of the Horse}

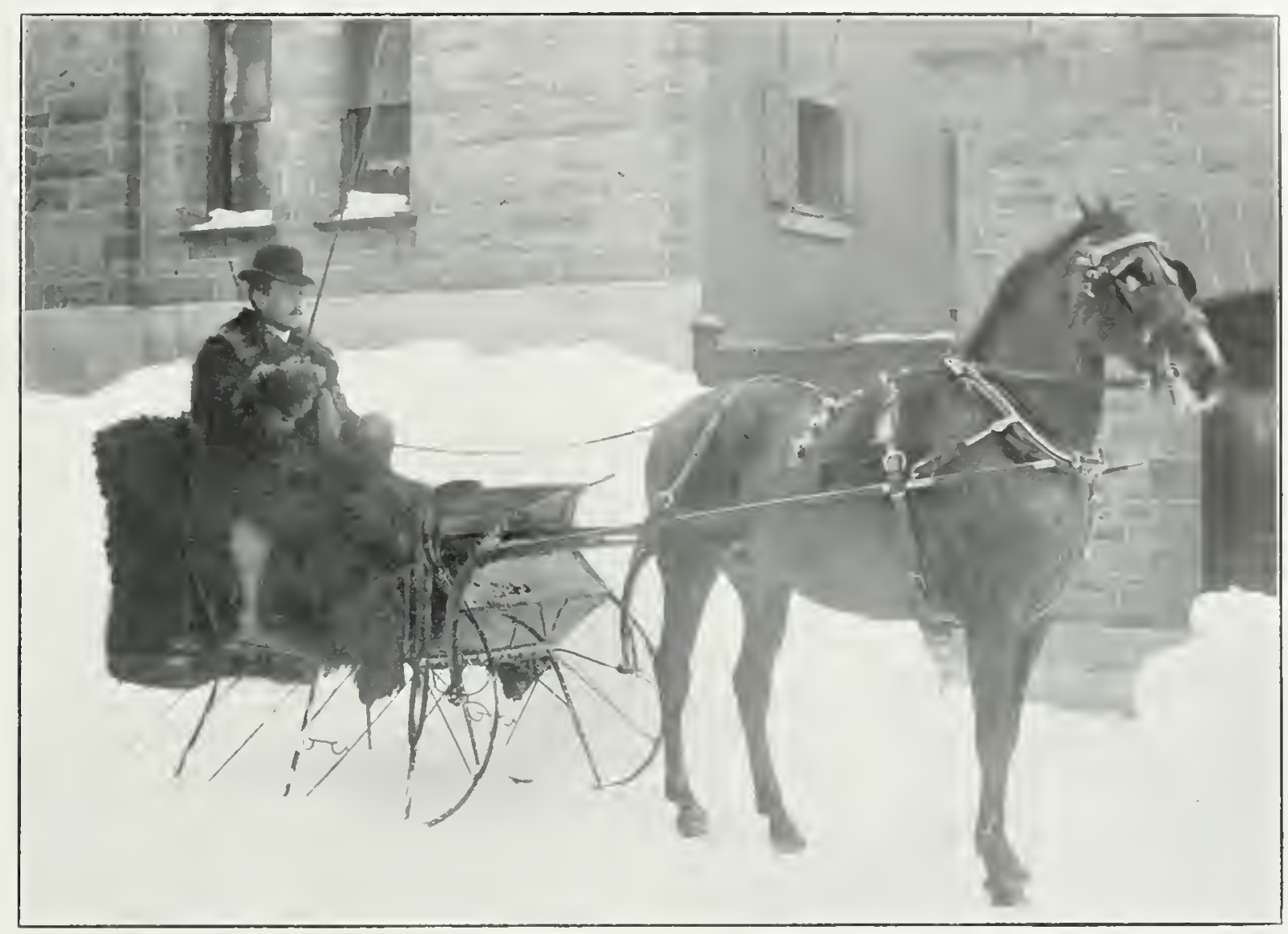

Little boy Blue. Heskey Sire Jearlee chef

Ile is well bred, having just enough of the trotting stock in lim to temper the nervousuess of the thoronghbred. while at the same time he hats plenty of speed. Il

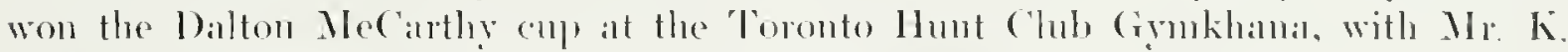
R. Marshall ats rider, and was alse a winner at Montreal and other platere

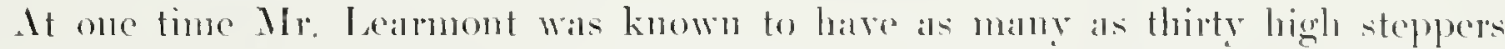
in his stable at Montreal. Widl this string. lo wom over five humberl ribbous and

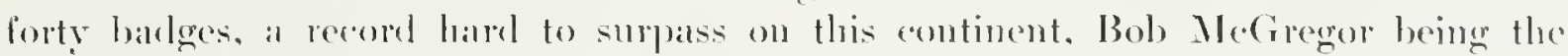
sreatest wimer. with nine firsts and two seconcls to his eredit.

Nothing gives Mr. I a armont more pleasure than to take al green horse and fit it for the ring. 1le has an exechlent method of training, amb when a horse leares his stibles, it is realy for the work expereted of it. Many of his horses have been solel to

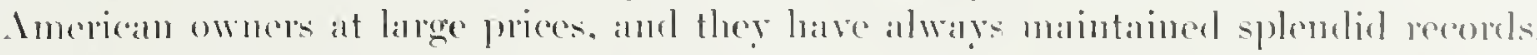

Mr. Lamont hats won prizes at the famoms Bustom horee show, and at Matison

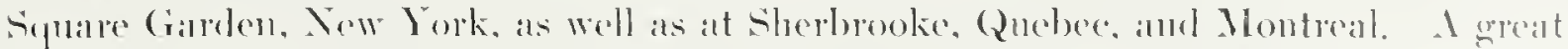
deal of the credit for the anmual holse show at Montreal is due to Mr. I earmont, who has maintained his stable at gareat expense.

Mr. Lammont is prominent in business circles in Moutreal, is al member of the Montreal Jackey Club, the St. James Club, anel the Montreal Athletie Issociation. 


\section{LOTHAR REINHARDT}

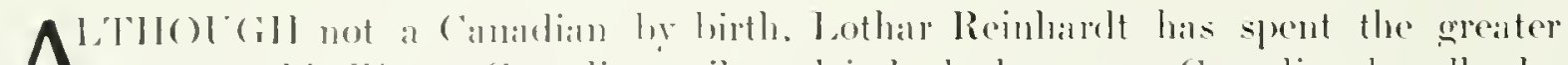
A part of his life on camalian soil. and is looked on as a Camaldian by all who know him. Tle is the oldest son of l,othan Reinhamelt. of Toronto, who is one of Hoit eity"s nue-t prominent husiness men.

Lothall Reinhardt junion received his education at Toronto. being one of the many

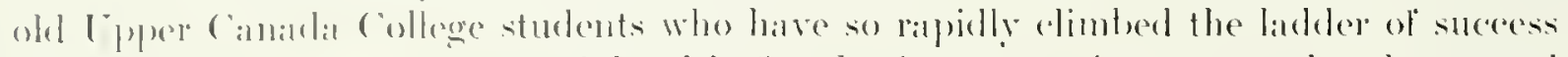
in the businese world. Mr. Reinhaldt's first husiness experience wats when he started

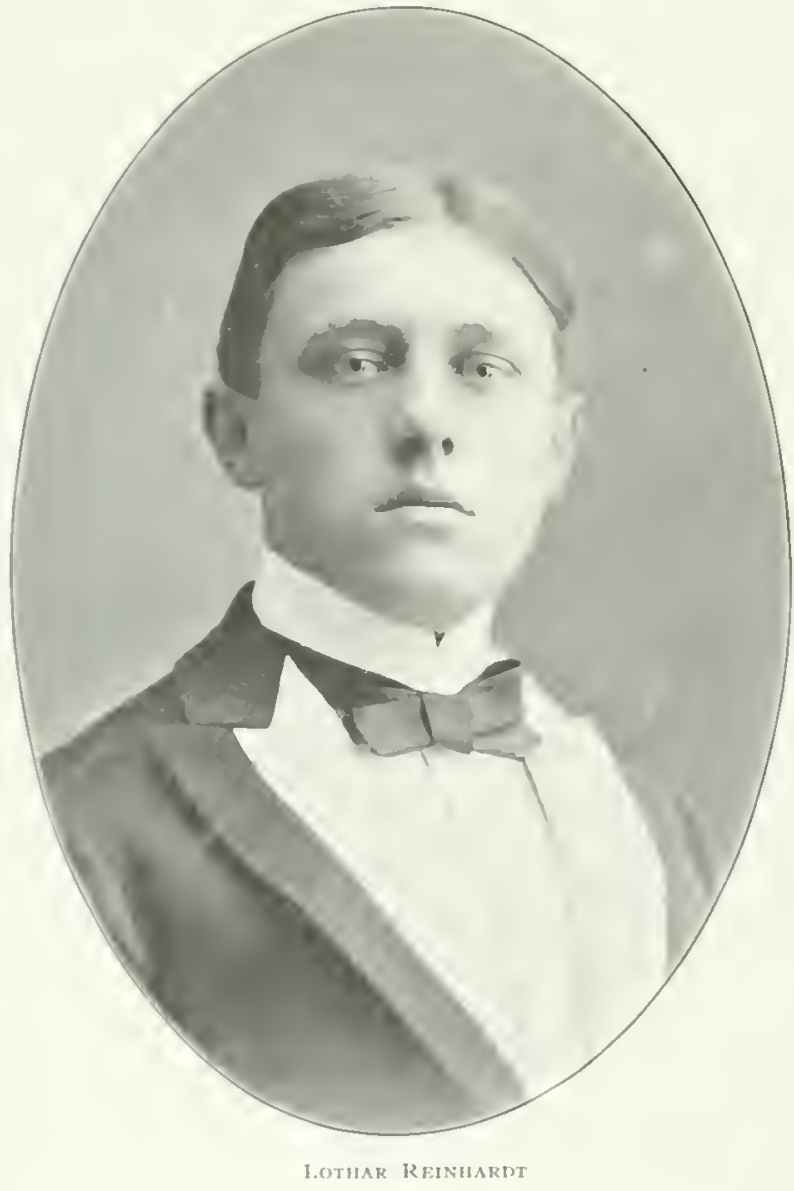
out in the Reinhardt Brewing ('ompany with his lather. After sereral yealss he left the 'loronto office to geo into business for himself in Montreal, where lee formel a latre field. He Wiss so stle(essiful in this renture that al company wats formed in the eatst to purehase his business, which was antred on moler the name of the sialvalor Brewing ('omprany. The new eompany took orel the business, arrying it on numler the name of the Imperial Brewing ('ompany, retaining Mr. Rembardt as the Mamager. which position he holds at the present linire.

from anly ahildhood he showed a love for the luorse, and lats been connecterl with them almost continmomsty creer sincere Ilis first purchlatse was the horse Romaneere who was boughtit at at sale of the seatgrallu stathle als a two-

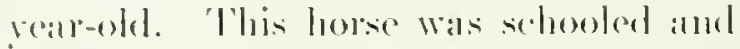

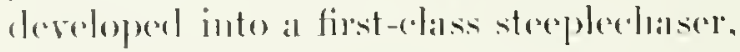
wimning many events at the llunt ('lul) meetings with his owner in the siddlle. Romandere was soon followed by others.

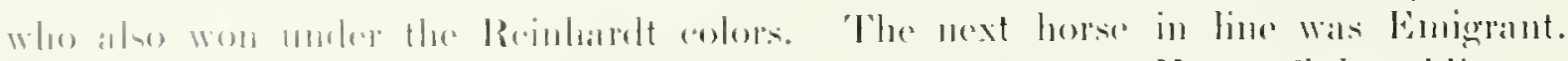

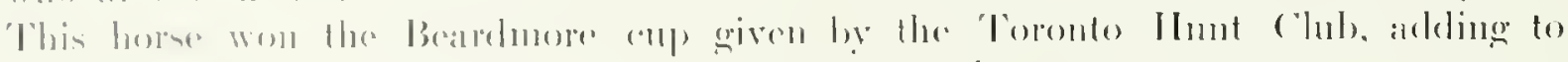

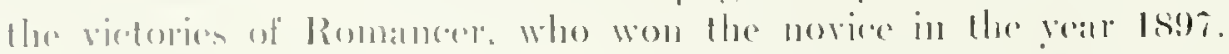

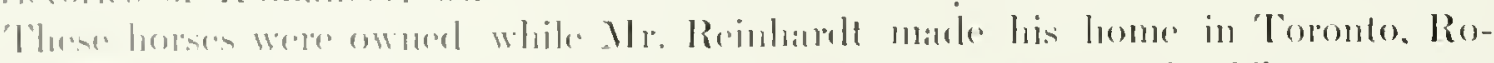

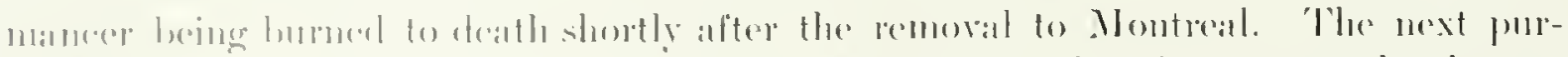

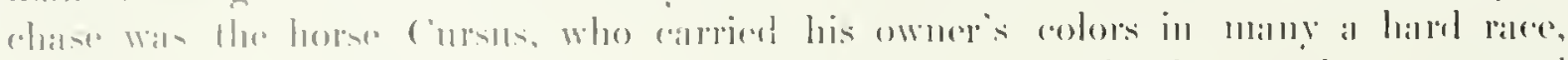

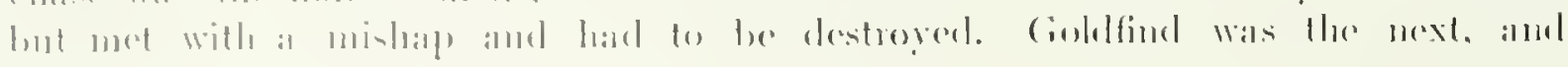




\section{Lovers of the Horse}

althongh nothing much was done with this one as a two-year-old. he dirl better ats at three.

Besides his liking for the racing game, Mr. Reinhardt las paid a good deal of attention to the show ring. and has carred off honors with some of his entries. Ile has always been realy to further the interests of the horse and hats donated mores than one enp for eompetition; lone purely for the encomagement of the equine more than for any benefit to be samed by it. Mr. Reinharalt is married to a daughter of Robert Davies, of 'Tomonto. They have one child, a son, who takes a grealt interest in the horses. wiming his first prize in the show ring 190\%, at the age of four. with a pony purelatsed for lim by lis father.

Other outroor sports have not heen neglected by Mr. Rembandt. for he is a great lockey enthusiast. also showing a keen interest in lacesse. the national game of ("anaclis. Ile is a member of the St. James Club of Montreal, the Montreal doekey ('lub, as well as several other social organizations, and is a general farorite among his chubfellows.

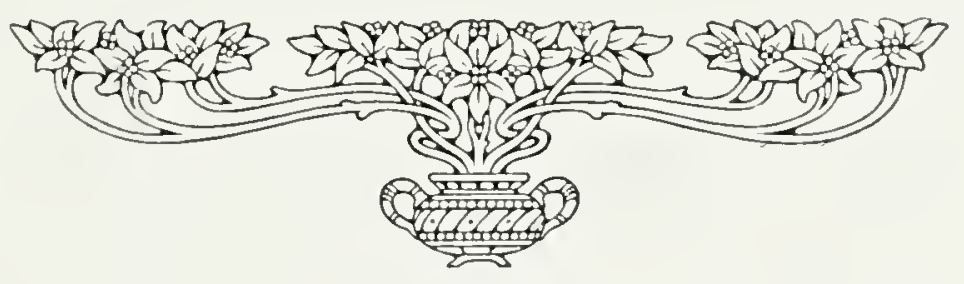




\section{ANDREW SHEARER}

$\mathrm{O}$ YE of Momtreal's most entlusiastic horsemen is Mle. Andrew shearer, who was born in the metropelis of Canadal, and has alwaly known Montreal for his home

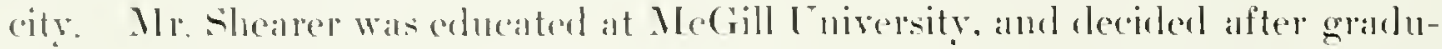
ation to enter upon his father"s business. Ifterwads le went into the lumber trade

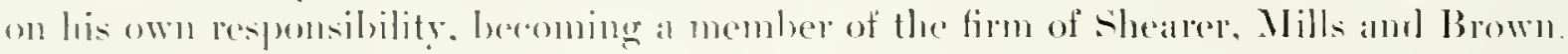
This is one of the best known firms in that business in the Province of (Queleec. Mon-

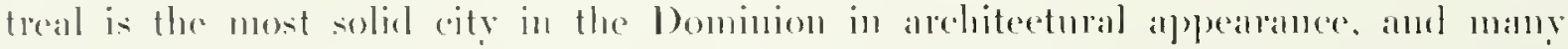
of its lusiness institutions partake of that substantial chandeteristice. The Shearers. fiather and som. lave heen of that type, and have consequently been eitizens of value to the (ommmonity.

It has been frepuently sald of the business men of this continent that they devote

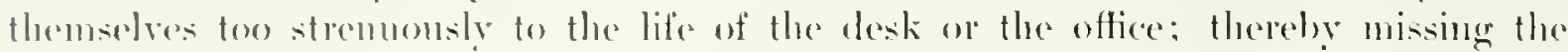
relasation of spont and the good-compaleship wheh participation in athletics or ont-

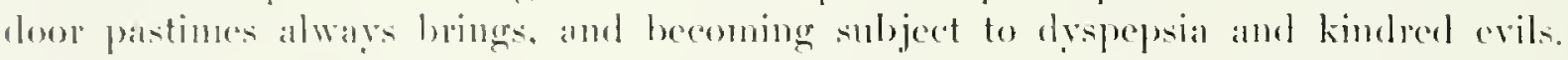

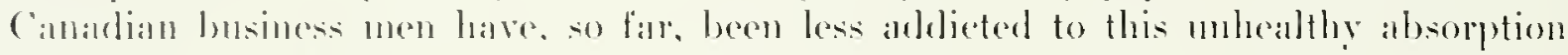
in the money market than have their. United States comsins. Mr. Shearer is among those wise finamorers who make a practice of keeping themselves "lit" hy golf. polo

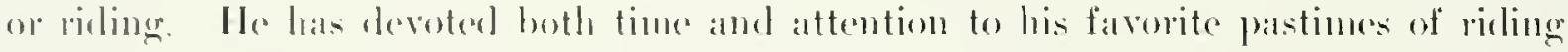
and driving. and spends many homls in the satelle, alceompanied by his wife, who is regalmed in Montrall as one of the hest horsewomen in the city. Mr. Shearer"s first ansociation with the horse was in the year 1899, when he purchased the mate My Jizzie. and won mang races with here. "l'he first trimph for this homie winner was in the

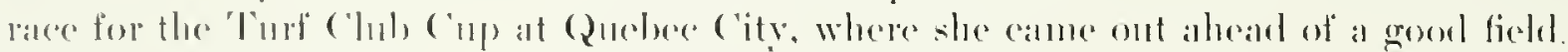
This matre was followed in ownership hy the matre lizzie, a half-bresl, which has berell

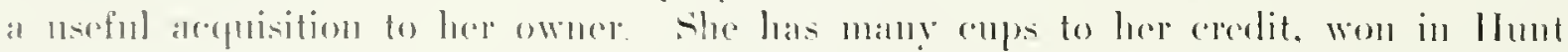
("lub erents. 'l'he next horse of importance was stalker, which has adeled to the

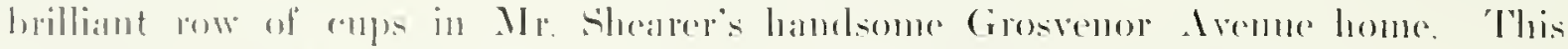

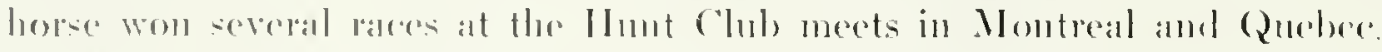

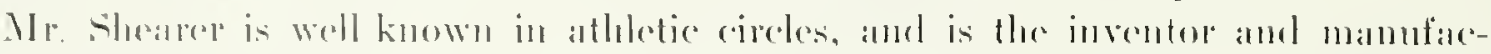

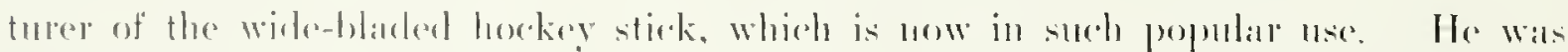

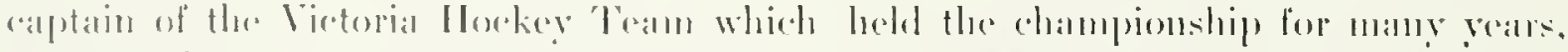

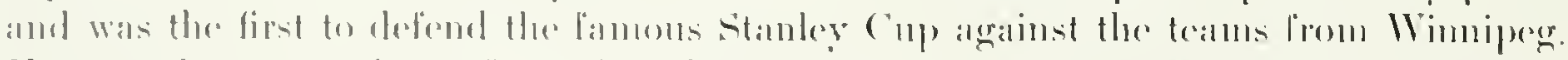

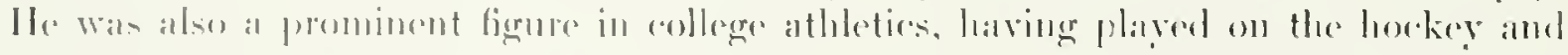

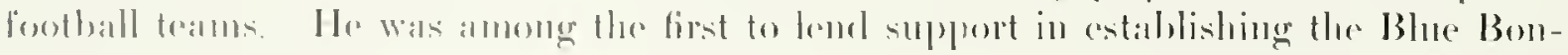

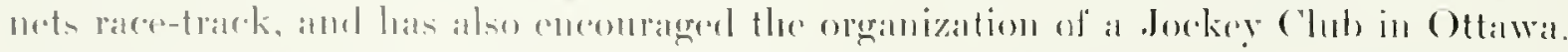

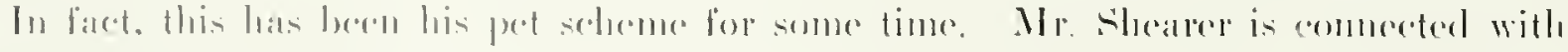

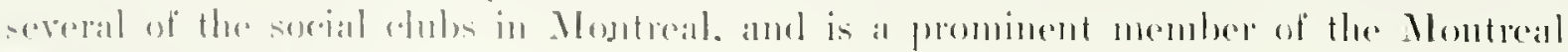
Mlliletice Msisoriation. 


\section{Lovers of the Horse}

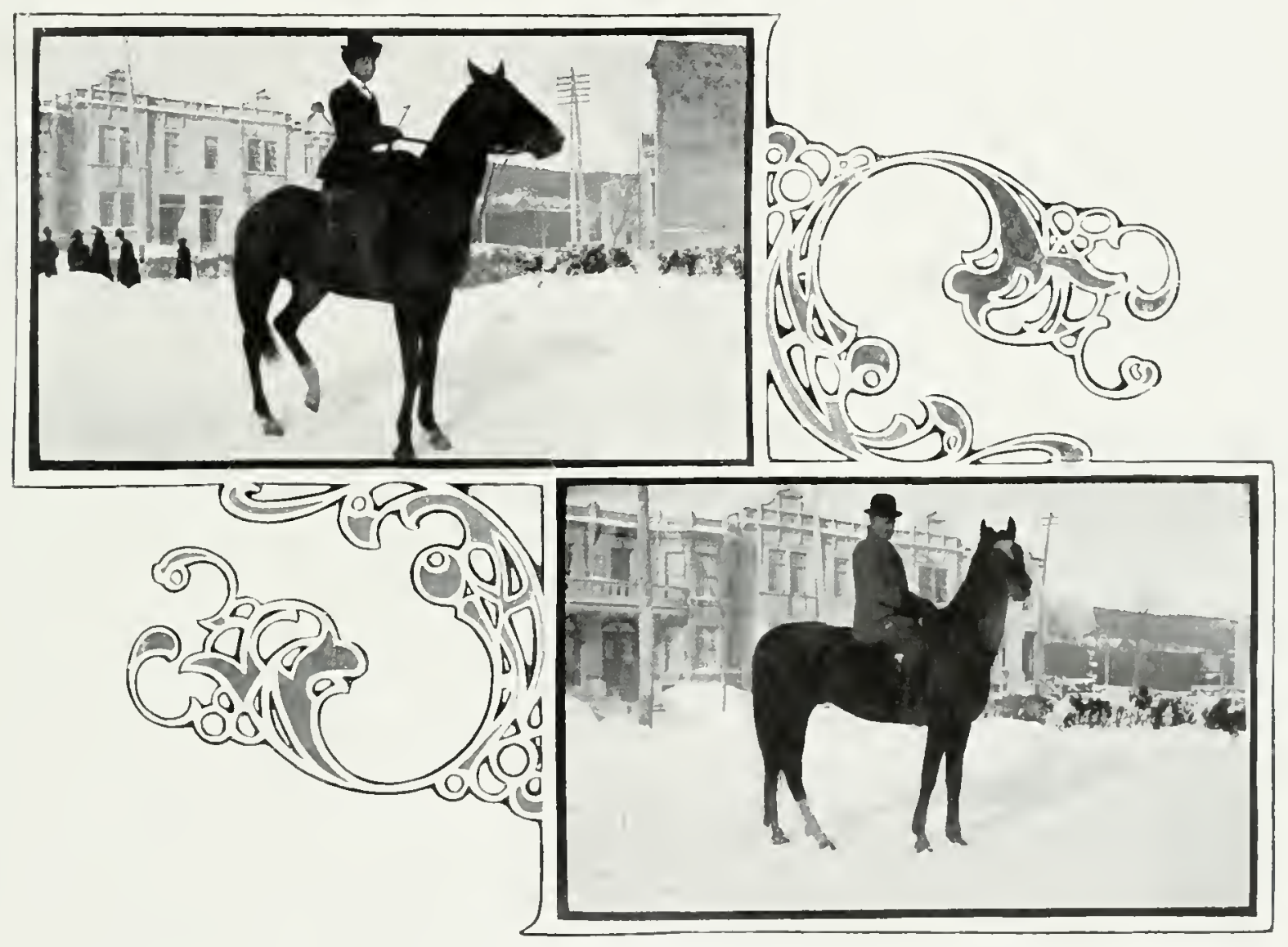

Mr. MND Mrs, ANDREW SHE,Rer, MONTKEAl 


\section{$172 \quad$ Lovers of the Horse}

\section{GRAHAM BROTHERS, OF CLAREMONT}

$\mathrm{T}$

IlE firm of (iraliam Brothers. owners of one of the lamest and one of the most prominent stoek finms of this continent. origninterl in the oted firm of Richard Gablam. which was astallished some thirty-five or forty rears ago at ('lasemont. 'The present members of the firm are William and 'Thomas, the

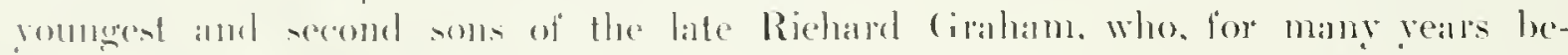

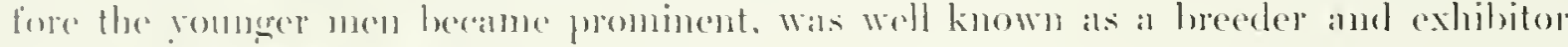

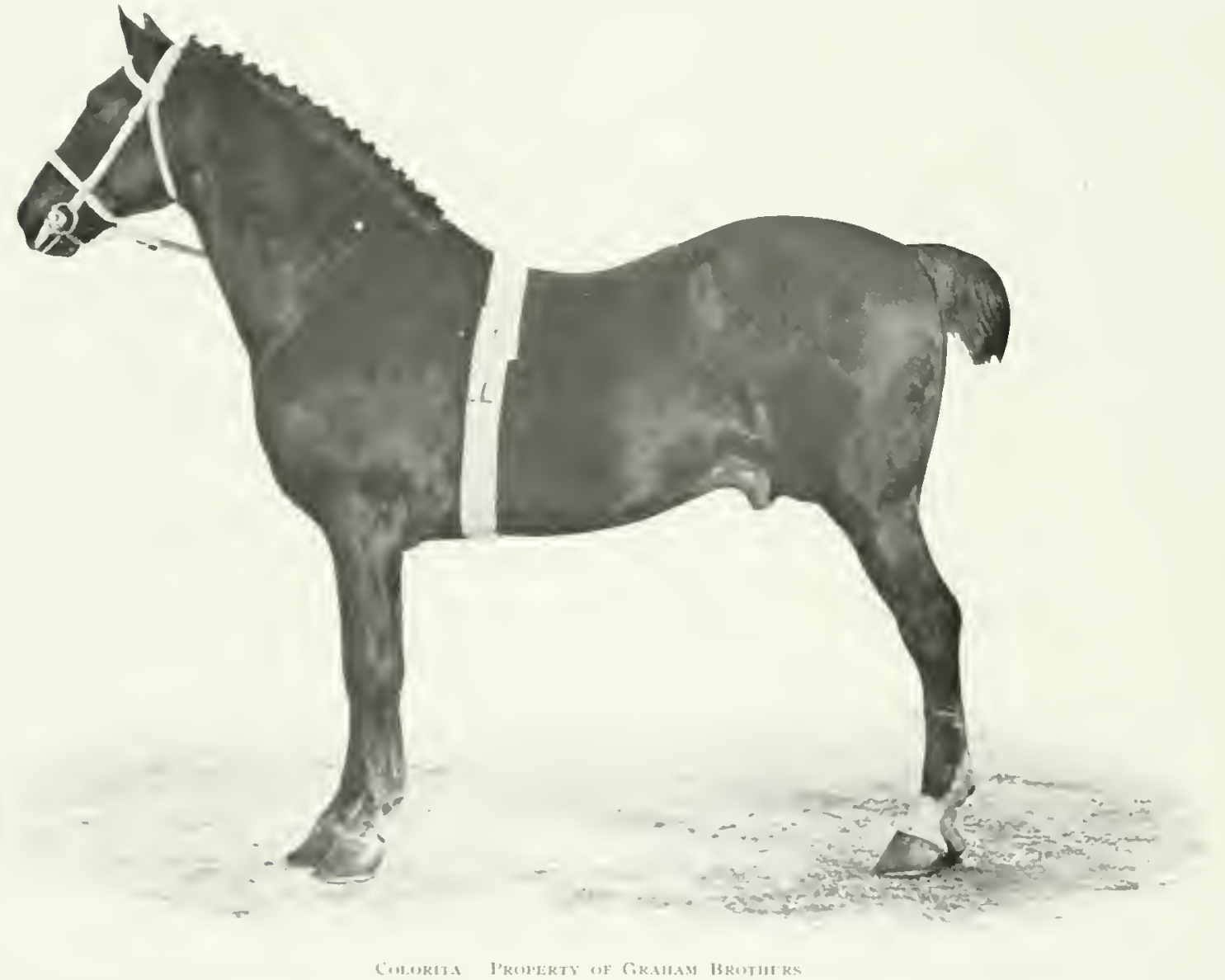

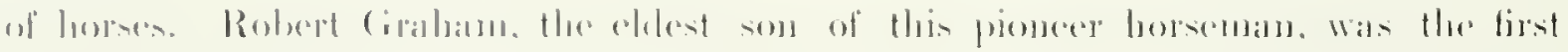

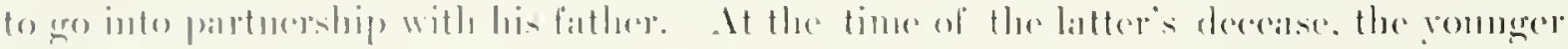

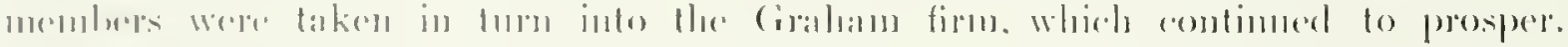

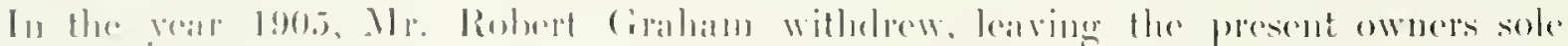
preprin.torn.

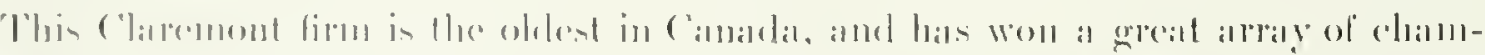

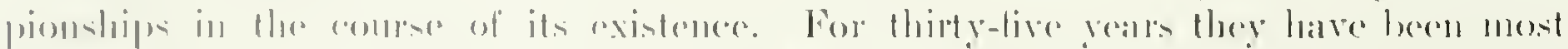

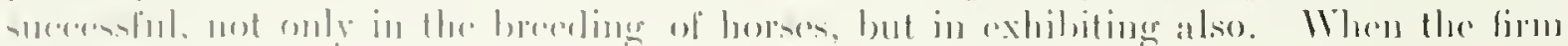




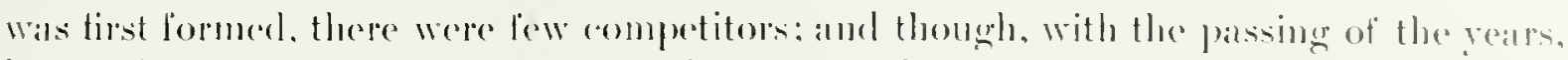
keener interest has been taken in such matters, the phare of the Guaham Brotlaers, of

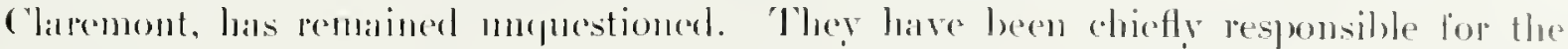

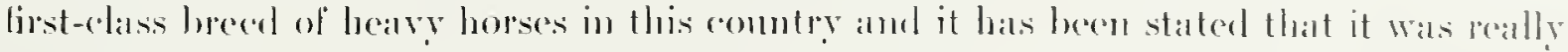

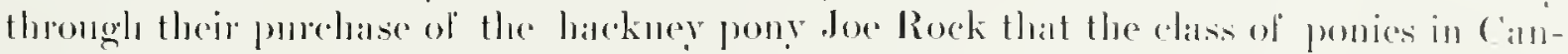
arla was materially improved.

The (imahams have heen especially fortunate in wimning almost every ahampionship) that has lieen offered at the Toronto lumbstrial Exhibition, now known als ('anadal's

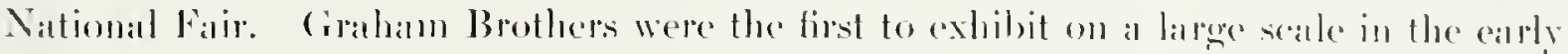

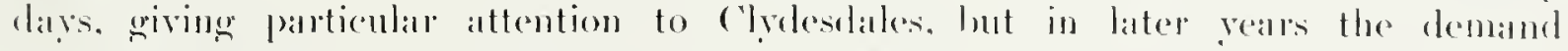
for the IIackney induced them to enter this department of expine derelopment and they have handled some of the linest shown in the comntry. With such horses ats they have shown. the breed in Canada was hound to improve, and ofler exhibitors

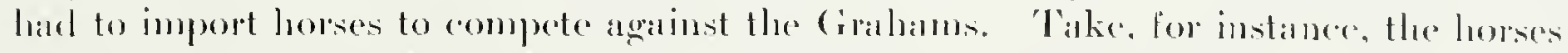
Whitewall. Fashion, Royal Standard and l)alton King. This was a trio, invincilda for a long time, and each of them brought a high price when linally sold. Colorital,

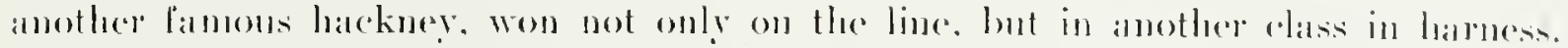
This triumph was won at the 'loronto Exhibition of 1908, and ('olorita also secoured

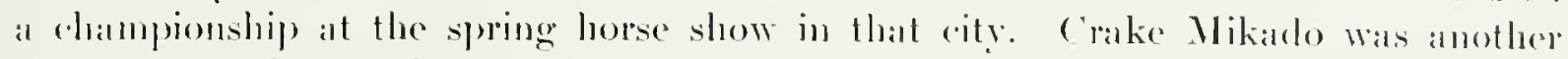
wondertul hackney, wiming at nearly all of the latger shows and having to bis coredit

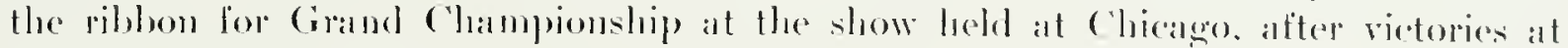
New Jork and 'loronto.

'Ple Graham Brothers won many (Championships with sir Marels alter pureluasing him. 'The pear previous to his purchase they beat him with the stallion Iansdowne-probably the best clyele they ever owned. Baron sterling and Refiner were two others that added many ribbons to the long list. Back in the early days the two

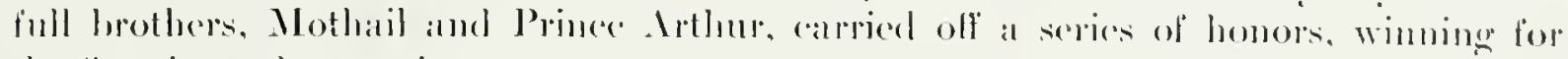
the firm its early prominence.

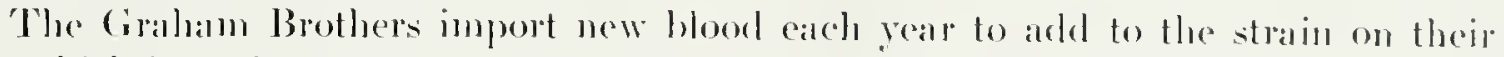
farm, which is of the purest. 'They also do a lange importing husiness for oflee lureeders and proprietors, and some of their sales have been comsidered of international inportance. Mr. Thomas Graham, who is the younger of the two now left in the lim, is generally the one chosen to make the trip across the Ithantice, and this conterprising gentleman luas gone as often as three times in a rear, bringing back with him, on carch oceasion. horses that are hatrel to copual. He is an excellent jurlge of equine pruality and is comsidered monsugussed when the task is to display the good points of a horse

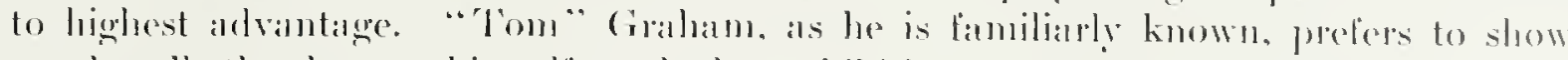
nearly all the lomses himself, and the exhibition justilies his personal attention. IIe is a tirst-chass reinsman and knows something allout work in the saddle, although little time is devoted to that elass of horse. His first trip aleross the Mthantice was in

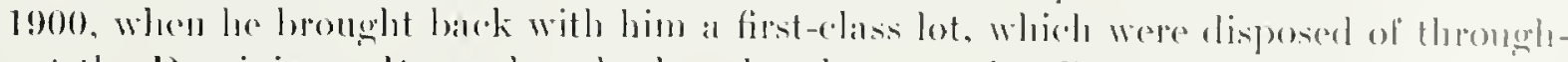

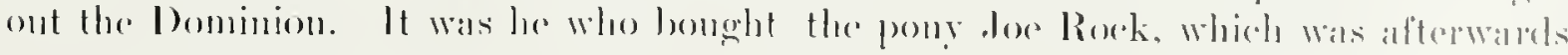




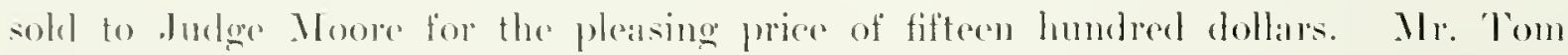
Graham has won mome ribhons than most horsemen dream of and is known wherever lovers of the horse ilre to be loumbl.

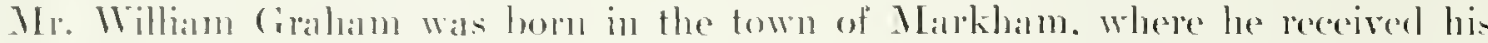
early eduration and nalde his lonme for many reats, lle was the second fo follow in

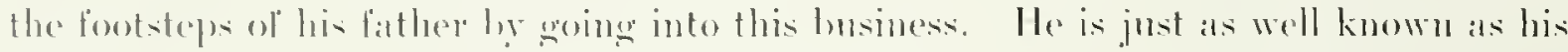
frothers in the horse worlel, having held numeroms and responsible oflices in the different asomelations. Mr. Willian Grabam. howerer. is nore devoted to the business side of the firm: interests. leaving to his hother "lom the department of apuine dis-

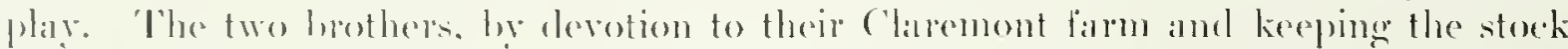
rephenished hy the best hood. have wom for themselves an enviable position among all

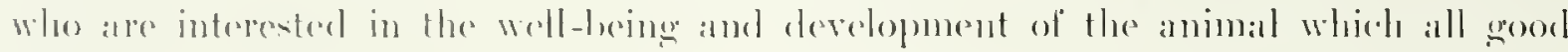
sportemen latro platered first.

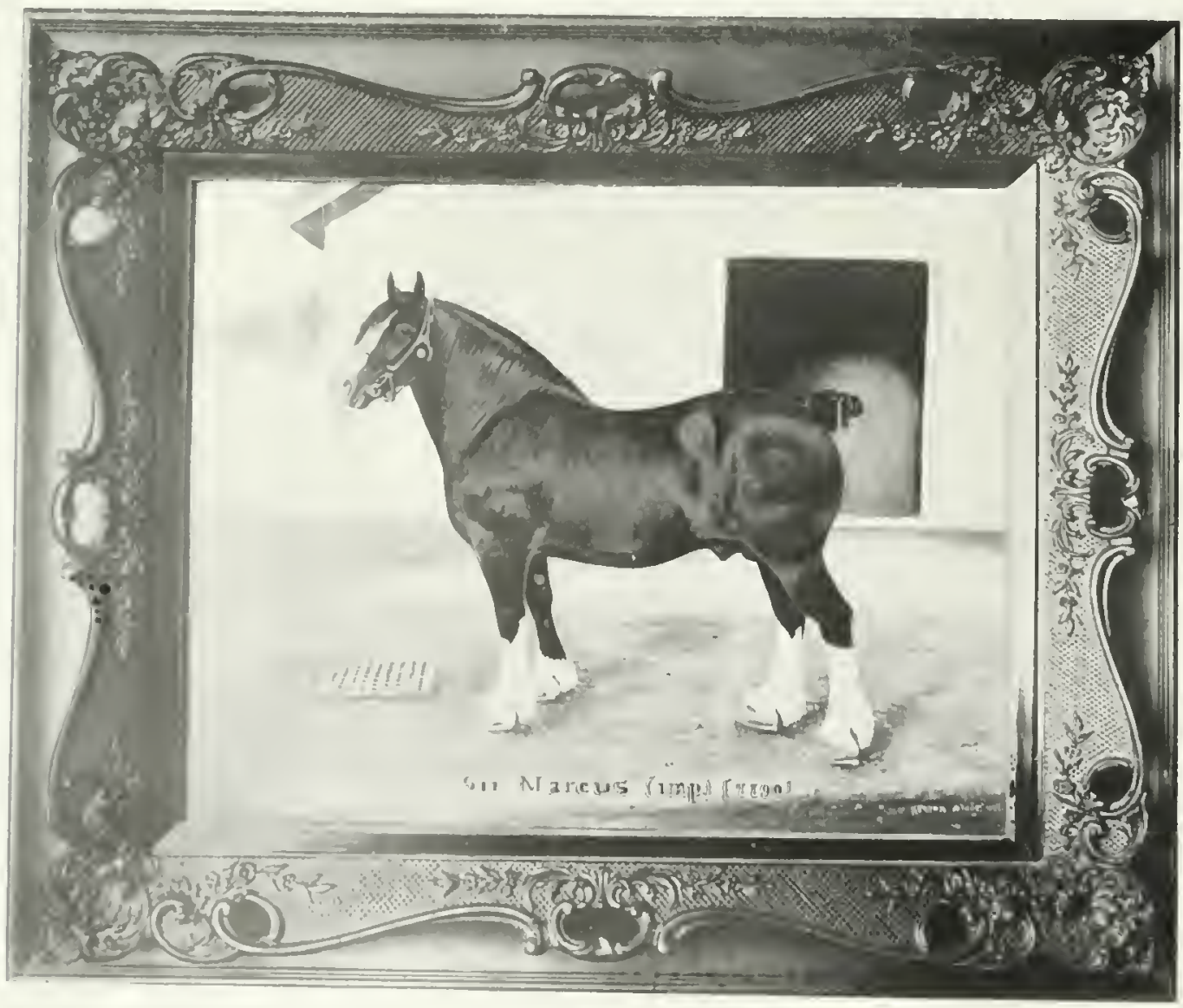




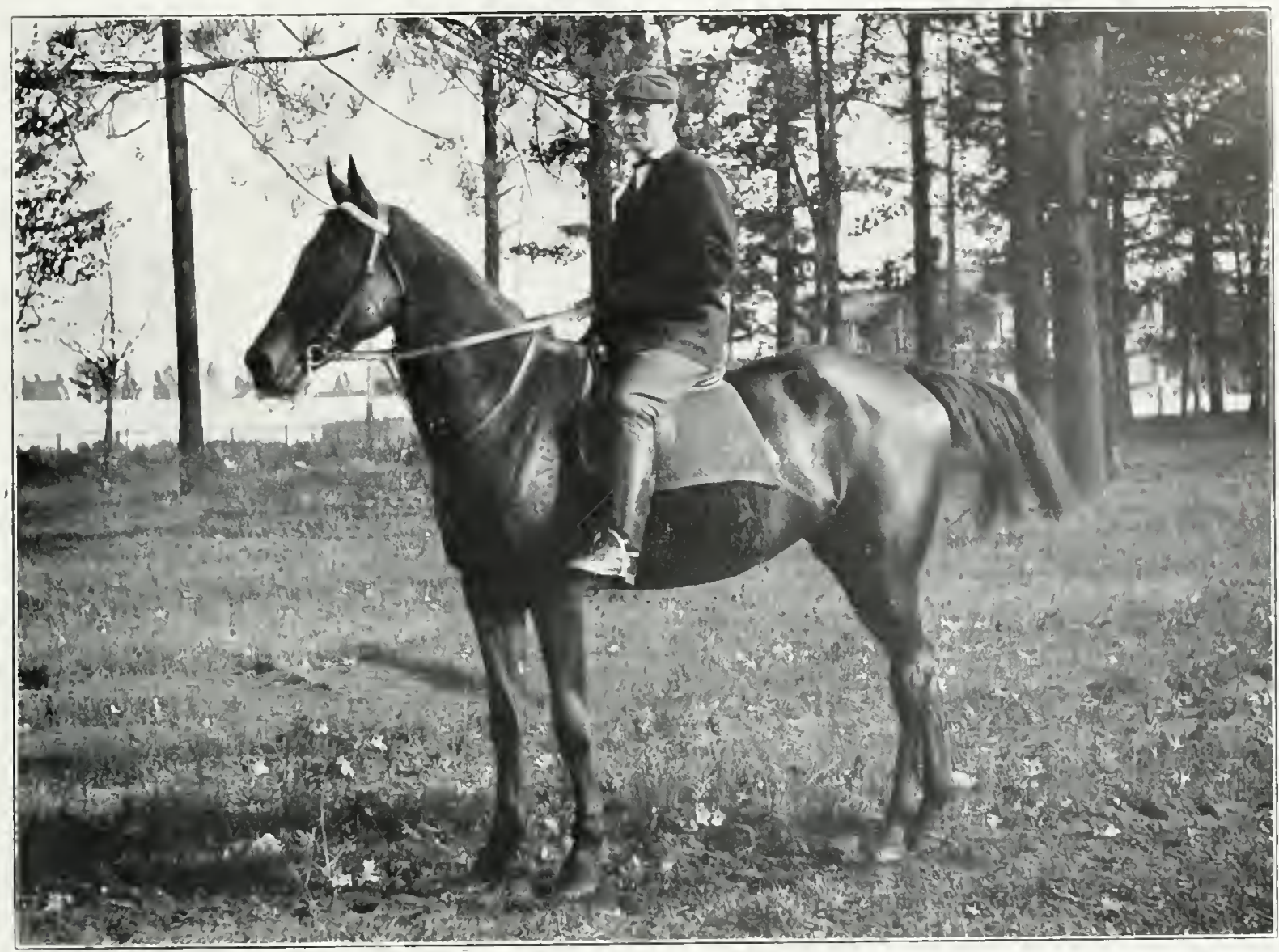

Captatn Charles A. Canpbeli., Toronto

\section{CAPTAIN CHARLES A. CAMPBELL}

$\mathrm{T}$

HERE is probal,y no better known man in the l'rovince of Ontario than ('aptain Clarles 1. Camphell, one of Camalal's most prominent hotel men, and who was born and has spent the escater part of his life in 'Toronto.

Beginning his alueation at Ryerson Public School. he finished at 'l'rinity ('ollege School, Port Ilope. On learing college captain campledl joined his lather in lusiness, alterwalels entering other commercial enterprises. After two years in the

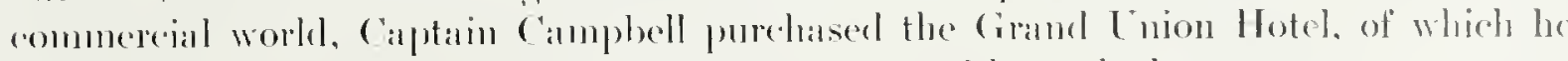
is now the proprotetor, and which vonture has met with matred suceess.

Captain ('ampluell has always taken a great interest in outdone sports as a

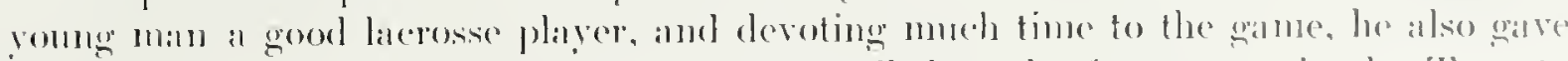
immele altention to rowing and boxing. He pulled stroke for a "rew in the foronter Rowing ('hoh, andel strokerl it to vietory on more than one oreasion. ('arreving ont the

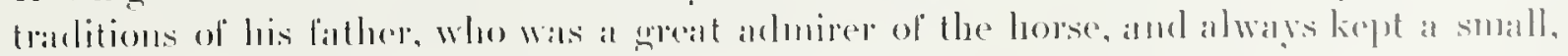




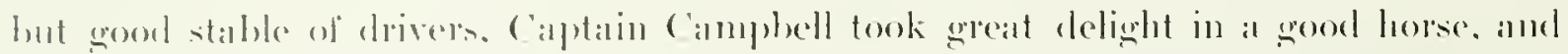

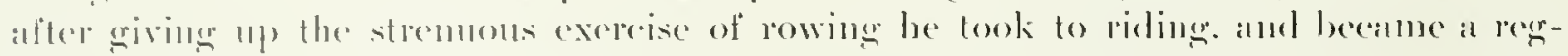

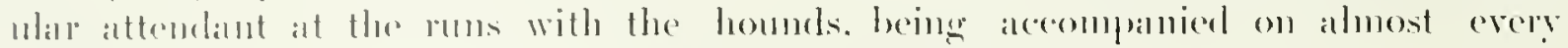

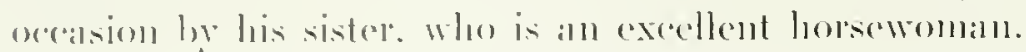

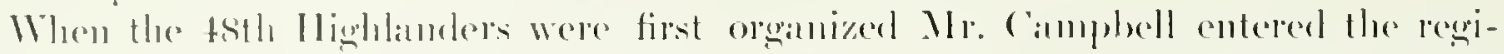

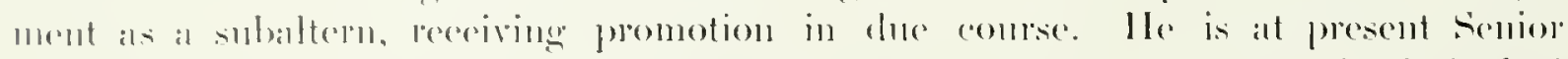
captain of the reximent. and taking a keen interest in matters military he is looked

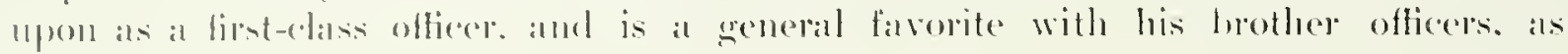
wedl as his men.

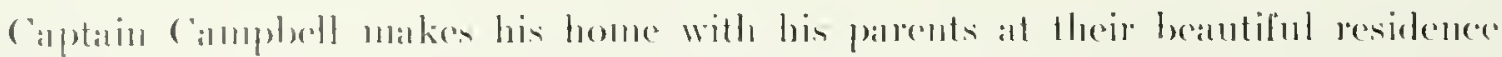

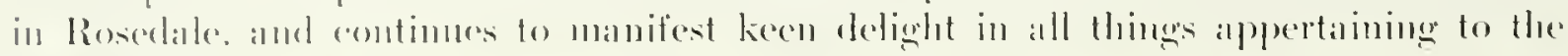
hor:are workl.

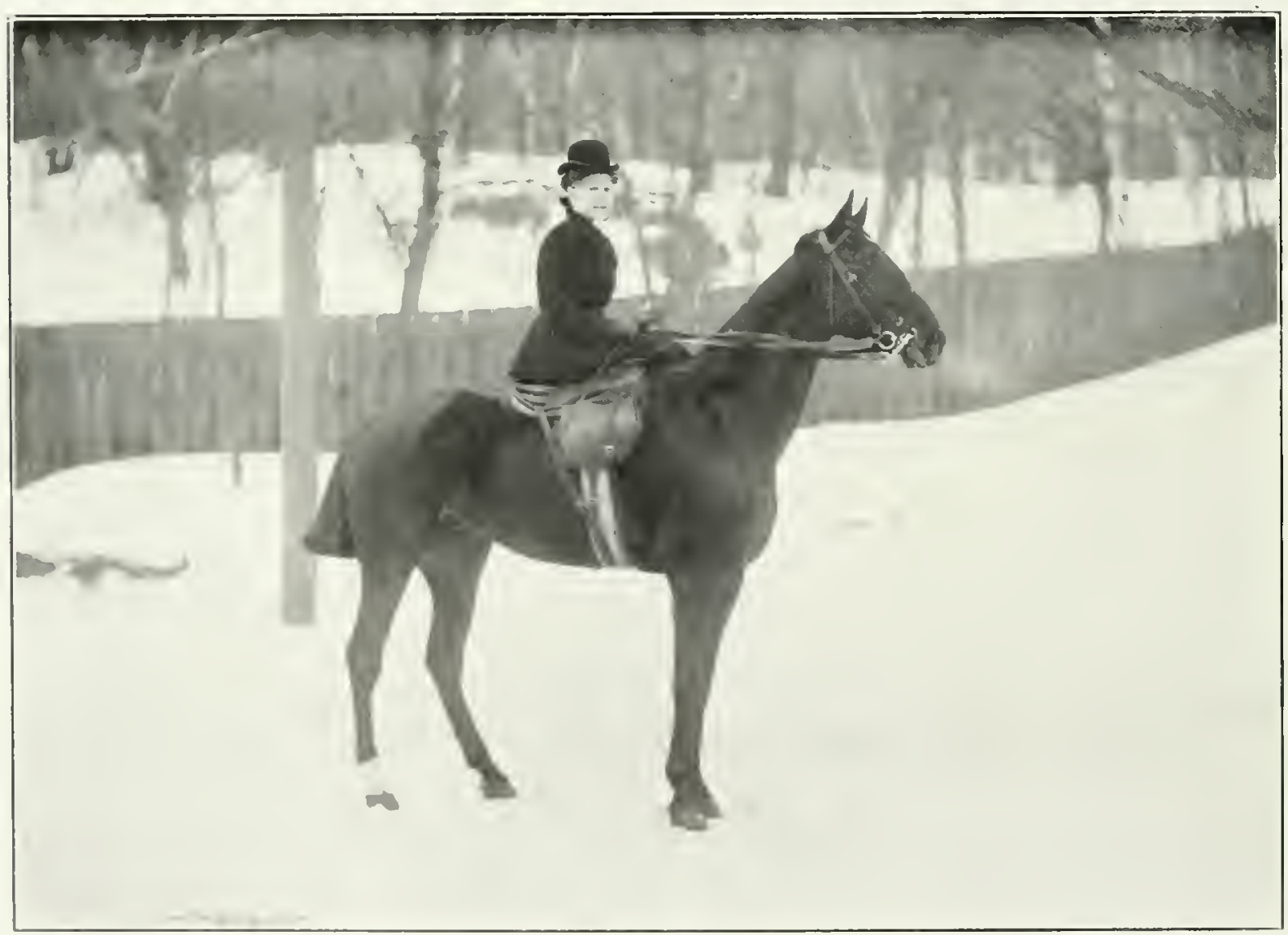




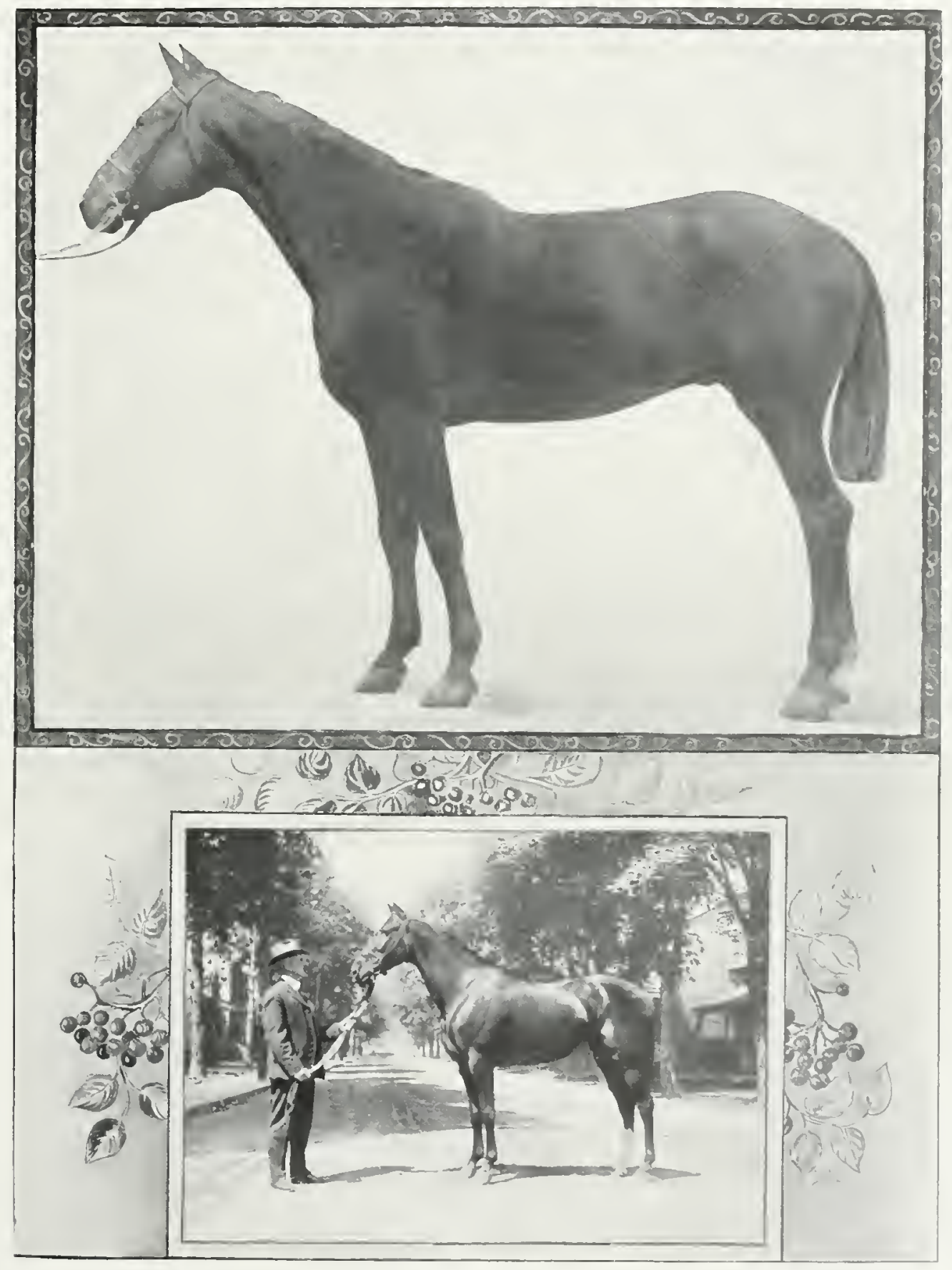

JERCUI.LS ANI 1BACK FRMR. I'RUPHRTY OF EMHLT'S JARVIS. TURONTU 


\section{ARTHUR REINHARDT}

$\mathrm{A}^{\prime \prime}$

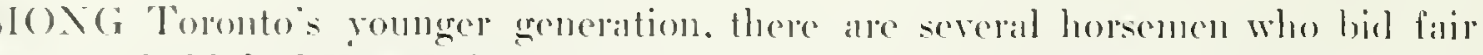
to upholut the best sporting traditions of the City of the Woolbine. Mr. Arthur Reinlandt belongs to this ambitious group, and is one of its most promising members. Ile is a Torontonian. indeed. having been born in that aity, and edncated at leper Canada College, an institution which has always stood high in the records of clean spont, and whose "old bogs" ane seldom satisficd with anything less thim

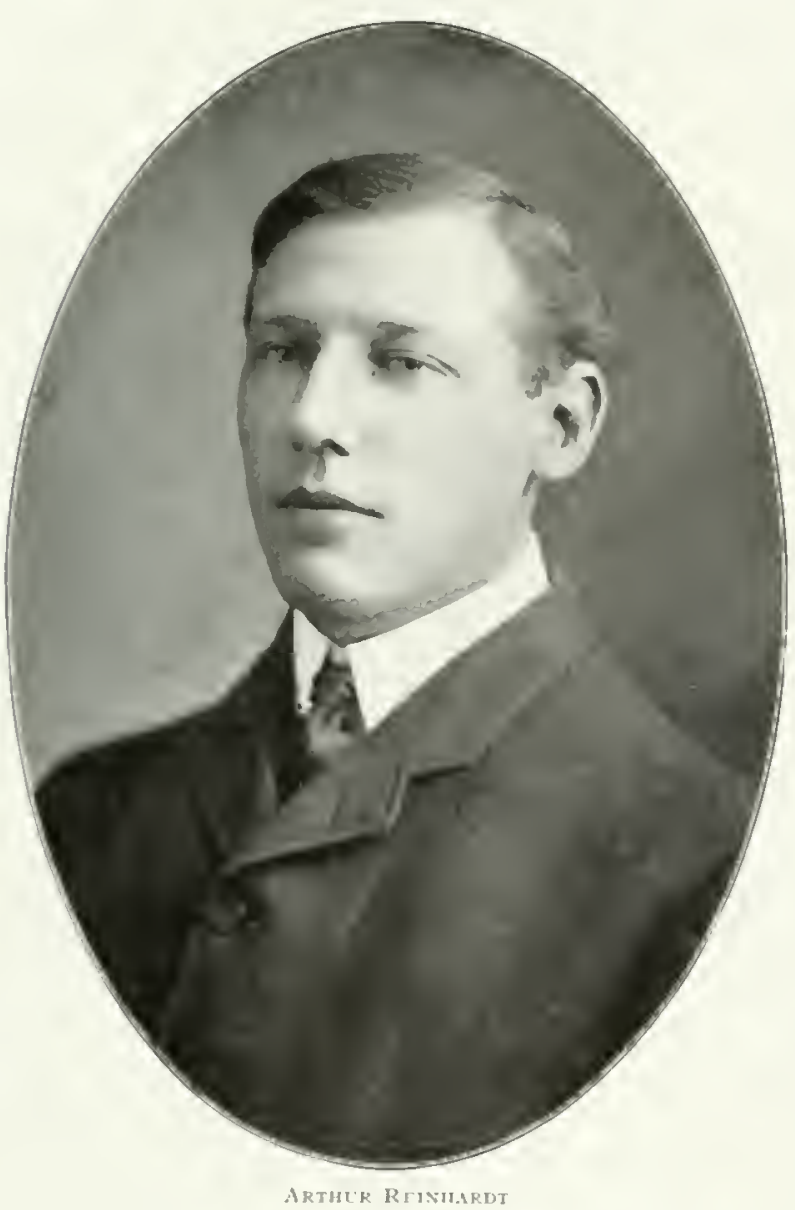
first platce.

() his entering business life, he was associated with his father. Mr. Jothar Reimhardt, and is now manager of the Reinhardt Browing Company. Mr. Reinhardt has already show a maked interest in the equine aflatirs of the eity, and has devoted serioms attention to the best of all sports. He has owned several horses which have made envialble reeords, and justified the judgment and taste of their purehaser. His first purchase was the horse Mario, to whose trining he devoted so mueh personal atfention that the object of his eare developed into a first-chass leppert, who won many laces. This horse wats purdatsed at that famous racing point. Fort Erie, and won his first race with Mr. Arthur Reinhardt in the sachlle.

'The successtul owner then went into partuceship with his brotler. Mr. I athar Reinharett, junior, and these two horsement have become joint owners of many at wimner, hoth in exhibition and on the track. Mr. Arthur Roinhardt bought the male Anticosti from the Hendre stable in Hanniton, and won the swerpstakes with her at the Industrial Exhibition, 'Toronto. This was his first hig vietory in the show ring.

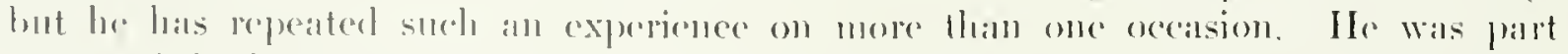
ownere of the horse linigrant, which won the Bealdmore ('up, the rider on the halply

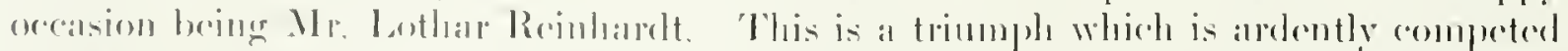

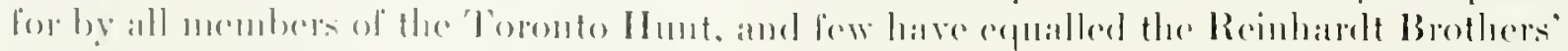

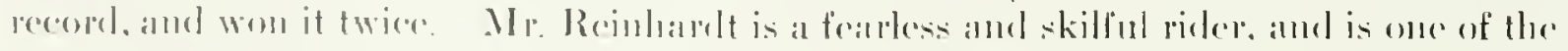

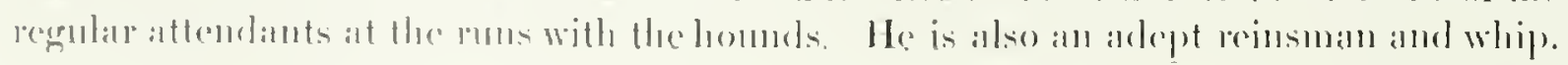




\section{Lovers of the Horse}

\section{CANADIAN HUNT CLUB}

$\mathrm{N}$ O'T many years ago there was hut one regularly organized hunt upon the continent, and to-day there are at least a humbed in operation in varions parts of Camala and the United States. Duriug the past year lunting has become guite a fad on this side of the Athantie. Where previonsly the trotter was the farvorite among the horsemen, he has now given place to the hunter and the thoronglibred, and as a result of this change of oprinion as to the usage of high-class horses, not only hunt chols, but horse shows, have sprumg up all over the continent of Imerica.

The ('anatian llunt C'mb wats organized in the year 1897 with at membership of twenty-five, the first officers being Dr. I. R. I. Marsolais, Presiclent: Mr. I. H. Painchand. Vice-President: P. A. Beambloin, 'Treasurer: and J. B. Iamarche, Sectetary. The kennels were locited at Lomguenil. During this year the work fone was more of the character of organizing and getting together a liull complement of homols, to hunt on regular days. and to become familial with the possibilities of the combly over which they were to hunt. Many of the members took at deep interest in the initial work of the Club and their eflorts were rewarded far beyond their expectations.

Foxes were found in abmalanee, and contrary to custom the fanders in the vicinity of Longuenil welcomed rather than opposed their coming, as was the case in St. Ilubert. St. Brmo, and st. Lambert. The year of 189!) was most favorable, the membership having increased to one hundred, while large and valuable anditions were made to the pack. This year the bunting season opened in september, and continned until early in December. The sport created a new enthusiansu, while the comntry hunted over was the best to be foumb in the Province of (Ruebec. Dming this year Mr. Geo. 1. Fimam was the master.

Since that time a eluh-house hats been built, situated at St. Lambert; almost immerliately in front of the chub-homse is located a beantiful biy, where excellent fishing, boating and bathing are obtainable, which adds materially to the attractions of the Club. "I'he" members have also training gromels where the poung horses am be seloooled and huntsmen in embryo are given their first lessons in horsemanship, a feature which wonld, of itself. make the ( lub desirahle amd which, adeled to its numerous other attrictions. unites to form one of the hest Clubs for horsemen in Canadia.

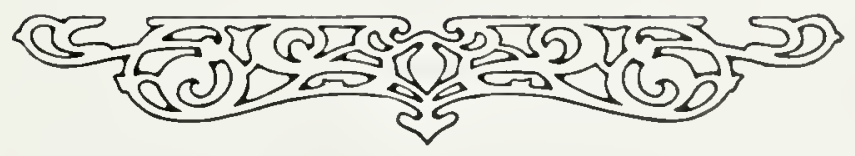




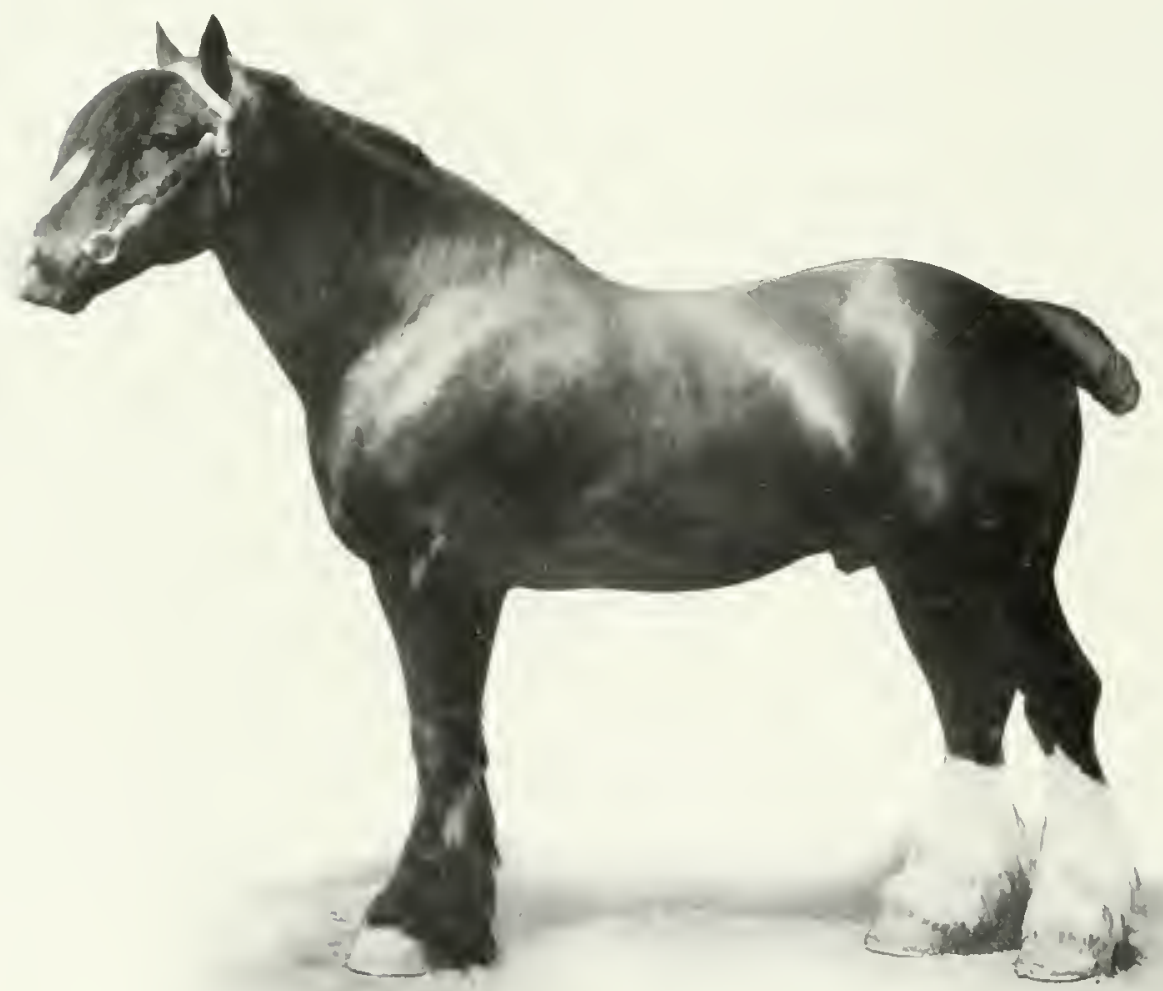

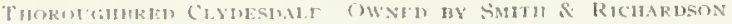




\section{Lovers of the Horse}

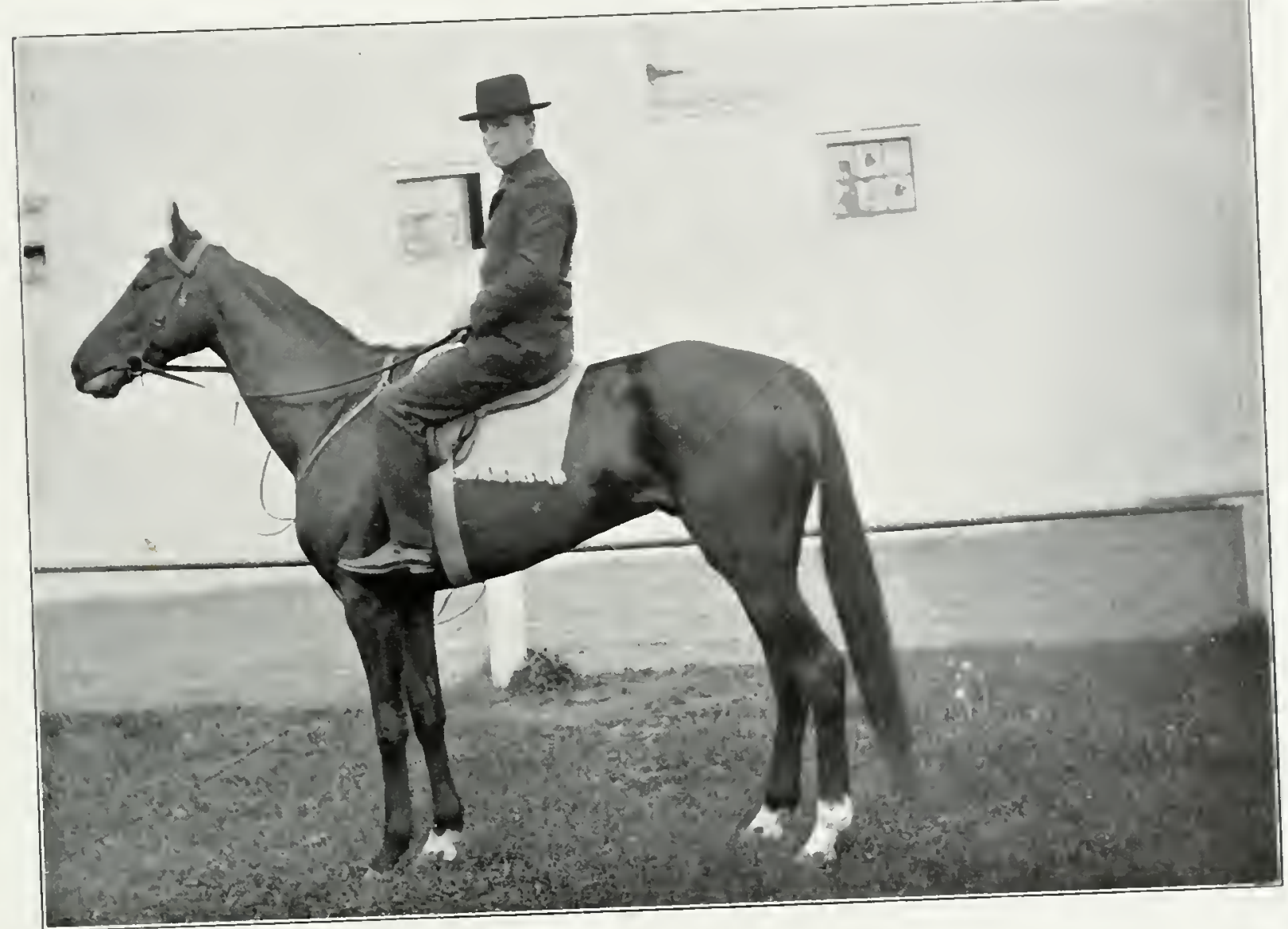

\section{NATHANIEL D. RAY}

$\mathrm{H}^{\prime}$

RSEMEN all over the continent have wateher with great interest the wonder-

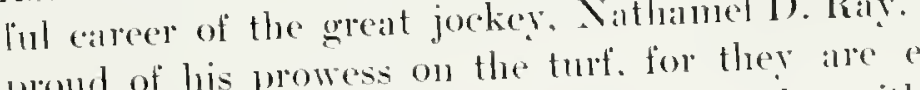

prond of his prowess on the turf. for they are entitled to clam him as a

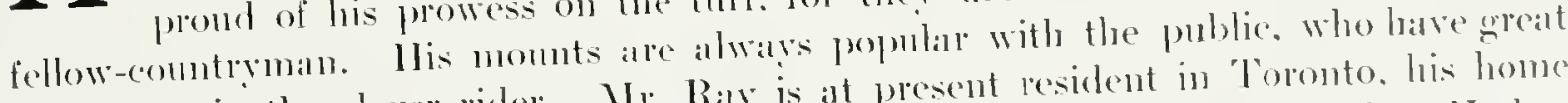
ronfidence in the clever vider. Mr. Ray is at present resident in Toronto, his home being at 1493 Queen St. East. not far from the famous Woodbine race-track. He has alwaly been in close tonch with horses: in farct, he was only four yours old when he was ribling at the fall fairs in Ontario. Itis mount then was the beantiful pong Queen May. the property of Homorable Robert Beith, Bowmanville. 'This. Mr. Ray says was his first association with the horse as falr as he call remember. and it is a very pleasiant recollection. He was educated at the Model school. Whithy and is widety known

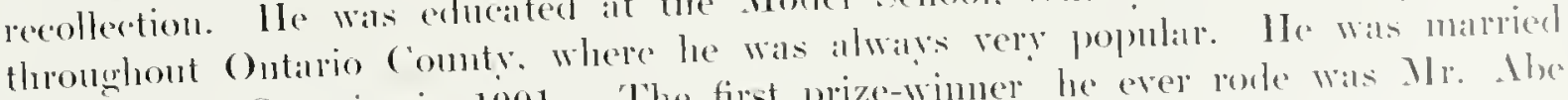
in Wimlsor, Ontalio. in 1901. The first prize-winner he ever rode was Mr. Ahe

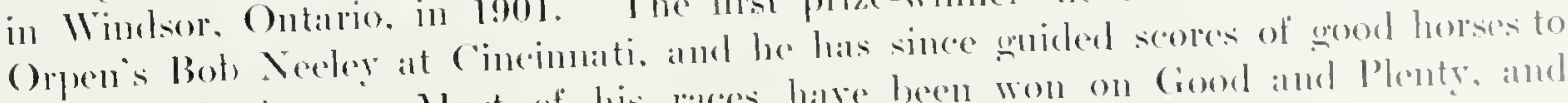

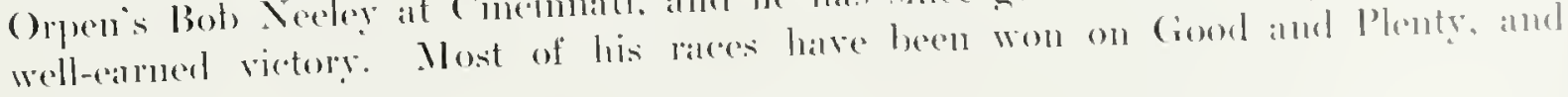




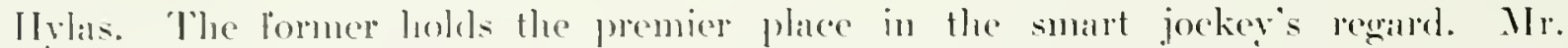
Ray is prond of the fact that he was never beaten on food and Plenty an anmal which he elasised as the areatest jumper the Ameriean turf had ever seen.

During the year 1906. Mr. Ray developed a liking for the light hanness horse, a taste probalbly inherited from his father. lle purelatsed several good ones. the first besing the horse Prince Creenlander. which did well under the care of Mlr. Ray and his father. John Mekeown wits the next to be acquired for the stable, and won many stakes for his fortmate owner, lacing for the first time over the ice at the famous meeting at ()ttawa, 1907. In spite of his extrablinasy speerl. he hall to be retised for the

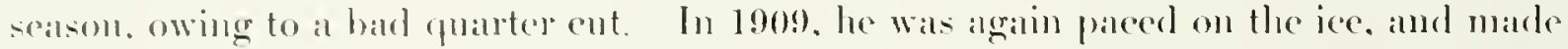
a good slowing. The next purehase was the horse Guy, wheh was bought duming the iere meeting at Toronto and was campaigned by "Nat " Ray with decided success.

Mr. Ray was not only known as a steeplechase rider, but earned a reputation als inl excellent driver, ham dling his own horses in the majority of the races won by them. In 1908, le made a departure and hecame an ownes, after having refused to sign contracts to ride for anyone else. He purehased the lepjers spencer Reifl and Dr. Mikens. With these two horses, partieularly the former, he diel well on the Canadian Cirenit that reall. He bought the grood colt Bhaggadocial, With which he won several stake races. and was seldom ont of the money in 1908 .

Mr. Ray is a member of the Sheepshead Bay (im Chuh and the Sheepshearl social chuh. He is a cheerlul fellow, with a jolly, open conntenance that begets confidence. It is, ats the New Vork Telegraph recently said: "I gool honest type of face that ever" looks sefuarely into rour own. and a bulldog underjaw that probably accounts for his wins." He is modest to a degrees, and does not care to siy much himself regarding his eneat perfomances. His career has certainly been a remarkable one. For four rears he headed the list of wiming steeplechase jockeys on the Imerican turt, making a new reeord earle youll. Ile has won the Cirand National four times, the Whituey Memorial there times. and the Champlon sterplechase thee times. In 1905 he won $\$ 50.000$ in purses for lis owners. In 1906 h he won $\$ 64,000$ in purses with six horses. Truly a most areditable showinger.

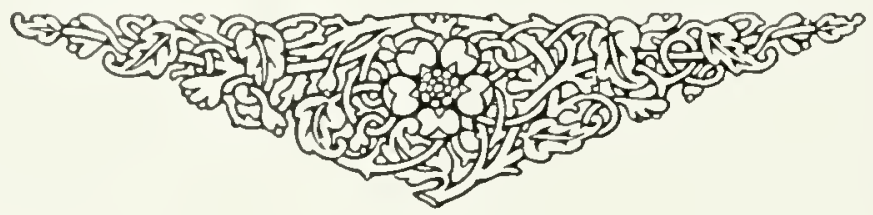




\section{Lovers of the Horse}

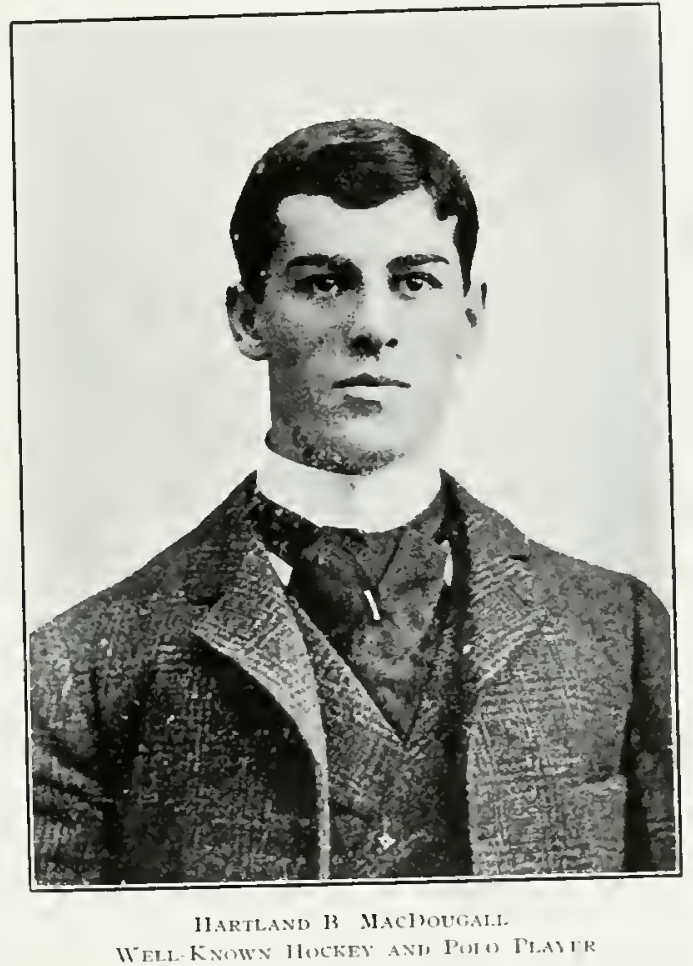




\section{THE MONTREAL HORSE SHOW}

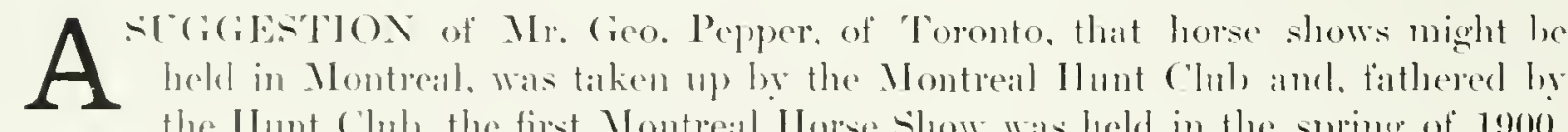
the IIunt ('luh, the first Montreal IJorse slow was held in the sprime of 1900 .

sir II. Montagn Mllan and II. B. Macl)ongall were more than instrumental in making the first show a snecess. and while the elasses were not so large as anticipated. they have grown in fuality and size during the succeeding rears. mutil now the Montreal Ilorse show Association is regatreded as one of the strongest in the loominion of ('analal, and has commected with it some of Montreal's most prominent men.

'The first slow was helel in the Arena Rink, with the following gentlemen as judges:

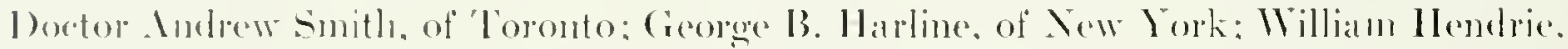

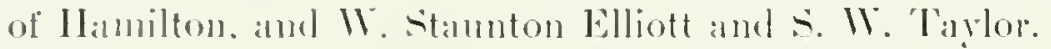

It was found that the necessity of stabling the horses outside the rink was most inconvenient for owners and brecelers. so that it was deciderl he the directors of the show to arrange for stahling alceomunotation at the drena.

I stalble. housing a great many horses, was built on the serond storey and later.

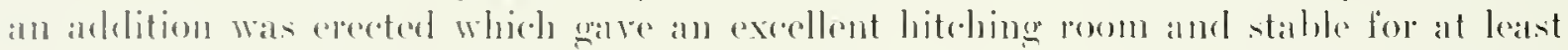
two hindreal more horaces.

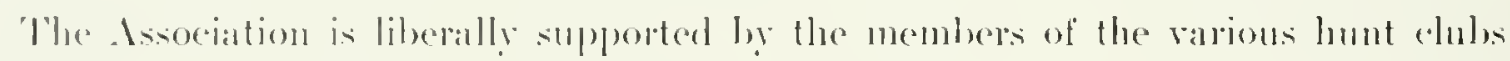

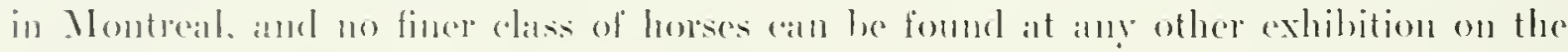
rontinent.

Ml. ('. I. Mlloway, a well-known Mentreal malu, is a prominent figure at these

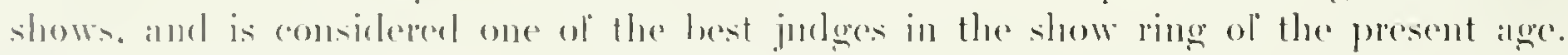

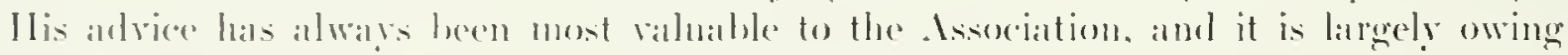

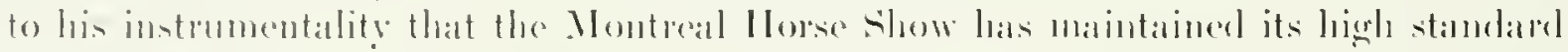
so sirecenstully.

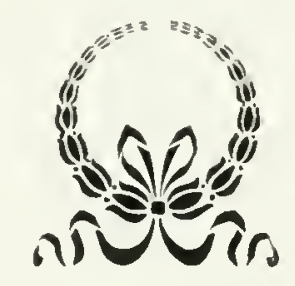




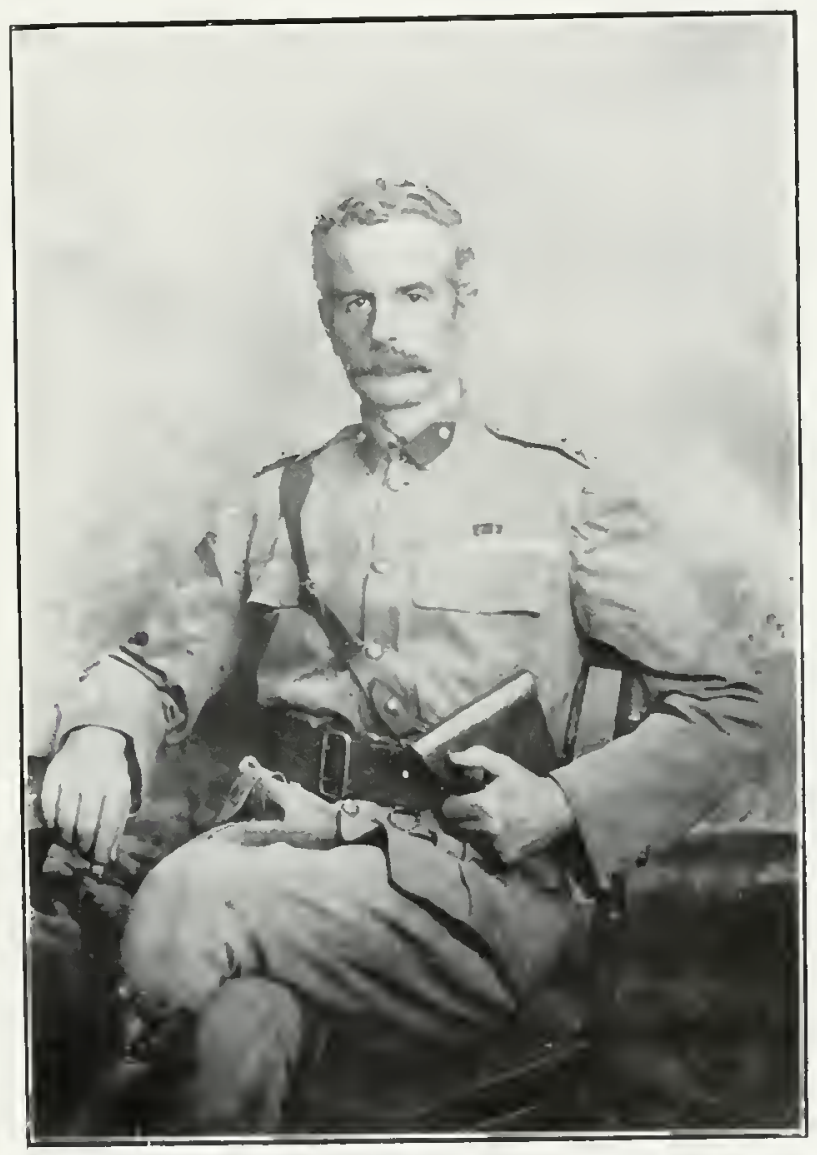

THE RIGH HON THE FARL, OF DUNDONAL1, C V.O., C.13. 


\section{DENNIS HIGGINS}

$\mathrm{T}$

IERE is probably no more entlusiastic horseman in Canada than Mr. Demis lliggins, a calladian by birth. Who boasts of the fact that he was born in the little eastem town of Prescott. Where he lived with his father during the early yours of his life. and where he afterwats entered into business

From childtood $\mathrm{Vr}$. Higgins showed a liking for the horse, and particularly the

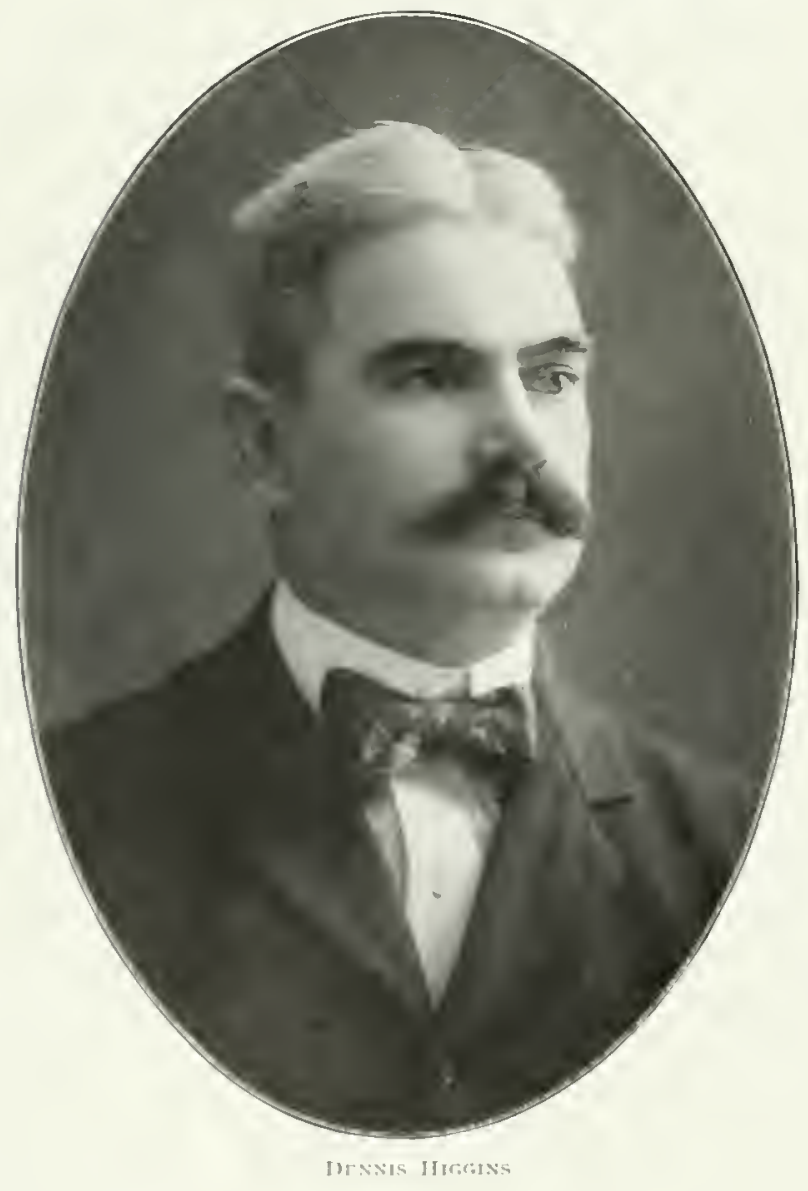

thorenglbured, and when still only a youth lie got together one of the best stables owned in Canada at that time.

His first purcluase was a horse called Lockwood, which marked the beginming of a most sucecssful racing calcees, and with which he had the distinction of wimning the first race ever run over the old track in the east end of Toronto. owned ly E. King Dodils

Vext came the mare Shamrock. which camed larackets for Mr. Higgins on more than one accision, and which was the wimer of the first raee ever rum at the old Bel Air track in Momtreal. then the property of the late J.

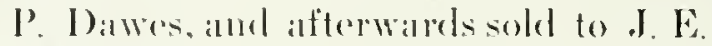
Siramralll.

from this time Mr. Iliggins devoted a great deal of time to heresting and racing horses, not for the financial lenefit, but for the pleasure he derived limom thesport

He is the omly Camalian creresure

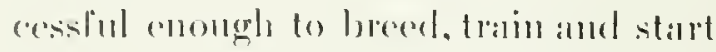

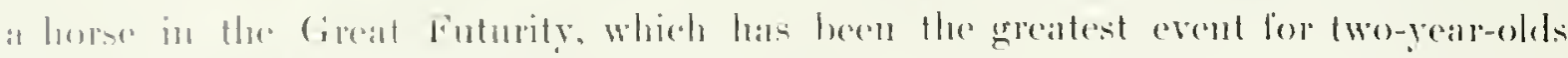
run on the Amerienen continent.

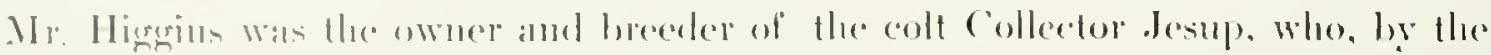

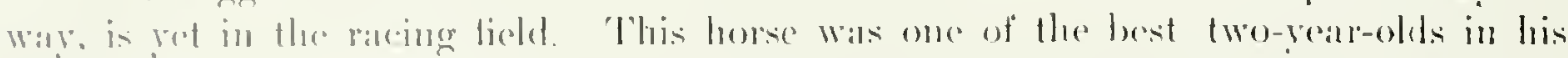

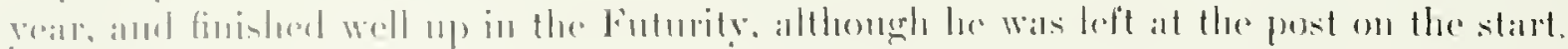

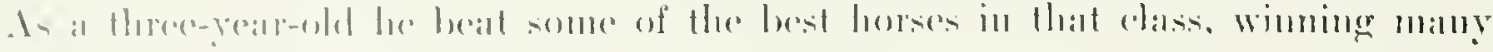
staken for his onstor.

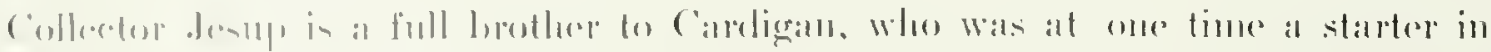

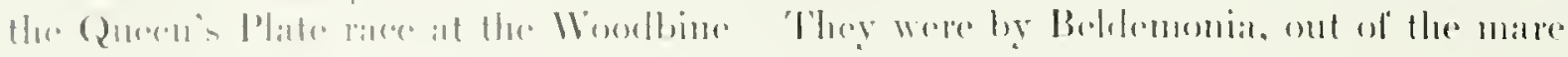




\section{Lovers of the Horse}

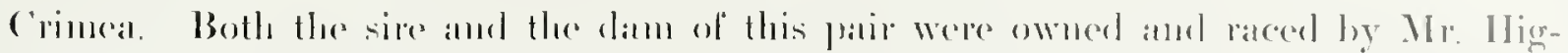

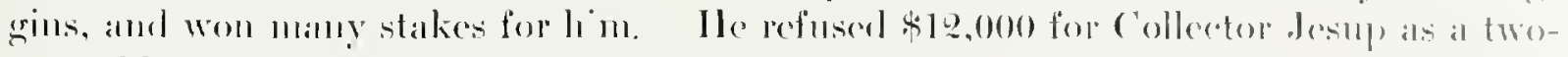
yearir-old.

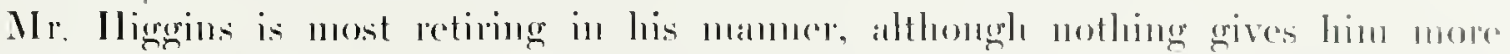
pleasure than to sit down with his friends and talk over the horses he has owned and raced. It one perionl of his racing carcer he went inte partuershipe with Jatnes

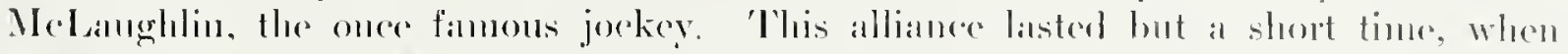

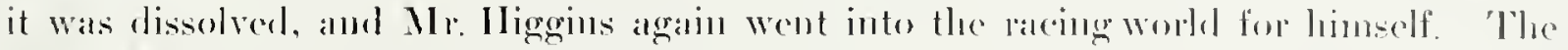
horse My Fellow was another that carried the orange ambl bhue of the Iliggins stal,le to the front many times. having almost mubroken suecess during a whole season, and wimning nine straight rales.

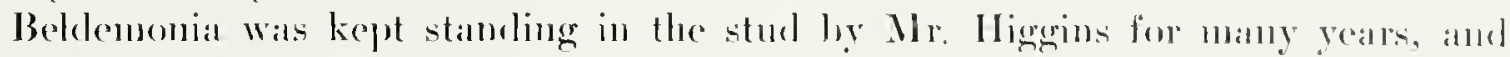
sired sereral well-known race-horses. He was then sold at publie anction for three thousand dothars, which was, at that time, the greatest priee ever paid in ('analat for a thoroughbred.

Mr. Iliggins has retired from the racingr workl, although he still takes a kecon interest in the sport, and is ever ready to do all in his power for its benefit. Ile is always ready to help anyone to break into the racing geroume, and this kindly quality has condeared him to many friends.

It present Mr. Higgins is the owner of the hotel at Preseott, his native town. There a firstelass driver may be always fomd in his stable. Mle has flevoted much of his tine to the show ring, and has won many libhons and prizes with his horses. While he has never been connected publicly with any of the jockey elnbs, he has been a regular attendant at the mumerons meets held in Camadal and the Luited States. For many years he was a pominent figure at the old Guttenberes track, where he aehieved many sucesses, and was also well known at the old Bel Cir triak at Montreal, als well als it the Woollhine, T'oronto.

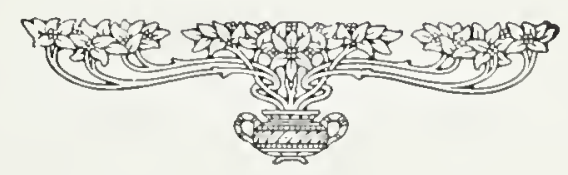




\section{8 \\ Lovers of the Horse}

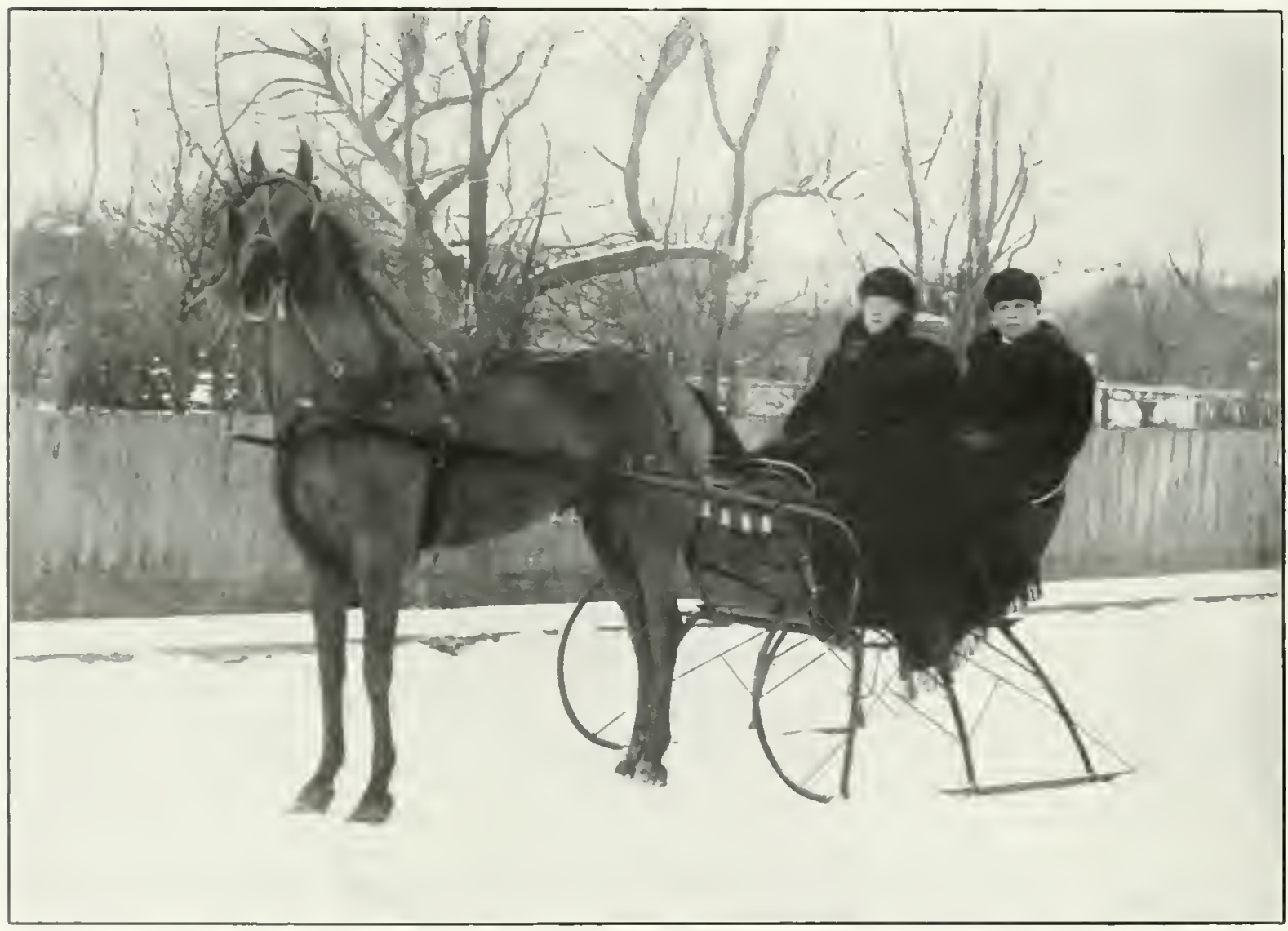

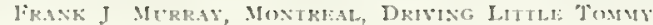




\section{Lovers of the Horse}

\section{HARRY I. STONE}

$\mathrm{O}$

NE of the Canarlian horsemen who has won distinction on the other side is Harry 1. Stone, of Sheepsheanl Bay. New York. Bom in 'Toronto, he received his early education at the Model School and the Jallovis Street collegriate lustitute. rloe pursuit of edncation, however, did not interfere with his interest in the horse. and from his earliest childhood, Mr. Stone manifested his predilection for the equine. a taste which was fostered by his father and nother. who were both good riders he being the first son of IV. H. Stone of 'lomonto.

Mr. Stone won his first trimmph on a pony in heat races at the T'oronto Exhibition. while his first suecess on a regular track was at the Woodbine Conrse in $189 \%$, in a hunt race for gentlenen riclers. lis mount being Clank. It that time Mr. Stone was a member of the old 'lorouto llunt ('lub), muler 1)r. Sinith.

From 1897 to 1903. the subject of onr sketch wis not connected with horses, hut was engaged in husiness in Buflalo and New lork.

Onere a liorseman always a horseman. however, and his olal love clamed him again in 1904, when he took up lacing on the big tracks in New York, as a gentleman rider. 'This was one of his most successful seasons in the sardelle. He won all of the stakes on the Ameriean track for gentleman rider up, the first heing won with the holse Conover from a good tielet. In the spring of 1906 he tumed professional. making a sucecss of it, fintishing well up on the list of leading riders. 1906 was a binl-

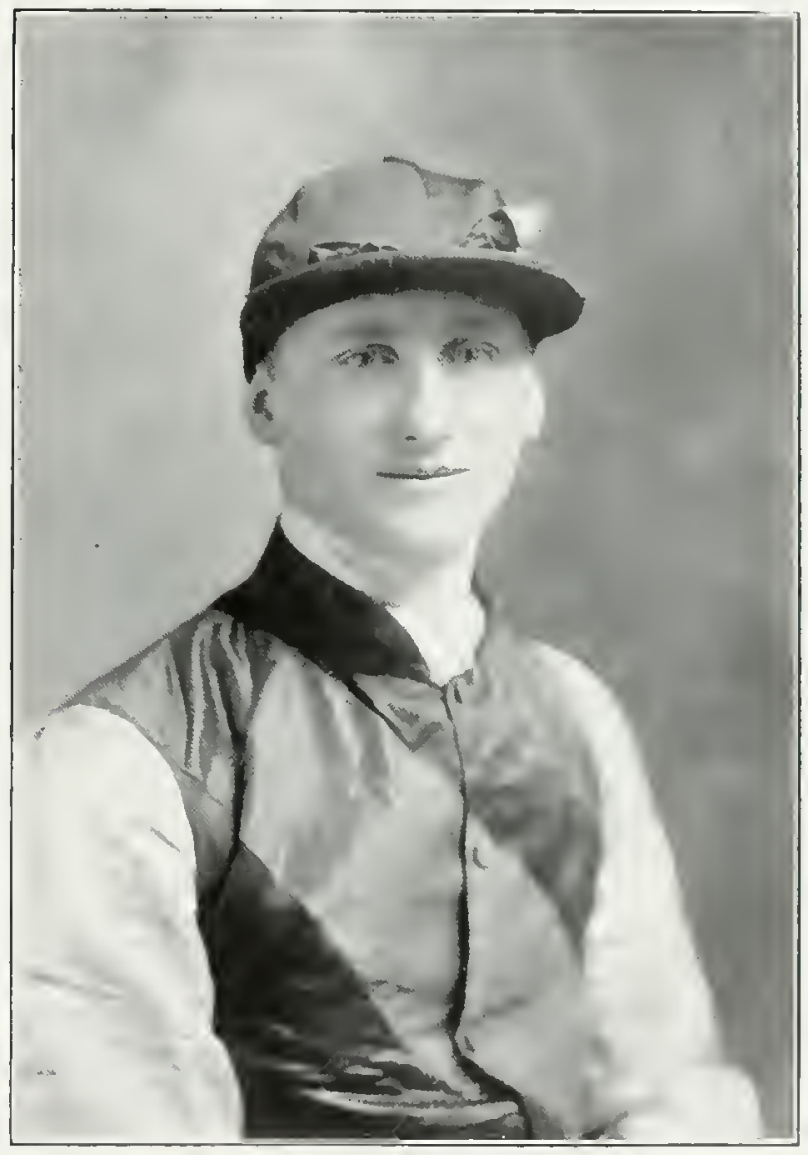

HАКк I STON:

ner reall, and $\mathrm{Mr}$. Stone was second on the list of steeplechase riders, doing the sidclle work for many of the hige stables. During the next season his suceess wats continued. he heading the list, having more momnts to his coedit than any other" steeplechase rider on this continent.

Mr. Stone was married in Now lork in 1906. 


\section{WILLIAM G. WILSON}

$\mathrm{W}$

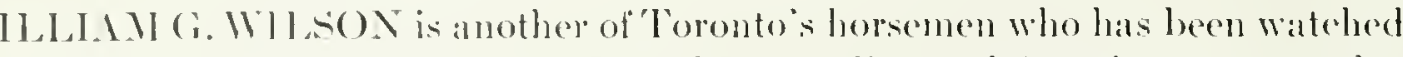
with a great deal of interest on hoth the Camalian and American ralee-tracks.

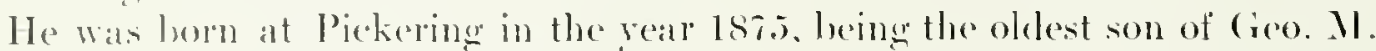
Wilsom. Who was a well-known horseman. When only a hoy Mr. Wilson Went to Wimipeg with his parents. making his home there. lle alterwarks ame to Toronto with his father. Mr. Wikon first showed a liking for riding when only a roungster. and rocle many of his father"s horses. After coming to Toronto he hecame associated with boctor Xorehouse and Geo. Pepper, dereloping his art as a rider moler the grublance of the ons-time famons riller Tim Blong. Ile rode many of the horses

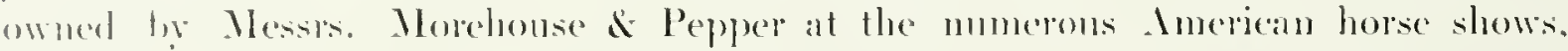
whning his lanrels as a rider of high jumpers at ('hicago and New Vork, where

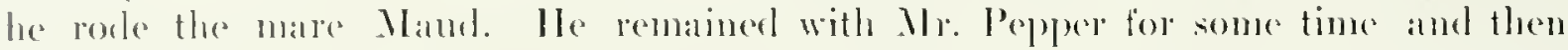
took a position with the Ilon. Aram Beck. of london. looking after his horse interest.t. From the experience ganerl with Mr. Beck he went into business for himself as an owner, and has met with great suceess. Ife handled many prize-wimers in the show ring, and soon hecame interested in the thoromghbreds.

He was alway's more partial to the jumpers than alur other colass of horses, and thromeh this developed into a first-class steeplechase joekey. Sothing anve him more

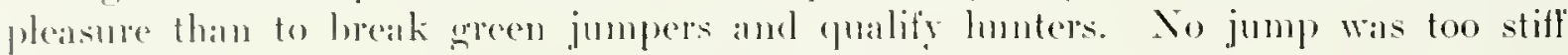
for him to try, having plenty of nerve and combere. When Mr. Wilson embarked as an owner of thomomehhreals, his tirst purchase was the horse st. Iolly. Ile met with

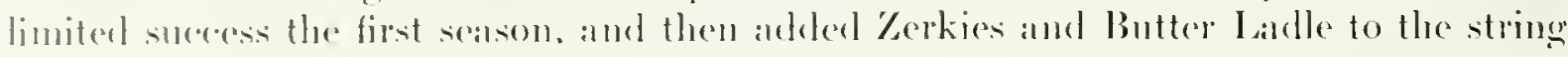
the following spring. The next purchase was the horse Red carr. lored by the late

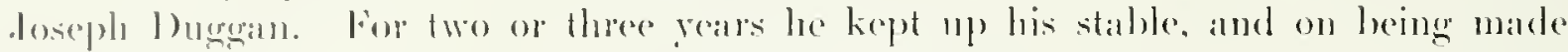
a handsomese ofler for it sold ont lo the Brocrofts of New Jork. He remained with

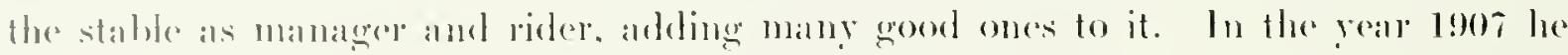

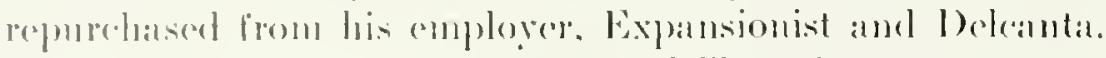

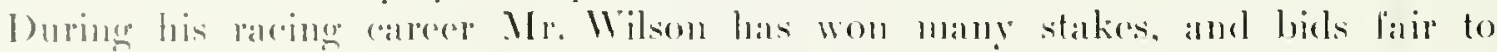

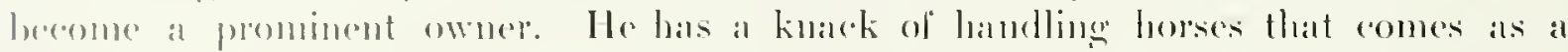
grift, and in many cases he has made a suceessful horse out of what was looked on

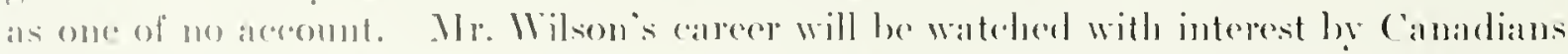
in the yeals to eome, for he is of a happy and gental dispositions, and has made miane limels.

Mr. Milson makes his lome at Sheepshead Bay during the winter months, where his statblen are sitnated, amel where the horses are trabed in the early spring. Ile

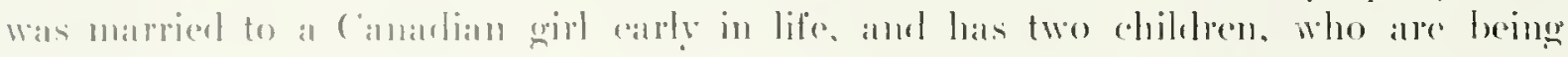

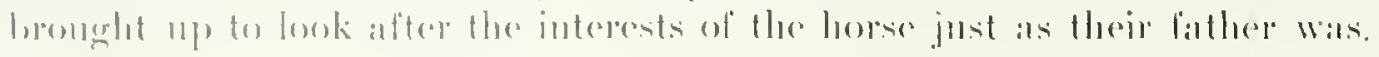




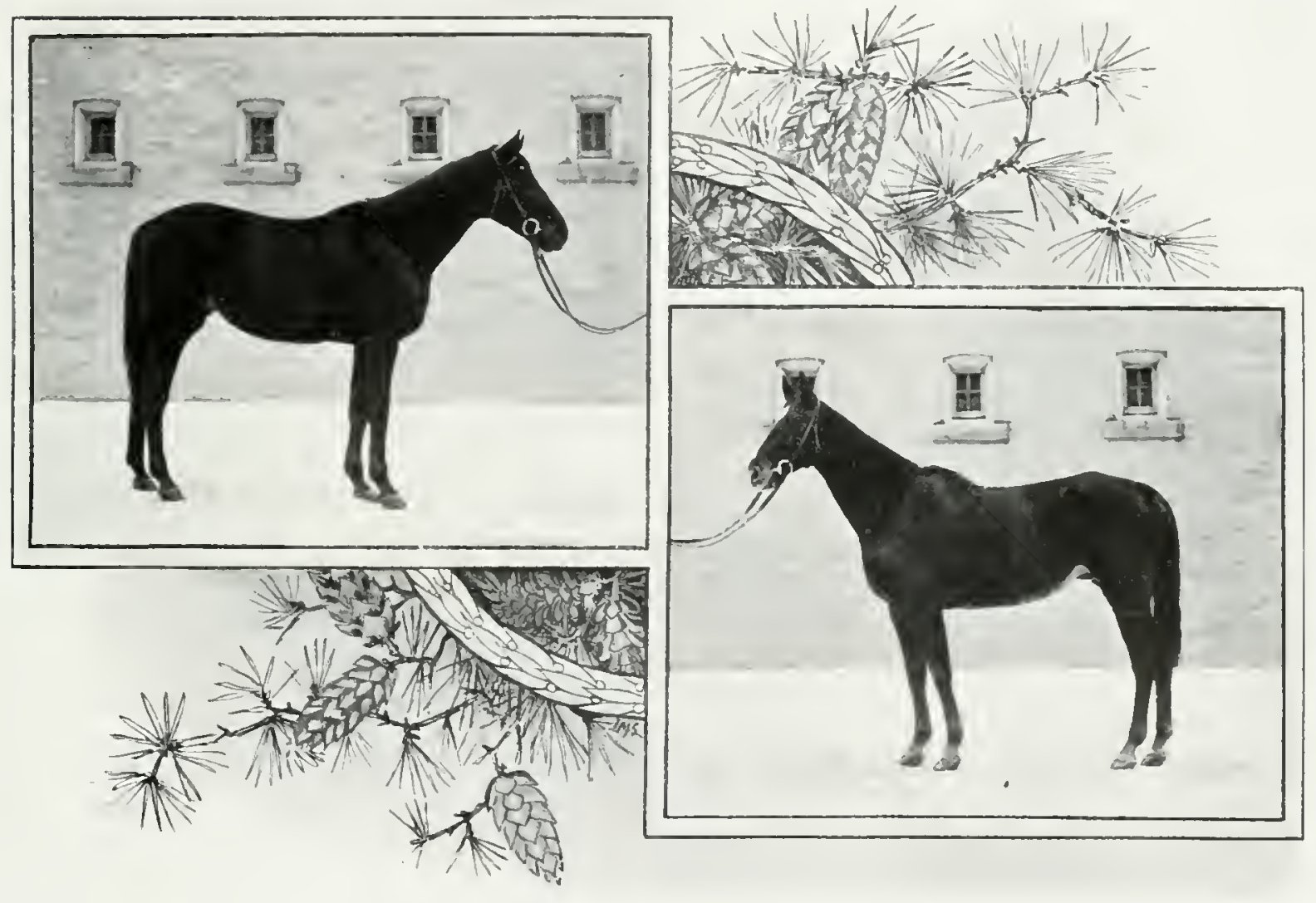

P.JGAN HEY

PROPERT OF WILLIAM G. WUSON 


\section{CHARLES SNOW}

$\mathrm{N}$

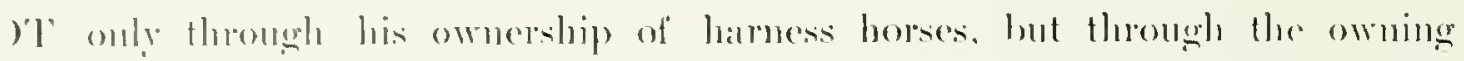
of rmuners, is . Mr. ('hames snow known to the horsemen of Camalat. Born ind enturated at Whithe. Mr. Snow came to Toponto in 1895 to gro into husimen with lis fatluer. In 1899 lae entered the wholesale confectionery business for

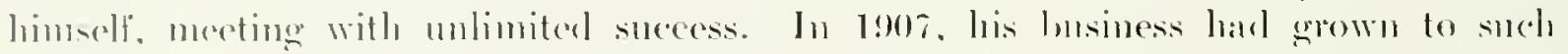
an extent. that it was neesesaly to look for new premises, and his present place of lusiness on college street llest was purchased.

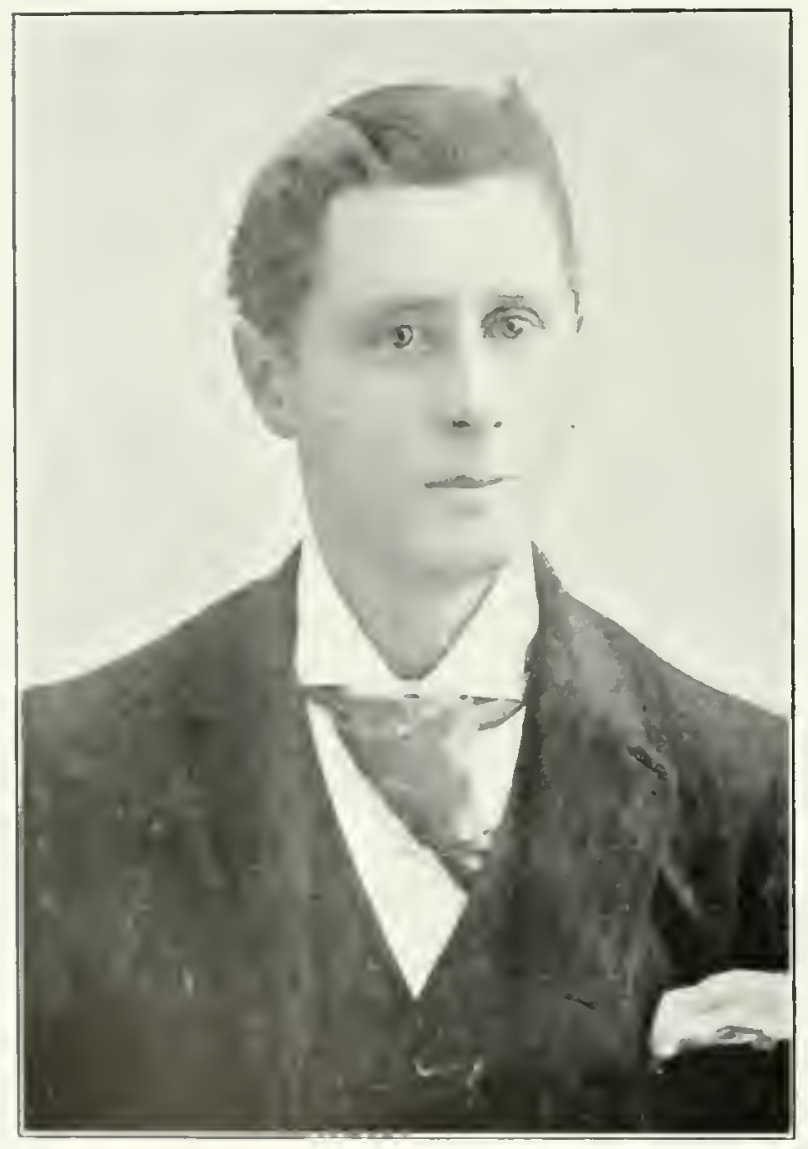

CIMRTIS Sivow

Mr. Snow's first renture into the racoing worlel was when he purrelased Burr ()ak, with whom he won maly rares thromgly the fields. It was on this lorse that Nat Ray. the lamons steeplechase jockey, rode his first rietory.

When Burr Oak was retired, he was replaced ly king John. who wour the 'lolento llunt ('lule anp on the flat, hut who was a lailure over the jumpse.

11r. Snow then tumed his attention to lammess horses, and bought and sold many betore he secomed his first wimmer, the pateer little Boy. who wont the (liampronship of 'Tomonto in 1905. and was considered once of the lastest palcers ever owner in the city.

'l'he next purchase wats the malle Rherlal Wilks, who won mamy prizes at the matinees of the 'Toronto amel I haflerin l'ank l) riving ( luls.

() Hare horses lave locen bought and sold hy Mr. Snow, hut Rlueda Milks will cull lee life in lis stable.

Mr. SHow hats alwaly beren all olficial at the local racess while he has also oflici-

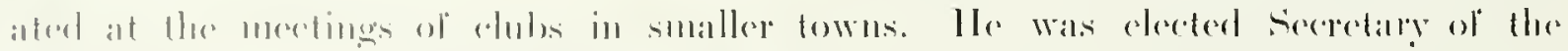

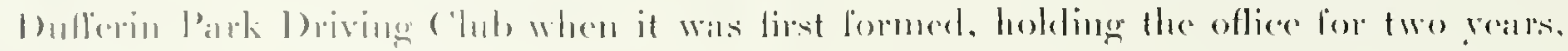

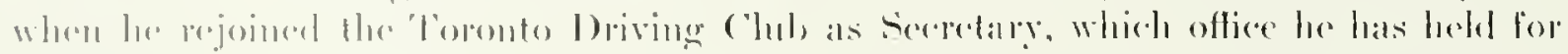

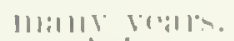

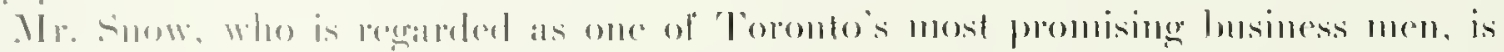

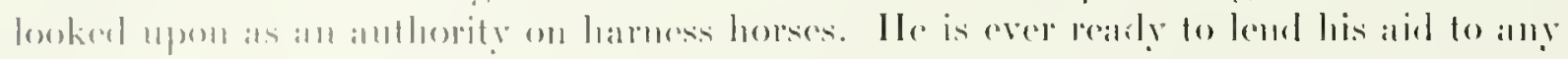

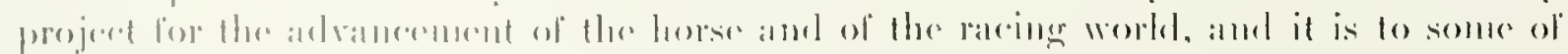

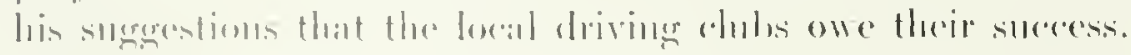




\section{E. W. COX}

$\mathrm{M}^{\prime}$

R. E. W. COX, a native Camarlian, was born in Peterborough, Ontario, in 1 s6t.

Is everybody knows, who is at all familial with the personnel of Canadian business life, he is the eldest son of Senator George A. Cox, widely knomn as President of the Canadil Life and as the moving spirit in a number of the ereat enterprises which are attracting to ranada the attention of the civilized world.

Many a young man with similar alvantages to those enjoyed hy E. W. Cox, hats used those arlvantages to indulge limself in a life of selfish idleness. But inherent good fualities, backed ly sommel training. bronght Mr. Cox into the ranks of the workers. amongst whom le was destined to finel so hight a place.

After a high school traming in his native town, and two rears spent in University Collegere. 'Toronto, Mr. Cox entered the office of his father, who was then general agent for Lastern Outario for the Camadal Life. He proved himself wortly of trust. and was taken into partnership hy his fither, the firm being known as Geo. 1. and E. W. Cox. The braneh had always been one of the most sureessful and satisfactory in the whole of the compilly's organization, and it eren improved its position with the foreeful and devoted service given by the new partner in the agency firm. The good work

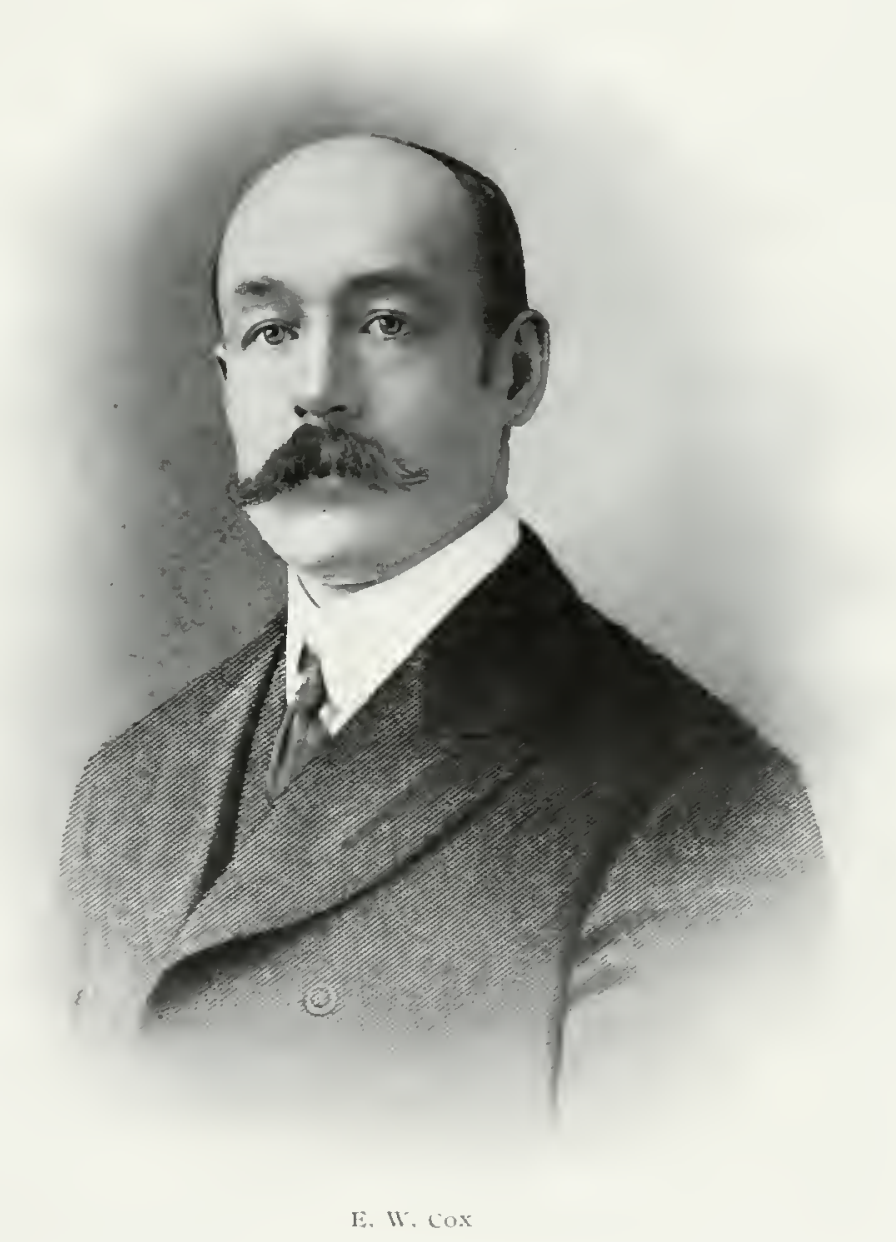

done was recognized ly the company in the most practical wat by giving these sulecessful agents more territory in which to carry on their work. In 1886 the linits of the branch were extended westwarl to include Toronto, and the hranch head office was removed to this city.

From this time mitil a still more extensive sphere of aretion was opened to him. the main work of the Eastern Ontario branch was lone by Mr. E. W. Cox: his father devoting those abilities which have made him famous, more in an advisory capacity 
and as a director of the compram. I notalule instance of how ability and hard work

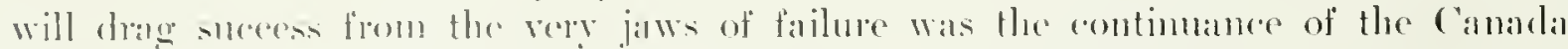

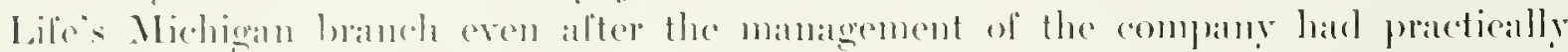

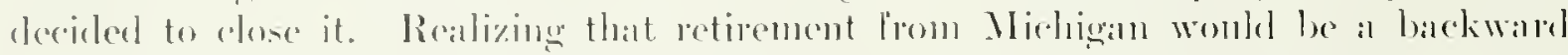
step). which would he injurious to the company organization generally. Mr. George

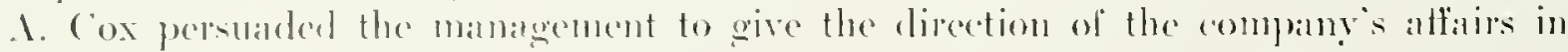
that state to the Eastem ()ntario branch. It an be imagined that the work was one

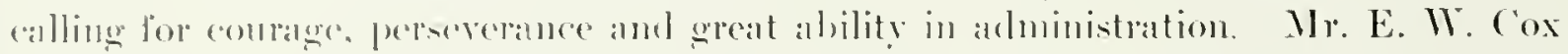

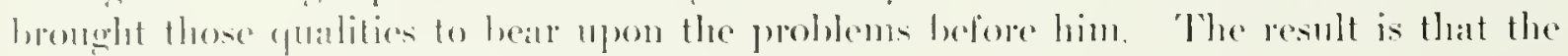

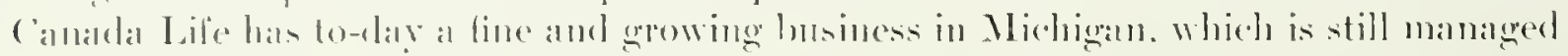
muder the Eastern (Ontario algener.

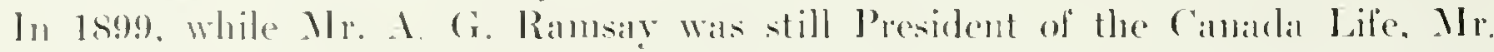
E. II. Cox wats called to the general service of the company, heing given the important

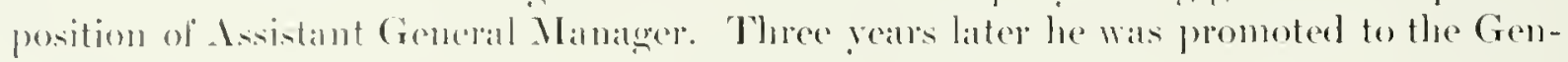
aral Managerohiph, which position he has helel rerer since.

Before Mr. Cox ferame General Janager. the present organization of the rom-

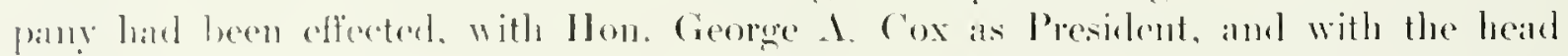

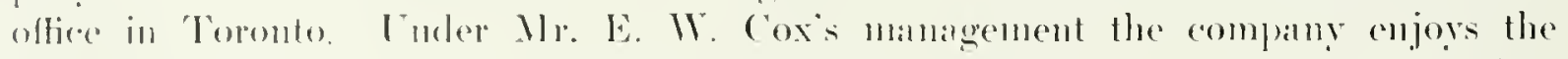
most prosperous daps in its splemelid history. Jt has extemded its operations to New

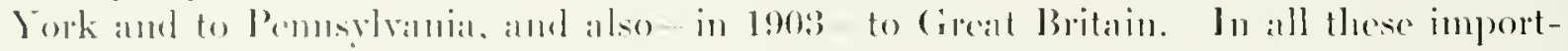
ant fichls its husiness is well called for and is steadily increasing. Throughout the

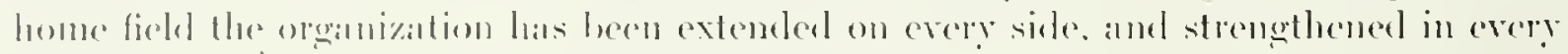
way, so that the epreat volume of husiness which the company and handle ean be rolled

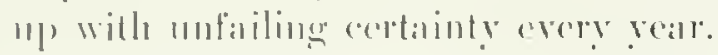

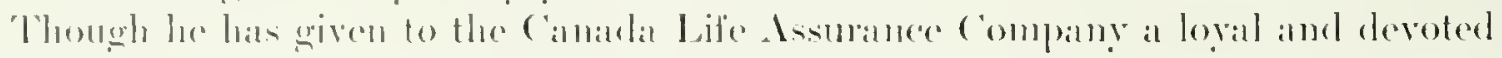
servere. Mr. (os la's not withludel his influence and ability from the promotion and

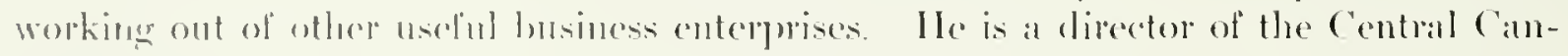

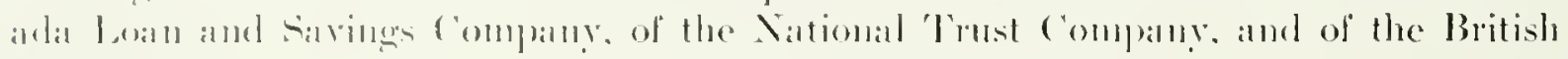

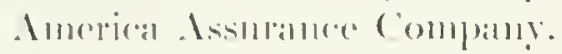

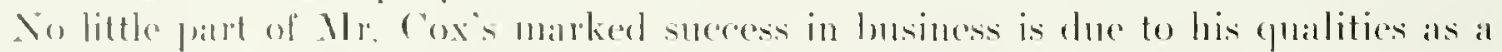

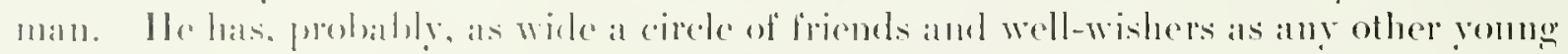

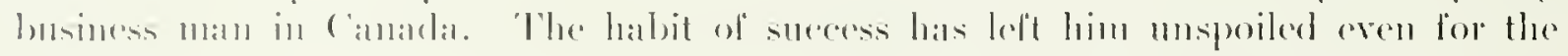

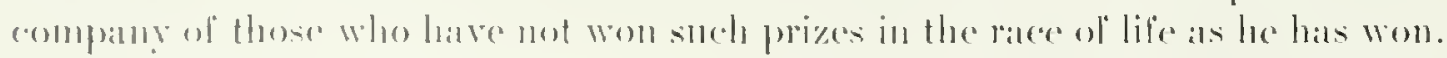

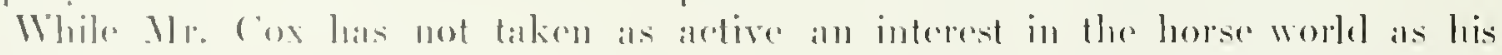

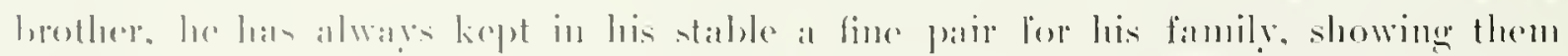

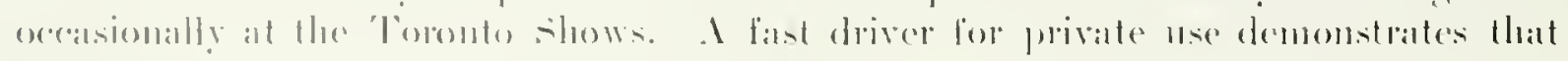

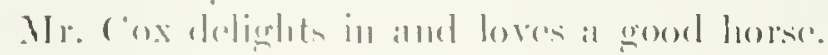




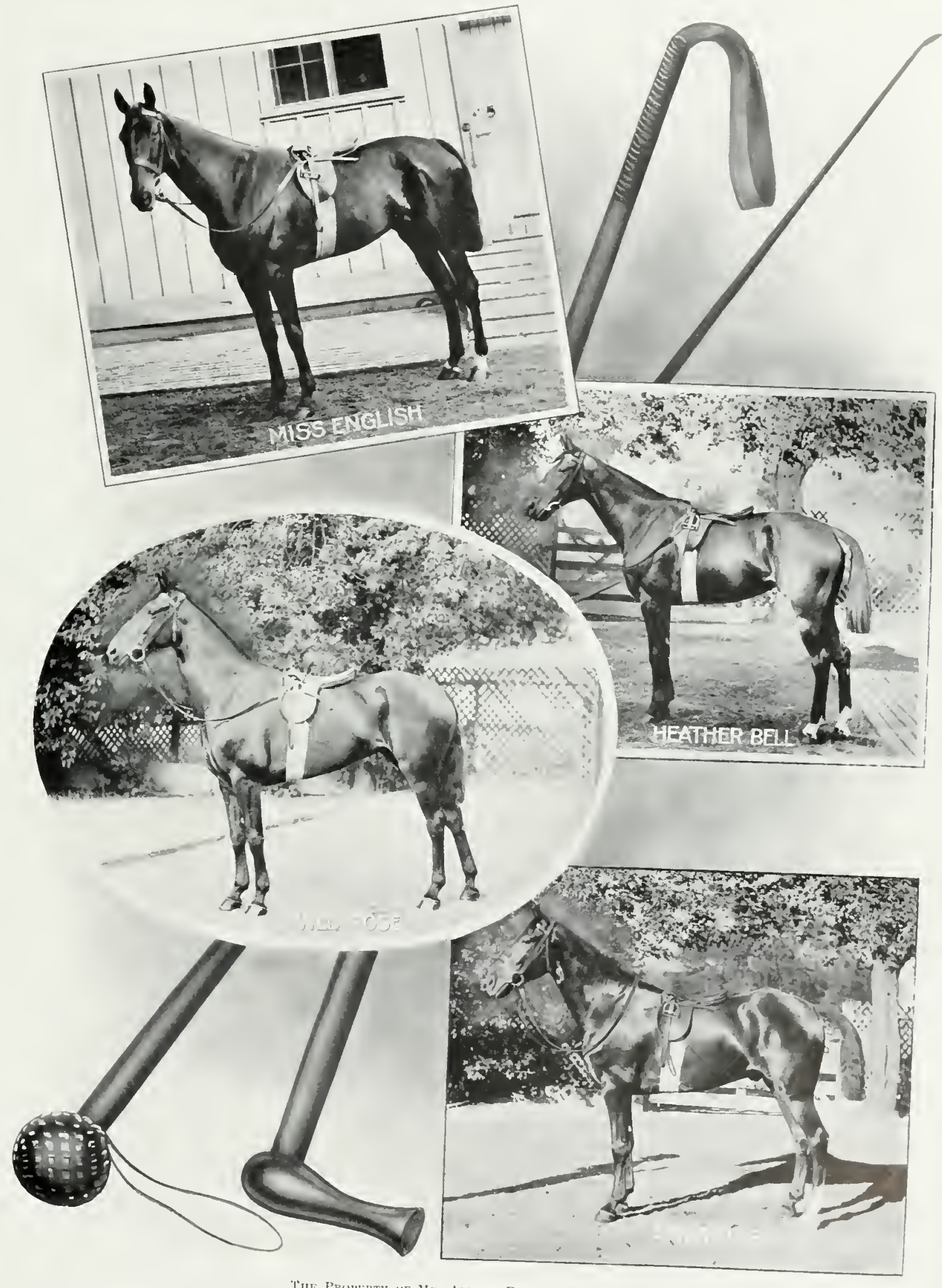




\section{RALPH DOUGLASS}

$\mathrm{A}^{\mathrm{T}}$ the early age of seventeen years. Ralphl louglass, of Ste. Therese. Qua.. hecame decidedly interested in the horse. Mr. Doughass is president of the brewery firm

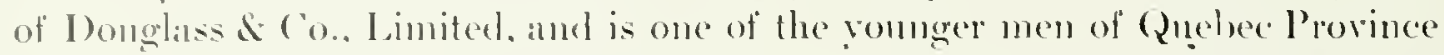
whe are helping the interests of the horse in a pratical way all the time. Ite wats horn in Broeklyos. X.Y. in 185. He spent his summers in Champlan. X.I.. and

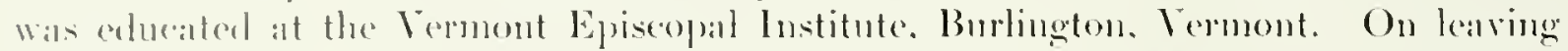
school. he became interesterl in horsedom particularly, for he had alepuired possession

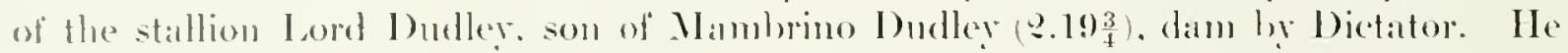

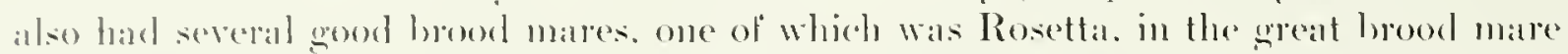

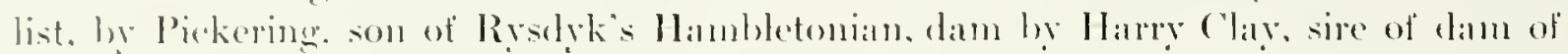
Elecotionerer. Amongest tho horses he possesses now. Mr. longlass is fondest of Rosetta.

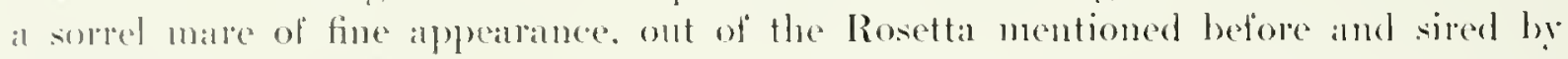
Mlamuler. sire of 1)ariel. 9.00 $\frac{1}{2}$. In redating some of the rery interesting horse facts Halt have eome within his wile experience in a few reals. Mr. Donglass mentions that probably one of the hest horses for road and anriage ever owned in Burlington. Vt..

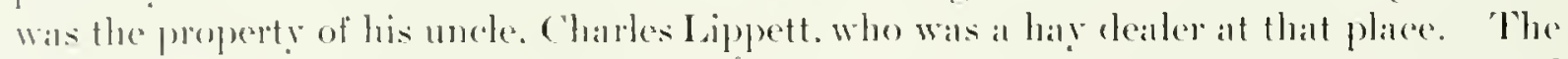

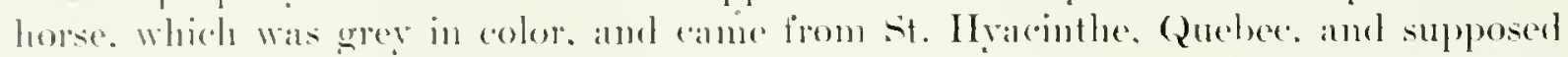

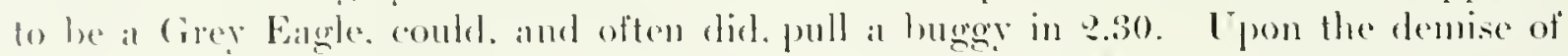
Mr. Iippert. this splemdid horse hecame the property of Mr. Doughass father. and the animal malle al wenderful reputation in northern New lork state. Ile was mol hleserl with any high-soumding name, heing known just as common. plan. ordinary. evervelay " Joe." and apparently quite satisfied that it should be that way.

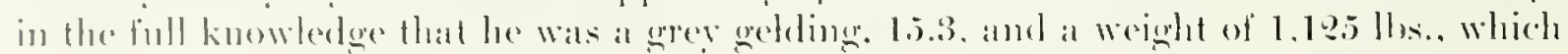
wass contirely out of propertion with his importance.

Ile fomelass was for some time commerted with the shermans rery wealthy

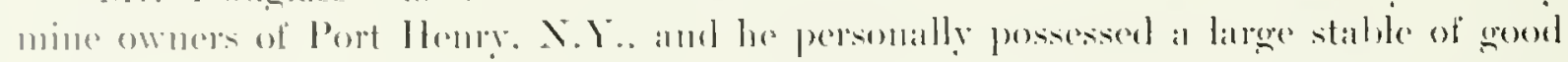

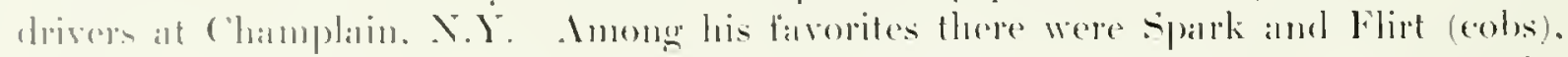

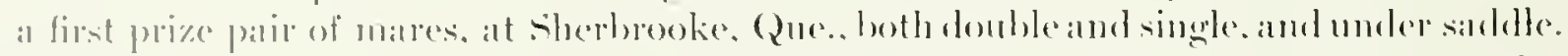

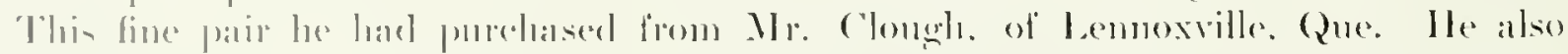

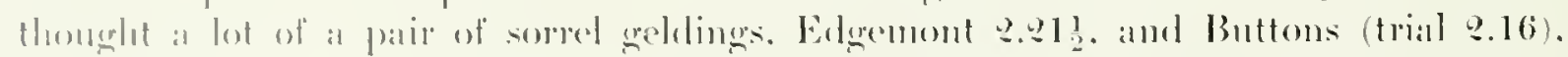

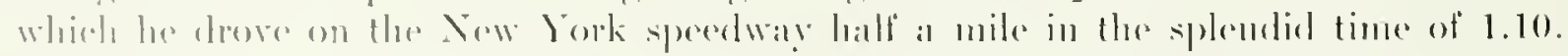

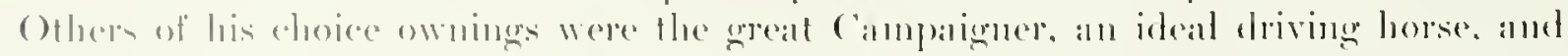

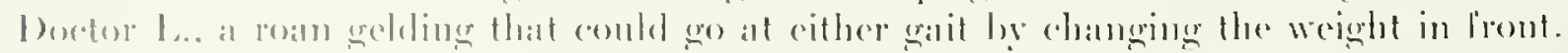

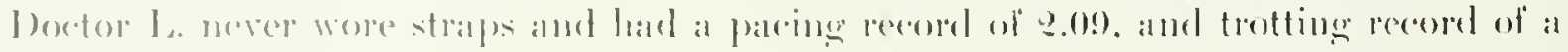
frartion orep s.1?

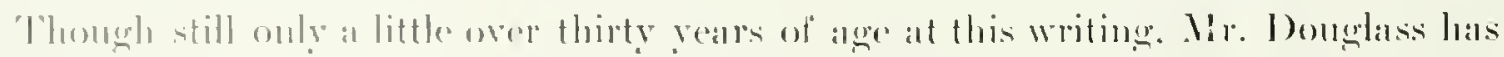

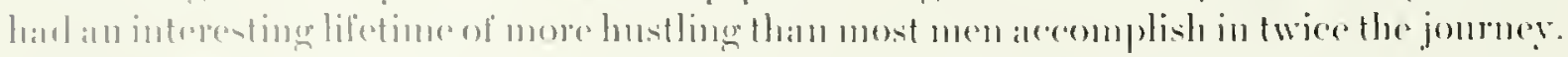

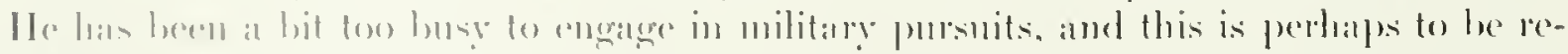

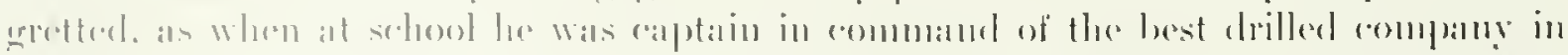

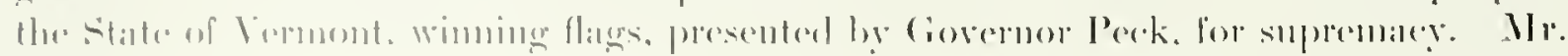


Douglass is of cheerful mind, being atescribed by one who know's him well, as "a good friend and a bitter enemy," who has been through all sorts of husiness suecess and misfortune, but so fin has not refused aid to one in trouble, helieving it hetter to oceasionally help one undeserving case than to overlook one worthy. He is said to have spent a self-male fortme in helping others whenever his and was sought, and as he says himself, with some vigor, he came to Canada criticized and condemmed for anything and everything he ever did, particularly because he had no money left. But by hard work and persistent effort he has now huilt up a prosperous business in ste. 'Therese. He hadn't much to work on, but took as a basis of his present big interests the Morris brewery, whieh was one of the oldest in Camala.

Mr. Doughass is a deroted family man. IJe was married in Champlain, X.Y., eight years ago, and the mion has been happily blessed hy two daughters They are bright children, and inherit their father's love for horses. Like him, too, they are particularly fond of dogs. IIe has owned many good ones of varions breeds, and is at present the owner of some fine foxhounds.

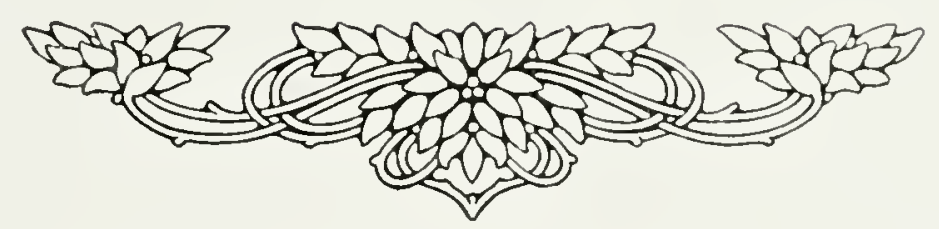




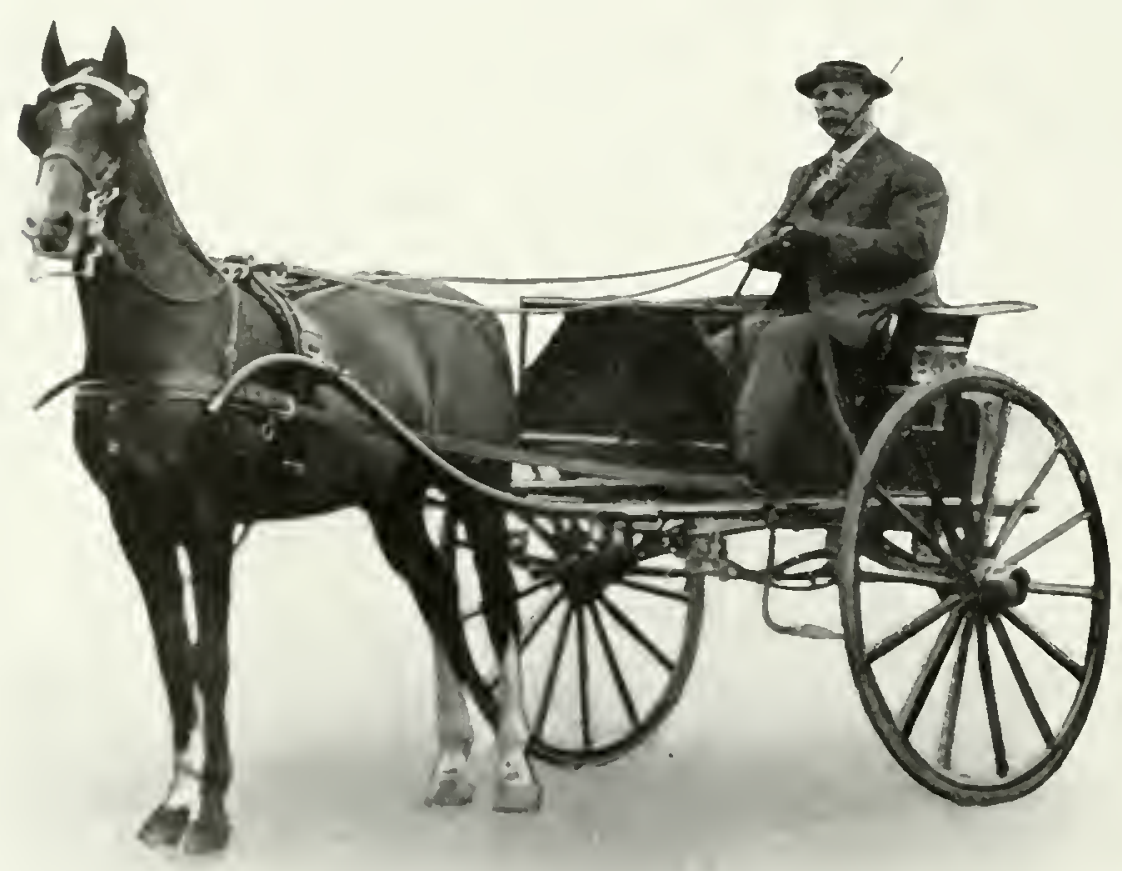

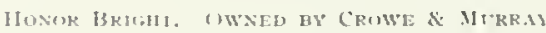




\section{Lovers of the Horse}

\section{DR. R. E. WEBSTER}

$\mathrm{N}^{\prime \prime}$

OT so olten as desired does one see the combination of a man very busy in his profession or practice. and equally husy in the introduction of good horses. None the less. I)r. R. E. Wehster. a leading grnaecologist of Ontario. finds time or makes time to devote much of his attention to horse-flesh. and that he is a lorer of it goes without sayng. Ile is a prominent practitioner in Ottama. devoting his attention altogether to smaery. He is a native of Brockville, and took np residence in Ottawa nine years ago. I gratuate of Me(sill. he eompleted a post-graduate course in New York, and afterwards practised in Texas. where he was lecturer on surgery in the Texas Medical College. Beeause of ill-health he returned to Canada. and he is now chief surgeon of the C'arleton Connty Ceneral llospital. 1)r. Webster las alway been a horseman. and since his early days has had an inclination towards the thoroughbred. Ilis horses have heen many, and have heen shown at all the leading Canadian shows. Among them was the Earl, afterwards sold to the late Mr. Mlives, who won

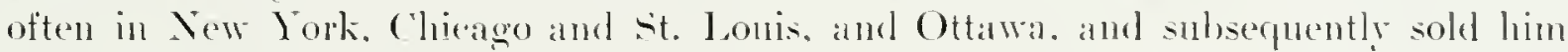
to (. W. Watson, of Baltimore.

Mrs. Webster. Who was Miss Irene Jones. of Brockville. is equally as entlusiastic as her hushand. She is the owner of Rosanal. Whieh is still in her stable. Is a lightweight sadelle horse Roxana seems to be in a class hy herself. and last rear was an easy winner at Montreal. Inother fine horse in Mr. Welster"s stahle is skrbark. who won secont in the middleweight humters at Montreal in 1907. Still another is Woodlark. Which will be monght ont in the spring. and is said to be one of the ligggest jumpers in (anada. Dr. Webster is Master of the Ottawal Iunt Club, and Was practically responsible for the formation of that flompling organization two years ago. Ontside of the fact that his position is a responsible one, he is interested at all times. and much of the sueeess of the Club is due to his inclefintigable efforts.

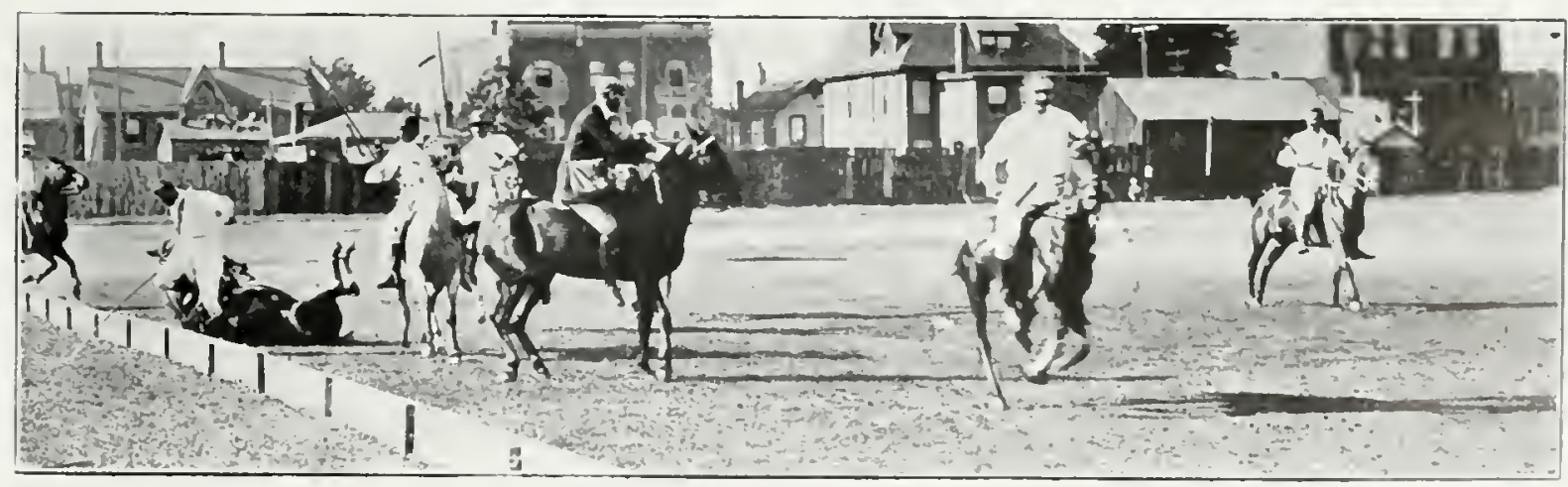




\section{DR. ANDREW SMITH}

$\mathrm{P}^{\prime}$

ROBB.IBLA there is no better known horseman in Ameriea than Dr. Andrew

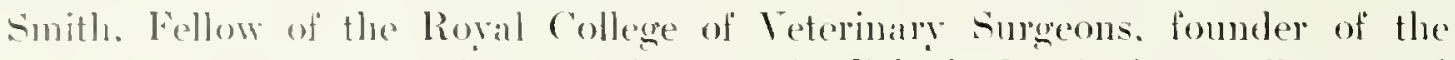
(Ontanio Velerinary college. until recently I'rineipal of that college and

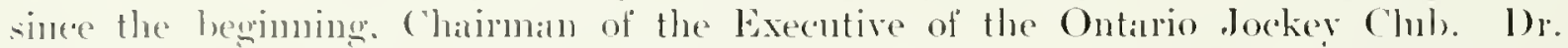
sunth was also l'resiclent of the Exhibition in suecession to the late J. J. Withrow in 1901 and 1909. IIe was hom at l)alrymple. Arrshire. Where his father was a large brester and lammere. "The loretor thus niturally hecame a lover of live stock prior to

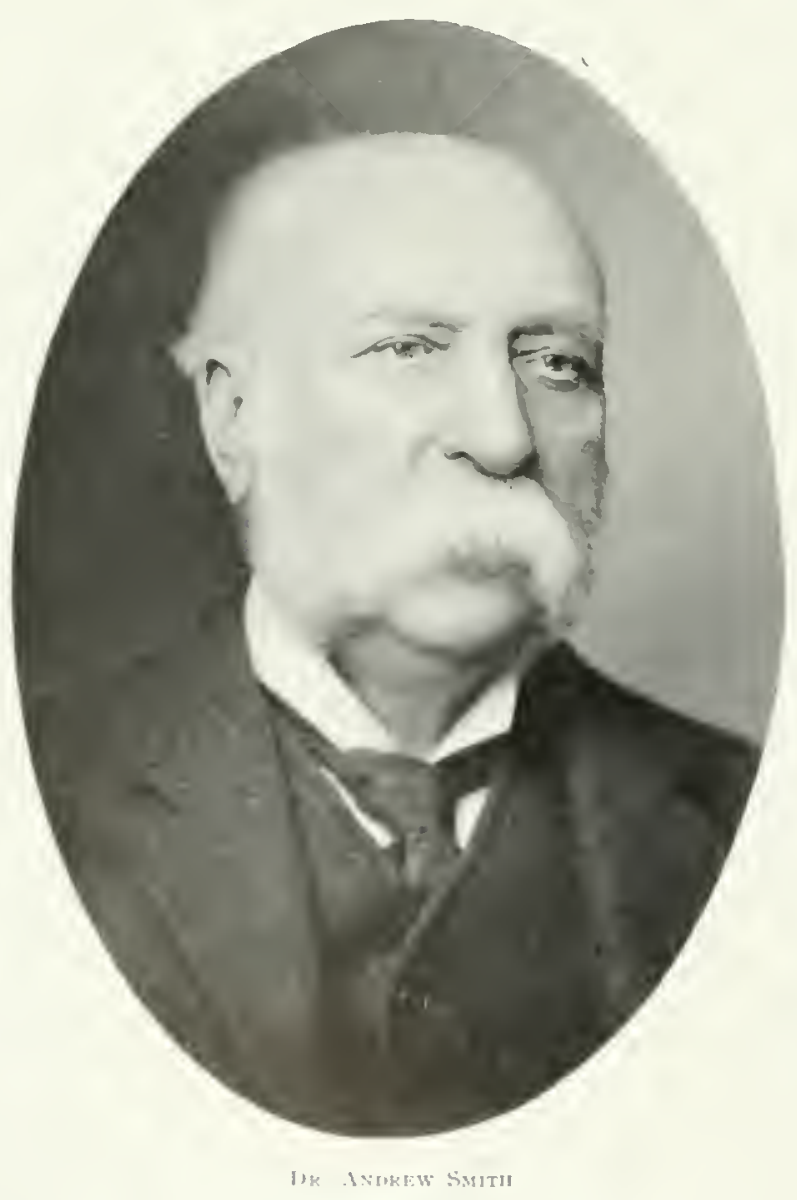
taking "1] the profession that he has followed all his life. He gramluated from Eslinburgh Veterinary College in 1801 with the higlest lonors and medials, in"luching the Highand soejety medal. Ile (pualified for the directorship of 'l'oronte Exhibition and for the presieleney hy heing for two or thee years secenetary of the Inmal show hedel in his mative district.

ln Istil the Provineial Boalel of Inpieulture decided that it was desiralule that the veterinary profession shombl be put on a better and more classified footinger. They consequently deputed the late Prof. (ieco. Bucklanel to visit Seotlancl and (onsult Principal D)ick of the Edinhuregh Veterinary ("ollege as to a gentleman that wonkl be able and desirable to take charge of a veterinaly college at Poronto. Principal D)iek warmlyalrised the oflering of the appointment to l)r. sinitl. The Docotor conserfuently ealume to Camadal forty-siren pealrs ago, and fombled the Ontario Veterinary College, which has been noted as securing stu-

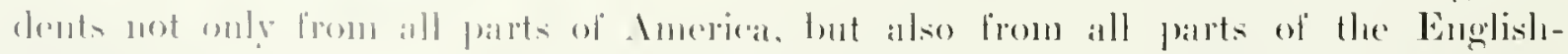

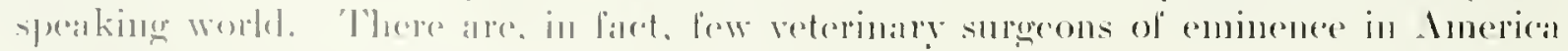

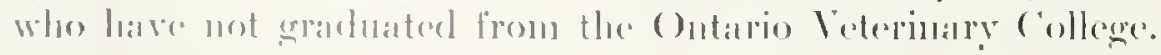

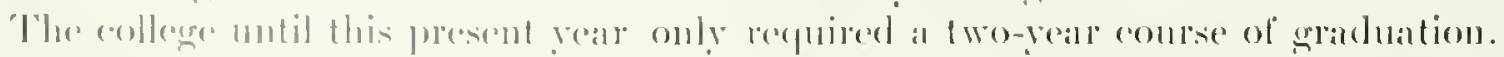

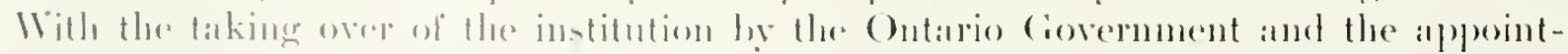

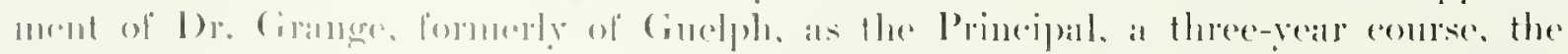

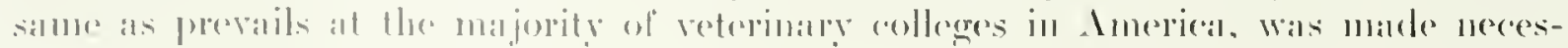


sary. What effect this change may have mon the attendance. if any is not yet risible. as the number of fresh stulents this vear is well up to the average of any previous year.

Dr. Smith was Veterinary Sureon of the Provincial Inricultural Association. Dominion Governument Inspector of Stock for Ontario. Veterinary Surgeon of the Toronto Field Battery, and for ten years Master of the 'loronto Ilunt. Me has also officiated many times as judge at loorse and other live stock shows. not only in his adopted country, but at New York. Philadelphiar. (hicago and other places in the states. Ile is a member of St. Andrew's Society, and also of the Caledonian soejety. Ile is l'ast Master of St. Andrew's Lodge, A.F. \& X.MI. Dr. Sunth's som, Dr. David King smith, is surgeon to the 48th I Iighlanders, so that the fandy has a matural leaning towards the military.

'The Doetor in his younger days was a good steeplechase rider, and has ridden in many a wimning race. He is now, although advanced in age, a follower of the homds, and is invariably well ul at the finish. Among the noted horses that the loctor owned was Brown Dick, a winner of mally a rattling race across country; another was Namne Craddock, an cxeptionally good race mare, and wimner of many a diase: Luxemburg was a thind horse that the Doctor was very much attached to. and was worthy of the attachment. Ile also at one time owned Lady Red. dam of the lamous Ilamhure. and other good wimers. Lady D'Arey, owned hy Dr. Smith, was as a tworear-old the fastest sprinter in Camada. Few who remember her first race will forget how she shot ont from her fiekd and lelt the others as if ancluored. Sir tames. a horse show champion, was a high-edass saddle horse that the Doetor had a great liking for, and among others that he was wholly or partly interested in have heen War Cry. Vespucius, imp. First Attempt.

When twenty-seven or twenty-eight years ago the Ontario Jockey (Jub was formed. 1)r. Snith was naturally regarded as a sure and certain smporter. Ile heartily endorsed the late 'T. C. Patteson in his eflorts to oryanize the ('hub. and was made a Director and member of the Executive at its inception. Early and late the Doctor has worked for the suceess of the O.J.C.. and the high standard that it hats reatehed is very largely due to his persistent efforts. Ile is a man of sombl jumbment and uniform courtesy. Probalbly no Principal of any college has been more highly estecmed, renerated and loved than 1)r. Smith has he the students of the Ontario Veterinaly College. If a student failed to pass. it was to the principal that he went to pour out his woes and to receive sympathy, and he never left disilppointed. for the l boctor ever proved a true friend, a wise combellor, and virtmally a fathor to all. 


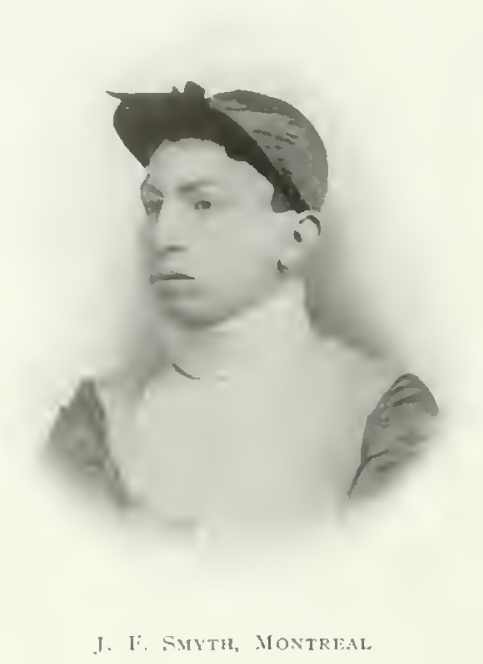

\section{JOHN FORESTER SMYTH}

$\mathrm{J}$

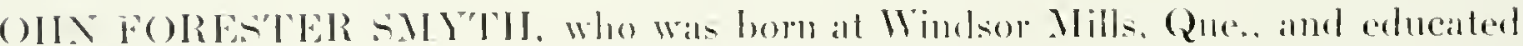
at Montreal. is one of the yommgest owners in cimalal. He first leamed to ride

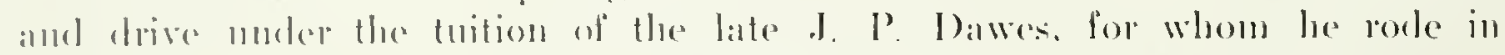

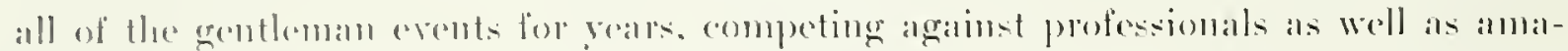

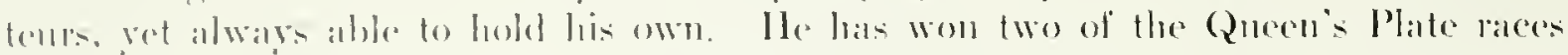

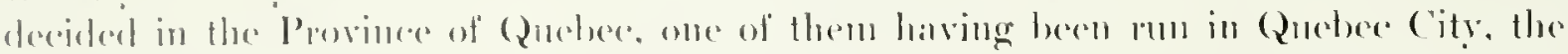

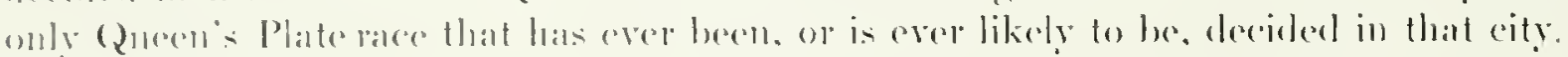

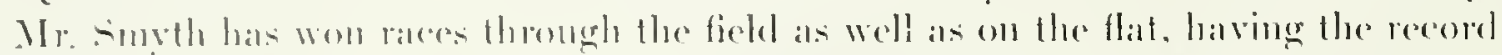

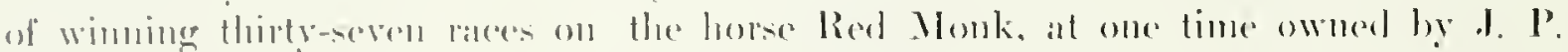

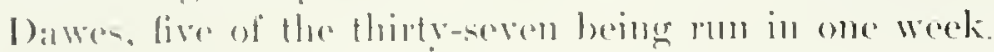

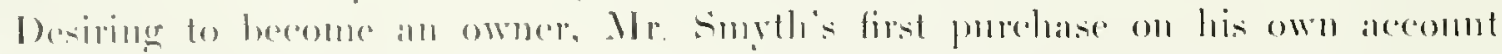

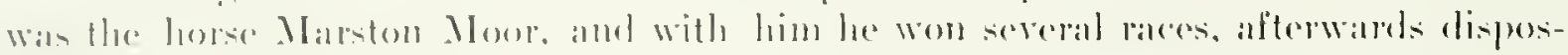

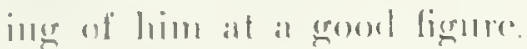

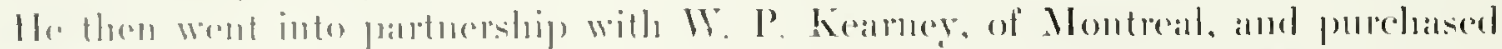

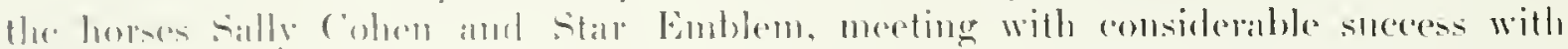
the pair.

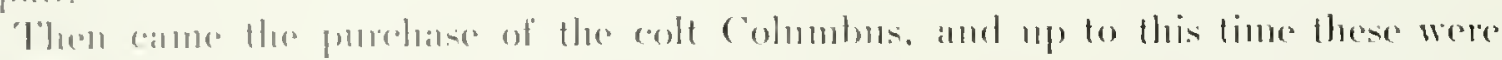

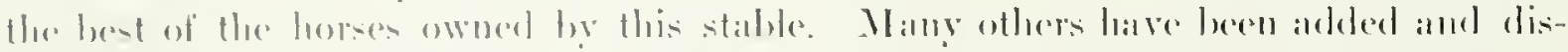

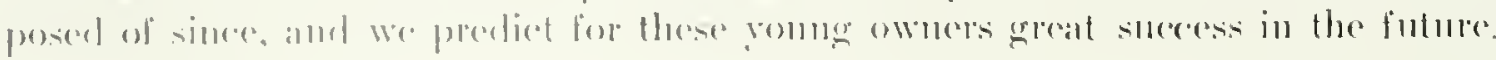




\section{Lovers of the Horse}

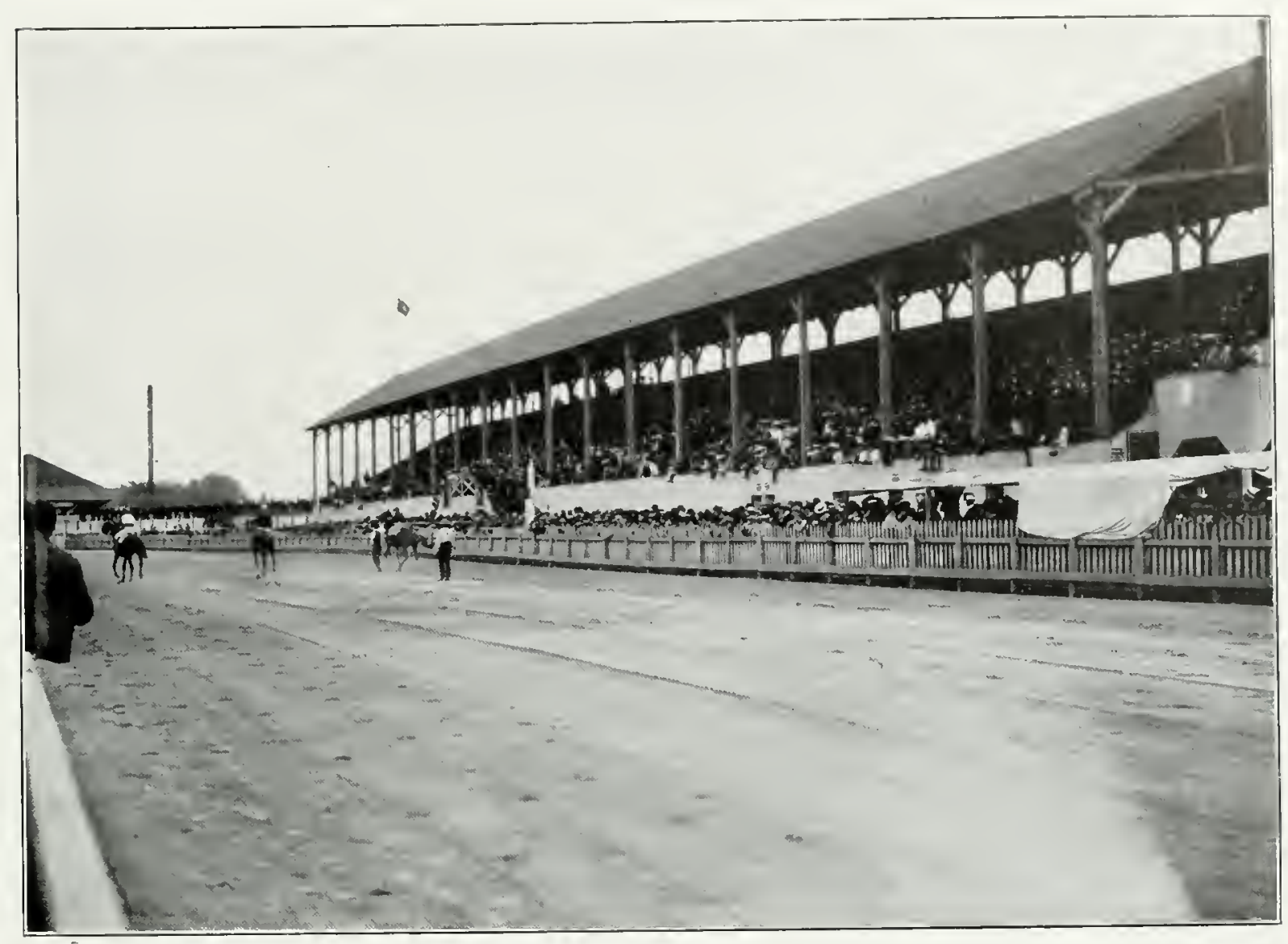

GRANI STAND GUEBEC TURF Club

\section{THE QUEBEC TURF CLUB}

$\mathrm{U}$

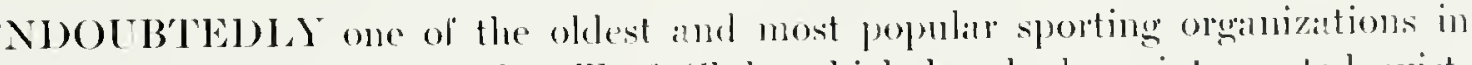

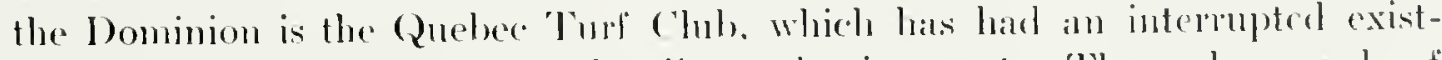
ence reaching away batek into the dim and misty past. The cally records of the ('bub are not now araiblale, hut Lient.-Col. Ashmead, the present genial and active secretary. has in his possession minute books dating from the year $18360^{\circ}$. I

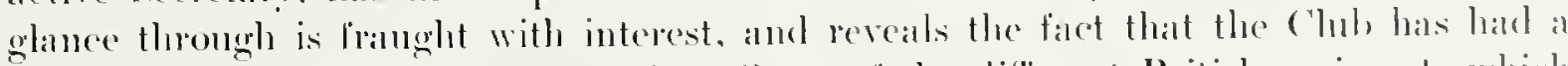
notable carrer. In its eally days the officers of the different British regrinents which

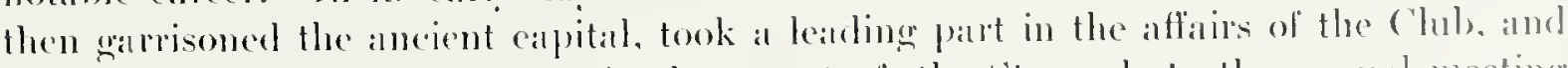
in the year 18t5 there is a note in the report of the stervards to the ammal meeting of the ('lub, to the efloct that they viewed with regret the departure of the itth Regiment and the 6oth Rifles. which would deprive the ('hul of some members. But the arrival of the soth Regiment, it was hoperl. womkl make up the defiedencer. In these

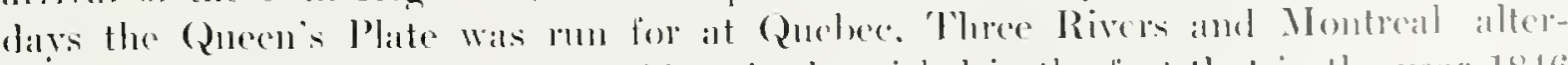
nately, and another renarkable incident is chonieled in the laset that in the year 18 to 


\section{$204 \quad$ Lovers of the Horse}

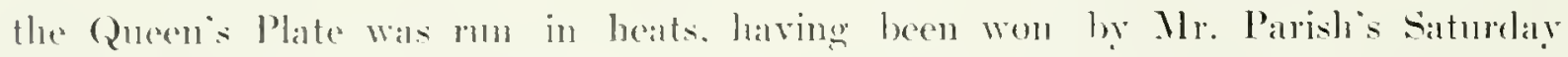
Night. two straght. 'Jlere were enod stakes oflered in those diys, the purses often

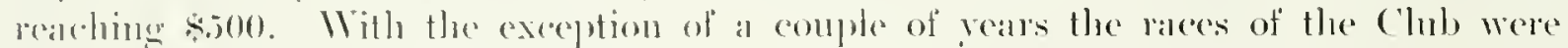

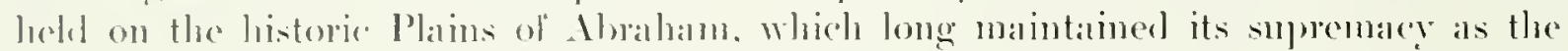
finest turf track in the comstry. The ammual meet of the Thut chuls has always been the oceasion for the gathering of the wealth. beanty. and fashon of the city and aldjoming district. and competition has ever been keen between the owners of horses in

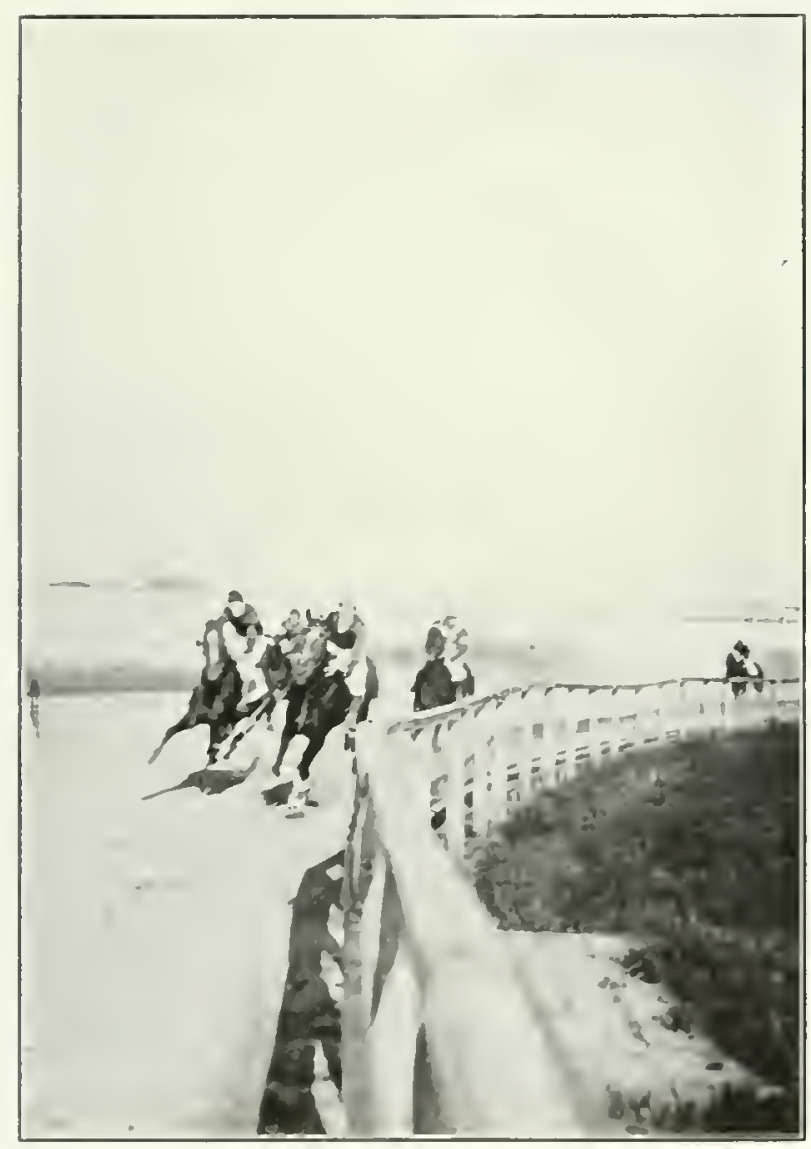

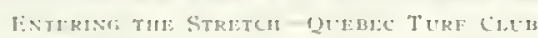
this section of the comntry.

Simong the arly members of the ('lul, who took a hige part in its pomotion was the late Mr. C. Il. Parke. Between the realrs 1836 and 1840 was the period in which he took his deepest interest in racing. during which time he won. not alone the (Queen's Plate. Hut also many other valuable prizes. I wortly som, in the person of Dr. ('. S. Parke, died but a few vears ago. He was an ex-President of the ('huh, and also did ereat work for it. In homored veteran of the ('luls, who is to-day still hale and hearty, is Major F. Lamkson, who for twenty realss acted ats Treasurer, only resigning a rouple of vears ago, when lae was manimonsly elected a life member. Another name in the history of the (lub which will always be remembered witle feelings of admiration. Was the late Major Sliort, of " B " Battery, whose sald thomgh heroice deatlin in the enpeat fire of st.

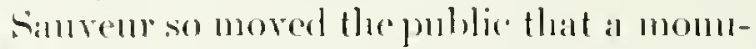
ment to his memory may mow be sem in frent of the Drill ilall on Giande Nllece.

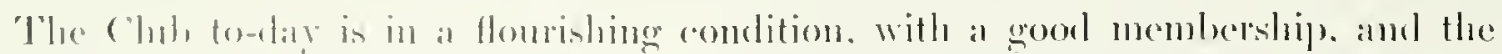

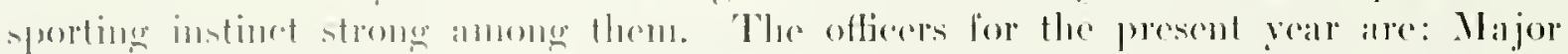

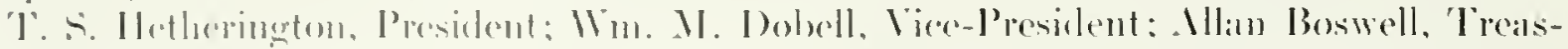

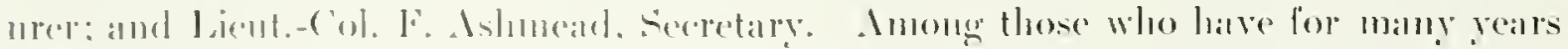

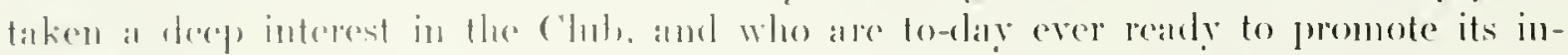

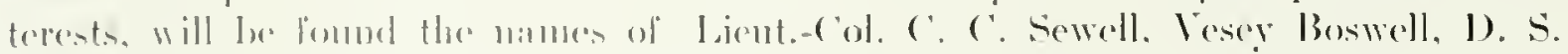

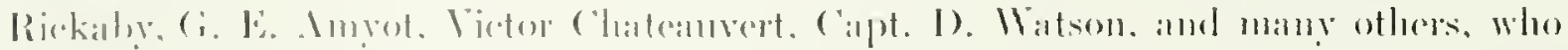

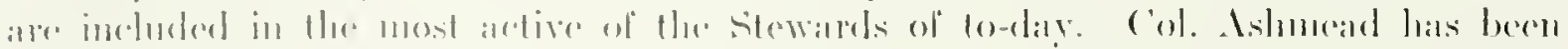

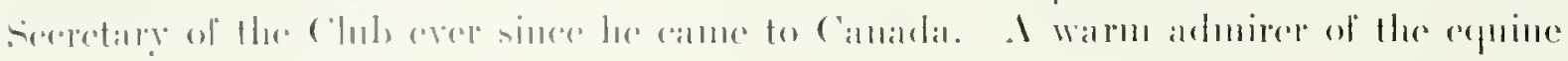




\section{Lovers of the Horse}

race, and a crosi-enuntry rider witl few equals, the gallant Colonel has brought home many a horse to vietory. It is now slightly over twenty years since he rorle his last steeplechase in England. and lis feats ats a gentleman rider in cimatal have been no less successful. Mr. D. S. Rickaby is also entitled to a meed of pratise for the energy and enthusiasm whiel lae has displayed in the promotion of the sport of kings in Quehere. For a great number of reals he acted as starter, a duty which he never failed to perform with aredit, only retiring three or four years ago, when the Clut secured the services of at professional in the person of Mr. Mce(imuis. Mr. Francis Nelson,

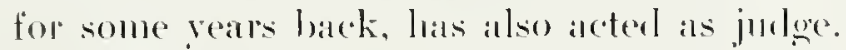

With its long and montermpted atreer the ('lub has never failed. except upon one or two occisions, to lobl its ammual two or three-tay meet. 'The last of these was the season just past. When the stewards thought it expedient to forego the ammal event owing to the races hedel hy an outside organization during the lercentenary

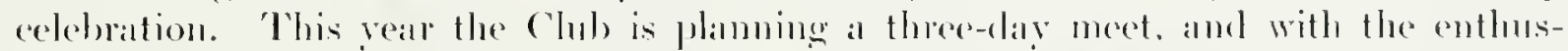
iasm and vigror whele the members at all times exhibit, there seems to be little doubt that it will prove the same great suceess which has always pewarderl their eflorts.

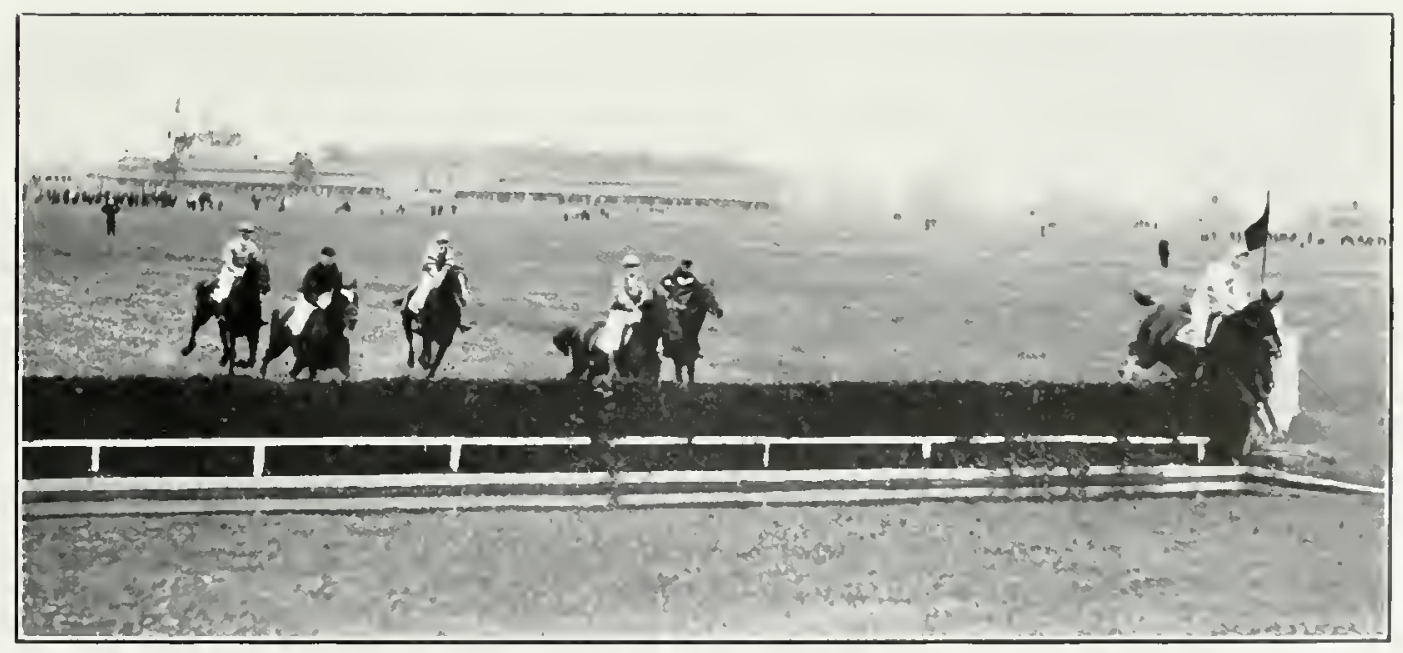




\section{6 \\ Lovers of the Horse}

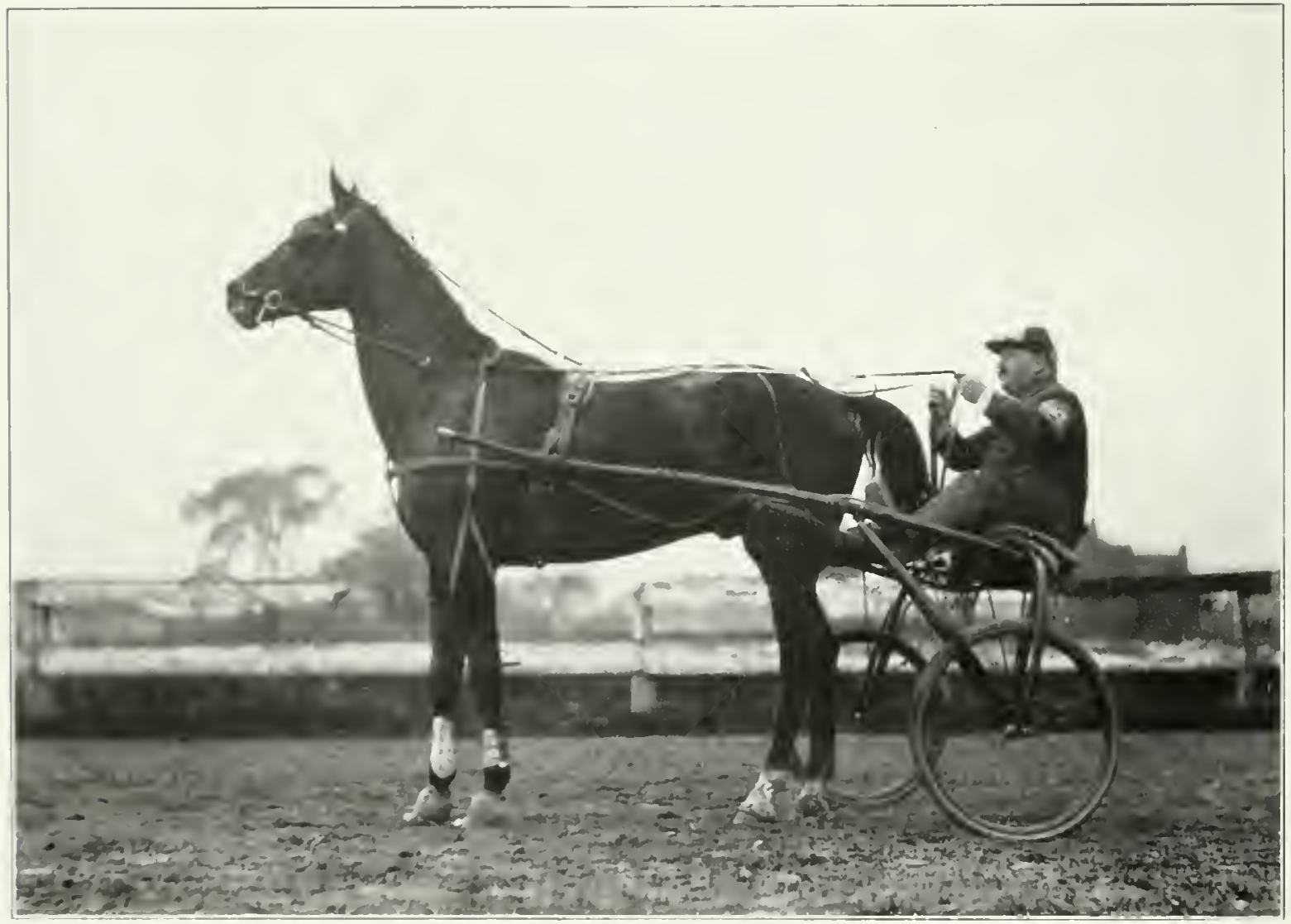




\section{P. M. FEENEY}

$\mathrm{N}^{\prime}$

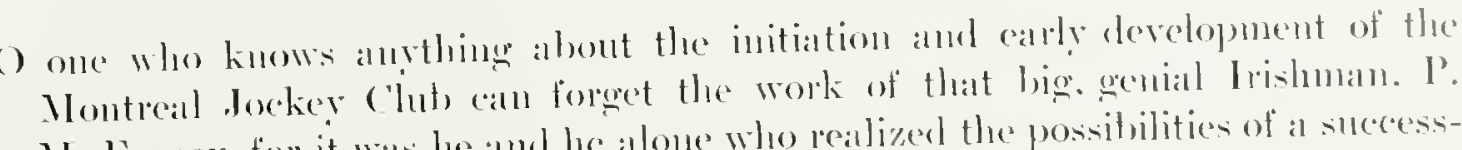
II. Feeney, for it was he amal he alone who realized the posibilities of a successful race meeting in the Metropolitan ( ity. The difficulties he had to contend with in secoring snitable land. olstaning options, and getting the right perple interested, would tave discombaged a less sallgruine mind, hut P. M.. with the same determination that has julled him thromgh many difficulties, hronght the negotiations to such a head that laid the fommlations of the present success of the Montreal Jockey (lub).

Ir. Feeney is an up-to-rlate, alert husiness man. Who has had a large experience in handling lange eoneerns and making them pay. Ile started business ats a saw manufacturer in a small way some rears ago. and in time alsorbed factories in St. John, N.B.: Quelsec. Ottalwa and Montreal, holding the controlling interest in the amalgamated factories. which were known as "The Camada sall C'o." Mr. Feeney afterwards sold his interest in the company, and invested his calpital in other concerns, all of which have heen suc-

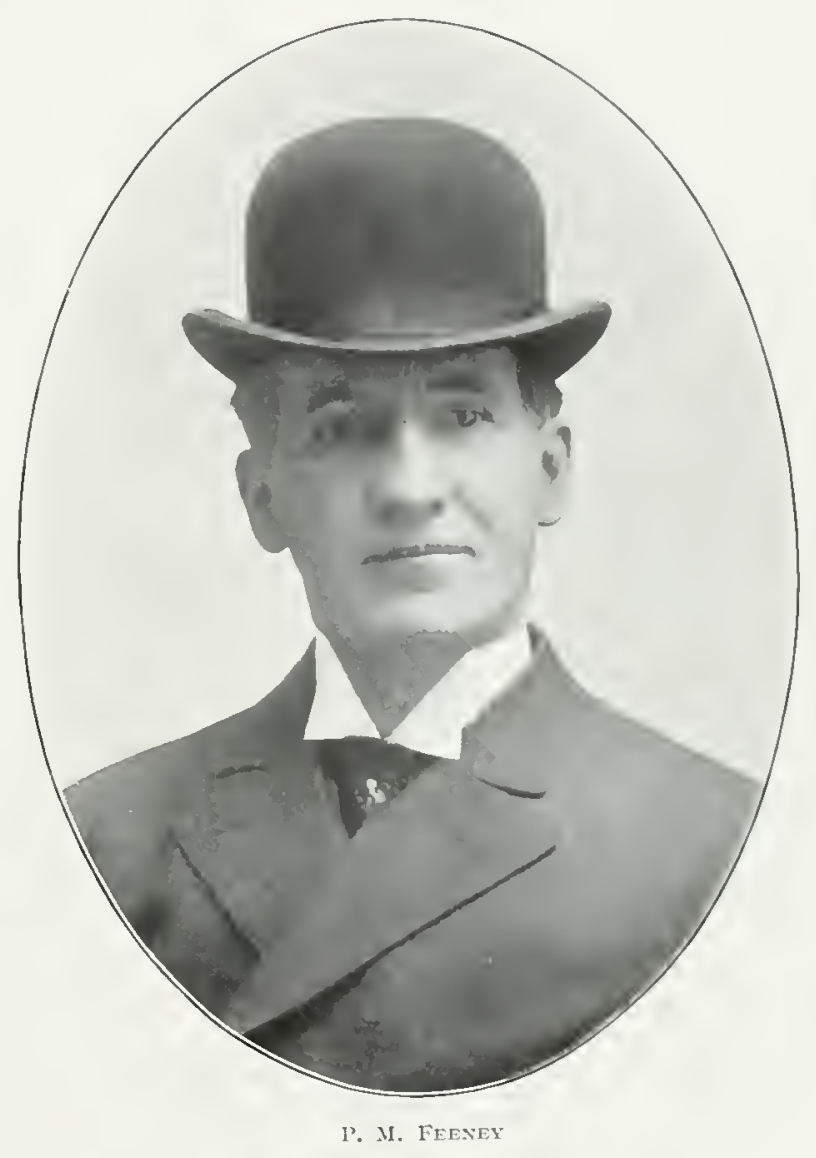
cessful.

Is a sportsman Mr. liecney is one of the best. always rearly to encourane struggling young jockegs and horsenten, and so longe as Camadal calli produce his like. so loug will sport prosper. 
$208 \quad$ Lovers of the Horse

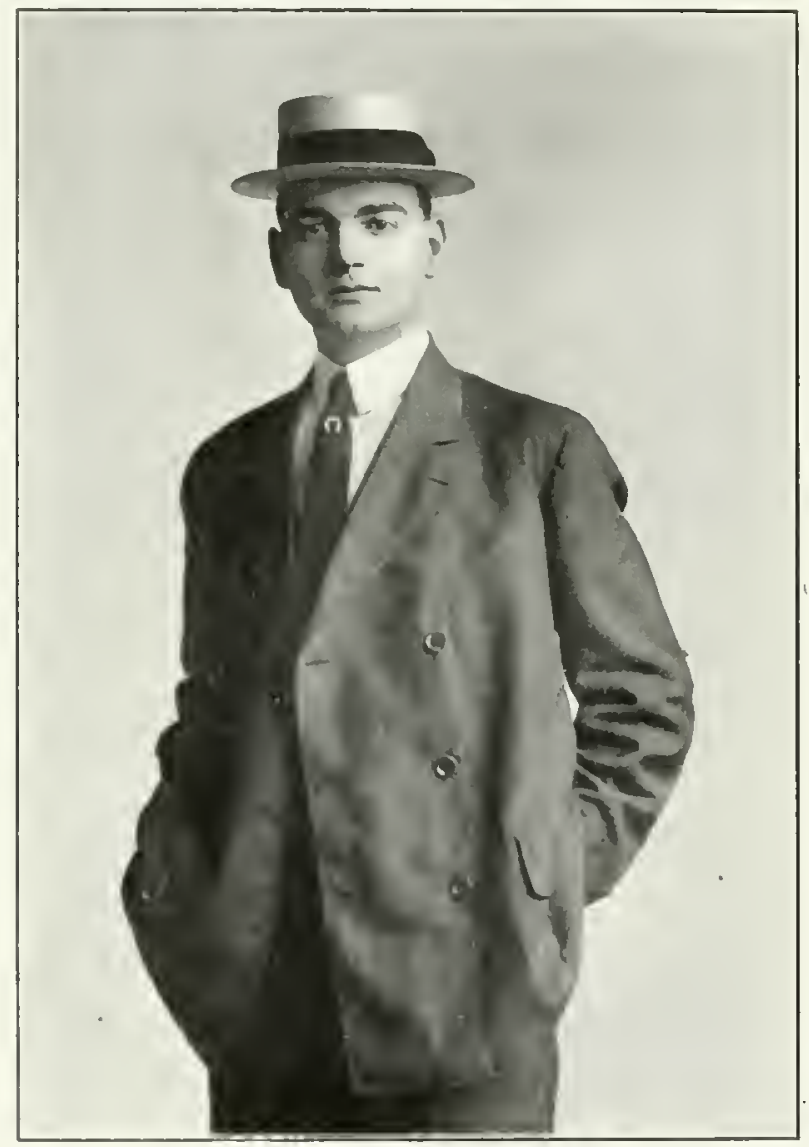

IV. G. Kelly, TORONito 


\section{Lovers of the Horse}

\section{ROBERT DAVIES}

$\mathrm{O}$

TE of the best known horsemen in Amerieal is Mr. Rolert I) aries, not only from the hrecting standpoint. Wut from the ciremmstance that he has ratised

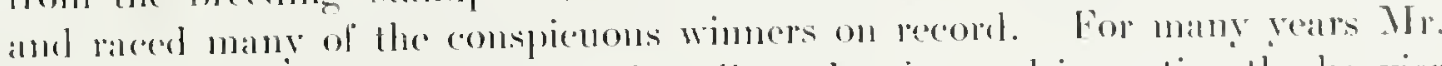
Davies was ahost exchusively devoted to hreeding, showing and importing the hearies class of horses, before he showed a hking for the thoromghbred. llis farm. familiaty known as "Thornctilte." has sent to the show ring many chantipions in almost every class. It was on this farm that Mr. Davien raised his first thoroughtored and met with a gereat deal of success in the ralcing world.

Mr. Davies has a choier collection of ribluons, won at the mumerous horse shows throughout Canada, particularly at the 'lorouto Exhibition, where it is probiably latreler to win than at most shows on this antinent. He hats won ribhoms in the chasses for ('Jyrtestales. slires and thoromehboreds, someling back to the farm many a riblon as trophy. Of recent veals be has not devoted so much time to the heavier elasses, but to the thoroughberl. In this classs. he hals in his stud Orme Shore, probibly one of the best stallions ever bromght to (amalal. This horse should prove a famous sire, and, though imported ly Mr. Davies some four yeats algo, was not raced to any extent after coming to cambatal.

'The first loose to hring this owner into prominence in ('allatal was 'Thornchiffe. one of the lrest leppers that ever looked through a bridle. Ile won again

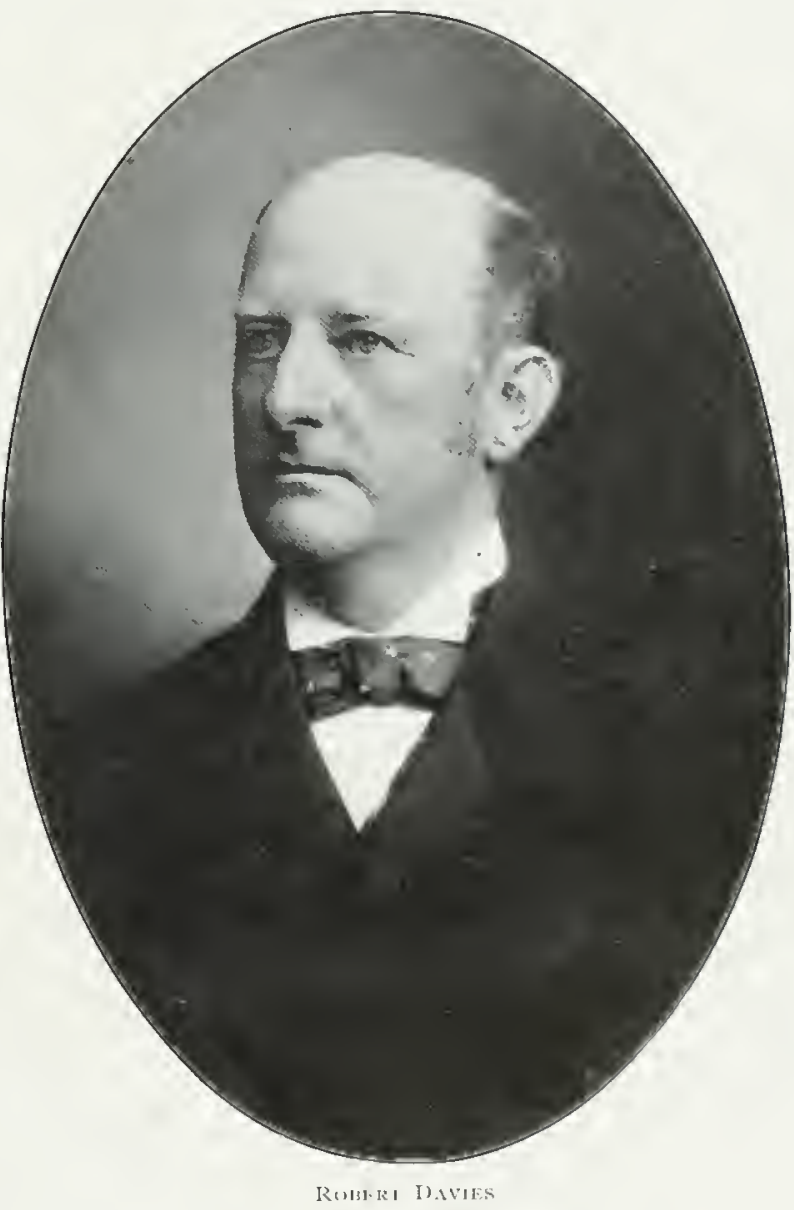
and again for his mecoler, and, alter being sole! to a Buffalo owner, continuce his vietorious atreer. Another of Mr.

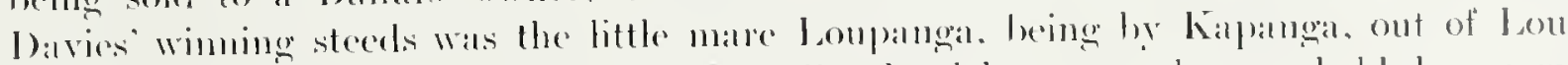
1). Sle won many of the stakes for canadian-bred horses and eren helet ber own against some of the best racers on the ('anadian track.

For many years, Mr. Davies wats one of the Viee-IPesidents of the ( )ntario doekey

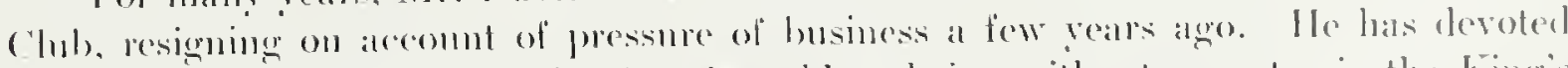
much tince to racing interests in camala, seldom being withont an entry in the King's 


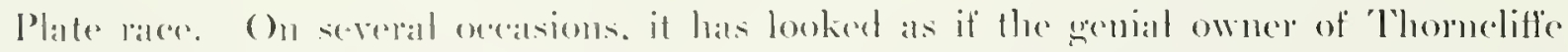

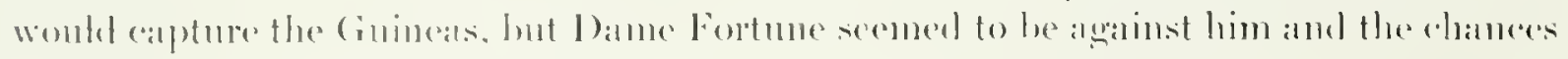
were spoiled be minor alecilents.

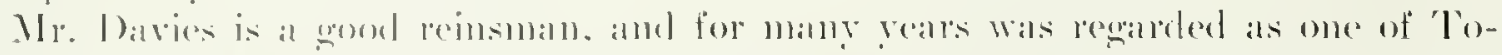

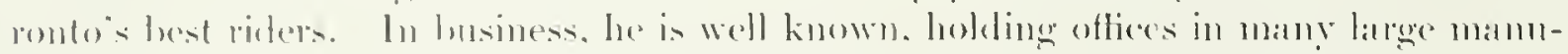

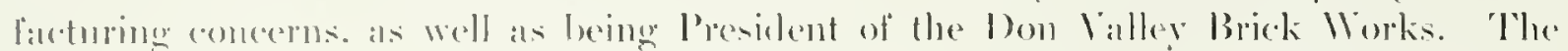

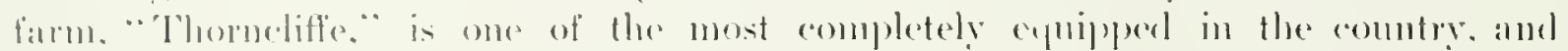

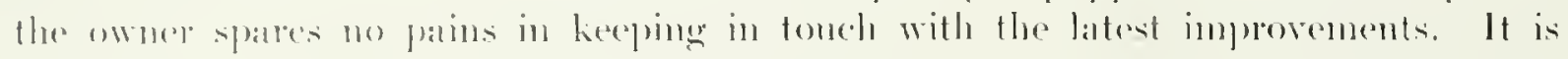

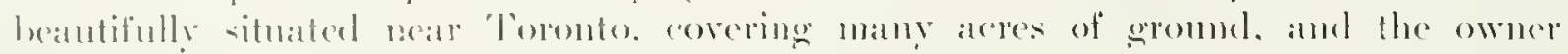

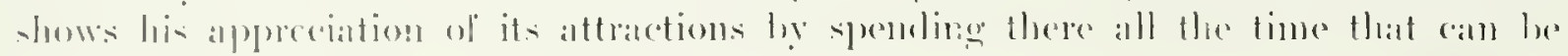
laken form husinesen atres amb responsibility.

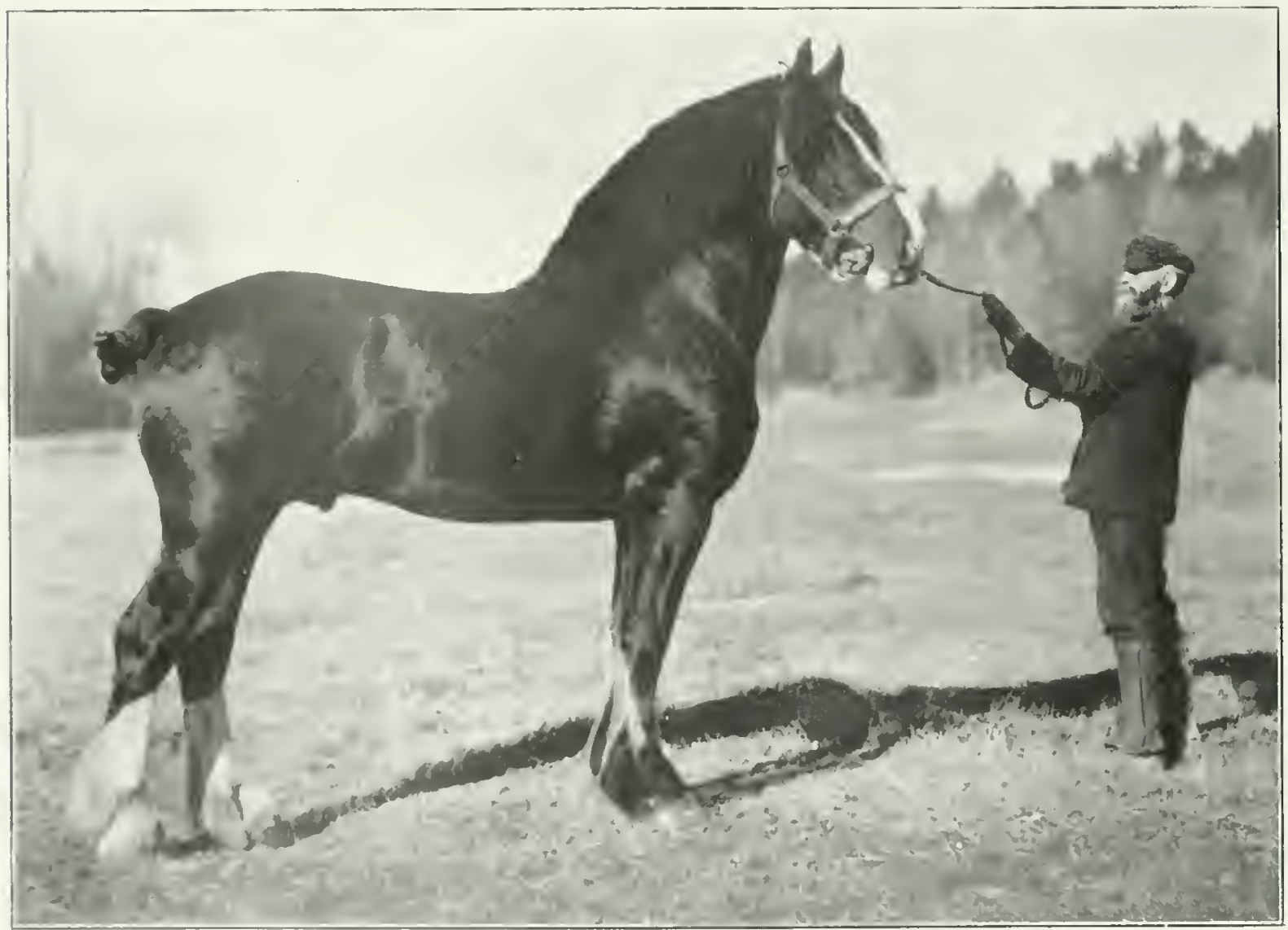




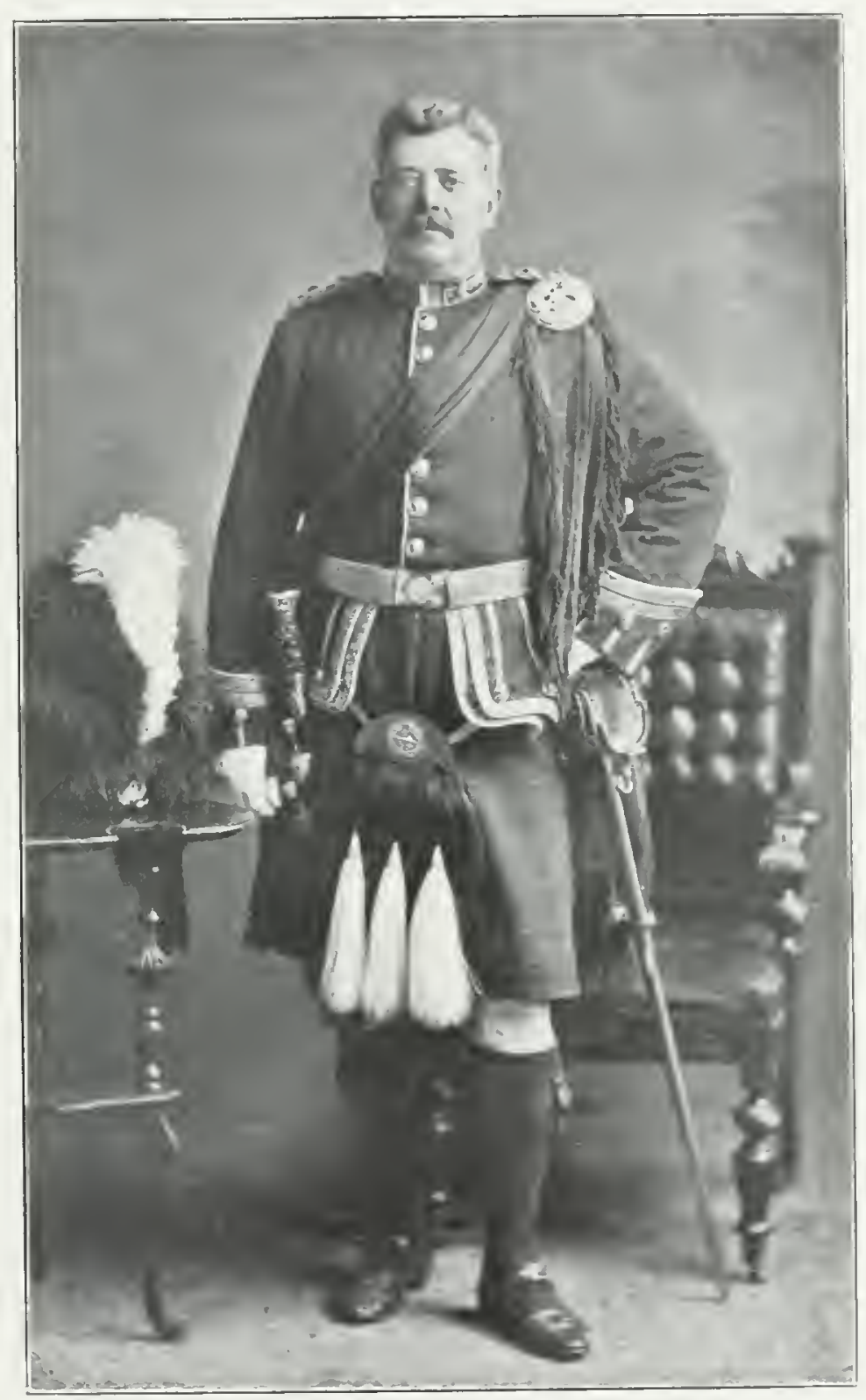

I.1EUT Colonel DONald M ROBERTSON. M.Y.().

4KTH Highlanders. TORONTU. Caxada 


\section{FRANCIS NELSON, M.A.}

$\mathrm{F}$

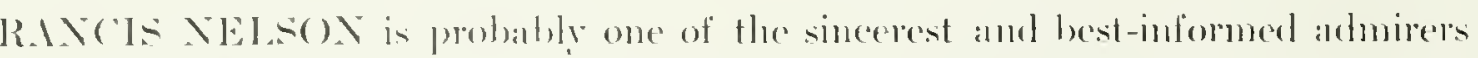
of the horse in the Dominion. From hoyhood he has deroted time and attention to the interests of the equestrian order, and has always upheld a high standard lor rabing and ansoriated sports.

Mr. Nelson is a ranalian hy hirth. having lesem tom in the city of Hamilton, noter for its ambition in spolt as well as manulareture. Mr. Nelson entered the field

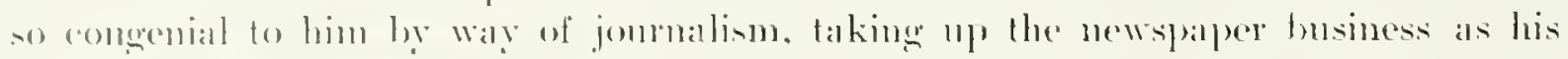

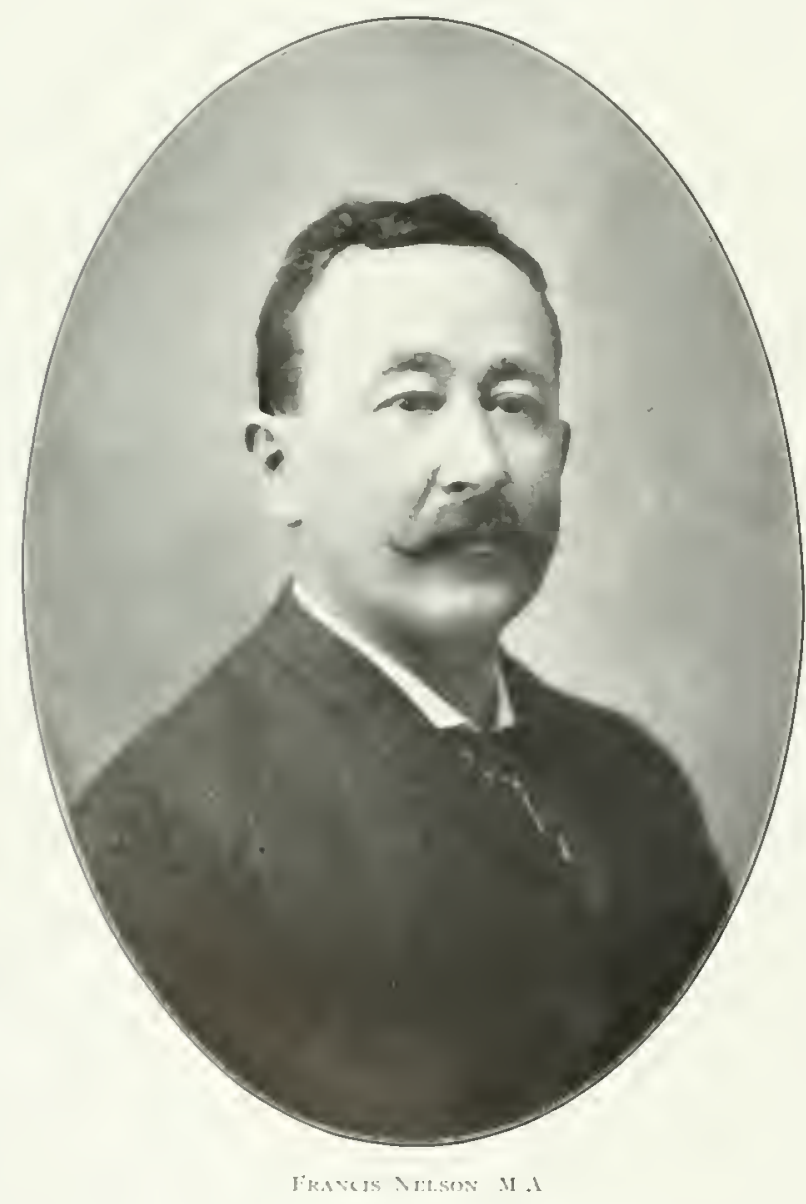
first professional work. Ho berame sportinger erlitor of the Ilamilon Times, and for many reatre hede this responsible position. Hutil he ealuse to 'Tomento, some

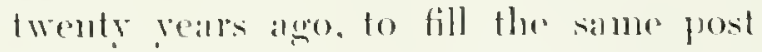
on the Torouto Elobe. This position le retains with momede credit to his farmess and experiences.

Mr. Nalson's first enomection with the holse was made moler most finorable allspices, as he paid liecpuent risits to the farm of the late William IIendric. from this andy aleplatintanceship he took 11) the torf work als a specialty for the press lore reperented, and soon berame

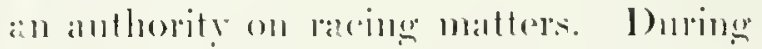
the reall 189.). he wats asked to judger at the 'loronto Exhihition, as associate ol the bate "Rodily" Pringle. For several rears he ofliciated in this field, and in 1897 he was eloserl as the associate juclege at the Hamiltum mectimg. acting in that alpareity at that track erert sinere.

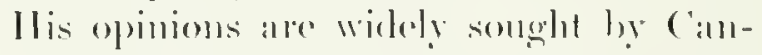

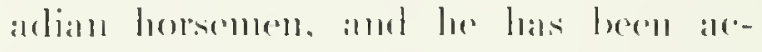

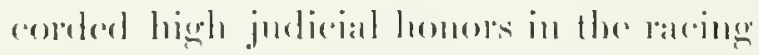

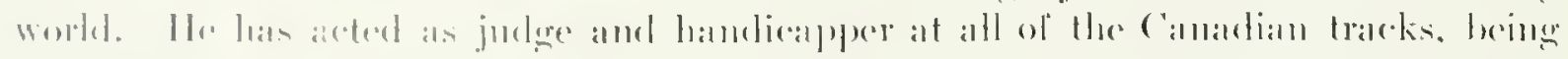

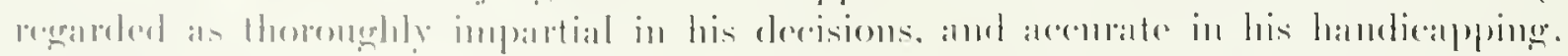

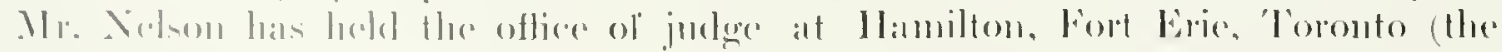

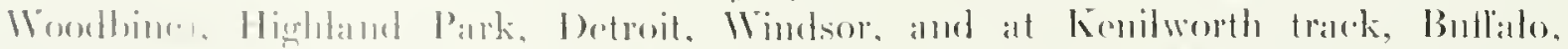

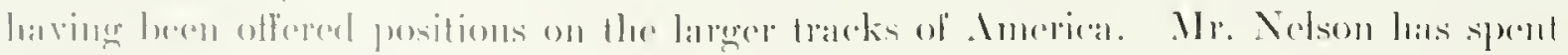

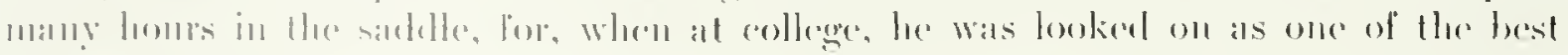

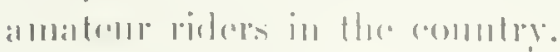


Lovers of the Horse

213

Besides being an ardent admirer of the horse. Mr. Nelson is an all-round sportsman. Inuring the winter months the stirring game of curling is one of his favorer pastimes. For many years he filled the office of Vice-President of the Canadian Latrose Association, as well as the same office in the Ontario Hockey Association. If lats frequently acted in an official capacity in the Canadian Association of Amateur Oarsmen at their regatta, and the strenuous game of "Rugby" at so has his expert attention. Hence it may readily be seen that this jomrnalist-sportsman has been broad and varied in his development. and is prepared to give the benefit of provessional knowledge to any event in the broad field of sport. 


\section{$214 \quad$ Lovers of the Horse}

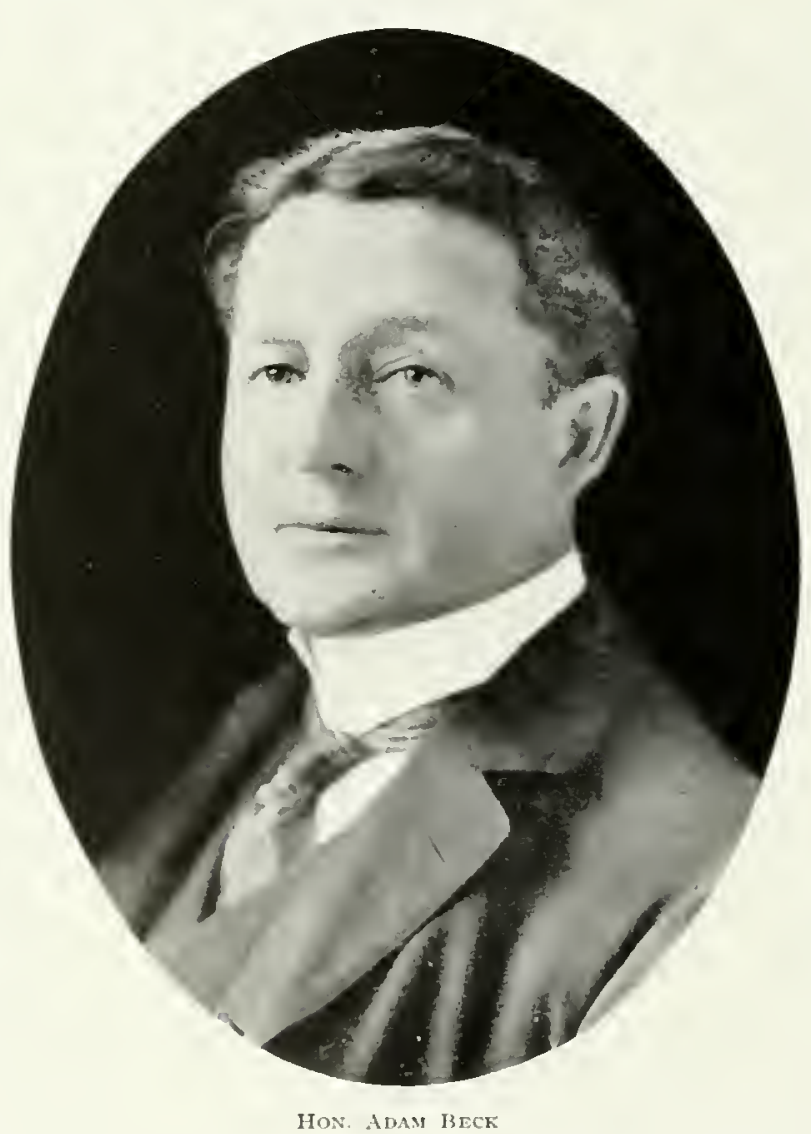




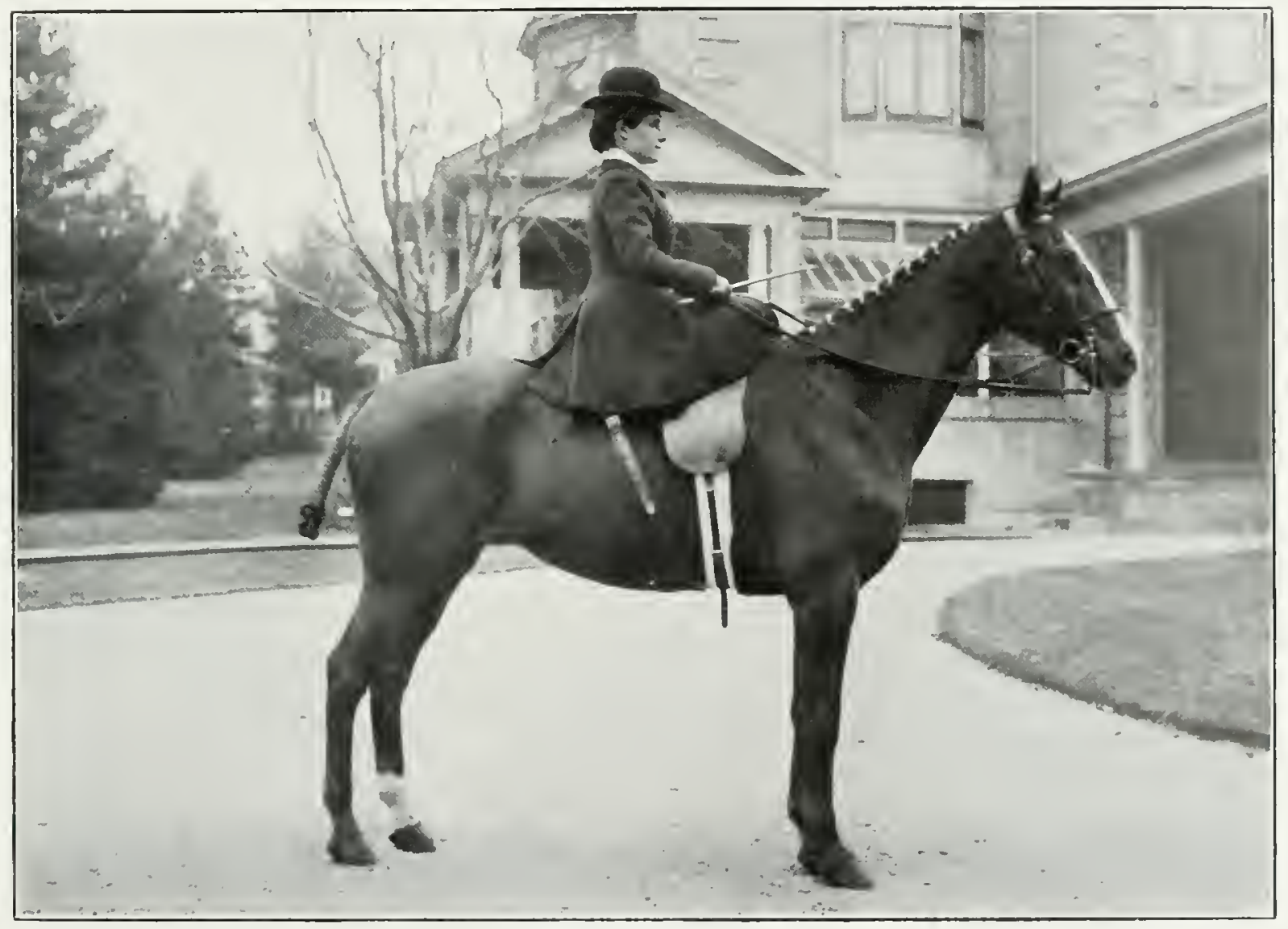

MRS. ADAM BECK 


\section{THE CANADIAN NATIONAL HORSE SHOW ASSOCIATION}

$\mathrm{T}$

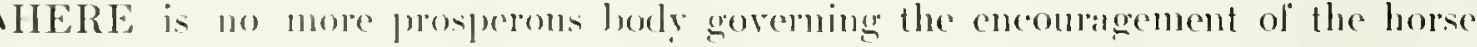
on this continent than the Canadian National Horse show Lssociation. For rears the horse shows in Tomonte were hedel under the anspices of the 'Toronto Innt Club and the Breeders Association. While the necessity for a really anthoritative hody, with pominent men at its learel, was keenly felt.

For many years the Hunt ('Jul) and the Breeders" Association ran their shows in conjunction with the military hody in the aity. hut when the new association was organized. the military end of it was pratetically climinated.

The herse hreeders of 'l'oronto alecided that the spring show was held too late in the season for them. so a horly known as the Ontario Brecelers Association was formed for the purpose of hodeling stallion shows earlier in the year.

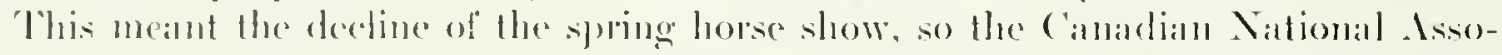
ciation was formed with the following gentlemen as charter mentuers: George $W$.

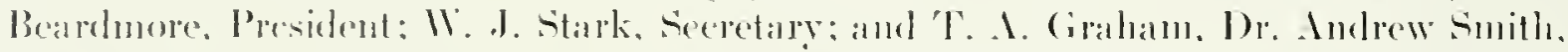

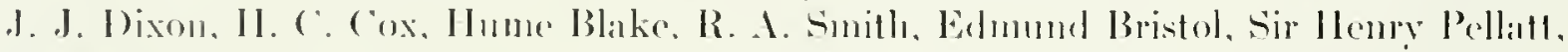

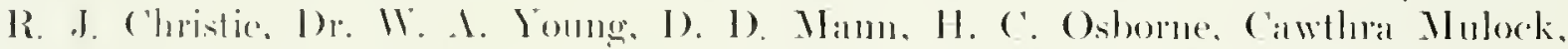
Geo. W. Pepper. J. I). Montgonery, Suant I lonston and Miss K. L. Wilks, as directors.

'lhe first show of the newly oreanized hody was helel in the spring of 1906 , and

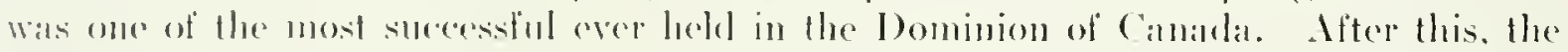

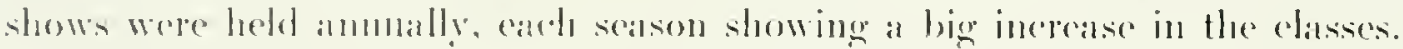

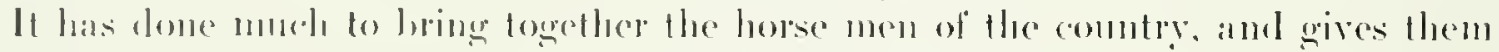

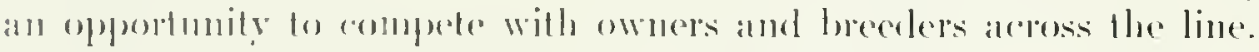

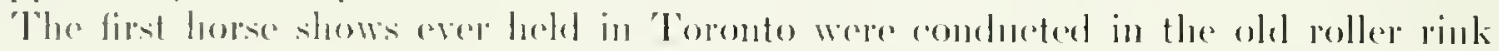

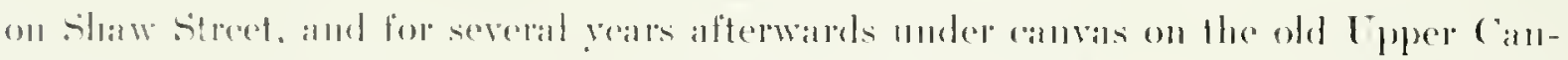

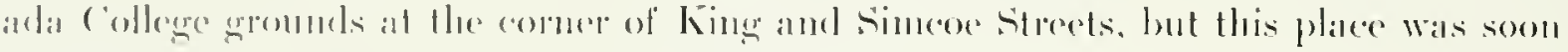

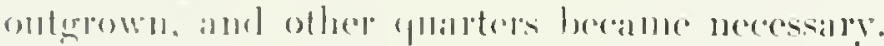

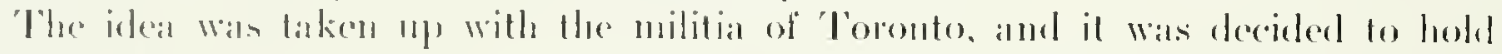

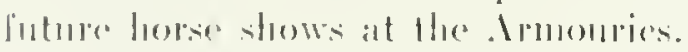

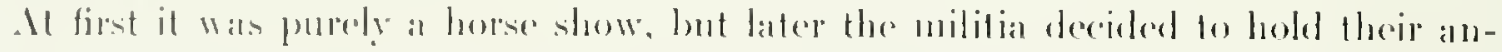

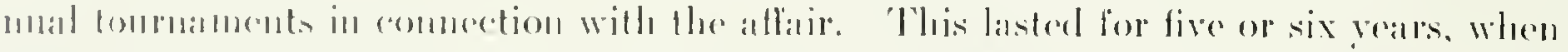

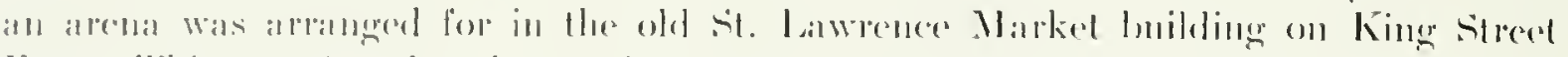

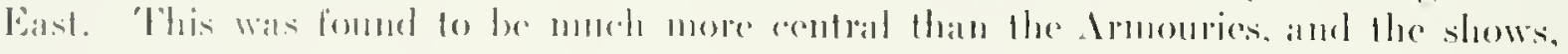

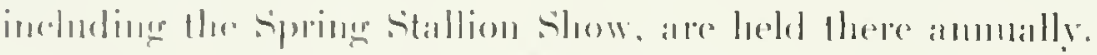

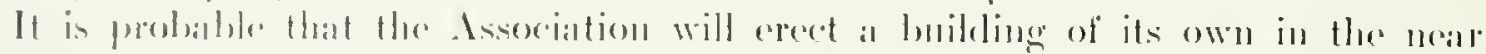

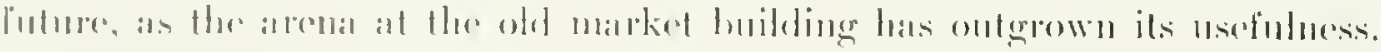

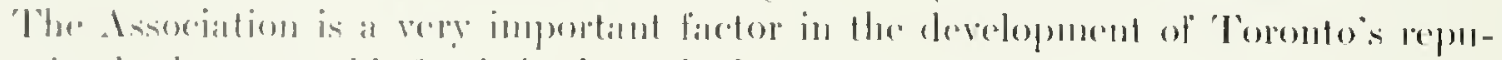

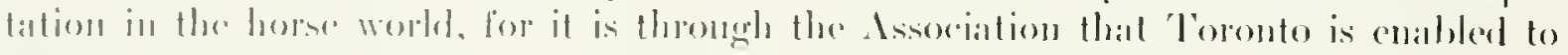

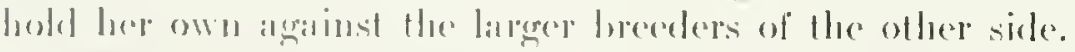

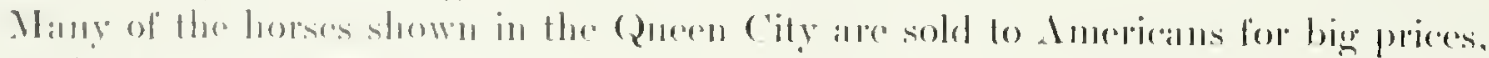

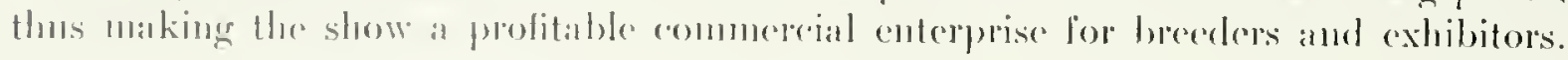




\section{WILLIAM J. STARK}

$\mathrm{T}$

IERE is no better judge of hamess horses and high steppers than Mr. William

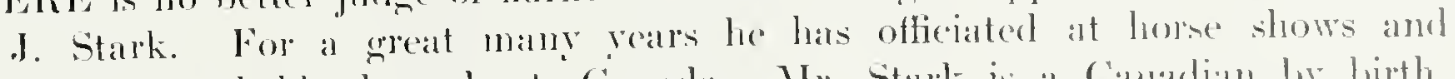
exhibitions held throughout Canadat. Mr. Stark is a Canadian by hirth. being hom at stontfville. where he made his home for the greater part of his cally life Ile matriculated into 'Toronto Iniversity from Markhm ligh school, and attending the University for two pairs, went into the banking business with Miller ambl Company, of Stouffrilte, and erentually assumed control of this institution uncer the mame of Stark \& Barmes, and comtimued in husiness for ten pears. From stonfliville be ande to Toronto to assums the management of the Market Branch of the Metropolitin Bank.

While in stonffille he was prominent in public life, and helel various officess for sereral years heing Mayor of the town, and is yet a manistrate for the County of lork.

lie was also a prominent fiector in the sucress of the ("anadian Lacrosse Assoedition, and while President of that organization introdned many valuable changers. which have done much to improve the grame.

Ho has been inentified for years with rarious horse sorieties and. its President of the Camadian Pony Sordety. applied for incorporation for that association, with the result that a recosd was

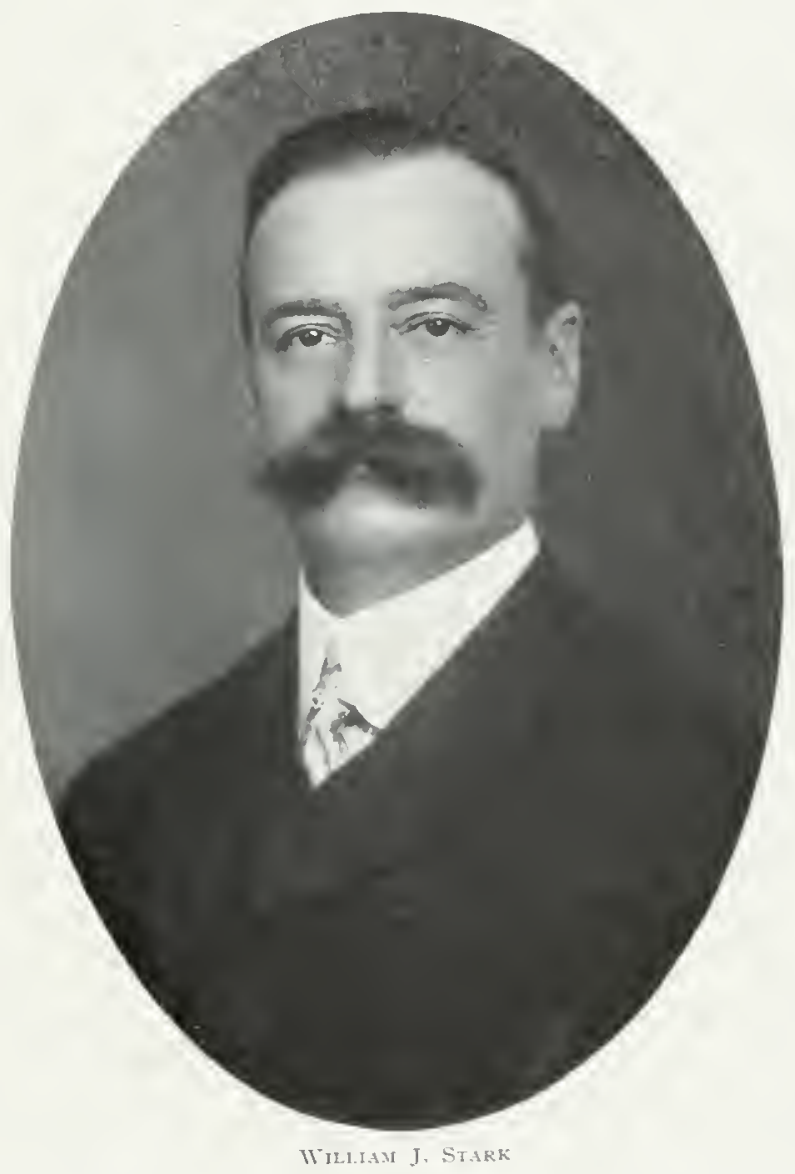

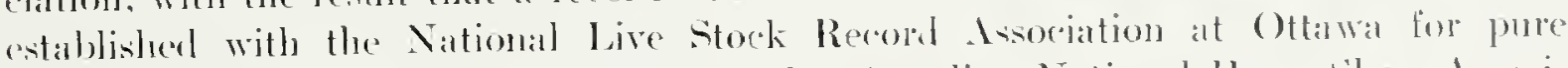
breeds. Ile is also a charter nember of the ('analian National llows slow Association, of which he is the seceretary-l'reasurer.

In 1909) he was eleeted a Director of the ('analian National Exhibition of 'Thronto. and was made Chaiman of the Ilorse committer. 


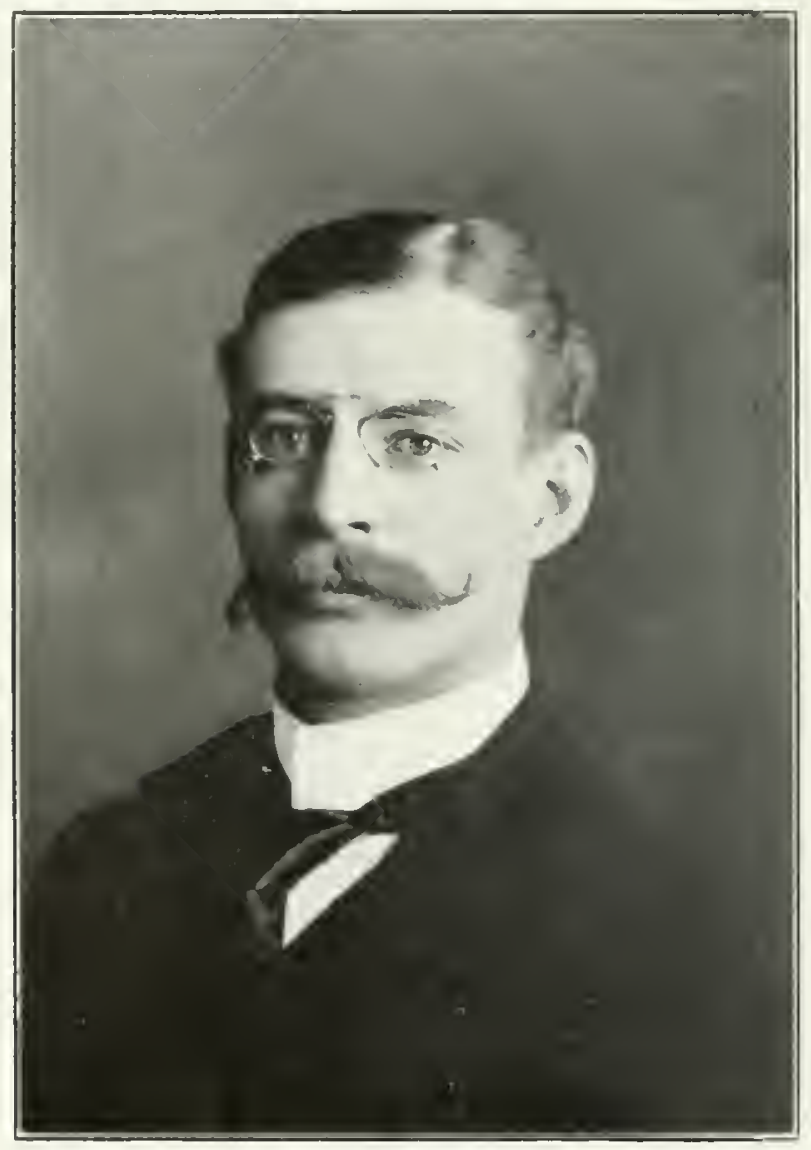

W. I'. FRASI

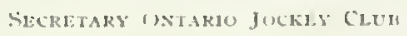




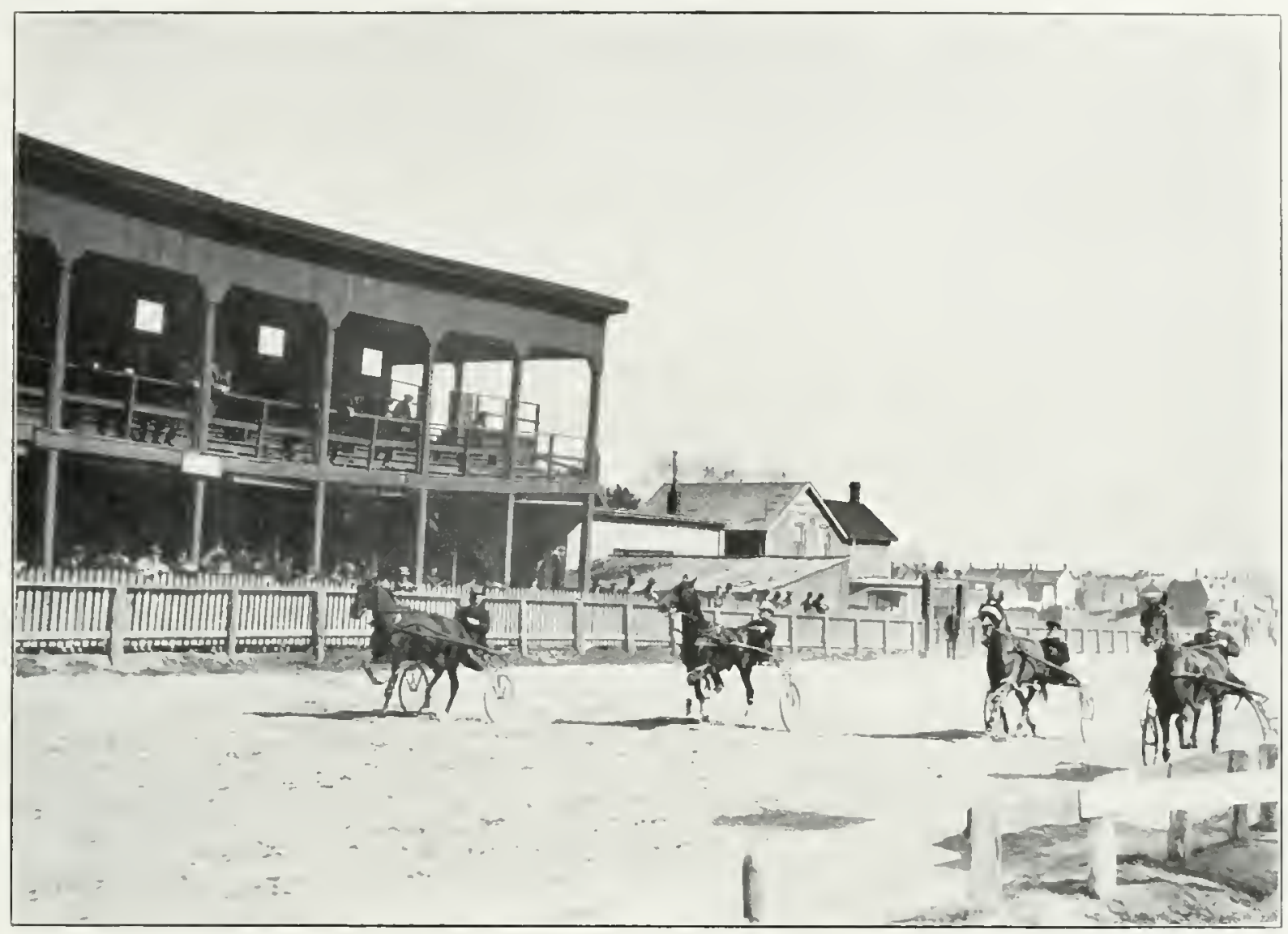

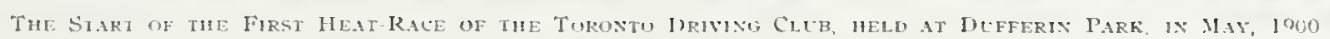

\section{TORONTO DRIVING CLUB}

Nule 'loronto Driving ('lul, is probably one of the oldest organizations of it:

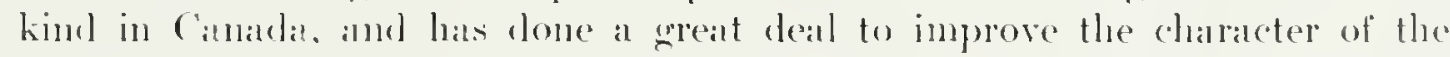
horses hronght to Toronto. It was throngh this Association that the 'Toronto speedway Was huilt on the east side of the Don River. and the tratek, though not as long as some of the others, is kept in such excellent conclition, that the going is always first-class, and many a friendly brush has been decided oreer it.

The weokly matinee races have promoterl a kindly rivalry between the members. which has resulted in the purchase of matny a first-chass horse. Indeed, it was through

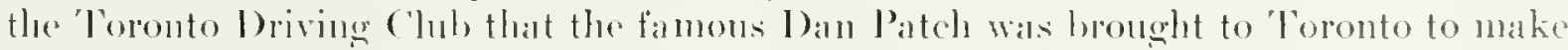

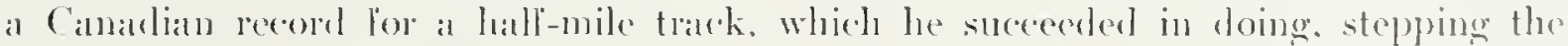
distance in 9.06 .

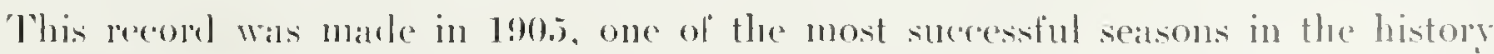
of the Club, which held its first annual meeting in 1900, with only eteren grentlemen present, the dhater members being samuel MclBricle, 1. Cuthbert. Challes snow. 


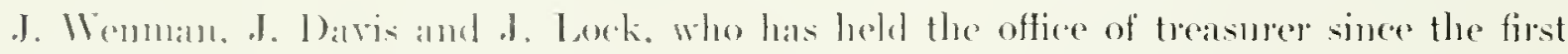
mectinge.

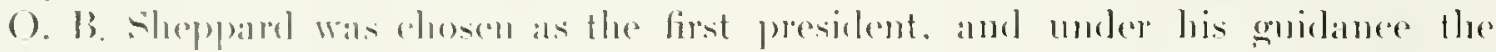

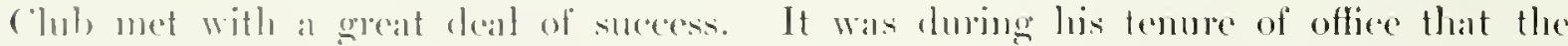

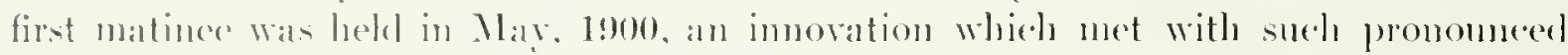
suldeess thill every one held since hiss shown a hetter class of horses.

At the anmonal meoting in 1901. Silmuel Mebride was elected Presiblent. Which

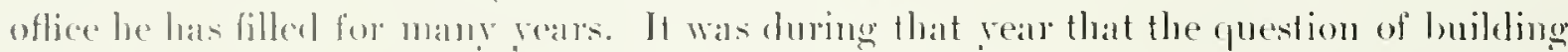

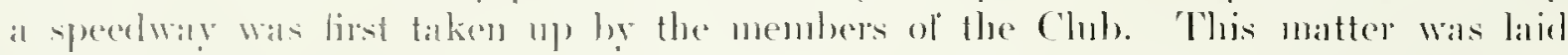
before the couneil of the city of Toronto. Who put it through, and the specelway was huilt.

In the solring of 1906 it was thenght adrivalule by some of the members that the

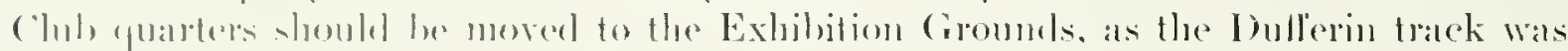

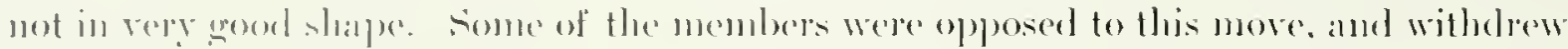

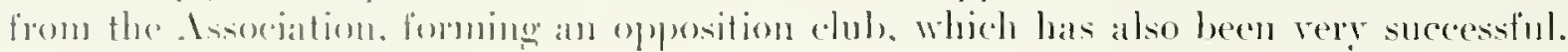

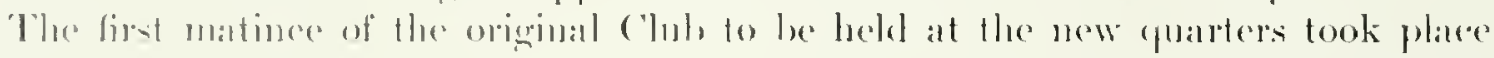

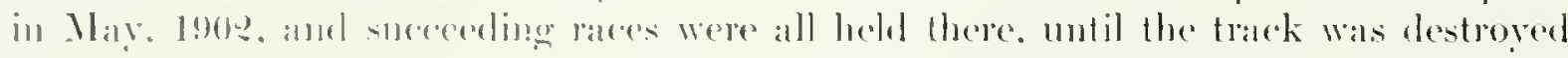

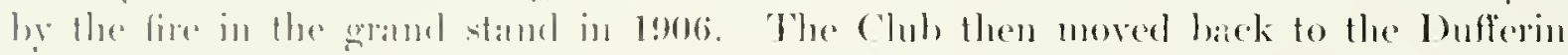

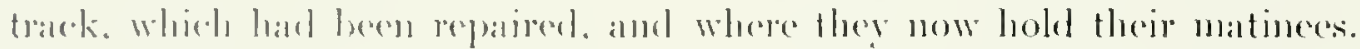

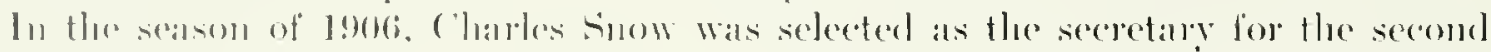

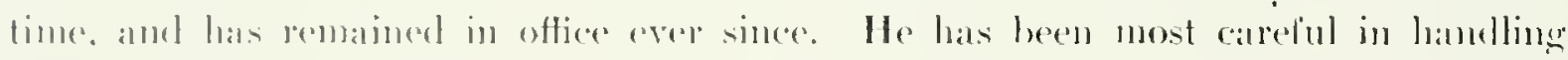

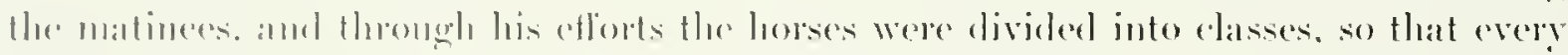

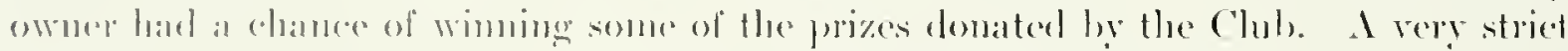

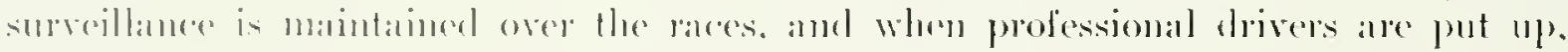

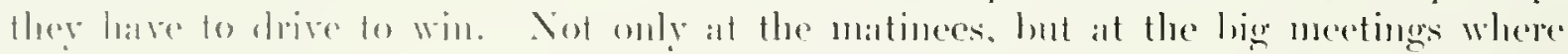

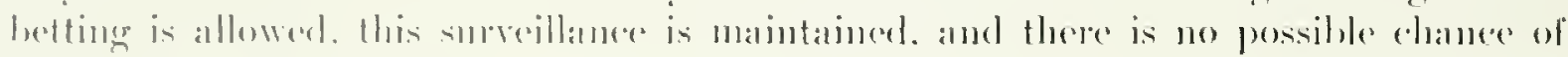

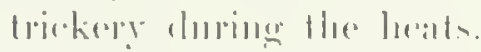

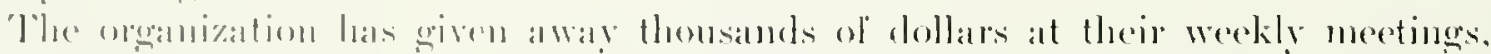

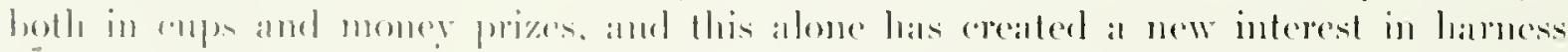

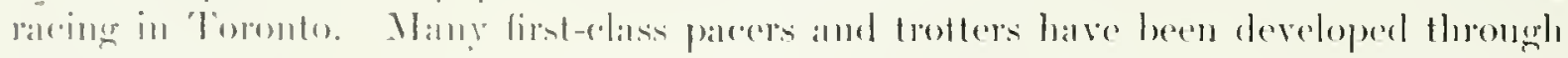

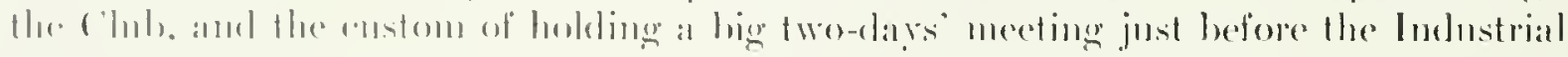

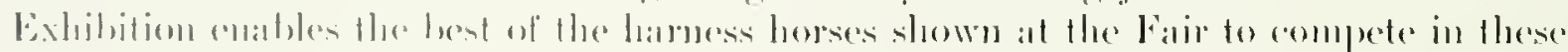
races without arlitional expensese.

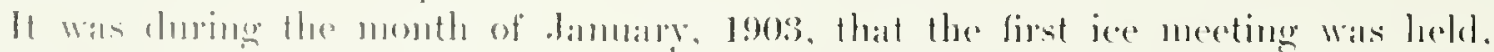

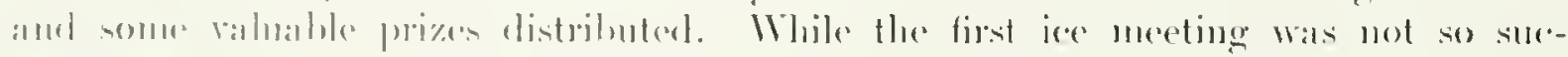

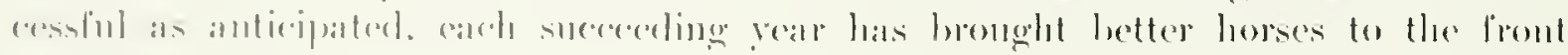
iil thene averists

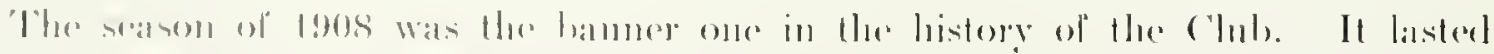

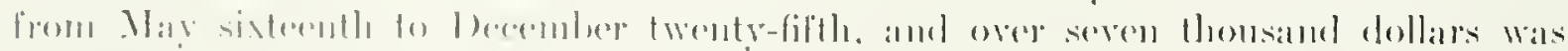

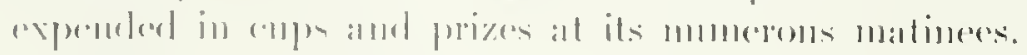

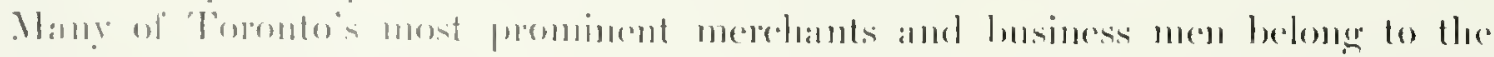

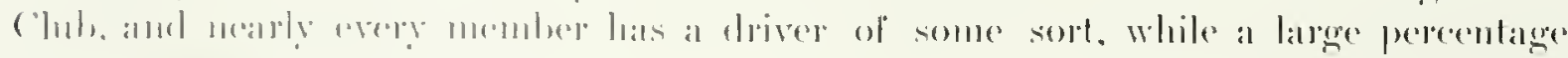

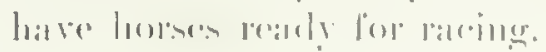




\section{H. J. P. GOOD}

$\mathrm{H}$.

J. P. (rOOl) is the oldest sporting editor in alctive work in Toronto to-day. Coming from England forty years ago. he attached himself to the Canalian News and Publishinge Co. and had not been in Camalda two months bedore he edited the Eelectic Magazime, a publication that at that time had considerable circulation in the Dominion. From the Canalian News and Publishing Co. he grarduated to the Daily Telegraph, a morning pilper then published by the present propriet or of the Eevening Telegram. From there at the starting of the Mail in 1879 he joined the staff of that palper. on which he filled valrions positions. Finally, in 18it, he established the first sporting page known to the daily papers in all America. Mr. Good was in reality the first man on this continent to be sporting editor of a daily paper. Up to the time that he originated the classification of sporting malter, it was customary to publish such information as ortinary news on any columm that it happened to fit. Even the big New lork dailies dicl not at that time "lassify the sporting neers: so that to Mr. Gool must be given the credit of inangmatiug a system that has now become world-wide. For many rears he contimued to les sporting editor of the Mail. and then became attareded to the Irorld. From that paper he returned to the Mail. and in $185 \%$ became a member of the Empire staff at its initiation. From the Empire he became editor of the

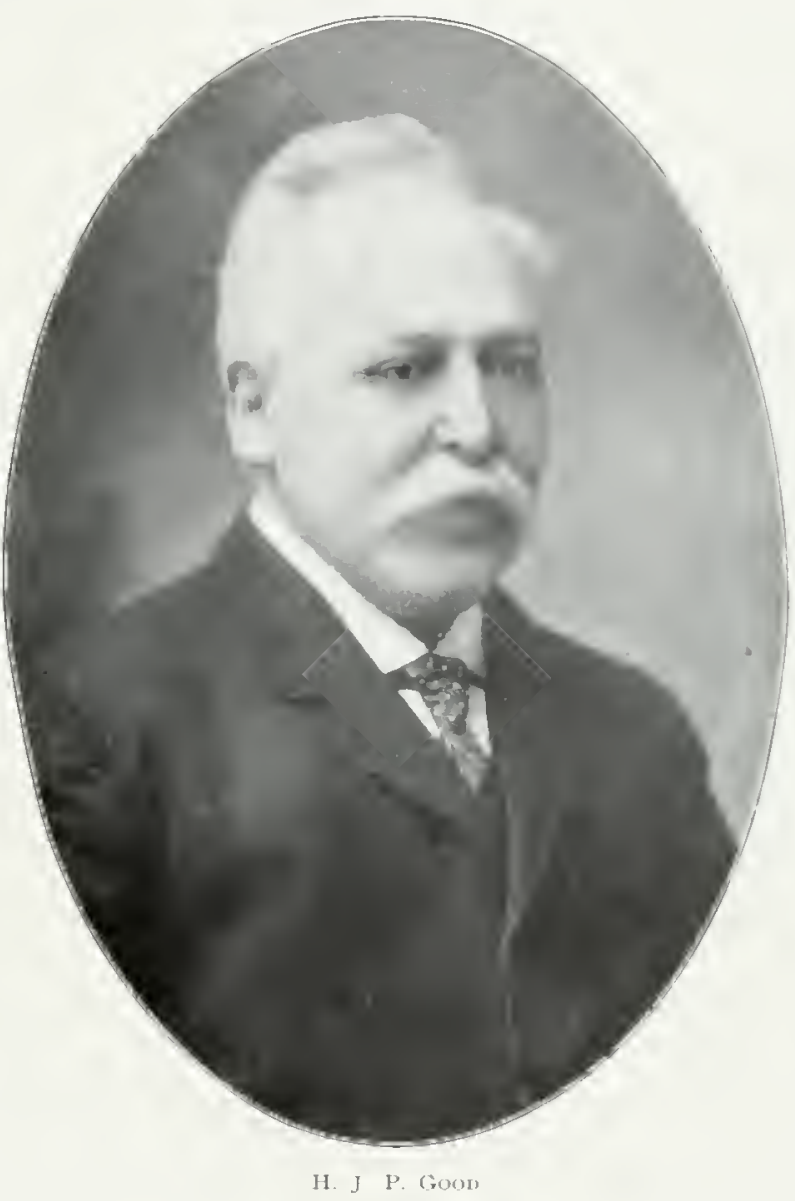
Toronto Sunday World. a position he helel until two or thee veals ago. When he was appointed permanent press agent of the Industrial Exhitition. He. howerer, still writes for varions publications. and still contributes a whole page on the horse and turf matters to the sundey World wader his well-known nom-de-plume of - l'op." 


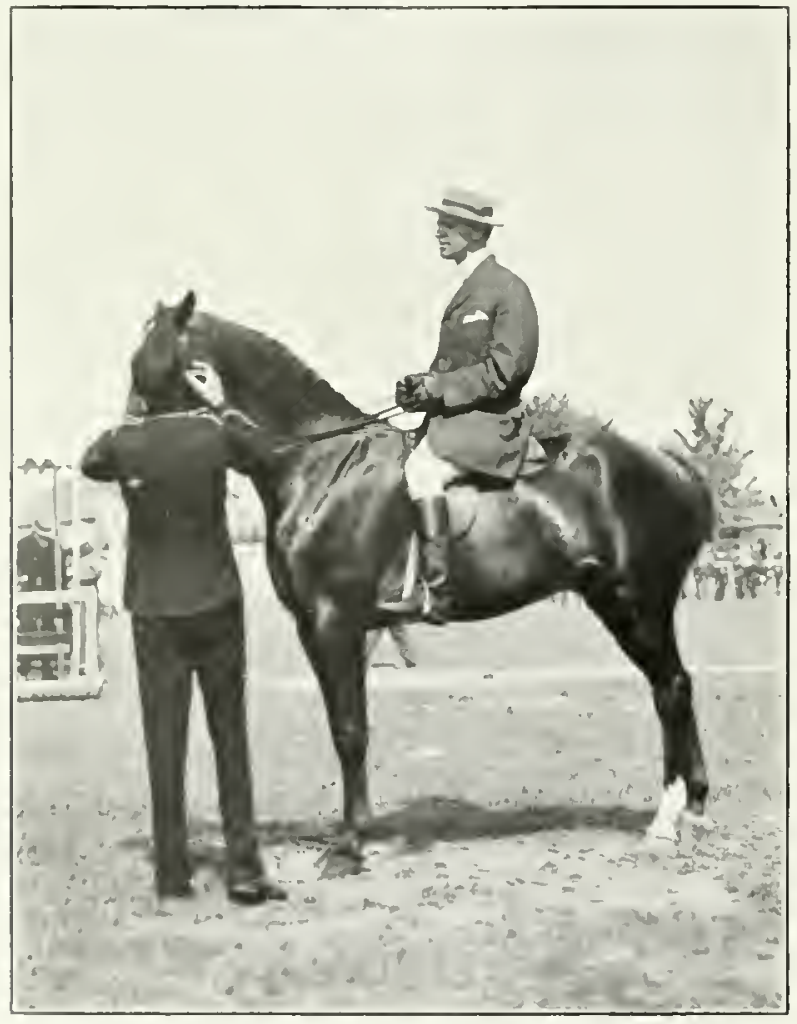

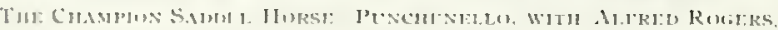

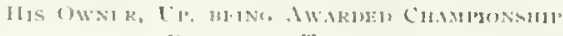

RHAGN of Truenso 


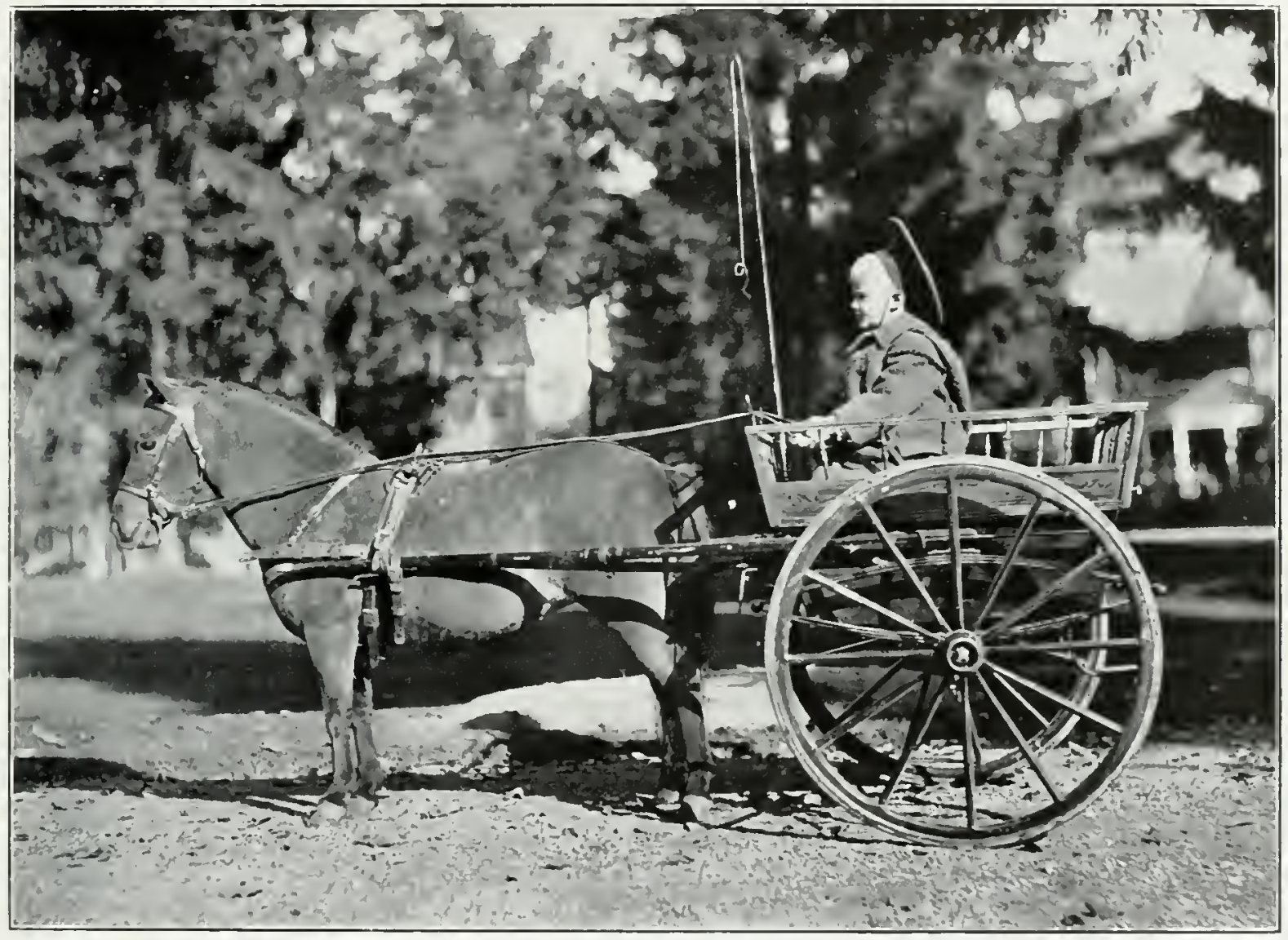

Master Alfren II Rogers 


\section{J. W. RYAN}

$\mathrm{T}$

IIE Ontario Jockey ('lul, lass always leen fortunate in the enthusiasm and groorlfellowslip) which latre animated that institution. and have improved. from real to veale. the racing records of the province. Among the members.

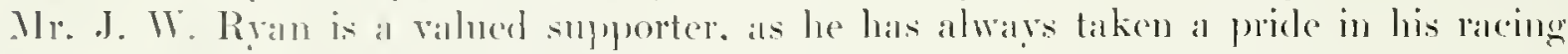
string. and, inderd. superintends personally the training of his horses.

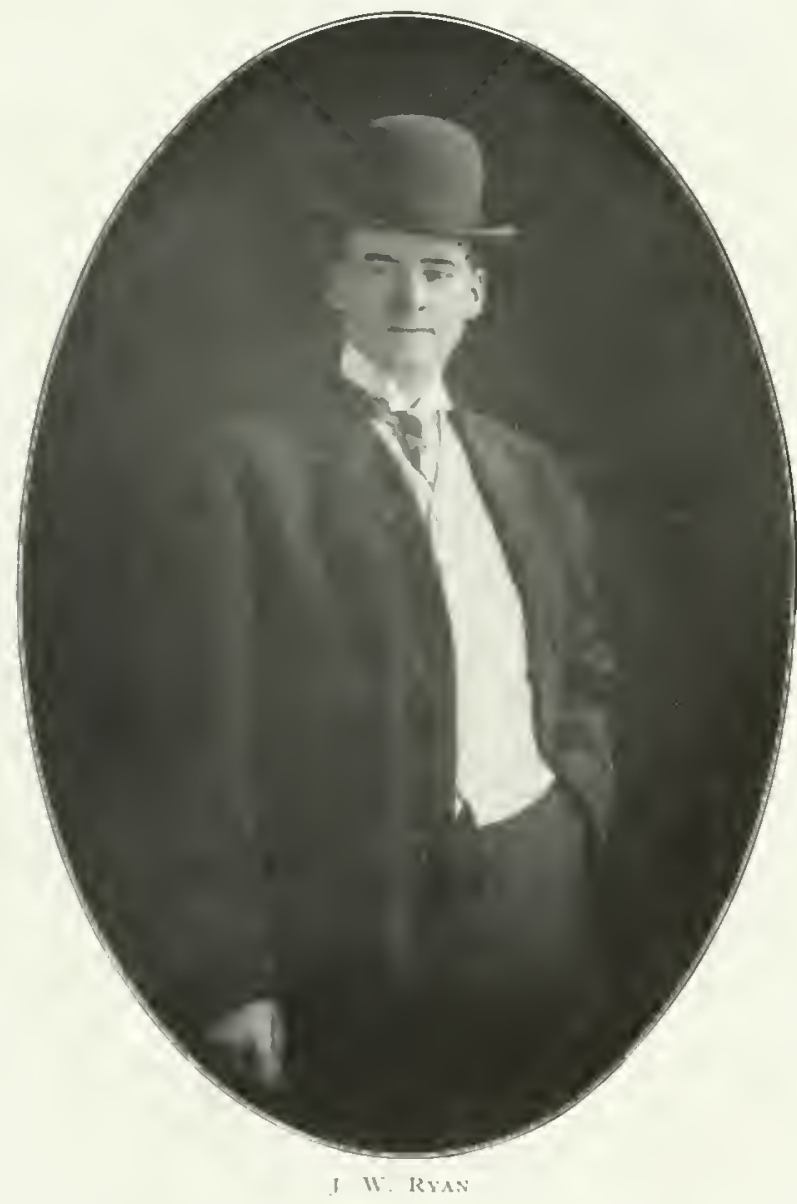

Mr. Ryan is a gentleman to whom is due much credit for the good standing of rateing throughout the fickd. Is. has deroted al gireat deal of time to the development of steeplechasers, and it goes without saying that much money has also been spent before his farorites were raised and fitted for the fickl. where they were to win the trimmps deall to the horseman. In one respect. Mr. Ryaln lats been especially generons and sportsmanlike. He has always been ready to enter one of his horses. even at a disadvantage. to fill the list where entries have been soaree. This rearliness to contribute. (reen at a personal risk, to the completeness of riseing events. has made Mr. Ryan a prime favorite on the mamy tracks where his horses have rated.

l'robably the best lepper ever owned in the stable of " teann" Ryan. as he is familialy known. Was the lorse Butwerl. This steod proved himself a winner for some tiuls, captuling several stakes and urever failing to bring in some of the Endelen profits. Jimmy Jannes was another horse which promised great vietories as at

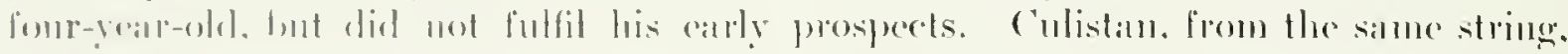

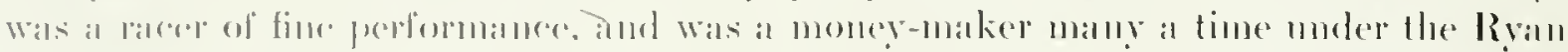
(a)lors.

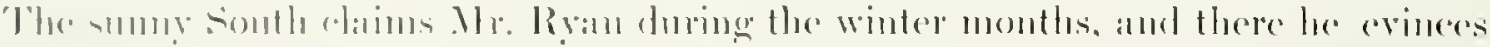

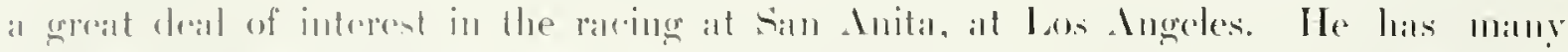

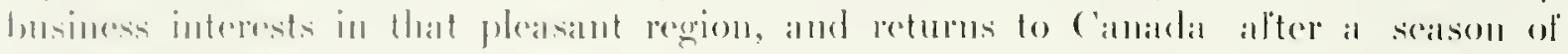
anjoyment and porfit in the southeru resorts. 


\section{TISDALE \& HODGKINSON}

\section{$\mathrm{T}$}

IIE oldest and among the most successful of the loreeders of clyrlesdales in the Dominion of Canada is the firm known as 'Tisdale and IIodgkinson, belonging to the thriving little town of Beaverton, Outario. Many years ago, at simeoe Lodge Firm. T. C. IJodgkinson made his name famous in connection with this department of equestrian experiment. 'Thirty-five years ago, Mr. Horlgkinson took up his residence in that town, which has proverl him a worthy citizen. The light hamess horse was the first variety to elam his interest, but he extended his attention to the Clyclesclale about twenty years ano, and his success lats shown the wistom of his comrse.

In 1899. Mr. Modgkinson took his nepliew. Mr. E. C. II. 'Tisclale, who haxl lived with him for some years, as a partnele in the increasing husiness, and from that time the romnger member of the firm has assumed the greater share of the work involved in looking alter the horses. showing them in the ring with pronounced success. The new firm took II) the hackney class, and showed some cxcellent specimens, confining their attention to breeding them for the matret. Instead of importing. they have almost the exchusive business in ('anadian, or. as they are called across the border. "Anerican" Ired horses.

In 1906 there was a class established at the National Exhibition at 'Toronto for horses owned hy mon-importers. 'This las been a trimmpli every season lor 'Tistale and Ilorlgkinson, the majority of their winners being by the chvelestale

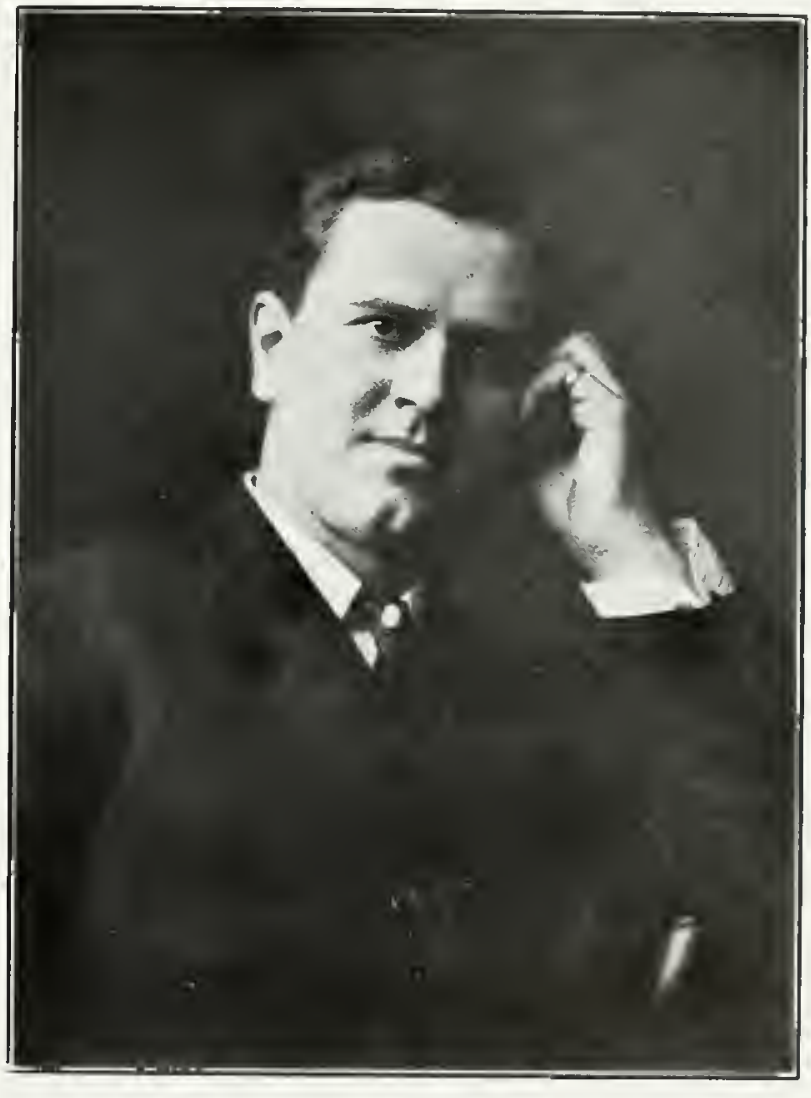

i. C. II "tisndL

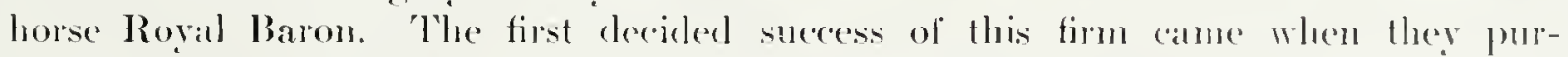
chased the stallion Baron Sterling. This horse, never beaten in the ring, was gen-

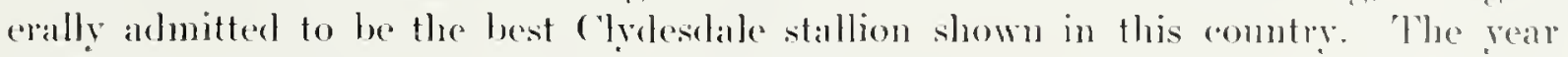
1904 saw his most marked suceess, and his deatly in the following yeall was a distinct loss to his owners. The next in line was the horse Royal Baron, which is still in the string of the firm. Ile has proved a famons sire, the mare Baron's (2ueen. by this prize-winner, carring off many a ribbon.

Chicago, Ottawa, 'Toronto and other cities hare witnessed many a success for 
this borroron firm. Prohahly their greatest victory was that scored at the Pan Imerican Expuntion in Bulbulo. 1901. When they showed six mares in crents for Ameri-

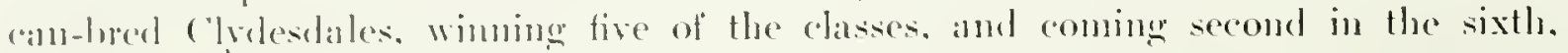
while they won the ehampionships in the same chasses.

'The sonior menther of the firm. Mr. 'T'. C. Ilodgkinson. Was regurded in his romere dass as one of the best rideres and drivers in the combery and also an excellent

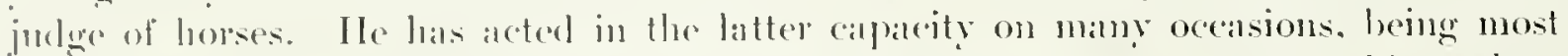

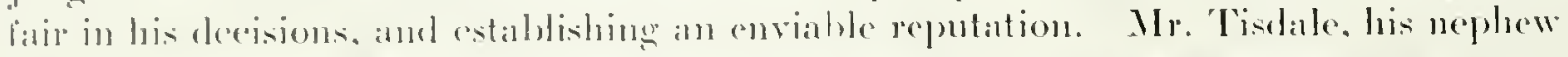

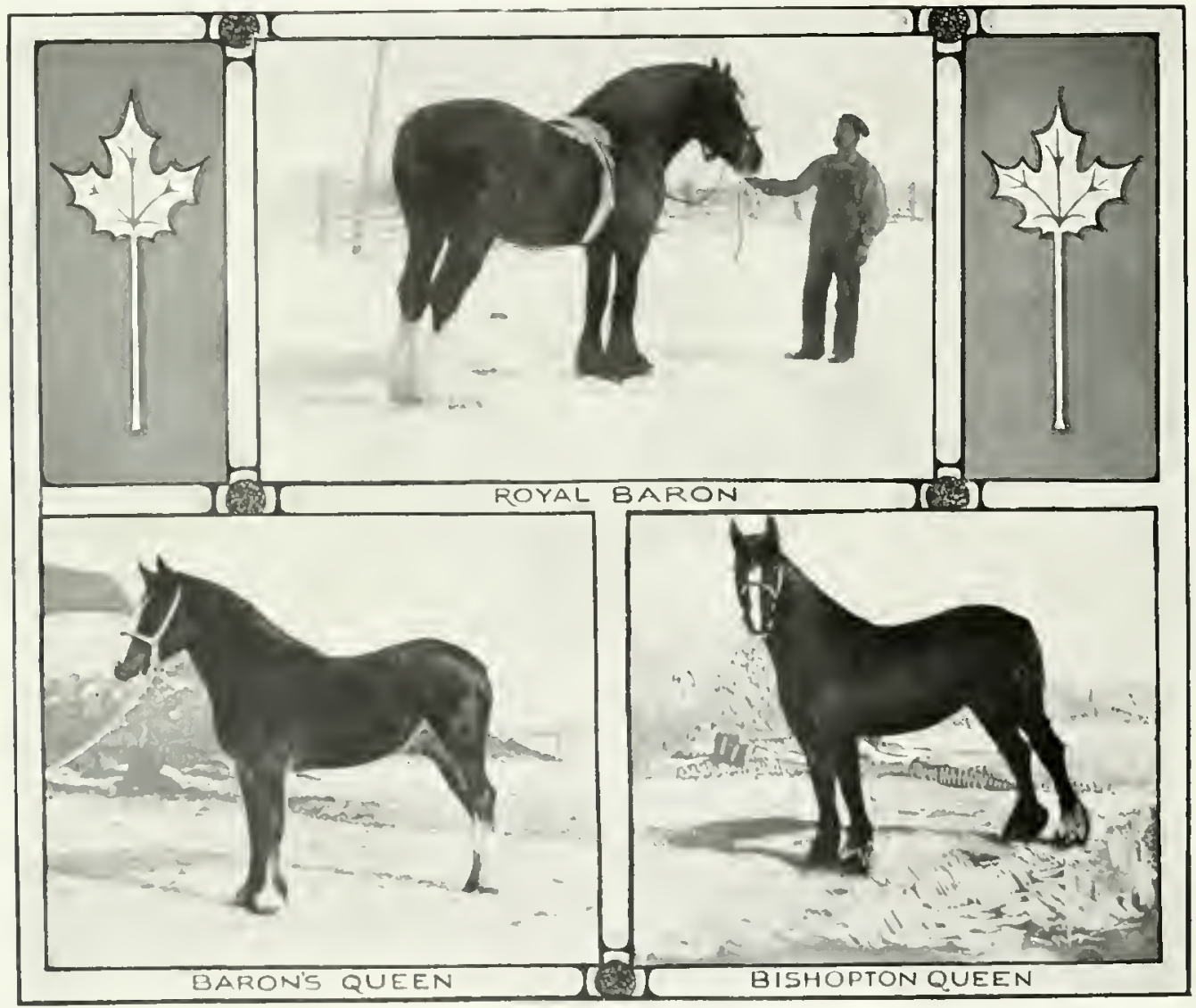

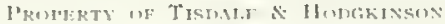

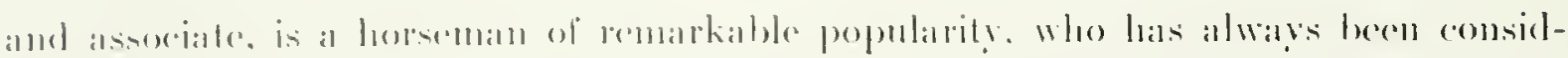

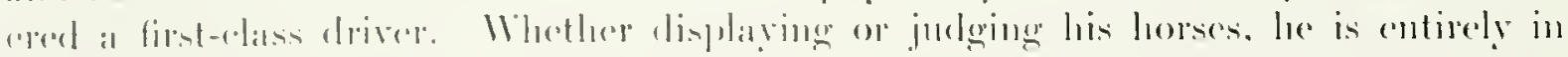

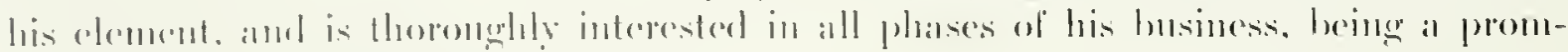

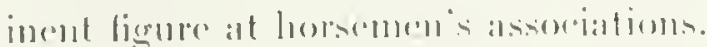

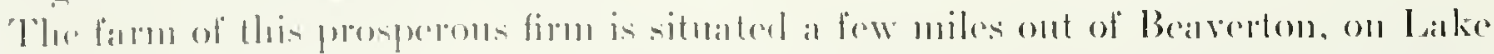

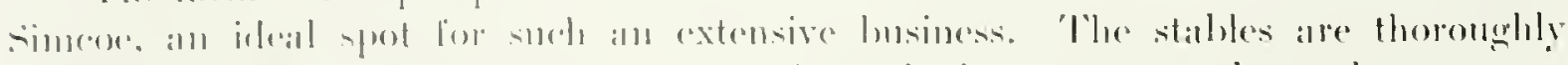

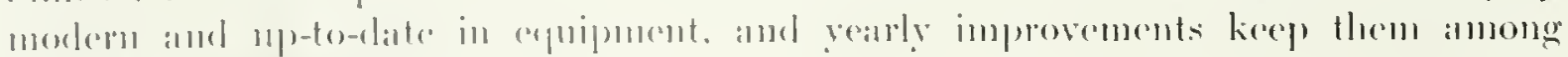
the hest of these estahlishments. 


\section{ROBERT W. DAVIES}

$\mathrm{R}$

(OBER'T W. DAVIES is the son of Robert Daries, of "Thormeliffe." and, of Canadian hirth, and received his eduration at Lpper Camada college. the historice "Eton of Ontario." From early hoyhood. Mr. Davies showed an enthusiastic interest in equine affirirs. developing an appreciation for the thoroughted and also for the harness horse. Both riding and driving fomd lrim "to one of canada's most sucressful amatemes in either' dass. He is quite at home in al "sulky" hehind it fast-stepping steed. while he is a rapatile and successful rider, being a regular attendant at the runs with the bounds. For some veits he las heen a prominent figure at the horse shows. treing regarded as an excellent judge.

Mr. Davies is probahly me of the poungest timers officiating on any of the lateres race-tracks on this continent. Ile has held the pusition of official timer at the meets of the Ontario Jockey Clut for some years. and is most calreful and atcrurate in his work. There is no better nember of the anateur rankis to detect the good points of the thoroughbred. Mr. Davies has ridclen in many

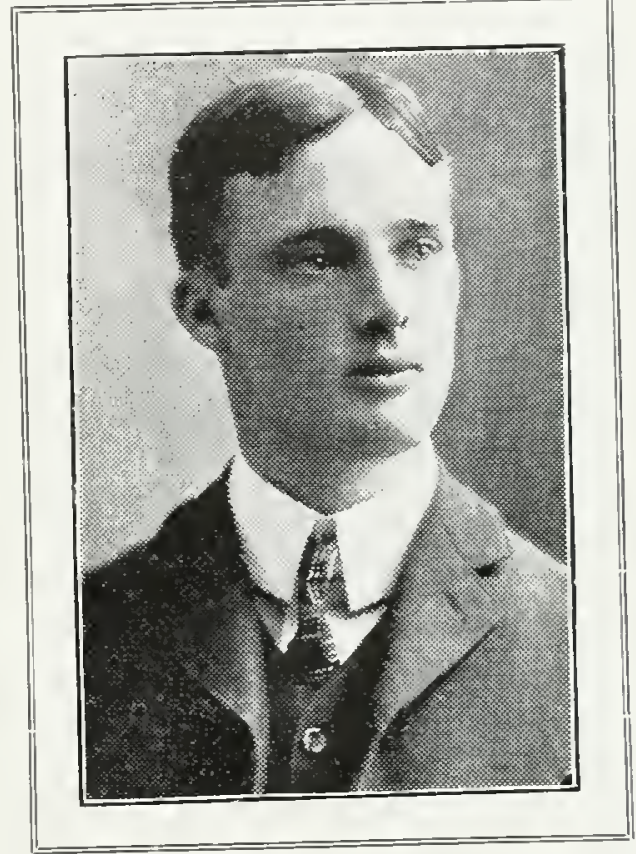

KUBERT W. MAVIES erents for gentlemen riders and hats a goodly numher of victories to his credit. Each rear he is a prominent figure at the ammul gromkhana of the Toronto llunt ('luh, and invariahly has at fine horse to carry his colors. Two or thee rears ago he turned his attention to the harness horse. and some good ones were purchased hy this young owner. He soon learned to handle them himself. becoming. in a short time, an expert reinsman.

Mr. Divies started his business carcer with his father. afterwalds grome with the Copland Brewing Company. Where he now holds a responsible position. latring a prominent part in the business.

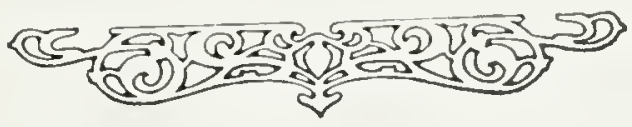




\section{CHARLES J. MURRAY}

AHE spirited repost of steeplechasing is that in which Mr. Clatrles J. Murray

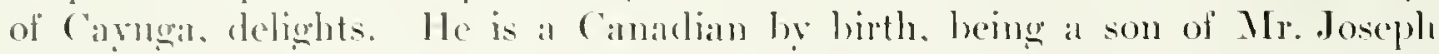
Muray. a well-known husiness man in the Haldimand town. From his early horhook, Mr." "latres" showed a fondness for the eloss-eountry horses, and left lome at an early age to follow it up. Ile has never loft the amateur ranks as rider, althomele lue won many erents in the sadelle in his yomger days. Mr. Muray is loyal to the old town and trains and winters his string in his hoyhood home.

He has always paicl more attention to the leppers thain to any other elass of thoroughbreds. schooling amel arluating them himself. When he semds a horse to the post.

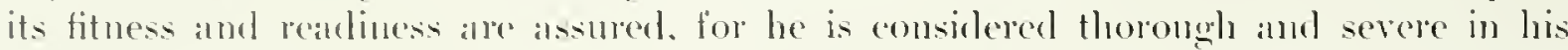
mode of training. The first monnt that Mr. Mluray ever hat was the mare Nora. owned hy. J. R. Matin. with which he was eminently successful. From that time he has won matny of the hig stakes at varrous tracks.

Some of the horses owned ly the sulpject of this sketch, which will be remembered hy Camalians, an "lhree Bars. the wimer of several erents and the sire of some wimers: 1)uldan, who won the (iband National steeplechase event at the Blue Bonnets tratek.

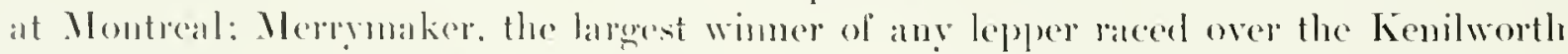

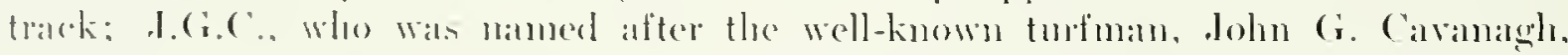

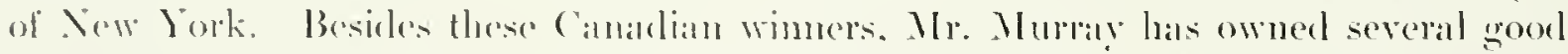
ones that are known only on the trateks of the lented states. Mr. Murray has won not only suceress. but popmlarity also. ly his plucky and sportsmanlike bearing.

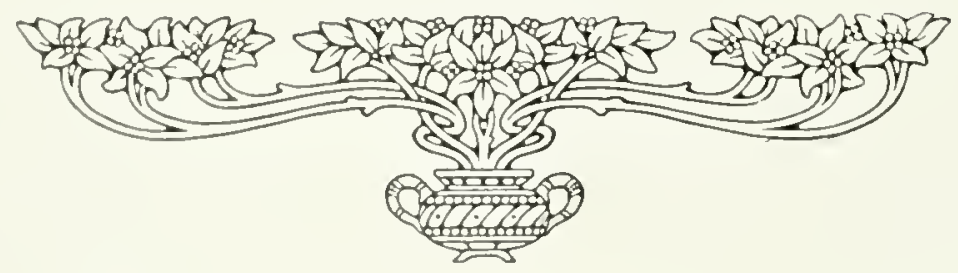




\section{THE HAMILTON JOCKEY CLUB}

$\mathrm{T}$

IE City of Ifamilton. famous for its "ambition," has shown as muels initiative and energy in equestrian affairs as in those of trate and manufacture: so that the Iamilton Jockey Cluh is an institution of high repute among the horsemen of the continent. It is of an honorable age for a club of that nature. going back over a score of years to 1888, when the first meeting of this Chub was formed by at few prominent citizens, the late William Itendrie being the most enthusiastic supporter of the movement. He, like the majority of the charter members, livel to see the Joekey Club a flourishing association, while Mr. Frank Bruce. of the firm of John Bruce and Company, is the only survivor of the original charter members of this Chub.

It was in the season of 1892 that the present site was purchased for the purpose of making an up-to-date track, and from year to year it has been improved until, at the present, it holds an enviable condition of completeness among the racing tracks of America. 'Taking an espeeial interest in events of field and turl', this Chul, had a firstclass turf course eonstrueted. The steeplechase fiekt is one of the hest, and many memorable recorts have been mate over it.

The Cluh has a large membership, which shows an amual increase. It first. only one meeting a season was held. until the racing game beame popular in the ("ity of Itamilton, and then it was deeided to adopt the enstom of other Canarlian cities and hokl both a spring and a Fall Meet. Some valuable stakes are won at these meetings. and there has been a steady increase in the value of the purse. In the olden days, the purse never amounted to much more tham two hundred dollars, while now it is as valuable as that of the Woollnine or Montreal. Some three rears ago. the Ilamilton Derby was inaugurated and this has proved the attraction for some of the latrest strings in America. It has, however, nearly always been won by a Canalian owner. Mr. Allie Louton, who holds the office of Secretary, has been instrumentat in placing this Chub in its present position. Ile has devoted special attention to the comfort of the horsemen. with the result of an increased demand for stabling accommodation each Spring. 'The Hamilton Jockey Club has proved itself quite wortly of the Anbitious City and of its original members.

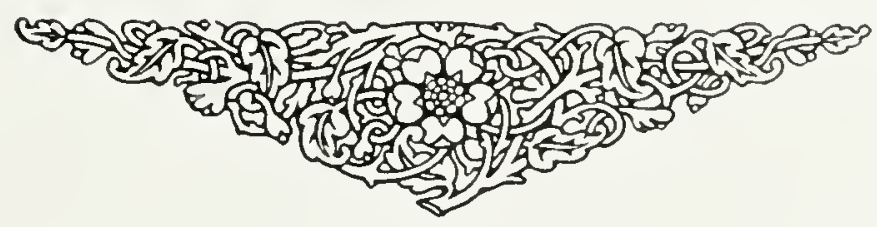











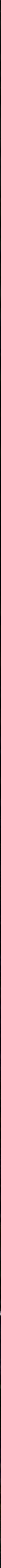





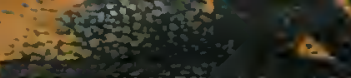

(5) 

